UNIVERSIDADE DE SÃO PAULO

FACULDADE DE FILOSOFIA, LETRAS E CIÊNCIAS HUMANAS

DEPARTAMENTO DE LETRAS CLÁSSICAS E VERNÁCULAS

PROGRAMA DE PÓS-GRADUAÇÃO EM FILOLOGIA E LÍNGUA PORTUGUESA

DANIELA APARECIDA EUFRÁSIO

\title{
O ENSINO DE LÍNGUA PORTUGUESA E SUA CONFIGURAÇÃO DISCIPLINAR EM DISSERTAÇÕES DE MESTRADO
}

Versão corrigida

São Paulo 


\section{O ENSINO DE LÍNGUA PORTUGUESA E SUA CONFIGURAÇÃO DISCIPLINAR EM DISSERTAÇÕES DE MESTRADO}

Tese apresentada ao Programa de Pós-Graduação em Filologia e Língua Portuguesa do Departamento de Letras Clássicas e Vernáculas da Faculdade de Filosofia, Letras e Ciências Humanas da Universidade de São Paulo para obtenção do título de Doutor em Letras.

Área de Concentração: Filologia e Língua Portuguesa

Orientador: Prof. Dr. Valdir Heitor Barzotto

De acordo,

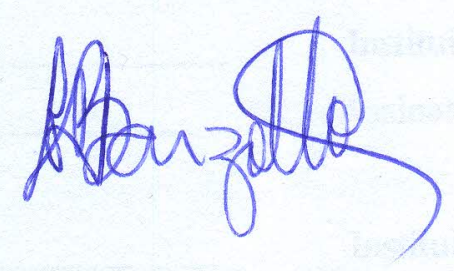

Versão corrigida

São Paulo

2013 
DANIELA APARECIDA EUFRÁSIO

\title{
O ENSINO DE LÍNGUA PORTUGUESA E SUA CONFIGURAÇÃO DISCIPLINAR EM DISSERTAÇÕES DE MESTRADO
}

Tese apresentada ao Programa de Pós-Graduação em Filologia e Língua Portuguesa do Departamento de Letras Clássicas e Vernáculas da Faculdade de Filosofia, Letras e Ciências Humanas da Universidade de São Paulo para obtenção do título de Doutor em Letras.

Área de Concentração: Filologia e Língua Portuguesa

Orientador: Prof. Dr. Valdir Heitor Barzotto

De acordo,

\author{
Versão corrigida \\ São Paulo


Autorizo a reprodução e divulgação total ou parcial deste trabalho, por qualquer meio convencional ou eletrônico, para fins de estudo e pesquisa, desde que citada a fonte.

Nome: EUFRÁSIO, Daniela Aparecida

Título: O ensino de Língua Portuguesa e sua configuração disciplinar em dissertações de mestrado

Tese apresentada ao Programa de Pós-Graduação em Filologia e Língua Portuguesa do Departamento de Letras Clássicas e Vernáculas da Faculdade de Filosofia, Letras e Ciências Humanas da Universidade de São Paulo para obtenção do título de Doutor em Letras.

Área de Concentração: Filologia e Língua Portuguesa

Aprovado em:

Banca Examinadora

Prof. Dr.

Julgamento:

Prof. Dr.

Julgamento:

Prof. Dr.

Julgamento:

Prof. Dr.

Julgamento:

Prof. Dr.

Julgamento:
Instituição:

Assinatura:

Instituição:

Assinatura:

Instituição:

Assinatura:

Instituição:

Assinatura:

Instituição:

Assinatura: 


\section{DEDICATÓRIA}

Para meus pais, Wanderley Almeida Eufrásio e Maria das Graças Soares Eufrásio.

Para minha irmã, Amanda Eufrásio. 
Agradeço...

Ao Prof. Dr. Valdir Heitor Barzotto, pela orientação, por sua disponibilidade, por sua generosidade intelectual e de espírito. Meus agradecimentos pelas orientações que priorizam o desafio de problematizar as respostas bem aceitas.

Aos Professores Dr. Émerson de Pietri e Dr. Luiz Antônio da Silva, pelas valiosas contribuições dadas por ocasião do exame de qualificação.

A todos os professores da banca, titulares e suplentes, pela atenção e disponibilidade.

À minha irmã Amanda, por ter colaborado de modos tão singelos, que talvez ela não tenha a dimensão do quão importante foram para a elaboração desta tese.

À Maristela, ao Rodrigo e aos outros colegas do GEPPEP, pela leitura atenciosa deste trabalho e pelas pertinentes sugestões.

Aos Amigos Elias Ribeiro, Vanessa Girotto, André Marciano e tantos outros que, não só compreenderam o momento de produção deste trabalho, como me forneceram intenso apoio.

À Universidade Federal de Alfenas, pelo apoio recebido para que esta tese fosse finalizada.

Aos funcionários da Pós-Graduação do Departamento de Letras Clássicas e Vernáculas, da FFLCH/USP.

A todos aqueles que, de diferentes modos, contribuíram para a efetivação deste trabalho. 
O que não "falta" importância é ao mistério evocado de fato pelo visível e pelo invisivel, e que une "as coisas" na ordem que o mistério evoca.

René Magritte 


\section{RESUMO}

\section{EUFRÁSIO, DANIELA APARECIDA. O ensino de Língua Portuguesa e sua configuração disciplinar em dissertações de mestrado. 2013. 336 f.Tese (Doutorado).}

Faculdade de Filosofia, Letras e Ciências Humanas, Universidade de São Paulo, São Paulo, 2013.

Esta tese propõe o delineamento da produção de conhecimento sobre ensino de Língua Portuguesa em dissertações de mestrado. Essa proposta de investigação foi construída a partir da pergunta: "O ensino de Língua Portuguesa é uma disciplina?". O conceito de "disciplina" remete-se a Michel Foucault e está formulado no livro, publicado no Brasil, com o título $A$ ordem do Discurso. Desde o tratamento inicial dos dados, verificamos que a resposta a essa pergunta era sim. Essa constatação fundamentou os procedimentos de análise que adotamos. Essa análise decorreu da depreensão de regularidades discursivas quanto aos objetos, às referências teóricas, às proposições e aos métodos de pesquisa validados no discurso científico-acadêmico sobre ensino de Língua Portuguesa. Esse discurso foi analisado em dissertações de mestrado, mapeadas em consulta ao Banco de Teses da CAPES. Nele, buscamos as dissertações publicadas, no período entre 2001 e 2010, por meio da expressão exata "ensino de Língua Portuguesa" no campo "assunto". Localizamos o total de 321 dissertações, defendidas em Instituições do Ensino Superior de todo o país. A caracterização quantitativa desta produção foi apresentada no capítulo 1. Desse montante de trabalhos identificados na primeira etapa de nossa investigação, delimitamos o nosso corpus em 18 dissertações de mestrado, conforme tratamos no capítulo 2. Nesse capítulo, expusemos os aspectos envolvidos na formação do nosso corpus e abordamos distinções entre "coleta de dados" e "composição do corpus". No terceiro e quarto capítulos, tratamos da configuração do discurso, no que diz respeito aos objetos e métodos de pesquisa recorrentes, ao quadro teórico legitimado e às formulações proposicionais defendidas. Da análise de suas regularidades, verificou-se a "negação" como componente elementar na constituição do discurso científico-acadêmico sobre ensino de Língua Portuguesa. No capítulo 5, analisamos como esta refutação compareceu em "negações polêmicas" que contrastam o que foi observado em sala de aula e em materiais didáticos ao quadro teórico referenciado. Por fim, expomos nossas considerações sobre a produção de conhecimento em ensino de Língua Portuguesa, tendo em vista o que tratamos como "estabilização da polêmica".

Palavras-chave: Produção do Conhecimento. Pesquisa em Ensino de Língua Portuguesa. Análise do Discurso. 


\begin{abstract}
EUFRÁSIO, DANIELA APARECIDA. Teaching of Portuguese as a discipline in Master's

theses. 2013. 336 f. Tese (Doutorado). Faculdade de Filosofia, Letras e Ciências Humanas, Universidade de São Paulo, São Paulo, 2013.
\end{abstract}

This dissertation aims to characterize the production of knowledge about the Teaching of Portuguese in Master's theses in Brazil. This research proposal was based on the following research question: "Is the Teaching of Portuguese a discipline?". The concept of "discipline" refers to Michel Foucault's work and it is stated in the book The Discourse on Language, published in Brazil under the title of A Ordem do Discurso. From the very beginning of the data analysis, we found out that the answer to that question was affirmative. These findings gave us the bases for building the data analysis procedures. On the analysis of the data, we tried to find out discursive regularities with regard to research objects, theoretical frameworks adopted, basic propositions, and research methods validated by the academic and scientific discourse about the Teaching of Portuguese. Such discourse was analyzed on corpora composed by theses available on an academic database kept by "Coordenação de Aperfeiçoamento de Pessoal de Nível Superior (CAPES)", an agency of the Brazilian Ministry of Education. In order to compose the corpora, we selected theses concluded in the period from 2001 to 2010 whose keywords include the expression "Teaching of Portuguese". It was possible to identify 321 theses concluded in Brazilian Universities in this period. The quantitative characterization of this academic production is described on Chapter 1. From this total amount, 18 theses were selected to be analyzed as discussed on Chapter 2. Also on this chapter, we discussed some matters regarding the composition of our research corpora and the existing distinction between "data gathering" and "corpora composition". On the Third and Fourth Chapters, we dealt with the configuration of discourse regarding the recurrent topics and methods of research, the theoretical framework legitimized by the authors, and the prepositional formulations defended by them. By analyzing the data, we found out that "negation" is a basic component on the organization of the scientificacademic discourse about the teaching of Portuguese. On Chapter 5, we analyzed the working of this feature on "polemic negations" that differs from the observed use of it in the classroom and on textbooks by establishing a contrast between those uses and the theoretical framework adopted by the authors. Lastly, we presented our considerations regarding the production of knowledge in the field of Portuguese Teaching taking into account what we have considered as the "stabilization of the controversy".

Keywords: Production of Knowledge. Research on Teaching of Portuguese. Discourse Analysis. 


\section{Sumário}

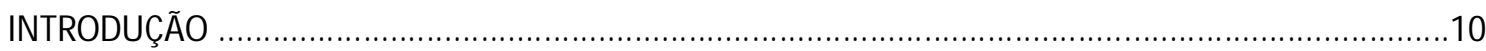

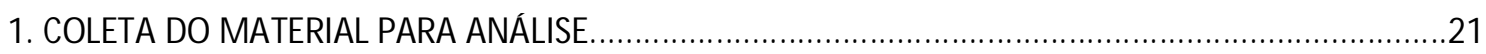

1.1. A pesquisa de mestrado sobre ensino de Língua Portuguesa por vínculo administrativo,

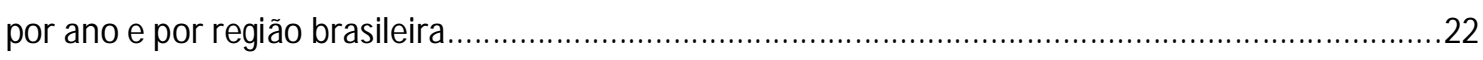

1.2. A pesquisa em ensino de Língua Portuguesa diante do panorama geral de formação acadêmica

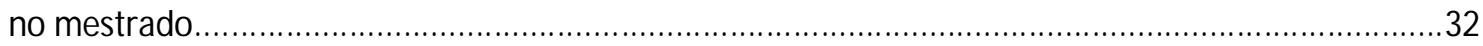

1.3. Demais aspectos descritivos da pesquisa de mestrado sobre ensino de Língua Portuguesa........35

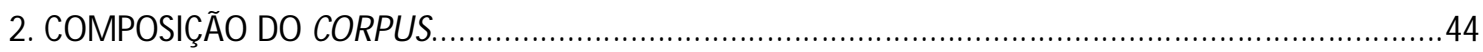

2.1. Critérios para seleção das dissertações consideradas no nosso corpus......................................45

2.2. Composição do corpus pela análise da argumentação ............................................................47

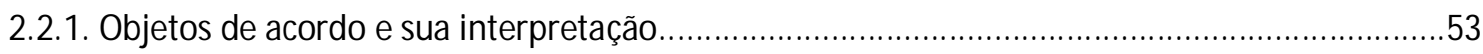

2.2.2. Abordagem argumentativa das dissertações de mestrado .....................................................55

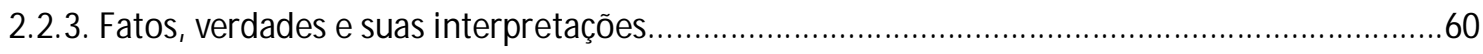

2.2.4. Nosso corpus: dados e interpretações com mais "presença" nas dissertações analisadas.......65

2.3. Distinções entre coleta de dados e composição do corpus................................................91

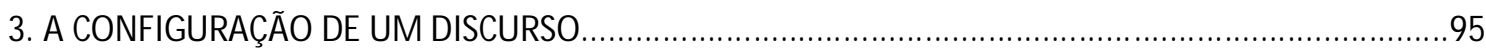

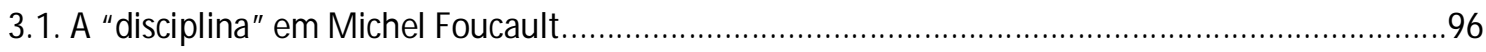

3.1.1 Algumas distinções entre frase, proposição e enunciado ...............................................107

4. CONFIGURAÇÃO DISCIPLINAR DA PESQUISA SOBRE ENSINO DE LÍNGUA PORTUGUESA EM

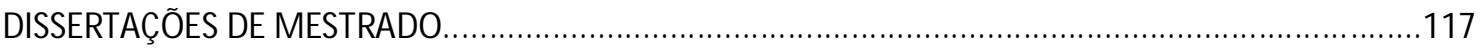

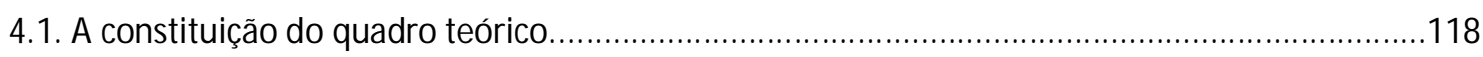

4.2. A constituição dos objetos e os métodos empregados.....................................................133

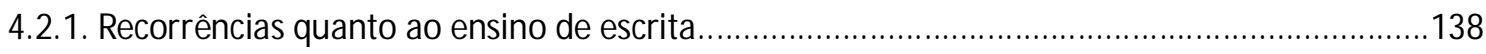




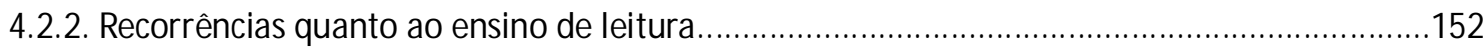

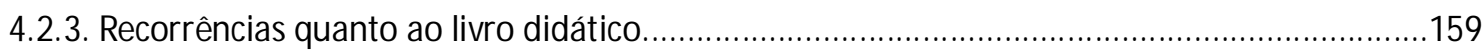

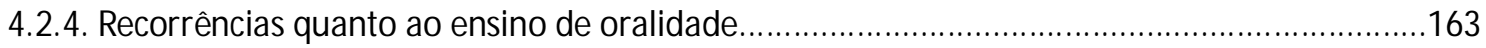

4.2.5. Recorrências quanto ao ensino de gramática.............................................................166

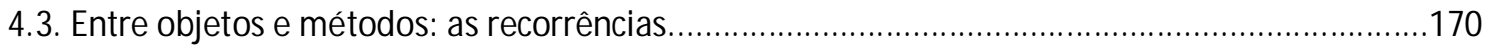

4.4. Proposições e âmbitos de legitimação ...........................................................................173

5. A ANÁLISE DO DISCURSO CIENTÍFICO-ACADÊMICO SOBRE ENSINO DE LÍNGUA PORTUGUESA.....182

5.1. A negação polêmica em investigações de mestrado sobre ensino de Língua Portuguesa...........185

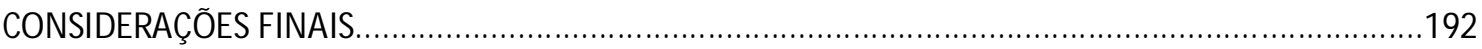

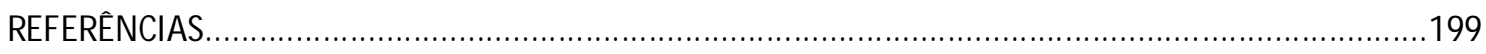

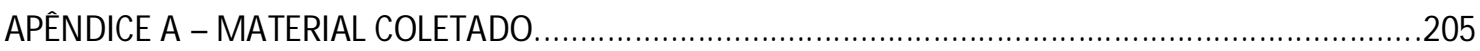

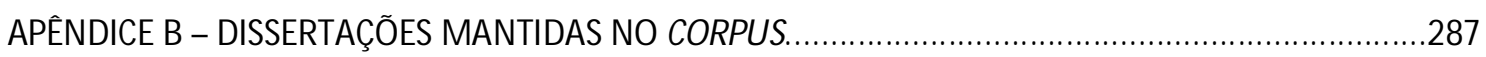

APÊNDICE C - DEM AIS DADOS E INTERPRETAÇÕES CONSTITUINTES DO CORPUS...........................290

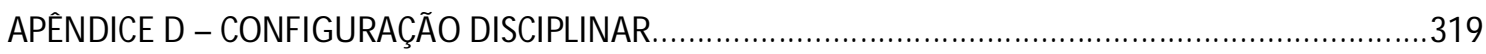




\section{INTRODUÇÃO}

Esta tese encontra o porquê de sua existência na reflexão sobre a produção do conhecimento no interior da universidade. A inquietação que lhe subjaz não é banal. Ela diz respeito ao quanto as propostas de formação acadêmica, por meio de projetos e procedimentos de pesquisa, têm colaborado para a formação de pessoas interessadas em questionar o seu tempo e em desconstruir aquilo que lhe pareceu, em algum momento, como sendo a última resposta, mas que, a partir de posicionamentos interrogativos, mostram-se possíveis de serem tratados de maneiras, até então, impensadas.

As opções por questionar e desconstruir já deixam antever um tipo de dificuldade intrínseca à produção de conhecimento. Ao se questionar e desconstruir o que quer que seja, impõe-se o ato de retomada e de reflexão sobre o que já existe, sobre o nosso próprio tempo, não com finalidade destrutiva, simplesmente, mas almejando a construção de novas possibilidades e novas formas de compreensão da realidade.

No que tange ao papel da universidade na formação de seus alunos, concordamos com Severino (2007, p. 15), quando afirma que:

Evidentemente, todo o investimento teórico e prático com vistas a uma qualificada formação universitária só encontra sua legitimação no compromisso com uma educação que seja efetivamente uma força emancipatória. Seu compromisso fundamental é com a construção da cidadania, qualidade de vida humana digna. A formação universitária não se faz apenas como habilitação técnica, profissional e científica, no sentido estrito dessas expressões. Está necessariamente em pauta também uma dimensão ético-política. Trata-se de um equacionamento propriamente filosófico, ou seja, impõe-se explicitar qual o sentido possível da existência do homem brasileiro como pessoa situada na sua comunidade de tais contornos e em tal momento histórico.

Para a formação discente, o tripé ensino-pesquisa-extensão é eleito por universidades que defendem constituir-se pela afirmação do conhecimento científico como elo entre esses 
três eixos, sendo que é, na pesquisa, que o "trabalho científico" irá ganhar concretude. Salomon (2004, p. 18) convida-nos a pensar:

no trabalho científico como uma imagem projetada do processo da pesquisa científica, em seus três grandes contextos ou momentos, o qual se desdobra sucessiva e progressivamente, perseguindo um desfecho final.

O primeiro desses momentos é categorizado, pelo autor, como o período de problematizar, seria o momento da "descoberta". Insere-se nesta etapa a proposição de certos problemas e também a formulação de algumas hipóteses para a investigação em foco. $\mathrm{O}$ segundo momento vislumbra o "contexto de justificação" da pesquisa. Nele, os procedimentos analíticos - quantitativos e qualitativos - comparecem na defesa ou recusa das hipóteses anteriormente defendidas. Da justificativa feita, decorrem os conhecimentos científicos. O terceiro momento é denominado "contexto da aplicação", em que o conhecimento pode transformar-se em ação e em que pode encaminhar-se de modo concreto o que, antes, era somente abstração construída pela pesquisa. Ou ainda, pode ocorrer a elaboração e sinalização de novos problemas. (SALOMON, 2004, p. 19)

Compreendemos a presente pesquisa como imbuída de um caráter metalinguístico, pois usamos nosso texto escrito para tratar de outros textos escritos, como modo de reflexão sobre a própria produção de conhecimento. O desafio inerente a este trabalho é indagar a produção do conhecimento científico "do lado de dentro". Ou seja, interrogam-se aspectos do trabalho científico que, no próprio ato da interrogação, compõem o foco e o tipo de abordagem que esta tese concretiza em sua elaboração. O benefício desse empreendimento é que fica manifesto que esta investigação não é imune à reflexão que propomos, pelo contrário, ela é também atingida pelas ponderações apresentadas.

No que tange ao conhecimento científico, é válido retomar as considerações de Chauí (2001, p. 23) sobre "ciência": 
A ciência antiga definia-se como teoria, isto é, para usarmos a expressão de Aristóteles, estudava aquela realidade que independe de toda ação e intervenção humanas. A ciência moderna, ao contrário, afirmou que a teoria tinha como finalidade abrir o caminho para que os humanos se tornassem senhores da realidade natural e social. Todavia, a ciência moderna ainda acreditava que a realidade existia em si mesma, separada do sujeito do conhecimento e que este apenas podia descrevê-la por meio de leis e agir sobre elas por meio das técnicas. A ciência contemporânea, porém, acredita que não contempla nem descreve realidades, mas a constrói intelectual e experimentalmente nos laboratórios. Essa visão pós-moderna da ciência como engenharia e não como conhecimento, desprezando a opacidade do real e as difíceis condições para instituir as relações entre o subjetivo e o objetivo, leva à ilusão de que os humanos realizariam, hoje, o sonho dos magos da Renascença, isto é, serem deuses porque capazes de criar a própria realidade e, agora, a própria vida. (grifo da autora)

A provisoriedade do conhecimento científico não se restringe aos resultados que divulga, pois se refere, em especial, à própria concepção do que seja "ciência", conforme discorre a citação anterior. Considerando o exposto, torna-se interessante refletir sobre a latência da ideia de "criação da própria realidade" no fazer científico.

Nos dados que analisamos, por exemplo, verificamos ocorrências como a seguinte: " $a$ professora conclui a discussão do texto, discussão esta que se limitou à observação do conteúdo temático e que foi finalizada pelo fechamento do sentido do texto realizado pela docente. Com essas palavras e com essa finalização, a professora findou também a unidade 7 do livro didático que, como dissemos anteriormente, denomina-se "Charges e Tiras". Esse texto final poderia ter sido utilizado pela professora para retomar o tema central dessa unidade, recordando os textos anteriormente discutidos, tirando possíveis dúvidas dos alunos referentes aos gêneros "charge" e "tira" e concluindo os estudos realizados durante a unidade 7 sobre esses gêneros. Entretanto, isso não foi feito e imediatamente após as palavras da professora de fechamento do sentido do texto, ela inicia a unidade seguinte, denominada "Assumir uma posição", com outros textos, outros gêneros, outras discussões."

Trata-se de um fragmento extraído das páginas 79 e 80 de uma dissertação de mestrado, defendida em 2007, em universidade federal da Paraíba. Com a passagem sublinhada, destaca-se a "realidade" que não existe enquanto tal, mas como construção elaborada no interior da pesquisa em questão. Nesta construção, dá-se a ver a simulação de uma abordagem docente em que o referido texto seria utilizado para uma retomada da 
temática principal da unidade do livro didático em estudo, de modo a serem esclarecidas questões referentes às charges e às tiras anteriormente focalizadas.

A negação de uma "realidade" que só existe enquanto "criação científica" provocanos a considerar as apreciações de Michel Foucault no livro Isto não é um cachimbo. Nele, como o seu título demonstra, a atenção volta-se para algumas reproduções de quadros do pintor René Magritte. Dentre elas, destaca-se aquela em que a figura de um "cachimbo" e a inscrição "Ceci n'est pas une pipe" estão postos no interior de uma moldura, que, por sua vez, apóia-se sobre um cavalete. Acima desta moldura, há outro cachimbo, igual ao primeiro, mas maior em tamanho.

Destaca-se, desse livro, a seguinte afirmação:

Voltemos a esse desenho de um cachimbo que se assemelha tanto a um cachimbo; a esse texto escrito que se assemelha, tão exatamente, ao desenho de um texto escrito. De fato, lançados uns contra os outros ou mesmo simplesmente justapostos, esses elementos anulam a semelhança intrínseca que parecem trazer consigo, e pouco a pouco se esboça uma rede aberta de similitudes. Aberta, não para o cachimbo "real", ausente de todos esses desenhos e de todas essas palavras, mas aberta para todos os outros elementos similares (compreendendo nisso todos os cachimbos "reais", de barro, de escuma, de madeira etc.) que, uma vez tomados nessa rede, teriam lugar e função de simulacro. E cada um dos elementos de "isto não é um cachimbo" bem poderia manter um discurso em aparência negativo, pois se trata de negar, com a semelhança, a asserção de realidade que ela comporta, mas que é no fundo afirmativo: afirmação do simulacro, afirmação do elemento na rede do similar. (FOUCAULT, 1988, p. 64-5)

Como se vê, esta citação analisa a presença do "cachimbo" e do "texto escrito" na obra de René Magritte, chamando a atenção para a rede de similitudes existentes entre o desenho e aqueles que seriam os "cachimbos reais". Se entre a figura desenhada e o objeto em si, há um simulacro em jogo, o mesmo ocorre quanto ao "texto escrito", pois, por meio da negação, o simulacro comparece como sendo aquilo que se afirma, isso é, afirma-se que ali existe a simulação do que poderia ser um "cachimbo".

Ao trabalharmos sobre o nosso corpus, foi-se evidenciando aquilo que compareceu como determinante nos resultados a que a presente investigação chegou. Trata-se da 
percepção de que havia uma "negação" constituinte do discurso de pesquisa em ensino de Língua Portuguesa que possuía, como fundamento, a afirmação de uma "realidade criada" no interior da pesquisa em si. O fragmento de dissertação de mestrado, anteriormente transcrito, dá exemplo desse tipo de "criação da realidade".

O processo investigativo que percorremos, do início da pesquisa até chegar a suas conclusões, foi longo. Antes de determo-nos sobre ele, é importante ressaltar que, examinando-o, identificamos que o seu germe já estava na dissertação de mestrado defendida por esta pesquisadora em 2007, na Faculdade de Educação da Universidade de São Paulo. Sob o título Traços das formações discursivas do dogma e da investigação em relatórios de pesquisa e de estágio: reflexão sobre o papel da pesquisa na formação docente, indagávamos como se dava a formação do estudante de Letras quando ele estava envolvido em um projeto de pesquisa, na modalidade "Iniciação Científica" (IC) e também trabalhando com propostas investigativas nos estágios curriculares que cumpriam.

O objetivo era avaliar se os modos de tratamento do conhecimento constante do ensino de Língua Portuguesa, presentes nos relatórios de estágio, eram influenciados pela sistematização e criticidade demandadas pelo fazer científico, que eram, por sua vez, investigadas quanto às suas formas de concretização nos relatórios de IC. Como hipótese de trabalho, considerou-se que:

[...] se, em relação ao fazer científico, o graduando em Letras toma contato com o processo investigativo no tratamento dos objetos de conhecimento, assumindo um posicionamento que seja realmente ativo, reflexivo e crítico, ele também poderá assumir posicionamentos semelhantes quando estiver lidando com o conhecimento que advém da observação e da regência de aulas de língua portuguesa do ensino básico. (EUFRÁSIO, 2007, p. 13-4)

Na conclusão, apresentamos o que segue:

Assumimos, então, nesta dissertação, o ponto-de-vista de quem entende a pesquisa como prática fundamental no desenvolvimento do profissional de Letras e, mais que isso, de que é necessário partirmos para o debate sobre 
que pesquisa estamos defendendo enquanto instrumento de formação, como ela se desenvolve e que relações permite estabelecer entre um sujeito em formação na universidade e a produção do conhecimento. Pois, como defendido na presente dissertação, a prática da pesquisa em cursos de graduação em Letras pode concretizar posicionamentos dogmáticos, contrapondo-se assim a posturas questionadoras e investigativas, capazes de proporcionarem aos alunos intervenções críticas na sua relação com o conhecimento. (EUFRÁSIO, 2007, p. 189)

Na referência a posicionamentos dogmáticos, já se esboçava a inquietação que foi mencionada no início deste capítulo introdutório, quando expusemos a difícil retomada de referenciais científicos considerados importantes, sem restringir-se à sua simples reprodução, o que poderia caracterizar-se mais como uma prática acadêmica cuja natureza seria somente didática:

[...] Geralmente, são atividades repetitivas de experiências já feitas, síntese de textos e semelhantes. Rigorosamente, não se lhes pode atribuir o caráter científico, por faltar-lhes alguns requisitos básicos: a criatividade, a contribuição substancial no processo cumulativo do conhecimento científico e, às vezes, até o nível de abstração e generalização que se exige para a investigação científica propriamente dita. (SALOMON, 2004, p. 152)

Considerando o exposto, verificamos que o nosso interesse em refletir sobre a produção de conhecimento, avaliando as regularidades presentes na constituição dos saberes, já se esboçava na dissertação de mestrado que defendemos, conforme descrito. Somado a isso, outro fator relevante para a proposta de investigação desta tese foi o Projeto de Pesquisa "Disciplinas da licenciatura voltadas para o ensino de Língua Portuguesa: cooperação acadêmica entre UNIFAL-MG e USP" .

\footnotetext{
${ }^{1}$ Este projeto foi coordenado pelas professoras Fabiana de Oliveira (UNIFAL-MG) e Cláudia Rosa Riolfi (USP). Também integraram a equipe os professores: Valdir Heitor Barzotto (USP), Emerson de Pietri (USP), Neide Luzia de Rezende (USP), Fernanda Vilhena Mafra Bazon (UFSCar), Mical de Melo Marcelino Magalhães (UFU) e eu, que fiz parte como docente da UNIFAL-MG.
} 
Tratou-se de um projeto realizado entre 2010 e 2012, desenvolvido por meio da parceria entre as duas instituições supracitadas, com o apoio da Fundação de Amparo à Pesquisa do Estado de Minas Gerais (FAPEMIG). Ao serem iniciados os seus trabalhos, esta pesquisadora integrou a equipe, haja vista que, desde 2008, atuava no quadro docente da Universidade Federal de Alfenas (UNIFAL-MG). Em linhas gerais, esse projeto propôs:

[...] delimitar o estado da arte acerca da formação de professores de Língua Portuguesa, a partir da análise dos conteúdos ministrados na disciplina Metodologia do Ensino de Língua Portuguesa, presente nos currículos dos cursos de Pedagogia e de Letras. Volta-se à elucidação da seguinte pergunta de pesquisa: a partir das mudanças educacionais que se instituíram no ensino de Língua Portuguesa na década de 90, como, no âmbito da disciplina MELP, tem se dado a formação do professor de língua materna? A partir da investigação dos currículos e dos programas de ensino dos cursos supramencionados, em universidades do Estado de Minas Gerais e São Paulo, visa a circunscrever a existência ou não de um objeto específico que caracterize o campo do qual se encarrega a disciplina estudada. Visa, ainda, analisar a constituição, ou não, de uma "disciplina" (no sentido foucaultiano do termo), a partir dos conhecimentos veiculados na disciplina MELP e na produção dela decorrente. (OLIVEIRA et al., 2009, p. 1)

Como se vê, nesse projeto comparecia, como um de seus enfoques, a análise da constituição disciplinar do componente curricular "Metodologia do Ensino de Língua Portuguesa". No tocante a isso, podemos compreender como ele fomentou, junto à pesquisa de mestrado, a proposta de investigação da presente tese.

Tendo em vista o desenvolvimento desse projeto, no que concerniu à investigação sobre as recorrências que poderiam apontar para uniformidades quanto à "Metodologia do Ensino de Língua Portuguesa", construímos a hipótese de que, em trabalhos acadêmicos como dissertações de mestrado, seria possível delimitar regularidades subjacentes à dispersão de seus objetos e métodos de pesquisa e aos seus referenciais e proposições, no que dissessem respeito a esse mesmo ensino.

Esta hipótese de trabalho foi desencadeada a partir das reflexões efetivadas na nossa dissertação de mestrado e, também, no referido projeto de pesquisa. Conforme discutido, na 
dissertação, concretizou-se a reflexão sobre como as referências constituintes dos processos de investigação eram mobilizadas e de que modo isso caracterizava os relatórios de estágio e de IC analisados. Já o projeto de pesquisa mencionado suscitou a abordagem do conceito de "disciplina" na verificação das regularidades inerentes à formação do professor de Língua Portuguesa.

Tendo em vista esse panorama, elaborou-se a proposta desta tese, constituída a partir do interesse de reflexão acerca da produção de conhecimento em "ensino de Língua Portuguesa" em trabalhos de mestrado. Esta proposta justifica-se, em boa medida, porque, com o aumento das publicações de Pós-Graduação, em especial, de pesquisas de mestrado, elas se estabelecem como um material privilegiado de investigação de suas características, concretizadas em um rol cada vez maior de trabalhos desse tipo, e propiciam a avaliação sobre o que tal caracterização tem gerado em termos qualitativos.

Estabeleceu-se, assim, como objetivo geral:

- Delinear a produção de conhecimento sobre ensino de Língua Portuguesa em dissertações de mestrado.

Como objetivos específicos, foram delimitados os seguintes:

- Caracterizar quantitativamente a produção de mestrado sobre ensino de Língua Portuguesa do período de 2001 a 2010;

- Avaliar a configuração disciplinar de dissertações de mestrado, em conformidade com o conceito foucaultiano de "disciplina";

- Problematizar a constituição disciplinar destas dissertações em relação às produções que lhes são posteriores.

Do exposto, decorreu que a presente investigação permitiu tanto uma abordagem de caráter quantitativo quanto qualitativo, conforme passamos a expor, tendo em vista as partes que compõem esta tese.

No capítulo 1, detivemo-nos no mapeamento da produção de mestrado sobre ensino de Língua Portuguesa - defendida no período de 2001 a 2010 -, quanto à sua configuração numérica de publicações por ano, por região brasileira, por vínculo administrativo das Instituições de Ensino Superior (doravante IES), e também relacionando-a com o panorama 
geral de formação acadêmica no mestrado. Ademais, também se verificou, em termos quantitativos, sua disponibilidade virtual e os contextos de pesquisa priorizados.

Ressalta-se que, ao optar por constituir o nosso corpus a partir de dissertações defendidas nos anos citados, voltamo-nos para um período recente da produção científicoacadêmica, mas que se seguiu a uma época bastante marcante para o ensino de Língua Portuguesa. Sobre esta época, referimo-nos, em especial, às propostas de ensino de Língua Portuguesa que emergiram, no Brasil, a partir da década de 70. Sobre isso, citamos Pietri (2003), que, em A constituição do discurso da mudança do ensino de língua materna no Brasil, afirma o que segue:

As discussões quanto a se ensinar ou não gramática, quanto à necessidade de desfazer as condições em que emerge o preconceito lingüístico, quanto a se fazer da escola um espaço transformador da realidade social através do respeito pela linguagem do aluno, o que possibilitaria levá-lo a se apropriar da variedade social de prestígio, são discussões que se fortaleceram, no Brasil, no transcorrer da década de 70 do século XX, e que se fazem atuais, ganhando novo fôlego nas contendas entre lingüistas e gramáticos tradicionais, seja através da publicação de obras voltadas ao assunto, seja nos espaços que a mídia em geral oferece, principalmente aos defensores do ensino tradicional. (PIETRI, 2003, p. 9)

A década citada destaca-se por ser um momento a partir do qual se constatam as problemáticas levantadas quanto ao ensino de Língua Portuguesa, em especial no que diz respeito à defesa ou refutação da gramática como componente desse ensino. Considerando isso, o período eleito pela presente investigação é válido na medida em que dá mostras sobre o que constitui o discurso sobre ensino de Língua Portuguesa, na década que abriu o século XXI e que se seguiu à referida época.

A escolha por fazer o mapeamento das dissertações, no Banco de Teses da CAPES, por meio da formação sintagmática "ensino de Língua Portuguesa" demonstrou-se eficaz, pois possibilitou o acesso a um variado leque de trabalhos que definem suas temáticas tendo em vista sua relação com esse ensino. Essa formação sintagmática funcionou como uma palavrachave que utilizamos ao preencher o campo "assunto", no referido banco de dados, como se verá no capítulo 1. 
A consulta aos tratados sobre metodologia científica elencados nas referências finais desta tese, não forneceu nenhuma pormenorização acerca do que sejam as "palavras-chave". Sua busca no dicionário Caldas Aulete, na sua versão digital, ofereceu as seguintes acepções:

1. Palavra ou expressão que resume o significado geral de um contexto: Em economia, atualmente a palavra-chave é globalização.

2. Num conjunto ordenado de informações (listas, arquivos, sites da internet etc.), palavra us. para identificar elementos afins ou que dizem respeito a um mesmo assunto. (AULETE) (grifo do autor)

Tendo em vista a segunda acepção fornecida, consideramos "ensino de Língua Portuguesa" uma formação sintagmática que, ao funcionar como "palavra-chave" no nosso procedimento de busca no Banco de Teses da CAPES, interessou devido ao seu grau de variabilidade enquanto composição lexical. (POTTIER, 1978) Esta variação diz respeito à compreensão de que, nesta formação sintagmática, "ensino de" caracteriza-se por sua estabilidade, quando comparada a outras composições como "ensino de história", "ensino de geografia", "ensino de matemática", "ensino de química", dentre outras. Desse modo, fica indicado que o "substantivo" inserido no sintagma preposicional, iniciado com "de", denota uma instabilidade, haja vista as diversas formas possíveis para o seu preenchimento.

O interesse de tal formação sintagmática evidenciou-se pela possibilidade que abriu à nossa coleta de dados para reunir um material marcado por sua dispersão, quanto ao ano, local de publicação e contexto de pesquisa, dentre outros elementos, das dissertações de mestrado que foram discutidas na presente tese.

Com isso, pudemos identificar distintos aspectos reunidos sob uma mesma designação, que, no caso, foi "ensino de Língua Portuguesa". Compreendemos que o agrupamento de dissertações que, à primeira vista, poderiam ser consideradas somente pelo prisma da desigualdade, colaborou para que pudéssemos testar nossa hipótese de verificação de regularidades no discurso científico-acadêmico sobre ensino de Língua Portuguesa, mesmo quando caracterizado por sua abrangência.

Uma vez concluída nossa coleta de dados, em conformidade com o exposto, passamos à composição de nosso corpus, relatada e discutida no capítulo 2 desta tese. Nele, tratamos 
dos critérios para seleção das dissertações consideradas no corpus, da sua composição pela análise da argumentação, referenciada pela nova retórica do tratado de Chaïm Perelman e Lucie Olbrechts-Tyteca, e apresentamos ponderações acerca das distinções entre "coleta de dados" e "composição do corpus".

No capítulo 3, abordamos a configuração discursiva de uma "disciplina", no seu sentido foucaultiano. Enfoque que foi detalhado, no capítulo 4, quando nos voltamos para a análise desta configuração disciplinar nos trabalhos de mestrado sobre "ensino de Língua Portuguesa”. O capítulo 5, por sua vez, constituiu-se pela caracterização desse discurso na abordagem de seus enunciados. Nas considerações finais, tratamos do que, no decorrer desta pesquisa, compreendeu-se como a "estabilização da polêmica". 


\section{COLETA DO MATERIAL PARA ANÁLISE}

Para a coleta do material analisado nesta tese, fizemos uma busca por dissertações de mestrado sobre ensino de Língua Portuguesa, defendidas no país. Estabelecemos como período de interesse a primeira década do século XXI, isso é, do ano 2001 a 2010. Para esta coleta, recorremos ao Banco de Teses da CAPES ${ }^{2}$. Trata-se de um banco de dados on-line que possibilita, conforme informações disponibilizadas na Página de Internet desta instituição, a consulta a resumos de dissertações e teses defendidas desde 1987.

Para esta consulta, são disponibilizados os seguintes campos para busca: "autor"; "assunto"; "instituição" e "nível/ano base". Adotamos o procedimento de completar o campo "assunto" com a expressão exata "ensino de língua portuguesa" e o campo "nível/ano base" com "mestrado" e cada um dos anos sob enfoque, de 2001 a 2010. Os outros campos ficaram em branco.

Desta busca, resultou a localização de 321 resumos de dissertações de mestrado, que foram defendidas em IES brasileiras e que anunciaram tematizar o ensino de Língua Portuguesa. No que segue, passamos a discutir, quantitativamente ${ }^{3}$, as características desta produção, a partir da leitura e análise dos resumos coletados. Para tanto, dividimos este capítulo em três seções.

A primeira seção, intitulada "A pesquisa de mestrado sobre ensino de Língua Portuguesa por vínculo administrativo, por ano e por região brasileira" apresenta dados, ano a ano, referentes às esferas administrativas das universidades nas quais as dissertações foram defendidas, destacando características de sua produção estadual, federal, municipal e particular. Nela, também localizamos a apresentação de dados voltados para a distribuição regional da pesquisa de mestrado sobre a temática em questão. A segunda seção, “A pesquisa em ensino de Língua Portuguesa diante do panorama geral de formação acadêmica no mestrado", destacou informações numéricas acerca da oferta de cursos de mestrado em todo o país, aproveitando-as para comparações entre esses números e os dados específicos sobre a

\footnotetext{
${ }^{2}$ Disponível em http://capesdw.capes.gov.br/capesdw/. Acesso em mar. 2013.

${ }^{3}$ Em nossa abordagem quantitativa dos dados, não foi possível a leitura integral das dissertações, de modo que não houve a possibilidade de se verificar se todos os resumos que, no referido Banco, enquadraram-se dentre aqueles com referência ao ensino de Língua Portuguesa, de fato o fazem tomando este ensino como objeto central de reflexão ou somente o tangenciam.
} 
pesquisa em ensino de Língua Portuguesa. A última seção deste capítulo, "Demais aspectos descritivos da pesquisa de mestrado sobre ensino de Língua Portuguesa", focalizou os contextos de pesquisa anunciados pelas dissertações e também a sua disponibilidade virtual.

\title{
1.1. A pesquisa de mestrado sobre ensino de Língua Portuguesa por vínculo administrativo, por ano e por região brasileira
}

\begin{abstract}
$\mathrm{Na}$ análise dos resumos coletados no referido Banco de Dados, da CAPES, foi possível organizar quantitativamente as informações sobre o Estado e o vínculo administrativo das IES nas quais as dissertações foram defendidas, bem como o ano de sua publicação.

Iniciamos, pois, tratando dos vínculos administrativos. Na Tabela 1, apresentamos esses dados, distribuídos por anos, conforme eles foram declarados nos resumos das dissertações:
\end{abstract}

Tabela 1 - Vínculo administrativo declarado nas Páginas dos resumos coletados

\begin{tabular}{lcccc}
\hline Ano & IES Estaduais & IES Federais & IES M unicipais & IES Particulares \\
\hline 2001 & 04 & 04 & - & 07 \\
2002 & 05 & 07 & - & 04 \\
2003 & 06 & 07 & 01 & 06 \\
2004 & 06 & 11 & - & 12 \\
2005 & 04 & 15 & 02 & 16 \\
2006 & 06 & 12 & &
\end{tabular}


"Conclusão"

\begin{tabular}{llccc}
2007 & 09 & 15 & 04 & 13 \\
2008 & 07 & 20 & 01 & 16 \\
2009 & 11 & 19 & 01 & 21 \\
2010 & 09 & 16 & 01 & 15 \\
Total & 67 & 126 & 10 & 118 \\
\hline
\end{tabular}

Fonte: Banco de Teses da CAPES.

Nesta tabela, observa-se a presença majoritária de universidades com vínculo federal ou particular no tocante à pesquisa em mestrado sobre ensino de Língua Portuguesa, publicada entre 2001 e 2010. Somada a publicação das IES de administração federal e particular, chegamos a $76 \%^{4}$ de toda a produção desse período. Observa-se que a maior parte da produção vincula-se à esfera federal (39\%), seguida de perto pelas dissertações vinculadas a instituições particulares (37\%). É válido registrar que, historicamente, as IES brasileiras federais e particulares receberam atenção governamental, com raízes que remetem ao Governo Vargas. Esse enraizamento encontra explicações dentre as ações, na era varguista, de federalização de faculdades estaduais e privadas, bem como de incentivo para a abertura e o funcionamento de novas universidades particulares. Sobre a federalização, Cunha (2004, p. 815) cita os seguintes exemplos:

Em Niterói, a Faculdade Fluminense de Filosofia, em dificuldades financeiras, foi federalizada e integrou a UFF. Em Juiz de Fora, as faculdades católicas e protestantes, "empatadas" na luta pela criação de universidades confessionais, acordaram em transferir seus ativos e passivos ao governo federal, que criou a UFJF, e acomodou os contendores, inclusive mediante a criação do inédito Instituto de Estudos da Religião.

\footnotetext{
${ }^{4}$ No cálculo das porcentagens apresentadas neste capítulo, efetivamos arredondamentos da seguinte ordem: os algarismos decimais colocados depois da vírgula, se iguais ou maiores que 50, modificaram os algarismos decimais antes da vírgula em uma unidade. Quando os algarismos decimais depois da vírgula eram menores que 50, não houve alteração dos algarismos decimais antes da vírgula. Exemplos: a porcentagem 39,25\% foi arredondada para $39 \%$, enquanto a porcentagem $36,76 \%$ foi arredondada para $37 \%$.
} 
Ao mesmo tempo em que havia a federalização de universidades, o setor privado também foi favorecido por meio de imunidade fiscal e pela criação de novas instituições, dentre outras iniciativas. (CUNHA, 2004, p. 801) Tal panorama acerca da constituição histórica das universidades no Brasil aponta para questões a serem consideradas quando tratamos da produção científico-acadêmica nacional. Esta reflexão é cabível quanto à pesquisa de diferentes áreas do conhecimento, mas, no que segue, continuaremos a apresentar mapeamento da produção de mestrado em ensino de Língua Portuguesa.

Para melhor compreensão da situação específica desta produção em relação aos seus vínculos administrativos, expomos a vinculação das IES por Estado brasileiro, conforme segue:

Tabela 2 - Vínculo administrativo das IES por Estado

\begin{tabular}{cccccc}
\hline Estado & IES Estadual & IES Federal & IES Municipal & IES Particular & Total \\
\hline AC & - & 01 & - & - & 01 \\
AM & - & 02 & - & - & 02 \\
AL & - & 05 & - & - & 05 \\
BA & - & 06 & - & - & 06 \\
CE & - & 05 & - & - & 05 \\
DF & - & 09 & - & 02 & 11 \\
ES & - & 02 & - & - & 02 \\
GO & - & 04 & - & 03 & 07 \\
MG & - & 12 & - & 06 & 18 \\
MS & - & 07 & - & - & 07
\end{tabular}

"Continua" 


\begin{tabular}{cccccc} 
“Conclusão" & & & & \\
Estado & IES Estadual & IES Federal & IES Municipal & IES Particular & Total \\
\hline MT & - & 09 & - & - & 09 \\
PA & 01 & 06 & - & - & 07 \\
PB & - & 10 & - & - & 10 \\
PE & - & 10 & - & 04 & 14 \\
PR & 24 & 04 & - & 04 & 32 \\
RJ & 08 & 13 & - & 04 & 25 \\
RN & 01 & 08 & - & - & 09 \\
RO & - & 01 & - & - & 01 \\
RS & - & 04 & - & 16 & 20 \\
SC & - & 05 & 01 & 01 & 07 \\
SE & - & 02 & - & - & 02 \\
SP & 33 & 02 & 09 & 77 & 121 \\
\hline
\end{tabular}

Fonte: Banco de Teses da CAPES.

Ao observarmos a tabela anterior, verificamos que o Estado com maior produção foi São Paulo. As IES responsáveis por esta produção eram vinculadas, majoritariamente, à esfera particular de ensino e à rede estadual de Ensino Superior. Isso significa que, quando verificamos a produção total do mestrado em ensino de Língua Portuguesa, na década pesquisada, destacaram-se as IES federais e particulares, como demonstrado anteriormente. Já quando observamos esta mesma produção por Estado, há especificidades como a paulista, na qual se mostraram preponderantes as universidades estaduais, juntamente àquelas de administração particular.

Tal preponderância pode ser confirmada quando consideramos que São Paulo foi responsável por $49 \%$ de toda a produção investigada e vinculada à esfera estadual e por $65 \%$ de todo o montante calculado em relação às instituições particulares.

Em termos de produção estadual, São Paulo, que teve 33 defesas no período analisado, foi seguido pelo Estado do Paraná, com 24 dissertações defendidas. Esses dois Estados juntos, 
conforme os dados da Tabela 2, foram responsáveis por $85 \%$ das dissertações vinculadas às IES estaduais.

Quanto à produção vinculada à esfera particular, São Paulo, com 77 dissertações defendidas, apresentou mais que a metade do total de defesas no período investigado. Nas dissertações com esse tipo de vínculo, São Paulo foi seguido pelo Rio Grande do Sul, que teve 16 defesas. Esses dois Estados responderam, em conformidade com a Tabela 2, por $79 \%$ do todo.

Compreende-se que a preponderância de São Paulo nos dados apresentados reflete, de um lado, a magnitude do sistema educacional paulista vinculado à esfera estadual, representado pela Universidade de São Paulo, pela Universidade Estadual de Campinas e pela Universidade Estadual Paulista "Júlio de Mesquita Filho". De outro lado, não podemos nos esquecer de que, apesar de estas três universidades públicas estaduais possuírem importante representatividade para a o Ensino Superior brasileiro, em termos quantitativos e qualitativos, elas ainda deixam um amplo espaço para as universidades particulares. Os dados que coletamos, referentes às dissertações de mestrado sobre ensino de Língua Portuguesa defendidas nas IES paulistas, entre 2001 e 2010, revelaram que $27 \%$ de toda a produção relaciona-se à esfera estadual, enquanto $64 \%$ é oriunda da esfera particular de ensino.

A presença de instituições particulares no Ensino Superior de São Paulo, em especial, em sua capital, é, de fato, algo notável. Esta realidade comparece tanto ao analisarmos dados específicos, como os desta tese, como em análises panorâmicas, como a realizada por Calderón (2000). No texto denominado "Universidades Mercantis: a institucionalização do mercado universitário em questão", o autor discute o cenário das universidades paulistanas a partir da década de 90, que deixa de ser um espaço de universidades públicas e de cunho confessional e passa a caracterizar-se pela entrada das universidades particulares com evidentes fins lucrativos. Tais universidades são nomeadas pelo autor como "universidades mercantis". (CALDERÓN, 2000, p. 61)

Segundo o autor:

[...] No Município de São Paulo foram criadas no espaço de nove anos, entre 1988 e 1997, dez universidades mercantis [...] e uma universidade pública (a Escola Paulista de Medicina transformou-se na Universidade Federal de São Paulo). 
Se considerarmos que até 1988 existiam em São Paulo somente quatro universidades (uma universidade pública - USP -, e três confessionais comunitárias - PUC-SP, Mackenzie e a nova Universidade São Francisco), até 1997 houve um crescimento de 250\% [...], totalizando 15 universidades.

Em 2000, existe o total de dez universidades mercantis e cinco centros universitários, com o mesmo caráter mercantil desse modelo de universidade emergente (Uninove, Unibero, Uni Sant'Anna, UNI-FMU, São Camilo). Em termos de opções de ensino universitário, considerando os centros universitários, que para concorrer no mercado de ensino superior apresentam-se ao consumidor com a palavra UNI antecedendo seus nomes para ressaltar seu caráter universitário, pode-se afirmar que em 2000 a oferta de ensino universitário foi ampliada de tal forma que ele está sendo oferecido por 20 instituições universitárias: duas universidades públicas, três universidades confessionais e 15 instituições mercantis (dez universidades e cinco centros universitários). (CALDERÓN, 2000, p. 64)

Considerando, pois, o avanço das instituições particulares nesse município, coube-nos entender o que os números referentes à produção de dissertações sobre ensino de Língua Portuguesa em IES particulares revelavam sobre esse nível de formação na capital paulista.

A análise da procedência das dissertações de mestrado sob enfoque demonstrou que, das 77 dissertações defendidas em IES particulares de São Paulo, 59 vinculavam-se à Pontifícia Universidade Católica de São Paulo (PUC) e 06 à Universidade Presbiteriana Mackenzie (UPM). Ao somarmos a produção destas duas IES, que totalizou 65 dissertações, verificamos que $84 \%$ de toda a produção de mestrado sobre ensino de Língua Portuguesa de instituições particulares paulistas adveio da UPM e, majoritariamente, da PUC.

Esse resultado demonstrou que, por mais que tenha havido grande abertura do mercado paulistano para IES particulares, a formação em nível de mestrado permaneceu, na década analisada, naquelas instituições tradicionais, como a PUC de São Paulo. Os outros $16 \%$ da produção sob enfoque vinculou-se, em sua maior parte, àquelas instituições que podem ser denominadas como "universidades mercantis", as quais, majoritariamente, não se localizam na capital, mas no interior do Estado, em municípios como Piracicaba, Sorocaba, Presidente Prudente e Marília.

Voltando à Tabela 2, observamos que São Paulo apareceu também como o Estado com maior produção de dissertações de mestrado sobre ensino de Língua Portuguesa nas IES municipais. Contudo, ao contrário do que foi observado nas esferas estadual e particular, a produção inerente à esfera municipal foi pouco representativa. Sua pequena 
representatividade dá-se tanto em termos quantitativos - ao todo 10 dissertações foram localizadas - quanto em termos de distribuição territorial - foram identificadas 09 dissertações em uma mesma instituição paulista, localizada no município de Taubaté, e 01 dissertação em instituição catarinense.

Os dados expostos, nos quais se observou o predomínio de São Paulo quanto às dissertações sobre ensino de Língua Portuguesa nas esferas estadual, municipal e particular, interferiram diretamente quando analisamos quantitativamente a produção por região brasileira. Desse modo, a região Sudeste sobressaiu no que disse respeito ao total de dissertações produzidas.

O Sudeste foi favorecido pela alta produção do Estado paulista e também por aquela vinculada às instituições cariocas e mineiras. Rio de Janeiro e Minas Gerais, de acordo com a Tabela 2, apresentaram o maior número de dissertações sobre ensino de Língua Portuguesa em IES federais. O primeiro Estado com 13 e o segundo com 12 dissertações defendidas, o que, somado, correspondeu a praticamente $20 \%$ do todo.

Os números referentes a universidades públicas federais deixam entrever que, nelas, não há uma desproporcionalidade alta de um Estado para o outro, diferentemente do que foi avaliado nas IES estaduais, municipais e particulares. Destaca-se, assim, que a quantidade de dissertações vinculadas a universidades federais foi a mais elevada e a mais diversificada, ou seja, ao contrário do que foi demonstrado em relação às outras esferas administrativas das IES, nas quais predominou a produção paulista, as dissertações com vínculo federal concerniram a todos os Estados brasileiros elencados na Tabela 2.

A seguir, na Tabela 3, expomos dados referentes à produção anual de cada um dos Estados brasileiros com defesa de dissertações de mestrado sobre ensino de Língua Portuguesa. Por meio de sua análise, conseguimos esmiuçar aspectos que também importam constar dentre aqueles que influenciaram para uma maior ou menor produção. 
Tabela 3 - Produção por ano e por Estado brasileiro

\begin{tabular}{|c|c|c|c|c|c|c|c|c|c|c|c|}
\hline Estado & 2001 & 2002 & 2003 & 2004 & 2005 & 2006 & 2007 & 2008 & 2009 & 2010 & Total \\
\hline $\mathrm{AC}$ & - & - & - & - & - & - & - & - & - & 01 & 01 \\
\hline $\mathrm{AL}$ & - & - & - & - & - & 01 & 01 & 01 & 01 & 01 & 05 \\
\hline $\mathrm{AM}$ & - & 01 & - & - & - & - & - & - & 01 & - & 02 \\
\hline BA & - & - & - & - & - & 01 & 03 & 01 & - & 01 & 06 \\
\hline CE & - & 01 & - & - & - & - & 01 & 01 & 02 & - & 05 \\
\hline DF & 01 & 01 & - & - & 02 & 01 & 01 & 03 & 01 & 01 & 11 \\
\hline ES & - & - & - & 02 & - & - & - & - & - & - & 02 \\
\hline GO & 01 & 01 & - & 01 & 02 & - & - & - & 02 & - & 07 \\
\hline MA & - & - & - & - & - & - & - & - & 01 & - & 01 \\
\hline MG & 01 & - & 04 & 01 & 04 & 01 & - & 02 & 03 & 02 & 18 \\
\hline MS & - & - & - & 01 & 01 & - & 02 & 01 & 01 & 01 & 07 \\
\hline MT & - & - & - & - & 02 & 02 & 01 & 03 & - & 01 & 09 \\
\hline PA & - & - & - & - & 01 & 01 & 02 & 02 & - & 01 & 07 \\
\hline PB & - & 01 & 01 & 01 & 01 & - & 01 & 04 & 01 & - & 10 \\
\hline PE & - & 02 & 02 & 02 & - & 02 & - & - & 04 & 02 & 14 \\
\hline PR & 01 & 04 & 04 & 03 & 03 & 03 & 06 & 04 & 03 & 01 & 32 \\
\hline RJ & 01 & - & 04 & 02 & 05 & 02 & - & 02 & 04 & 04 & 24 \\
\hline $\mathrm{RN}$ & 01 & - & - & - & - & 03 & - & - & 02 & 03 & 09 \\
\hline RO & - & - & - & - & - & - & - & - & - & 01 & 01 \\
\hline RS & 02 & 02 & 01 & 03 & 02 & 01 & 02 & 03 & 02 & 02 & 20 \\
\hline $\mathrm{SC}$ & - & 01 & 01 & 01 & 02 & - & - & 01 & - & 01 & 07 \\
\hline SE & - & - & - & - & - & - & - & - & - & 02 & 02 \\
\hline SP & 07 & 02 & 04 & 07 & 06 & 18 & 21 & 16 & 24 & 16 & 121 \\
\hline
\end{tabular}

Fonte: Banco de Teses da CAPES. 
Os dados então expostos demonstram que os dois Estados com maior produção também foram aqueles que apresentaram continuidade na publicação de dissertações, durante os anos de 2001 a 2010. Observamos que, em São Paulo, dissertações sobre ensino de Língua Portuguesa foram defendidas em todos os anos da década estudada. Fato que não ocorreu nos demais Estados brasileiros, com exceção do Paraná.

O fato de o Paraná apresentar esta constância temporal na publicação de dissertações, na década analisada, influenciou para que ele fosse o segundo Estado com maior produção e para que a região Sul aparecesse como a segunda detentora de mais mestrados concluídos com trabalhos que tematizassem o ensino de Língua Portuguesa. Ao retomarmos a Tabela 2, verificamos que esta produção paranaense foi, em sua maior parte, vinculada a IES estaduais, com pequena participação de instituições federais e particulares ${ }^{5}$.

Na região sulista, também se destacou o Rio Grande do Sul. Esse Estado, que demonstrou ter o quarto maior número de dissertações sobre ensino de Língua Portuguesa, apresentou, a exemplo de São Paulo e do Paraná, continuidade na produção analisada por toda a década em questão. Avaliamos isso como um fator que também contribuiu para que o Sul se mantivesse como a segunda região brasileira com o maior número de dissertações acerca do tema sob enfoque. A produção gaúcha caracterizou-se por ser, principalmente, vinculada a IES particulares, conforme dados que podem ser recuperados da Tabela $2^{6}$.

Diferentemente desse panorama, observamos que, nas IES das regiões Nordeste e Centro-Oeste, há espaçamentos temporais na defesa das dissertações. No Rio Grande do Norte, por exemplo, identificou-se a defesa de dissertação em 2001 e, depois, somente em 2006, em seguida, em 2009, e, por fim, em 2010. Espaçamentos temporais assim também foram identificados nos demais Estados das regiões supracitadas, conforme pode ser confirmado na Tabela 3.

Esses espaçamentos temporais refletiram no cômputo total de publicações de dissertações nestas regiões. Desse modo, a região Nordeste foi a terceira com mais defesas de dissertações sobre ensino de Língua Portuguesa e a região Centro-Oeste, a quarta.

Por fim, a região Norte apresenta-se com o menor número de dissertações sobre a temática sob enfoque, o que decorre de suas produções constarem dos últimos anos da década

\footnotetext{
${ }^{5}$ Em relação ao Paraná, localizamos 24 dissertações vinculadas a IES públicas estaduais, 04 a IES públicas federais e 04 a IES particulares (Vide tabela 2).

${ }^{6}$ Nesta tabela, expomos informações sobre a produção gaúcha, condizentes à publicação de 20 dissertações, sendo 16 vinculadas a IES particulares e 04 a IES públicas federais.
} 
estudada em mais de um Estado, como foi o caso do Acre e de Rondônia, conforme demonstra a Tabela 3.

Acerca ainda do panorama por região brasileira da pesquisa de mestrado sobre ensino de Língua Portuguesa, apresentamos a tabela a seguir, por meio da qual é possível verificar o progresso e a oscilação desta produção regional por ano:

Tabela 4 - Produção regional por ano

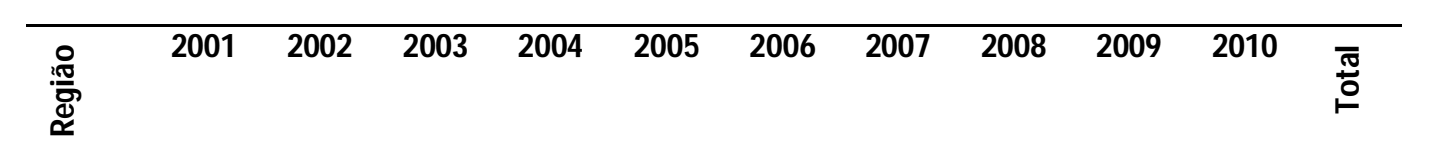

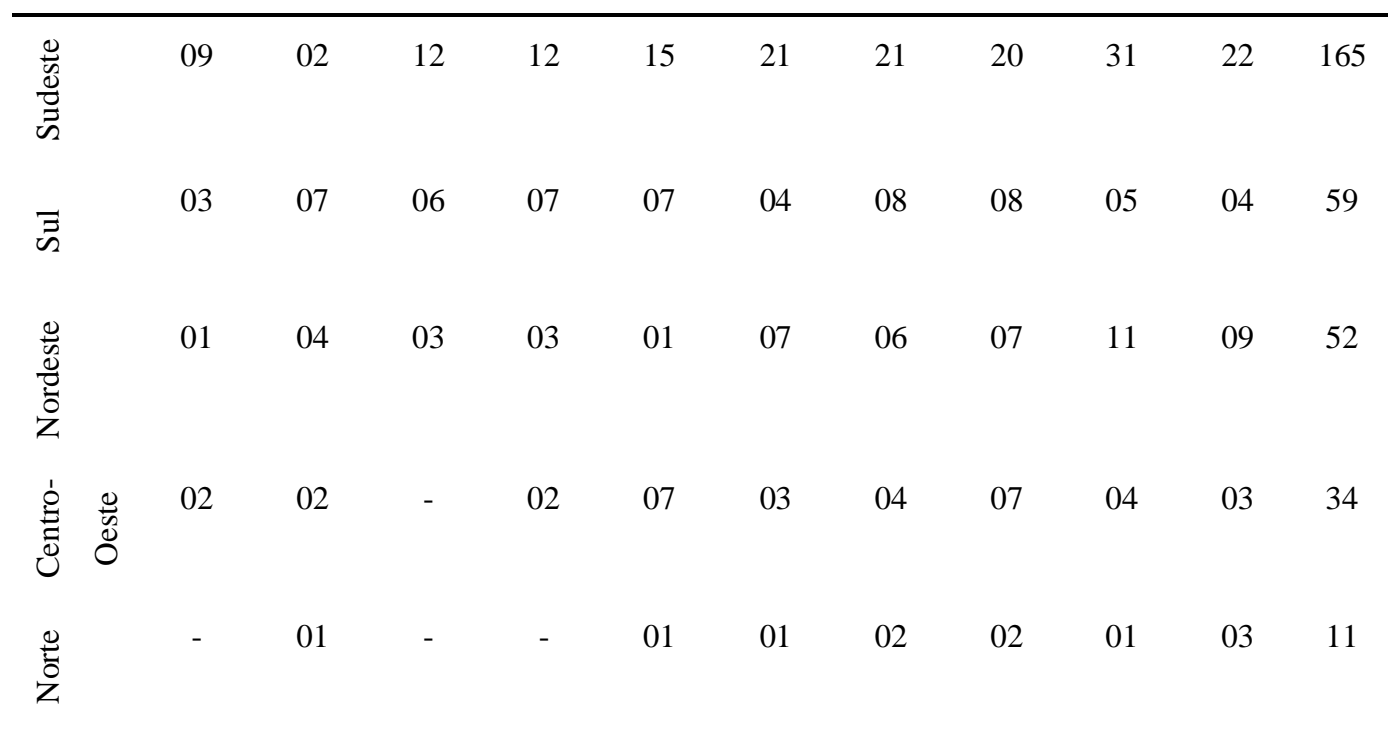

Fonte: Banco de Teses da CAPES.

Como observamos, houve, no geral, uma ascendência no número de dissertações defendidas em todas as regiões brasileiras, ainda que tenha havido, em alguns anos, relativa baixa quanto ao ano anterior. O caso que apresentou maior desproporcionalidade foi o da região Sudeste, entre os anos de 2001 e 2003. Nesse período, a produção oscilou entre 09, 02 e 12 dissertações defendidas, chamando a atenção o fato de, no ano de 2002, terem sido localizadas somente 02 publicações. A explicação para isso teria de ser procurada em 
informações diferentes das que estão sendo disponibilizadas e discutidas neste capítulo, por isso não nos deteremos nela.

Quanto à produção da região Norte, pela Tabela 4, verifica-se a presença de uma única defesa no ano de 2002, ocorrida na Universidade Federal do Amazonas, depois do que se seguiu o espaçamento de dois anos até que houvesse uma nova publicação sobre ensino de Língua Portuguesa na região. Observamos também que a região Norte é a única a terminar a década com uma curva ascendente, pois todas as outras regiões apresentaram alguma queda de publicação no ano de 2010 em relação ao de 2009.

Por fim, ressaltamos o crescimento percebido na região Nordeste a partir do ano 2006. Antes disso, o máximo de publicações localizadas foi de 04 dissertações defendidas e, posteriormente ao ano de 2005, as publicações foram para 07 dissertações, alcançando a quantidade de 11 em 2009.

A apresentação desses dados incita-nos a compreender o que significa a situação quantitativa das pesquisas sobre ensino de Língua Portuguesa em relação ao quadro geral dos cursos de mestrado acadêmico no país. Sendo assim, no que segue, apresentamos algumas informações referentes à Pós-Graduação no cenário brasileiro, a fim de contrastá-las com os resultados quantitativos até então pontuados.

\subsection{A pesquisa em ensino de Língua Portuguesa diante do panorama geral de formação acadêmica no mestrado}

Conforme os dados disponibilizados pela CAPES (BRASIL, 2010, p. 46), os cursos de mestrado acadêmico recomendados e habilitados para funcionamento, em todas as áreas do conhecimento, apresentam-se em evolução quantitativa desde 1976. A formação no mestrado contava aproximadamente com 500 cursos em 1976 e atingiu, em 2009 , mais de 2.500 cursos, representando um crescimento da ordem de $370 \%$.

\footnotetext{
${ }^{7}$ O documento da CAPES citado é o Plano Nacional de Pós-Graduação - PNPG 2011-2020 (BRASIL, 2010, p. 46), que apresenta estatísticas que abarcam o período de 1976 a 2009. Por isso, nas referências que fazemos a este documento abordamos dados relativos, no máximo, ao ano de 2009.
} 
Em consequência à ampliação da oferta de tais cursos, houve um considerável aumento no número de titulações. Em termos nacionais, verifica-se que, de 3.665 titulados mestres, no ano de 1987, foi-se, em 2009, para 35.698 titulações, o que representou um crescimento de 874\%. (BRASIL, 2010, p. 66) Focalizando os anos de 2001 a 2009, verificamos que, enquanto no ano de 2001, houve 19.670 titulações no mestrado, no ano de 2009, houve 35.698. CAPES (BRASIL, 2010, p. 66) Isso representou uma ampliação de aproximadamente $45 \%$. Os números referentes, especificamente, às titulações provenientes da defesa de dissertações de mestrado sobre ensino de Língua Portuguesa, conforme dados da Tabela 3 deste capítulo, são de 15 defesas em 2001 e 52, em 2009, o que significa um aumento da ordem de $71 \%$.

Ao compararmos as duas últimas porcentagens a que fizemos referência, notamos que as pesquisas sobre ensino de Língua Portuguesa evoluíram quantitativamente mais do que o crescimento averiguado em relação ao panorama global de titulações em todas as áreas do conhecimento.

No que diz respeito à distribuição regional dos cursos de mestrado, a CAPES (BRASIL, 2010, p. 54) disponibilizou os seguintes dados: a região Sudeste predominou com a oferta de aproximadamente $50 \%$ do total, sendo seguida pela região Sul, com a oferta de $20 \%$ dos cursos, pelo Nordeste, com 18\%, pelo Centro-Oeste, com 7\% e, por fim, pelo Norte, com quase $5 \%$. Esse escalonamento das regiões brasileiras quanto à oferta dos cursos de mestrado foi o mesmo identificado quanto à defesa de dissertações sobre ensino de Língua Portuguesa, como pode ser revisto na Tabela 4 deste capítulo.

Observamos, assim, que há correspondência entre os dados fornecidos pela CAPES, sobre a oferta dos cursos de mestrado por região brasileira, e os dados fornecidos por esta tese. Similaridades assim indicam a possibilidade de análise da realidade micro sem apartá-la da situação macro de que ela faz parte, ou seja, sinalizam a viabilidade de se investigar os dados sob enfoque como representantes de algumas particularidades que constituem o todo.

Desse modo, no desenvolvimento desta tese, debruçamo-nos sobre dissertações de mestrado que tratam do ensino de Língua Portuguesa ${ }^{8}$, a fim de entender que regularidades

\footnotetext{
${ }^{8}$ Para esta tese, escolhemos analisar a primeira década do presente século, a fim de entender a produção de dissertações sobre ensino de Língua Portuguesa no período inicial deste novo milênio. Observa-se, contudo, que a produção destas dissertações continua em crescimento. Segundo os dados do Banco de Teses da CAPES, em 2011, houve 42 mestrados defendidos sobre ensino de Língua Portuguesa, e, em 2012, 68. Fonte: http://capesdw.capes.gov.br/capesdw/. Acesso em jul. 2013.
} 
constituem-na, mas procuramos proceder de modo a não perder de vista o todo. Avaliamos, assim, ser possível debater algumas tendências do cenário global a partir da análise focalizada nas dissertações em questão.

Os números até então apresentados, sobre a formação no mestrado acadêmico, permitem afirmar a relevância de se tomar a produção decorrente desse nível de formação como foco de investigação, haja vista que sua evolução quantitativa favorece a efetivação da análise qualitativa dos seus objetos de estudo, de suas metodologias, dos seus referenciais teóricos e dos resultados que têm sido alcançados.

Para apresentação dos dados expostos até então, recorremos às informações advindas da CAPES, extraídas do seu Banco de Teses e do Plano Nacional de Pós-Graduação - PNPG 2011-2020 (BRASIL, 2010). Compreendemos que os dados disponibilizados por esta instituição sobre os números e as características que envolvem a Pós-Graduação são importantes para o desenvolvimento de pesquisas que tomam os cursos de especialização, mestrado e doutorado como fontes de discussão.

O PNPG 2011-2020 (BRASIL, 2010) colaborou para que levantássemos as informações numéricas em relação à Pós-Graduação de todo o país, em todas as áreas do conhecimento. A partir dele, expusemos algumas comparações entre os dados específicos desta pesquisa e aqueles informados no referido documento.

Com a coleta dos resumos, tratados quantitativamente na primeira seção deste capítulo, conseguimos mapear os dados da pesquisa de mestrado fornecidos pelas próprias IES para a composição do Banco de Teses da CAPES. Esse instrumento de coleta de dados demonstrou-se acessível e simples para a consulta das informações que buscávamos para a efetivação da presente tese. Isso não significa, porém, que não haja melhorias a serem feitas nesse Banco.

Vieira e Maciel (2007), por exemplo, relatam que, ao consultarem-no para uma pesquisa documental a partir da palavra-chave "preconceito", identificaram problemas nos resumos disponibilizados por esse Banco, dentre os quais citam: ausência de informações sobre as linhas de pesquisa de vinculação de vários trabalhos e ampla variação quanto à extensão dos resumos, sendo alguns deles constituídos por 22 palavras, enquanto outros possuíam 2.022 palavras.

Compreendemos assim que a viabilidade desse Banco fica prejudicada para trabalhos que investigam as linhas de pesquisa das dissertações e teses defendidas no nosso país, uma 
vez que tais informações nem sempre são apresentadas. Somando-se isso à alta variação no número de palavras por resumo, avalia-se que falta a esse Banco uma diretriz clara, que seja enviada às Instituições de Pós-Graduação, responsáveis por transmitir as informações de seus cursos à CAPES, acerca do que seja adequado para cada um dos campos presentes nos resumos integrantes do referido Banco.

Até este ponto, focalizamos a exposição do número total de dissertações sobre ensino de Língua Portuguesa de que localizamos os resumos no Banco de Teses da CAPES. Tais dissertações foram defendidas entre 2001 e 2010, em Instituições de Ensino Superior de todo o país. Na caracterização quantitativa que apresentamos, incluímos a distribuição das dissertações por Estado, por região, por ano e por vínculo administrativo. Também fornecemos algumas informações referentes à Pós-Graduação em todo o país, a partir do que realizamos comparações entre alguns números pertinentes à pesquisa em ensino de Língua Portuguesa e outros referentes ao cenário de oferta e titulação em cursos de mestrado em todas as áreas do conhecimento.

No apêndice A, apresentamos a transcrição abreviada de todos os 321 resumos localizados no Banco de Teses da CAPES, em conjunto com outras informações pertinentes. No que segue, passamos, então, a descrever e explicar a organização desse apêndice, tendo em vista o modo como as informações apareceram categorizadas nele.

\subsection{Demais aspectos descritivos da pesquisa de mestrado sobre ensino de Língua Portuguesa}

Nesta seção, continuamos expondo características das dissertações de mestrado sob enfoque a partir da leitura dos resumos coletados. A descrição desse material será feita tendo em vista o apêndice A desta tese. Nele, transcrevemos fragmentos dos resumos localizados, em conjunto com as seguintes informações: "ano de defesa", "contexto pesquisado", "vínculo administrativo/localização" e "disponibilidade da versão eletrônica".

Os dados referentes aos anos de defesa das dissertações, aos seus vínculos administrativos e à localização das IES foram suficientemente tratados na primeira seção 
deste capítulo. Por isso, no que segue, iremos nos concentrar em discutir as demais informações apresentadas no apêndice A. Antes, porém, ressaltamos que, na sua elaboração, procuramos uniformizar o número de palavras de cada um dos fragmentos dos resumos transcritos. Contudo, isso não foi possível porque, na localização das informações estruturais em cada um dos resumos - tais como objeto de análise, metodologia de pesquisa, referenciais e resultados -, alguns se apresentaram mais breves que outros. Ademais, certos resumos não possuíam todas estas informações e, consequentemente, sua transcrição ficou menor do que de outros que dispunham de todos os itens procurados ${ }^{9}$.

Optamos por organizar cada um dos quadros do apêndice A apresentando-os em sequência cronológica, de 2001 a 2010. Dos cinco itens que o compõem, dois deles não foram ainda devidamente esclarecidos, quais sejam: "disponibilidade da versão eletrônica" e “contexto pesquisado". Passamos, então, à discussão desse último, em relação ao qual nossa postura inicial foi a de verificar que contexto de ensino tinha sido alvo de reflexão, uma vez que todos os resumos coletados foram localizados por anunciarem "o ensino" como assunto de pesquisa, especificamente, o "ensino de Língua Portuguesa".

Nesta primeira etapa, conseguimos separar as dissertações em três grandes grupos, são eles: a) Pesquisa em contextos brasileiros de educação escolar; b) Demais contextos pesquisados; e c) Contextos de pesquisa indefinidos.

Em "Educação escolar brasileira", agrupamos os resumos que faziam referência tanto à educação escolar contemporânea quanto não-contemporânea. Em "Demais contextos", inserimos todos os resumos que faziam referência a contextos de educação não-escolar e também ao ensino fora do Brasil. Em "Indefinidos", foram reunidos os resumos que não evidenciaram o contexto de ensino pesquisado e nem forneceram indícios suficientes para que pudéssemos inferi-lo.

Passamos a detalhar cada um desses grupos, começando pelo que foi menos recorrente, que totalizou $5 \%$ dos resumos coletados. Nele, foram agrupados os resumos que se referiram aos seguintes contextos de pesquisa: a) ensino em país africano: tratou do ensino da Língua Portuguesa na Guiné-Bissau e em Moçambique; b) exame de proficiência: concerniu à pesquisa sobre prova de proficiência em português para estrangeiros e o ensino preparatório para esse exame; c) concurso público: referiu-se a exames de Língua Portuguesa para vagas no serviço público e ao ensino preparatório para estas provas; d) curso virtual: focalizou o

\footnotetext{
${ }^{9}$ Verifica-se, quanto a este quesito, algo a também ser aperfeiçoado pelo Banco de Teses da CAPES.
} 
ensino de Língua Portuguesa via Internet; e) grupo de estudos: pesquisou sobre grupo de estudos para formação docente continuada; e f) mídia: disse respeito a programas televisivos sobre a Língua Portuguesa, tomados como meio de ensino da língua.

Como se vê, nesse grupo, ficaram os resumos que não fizeram menção a contextos escolares brasileiros, ou seja, aqueles que não se referiram à educação em instituições brasileiras do Ensino Básico e Superior. Em números absolutos, 15 resumos foram enquadrados nele.

No grupo em que compilamos os resumos com contextos de pesquisa indefinidos, foram reunidos 23 ao todo, o que correspondeu a 7\% em relação aos 321 trabalhos identificados. Os resumos reunidos nesse grupo, como explicado anteriormente, foram categorizados como "indefinidos" porque apresentaram suas abordagens investigativas sem expor informações suficientes para que compreendêssemos sua relação com os contextos de ensino escolar ou não-escolar.

Nele, acoplamos resumos que apresentaram abordagens bastante distintas entre si, dentre as quais expomos as que seguem a fim de ilustrar, em parte, a diversidade das temáticas tratadas:

- análise semiótico-linguístico-discursiva de textos publicitários impressos;

- análise de fatores pragmáticos da textualidade em dez letras de canções de Caetano Veloso;

- estudo das definições e de exemplos pertinentes à categoria gramatical "sujeito";

- investigação do processo de argumentação em artigos científicos publicados em Anais do VI Congresso Internacional da Associação Brasileira de Lingüística (ABRALIN).

As análises deste capítulo não apresentam detalhamento das variadas vertentes de discussão dos resumos coletados, haja vista que isso implicaria a leitura integral de todas as dissertações em questão. Esta análise aprofundada será realizada a partir do capítulo 3, no qual apresentaremos o corpus tratado na presente pesquisa. Desse modo, observamos que uma das discussões que não tiveram espaço, nesse momento, foi a verificação da dimensão que o ensino de Língua Portuguesa teve em cada uma das dissertações. Com isso, referimo-nos ao fato de, algumas vezes, ocorrer de um resumo citar o ensino de português como assunto da pesquisa, mas, na verdade, somente tangenciá-lo, sem lhe dar centralidade na investigação 
desenvolvida. Esse é um questionamento pertinente, em especial, aos resumos compilados no grupo que denominamos "indefinido", pois neles encontramos informações insuficientes sobre o contexto de ensino pesquisado.

O grupo que concentrou o maior número de trabalhos foi o de "Educação escolar brasileira", no qual se enquadraram 283 resumos do total de 321 localizados, o que correspondeu a 88\%. Nele, agrupamos 266 resumos que se referiram à educação escolar brasileira na contemporaneidade: 226 dos quais fizeram menção à Educação Básica, 36 à Educação Superior e 04 resumos compilaram dados desses dois níveis escolares. Vale lembrar que na Lei de Diretrizes e Bases da Educação Nacional, Lei nº 9.394/96, a Educação Básica é constituída pela pré-escola, pelo Ensino Fundamental e pelo Ensino Médio, e a Educação Superior compreende cursos sequenciais, de graduação, de pós-graduação e de extensão.

Os outros 17 resumos, do grupo em questão, trataram de contextos de ensino que não são contemporâneos e, por isso, foram categorizados como um subgrupo que denominamos como "Antiga Educação Escolar". Nele, foram incorporados os resumos que delimitaram como contexto de pesquisa o ensino na segunda metade do século XIX, ou o período que compreende o final do século XIX e o início do XX e, também, aqueles que anunciaram discutir o ensino de Língua Portuguesa até a década de 70 do século XX. Como anunciado anteriormente, todas as transcrições de fragmentos dos resumos encontram-se no apêndice A.

No grupo "Educação escolar brasileira", observamos predominância de resumos que citaram a Educação Básica como foco de reflexão, correspondendo a $81 \%$ de todos os resumos reunidos nesse grupo. Quanto às outras produções desse grupo, verificamos que aquela referente à "antiga educação escolar" representou $6 \%$ do total de 283 resumos e a produção referente à Educação Superior foi calculada em 13\% em relação a esse mesmo valor total.

Ressaltamos que, no que tange à Educação Superior, identificamos três fontes distintas de obtenção dos dados, conforme seguem:

- 30 resumos mencionaram cursos de Ensino Superior, são eles: Administração, Arte, Curso Normal Superior, Direito, Hotelaria, Letras, Pedagogia e Secretariado Executivo;

- 04 resumos delimitaram os exames vestibulares;

- 02 resumos citaram cursos de formação docente continuada. 
Dentre os resumos sobre Educação Superior, incluímos aqueles referentes aos concursos vestibulares porque os compreendemos como relacionados ao ensino universitário, uma vez que ele funciona como etapa comum para ingresso nesse nível de ensino. Incluímos também os resumos que fizeram referência à formação continuada docente, pois esta se voltou, nos resumos analisados, aos docentes já possuidores de formação acadêmica inicial.

A fim de termos um panorama global dos contextos de pesquisa que viemos categorizando, expomos na tabela a seguir, ano a ano, a quantidade de resumos que citaram os distintos contextos: 
Tabela 5 - Contextos pesquisados

\begin{tabular}{llllllllllll}
\hline $\begin{array}{l}\text { Contexto } \\
\text { pesquisado }\end{array}$ & 2001 & 2002 & 2003 & 2004 & 2005 & 2006 & 2007 & 2008 & 2009 & 2010 & Total \\
\end{tabular}

\begin{tabular}{|c|c|c|c|c|c|c|c|c|c|c|c|}
\hline $\begin{array}{l}\text { Antiga } \\
\text { Educação } \\
\text { Escolar }\end{array}$ & - & - & - & 2 & 3 & 4 & 2 & 1 & 3 & 2 & 17 \\
\hline $\begin{array}{l}\text { Educação } \\
\text { Básica }\end{array}$ & 13 & 13 & 14 & 14 & 21 & 21 & 32 & 36 & 35 & 27 & 226 \\
\hline $\begin{array}{l}\text { Ed. Básica } \\
+ \text { Ed. } \\
\text { Superior }\end{array}$ & - & 1 & - & - & - & 1 & 1 & 1 & - & - & 4 \\
\hline $\begin{array}{l}\text { Educação } \\
\text { Superior }\end{array}$ & 2 & 2 & 3 & 1 & 4 & 3 & 6 & 3 & 7 & 5 & 36 \\
\hline $\begin{array}{l}\text { Concurso } \\
\text { Público }\end{array}$ & - & - & - & - & - & 1 & - & 1 & 1 & - & 3 \\
\hline $\begin{array}{l}\text { Curso } \\
\text { Virtual }\end{array}$ & - & - & - & 1 & - & - & - & - & 3 & - & 4 \\
\hline $\begin{array}{l}\text { Ensino em } \\
\text { País } \\
\text { Africano }\end{array}$ & - & - & - & - & - & 3 & - & 1 & - & - & 4 \\
\hline $\begin{array}{l}\text { Exame de } \\
\text { Proficiência }\end{array}$ & - & - & 1 & - & - & - & - & - & - & - & 1 \\
\hline $\begin{array}{l}\text { Grupo de } \\
\text { Estudo }\end{array}$ & - & - & - & 1 & - & - & - & - & - & - & 1 \\
\hline Mídia & - & - & 1 & - & - & 1 & - & - & - & - & 2 \\
\hline Indefinido & - & - & 2 & 5 & 3 & 2 & - & 1 & 3 & 7 & 23 \\
\hline
\end{tabular}

Fonte: Banco de Teses da CAPES.

Ficou evidenciado na tabela anterior que a Educação Básica foi o nível de ensino mais recorrente nos resumos coletados. Passamos, então, ao detalhamento de como esse contexto de pesquisa foi citado:

- 96 resumos anunciaram tratar do Ensino Fundamental (I e II);

- 49 resumos referiram-se ao Ensino Básico, sem especificar uma etapa, fosse o Fundamental, o Médio ou outra; 
- 38 resumos fizeram referência ao Ensino Médio;

- 15 resumos citaram a Educação Profissional Técnica de Nível Médio;

- 12 resumos mencionaram a Educação de Jovens e Adultos;

- 11 resumos compilaram dados tanto do Ensino Fundamental quanto do Ensino Médio;

- 05 resumos delimitaram o contexto escolar bilíngue.

É válido explicar que, em relação aos resumos que selecionaram a Educação Básica como contexto de pesquisa, boa parte deles especificou algum nível de ensino, tanto o Fundamental ou o Médio, ou uma modalidade de ensino como a Educação de Jovens e Adultos. Contudo, em 49 resumos, não houve esta especificação, pois a referência foi feita à escola brasileira contemporânea de modo geral, aos documentos que regem a Educação Básica, como a atual Lei de Diretrizes e Bases da Educação Nacional e os Parâmetros Curriculares Nacionais, ou ainda aos livros didáticos que circulam nesse nível de escolaridade.

Esclarecemos ainda que, no que tange à Educação Profissional Técnica de Nível Médio, foram citadas escolas técnicas como o Centro Federal de Educação Tecnológica de Mato Grosso (CEFET-MT), a Escola Agrotécnica Federal de São João Evangelista (EAFSJEMG), dentre outras mencionadas nos resumos coletados. Quanto ao "contexto escolar bilíngue", foram feitas referências à educação escolar de crianças de língua materna que não o português, tais como línguas indígenas ou o francês, e que aprendem a Língua Portuguesa na rede de ensino brasileira. Também se apresentou abordagem bilinguista do ensino da Língua de Sinais.

Observou-se que o Ensino Fundamental foi o nível de escolarização mais mencionado nos resumos, seguido por aqueles trabalhos que se referiram ao ensino básico de modo geral e também por aqueles que concentraram suas discussões no Ensino Médio.

Reiteramos que todos os cálculos e as demais avaliações e reflexões que apresentamos, neste primeiro capítulo, foram construídos a partir da análise dos 321 resumos de dissertações de mestrado sobre ensino de Língua Portuguesa, localizados no Banco de Teses da CAPES. Esses resumos foram analisados quantitativamente. Nesta análise, buscamos apreender o que, no cenário pesquisado, demonstrava-se numericamente mais ou menos recorrente. 
A partir de tal avaliação, conseguimos fazer algumas reflexões sobre em que regiões e Estados brasileiros e em que anos a produção analisada mostrou-se mais presente. Pudemos também refletir sobre as esferas administrativas das IES às quais se vinculam as dissertações de que localizamos os resumos, dentre as demais questões que tratamos no presente capítulo. Ocorre que, para que se efetivasse uma análise aprofundada, de caráter qualitativo, dos trabalhos de mestrado em xeque, foi imprescindível o recorte do material que coletamos, conforme discutiremos no próximo capítulo.

Como explicitado anteriormente, corroboramos que, no tratamento quantitativo dos resumos, não houve o propósito de verificar se todos eles efetivamente tratavam do ensino de Língua Portuguesa ou se, por vezes, somente tangenciavam esta temática, que, por sua vez, poderia ficar encoberta por outras discussões, tais como o estudo de textos publicitários, de programas televisivos, dentre outras. Isso ocorre quando alguns resumos, apesar de anunciarem ter como foco de pesquisa o ensino de português, deixam de revelar que, na verdade, ele é tratado de modo secundário diante de outras questões que aparecem como predominantes.

Esse tipo de detalhamento analítico não foi possível no total dos 321 resumos coletados, por isso constituímos um corpus para análises aprofundadas, mediante a leitura não só dos resumos, mas também do texto integral das dissertações. Para a elaboração desse corpus, um dos aspectos importantes foi a existência da versão eletrônica dos trabalhos sob enfoque, haja vista que a sua disponibilidade on-line propiciou, no decorrer desta pesquisa, o fácil acesso aos textos escritos e o seu amplo manuseio. Sobre a disponibilidade virtual das dissertações, encontramos a realidade exposta na tabela a seguir:

Tabela 6 - Disponibilidade on-line das dissertações

\begin{tabular}{cccccccccccc}
\hline $\begin{array}{l}\text { Disponível } \\
\text { on-line }\end{array}$ & $\mathbf{2 0 0 1}$ & $\mathbf{2 0 0 2}$ & $\mathbf{2 0 0 3}$ & $\mathbf{2 0 0 4}$ & $\mathbf{2 0 0 5}$ & $\mathbf{2 0 0 6}$ & $\mathbf{2 0 0 7}$ & $\mathbf{2 0 0 8}$ & $\mathbf{2 0 0 9}$ & $\mathbf{2 0 1 0}$ & Total \\
& & & & & & & & & & & \\
\hline Não & 11 & 13 & 12 & 19 & 24 & 14 & 14 & 04 & 15 & 11 & 137 \\
Sim & 04 & 03 & 09 & 05 & 07 & 22 & 27 & 40 & 37 & 30 & 184 \\
& & & & & & & & & & & \\
& & & & & & & & & & & \\
\hline
\end{tabular}


Nesta tabela, observa-se claramente como no decorrer da década em estudo houve um rápido e constante crescimento na disponibilização das versões eletrônicas das dissertações. Verifica-se que, nos primeiros anos, os números apresentados na primeira linha da tabela referente à indisponibilidade on-line das dissertações - eram sempre maiores do que aquilo que aparecia na segunda linha - relacionada à disponibilização virtual do material. A partir do ano 2006, esta realidade inverteu-se, como ficou demonstrado na tabela anterior.

A dinamização da divulgação on-line dos trabalhos de pesquisa de mestrado sob análise, em especial a partir de meados da primeira década do século XXI, interferiu diretamente nos procedimentos que adotamos, nesta pesquisa, para coleta, armazenamento e tratamento dos dados, conforme detalharemos no próximo capítulo. 


\section{COMPOSIÇÃO DO CORPUS}

No capítulo anterior, demonstramos como foi feita a coleta de dissertações de mestrado sobre ensino de Língua Portuguesa. Destacamos que, na etapa de coleta do material, localizamos 321 resumos, a partir dos quais pudemos empreender reflexões sobre características quantitativas da pesquisa de mestrado em ensino de Língua Portuguesa. Como resultados, apresentamos dados referentes aos anos de publicação das dissertações sob enfoque, os seus vínculos administrativos, sua configuração por região e Estado brasileiros, dentre outros mapeamentos e discussões que expusemos no decorrer do capítulo 1.

A leitura e a análise dos resumos não favoreceram, contudo, o detalhamento sobre os modos como o ensino de Língua Portuguesa foi efetivamente tratado no interior das dissertações, quanto à sua configuração discursiva em termos de recorrências. Para que pudéssemos compreender como o discurso sobre ensino de Língua Portuguesa comparecia em pesquisas de mestrado, tivemos que incidir de modo a recortar uma quantidade de dissertações que tornasse possível a sua leitura integral, sem que esse recorte deixasse de ser representativo da produção nacional focalizada, na década analisada.

Considerando o exposto, abordaremos, no que segue, os procedimentos adotados em três seções, quais sejam: a) critérios para seleção das dissertações consideradas no nosso corpus; b) composição do corpus pela análise da argumentação; e c) distinções entre "coleta de dados" e "composição do corpus". Como indicam os títulos destas seções, passaremos a explicar as regras estabelecidas para manutenção de algumas dissertações e não de outras no centro da presente pesquisa. Depois disso, trataremos de apresentar os resultados da análise que efetivamos em algumas dissertações de mestrado, em relação às quais pontuamos quais foram os "fatos" e as "verdades", de acordo com os preceitos da nova retórica, que pareciam mais presentes na argumentação das produções em questão. Por fim, propomos uma reflexão sobre como, nesta tese, foram considerados o processo de "coleta de dados" e de "composição do corpus". 


\subsection{Critérios para seleção das dissertações consideradas no nosso corpus}

A partir das análises quantitativas dos 321 resumos coletados, expostas anteriormente, tivemos condições de estabelecer critérios para elencar o rol de trabalhos com os quais lidaremos deste ponto em diante.

No processo de seleção das dissertações a serem contempladas no corpus, o primeiro critério adotado foi restringir nossa pesquisa às dissertações de mestrado disponíveis on$\operatorname{line}^{10}$. A motivação para esta escolha deu-se por causa de dois fatores principais. O primeiro foi a facilidade de localização das dissertações que, uma vez identificadas, podiam ser armazenadas em notebooks, pen-drives e outros dispositivos de fácil portabilidade e manuseio.

Relacionado ao primeiro fator apontado, o segundo motivo fundamental para a escolha que fizemos, que se tornou essencial para o desenvolvimento desta tese, foi o acesso irrestrito às versões eletrônicas das dissertações, sobre as quais efetivamos a leitura e a análise de trechos selecionados que eram, por sua vez, transportados para outro documento do software Word. Adotamos esse último expediente porque ele foi um facilitador para a construção do texto final do nosso corpus.

Desse modo, fizemos o primeiro recorte do material, que resultou na manutenção de 184 dissertações disponíveis on-line. A Tabela 6, apresentada no capítulo anterior, demonstra a proporção entre produções que disponibilizaram suas versões eletrônicas e as que não as tornaram públicas virtualmente.

O segundo recorte resultou na seleção das dissertações de mestrado vinculadas a universidades públicas estaduais e federais. Esta opção explica-se pelo fato de que, caso tivéssemos optado por voltar nossa pesquisa às dissertações de IES particulares e municipais, não abarcaríamos nenhuma produção defendida em universidades da região Norte, por exemplo, e, mais que isso, concentraríamos nossa investigação nos Estados do Sudeste e do Sul, conforme pode ser observado na relação vínculo administrativo das IES por Estado brasileiro, exposta na Tabela 2, do capítulo 1, e das discussões que lhe foram decorrentes.

\footnotetext{
${ }^{10}$ Foram consideradas unicamente as dissertações que disponibilizavam na Internet sua versão eletrônica e que permitiam o acesso irrestrito ao texto gravado em Portable Document Format (PDF).
} 
Escolhendo constituir o corpus a partir de dissertações defendidas em IES públicas estaduais e federais, nós mantivemos produções publicadas em quase toda a década analisada, com exceção do ano 2005, e defendidas em instituições das cinco regiões brasileiras, havendo representatividade equilibrada entre elas, com exceção da região Sul do país, que, quantitativamente, compareceu mais, como pode ser observado no apêndice B. Nesse apêndice, denominado "Dissertações mantidas no corpus", informamos o vínculo administrativo e a localização de cada uma das IES em que as produções em questão foram defendidas, bem como outras informações pertinentes.

Continuamos, no que segue, a tratar dos critérios que utilizamos para a seleção das produções focalizadas no restante desta tese. Os dois últimos recortes empreendidos foram os de restringir nossas análises qualitativas aos trabalhos que não mobilizassem dados da Educação Especial e que focalizassem, unicamente, o Ensino Fundamental da Educação Básica.

A escolha por delimitar a presente pesquisa às dissertações voltadas para o Ensino Fundamental da Educação Básica justifica-se a partir dos dados expostos na Tabela 5 do capítulo 1. A tabela demonstrou que o nível de ensino mais pesquisado foi a Educação Básica e, nesse nível de ensino, conforme tratado anteriormente, o contexto de pesquisa mais recorrente foi o Ensino Fundamental. Levando em conta a grande representatividade das produções sobre esta etapa de ensino na pesquisa de mestrado em ensino de Língua Portuguesa, optamos por restringir nossa reflexão às dissertações sobre esse nível de ensino da educação escolar. Escolhemos, ainda, não trabalhar com as dissertações que mobilizassem dados da Educação Especial porque isso traria linhas investigativas próprias a esta abordagem, as quais não estariam, necessariamente, relacionadas ao ensino de língua em si.

Com esses procedimentos, chegamos a um corpus constituído a partir de 18 dissertações de mestrado. Os sucessivos recortes implicaram que, dos 321 resumos localizados, foram consideradas, inicialmente, somente as 96 dissertações que tinham como contexto de pesquisa o Ensino Fundamental da Educação Básica. Desses 96 trabalhos, foram mantidos somente aqueles defendidos em IES públicas estaduais ou federais, que não tomavam como foco de investigação dados da Educação Especial e dos quais tivessem sido publicadas suas versões eletrônicas.

Passamos, então, a apresentar e discutir as dissertações mantidas no corpus a partir da próxima seção, intitulada "composição do corpus pela análise da argumentação". Posteriormente, debateremos, na última seção deste capítulo, as diferenças entre "coleta de 
dados" e "composição do corpus", uma vez que, como se verificou quanto às opções que justificamos para a sua composição, fez-se necessário diminuir o montante de dissertações sob análise. Esta diminuição viabilizou a leitura integral desses trabalhos, o que, de um lado, favoreceu o aprofundamento dos resultados almejados, mas, de outro, não possibilitou o detalhamento de todas as nuances que constitui a diversidade característica da realidade em questão.

\subsection{Composição do corpus pela análise da argumentação}

No apêndice B, já citado, expusemos os dados de publicação das dissertações que passaremos a discutir. Nele, também informamos os códigos de referência a cada um dos trabalhos focalizados. Esses códigos unem as iniciais "E" ou "F", relativos, respectivamente, às esferas administrativas "Estadual" ou "Federal" das IES, à sigla do Estado brasileiro e ao ano de publicação do trabalho. Citamos como exemplo, "ESP01" e "FSC03". O primeiro alude à dissertação defendida, em 2001, em IES Estadual de São Paulo e o segundo à dissertação defendida, em 2003, em IES Federal de Santa Catarina.

Esclarecemos que, no processo de composição do corpus, voltamo-nos para a análise da argumentação presente em cada uma das dissertações, às quais vamos nos referir pelos códigos anteriormente elucidados.

Para esta análise, fundamentamo-nos no Tratado da argumentação: a nova retórica. (PERELMAN; OLBRECHTS-TYTECA, 2002) Nesta obra, os autores apresentam sua teoria geral da argumentação, dividindo-a em três partes, são elas: "os âmbitos da argumentação", "o ponto de partida da argumentação" e "as técnicas argumentativas". Antes de iniciar o tratado propriamente dito, ainda na introdução da obra, os autores esclarecem o subtítulo "a nova retórica”, ratificando sua filiação à herança helênica, especificamente às referências aristotélicas sobre argumentação.

Herdeiro da retórica e da dialética, o tratado defende e sistematiza a argumentação do ponto de vista de sua racionalidade. As duas obras aristotélicas fundamentais para a 
constituição do Tratado da Argumentação, conforme expõem os seus próprios autores, foram Tópicos e Retórica.

Tópicos, quinto capítulo da obra Órganon, é definido por Aristóteles como um tratado que objetiva:

[...] descobrir um método que nos capacite a raciocinar, a partir de opiniões de aceitação geral, acerca de qualquer problema que se apresente diante de nós e nos habilite, na sustentação de um argumento, a nos esquivar da enunciação de qualquer coisa que o contrarie. (ARISTÓTELES, 2010, p. 348)

Na discussão desse método, na obra em questão, ganham relevo os silogismos, definidos como discursos argumentativos compostos de determinadas formulações das quais, imprescindivelmente, outra lhe é resultante. Ou seja, esta compreensão de silogismo implica o fato de uma asserção qualquer envolver outras asserções que lhe são relacionadas. Por exemplo, a afirmação "isto é um homem" implica, por exemplo, a concordância mútua de que “isto é um animal, um ser animado, um bípede e um ser capaz de razão e de conhecimento". (ARISTÓTELES, 2010, p. 382)

É, pois, na racionalidade silogística, advinda da plausibilidade dos argumentos defendidos, que $O$ Tratado da Argumentação alicerça-se. Alicerce que, por si só, aponta para a vinculação entre esse tratado e a dialética, que é, por sua vez, caracterizada por Aristóteles (2011, p. 44) como a arte responsável pelo discernimento entre os silogismos que seriam reais e aqueles que seriam aparentes.

Contudo, observamos que, no tratado de Perelman e Olbrechts-Tyteca, o subtítulo é "a nova retórica" e não "a nova dialética". Os autores justificam esta escolha afirmando que, apesar de analisarem aquilo que, em Tópicos, foi categorizado como pertencente à dialética, eles preteriram esta terminologia, principalmente porque ela, desde a antiguidade, não foi suficientemente relacionada aos diferentes graus de intensidade com que uma mesma opinião poderia ser aceita por seus ouvintes. (PERELMAN; OLBRECHTS-TYTECA, 2002, p. 5-6)

A partir desta justificativa, os autores revelam um aspecto central de sua teoria, ao defenderem que "é em função de um auditório que qualquer argumentação se desenvolve", ou 
seja, a argumentação aparece como estando diretamente relacionada ao grau de adesão que provoca nas pessoas. O "auditório", por sua vez, é definido como o grupo constituído por todos aqueles que o orador quer convencer ou persuadir com a sua argumentação. (PERELMAN; OLBRECHTS-TYTECA, 2002, p. 6; 22)

Em relação a esta noção de "auditório", percebemos a menção tanto à intenção de "convencer" quanto a de "persuadir". A persuasão é caracterizada pela tentativa de influenciar o auditório em questão, a fim de levá-lo a uma dada ação. Enquanto o único objetivo de se tentar convencer alguém seria o de provocar nele a adesão racional à argumentação que lhe é proposta. Independentemente da intenção de "persuadir" ou "convencer", no quadro da nova retórica, é, de antemão, sancionado positivamente o ato de alguém se colocar na posição de querer colocar sua palavra à prova diante de seus interlocutores, pois isso sinaliza uma postura de respeito à aprovação alheia e a ciência de que a sua palavra não se constitui como verdade absoluta. (PERELMAN; OLBRECHTS-TYTECA, 2002, p. 19; 30)

O entendimento de que a própria opinião pode ser rejeitada e, por isso, deve tornar-se motivo de argumentação, a fim de que ela seja aderida por seu auditório, está intrinsecamente relacionada, desde a antiguidade, à arte retórica. Daí porque, no subtítulo do Tratado da Argumentação, não comparece a noção de "dialética", mas a de "retórica". Segundo Aristóteles (2011, p. 44-5):

Pode-se definir a retórica como a faculdade de observar, em cada caso, o que este encerra de próprio para criar a persuasão. Nenhuma outra arte possui tal função. Toda outra arte pode instruir e persuadir acerca do assunto que lhe é próprio, por exemplo: a medicina, sobre o que é saudável e doentio; a geometria, acerca das propriedades das grandezas; a aritmética, a respeito dos números; o mesmo aplicando-se às outras artes e ciências. Quanto à retórica, todavia, vemo-la como o poder, diante de quase qualquer questão que nos é apresentada, de observar e descobrir o que é adequado para persuadir. E esta é a razão por que a retórica não aplica suas regras a nenhum gênero particular e definido.

Observa-se aí o destaque dado à ideia de persuasão no que tange à retórica, caracterizada como a arte segundo a qual se verifica a adequabilidade daquilo em relação ao 
que se pretende alcançar a aceitação alheia. Tal observação também foi feita quanto à teoria da argumentação da nova retórica, conforme expusemos anteriormente.

O reconhecimento da variabilidade da adesão do auditório, aos argumentos propostos, vai de encontro ao conceito de racionalidade cartesiana. No Discurso sobre o método, Descartes (2006) expõe sua proposta de busca pela verdade e formaliza, para tanto, algumas máximas, derivadas das contribuições de algumas ciências classificadas como adequadas para isso, são elas: a lógica e as matemáticas, especificamente a geometria analítica e a álgebra.

Nas proposições cartesianas, ganha relevo, inicialmente, a importância da lógica para o seu projeto de investigação da verdade. Dos princípios próprios desta ciência, decorre como primeiro preceito do seu método, o que segue:

[...] nunca aceitar como verdadeira nenhuma coisa que eu não conhecesse evidentemente como tal, isto é, em evitar, com todo o cuidado, a precipitação e a precaução, só incluindo nos meus juízos o que se apresentasse de modo tão claro e distinto à minha mente que não houvesse nenhuma razão para duvidar [....]. (DESCARTES, 2006, p. 28)

Enfatizando a evidência como fundamental para os procedimentos que adota, o autor refere-se ainda à matemática, como se pode observar:

[...] entre todos os que, antes de mim, procuraram a verdade nas ciências, apenas os matemáticos puderam achar algumas demonstrações, isto é, algumas razões certas e evidentes [...].(DESCARTES, 2006, p. 29)

Claro está que a teoria da argumentação coloca-se na contramão da concepção de racionalidade cartesiana, pois identifica no debate argumentativo meios para se chegar à verdade pelo grau de adesão do auditório ao que lhe está sendo proposto. Sobre isso, tem-se o que segue: 
A publicação de um tratado consagrado à argumentação e sua vinculação a uma velha tradição, a da retórica e da dialética gregas, constituem uma ruptura com uma concepção da razão e do raciocínio, oriunda de Descartes, que marcou com seu cunho a filosofia ocidental dos três últimos séculos. (PERELMAN; OLBRECHTS-TYTECA, 2002, p. 1) (grifos dos autores)

Para compreensão da concepção de racionalidade inerente à nova retórica, é necessário reconhecer a importância que têm a verossimilhança e a plausibilidade na argumentação que quer convencer o seu auditório, sendo esta última noção, de "auditório", essencial para a concepção de argumentação focalizada até aqui, como anteriormente abordamos.

Esta noção de "auditório" pode ser apreendida a partir da distinção entre "convencer" e "persuadir", conforme discussão prévia. Na teoria da argumentação, em consonância com o que viemos apresentando, aqueles que assumem o lugar de interlocutor podem preencher diferentes padrões de rigor na avaliação do que lhe é argumentado. Isso ressalta "[...] que por melhor que seja a argumentação e suas escolhas, ela não pretende ser a manifestação da verdade mas do provável, do crível, cabendo à comunidade [...] decidir a esse respeito". (MOSCA, 2001, p. 42) (grifos da autora)

Na caracterização do que seja persuasivo e convincente, Perelman e Olbrechts-Tyteca (2002, p. 31) indicam o que segue:

Propomo-nos chamar persuasiva a uma argumentação que pretende valer só para um auditório particular e chamar convincente àquela que deveria obter a adesão de todo ser racional. O matiz é bastante delicado e dependente, essencialmente, da ideia que o orador faz da encarnação da razão. Cada homem crê num conjunto de fatos, de verdades, que todo homem 'normal' deve, segundo ele, aceitar, porque são válidos para todo ser racional. Mas será realmente assim? Essa pretensão a uma validade absoluta para qualquer auditório composto de seres racionais não será exorbitante? Mesmo o autor mais consciencioso tem, nesse ponto, de submeter-se à prova dos fatos, ao juízo de seus leitores. [...] (grifos dos autores)

$\mathrm{Na}$ citação anterior, aborda-se uma nomenclatura bastante presente no tratado em questão, que diz respeito à diferença entre "auditório universal" e "auditório particular". 
Nesse contexto, a adesão "universal" do auditório refere-se à irrefutabilidade de certos argumentos que poderiam ser válidos para todas as pessoas dotadas de capacidades intelectuais consideradas normais. Enquanto "auditório particular" faz referência a certas comunidades, partidárias de referencial específico e de certos paradigmas e que, a partir das convenções que lhe são próprias, julgam sobre a validade ou não da argumentação proposta.

Todo o Tratado da Argumentação desenvolve-se em torno desses aspectos centrais, que rompem com a racionalidade cartesiana e assumem como ponto fulcral a adesão do auditório à argumentação proposta, que, idealmente, poderia ser validada pelo "auditório universal", ou seja, por todos os seres racionais.

É compreensível que a concepção de "auditório universal" remeta à ideia de que quanto mais os argumentos demonstram ser eficientes no poder de convencimento e de persuasão, mais eles se aproximam da completa adesão. Esta universalidade volta-se, no tratado, ao desafio permanente que se coloca a toda argumentação, não de modo que o seu alcance possa ser efetivamente calculado, mas no sentido de tornar-se cada vez mais rigorosa, conforme se depreende da citação anterior.

O tema do "auditório" é, especialmente, apresentado e discutido na primeira parte do Tratado da Argumentação, intitulada "Os âmbitos da argumentação". A segunda parte, "O ponto de partida da argumentação", como prenuncia o seu título, irá tratar, principalmente, das premissas que, de início, são presumidas como aceitáveis pelo auditório ao qual o orador tem em mente dirigir-se. Vale ressaltar que o termo "orador" advém da retórica antiga e é assim mantida na nova retórica, ainda que esta última ultrapasse a discussão de textos orais, pois também tem como alvo, em boa medida, os textos escritos. Observação igual é válida para o termo "ouvinte".

Ainda na segunda parte do tratado, ganha relevo a reflexão sobre como os dados são expostos durante a argumentação, o que implica dimensionar as formas do discurso pelas quais eles são apresentados, a interpretação sobre eles que é predominante e também os meios pelos quais se torna possível despertar a consciência dos ouvintes para determinados dados que se deseja ressaltar.

Por fim, na última parte do tratado, intitulada "As técnicas argumentativas", terão foco os processos de ligação e de dissociação de premissas, o primeiro voltado para a argumentação com vistas à união de elementos que, inicialmente, não formavam um todo e, o segundo, com enfoque na separação de elementos que são contrapostos. 
Para se entender o que é proposto na última parte de Argumentação, um exemplo é a análise de premissas que relacionam pessoa e ato. Nesse procedimento de associação, ilustrase o tipo de convencimento ou persuasão que se busca por meio da comprovação de que os atos anteriores e a boa reputação de uma pessoa são elementos que poderiam colaborar para a sua defesa pessoal. Já no que se refere à dissociação de premissas, destacam-se quanto ao par "aparência-realidade", por exemplo, as incompatibilidades entre as características dos dois termos em questão. (PERELMAN; OLBRECHTS-TYTECA, 2002)

$\mathrm{Na}$ análise que propusemos da argumentação defendida nas dissertações, voltamo-nos para as premissas e para as interpretações decorrentes dos dados que se mostraram mais presentes no corpo dos trabalhos. A partir desta análise, compusemos o corpus sobre o qual, em um momento posterior, debruçamo-nos em busca de recorrências caracterizadoras de aspectos da pesquisa de mestrado em ensino de Língua Portuguesa. Na próxima seção, elucidamos outros elementos acerca da análise que efetivamos no material em estudo.

\subsubsection{Objetos de acordo e sua interpretação}

Para a análise da argumentação das dissertações de mestrado selecionadas a partir dos critérios anteriormente tratados, consideramos, inicialmente, as abordagens propostas, na segunda parte do Tratado da Argumentação, quanto à "interpretação dos dados". Compreende-se que, na argumentação, o orador demonstra sua preferência a uma dada interpretação, segundo a qual revela o seu "sistema particular de crenças ou até de concepção do mundo" (PERELMAN; OLBRECHTS-TYTECA, 2002, p. 139), sendo que:

[...] diversas interpretações nem sempre são incompatíveis, mas o destaque de uma delas, o lugar que ela ocupa no primeiro plano da consciência, amiúde recua as outras para a sombra. $\mathrm{O}$ essencial de grande número de argumentações resulta desse jogo de inumeráveis interpretações e da luta para impor algumas delas, suprimir outras. (PERELMAN; OLBRECHTSTYTECA, 2002, p. 138) 
Em nossa análise, avaliamos as interpretações que eram elevadas a um lugar de destaque, caracterizadas como as mais adequadas ou as únicas possíveis em relação aos dados em questão. Metodologicamente, examinamos as interpretações tal como elas eram defendidas nos capítulos finais, que apareceram com os seguintes títulos em 16 das 18 dissertações mantidas para a composição do corpus: "Conclusão", "Conclusões" ou "Considerações finais". Em duas dissertações apareceram títulos diferenciados, quais sejam: "O que estamos construindo? Algumas considerações finais, mas não conclusivas, sobre o caminho percorrido" e "Considerações finais: por uma pedagogia da informática".

Depois da análise desses capítulos finais, passamos à análise do corpo dos trabalhos, mapeando os dados apresentados, sobre os quais pareciam sustentar-se as interpretações defendidas. Para a análise da argumentação dos capítulos anteriores aos finais, mobilizamos duas outras noções presentes no Tratado da Argumentação, que foram as de "objetos de acordo" e de "presença".

Os "objetos de acordo" são caracterizados como premissas nas quais o orador apóia sua argumentação, por crer que elas serão, de antemão, aceitas como se constituindo enquanto fatos, verdades, presunções ou valores válidos. O comum acordo, então presumido, participará da argumentação sustentando: a) certos dados como os que devem ser aceitos enquanto "fatos"; b) algumas teorias e concepções como representantes do que sejam "verdades", c) algumas "presunções", como aquelas ligadas ao que se poderá considerar como sendo o normal para aquele grupo; d) determinados "valores", quanto às concepções de belo e bom, dentre vários outros; e) certas "hierarquias", voltadas a temas concretos ou abstratos, como, por exemplo, à comparação entre homens e animais ou entre valores como "útil" e "justo", a fim de se depreender, dentre eles, o que seria superior em uma escala avaliativa bem aceita na comunidade em questão; e f) alguns "lugares", correspondentes a temáticas em relação às quais os argumentos são organizados, dentre os quais aparecem, por exemplo, os "lugares de quantidade", "de qualidade", dentre outros. (PERELMAN; OLBRECHTSTYTECA, 2002)

No exercício de depreendermos esses "objetos de acordo", do texto das dissertações, valemo-nos também da noção de "presença". Ela aparece intrinsecamente relacionada àquilo que o orador seleciona para expor, ou não, aos seus ouvintes. Isso significa que a escolha de 
certos elementos para serem apresentados ao auditório constitui-se como um dos aspectos essenciais na argumentação, pois os dados mais presentes e os diferentes modos como esta "presença" é construída influenciam sobre aquilo que será alvo de atenção no interior do texto em foco.

Os objetos de acordo destacados, nas dissertações em análise, corresponderam aos dados que fundamentaram a argumentação proposta e sobre os quais as interpretações, extraídas dos capítulos finais, conforme tratado anteriormente, detiveram-se. Em relação a esses objetos, afirma-se:

Os acordos de que dispõe o orador, nos quais pode apoiar-se para argumentar, constituem um dado, mas tão amplo e suscetível de ser utilizado de modos tão diversos, que a maneira de prevalecer-se dele apresenta uma importância capital. (PERELMAN; OLBRECHTS-TYTECA, 2002, p. 131)

Considerando as noções anteriormente abordadas, passamos à análise da argumentação das dissertações, apresentando suas interpretações e os dados com "presença" destacada no corpo desses trabalhos. Todas as referências às dissertações serão feitas por meio dos códigos anteriormente explicados e que podem ser revistos no apêndice B desta tese.

\subsubsection{Abordagem argumentativa das dissertações de mestrado}

Como abordado, os "objetos de acordo" são definidos, na nova retórica, como os dados apresentados pelo orador e que detêm, presumidamente, a adesão de seu auditório. Decorrem desses dados, as interpretações em relação às quais o orador argumenta a favor. Considerando-se o âmbito de desenvolvimento e de publicação das dissertações de mestrado, identificamos como auditório almejado, em primeira instância, os professores responsáveis pela orientação dos trabalhos e também aqueles que comporão as bancas de arguição. Em 
segunda instância, entende-se que esse auditório compõe-se de pesquisadores, professores e demais interessados no tema explorado pelos trabalhos em questão.

Observamos que esse auditório caracteriza-se, inicialmente, pela especificidade de formação daqueles que lerão e avaliarão o trabalho. Esta particularidade transparece nas dissertações na defesa de determinadas interpretações e também no uso de terminologias, conceitos e referências que se julga serem compartilhados pelos profissionais e estudiosos da área de conhecimento em foco.

A análise global da argumentação presente nas dissertações resultou no levantamento das informações apresentadas no quadro a seguir:

QUADRO A: Abordagem argumentativa das dissertações

\section{Código de}

referência às

Enfoque argumentativo das dissertações

dissertações

A dissertação defendida no ano de 2001, em uma universidade paulista estadual, referida na presente tese por ESP01, defende a

ESP01 incorporação de recursos computacionais no ensino. O enfoque volta-se para a discussão de um ambiente virtual para criação e edição de histórias em quadrinhos. Esse ambiente, denominado "HagáQuê", destina-se a alunos do $1^{\circ}$ e $2^{\circ}$ ciclos do Ensino Fundamental.

EPR02, como é mencionada, nesta tese, a dissertação defendida

EPR02 em uma universidade estadual paranaense, em 2002, investigou como a produção textual foi trabalhada pela professora observada em séries do segundo ciclo do Ensino Fundamental de uma escola pública de Guarapuava/PR.

FSC03 Denominamos, na presente tese, a dissertação defendida em 2003 em uma IES federal de Santa Catarina como FSC03. Nela, relatou-se uma intervenção colaborativa em uma quinta série do 
Colégio de Aplicação da Universidade Federal de Santa Catarina.

$\mathrm{O}$ foco foi a investigação sobre o processo de produção escrita de gêneros do discurso.

A investigação de interações orais no ensino de Língua Portuguesa, depois do surgimento dos Parâmetros Curriculares Nacionais, é focalizada pela dissertação referida por EPR04, defendida em uma IES estadual paranaense, em 2004. Para tanto, a EPR04 pesquisadora observou e gravou vinte aulas em duas turmas de quinta série do Ensino Fundamental, tanto em escola pública quanto em particular. Também foram inseridos no material de análise os planejamentos anuais das turmas em questão, os quais, segundo proposta de pesquisa, foram confrontados com as orientações dos Parâmetros Curriculares Nacionais.

EPR06, como é mencionada, nesta tese, a dissertação defendida em uma universidade estadual do Estado do Paraná, em 2006, propôs discutir a Sala de Apoio à Aprendizagem em Língua EPR06 Portuguesa (SAALP), programa implantado em algumas escolas estaduais de Maringá/PR para atender alunos de quinta série da rede pública, identificados como tendo dificuldades na leitura e na escrita. A proposta de análise voltou-se para os resultados obtidos, em 2004, pelos alunos inseridos nesse programa.

A dissertação defendida no ano de 2006, em uma universidade FMT06a federal do Mato Grosso, referida na presente tese por FMT06a, pesquisou aspectos do ensino da produção textual escrita em turmas de quarta série de uma escola cuiabana, na última década do século XX.

A investigação focalizada pela dissertação referida por FMT06b, FMT06b defendida em uma IES federal do Mato Grosso, em 2006, definese como "pesquisa-ação", executada em 80 horas-aula, na Escola Estadual "José Moraes", localizada no município de Rondonópolis/MT. Esta pesquisa propôs trabalhar a produção 
escrita por meio de atividades que contemplavam cartas do leitor, veiculadas nas revistas "Guia Astral", "Veja" e no jornal "A Tribuna".

Denominamos, na presente tese, a dissertação defendida, em 2007, em uma IES estadual paranaense como EPR07. Nela, EPR07 problematizaram-se a categoria de gênero gramatical e o modo como ela é ensinada em aulas de Língua Portuguesa, no decorrer do Ensino Fundamental. A discussão centralizou-se na influência exercida pela distinção entre sexo feminino e masculino nesse ensino.

ESP07, como é mencionada, nesta tese, a dissertação defendida em uma universidade estadual paulista, em 2007, propõe analisar

ESP07 livros didáticos da sétima série do Ensino Fundamental. O propósito é averiguar como esses materiais trabalham com textos, avaliando como se dá esse trabalho pelo prisma conceptual dos gêneros do discurso.

A dissertação defendida, no ano de 2007, em uma universidade federal do Mato Grosso, referida na presente tese por FMT07, FMT07 focaliza sua análise em livros didáticos de Língua Portuguesa, especialmente, de quinta série, a fim de verificar quais foram veiculados e usados por professores de Mato Grosso, entre 1970 e 2000. Nela, defende-se o livro didático pelo seu valor documental.

FPA07, como é mencionada, nesta tese, a dissertação defendida em uma universidade federal do Estado do Pará, em 2002, investigou os critérios adotados na seleção de livros didáticos de FPA07 Língua Portuguesa e como esses livros eram constituídos e usados em sala de aula. O âmbito considerado pela pesquisa foi de seis escolas públicas da cidade de Belém, propondo discutir a relação entre professor e livro didático da quarta série do Ensino Fundamental. 
Denominamos, na presente tese, a dissertação defendida em 2007 em uma IES federal da Paraíba como FPB07. Nela, relatou-se pesquisa desenvolvida no Ensino Fundamental, por meio de

FPB07 observação de aulas de Língua Portuguesa em uma escola pública da cidade de Campina Grande/PB. A proposta foi verificar o ensino de leitura em duas turmas, especificamente, uma de sétima série e outra de oitava.

A formação de professores, com base nos Parâmetros Curriculares Nacionais de Língua Portuguesa, é focalizada na dissertação referida, na presente tese, por EPA08, defendida em

EPA08 uma IES estadual do Pará, em 2008. Integraram a pesquisa, da dissertação em questão, professoras que participaram desta formação nos anos de 2001 e 2002. Tratou-se de docentes que ministravam aulas de Língua Portuguesa de quinta à oitava série do Ensino Fundamental, em uma escola pública de Oriximá/PA.

A dissertação defendida no ano de 2008, em uma universidade paulista estadual, referida na presente tese por ESP08, discutiu a formação do leitor a partir de um experimento desenvolvido com professores da rede pública estadual de São Paulo. Esses docentes ESP08 atuavam no Projeto denominado "Hora da Leitura", que, segundo a dissertação em foco, ocorria em aulas semanais dedicadas à leitura de textos literários para alunos do Ensino Fundamental. O experimento citado focalizou jogos improvisacionais no trabalho de formação docente.

FPB08a, como é mencionada, nesta tese, a dissertação defendida FPB08a em uma universidade federal paraibana, em 2008, propôs investigar como livros didáticos de português têm tratado a oralidade, contrastando-os com as diretrizes dos Parâmetros Curriculares Nacionais de Língua Portuguesa.

FPB08b Referimo-nos, como FPB08b, à dissertação defendida em 2008 em uma IES federal da Paraíba que relatou e discutiu uma 
pesquisa experimental. Conforme afirmado pela dissertação em questão, buscou-se comprovar a eficácia de um objeto digital para o ensino de conceitos de gramática para alunos do sétimo ano do Ensino Fundamental.

A discussão sobre a produção de vídeo digital com criação de roteiro pelos alunos, em sala de aula e com auxílio docente, foi

ESP09 focalizada pela dissertação referida por ESP09, defendida em uma IES estadual paulista, em 2009. Para tanto, propôs-se um estudo de caso em turmas de terceira e quarta série, de uma escola municipal de Campinas.

A dissertação defendida no ano de 2010, em uma universidade FRS10 federal do Rio Grande do Sul, referida, na presente tese, por FRS10, expõe como objetivos a descrição e a análise de elementos de coesão referencial em 48 textos de alunos de sexto ano, de uma escola municipal do Rio Grande/RS.

A partir destas dissertações, elaboramos o corpus desta tese compondo-o com os elementos que identificamos como centrais na argumentação dos trabalhos em questão. No que segue, passamos a outras elucidações acerca de sua composição.

\subsubsection{Fatos, verdades e suas interpretações}

O corpus desta pesquisa organizou-se em torno das interpretações com mais "presença", conceito que, como anteriormente citado, diz respeito ao que é destacado na argumentação de modo a se fazer "presente" na consciência daqueles que compõem o auditório almejado. (PERELMAN; OLBRECHTS-TYTECA, 2002, p. 135) 
De acordo com o exposto, na primeira etapa de análise da argumentação, extraímos, dos capítulos conclusivos das dissertações, as interpretações centrais defendidas e, na segunda etapa, depreendemos, dos demais capítulos, os "objetos de acordo" apresentados enquanto dados presumidamente aceitos pelo auditório almejado.

Para que fique claro o procedimento metodológico adotado, expomos um exemplo, extraído da dissertação EPR02. Nela, no seu capítulo conclusivo, localizamos a seguinte afirmação:

Em ambos os momentos ([de] escrita reprodução e escrita produção) foi possível detectar que a professora apresentava um déficit na sua formação, no que diz respeito ao ensinar língua portuguesa no ensino fundamental ${ }^{11}$. (EPR02, p. 148)

Depreende-se, deste excerto, que a pesquisadora interpreta a formação da professora, observada no decorrer da investigação, como deficiente. Esta interpretação decorre do que foi apresentado, na dissertação, enquanto "fatos", ou seja, enquanto aspectos da realidade observada. No caso, trata-se do que foi denominado como "momentos de escrita reprodução e escrita produção".

Em nossa análise, metodologicamente, seguimos o processo de buscar no corpo do trabalho os "objetos de acordo" que as interpretações defendidas ao final da dissertação retomavam. Desta busca, quanto ao exemplo anterior, identificamos a seguinte passagem, que fazia referência a aulas relatadas nas páginas 103 e 104 da dissertação em questão:

O conteúdo transmitido neste tipo de prática ficava atrelado às normas, regras, modelos padronizados e com predominância da função normativa. Essas aulas de escrita reprodução, observadas por nós, sempre seguiram o mesmo ritual [...] e apresentaram o mesmo objetivo: fixar normas e regras através de exercícios mecânicos e repetitivos. (EPR02, p. 100)

Neste fragmento, verificamos o "fato" citado na interpretação de dados, categorizado como "escrita reprodução", que é, por sua vez, caracterizada por focalizar no ensino de regras, normas e na aplicação de exercícios repetitivos. Esta abordagem é criticada em EPR02 e esse

\footnotetext{
${ }^{11}$ Todos os fragmentos das dissertações apresentam-se em itálico e sem recuo de parágrafo. Estes trechos foram copiados da mesma forma como se encontram no original.
} 
se torna um dos elementos elencados na interpretação que avalia negativamente a formação docente, conforme discussão prévia.

Outro exemplo pode ser exposto a partir da afirmação a seguir:

Outra atividade produtiva foi a refacção individual e coletiva dos textos, uma vez que os alunos demonstraram-se participativos e autocríticos do que produziam. Tal atividade proporcionou a eles momentos de reflexão quanto ao uso da língua materna. (FMT06b, p. 124)

Como fizemos em relação ao exemplo anterior, não vamos apresentar comentários acerca da pertinência das interpretações feitas. Limitaremo-nos a demonstrar como, nas interpretações finais das dissertações pesquisadas, localizamos a retomada de dados que foram expostos no corpo desses trabalhos.

Na passagem transcrita, avalia-se a atividade de reescrever um texto como positiva. Sobre isso, FMT06b relata o seguinte "fato":

Depois que todos produziram a primeira versão, selecionamos duas CLs [Cartas do leitor] para que juntos as reestruturássemos na lousa. Como os textos produzidos eram curtos, não escolhemos um ou dois aspectos a serem observados, mas todos os que os alunos percebessem. Escrevemos os textos em cartolinas e as fixamos no quadro para agilizar o trabalho. Antes que fizéssemos a primeira leitura oral ou que questionássemos sobre os textos, os alunos foram apontando o que deveria ser alterado. Dentre as sugestões, incluíram correções gráficas, concordância, pontuação, idéias incompletas, frases sem sentido, etc. Discutimos na CL 01 [referência à Carta do Leitor enumerada como a primeira e exposta na dissertação] a troca das letras " $f$ " $e$ " $v$ ". Gostaram de ficar pronunciando os fonemas para perceber a proximidade dos sons. Esse foi um assunto que muito interessou à turma; por isso, sugerimos à professora titular que o retomasse com maior ênfase em aulas posteriores. Também discutimos os nomes dos acentos, principalmente o circunflexo, conhecido até então como "chapeuzinho". O aluno produtor da CL [Carta do leitor] fora indagado se tinha certeza de que os bairros mencionados por ele em seu texto estavam de fato recebendo asfalto na linha de ônibus. Segundo ele, não tinha certeza. Havia apenas posto os nomes. Assim, a turma achou mais conveniente citar só o exemplo do bairro que conheciam e tinham certeza da veracidade dos fatos. Também comentaram o fato de a carta estar sem identificação. (FMT06b, p. 85-6)

Verificamos que a atividade de reescrever textos, avaliada positivamente na interpretação dos dados que expusemos anteriormente, está presente neste trecho de 
FMT06b. Nele, a pesquisadora relata a proposta de ensino da escrita elaborada e desenvolvida por ela mesma em sala de aula.

Os exemplos citados demonstram a possibilidade de se compreender a argumentação das dissertações sob análise por meio do procedimento de identificar, em etapa inicial, as interpretações de dados com as quais esses trabalhos encerram a discussão proposta e, em etapa posterior, os dados propriamente ditos, ou seja, os "objetos de acordo", em conformidade com a terminologia da nova retórica.

Concebemos esta divisão metodológica como um procedimento que colaborou para a padronização de um modo de lidar com textos longos e nos quais identificamos um conjunto disperso de elementos - dados, interpretações, abordagens metodológicas, referenciais teóricos, estilos de escrita - que compunham o todo textual, no caso, de dissertações de mestrado. Contudo, não ignoramos que a argumentação consolida-se no texto em sua íntegra, como defendem Perelman e Olbrechts-Tyteca (2002, p. 174): "Não devemos esquecer, é artificialmente e para a comodidade da análise que se separam premissas e argumentação; na realidade, já há argumentação na própria posição das premissas”.

Os "objetos de acordo" funcionam como premissas na argumentação, as quais são retomadas pelas interpretações dos dados. A separação que efetivamos em analisar, de um lado, estas interpretações, e de outro, os "objetos de acordo", foi uma opção metodológica para uniformizar uma postura de leitura de cada uma das dissertações do corpus. Também fez parte desta postura de leitura a extração das "interpretações finais" das dissertações, localizadas nos seus capítulos conclusivos, e a identificação de suas premissas nos demais capítulos.

Como se abordou, tais estratégias foram adotadas como modos de viabilizar um tratamento mais padronizado dos trabalhos em questão, o que não significa que as separações implicadas em nossa postura de leitura sejam estanques, tampouco que a argumentação concentre-se na "interpretação dos dados" e que a escolha das premissas não tenha valor argumentativo.

Esclarecemos que, em relação aos "objetos de acordo", focalizamos aqueles categorizados como "fatos" e "verdades". Os primeiros se voltam para o plano do observável, como se se referissem à realidade objetiva, ou possivelmente pudessem referir-se a ela. Já aqueles classificados como "verdades" definem-se como formulações subsidiadas por 
determinadas teorias ou concepções científicas, dentre outras. (PERELMAN; OLBRECHTSTYTECA, 2002)

Restringimos nossa análise da argumentação a esses dois "objetos de acordo" porque eles se caracterizaram como os mais esclarecedores do teor argumentativo das dissertações em questão, em relação ao "o que" era defendido, "como" e "por que" o era. Compreendemos que esse potencial elucidativo tem relação com o uso dos "fatos" e das "verdades" enquanto premissas defendidas pelo orador como "reais", isso é, como passíveis de serem comprovadas pela observação da realidade.

Pela apreensão desses dois objetos de acordo, como fizemos na análise da argumentação das dissertações, foi possível indicar "o que" os autores elencavam como foco de atenção e "como" e "por que" o faziam, tendo em vista aquilo que admitiam como "verdades" a serem consideradas no tratamento da realidade em questão.

No que tange a esse "o que", "como" e "por que", destacamos, por exemplo, o fragmento a seguir, retirado da dissertação EPA08:

De modo geral, as falas das professoras demonstraram uma concepção de oralidade bastante restrita. Não há preocupação com as regras sociais que estão em jogo nas mais diversas situações comunicativas. Quando as professoras descrevem como trabalham a oralidade, sempre buscam a homogeneização da fala e da escrita, segundo a norma culta escrita. (EPA08, p. 155)

Neste fragmento, o "o que" focalizado refere-se ao "ensino de oralidade". Já o "como" a argumentação é construída relaciona-se à análise de que os professores buscam a "homogeneização entre fala e escrita", o que é avaliado como inadequado. Tal argumentação decorre do que é apresentado pela dissertação em foco como sendo dados factuais, no caso, os depoimentos docentes. Esse recorte da realidade, apresentado enquanto "fato", e o modo como ele é analisado, que é associado a uma compreensão docente restrita da modalidade oral da língua, justifica-se pelas concepções assumidas como "verdades" no interior desta dissertação, na qual se defende que o ensino de oralidade ainda não desfruta de abordagem adequada, sendo esse o "porquê" considerado para que os "fatos" em questão sejam investigados.

$\mathrm{Na}$ análise da argumentação das dissertações sob enfoque, avaliamos, em conformidade com os motivos expostos, que esses dados eram os mais expressivos quanto ao 
que compareceu nas premissas de mais de uma dissertação. Os outros "objetos de acordo" discutidos na nova retórica - "presunções", "valores", "hierarquias" e "lugares do preferível" - não demonstraram o mesmo teor informativo quanto às características centrais dos trabalhos em questão, haja vista que não identificamos recorrências que estivessem relacionadas ao seu aparecimento.

Na elaboração do corpus, foi central a localização das recorrências argumentativas, que foram identificadas, em maior número, dentre os "fatos" e as "verdades" que passamos a expor na seção posterior, em conjunto com as "interpretações" que apareceram como correlacionadas.

\subsubsection{Nosso corpus: dados e interpretações com mais "presença” nas dissertações analisadas ${ }^{12}$}

Considerando o exposto, passamos à transcrição de fragmentos que apresentaram interpretações e dados com presença destacada nos trabalhos investigados. Focalizamos, inicialmente, aqueles que se voltaram para a indicação e discussão de falhas localizadas na atuação ou formação docente e também nos documentos analisados. Para tanto, retomamos um dos exemplos supracitados, retirado da dissertação EPR02 ${ }^{13}$ :

Em ambos os momentos [...] [referência a momentos de produção textual escrita] foi possível detectar que a professora apresentava um déficit na sua formação, no que diz respeito ao ensinar língua portuguesa no ensino fundamental. (EPR02, p. 148)

Como se vê, neste excerto, aponta-se para problemas na formação docente em decorrência de ocasiões de ensino de escrita observadas pela autora da dissertação. Esta

12 Nesta seção de apresentação do corpus, não transcrevemos todos os fragmentos considerados no desenvolvimento desta pesquisa, os quais foram extraídos das dissertações investigadas. Esta opção derivou da percepção de que o número elevado de transcrições poderia atrapalhar a leitura fluente do texto. Por este motivo, os fragmentos que não foram citados nesta seção, foram expostos no apêndice $\mathrm{C}$.

${ }^{13}$ Como anteriormente tratado, todos os fragmentos de dissertação expostos apresentam-se em itálico e sem recuo de parágrafo. Estes trechos foram copiados da mesma forma como se encontram no original. 
interpretação ancora-se, por exemplo, no dado, que pode ser verificado na passagem a seguir, também oriundo da observação de aulas:

Constatamos também, que os textos revisados e reescritos nas primeiras aulas não foram tratados pela professora como unidade complexa de comunicação e de significação, destinado a um interlocutor que com ele deveria interagir. Nesses casos o texto serviu apenas como pretexto para exercícios gramaticais [...] (EPR02, p. 116)

Nota-se que a crítica focaliza o tratamento textual direcionado pela docente ao treinamento de ordem gramatical. Como debatido, no Tratado da Argumentação, são considerados "fatos" aqueles que se referem à realidade objetiva e que são avaliados como observáveis, supostos, convencionais, possíveis ou prováveis. (PERELMAN; OLBRECHTSTYTECA, 2002, p.77) Categorizamos, assim, a passagem supracitada como "fato" porque menciona algo do plano do "observável", no caso, relacionado aos textos trabalhados em aula. Esta classificação também encontra respaldo no verbo utilizado para iniciar o período em questão, qual seja: "constatar".

Na passagem que segue, apresentamos outra interpretação que se volta para a atuação docente nas aulas observadas pela pesquisadora:

Evidenciou-se, na análise dos dados, que as interações orais ainda prevalecem em sala de aula como forma de transmissão de conteúdos gramaticais ligados à língua escrita e à sua norma culta, como ocorre na prática pedagógica da professora P. (EPR04, p. 90)

$\mathrm{Na}$ dissertação EPR04, discutem-se as aulas das docentes referidas por E e P. No trecho em destaque, critica-se a prática pedagógica desta última professora no que se refere às interações orais presenciadas, sobre as quais se relatou limitarem-se à gramática, na sua forma escrita culta. Relacionados a esta crítica, são defendidos enquanto "fatos" que influenciam nas aulas observadas as condições desfavoráveis para o trabalho com a oralidade e também a preterição do ensino da língua oral em relação a outros conteúdos:

Tal nível de oralidade [Referência a um nível de oralidade que não se limitasse à transmissão do conteúdo programático] não ficou evidenciado nas aulas das professoras $E$ e $P$, embora, com certeza, a professora E esteja buscando esse caminho. Acreditamos que a ausência desse nível de oralidade deve-se principalmente ao excessivo número de alunos na quinta série da 
escola estadual (por volta de 40, como já dissemos), o que provoca na professora um certo receio de perder o controle disciplinar da turma. No caso da professora $P$ (sua turma possui menos de 30 alunos; 28 mais exatamente), percebemos que dá maior importância à seqüência dos conteúdos gramaticais programados para o bimestre, além de fixar-se demasiadamente no livro didático, que precisa ser "vencido" a qualquer custo. (EPR04, p. 77-8)

Outra dissertação que aponta como problemática a forma como a "oralidade" é inserida no ensino de Língua Portuguesa é a EPA08. Nela, encontramos a seguinte argumentação:

No que diz respeito às práticas de ensino, as professoras manifestam uma concepção de oralidade circunscrita à expressividade dos alunos. Não há preocupação com as regras sociais que estão em jogo nas situações comunicativas. No trabalho com a oralidade, as professoras sempre buscam a homogeneização da fala e da escrita, segundo a norma culta escrita. Nas estratégias para o desenvolvimento de atividades de escrita fica evidente a preocupação com as correções e inadequações em relação ao padrão estabelecido. Não há preocupação com a utilização de mecanismos discursivos e lingüísticos de coerência e coesão textuais, conforme o gênero e o propósito do texto. O objeto de estudo da Língua Portuguesa ainda é língua em sua variedade culta, deixando-se de considerar a língua como um fato social. (EPA08, p. 185)

Tal interpretação ancora-se em registros das situações observadas, defendidos enquanto "fatos" no decorrer do texto da dissertação. Esses registros factuais são apresentados, na passagem a seguir, pela transcrição de falas docentes e pela descrição do que foi observado em sala de aula:

As falas das professoras $C$ e $B$ nos revelam que o trabalho com a oralidade na sala de aula é justificado pela necessidade dos alunos terem melhor expressão oral. Os instrumentos utilizados para a produção de textos orais são descritos dando-se pouca atenção à sua funcionalidade. Ao utilizarem textos orais, percebemos que as professoras não manifestam preocupação em proporcionar, por meio dos mais variados gêneros, o contato com diferentes usos. O trabalho apresenta um único fim, o de trabalhar a expressividade para superar a timidez dos alunos. (EPA08, p. 154)

Retomando as explicações a respeito dos "objetos de acordo", ressaltamos que, na passagem anteriormente transcrita, foram categorizados enquanto "fatos" aqueles dados apresentados como relato de aspectos da realidade observada pela pesquisadora, no que se referia ao tratamento que as professoras observadas cediam à oralidade, que, conforme foi destacado na dissertação em questão, restringia-se às formas de expressar-se oralmente. 
A busca do padrão culto do português na fala também é alvo de discussão na dissertação FPA07. Nela, avalia-se como inadequado o ensino de gramática que predomina nas aulas de Língua Portuguesa em nome de um ideal do "bem falar" e também do "bem escrever":

[...] as professoras continuam tomando a gramática (com um fim em si mesma) como objeto de ensino, apesar de os documentos oficiais e os pesquisadores da área defenderem um ensino baseado no uso da linguagem. Esse comportamento delas revelou que algumas não se apropriam desse discurso oficial e outras o replicam, pois acham que o estudo da nomenclatura e a identificação de questões gramaticais ajudam o aluno a escrever e a falar corretamente. (FPA07, p. 178)

Do corpo da dissertação, depreendemos como "fatos", relacionados a esta argumentação, referências a entrevistas realizadas e situações de aula observadas pela autora de FPA07:

As entrevistas mostraram que textos, principalmente do gênero poema, estão presentes em sala de aula. Isso poderia nos levar a pensar que a ação do professor esteja incidindo nos conteúdos indicados para as práticas do uso da linguagem, como: historicidade da linguagem e aspectos do contexto da produção dos enunciados, ou naqueles indicados para as práticas de reflexão sobre a língua, por exemplo: aspectos ligados à organização dos enunciados e ao modo de organização dos discursos. Todavia, quando comparamos o depoimento das professoras ao que presenciamos em sala, verificamos que as aulas de LP estão centradas no trabalho com a gramática como um fim em si mesma. São diversos os momentos em que as professoras utilizam o texto para explorar itens gramaticais, [...] justificando, muitas vezes, que tal trabalho contribui para o aluno aprender a escrever e a falar corretamente. (FPA07, p. 154)

No que segue, comparecem como "fatos" observáveis as dificuldades dos alunos, por meio de consulta a documentos de desempenho discente e a informações oriundas da coleta e registro de falas docentes:

[...] Esse déficit dos alunos é corroborado no Relatório de Desempenho de Alunos da escola, onde consta a afirmação do Regente da Escola B: "faltam neles os pré-requisitos mínimos de domínio da relação fonema-grafema, princípios do ensinamento dos primeiros anos de escolaridade". (EPR06, p. 87) 
Em EPR06, discutiu-se a dificuldade dos alunos para o aprendizado da leitura, devido a problemas que remetem ao não reconhecimento da relação fonema-grafema. $\mathrm{O}$ ensino da leitura é também criticado em FPB07, como pode ser verificado a seguir:

Nas aulas de leitura em que a docente trabalhou com textos em sala de aula, apenas o conteúdo temático destes foi discutido e de maneira superficial, restringindo-se a discussão ao conhecimento de mundo dos alunos. E mais sério ainda, em sua rotina, a professora iniciava as discussões sobre os conteúdos e não as finalizava, ficando em aberto o estudo mais aprofundado do texto. Em muitos momentos, o próprio objetivo do estudo do gênero editorial, "aprender a identificar a defesa do ponto de vista", permanecia distante dos alunos. Estes, por sua vez, pareciam desatentos nas aulas de leituras; poucos participavam dessas discussões. (FPB07, p. 110-111)

A concepção teórica de leitura que estava subjacente à prática de sala de aula da docente era a estruturalista. Essa nossa descoberta só foi possivel a partir da observação das aulas da professora, pois, durante a entrevista que realizamos com a mesma, ela não conseguiu falar sobre nenhuma concepção de leitura que tenha estudado em sua graduação, especialização ou em algum dos cursos de reciclagem que tenha participado. Ou seja, percebemos que a professora está trabalhando em sala de aula sem ter uma percepção clara de que há uma concepção teórica subjacente à sua prática docente e de que concepção teórica é essa (FPB07, p. 110)

A interpretação dos dados coletados e expostos na dissertação FPB07 avalia negativamente o ensino de leitura observado. A pesquisadora considera as posturas docentes superficiais porque ela se limitaria a recuperar a mensagem do texto, sem possibilitar a ampliação do conhecimento de mundo dos alunos, nem a discussão de mais de um sentido possível de ser atribuído aos textos.

A dissertação em questão também interroga a falta de preparo teórico da docente na definição conceptual sobre o modo como ela orienta o ensino de leitura em sala de aula. Estas conclusões são defendidas depois de serem apresentados registros "factuais" da seguinte ordem - citação de aulas observadas pela autora de FPB07 e de falas docentes coletadas por esta pesquisadora, conforme pode ser aferido no fragmento que passamos a apresentar:

Constatamos até aqui que os textos em sala de aula vêm sendo tratados de maneira bastante superficial. A professora, provavelmente por não ter conhecimento teórico sobre gêneros textuais, também não aborda os aspectos essenciais dos gêneros que estão sendo apresentados pelo livro didático. Além disso, os alunos desconhecem o suporte (jornal) no qual esses textos (a tira, as manchetes e os editoriais) estão inseridos. Todos esses aspectos envolvidos deságuam na dificuldade de construção de sentidos em sala de aula, e como conseqüencia, prevalece sempre a voz da professora. Isso é muito evidente principalmente durante a discussão desse primeiro editorial, "Multa contra a dengue". São raros os 
momentos de fala dos alunos e todas essas falas estão diretamente relacionadas ao seu conhecimento de mundo. Ou seja, não conseguimos visualizar momentos da aula em que a esse conhecimento de mundo que os alunos já têm seja acrescentado algum conhecimento extra, advindo da aula de língua materna. Não há discussão acerca da estrutura dos textos e o conteúdo textual não é suficientemente abordado em sala de aula. (FPB07, p. 87)

Como se vê, os "fatos" apresentados nestes excertos buscam presentificar aquilo que a pesquisadora testemunha ter observado no trabalho da docente em aulas de ensino de leitura. Na dissertação FPB07, esse ensino é caracterizado como limitado ao conteúdo temático, como subjugado ao sentido atribuído pela professora ao texto e como circunscrito a uma sequência pedagógica em que se prossegue a novas atividades sem finalizar as que as antecederam.

Ademais, observa-se também a crítica feita ao saber teórico da professora, em especial, quanto a uma teoria em específico ${ }^{14}$, que é defendida pela pesquisadora enquanto "verdade" necessária ao ensino de Língua Portuguesa, conforme aparece no excerto a seguir:

Em nenhum momento das aulas que observamos, a professora chegou a fazer uma análise do gênero textual, pois os demais aspectos constitutivos deste, segundo Bakhtin (1992) ${ }^{15}$, estilo e estrutura composicional não foram abordados. (FPB07, p. 110-111)

Reiteramos que, na nova retórica, as "verdades" são definidas enquanto "sistemas mais complexos, relativos a ligações entre os fatos, sejam teorias científicas, concepções filosóficas ou religiosas". (PERELMAN; OLBRECHTS-TYTECA, 2002, p. 77) Fundamentada nesta definição, expomos, no decorrer desta seção, os referenciais citados nos trabalhos analisados enquanto "verdades" defendidas como tal no interior das dissertações sob enfoque.

Esta categorização pode ser verificada no excerto anterior, do qual extraímos como verdade o referencial defendido pela pesquisadora como necessário ao ensino em questão, relacionando-o ao arcabouço teórico bakhtiniano.

\footnotetext{
${ }^{14}$ Nesta seção, transcrevemos "verdades" centrais para a argumentação das dissertações analisadas sem nos determos em explicar o quadro teórico a que elas estão relacionadas, haja vista que em seção posterior - "A constituição do quadro teórico" - esta abordagem será efetivada.

${ }^{15}$ A pesquisadora cita BAKHTIN, M. Os gêneros do discurso. In: BAKHTIN, M. Estética da Criação Verbal. São Paulo: Martins Fontes, 1992. p. 279-326.
} 
$\mathrm{Na}$ presente seção, não objetivamos adentrar no referencial teórico citado pelas dissertações, tampouco discutir sua terminologia, como de "gênero textual" e "perspectiva sócio-interacionista". Nosso foco será apresentar as verdades destacadas no texto argumentativo das dissertações para que, no próximo capítulo, possamos expor que referências mostraram-se mais recorrentes e que significados podem ter para a configuração do discurso sobre ensino de Língua Portuguesa, a partir da concepção de "disciplina" (FOUCAULT, 2004a), conforme expusemos no capítulo introdutório desta tese, quanto aos objetivos da presente pesquisa.

A atuação docente também é colocada em xeque e é avaliada negativamente na dissertação FPA07. Nela, afirma-se o seguinte:

Verificamos ainda que o tipo de ensino realizado pelas professoras não pode, sequer, ser caracterizado como tradicional, pois parece não haver situações em que elas explicam um conteúdo, passam um exercício e, em seguida, corrigem-no. O que presenciamos em sala de aula parece ser orientado pela visão de que o aluno aprende por si mesmo porque, com exceção das aulas da $\mathbf{E F 2}$, não há situações em que o aluno seja tomado como um ser ativo e interativo no processo, como aquele que aprende por meio da interação com o professor, com os outros colegas e com os demais membros de seu grupo social, os quais atuam como mediadores entre a cultura e o indivíduo. [Destaque em negrito presente no original] (FPA07, p. 181-2)

Esta interpretação decorre de dados apresentados em FPA07 como factuais, por referirem-se a aspectos da atuação docente observados pela pesquisadora, como pode ser verificado no trecho a seguir:

[...] a forma de tratar o texto, compartilhada pelas professoras, reflete a rotineira cultura escolar: aluno faz cópia do quadro de assuntos e exercícios e, em seguida, confirmam as respostas com as do professor; professor manda resolver atividades do livro sem estabelecer interações com os alunos a respeito, por exemplo, do assunto abordado no texto. (FPA07, p. 160-1)

Observamos que, no fragmento anterior, a pesquisadora critica a atuação docente, em especial, quanto à ausência de participação dos alunos nas aulas e à aplicação de exercícios mediados somente pela cópia e por resolução de questões, sem haver, segundo a dissertação em foco, a presença da professora em momentos de explicação dos conteúdos e de interlocução com os alunos. 
Os excertos até então expostos demonstram avaliações negativas, principalmente, à atuação docente. Contudo, na análise da argumentação das dissertações, também se destacaram problematizações quanto à formação dos professores, como em:

[...] [os professores] perceberam que não eram capazes de transferir habilidades que, provavelmente, possuem de produção de textos escritos para a produção oral de um gênero tão amplamente trabalhado na escola. Na construção de uma história, desprezaram elementos importantes da estrutura da narrativa (espaço e tempo), o que impossibilitou a elaboração de um enredo coerente e, também, de um conflito no interior da história a ser narrada, dificultando o seu desfecho. (ESP08,p. 154-5)

A problemática levantada por esta passagem refere-se a uma atividade de produção desenvolvida no decorrer de trabalhos de formação continuada para professores do Ensino Fundamental. Esta interpretação retomou "fatos" relacionados à situação vivenciada pela própria pesquisadora quanto a sua proposta de formação docente e ao resultado que lhe foi decorrente, conforme pode se depreendido dos relatos a seguir:

A proposta feita ao grupo era de que construíssem uma narrativa coletivamente. Um dos integrantes do grupo iniciaria uma história e, sempre que fizéssemos um sinal, o participante, sentado ao lado daquele que iniciou, teria de dar continuidade à narrativa que vinha sendo produzida. (ESP08, p. 119)

O desprezo de importantes elementos da estrutura da narrativa (espaço e tempo) impossibilitou a elaboração do que motivou o encontro das duas personagens (o quê) e a construção do conflito no interior da história a ser narrada. (ESP08, p. 122)

A dissertação ESP08, da qual extraímos os fragmentos anteriores, dedica-se à análise de uma proposta de formação continuada conduzida pela pesquisadora e da qual decorrem diversas interpretações, como as que seguem:

No experimento que desenvolvemos com um grupo de professores da Hora da leitura, recorremos aos jogos de improvisação teatral como ato de leitura a partir de análises pessoais e coletivas. Colocamos o texto em jogo, desmistificando e tornando prazerosa a relação com ele. Com isso, conseguimos reunir revelações surpreendentes e estimulantes para os próprios participantes, que foram capazes de reconhecer a transposição entre as linguagens literária e teatral como a efetivação de um ato de leitura produtivo, autoral e artístico em que os participantes, em vez de se deterem na tarefa de descobrir o que o texto quer comunicar, elaboram leituras que se configuram em discursos artísticos. (ESP08, p. 153) 
Nos trecho anterior, verifica-se que a pesquisadora aborda a experiência de formação de professores do projeto "Hora de Leitura" por meio de jogos de improvisação teatral. A respeito desta experiência, ela discorre sobre as características desta proposta, em especial, sobre os benefícios que se alega terem sido constatados no experimento realizado, concernentes à fruição estética do texto literário.

Nestas interpretações, são retomados alguns dos dados apresentados no decorrer da dissertação, dentre eles aqueles classificados enquanto "fatos" por retratarem o contexto de implementação do projeto "Hora da leitura" e os aspectos inerentes à formação dos profissionais envolvidos nele, os quais podem ser verificados nos seguintes excertos:

A idéia de implementar o projeto Hora da Leitura nas escolas da rede estadual surgiu no primeiro semestre de 2004, quando os relatórios estatísticos acerca dos resultados de rendimento escolar dos alunos do Ensino Fundamental indicaram índices de acerto preocupantes na prova de compreensão leitora. (ESP08, p. 16)

As ações centralizadas eram desenvolvidas por meio de videoconferências bimestrais, transmitidas da Praça da República (localidade central do prédio da SEE) para noventa Diretorias Regionais de Ensino (DEs) de todo o Estado de São Paulo (sessenta e duas localizadas no interior do Estado e vinte e oito na Grande São Paulo). Eram convocados para assistir às videoconferências do Projeto Hora da Leitura um assistente técnicopedagógico (responsável pelo projeto em cada uma das Diretorias de Ensino) e um professor da Hora da Leitura de cada escola de Ciclo II do Ensino Fundamental da DE. (ESP08, p. 267)

Outros dados factuais, apresentados na dissertação em questão como parte da realidade descrita, procuraram testemunhar como foi desenvolvida a proposta de formação em questão:

Os jogos de improvisação teatral, sem dar primazia à promoção de eventos espetaculares, permitem que atividades teatrais sejam experienciadas por todos os alunos de uma turma. Divididos em dois, três, quatro ou mais grupos, eles participam ativamente, assumindo ora a função de jogadores-atores (alunos que atuam em cena), ora a função de jogadoresespectadores (alunos que observam as realizações cênicas de seus parceiros). (ESP08, p. 60)

Neste excerto, destacam-se os modos como os jogadores participam dos jogos de improvisação teatral, tema central sobre o qual argumenta a dissertação sob enfoque. Em relação a esta participação, a passagem transcrita refere-se aos eventos espetaculares, aos quais o trecho a seguir também faz menção, por meio de apreciação negativa: 
$O$ "fechamento do projeto de leitura" [Referência a propostas de dramatização escolar], portanto, traduz-se na apresentação de um grupo de alunos-atores para uma platéia (os demais alunos da classe ou outros alunos da escola) que, com seu olhar externo ao processo, assiste a um espetáculo sustentado por um texto e alguns adereços de cena. Esta prática exclui grande parte dos alunos da turma e impede a todos (até àqueles que atuaram) a participação em um processo democrático, crítico e criativo que, na dialética dos jogos de improvisação teatral, poderia promover a ampliação da compreensão leitora assim como a construção coletiva do sentido do texto trabalhado, além da apropriação e do refinamento da cena teatral concebida pelo grupo. (ESP08, p. 58-9)

$\mathrm{Na}$ argumentação de ESP08, contrapõem-se os aspectos negativos dos espetáculos teatrais, focalizados na passagem anterior, aos pontos positivos dos jogos de improvisação teatral. A pesquisadora apresenta opiniões docentes como "fatos" a serem considerados nesta discussão:

Nos registros do diário de bordo, alguns professores relacionaram à experiência no jogo suas impressões sobre a co-participação autoral de cada um deles e suas implicações para a construção de sentido. "Esta atividade é realmente desafiadora, pois nunca sabemos como a história será conduzida devido às experiências anteriores de cada pessoa. (Profa. Vanessa Cristina Barboza Alves)”. (ESP08, p. 125)

Outro recurso argumentativo, utilizado por ESP08, foi relacionar os benefícios dos jogos dramáticos às "verdades" assumidas no interior do trabalho, dentre as quais transcrevemos a que segue, na qual são citados os Parâmetros Curriculares Nacionais:

Vale ressaltar ainda que, ao criar condições para o desenvolvimento de propostas que repousam na busca de elaborações coletivas, surgidas da investigação sobre uma determinada problemática (a compreensão de um texto, por exemplo), a partir do confronto daquilo que é do outro e afeta o grupo com aquilo que é do grupo e afeta o outro, os jogos de improvisação teatral harmonizam-se com postulações sobre situações de aprendizagem presentes nos Parâmetros Curriculares Nacionais" ${ }^{1 \hat{\sigma}}$. "Valorizar o conhecimento do aluno, considerando suas dúvidas e inquietações, implica promover situações de aprendizagem que façam sentido para ele. Exercer o convívio social no âmbito escolar favorece a construção de uma identidade pessoal, pois a socialização se caracteriza por um lado pela diferenciação individual e por outro pela construção de padrões de identidade coletiva". (ESP08, p. 59-60)

Além de ESP08, outras dissertações focalizaram a qualificação docente no que concerne a iniciativas de formação continuada. Um exemplo disso é a dissertação EPA08, que

\footnotetext{
${ }^{16}$ Citação, presente em ESP08, a BRASIL. Secretaria de Educação Fundamental. Parâmetros Curriculares Nacionais - Introdução: Ensino Fundamental. Brasília: SEF/MEC, 1998.
} 
se voltou à discussão de curso ministrado a professores de Oriximiná/PA, como se vê na seguinte argumentação:

A propósito da formação do professor com base nos PCN de Língua Portuguesa no município de Oriximiná, as falas dos sujeitos pesquisados e os relatórios constantemente nos apontam para as dificuldades na assimilação dos conteúdos, apresentadas pelos professores que atuavam naquele ano, no terceiro e quarto ciclos do Ensino Fundamental. Pudemos perceber que na implantação desse programa de formação continuada já se manifestaram os primeiros desafios a serem vencidos para que se alcançassem os objetivos desejados. A organização do tempo já se apresentava como o principal entrave para o sucesso do curso e é assinalado como responsável pelo afastamento de algumas pessoas do programa. Não obstante, a dificuldade de contato com o município pólo para melhores orientações é destacada como uma desvantagem nessa política para a educação no município de Oriximiná. (EPA08, p. 184)

Neste trecho, faz-se referência à formação de professores embasada pelos Parâmetros Curriculares Nacionais de Língua Portuguesa. No tocante a esta formação, aponta-se, em especial, para as dificuldades quanto aos conteúdos trabalhados e à comunicação estabelecida entre os municípios envolvidos nesse curso, bem como ao tempo necessário para a sua realização.

Antes de apresentar esta interpretação, dados referentes à organização estrutural dos municípios foram expostos e também foram apresentados alguns relatos. Esses dados, apresentados como "fatos" da realidade observada, foram extraídos de relatórios e da transcrição de falas docentes, que podem ser aferidos nos excertos que seguem:

Os municípios do Estado foram agregados em pólos para que se pudesse melhor organizar e coordenar a formação dos coordenadores que iriam atuar em cada um deles. Oriximiná foi uma das cidades que compuseram o pólo de Santarém. Em Oriximiná, segundo relatório da SEMED desse município, o programa foi iniciado em setembro de 2001 com o encontro de formadores do Programa "Parâmetros em Ação". (EPA08, p. 116)

No relatório do primeiro encontro realizado no município de Oriximiná, podemos observar que fica registrado como a organização do tempo foi um dos principais problemas enfrentados pela coordenadora do programa: "Outro fator que por vezes compromete a participação ativa do coordenador geral nos encontros dos segmentos é a sobrecarga de trabalho destes; tem ficado difícil conciliar tantos trabalhos em tão pouco tempo" (Relatório do $1^{\circ}$ Encontro em Oriximiná). (EPA08, p. 140) 
A questão do tempo insuficiente, bastante marcada em EPA08, quanto às dificuldades docentes para realização de sua formação, não foi tematizada somente nesta dissertação. Ela também compareceu na argumentação de EPR06, com outro tipo de enfoque. Enquanto no excerto anterior discutiu-se esse tema pelo viés do pouco tempo disponível dos professores para a sua própria formação, em EPR06 abordou-se a reduzida carga horária dos próprios cursos de qualificação docente, como se pode ver no que segue:

Diante da falta de teorias e de práticas voltadas para o desenvolvimento de trabalho na perspectiva interacionista, um curso de 24 horas em Faxinal do Céu [Referência a uma cidade paranaense] e dois encontros de quatro horas coordenados pelo Núcleo não poderiam suprir ou solucionar uma lacuna histórica dos professores da SAALP [Sala de Apoio à Aprendizagem em Língua Portuguesa]. (EPR06, p. 160)

Neste trecho, observa-se a interpretação que avalia negativamente o tempo previsto para o curso em questão, tendo em vista as lacunas alegadas pela pesquisadora quanto às teorias e práticas referentes à perspectiva de pesquisa por ela adotada. Esta interpretação retoma um dado referente ao exercício profissional de um dos professores observados, caracterizado enquanto algo que foi passível de verificação e que, por isso, foi apresentado como um "fato" a ser considerado:

[...] apesar da boa vontade do professor [Referência a um dos sujeitos de pesquisa]; do seu empenho em trabalhar com textos; de oferecer atividades diversificadas de produções textuais; de mudar o procedimento metodológico, quanto ao atendimento individualizado ao aluno; consideramos que a prática significativa e efetiva, na dimensão interacionista, ainda está por acontecer, mesmo após cursos e reuniões de estudos. (EPR06, p. 106)

Nesta dissertação, aparecem referências aos cursos de formação continuada, até então pontuados, e também aos de formação inicial. Na interpretação dos dados a seguir, observamos o tratamento cedido à graduação em Letras e em Pedagogia:

[...] diante do atual nível de competência lingüística de alunos da $5^{a}$ série, parece ser imprescindível que os cursos de Letras ofertem disciplinas que contemplem conteúdos relacionados à alfabetização, bem como os de Pedagogia oferecer disciplinas com conteúdos referentes à lingüística textual, já que alfabetizar e letrar requerem tais conhecimentos. (EPR06, p. 158) 
Os dados que parecem subsidiar esta argumentação voltam-se para "fatos" que, enquanto tal, são caracterizados como passíveis de observação. Eles dizem respeito à estrutura dos cursos de graduação em Letras e aos resultados de testes oficiais, citados nas passagens a seguir:

Sucessivas avaliações oficiais, realizadas ao final da $4^{a}$ ou da $8^{a}$ série do Ensino Fundamental, ou, ainda, ao final do $3^{\circ}$ ano do Ensino Médio, no Brasil e no Estado do Paraná, confirmam ano a ano que o desempenho dos alunos, especialmente em língua materna, tem piorado. Insucesso que ocorre apesar de a academia e de os pesquisadores debaterem, há mais de duas décadas, problemas afetos ao ineficiente desempenho lingüístico dos alunos. (EPR06, p. 13)

[...] alguns cursos de graduação em Letras ainda não estão voltados ao ensino dos processos de aprendizagem da leitura e da escrita em estágio inicial. Pensamos que esse déficit teórico precisa ser urgentemente corrigido, diante da presença de um grande percentual de alunos sem as mínimas condições de leitura e escrita na $5^{a}$ série do Ensino Fundamental. (EPR06, p. 66)

Os fragmentos até então expostos demonstraram que, em parte das dissertações investigadas, consolidou-se argumentação voltada para o apontamento de falhas na atuação e na formação docente. Além das produções já indicadas aqui, outra dissertação que discutiu os cursos de formação docente foi EPR02. Nela, a argumentação defendeu a importância dos estudos linguísticos, como se pode depreender do seguinte:

[...] é necessário [sic] uma formação inicial e continuada que ofereça, também, uma educação lingüística que qualifique o professor do ensino fundamental a trabalhar tanto com a língua escrita quanto com a língua falada. (EPR02, p. 148)

Esta interpretação respalda-se em referenciais assumidos como "verdades" no âmbito da dissertação sob enfoque, como o que segue:

Essa compreensão da nossa língua passa a ser realidade, quando o professor alfabetizador vai em busca de outras ciências como a Lingüística, para explicar uma série de fatos, como afirma Cagliari (1999, p.49) $)^{17}$,"com o objetivo de mostrar o que a Lingüística pode fazer para melhorar o ensino do português, sobretudo no que se refere à alfabetização, ajudando o

${ }^{17}$ Citação, em EPR02, a CAGLIARI, Luiz Carlos. Alfabetização \& lingüística. São Paulo: Scipione, 1999. 
professor a entender a realidade lingüística da classe e a ensinar ao aluno como a fala, a escrita e a leitura funcionam e quais os usos que têm". (EPR02, p. 26)

Ainda sobre a formação docente, um caráter negativo sobre o qual se argumenta é quanto à falta de melhoria no ensino, mesmo estando os professores em busca de formação por mais longo prazo, como se verifica adiante:

No conjunto de dados temos nove professores pós-graduados em nível de especialização, com expensas próprias, estudos que cada um buscou para o crescimento profissional e com o fito de também galgar mais um nível no quadro de carreira; sete com dois a dez cursos de atualização nos últimos dez anos, e com a informação de que esses traziam novas perspectivas às suas práticas. Apesar desse quadro percebemos poucas mudanças efetivas no ensino. (EPR06, p. 159)

Esta interpretação remete-se aos dados fornecidos, por EPR06, acerca da distância entre aquilo que foi registrado como fala docente e aquilo que foi observado na prática de sala de aula. Por tratar-se de dados que são creditados à realidade objetiva, são apresentados enquanto "fatos", extraídos das falas coletadas e da observação de aulas:

Quanto aos objetivos, houve unanimidade nas respostas. Isso concretiza, em tese, que a intenção e a crença desses professores estão voltadas para o ensino efetivo da leitura (interpretação) e da produção textual (escrita). Contudo, entre o discurso (intenção) e a prática há um hiato, em que os problemas são camuflados. (EPR06, p. 61)

No que se refere à prática docente, se, de um lado, viemos demonstrando como as dissertações argumentam sobre as falhas na formação e na atuação docente, por outro lado, como exporemos no que segue, elas incorporam interpretações que tratam de sua própria atuação, ao intervirem em sala de aula com suas propostas de pesquisa:

Em algum momento pode parecer que o gênero foi imposto como objeto de estudo na 5 a $C$. Mas, se levarmos em conta que, como professores, devemos desenvolver atividades significativas para o aluno e que o ambiente escolar é caracterizado justamente por nele se criarem condições favoráveis para que haja interlocução, o estudo de um gênero não pode ser considerado um mero exercício de escrita, pois esse objeto contempla outras dimensões além da materialidade lingüística. (FSC03, p. 80)

Na passagem transcrita, focaliza-se o ensino de Língua Portuguesa que contempla o estudo dos "gêneros". Antecedem tal interpretação os dados que seguem, voltados para o que 
efetivamente ocorreu em sala de aula e que, assim sendo, são apresentados enquanto "fatos" extraídos de situações de ensino:

Em nossa pesquisa, trabalhamos a produção escrita de alguns gêneros do discurso em sala de aula, estabelecendo como fio condutor dessa ação a criação de um álbum personalizado, composto a partir das produções dos alunos. (FSC03, p. 37)

Esclarecemos que no trabalho com os gêneros do discurso em sala de aula não esgotamos todas as características de cada gênero. Isso porque levamos em conta as possibilidades de aprendizagem dos alunos, ou seja, regulamos o grau de dificuldade das atividades de acordo com o nível de letramento deles. (FSC03, p. 45)

Uma das "verdades" assumidas quanto à concepção de ensino de Língua Portuguesa permeada pelos "gêneros" pode ser vista a seguir, em fragmento retirado da dissertação

\section{FMT06b:}

Acreditamos, assim, que o trabalho com o gênero deva ser planejado, organizado em seqüências didáticas que abordem a leitura do gênero, sua produção, refacção e circulação, como propõem os autores supracitados [Referência a Schneuwly e Dolz, 2004 ${ }^{18}$ ] [...]. (FMT06b, p. 53)

Os "fatos" e a "verdade", presentes nos trechos anteriores, abrangem o trabalho com os "gêneros" no ensino de Língua Portuguesa. Sobre esse ensino, foi apresentada argumentação, nos fragmentos anteriores, referente às aulas ministradas pelos próprios pesquisadores. No que diz respeito ainda às experiências de atuação docente conduzidas pelo próprio pesquisador, apresentamos o trecho que segue:

Na Escola Estadual "José Moraes", durante as 80 horas-aula da pesquisa-ação, os alunos encontraram nas revistas "Guia Astral" e "Veja" e no jornal "A Tribuna" a oportunidade de escrever textos para realmente serem lidos por seus colegas de sala, da escola e pelos leitores dos suportes. Sentimos que essa atividade de linguagem proporcionou certa desmistificação do ato de escrever. Os alunos não gostavam porque não estavam habituados a escrever. A redação escolar era escrita para ser lida pelo professor, que atribuiria uma nota. Com a produção das cartas e com a certeza de que seus textos seriam analisados mais em função da configuração do gênero do que em função de erros e acertos de gramática,

18 Citação, em FMT06b, a SCHNEUWLY, Bernard \& DOLZ, Joaquim. Gêneros Orais e escritos na escola. Campinas: Mercado de Letras, 2004. 
visto que para isso haveria o processo de revisão e de reescrita, os alunos se sentiram mais motivados, confiantes e capazes. Além disso, a possibilidade de interagir com a escola e com seus colegas, por seus textos publicados, deu mais legitimidade à atividade de linguagem, o que acabou afetando positivamente sua produção escrita. (FMT06b, p. 123)

Verifica-se, neste excerto, a avaliação positiva do ensino de escrita supramencionado, pois, segundo as interpretações anteriores, motivou os alunos a produzirem textos escritos. Esta argumentação foi precedida por dados como os que seguem, defendidos enquanto "factuais" ao serem extraídos de propostas de aula efetivadas em sala:

Para que a discussão do assunto se encerrasse, elaboramos com toda a turma um resumo das principais idéias acerca da Iluminação Pública, a fim de darmos início ao processo de produção. Solicitamos, então, que escrevessem uma carta ao jornal "A Tribuna", comentando sobre o assunto da matéria "Presidentes expõem principais problemas" ("A Tribuna”, 05 de fevereiro de 2005 [...]). (FMT06b, p. 62)

Outro dado precedente às interpretações defendidas em FMT06b foi a referência a seguir, incluída no texto da dissertação enquanto "verdade" válida para a argumentação exposta:

As redações das escolas não incentivavam a escrita, porque não possuíam correspondência com o mundo real nem destinatário real. Eram escritas para o professor não como uma pessoa a quem se comunica algo, mas como avaliador. Segundo Geraldi (2003, p. 128)" " "na redação, não há um sujeito que diz, mas um aluno que devolve ao professor a palavra que lhe foi dita pela escola”. (FMT06b, p. 11)

Demais argumentações quanto ao ensino de leitura e de escrita comparecem no que segue:

Por reconhecer o interlocutor, e o valor de seu enunciado é que o sujeito (aluno) revela em seu texto uma carga ideológica e seu estilo. É assim que formamos leitores e escritores capazes de vislumbrar na linguagem as diferentes dimensões e de manter diálogo vivo na cadeia verbal. (FSC03, p. 80)

\footnotetext{
${ }^{19}$ Citação, em FMT06b, a GERALDI, João Wanderley (Org.). O texto na sala de aula. $3^{\text {a }}$ ed. São Paulo: Ática,
} 2003. 
À interpretação anterior, extraída de FSC03, aparecem relacionados alguns dados que dizem respeito à produção de biografias e de um álbum, apresentados enquanto "fatos" extraídos do contexto de aula:

Já para a escrita da autobiografia, enumeramos alguns dados: nascimento (local, data); infância; vida escolar; vida familiar; hobby; algum prêmio; alguma curiosidade. Mais uma vez, atentamos para o fato de que haveria leitores e que os alunos deveriam selecionar o que iriam dizer sobre si mesmos, de acordo com o que gostariam que as pessoas soubessem sobre eles. (FSC03, p. 60)

Também antecede a argumentação final de FSC03, a seguinte referência tomada como "verdade":

Conforme Bakhtin ${ }^{20}$,é no diálogo com o outro que construímos nossos enunciados, pois respondemos ao já-dito e aos enunciados que ainda estão por vir. É exatamente o que vem caracterizar esse momento de construção do convite, quando os alunos procuraram atender às inúmeras questões que surgiam a cada passo, buscando tornar o texto o mais claro possível ao seu leitor. (FSC03, p. 73)

A análise da argumentação do corpus, conforme foi até então apresentada, demonstrou que as interpretações e os dados mais presentes voltaram-se para o apontamento de falhas na atuação e na formação docente, bem como focalizaram os temas da escrita, da leitura e da oralidade no ensino de Língua Portuguesa. A abordagem destas temáticas, em larga medida, apareceu delineada pela perspectiva dos "gêneros".

Ao lado desta discussão sobre o ensino da leitura, escrita e oralidade, também apareceu como foco de investigação a metodologia de ensino em aula, no que se refere a projetos interdisciplinares e a trabalhos coletivos, ou em grupos, envolvendo recursos tecnológicos, como segue:

O trabalho com projetos permitiu às professoras que abordassem os temas selecionados de forma interdisciplinar favorecendo assim a aprendizagem significativa de seus alunos. (ESP09, p. 84)

A criação de roteiros para as produções de vídeo digital é apenas uma das opções que o professor tem para incentivar o exercício da escrita de forma contextualizada. $O$ envolvimento das tecnologias, presentes em nosso cotidiano, na educação - como a

\footnotetext{
${ }^{20}$ Citação, em a FSC03, BAKHTIN, M.. Estética da criação verbal. São Paulo: Martins Fontes, 1997.
} 
filmadora, a máquina digital e o computador - é também algo que ainda está sendo trilhado e merece a nossa atenção, na busca pela ampliação do conceito de aula [...]. (ESP09, p. 87)

ESP09 tratou de roteiros para a produção de vídeos digitais a partir de trabalhos desenvolvidos em conformidade com a metodologia de ensino focalizada nos fragmentos anteriores, relacionada a projetos trabalhados em sala de aula em grupos ou coletivamente e com o uso de ferramentas tecnológicas. As interpretações feitas sobre esta metodologia aparecem subsidiadas por relatos como o que segue:

A professora $C$, quando questionada sobre o trabalho com projetos, esclareceu: "Trabalhar com projetos em sala de aula torna o conteúdo mais atrativo para o aluno e facilita o trabalho interdisciplinar. Os temas escolhidos estão sempre atrelados ao conteúdo programático da série e são de interesse do aluno. Destacamos em sala quais os temas que gostariam de estudar e então tiramos os mais votados. A partir daí seleciono aquele tema que mais interessou a todos e começo o projeto. As produções de texto partem de leituras de textos, livros lidos pelos alunos ou pelo professor e até mesmo de um filme ou peça teatral. Produzir textos a partir de diversos gêneros passa a fazer parte da rotina escolar deles. Eles sentem prazer em escrever e ler, gostam de ouvir histórias e escrever sobre elas" (Professora C). (ESP09, p. 40-1)

Sobre a metodologia de ensino relatada nesta dissertação, a pesquisadora relaciona-a àquilo que assume como "verdade" no interior do seu trabalho:

Além disso, no momento da criação do roteiro, a professora buscava interagir com os grupos, orientando as atividades, buscando facilitar a aprendizagem: "A mediação pedagógica coloca em evidência o papel de sujeito do aprendiz e o fortalece como ator de atividades que lhe permitirão aprender e conseguir atingir seus objetivos; e dá um novo colorido ao papel do professor e aos novos materiais e elementos com que ele deverá trabalhar para crescer e se desenvolver" ${ }^{, 21}$. (ESP09, p. 70)

Como se vê, a dissertação ESP09, da qual foram extraídos os fragmentos anteriores, trata do ensino de Língua Portuguesa incluindo recursos tecnológicos para a produção de vídeos digitais. Outras dissertações também defendem o uso de dispositivos tecnológicos em aulas de português, como pode ser inferido das interpretações transcritas a seguir:

\footnotetext{
${ }^{21}$ Citação, em ESP09, a MORAN, J. M., MASETTO, M. T., BEHRENS, M.A. Novas tecnologias e mediação pedagógica. Campinas, SP: Papirus, 2000.
} 
Um dos resultados desta pesquisa é o protótipo de um editor de histórias em quadrinhos, o HagaQuê, que busca oferecer um ambiente mais propício para as atividades idealizadas pelos professores. (ESP01, p. 59)

Toda a turma se apresentou bastante disposta para fazer o experimento [Referência ao jogo virtual sobre morfossintaxe], principalmente por se tratar de recursos computacionais, já que houve demonstração de uma cultura de informática formada, uma vez que a escola tem um laboratório de informática e trata a informática como área específica do conhecimento. Ou seja, eles estudam informática como uma disciplina além de serem estimulados a realizarem pesquisas e trabalhos escolares em suas casas com os recursos da informática. (FPB08b, p. 117)

Nos excertos anteriores, as argumentações expostas avaliam positivamente a utilização de computação em aula. Os "fatos" elencados nestas dissertações, apresentados como decorrentes do que foi observado no contexto escolar, podem ser apreendidos do que segue:

O HagáQuê destina-se à criação de histórias em quadrinhos por alunos do $1^{\circ}$ e $2^{\circ}$ ciclos do Ensino Fundamental [...]. (ESP01, p. 35)

Para a realização dessa pesquisa, foram analisados alunos da educação básica, de duas turmas de sétimo $\left(7^{\circ}\right)$ ano do ensino fundamental, da disciplina gramática portuguesa, do colégio GEO Sul da cidade de João Pessoa/PB. A análise se deu sobre sua disposição para aprender gramática e a aprendizagem de morfossintaxe mediada por um objeto digital de aprendizagem. Desse modo, foi testado um OA [Objeto de Aprendizagem] sobre análise morfossintaxe a fim de verificar as potencialidades ou não do referido objeto com a aplicação de pré e pós-testes. (FPB08b, p. 24)

São elencadas como "verdades" as referências a seguir, que tratam dos recursos computacionais como ferramentas de ensino e argumentam sobre a formação docente necessária para que a computação ganhe espaço no ensino:

“o uso da tecnologia não como 'máquina de ensinar' mas, como uma nova mídia educacional: o computador passa a ser uma ferramenta educacional, uma ferramenta de complementação, de aperfeiçoamento e de possível mudança na qualidade do ensino,22. (ESP01, p. 18)

Segundo Sancho $(2006)^{23}$, as Tecnologias da Informação e Comunicação (TIC) provocaram uma série de mudanças também na vida acadêmica. Apesar de relevante, essa mudança

\footnotetext{
${ }^{22}$ Citação, em ESP01, a VALENTE, José Armando. Computadores e conhecimento: repensando a educação. Campinas: Editora da Unicamp, 1993.

${ }^{23}$ Citação, em FPB08b, a SANCHO, Juana Maria et al. Tecnologias para Transformar a Educação. Tradução Valério Campos. Porto Alegre: Artmed, 2006.
} 
enfrenta resistência por parte de professores no que diz respeito à qualificação profissional, já que a primeira mudança tem que partir dos mesmos, uma vez que a condução do ensino começa com o educador. Outras dificuldades encontradas referem-se à falta de estrutura física das escolas, como também a ausência de subsídios por parte dos poderes públicos, o que dificulta o ensino e conseqüentemente a aprendizagem. (FPB08b, p. 23)

No que tange à contribuição pedagógica dos recursos de informática no ensino de Língua Portuguesa, as interpretações a seguir dão outros exemplos de argumentações que seguem esta linha de reflexão:

No caso dos alunos investigados, o jogolobjeto de aprendizagem se mostrou como material potencialmente significativo para o ensino-aprendizagem de gramática portuguesa. Com efeito, esta investigação prospectiva mostra que o referido jogo/objeto pode facilitar a aprendizagem significativa de conceitos da gramática normativa e a aplicação destes em situações concretas do dia-a-dia como na compreensão textual. (FPB08b, p. 119)

Tais considerações seguem-se ao relato do que se defendeu enquanto "fatos" que fizeram parte do desenvolvimento do trabalho em questão:

Os sujeitos estavam divididos em dois grupos: Experimental $(N=47)$ e Controle $(N=39)$ [...]. (FPB08b, p. 111)

[...] há evidência estatística de que o grupo Experimental apresentou nota média superior à nota média do grupo Controle. É muito provável que a aprendizagem significativa tenha sido favorecida com o uso do OA e que isso contenha um diferencial estatístico comprovadamente superior à metodologia padrão. (FPB08b, p. 113)

Como vem sendo apresentado neste corpus, houve convergências localizadas nas dissertações quanto a abordagens que focalizaram, de um lado, falhas na formação e na atuação dos professores observados e, de outro lado, destacaram propostas de ensino com bons resultados, dentre as quais compareceram o ensino dos "gêneros" e o uso de recursos computacionais. No que segue, apresenta-se outra vertente de análise, que destacou o aprendizado dos alunos em trabalhos que privilegiaram a contínua revisão e reelaboração dos textos: 
[...] o gênero carta do leitor foi apreendido satisfatoriamente e [...] os alunos tiveram uma progressão lingüística considerável, haja vista que algumas dificuldades foram sendo sanadas a cada nova produção. (FMT06b, p. 123)

Como dados observados foram apresentados "fatos" como o que segue:

Nas primeiras versões produzidas, apareceram alguns desvios acerca da grafia das palavras. Acreditamos que esse fato ocorre por alguns alunos não possuírem o hábito de reler o que escrevem. Afirmamos isso, tendo em vista que, nas versões finais, praticamente todas as inadequações desapareceram. Observaremos isso nos exemplos seguintes [Referência a textos discentes apresentados no decorrer da dissertação]. (FMT06b, p. 108)

Relacionando-se a esses dados, compareceu a referência a seguir, admitida enquanto "verdade" no trabalho em questão:

As expressões sinônimas ou quase são categorizadas por Koch $(2002)^{24}$ como formas remissivas lexicais. É um recurso que permite dar continuidade ao texto, mostrando que dois ou mais segmentos estão semanticamente inter-relacionados. Um primeiro olhar sobre a escrita inicial e a reescrita dos resumos produzidos pelos alunos estudados, no que diz respeito ao uso desse recurso, permitiu que fosse feito um agrupamento dos sujeitos para que se procedesse à apresentação dos dados. (FRS10, p. 46)

Como tratado anteriormente, apresentamos neste corpus os dados e as interpretações que tiveram mais "presença" nos trabalhos analisados. Para tanto, transcrevemos fragmentos das dissertações, sem a intenção de avaliar o mérito ou o demérito das argumentações efetivadas, haja vista que esse material foi o foco de análise posterior.

Análise que, por sua vez, voltou-se para as recorrências no tocante à investigação de mestrado sobre ensino de Língua Portuguesa, quanto ao que efetivamente tem circulado nesse tipo de pesquisa e não quanto ao que lhe seria mais ou menos adequado, tendo em vista algum padrão de "fazer acadêmico" predeterminado.

Prosseguindo na apresentação do material extraído das produções sob análise, destacamos que se, por um lado, houve abordagens que trataram de avanços na aprendizagem dos alunos, por outro lado, outros trabalhos ressaltaram as dificuldades discentes, como se exemplifica a seguir:

\footnotetext{
${ }^{24}$ Referência a KOCH, Ingedore Villaça. A Coesão Textual. São Paulo: Contexto, 2002.
} 
Uma leitura sob o viés da produtividade, a respeito [...] do índice total de $36 \%$ de reprovação consideraria que o Programa [Referência ao Programa Sala de Apoio à Aprendizagem em Língua Portuguesa - SAALP] não obteve sucesso, enxergando apenas aquilo que ele deixou de atingir. Todavia, uma leitura construtiva possibilita refletir e compreender que os problemas de leitura, compreensão e escrita dos alunos diminuíram, apesar de o nível mínimo exigido não ter sido atingido pelos alunos, ao final do ano letivo, para a promoção para a série seguinte. Mesmo porque o tempo estabelecido pelo Programa não coincidiu com aquele compatível com a necessidade do aluno. (EPR06, p. 157)

Ao investigar os conceitos de gênero gramatical dos alunos, confirmarmos, por meio da prova escrita e das entrevistas, que, em todas as séries investigadas, eles utilizaram com grande freqüência seus conceitos semânticos para proceder à identificação do gênero das palavras. $O$ conceito gramatical fora relegado a um segundo plano na $2^{a}$, na $4^{a}$ e na $6^{a}$ série, predominando somente na $8^{a}$ série. Este desempenho assinala a confusão conceitual estabelecida pelos alunos em torno do tema gênero, uma confusão que se deve, em grande parte, ao fato de que as noções que podem ser consideradas "naturais" são construídas desde o nascimento da categoria de gênero e, apesar de atualmente constituírem critérios parciais, ainda continuam fortes e muito presentes na abordagem do tema nas séries investigadas. (EPR07, p. 141)

Estas interpretações foram, no interior da dissertação, precedidas por relatos factuais, com remissão ao que foi observado. Em EPR06, tratou-se da "Sala de Apoio à Aprendizagem em Língua Portuguesa", e em EPR07, do ensino dos "gêneros gramaticais":

Verificamos que, na escola B, o tempo de oito meses de funcionamento da SAALP [Sala de Apoio à Aprendizagem em Língua Portuguesa] foi insuficiente para que 12, dos 23 alunos pudessem ser capacitados para dar prosseguimento, com autonomia, nos seus estudos, sem deixar de considerar que os alunos freqüentaram o turno regular. E, segundo a secretária desse estabelecimento, esses alunos foram reprovados em todas as disciplinas, com exceção da Educação Física, por chegarem ao final do ano ainda com dificuldades na leitura e na escrita. (EPR06, p. 91)

Os dados revelam que, apesar de, na maioria das vezes, os alunos obterem exito na identificação do gênero dos substantivos, há um percentual significativo de não-êxitos em todas as séries. Esse fato permite a observação de dificuldade no que tange à compreensão desse conteúdo, remetido muitas vezes a segundo plano em sua abordagem por uma falsa crença em uma "simplicidade" de aplicação. (EPR07, p. 99-100)

No que diz respeito ao ensino do gênero gramatical, conforme tratado na dissertação EPR07, foram defendidas considerações, como a que segue, enquanto "verdades": 
Outro problema inerente à classificação do gênero, conforme Câmara Jr. $(1984 b)^{25}$, é a confusão que se costuma fazer entre flexão de gênero e outras formas aleatórias, certos processos lexicais ou sintáticos de marcar o sexo. Ele mostra que esse é um problema comum, principalmente nas gramáticas normativas, nos quais se costuma opor o substantivo mulher como feminino de homem. Na verdade, mulher é um substantivo privativamente feminino, que está relacionado ao substantivo homem, privativamente masculino, apenas por uma correlação semântica. Esses casos que costumamos chamar de "heteronímia" não entram na flexão de gênero português, são apenas formas de marcar o sexo dos seres. Lyons $(1979, \text { p. } 303)^{26}$ atenta para o fato de que esses são casos em que palavras estão "semanticamente relacionadas por uma marca de gênero". Acreditamos, porém, que essa marca seja exclusivamente a questão sexual. (EPR07, p. 37)

Além dos tópicos de leitura, escrita e gramática, o livro didático de Língua Portuguesa foi tratado por algumas dissertações como foco de pesquisa. Os três trabalhos que deram destaque a esse tipo de abordagem foram defendidos em 2007 e argumentaram a favor de interpretações de dados como a transcrita a seguir:

O trabalho com gêneros mais acentuado nos quatro livros [Referência aos livros didáticos analisados] apresenta-se na seleção de textos de diferentes gêneros. O objetivo dos autores é trazer os textos que circulam nas variadas esferas sociais para o meio escolar, por isso, os artigos de jornais e revistas, propaganda, sites estão presentes em grande porcentagem. A preocupação com a diversidade faz com que os livros disponibilizem outras fontes de pesquisa para o aluno entrar em contato (pela internet, em livros ou filmes), além dos textos que o livro já oferece para leituras. Nesse sentido, consideramos que os livros proporcionam uma oportunidade de trabalho com leitura de maneira discursiva, ou seja, desenvolvem a capacidade leitora porque os exercícios de interpretação, com raras exceções, promovem reflexão sobre as situações de produção e uso. (ESP07, p. 97)

Interpretações como esta foram antecedidas por dados que, em especial, expuseram falas dos docentes, abordaram o conteúdo dos livros e discutiram como eles foram usados em sala de aula. Tais dados referiram-se ao plano do observável e foram incorporados, às dissertações em questão, enquanto "fatos" a serem considerados, conforme ilustramos no que segue:

As resenhas do PNLD [Programa Nacional do Livro Didático] também comentam que há um excesso de normas gramaticais expostas em alguns materiais, como é o caso, em nossa opinião, do livro "Linguagem Nova". Os outros três livros buscam tratar os elementos

\footnotetext{
${ }^{25}$ Referência a CÂMARA JUNIOR, J. M. Estrutura da Língua Portuguesa. 14. Ed. Petrópolis: Vozes, 1984.

${ }^{26}$ Referência a LYONS, J. Introdução à Linguística Teórica. São Paulo: Editora Nacional, 1979.
} 
descritivos da língua em situações contextualizadas, mesmo apresentando regras e estruturas formais em alguns momentos. O livro "Língua Portuguesa: Rumo ao Letramento" em nosso entender é o livro que melhor expõe os conteúdos gramaticais de maneira discursiva, apoiando o ensino nos gêneros discursivos. Quanto aos textos, para o estudo de leitura e interpretação, consideramos que os quatro livros apresentam boa seleção numa abordagem discursiva da língua. Quanto à produção textual, os livros propõem atividades motivadoras; porém, faltam esclarecimentos, muitas vezes, das condições efetivas para a produção. (ESP07, p. 95)

Outro enfoque, estabelecido pelas dissertações que analisaram livros didáticos, foi verificar sua adequabilidade considerando-se as diretrizes curriculares oficiais, como se nota no que segue:

Podemos concluir que um grande passo foi dado para o ensino discursivo de LP por parte dos órgãos oficiais de ensino com a publicação dos PCN [Parâmetros Curriculares Nacionais] e por parte das editoras que publicam cada vez mais livros didáticos tomando gêneros como conteúdo, inclusive atendendo às exigências de avaliação do PNLD [Programa Nacional do Livro Didático]. Mas temos consciência de que muito ainda precisa ser feito para que os gêneros atinjam maior abrangência nos livros e nos planejamentos escolares em busca de uma universalização da educação. (ESP07, p. 98)

Nesta dissertação, ESP07, apareceram como "verdades" as referências aos Parâmetros Curriculares Nacionais:

Nos últimos anos, uma significativa reforma vem acontecendo desde a promulgação da LDB, lei de diretrizes e bases $n^{\circ}$. 9.394/96, juntamente com os Parâmetros Curriculares Nacionais [...] publicados pelo MEC/SEF, em 1998. Pela primeira vez na história do país, temos, num documento oficial, o ensino atrelado à natureza da linguagem, associando a língua a seus aspectos discursivos. Consta na apresentação da área de LP que "todo texto se organiza dentro de um determinado gênero em função das intenções comunicativas, como parte das condições de produção dos discursos” (PCN, p.21) ${ }^{27}$ [sic]. A proposta de ensinar a língua materna a partir da noção de gênero busca, sem dúvida, adaptar os saberes lingüísticos à prática da cidadania, a nova tendência para o século XXI. (ESP07, p. 10)

No que tange à argumentação voltada para as prescrições curriculares, a interpretação que segue enquadrou-se dentre aquelas que propuseram o contraste entre o prescrito para o ensino de Língua Portuguesa e o que é efetivado em sala de aula:

${ }^{27}$ Citação, em ESP07, a BRASIL. Secretaria da Educação Fundamental. Parâmetros Curriculares Nacionais: terceiro e quarto ciclos do ensino fundamental: língua portuguesa/ Secretaria da Educação Fundamental Brasília: MEC/ SEF, 1998. 
Tomando os aspectos didático-pedagógicos que foram percebidos nos materiais coletados, pude constatar que os métodos de ensino da produção textual escrita se assemelhavam na ênfase aplicada ao ensino gramatical antes e depois da promulgação da LDB 9.394/96 persistindo até 1998 nas práticas das professoras. A partir de então, começaram a se diferenciar a partir da inclusão de um trabalho voltado ao texto, pois a promulgação da última $L D B$ contribuiu para a constituição/consolidação de novos referenciais teóricometodológicos (PCN, CBA, Escola Ciclada), que acabaram por fundamentar outras propostas de organização do ensino e, em especial, o ensino de língua escrita. (FMT06a, p. 182-3)

Os dados apresentados no trecho a seguir relacionaram-se a interpretações como à supracitada e expuseram opiniões docentes ou registros das aulas observadas, que foram tratados como "fatos" provenientes da realidade escolar:

A consonância entre o planejamento anual da professora Aline e seus registros oficiais manifestados [...] fortalecia a negação às prescrições de caráter estadual e afirmava a aceitação das normas prescritas na LDB 5.692/71, que regulamentou como meta para o ensino de Língua Portuguesa a formação de um aluno que tivesse desenvolvidas suas habilidades funcionais, ou seja, apto para atuar no mercado de trabalho, induzindo a um ensino tecnicista, com uma concepção de linguagem voltada à comunicação. Eram priorizados para este ensino a comunicação e a expressão, e, para tal, eram dadas regras, tanto de estruturas lingüísticas como de interpretação textual, como se os efeitos de sentido pudessem ser controlados. Ambos os documentos: tanto o planejamento anual quanto os registros nos diários da professora Aline, revelaram que a produção escrita acontecia, mas, ainda não era considerada o objeto de ensino principal naquele momento. (FMT06a, p. 119120)

Outra argumentação que merece menção é aquela que se voltou para os aspectos apresentados como característicos das condições do ensino brasileiro. Esta proposta de reflexão compareceu em EPR04, EPR06 e EPA08. Desta última, citamos um exemplo:

Nossas reflexões acerca das orientações ao professor postas nos PCN de Lingua Portuguesa para o terceiro e quarto ciclos do Ensino Fundamental permitem afirmar que o discurso construído para orientar o público a quem eles se destinam ignora a falta de investimentos na educação e desvia os problemas decorrentes disso à escola e ao professor. (EPA08, p. 183)

As ponderações acerca do contexto educacional brasileiro são defendidas tendo em vista dados, como o que segue, apresentados como "factuais": 
São desconsideradas também as ações políticas partidárias as quais esses profissionais estão expostos. Pois, nas comunidades mais isoladas dos centros urbanos, por resistirem às imposições políticas, os professores são constantemente remanejados para outros ambientes de trabalho, o que não lhes permite desenvolver uma coerência e acompanhar a formação de seus alunos. Dadas essas circunstâncias, muitas vezes, o trabalho da escola corresponde apenas à soma do trabalho isolado de cada professor e não ao produto da ação coletiva dos educadores. (EPA08, p. 112)

Além desses dados, a referência a seguir foi tomada como "verdade" admitida no interior do trabalho:

Questionamos que esse discurso [Referência aos Parâmetros Curriculares Nacionais] ignora a falta de investimentos na educação brasileira e atribui os problemas decorrentes desse fato apenas à escola. Com relação a essa questão, Soares $(1998)^{28}$ diz que a educação compensatória fracassa porque atribui à escola um poder que ela não tem: o de "compensar as desigualdades sociais que estão fora dela e que têm sua origem no antagonismo das relações sociais e econômicas, de que a escola não tem condições de fugir" (p. 36). Dessa forma, podemos dizer que esses argumentos acabam por colocar na escola uma série de responsabilidades que não são especificamente educacionais, mas também da ineficácia das políticas sociais, inclusive para a educação. (EPA08, p. 102)

Como anunciado, o nosso corpus ressaltou os "fatos" e as "verdades" mais presentes na argumentação das dissertações sob enfoque. Conforme demonstramos, elas se voltaram para a defesa do ensino de Língua Portuguesa incorporando os "gêneros" e as atividades de revisão e reelaboração textual, bem como apontaram falhas na formação e na atuação docente. Também citaram insuficiências quanto ao aprendizado dos alunos e discutiram metodologias de ensino, envolvendo, ou não, recursos computacionais. Ademais, focalizaram o livro didático quanto ao seu uso, conteúdo e às formas como são selecionados pelos professores e ponderaram acerca das condições de ensino observadas.

Uma vez concluída a apresentação do nosso corpus, quanto às interpretações de dados, aos "fatos" e às "verdades" centrais na argumentação das produções sob análise, passamos à reflexão sobre o que foi, no interior da presente tese, diferenciado enquanto "coleta de dados" e "composição do corpus".

\footnotetext{
${ }^{28}$ Citação, em EPA08, a SOARES, M. Concepções de linguagem e o ensino de língua portuguesa: In: BASTOS, N. B. (Org.) Língua portuguesa: história, perspectivas, ensino. São Paulo: EDUC, 1998.
} 


\subsection{Distinções entre coleta de dados e composição do corpus}

Observando o apêndice A, localizamos a transcrição dos excertos dos resumos das 321 dissertações de mestrado localizadas por meio da busca on-line. O levantamento desses resumos permitiu os mapeamentos e as reflexões que foram apresentados no capítulo 1 desta tese. Contudo, a necessidade de aprofundar as análises do material coletado implicou a composição de um corpus que viabilizasse a leitura integral das dissertações.

Para a elaboração desse corpus, foram estabelecidos os critérios anteriormente relatados. Esta passagem, que redundou na diminuição de todo o material coletado para algumas produções selecionadas para serem focalizadas no restante desta tese, demanda algumas reflexões acerca das distinções entre coleta de dados e composição do corpus.

Para esta reflexão, levamos em conta a dispersão de informações que nos chegam, haja vista, inclusive, o grande número de publicações em ambientes virtuais. Severino (2007, p. 140) destaca esta problemática, conforme segue:

O que se pode pesquisar na Internet? Como se trata de uma enorme rede, com um excessivo volume de informações, sobre todos os domínios e assuntos, é preciso saber garimpar, sobretudo dirigindo-se a endereços certos.

A disponibilização de tantas formas de acesso às informações, potencializada pela Internet, não pode ser desconsiderada por nenhum pesquisador durante a busca de dados a serem pesquisados. Firma-se, então, como conduta necessária contrastar o que seria todo o material pertinente para análise, decorrente, no caso, de sua investigação virtual, e o que foi efetivamente selecionado para constituir o corpus.

Submetendo-nos a esse exercício de reflexão, ponderamos que a coleta de dados, na presente tese, caracterizou-se como o movimento de identificação do conjunto vário de dissertações que, potencialmente, mantinham relações com o foco de reflexão desta pesquisa. Já a composição do corpus delimitou-se pela intervenção intencional na realidade focalizada, 
segundo os critérios que foram estabelecidos nesta tese como viáveis para a seleção do material que será analisado nos capítulos que seguem.

A partir disso, interessa-nos ressaltar que os resultados a que chegamos foram aqueles que se destacaram segundo o processo analítico que adotamos, o que não se confunde com qualquer hegemonia interpretativa. O interesse das análises e discussões que defendemos localiza-se, não em uma suposta unicidade interpretativa, mas na representatividade que elas têm da realidade investigada, que foi observada e interpretada pelo prisma dos subsídios metodológicos e conceituais em que a presente pesquisa ancora-se.

Um entendimento como esse, por um lado, impõe que os resultados sejam tratados adequadamente, isso é, como representativos de algumas características do universo que integra, e, por outro lado, reivindica pesquisas posteriores que possam ir, paulatinamente, ampliando a compreensão do cenário pesquisado, considerando, inclusive, a sua relação com outras investigações sobre o mesmo tema ou com abordagens similares. Avaliamos que os objetivos elencados por esta tese podem dar vazão a novas pesquisas, que continuem analisando a produção de pós-graduação sobre ensino de Língua Portuguesa e o que esta produção acaba por reproduzir e também por disseminar.

Vale ressaltar que livros de metodologia científica costumam tratar da relação entre o conjunto total de dados e seus subconjuntos na elaboração de pesquisas científicas. Considerações desse caráter podem ser localizadas em afirmações como "A amostra é uma parcela convenientemente selecionada do universo [...]" (LAKATOS, E. M.; MARCONI, M. de A., 2010, p. 147) ou de que:

[...] de acordo com a natureza da pesquisa, devem-se determinar as técnicas que serão empregadas na coleta de dados e na determinação da amostra, que deverá ser representativa e suficiente para apoiar as conclusões. (LAKATOS, E. M.; MARCONI, M. de A., 2010, p. 169)

Robert Bogdan e Sari Biklen (1994, p. 207), no livro Investigação qualitativa em educação, sugerem a importância de se restringir o universo de coleta de dados, diminuindo-o de acordo com as especificidades da pesquisa em desenvolvimento. Esta recomendação vem 
expressa pelo seguinte aforismo: "Obrigue-se a tomar decisões que estreitem o âmbito do estudo". Sobre ele, explicam:

[...] na maioria dos estudos, a recolha de dados assemelha-se a um funil. Primeiramente, recolhe os dados de uma forma mais ampla [...] Depois de ter encontrado um assunto para investigar, baseado tanto naquilo que é possível realizar como naquilo que lhe interessa, estreite o âmbito da recolha de dados. (BOGDAN, R.; BIKLEN, S., 1994, p. 207)

Dos trechos citados anteriormente, captam-se as ideias de amostragem e de restrição dos ambientes de coleta de dados. Considerando os distintos vieses de discussão trazidos pelos fragmentos anteriores e sem adentrar em suas especificidades, importa-nos registrar a percepção de que as reduções provocadas pelos dispositivos investigativos abordados nas citações anteriores, obrigatoriamente, reduzem o campo de representatividade dos dados com que se trabalha. Isso significa que quando se trabalha com uma parte dos dados, ela tem valor por representar algumas características do material analisado, o que não legitima enxergar o todo como se ele se limitasse a tal caracterização.

No caso da presente investigação, restringimos nossa coleta de dados ao Banco de Teses da CAPES, no qual buscamos material relacionado ao período estudado. A isso, seguiuse um novo recorte, desta vez, localizado em especificidades condizentes com o interesse desta pesquisa: analisar unicamente versões eletrônicas de dissertações de mestrado defendidas em IES públicas estaduais ou federais e que focalizassem o Ensino Fundamental da Educação Básica, sem mobilizar dados da Educação Especial. Como terceira e última etapa de estreitamento dos dados a serem considerados, formamos um corpus que resultou da análise da argumentação das dissertações, a partir do referencial da nova retórica.

A abordagem desta distinção entre coleta de dados e composição do corpus, bem como suas implicações, marca a proposta de alinharmo-nos às ideias que capturam as relações entre "fazer científico" e "subjetividade". Sobre esta questão, é importante retomar o trabalho de Coracini (1991, p. 46), em que a autora defende que o discurso científico constrói, por meio da linguagem, a ilusão de efetiva aproximação da realidade, a fim de convencer os interlocutores daquilo que estão defendendo. 
Ao contrário desta aproximação efetiva da realidade, ocorre que as teses enunciadas no trabalho científico são fruto da construção textual-discursiva elaborada a partir de critérios que, ainda que possam ser testados pela avaliação racional, não excluem sua caracterização enquanto concretização de determinadas opções teóricas, conceptuais e metodológicas que determinarão não somente o prisma pelo qual será tratado o tema sob enfoque, mas condicionarão sua própria validade científica, tal como foi concebido por Ferdinand de Saussure no Curso de Linguística Geral (2006, p. 15): “[...] Bem longe de dizer que o objeto precede o ponto de vista, diríamos que é o ponto de vista que cria o objeto [...]".

A inexistência da total objetividade no discurso científico não implica o seu descrédito enquanto gerador de conhecimentos socialmente válidos, haja vista que, conforme afirma Geraldi (1991, p. 76):

[...] o abandono da 'ilusão objetivista' [NÃO] corresponde pura e simplesmente à abertura de um espaço para a 'ilusão da opinião': em todas as ciências se constituíram rotinas e métodos de pesquisa que impedem tanto a subjetividade da opinião quanto a influência incontrolada de interesses pessoais. Isto não quer dizer que não seja o interesse que guie a construção do conhecimento. Antes, aponta para a necessidade contínua da avaliação crítica dos padrões que constituíram as condições históricas da objetividade possível em determinado momento.

Considerando as ponderações até aqui expostas, voltamo-nos à configuração do discurso, tal como ele foi materializado no nosso corpus. 


\section{A CONFIGURAÇÃO DE UM DISCURSO}

Tendo em vista as referências teóricas com as quais dialoga a presente tese, o "discurso" possui como unidade básica o "enunciado", que é, por sua vez, compreendido enquanto condição de possibilidade para que uma frase ou proposição ocorra em uma produção, no caso do nosso corpus, de caráter científico.

Tal condição de possibilidade é materializada pelo enunciado, que "não é em si mesmo uma unidade, mas sim uma função que cruza um domínio de estruturas e de unidades possíveis e que faz com [signos] apareçam, com conteúdos concretos, no tempo e no espaço". (FOUCAULT, 2005, p. 98)

Esta formulação conceptual do "enunciado", enquanto função que perpassa transversalmente conjuntos de signos determinando o que seja passível de compor um "discurso", parece compatível com uma das passagens que comparece na abertura de A ordem do discurso, quando Foucault (2004a, p. 7) propõe o seguinte diálogo:

O desejo diz: "Eu não queria ter de entrar nesta ordem arriscada do discurso; não queria ter de me haver com o que tem de categórico e decisivo; gostaria que fosse ao meu redor como uma transparência calma, profunda, indefinidamente aberta, em que os outros respondessem à minha expectativa, e de onde as verdades se elevassem, uma a uma; eu não teria senão de me deixar levar, nela e por ela, como um destroço feliz". E a instituição responde: "Você não tem por que temer começar; estamos todos aí para lhe mostrar que o discurso está na ordem das leis; que há muito tempo se cuida de sua aparição; que lhe foi preparado um lugar que o honra mas o desarma; e que, se lhe ocorre ter algum poder, é de nós, só de nós, que ele lhe advém”.

Nesta citação, contrariamente à transparência de uma produção discursiva ligada unicamente ao seu momento de enunciação, comparece o "discurso" com os seus sentidos sob a "ordem das leis", institucionalizada. No caso das dissertações de mestrado que analisamos, propomos compreender esta "ordem" por meio do conceito de "disciplina". Por isso, ao voltarmo-nos para a análise do discurso do nosso corpus temos como propósito discorrer 
sobre o quadro teórico-metodológico que se destaca como legítimo na pesquisa em ensino de Língua Portuguesa.

Considera-se, assim, que a "ordem do discurso" possui "uma função normativa e reguladora”. (REVEL, 2005, p. 37) Conforme Foucault (2005, p. 132-3), o discurso "não forma uma unidade retórica ou formal, indefinidamente repetível e cujo aparecimento ou utilização poderíamos assinalar [...] na história; é constituído de um número limitado de enunciados para os quais podemos definir um conjunto de condições de existência”.

$\mathrm{Na}$ análise do discurso do nosso corpus, não procuramos, pois, localizar um mesmo discurso enquanto "unidade retórica ou formal", buscamos avaliar, na dispersão de seus argumentos, "enunciados" que se repetem e, a partir dos quais, o discurso sob enfoque se configura em termos "disciplinares". Desse modo, no que segue, apresentamos algumas considerações sobre o conceito de "disciplina".

\subsection{A “disciplina” em Michel Foucault}

Nesta tese, mobilizamos o conceito de "disciplina", tal como ele é apresentado em $A$ ordem do discurso (FOUCAULT, 2004). Originalmente, trata-se de um livro que apresenta a aula inaugural que foi ministrada por Michel Foucault, no Collège de France, em 1970. A ideia de "disciplina", que compõe a ordem do discurso analisada por esse autor, caracteriza-se pela regulamentação do que se considera como aceitável na produção discursiva que constitui determinada área do conhecimento científico.

Sobre o conceito de "disciplina", postula-se o seguinte:

A organização das disciplinas se opõe tanto ao princípio do comentário como ao do autor. Ao do autor, visto que uma disciplina se define por um domínio de objetos, um conjunto de métodos, um corpus de proposições consideradas verdadeiras, um jogo de regras e de definições, de técnicas e de instrumentos: tudo isto constitui uma espécie de sistema anônimo à 
disposição de quem quer ou pode servir-se dele, sem que seu sentido ou sua validade estejam ligados a quem sucedeu ser seu inventor. Mas o princípio da disciplina se opõe também ao do comentário: em uma disciplina, diferentemente do comentário, o que é suposto no ponto de partida, não é um sentido que deve ser repetida; é aquilo que é requerido para a construção de novos enunciados. Para que haja disciplina é preciso, pois, que haja possibilidade de formular, e de formular indefinidamente, proposições novas. (FOUCAULT, 2004a, p. 30)

$\mathrm{Na}$ citação anterior, observa-se que a "disciplina" é contraposta a outros dois conceitos, a de "autor" e a de "comentário". Os três compõem o que Foucault definiu como procedimentos internos de controle do discurso. Esta classificação foi decorrente de eles serem compreendidos como mecanismos segundo os quais os próprios discursos exercem o seu controle, de modo a evitar a aparição do acaso, isso é, daquilo que ainda não faz parte do domínio discursivo em questão.

De acordo com esta concepção, o "autor" exerce uma função de controle ao viabilizar a concretização de um projeto de escrita que une dizeres que obedecem a critérios de coerência que acabam por evitar a dispersão dos significados, uma vez que o projeto em questão é construído tendo em vista um mesmo eixo "autoral". O autor é então caracterizado como um "princípio de agrupamento do discurso, como unidade e origem de suas significações, como foco de sua coerência”. (FOUCAULT, 2004a, p. 26)

A função-autor caracteriza-se, pois, como um mecanismo de coerção que se efetiva no exercício concretizado pelas escolhas do que deve ser mantido em um mesmo discurso e o que deve ser descartado, rejeitado. Esse entrelaçamento de algumas ideias e recusa de outras não equivale ao indivíduo que assina o texto, mas ao "princípio de uniformização" que subjaz à produção de um discurso e que, enquanto tal, norteia os posicionamentos daquele que assume a função de responsabilizar-se por sua autoria.

Além da função-autor, também se destaca, na efetivação do controle do discurso por ele mesmo, aquilo que é denominado como “comentário", que é, por sua vez, defendido como um recurso presente em todas as sociedades que contam, repetem e fazem variar suas narrativas, já que se define como: 
[...] uma espécie de desnivelamento entre os discursos: os discursos que "se dizem" no correr dos dias e das trocas, e que passam com o ato mesmo que os pronunciou; e os discursos que estão na origem de certo número de atos novos de fala que os retomam, os transformam ou falam deles, ou seja, os discursos que, indefinidamente, para além de sua formulação são ditos, permanecem ditos e estão ainda por dizer. (FOUCAULT, 2004a, p. 22)

Nesta citação, aponta-se para o "comentário" como decorrente da necessidade que certos discursos impõem de serem retomados. Pela adoção desse procedimento, o que foi dito é reiterado a partir de outro ponto de vista, para assim se considerar outros enfoques, em relação aos quais se busca compreender no discurso uma vez pronunciado elementos pertinentes para novas interpretações. Esta movimentação em torno do que e como se comenta está no bojo da produção científica e, sendo assim, também caracteriza a presente tese.

Na retomada que estamos fazendo da obra de Michel Foucault e de outros autores que estamos citando, também concretizamos o exercício de compreender o que foi dito enquanto ele mesmo é aqui repetido. Há nisso um "comentário" de que falamos e sobre o qual nos ancoramos.

A reiteração do que é problematizado no próprio ato de problematização foi relacionada à obra de Michel Foucault por Dreyfus e Rabinow (2010, p. 137), que afirmaram o que segue:

A definição de Foucault de sua própria posição com respeito às ciências humanas subentende uma transformação radical. O investigador não é mais o espectador desligado dos monumentos discursivos mudos. Foucault compreende e aborda o tema de estar ele mesmo - como qualquer outro investigador - envolvido com e ser, em grande parte, produzido pelas práticas sociais que estuda.

A inexistência desta linha separatória entre o investigador e o mundo que ele investiga coloca a difícil tarefa de abordar alguns problemas estando "no olho do furacão". Esta expressão aparece aqui com o intuito de metaforizar o aspecto mais desafiador da presente 
tese, que é, exatamente, o de abordar as conjecturas disciplinares presentes na produção de mestrado sobre ensino de Língua Portuguesa estando ela mesma, enquanto trabalho científicoacadêmico, sujeitada e amparada pelas delimitações do campo de atuação em que também se encontra, qual seja, o da universidade.

Sobre a ideia de "universidade" e embasados pelo que seria o ponto de vista estruturalista de Foucault, Dreyfus e Rabinow (2010, p. 87) colocam que o:

[...] funcionamento da universidade depende de um grande número de relações primárias - incluindo as práticas econômicas, políticas, familiares, institucionais, arquitetais e pedagógicas -, porém, esses diferentes elementos podem coexistir na universidade moderna apenas devido a algo que foi denominado "a ideia de Universidade". Contudo, esse conceito, até certo ponto comum aos administradores, professores e estudantes, é ele mesmo uma "relação secundária" condicionada por algo mais. Este fator final unificador não pode ser descrito em termos objetivos nem mentais. É, ao contrário, um modo aceitável de falar (descrever, discursar, demandar, anunciar) que é tomado seriamente em um domínio chamado educação superior. Esse tipo específico de discurso, sem dúvida, é relacionado àquilo que os administradores, professores e estudantes pensam sobre educação universitária, mas esse modo de pensar não organiza todas as funções que constituem o sistema universitário assim como o fazem as várias forças sociais e econômicas. O que organiza as relações institucionais e o pensamento é, finalmente, que o sistema de regras que determinam a espécie de discurso sobre educação (e quais os sujeitos de discurso) pode, em um dado período, ser considerado sério. São essas regras que "regulam" aquilo que pode ser dito seriamente, que, por mais contra a intuição que possa parecer à primeira vista, "efetuam" ou "instauram" a vida da universidade tal qual a conhecemos.

$\mathrm{Na}$ presente pesquisa, fomos buscar como esse modo aceitável de falar, discursar, descrever concretizava-se em pesquisas de mestrado e como elas se sustentavam enquanto um modo sério e aceitável de circularem no espaço da universidade. Os resultados dessa busca foram expostos em descrições, análises e interpretações que constituem o texto desta tese que, por sua vez, também não escapa à coerção de ser aceita como exemplo de comprometimento ao rigor necessário às produções que se querem legítimas no âmbito universitário.

Essa reflexão leva-nos ao entendimento de que não cabem, na discussão que fazemos sobre as dissertações de mestrado sob enfoque, julgamentos valorativos, quanto ao que seria melhor ou pior, mas avaliar e debater aspectos que caracterizam a pesquisa de mestrado em 
ensino de Língua Portuguesa e o que isso pode demonstrar sobre o que se legitima nesse tipo de investigação e como essa legitimação desdobra-se em termos de coerções disciplinares.

A escolha do conceito foucaultiano de "disciplina" veio ao encontro de nossa expectativa de tratamento das dissertações, pois, por meio dele, acreditamos deixar claro o propósito de verificar características do quadro coercitivo aceito na investigação sobre ensino de Língua Portuguesa, sem esquecermos que também estamos abordando esse tema do interior de um arcabouço teórico-metodológico específico, o que implica não apresentar nossos resultados em termos de "acerto" e de "erro", mas discutindo-os quanto ao que compareceu como sendo "sério" - de modo a retomar o adjetivo presente na citação anterior de ser defendido quando o tema de pesquisa é o ensino de português.

Sobre a questão do que seja "acertado" ou "equivocado" no que se refere à produção científica, Foucault (2004a, p. 34-5) elucida-a do seguinte modo:

Muitas vezes se perguntou como os botânicos ou os biólogos do século XIX puderam não ver que o que Mendel dizia era verdade. Acontece que Mendel falava de objetos, empregava métodos, situava-se num horizonte teórico estranhos à biologia de sua época. Sem dúvida Naudin, antes dele, sustentara a tese de que os traços hereditários eram descontínuos; entretanto, embora esse princípio fosse novo ou estranho, podia fazer parte - ao menos a título de enigma - do discurso biológico. Mendel, entretanto, constitui o traço hereditário como objeto biológico absolutamente novo, graças a uma filtragem que jamais havia sido utilizada até então: ele o destaca da espécie e também do sexo que o transmite; e o domínio onde o observa é a série indefinidamente aberta das gerações na qual o traço hereditário aparece segundo regularidades estatísticas. Novo objeto que pede novos instrumentos conceituais e novos fundamentos teóricos. Mendel dizia a verdade, mas não estava "no verdadeiro" do discurso biológico de sua época: não era segundo tais regras que se constituíam objetos e conceitos biológicos; foi preciso toda uma mudança de escala, o desdobramento de todo um novo plano de objetos na biologia para que Mendel entrasse "no verdadeiro" e suas proposições aparecessem, então, (em boa parte) exatas. Mendel era um monstro verdadeiro, o que fazia com que a ciência não pudesse falar nele; enquanto Schleiden, por exemplo, uns trinta anos antes, negando, em pleno século XIX, a sexualidade vegetal, mas conforme as regras do discurso biológico, não formulava senão um erro disciplinado.

A expressão "erro disciplinado", com a qual encerra esta citação, salienta que um equívoco apresentado em conformidade com os padrões aceitos na produção científica tem 
um lugar garantido de discussão, mesmo que seja para ser refutado. Contudo, aquilo que se apresenta para além desses padrões, desloca-se para um lugar de mutismo, que se caracteriza por toda uma "teratologia do saber" (FOUCAULT, 2004a, p. 33), ou seja, define-se enquanto um espaço que não é reconhecido como parte do saber científico. Nesse segundo caso, enquadrou-se Mendel, em relação ao novo conhecimento biológico que ele trazia e que foi retratado na citação anterior.

A "disciplina" entendida como esse agrupamento de diretrizes delimitadoras do que pode ou não pode compor a produção científica demonstra, de um lado, sua capacidade multiplicadora e, de outro, o papel restritivo que exerce. Esse potencial multiplicador advém do entendimento de que a delimitação de um modo de produzir conhecimento fornece mecanismos de aprofundamento das investigações em jogo, o que favorece sua ampliação em termos de avanços científicos e de sua literatura específica. Essa delimitação, contudo, também efetiva restrições ao colocar à margem tudo aquilo que não foi, até o momento, legitimado e que somente o será quando se chegar a um grande questionamento dos padrões aceitos, os quais, por sua vez, passam a ser revistos, tal como ficou evidenciado pelo exemplo trazido na citação anterior.

A partir dessa abordagem, analisamos o corpus da presente pesquisa buscando avaliar características que determinam alguns aspectos delimitadores do que é aceito como legítimo na pesquisa de ensino de Língua Portuguesa. Nossa proposta não é, então, avaliá-la classificando-a como equivocada ou correta, mas voltando nosso enfoque para o que parece ser aceito no interior do quadro disciplinar em que o conhecimento sobre ensino de português ganha estatuto de aceitabilidade científica, podendo assim circular nos espaços científicoacadêmicos.

O interesse desse tipo de análise reside no teor de problematização acerca do conhecimento produzido, em termos de aceitabilidade e de recusa. A reflexão sobre o que tem recorrentemente comparecido na pesquisa sobre ensino de Língua Portuguesa favorece a discussão dos objetos, métodos, referenciais legitimados e das proposições aceitas, ao invés da tomada de partido por cada uma dessas opções.

Tendo em vista essa proposta de reflexão, reiteramos que escolhemos lidar com o conceito de "disciplina", tal como foi exposto, pois ele veio ao encontro da discussão sobre como, em um dado momento, as escolhas científicas podem ser analisadas pelo que têm de homogêneo, isso é, pelo que têm de recorrente. 
Apesar de termos pontuado esse conceito em específico, compreendemos que toda a obra de Michel Foucault traz elementos propiciadores ao questionamento sobre como a produção científica consolida-se. Desse universo de discussão, procuramos nos aproximar por meio da investigação ora apresentada nesta tese.

Sobre tal universo de discussão, vale citar como Foucault (2004b, p. 3-4) expõe sua problemática:

Meu problema não foi absolutamente de dizer: viva a descontinuidade, estamos nela e nela ficamos; mas de colocar a questão: como é possível que se tenha em certos momentos e em certas ordens de saber, estas mudanças bruscas, estas precipitações de evolução, estas transformações que não correspondem à imagem tranqüila e continuista que normalmente se faz? Mas o importante em tais mudanças não é se serão rápidas ou de grande amplitude, ou melhor, esta rapidez e esta amplitude são apenas o sinal de outras coisas: uma modificação nas regras de formação dos enunciados que são aceitos como cientificamente verdadeiros. Não é portanto uma mudança de conteúdo (refutação de erros antigos, nascimento de novas verdades), nem tampouco uma alteração da forma teórica (renovação do paradigma, modificação dos conjuntos sistemáticos). O que está em questão é o que rege os enunciados e a forma como estes se regem entre si para constituir um conjunto de proposições aceitáveis cientificamente e, consequentemente, susceptíveis de serem verificadas ou infirmadas por procedimentos científicos.

O "regime de verdade" que se torna predominante em determinado momento histórico e as relações de poder que são engendradas nesse regime é uma reflexão a ser considerada a partir desta citação. Em As Palavras e as Coisas (FOUCAULT, 1999), por exemplo, essa problemática foi discutida pelo autor no que se referiu à constituição de saberes que tematizaram o homem como objeto e como sujeito de conhecimento.

Nessa obra, o autor discute como o pensamento moderno põe fim à metafísica da vida e detém-se no "homem" enquanto objeto de conhecimento. Essas irrupções na história das ideias são tratadas na obra em questão considerando-se sua descontinuidade: "O descontínuo - o fato de que em alguns anos, por vezes, uma cultura deixa de pensar como fizera até então e se põe a pensar outra coisa e de outro modo [...]". (FOUCAULT, 1999, p. 69) 
As descontinuidades detectáveis na constituição dos saberes também foram tematizadas nas análises apresentadas em História da Loucura (FOUCAULT, 2010) e $O$ Nascimento da Clínica (FOUCAULT, 2011), nas quais se focalizaram as rupturas ocorridas na constituição e legitimação dos saberes. Nessa última obra, o foco foi a passagem do que seria a medicina clássica para a medicina moderna. Já em História da Loucura (2010), apresentou-se a sucessão de métodos e referenciais conceptuais que abriram espaço para o surgimento da psicologia:

Para além do longo silêncio clássico, a loucura reencontra assim sua linguagem. Mas uma linguagem com significações bem diferentes; ela esqueceu os velhos discursos trágicos da Renascença onde se falava do dilaceramento do mundo, do fim dos tempos, do homem devorado pela animalidade. Ela renasce, essa linguagem da loucura, mas como uma explosão lírica: descoberta de que no homem o interior é também o exterior, de que o ponto extremo da subjetividade se identifica com o fascínio imediato do objeto, de que todo fim está voltado à obstinação do retorno. Linguagem na qual não mais transparecem as figuras invisíveis do mundo, mas as verdades secretas do homem. (FOUCAULT, 2010, p. 511)

Do enclausuramento ao tratamento médico é o percurso que vai sendo analisado em História da Loucura, tendo em vista suas descontinuidades culturais e a descrição dos espaços de internamento e de exclusão. Dreyfus e Rabinow (2010) retomam essa obra destacando as mudanças ocorridas do Renascimento à Época Clássica, em que os leprosários da Europa deixaram de receber os leprosos para servirem como casas de internação de loucos. A essa mudança perceptiva dessa figura histórica, "o louco", seguiu-se outra transformação, segundo a qual a razão e a loucura do período clássico deixaram de assim serem percebidas pelas épocas que lhe foram posteriores, nas quais se passou a tratar o que, antes, era o "louco" como o "insano": "É através da pessoa do médico que a loucura se transforma em insanidade e assim é integrada como um objeto de investigação no domínio da medicina”. (DREYFUS; RABINOW, 2010, p. 11)

As obras destacadas até então instigam a proposta de pesquisa desta tese, uma vez que ela extraiu o seu foco de interesse dessas reflexões que se voltam para aquilo que o conhecimento humano defende como verdadeiro, mas sem ignorá-lo como resultante de forças sociais, econômicas, culturais e políticas que se presentificam no conjunto de fatos e de 
interpretações legitimados numa dada esfera do saber. Compreendemos que o delineamento da exata dimensão dos acontecimentos que convergem para um conjunto de referenciais e de proposições que passam a ser aceitos - como a mudança da caracterização de "louco" para "insano", que se abordou anteriormente, ou a alteração no estatuto cedido à autópsia, que deixa de ser considerada uma prática indevida para ser compreendida como um uso médico legítimo, conforme explorado em O Nascimento da Clínica (2011) - não fosse o objetivo das obras em questão, mas sim a problematização da constituição desses saberes quanto ao seu aspecto de verdade absoluta.

Esse tipo de problematização inspirou pensarmos a produção de conhecimento sobre ensino de Língua Portuguesa, em investigações de mestrado, não quanto aos seus possíveis avanços teóricos e à ampliação das reflexões sobre essa temática, mas tentando avaliar como a legitimidade do que seja pesquisar ensino de Língua Portuguesa comparece na recorrência dos objetos que são construídos e dos modos aceitos para abordá-los. Entendemos que as análises e os resultados apontados nesta tese são circunscritos às escolhas que fizemos em relação ao nosso corpus, conforme debatemos na seção 2.3, e às referências teórico-metodológicas adotadas.

Contudo, isso não invalida que, desta pesquisa de doutorado, possam decorrer outras investigações que queiram percorrer a constituição dos saberes em ensino de Língua Portuguesa pelo prisma dos métodos e dos referenciais presentes neste trabalho. Ou seja, com isso, queremos defender que esta pesquisa abre um leque de possibilidades de reflexão, em especial, para a presente pesquisadora e, também, para outros que verifiquem nele aspectos merecedores de discussão futura.

Como aponta Roberto Machado (2004, p. X), o interesse por compreender a constituição dos saberes e suas transformações é central para as obras de Foucault. Projeto que é efetivado segundo o seu método arqueológico em livros da década de 60, História da Loucura, O Nascimento da Clínica e As Palavras e as Coisas. Sobre esse método, A Arqueologia do Saber apresenta reflexões sistematizadoras. Na citação a seguir, são citadas essas e outras características da obra de Michel Foucault:

Ora, quando consideramos a produção teórica materializada nesses livros [trata-se dos livros a que fizemos referência no parágrafo anterior] e, minimizando as pequenas ou grandes diferenças que podem existir entre 
eles, os comparamos em bloco ao que será realizado a partir de então, percebemos claramente se abrir um novo caminho para as análises históricas sobre as ciências. Se Foucault não invalida o passado, ele agora parte de outra questão. Digamos que a arqueologia, procurando estabelecer a constituição dos saberes privilegiando as interrelações discursivas e sua articulação com as instituições, respondia a como os saberes apareciam e se transformavam. Podemos então dizer que a análise que em seguida é proposta tem como ponto de partida a questão do porquê. [...] É essa análise do porquê dos saberes, que pretende explicar sua existência e suas transformações situando-o como peça de relações de poder ou incluindo-o em um dispositivo político, que em uma terminologia nietzcheana Foucault chamará genealogia. Parece-me, em suma, que a mutação assinalada por livros como Vigiar e Punir, de 1975, e A Vontade de Saber, de 1976, primeiro volume da História da Sexualidade, foi a introdução nas análises históricas da questão do poder como um instrumento de análise capaz de explicar a produção dos saberes. (MACHADO, 2004, p. X)

Nesta citação, faz-se uma avaliação que remete aos livros considerados de duas épocas distintas, a primeira, denominada "arqueológica", voltada para a análise dos saberes que são formulados e que ganham legitimidade e a outra, chamada "genealógica", que interroga os porquês da consolidação de dados saberes. Michel Foucault (2004b, p. 172) diferencia esses dois métodos assim:

Enquanto a arqueologia é o método próprio à análise da discursividade local, a genealogia é a tática que, a partir da discursividade local assim descrita, ativa os saberes libertos da sujeição que emergem desta discursividade. Isto para situar o projeto geral.

Nas análises de caráter genealógico estava em jogo, então, não somente a delimitação do saber e as transformações que o envolvia, como também a análise da sujeição de determinados saberes ao discurso científico e também dos efeitos de poder desse mesmo discurso.

Voltamo-nos a essas caracterizações do pensamento de Michel Foucault porque assim podemos situar o conceito de "disciplina" a que nos remetemos, restringindo-o ao modo como ele compareceu em A ordem do discurso, que foi distinto da forma como ele apareceu em 
livros como Vigiar e Punir e no primeiro volume de História da Sexualidade, intitulado "A vontade de saber" e que abre a trilogia voltada para a investigação sobre a "sexualidade humana"

Nas duas últimas obras citadas, evidencia-se a "disciplina" como uma estratégia presente nas relações de poder. Sobre esse conceito no livro Vigiar e Punir, por exemplo, Deleuze (2005, p. 35) afirma que:

Uma das idéias essenciais de Vigiar e Punir é que as sociedades modernas podem ser definidas como sociedades "disciplinares", mas a disciplina não pode ser identificada com uma instituição nem com um aparelho, exatamente porque ela é um tipo de poder, uma tecnologia, que atravessa todas as espécies de aparelhos e de instituições para reuni-los, prolongá-los, fazê-los convergir, fazer com que se apliquem de um novo modo.

$\mathrm{Na}$ presente tese, não propomos análises que discorram sobre as "sociedades disciplinares", mencionadas no fragmento anterior. Buscamos, ao contrário, delinear a produção de mestrado sobre ensino de Língua Portuguesa quanto à constituição dos saberes que legitima, compreendendo-os como resultantes de delimitações pautadas pela normatização e caracterizadas como regulares, constituindo-se, assim, como uma "disciplina" específica.

Isso não significa que tal "disciplina" seja alheia aos suportes institucionais, ao contrário, ela é reforçada por meio de livros e é praticada no espaço da universidade. Na abordagem numérica que apresentamos, anteriormente, sobre a distribuição das dissertações de mestrado, por ano e por Estado brasileiro, ficam evidentes os vínculos entre a pesquisa em ensino de Língua Portuguesa e as IES.

No que diz respeito ao corpus especificamente, localizamos 06 dissertações vinculadas à Pós-Graduação em Educação, 05 à Letras, 02 à Linguística, 02 aos Estudos da Linguagem, 01 à Linguística Aplicada, 01 à Computação e 01 às Artes Cênicas. Compreendemos que tais vínculos institucionais participam das relações de poder na constituição dos saberes.

Contudo, tendo em vista o escopo desta pesquisa, conforme viemos expondo, em especial, no presente capítulo, não enveredaremos no sentido de analisar as relações de força 
implicadas, institucionalmente, na produção dos saberes do mestrado em ensino de Língua Portuguesa. Ponderamos, unicamente, que, além das informações que, por ora, apresentamos, também interessaria, para o caso de se refletir sobre o panorama de forças implicadas, a verificação da formação dos professores orientadores. No caso da dissertação vinculada à PósGraduação em Artes Cênicas, por exemplo, um dado que se soma a essa conjectura institucional é o doutoramento do professor orientador na área da Educação.

Diante do exposto, passamos às distinções pertinentes para a caracterização do que sejam proposições disciplinares, em contraste a frases e enunciados.

\subsubsection{Algumas distinções entre frase, proposição e enunciado}

Como exposto acerca do conceito de "disciplina", presente em A Ordem do Discurso (FOUCAULT, 2004a), a "proposição" é um dos itens que funcionam na coerção do discurso, juntamente com a delimitação dos objetos e métodos de pesquisa e dos seus referenciais teóricos, conforme enfoque da presente tese.

Deleuze (2005, p. 13-4), no livro Foucault, enfatiza as distinções entre "frase", "proposição" e "enunciado", como se vê na citação a seguir:

Ele [Michel Foucault] não vai tratar daquilo que era, de mil maneiras, a preocupação dos arquivistas anteriores: as proposições e as frases. Ele vai negligenciar a hierarquia vertical das proposições, que se dispõem umas sobre as outras, e também a lateralidade das frases, onde cada uma parece responder a outra. Móvel, ele se instalará numa espécie de diagonal, que tornará legível o que não podia ser apreendido de nenhum outro lugar, precisamente os enunciados.

Da obra de Michel Foucault, da fase caracterizada como "arqueológica", conseguimos depreender variadas referências às noções de "enunciado", "proposição" e "frase". Antes de 
nos voltarmos aos seus livros propriamente ditos, citamos uma passagem de Deleuze (2005, p. 18) no que diz respeito às "frases":

[...] As frases, com efeito, remetem a um sujeito dito de enunciação, que parece ter o poder de fazer começar o discurso: trata-se do EU como pessoa linguística irredutível ao ELE, ainda que não seja explicitamente formulado, o "Eu" como embrayeur ou sui-referencial. A frase é então analisada de um duplo ponto de vista: da constante intrínseca (a forma do $\mathrm{Eu}$ ) e das variáveis extrínsecas (aquele que diz Eu vindo preencher a forma).

De acordo com o exposto, a "frase" é compreendida pelo seu funcionamento a partir dos elementos que a compõem em torno das pessoas do discurso. No caso, com especial atenção à primeira pessoa, que, no seu funcionamento intrínseco, estabelece-se como elemento sui-referencial, e, enquanto referência externa, volta-se a um ser no mundo que preenche essa forma do "eu".

Foucault (2005, p. 108-12) destaca que uma das características da frase é que o seu sujeito, enquanto elemento gramatical, localiza-se no interior do sintagma linguístico, diferentemente do que ocorre, por exemplo, no enunciado. Citam-se como "frases" aquelas formulações que se colocam sob análise a partir de suas características contextuais, a serem recuperadas, por exemplo, em relação aos dêiticos. No caso de uma formulação como "Já demonstramos que", suas condições de enunciação aparecem determinadas tendo em vista sua temporalidade, a que faz referência o advérbio "já", e aquele que faz a dupla operação de enunciar e preencher, enquanto referência externa, a forma pronominal elíptica "nós".

Em outros momentos, Foucault apresenta algumas frases ressaltando a interpretação de seus sentidos e os efeitos que geram nos seus leitores, sem se aprofundar em análises concernentes à "maquinaria linguística" propriamente dita.

Em História da Loucura (2010, p. 435), localizamos a menção a uma frase destacada enquanto dado incorporado à análise em questão, conforme segue: "Ele é digno de piedade, bem como dois ou três outros que ficariam melhor em alguma cidadela, por causa da companhia de seis outros que são loucos, e que os atormentam dia e noite". Foucault apresenta essa passagem como sendo uma frase dita por um prior da comuna francesa de 
Senlis pela defesa de que, no momento histórico abordado, fosse efetivada uma separação entre loucos e correcionários.

A menção a essa frase incorpora a análise de Foucault enquanto um dado que foi abordado da seguinte maneira: "E o sentido dessa frase será bem entendido pelo tenente de polícia, já que os internos em questão serão postos em liberdade”. (FOUCAULT, 2010, p. 435) Detendo-nos na análise foucaultiana sobre a frase em questão, observamos a ênfase dada, primeiro, ao seu "sentido" e, segundo, à ação decorrente de sua compreensão.

Quanto a esse segundo ponto, nota-se o destaque dado à força perlocucionária da passagem em questão, que leva o referido tenente a soltar alguns internos, no período histórico tratado pelo livro. Já no que diz respeito ao primeiro ponto, observa-se a referência à frase como uma unidade linguístico-semântica, caracterizada por ser: a) efetivamente pronunciada ou escrita; b) passível de ser recortada, enquanto "dado" a constituir um corpus, e c) interpretável, de modo a possibilitar a apreensão de seus sentidos.

Essas três características podem ser observadas na frase citada em História da Loucura, que transcrevemos anteriormente. Mas não só, em O Nascimento da Clínica (2011, p. 136), localizamos uma passagem em que se afirma que na “[...] primeira edição de Nosographie, Bichat tinha podido ler essa frase que foi para ele como que uma revelação: 'Que importa que a aracnóide, a pleura e o peritônio se situem em diferentes regiões do corpo, se suas membranas têm uma conformidade geral de estrutura? Não sofrem lesões análogas no estado de flegmasia?"”.

Não adentraremos na terminologia presente nesta citação, tampouco no seu papel no âmbito da proposta argumentativa de Foucault acerca da constituição da medicina moderna. Concentramo-nos em verificar neste excerto as características anteriormente pontuadas. Tratase, pois, de uma frase efetivamente escrita, tomada como um "dado" no interior das análises propostas por Foucault, no livro supramencionado, e que permite a apreensão de seus sentidos, tanto é assim que, conforme a citação anterior, ela foi como uma "revelação" para o médico do século XVIII.

Tais sentidos, passíveis de serem depreendidos de uma frase, aparecem discutidos do seguinte modo, em As palavras e as coisas (1999, p. 119-20): 
[...] É preciso tratar a língua como essas máquinas que, pouco a pouco, se aperfeiçoam: em sua forma mais simples, a frase é composta apenas de um sujeito, de um verbo, de um atributo; e toda adição de sentido exige uma proposição nova e inteira; assim as mais rudimentares máquinas supõem princípios de movimento que diferem para cada um de seus órgãos. Mas, quando elas se aperfeiçoam, submetem a um só e mesmo princípio todos os seus órgãos que, desse princípio, não são então mais do que intermediários, meios de transformação, pontos de aplicação; do mesmo modo, aperfeiçoando-se, as línguas fazem passar o sentido de uma proposição por órgãos gramaticais que não têm, eles mesmos, valor representativo, mas cujo papel é precisá-lo, religar seus elementos, indicar suas determinações atuais. Numa frase, e num só movimento, podem-se marcar relações de tempo, de consequência, de possessão, de localização, que entram realmente na série sujeito-verbo-atributo, mas não podem ser demarcadas por uma distinção tão vasta.

Neste ponto, aborda-se a apreensão dos sentidos de uma frase que, no seu formato, já não se limita à atribuição de um qualificativo a um sujeito ao qual se refere. Focalizam-se os sentidos construídos não pelas unidades linguísticas em si, mas pelas relações que elas estabelecem entre si. Sendo que, algumas delas, possuem somente um valor gramatical, como marcas de singular-plural, e que só podem ser compreendidas no tipo de fusão que realizam, como é o caso de uma conjunção como "que".

A essa "máquina" que é a língua, Foucault irá voltar-se, de acordo com a exposição que viemos apresentando, não para analisá-la em toda a sua complexidade, mas com a finalidade de diferenciar três níveis distintos de abordagem que partem da materialidade linguística como elemento de investigação, são eles: a frase, a proposição e o enunciado.

Essa distinção, quanto à frase e à proposição, pode ser identificada, por exemplo, na citação a seguir:

Consideremos um conjunto de palavras ou de símbolos. Para decidir se eles constituem uma unidade gramatical como a frase, ou uma unidade lógica como a proposição, é necessário e suficiente determinar segundo que regras foi construído. "Pierre est arrivé hier" forma uma frase, mas "Hier est Pierre arrivé", não; $A+B=C+D$ constitui uma proposição, mas $A B C+=$ $D$, não. Apenas o exame dos elementos e de sua distribuição em referência ao sistema - natural ou artificial - da língua permite estabelecer a diferença entre o que é proposição e o que não é, entre o que é frase e o que é mero acúmulo de palavras. Além disso, esse exame basta para determinar a que tipo de estrutura gramatical pertence a frase em questão (frase afirmativa, no 
passado, comportando um sujeito nominal etc.), ou a que tipo de proposição corresponde a série de signos visada (uma equivalência entre duas adições). (FOUCAULT, 2005, p. 113)

Neste trecho, verifica-se a abordagem da "proposição" enquanto uma unidade lógica e da "frase" enquanto uma unidade gramatical. Sobre essa, destaca-se que a não- compreensão de todos os sentidos de uma frase não é impedimento para que ela funcione gramaticalmente. O exemplo fornecido é "Isso eu lhe direi amanhã". (FOUCAULT, 2005, p. 114) Ainda que não possam ser precisados os referentes no mundo a que faz menção uma frase como esta, em termos gramaticais, ela é analisada como autônoma e completa. Quanto à proposição, defende-se que mesmo quando não se pode determinar sua veracidade ou falsidade, por exemplo, em proposições não-tautológicas das quais não se conhece os seus referentes, ela permanecerá como uma proposição, ainda que não se saiba sobre sua legitimidade.

O que caracteriza a proposição é a relação entre dois nomes por meio da cópula. Na proposição,

[...] todas as funções da linguagem são reconduzidas aos três únicos elementos que são indispensáveis para formar uma proposição: o sujeito, o atributo e o seu liame. O sujeito e o atributo são ainda da mesma natureza, pois que a proposição afirma que um é idêntico ou pertence ao outro: eles podem, pois, sob certas condições, trocar suas funções. (FOUCAULT, 1999, p. 111)

A isso, acrescenta-se:

[...] Há proposição - e discurso - quando se afirma entre duas coisas um liame de atribuição, quando se diz que isto é aquilo. A espécie inteira do verbo se reduz ao único que significa: ser. Todos os outros se servem secretamente dessa função única, mas a recobriram com determinações que a ocultam: acrescentaram-se-lhe atributos e, em vez de dizer "eu sou cantante", diz-se "eu canto"; acrescentaram-se-lhe indicações de tempo e, no lugar de se dizer "outrora eu sou cantante", diz-se "eu cantava"[...]. (FOUCAULT, 1999, p. 112-3) 
A relação de cópula, característica da proposição, é evidenciada na formulação "Duas quantidades iguais a uma terceira são iguais entre si”, citada em Arqueologia do Saber. (FOUCAULT, 2005, p. 106) Nela, o verbo realiza a cópula que estabelece uma relação de equivalência, atribuída ao sujeito em questão, no caso, às três quantidades a que se refere essa proposição. Quanto ao seu sujeito, observa-se que ele se caracteriza como uma posição "neutra, indiferente ao tempo, ao espaço, às circunstâncias", (FOUCAULT, 2005, p. 106), de modo que o determinante para a legitimação dessa proposição não se relaciona às marcas de espaço-tempo, dentre outras, mas à sua coerência com o sistema de axiomas a que obedece.

Defende-se, pois, que uma proposição só pode ser assim definida quando se conhece o sistema de axiomas a que ela satisfaz, constituído por determinadas regras e convenções. Segundo Deleuze (2005, p. 17), as "proposições remetem verticalmente a axiomas de nível superior, que determinam as constantes intrínsecas e definem um sistema homogêneo".

Foucault (2011, p. 154) dá exemplo da correspondência entre axioma e proposição por meio da exposição de um dado que ele apresenta em $O$ Nascimento da Clínica. Referindo-se ao médico Jean-Baptiste Bouillaud, cita-se o que segue: "Se existe um axioma em medicina, é a proposição de que não há doença sem sede. [...]".

Desta citação, depreendemos a relação entre axioma e proposição no interior de um sistema constituído por determinados saberes do campo da medicina. As proposições relacionam-se aos saberes constituídos, funcionando, então, como uma das delimitações de uma "disciplina" científica. Em A Ordem do Discurso (2004a, p. 32-3), o caráter "disciplinar" de uma proposição é considerado tendo em vista o seu valor de legitimidade quanto aos saberes em xeque, conforme é exemplificado na citação a seguir:

[...] a partir do século XIX, uma proposição não era mais médica, ela caía "fora da medicina" e adquiria valor de fantasma individual ou de crendice popular se pusesse em gogo noções a uma só vez metafóricas, qualitativas e substanciais (como as de engasgo, de líquidos esquentados ou de sólidos ressecados); ela podia e devia recorrer, em contrapartida, a noções tão igualmente metafóricas, mas construídas sobre outro modelo, funcional e fisiológico (era a irritação, a inflamação ou a degenerescência dos tecidos). 
Este excerto colabora para a compreensão do que Deleuze - conforme pode ser visto na citação que apresentamos no início desta seção -, tratou como "hierarquia vertical das proposições, que se dispõem umas sobre as outras". A partir dessa concepção, torna-se possível compreender essa hierarquização em termos de verdade e de falsidade.

Se voltarmo-nos ao exemplo abarcado pela última citação transcrita, notamos que, a partir do século XIX, conforme afirmado no trecho em questão, proposições reorganizaram-se de modo que algumas, aquelas tidas como pertinentes ao saber médico, sobrepuseram-se a outras, identificadas como inaceitáveis no âmbito desse mesmo saber e, assim, passaram a ser julgadas como falsas. Sobre isso, tem-se que: "No interior de seus limites, cada disciplina reconhece proposições verdadeiras e falsas, mas ela repele, para fora de suas margens, toda uma teratologia do saber". (FOUCAULT, 2004a, p. 33)

A presente tese volta-se, pois, à análise das estruturas proposicionais da pesquisa em ensino de Língua Portuguesa a fim de verificar como elas compõem, em conjunto com outros aspectos de ordem "disciplinar", a investigação em ensino de Língua Portuguesa. Porém, antes de analisarmos as recorrências discursivas em questão, trataremos do "enunciado", o último item diferenciado por Foucault na tríade "frase-proposição-enunciado".

Compreendemos o "enunciado" como um terceiro nível de análise, distinto daqueles exigidos pela "frase" e pela "proposição". Esses dois itens constituem-se e analisam-se a partir da caracterização anteriormente exposta. O enunciado é definido enquanto função que torna possível as formulações proposicionais e, como se cita a seguir, a construção de frases:

[...] Se não houvesse enunciados, a língua não existiria; mas nenhum enunciado é indispensável à existência da língua (e podemos sempre supor, em lugar de qualquer enunciado, um outro enunciado que, nem por isso, modificaria a língua). A língua só existe a título do sistema de construção para enunciados (mais ou menos exaustiva) obtida a partir de um conjunto de enunciados reais. Língua e enunciado não estão no mesmo nível de existência; e não podemos dizer que há enunciados como dizemos que há línguas. (FOUCAULT, 2005, p. 96) 
Ainda que a possibilidade de defender proposições e de construir frases ganhe existência no interior de um conjunto de enunciados - acontecimentos discursivos passíveis de repetição -, ele não é veiculado, obrigatoriamente, no formato de "frase" ou de "proposição". Sobre isso, citam-se, como exemplo, as flexões pessoais de um verbo, elencados em coluna em uma gramática latina. Nesse caso, observa-se o enunciado desse tipo de organização verbal, mas não de uma frase ou proposição.

Por meio da língua, espalhamos nossas crenças, nossas reflexões sobre a vida, nossos modos de organização social. A citação anterior colabora para compreendermos que os sentidos compartilhados pela escrita ou pela fala não partem de um cogito, historicamente isolado. Situa-se junto ao que Foucault trata como um a priori:

[...] quero designar um a priori que não seria condição de validade para juízos, mas condição de realidade para enunciados. Não se trata de reencontrar o que poderia tornar legítima uma assertiva, mas isolar as condições de emergência dos enunciados, a lei de coexistência com outros, a forma específica de seu modo de ser, os princípios segundo os quais subsistem, se transformam e desaparecem. A priori, não de verdades que poderiam nunca ser ditas, nem realmente apresentadas à experiência, mas de uma história determinada, já que é das coisas efetivamente ditas. (FOUCAULT, 2005, p. 96)

O enunciado é delimitado como um acontecimento em relação ao qual interessa elucidar as condições históricas que lhe possibilitaram emergir. Compreende-se que ele se localiza no interior de um "diz-se" e, sendo assim, não inclui um sujeito, mas deixa em aberto posições que podem ser preenchidas em conformidade com suas variáveis intrínsecas, ou seja, com suas condições de existência consolidadas historicamente.

Segundo Deleuze (2005, p. 19), Foucault denuncia "toda 'personologia' linguística e situa os lugares do sujeito na espessura de um murmúrio anônimo". Esse "murmúrio" corresponde à realidade dos enunciados, isso é, ao que historicamente compareceu como efetivamente formulado. Tal característica é mais um fator que os diferencia das frases e das proposições. Dessas, porque elas se distribuem em relação à abstração dos axiomas. Àquelas, porque elas se definem pela possibilidade, nem sempre realizada, de contradizer outras frases. Dentre sequências de frases e estruturas proposicionais, os enunciados concretizam-se em 
diagonais que perpassam diferentes sistemas de organização dos saberes. (DELEUZE, 2005, p. 15)

Essa transversalidade do enunciado pode ser localizada em História da Loucura. Para Foucault, na era clássica, a loucura é a expressão do não-ser, o que decorre de ela ser a manifestação do desatino, de ser esvaziada de razão. O internamento do louco vai fazer jus a esse não-ser, a essa não-existência. Sobre o objetivo do internamento, afirma o autor:

[...] o internamento não pode ter por finalidade outra coisa que uma correção (isto é, a supressão da diferença ou a realização desse nada que é a loucura na morte). Donde esses desejos de morrer que se encontram tão frequentemente nos registros do internamento sob a pena dos guardiães e que não são, para o internamento, signo de selvageria, desumanidade ou perversão, mas estrito enunciado de seu sentido: uma operação de aniquilamento do nada. (FOUCAULT, 2010, p. 277)

No que tange à operação mencionada no fim desta citação, comparece como dado uma das anotações a respeito de um louco que estava internado há 17 anos. Essa anotação é "Sua saúde debilitou-se muito, pode-se esperar que logo morrerá”. (FOUCAULT, 2010, p. 249) Compreendemos que uma frase como esta é transpassada pelo enunciado de "aniquilamento do nada", o que, em outras palavras, significa a morte do não-ser, do louco. Disso, depreendemos que tal enunciado rege uma frase como esta e muitas outras que possam corresponder aos sentidos que esse enunciado irá, transversalmente, repercutir em mais de um campo do saber.

Os referenciais a que está ligado um enunciado não se constituem de "coisas", "fatos" ou "seres". Ele emerge de regras de existência dos objetos e das relações postos em jogo. Desse modo, pode-se, por exemplo, abordar a "morte do louco" com naturalidade no interior de um campo de saber em que a loucura é, por si só, a "não-existência". O referencial do enunciado possibilita que a frase tenha sentido e a proposição o seu valor de verdade. (FOUCAULT, 2005, p. 108)

Já enfatizamos, no decorrer desta tese, o quanto as proposições ligam-se ao conceito de "disciplina”, mas elas não escapam às delimitações próprias ao campo de emergência dos 
enunciados. Em uma série de questionamentos acerca do seu método, Foucault insere a seguinte definição:

[...] chamamos 'disciplinas' a conjuntos de enunciados que tomam emprestado de modelos científicos sua organização, que tendem à coerência e à demonstratividade, que são recebidos, institucionalizados, transmitidos e às vezes ensinados como ciências [...].(FOUCAULT, 2005, p. 200)

A partir do conjunto de aspectos até então abordados, passamos, no próximo capítulo, a delinear a configuração disciplinar da pesquisa de mestrado em ensino de Língua Portuguesa. 


\section{CONFIGURAÇÃO DISCIPLINAR DA PESQUISA SOBRE ENSINO DE LÍNGUA PORTUGUESA EM DISSERTAÇÕES DE MESTRADO}

Os trabalhos de pesquisa em mestrado sobre ensino de Língua Portuguesa foram, no interior desta tese, interrogados quanto ao seu grau de uniformização diante da aparente dispersão das estratégias argumentativas, concretizadas por cada uma das dissertações. Para tanto, passamos a avaliá-las no que se referiam ao seu enquadre disciplinar, a partir do corpus constituído no decorrer da presente pesquisa e que foi apresentado em 2.4.

Na referida seção, expusemos os aspectos mais presentificados nas dissertações, ou seja, aqueles que obtiveram maior destaque na argumentação defendida. A análise da argumentação que efetivamos priorizou a identificação dos "fatos", das "verdades" e das interpretações desses dados, conforme discussão prévia.

Depois de constituído o corpus, pudemos nos deter nele tendo em vista não mais sua arquitetura argumentativa de caráter retórico, segundo o qual o objetivo de convencer e persuadir seus interlocutores coloca-se em primeiro lugar, mas pelo viés da concepção de “discurso" que localizamos em A ordem do discurso (FOUCAULT, 2004a), que, conforme já tratado, compreende-o a partir de regularidades de enunciados que vão sendo repetidos, em certa esfera do saber científico, por aqueles que assumem, em um dado momento, a funçãoautor.

Essa compreensão desdobra-se no entendimento de que, histórica e culturalmente, estabelecem-se modos de cerceamento que determinam o que seja ou não válido produzir em termos de discurso. Com a análise dos 18 trabalhos de mestrado citados no nosso corpus, tornaram-se perceptíveis algumas regularidades sobre a constituição disciplinar da pesquisa em ensino de Língua Portuguesa, conforme passamos a discutir ${ }^{29}$.

\footnotetext{
${ }^{29}$ Neste capítulo, detemo-nos na apresentação e discussão sobre como o discurso pesquisado configurou-se disciplinarmente. O apêndice D complementa esta reflexão, pois nele, expusemos, de forma esquemática, os "objetos", "métodos", "referenciais teóricos" e as "proposições" recorrentes no corpus.
} 


\subsection{A constituição do quadro teórico}

Indubitavelmente, a pesquisa em ensino de Língua Portuguesa construiu-se, nas dissertações investigadas, a partir dos Parâmetros Curriculares Nacionais de Língua Portuguesa e segundo o quadro teórico de Mikhail Bakhtin. Os volumes dos Parâmetros de Língua Portuguesa para o Ensino Fundamental I e/ou II foram citados nas 18 produções que constituíram o nosso corpus.

Como se sabe, os Parâmetros caracterizam-se por referências a Bakhtin, o que corrobora a legitimidade do quadro teórico desse autor na pesquisa em ensino de Língua Portuguesa. Identificamos que as dissertações que se voltaram para o "ensino de escrita" e para o "ensino de leitura" foram aquelas que mais apresentaram referências ao arcabouço teórico bakhtiniano. Já alguns trabalhos que focalizaram discussões de ordem gramatical ou trataram da utilização de recursos computacionais no ensino de Língua Portuguesa, não o citaram.

Mesmo não desfrutando da unanimidade de citações, como ocorreu como os Parâmetros Curriculares Nacionais, os livros Marxismo e Filosofia da Linguagem e Estética da Criação Verbal destacaram-se dentre aquelas mais referenciadas pelos trabalhos sob análise. A primeira foi mencionada em 13 produções e a segunda foi referida em 12, sendo citadas várias edições de ambas as obras.

Algumas dissertações em que Marxismo e Filosofia da Linguagem não apareceu referenciado foram aquelas que propuseram a discussão sobre a presença de recursos computacionais no ensino de Língua Portuguesa, como foi o caso de ESP01 e FPB08b. Nessas dissertações, conforme se verificará na próxima seção, a centralidade da discussão não foi quanto ao que caracteriza esse ensino, mas como determinados conteúdos, como a produção de histórias em quadrinhos e tópicos de morfossintaxe, podem ser incorporados em aulas que utilizam tecnologias educacionais.

A obra supramencionada também não foi citada em dissertação que focalizou reflexões de caráter gramatical, como demonstrou EPR07, que abordou os gêneros gramaticais no ensino de Língua Portuguesa. Outras dissertações que não mencionaram o livro em questão foram FMT06a e FRS10. Nessa, a discussão focalizou a análise de produções discentes, quanto aos seus aspectos de coesão textual e, naquela, foram descritas e 
analisadas aulas de Língua Portuguesa para sua posterior comparação com prescrições legais e curriculares.

Mais de uma dissertação que não referenciou Marxismo e Filosofia da Linguagem também não citou Estética da Criação Verbal, que foram: ESP01, EPR07, FPB08b e FRS10. Além dessas, outras que não fizeram referência à última obra mencionada foram EPR02 e FMT07. Essa trabalhou com a análise de livros didáticos, veiculados no estado do Mato Grosso, nas décadas finais do século XX, e aquela pesquisou aulas de produção textual a partir da observação de atuação docente. Por ora, deteremo-nos somente nessas explicações acerca das dissertações em questão, já que, nas próximas seções, serão apresentados os demais aspectos que ampliam a compreensão da configuração disciplinar dos trabalhos sob enfoque.

Além das obras que até então citamos, outros títulos reiteradamente referenciados foram O Texto na Sala de Aula e Portos de Passagem. Esse de autoria de João Wanderley Geraldi e aquele organizado por esse mesmo autor, tendo sido citados em 11 e 10 dissertações, respectivamente.

Houve similaridade quanto a produções que não fizeram referência a essas duas obras, como foi o caso de ESP01, FPB08b, EPR07, ESP07 e FSC03. As duas primeiras dissertações indicadas, como tratado anteriormente, voltaram-se para a apresentação de recursos computacionais no ensino de Língua Portuguesa, focalizando menos a caracterização do objeto de ensino em si e mais como a informática poderia funcionar na mediação de seu ensino. EPR07, como abordado por ocasião da não-referência às obras de Bakhtin, tratou de aspectos gramaticais no ensino de Língua Portuguesa, especialmente quanto a tópicos de morfossintaxe. Já ESP07 voltou-se para a análise de material didático direcionado ao Ensino Fundamental II. Por fim, FSC03 expôs proposta de produção textual, decorrente da intervenção da pesquisadora na turma investigada.

Especificamente o livro O Texto na Sala de Aula não foi citado em FPB07 e ESP09. Nessa, focalizou-se uma proposta de produção textual envolvendo a redação de roteiros para vídeos digitais. Naquela, discutiu-se o ensino de leitura a partir do que foi apresentado como sendo as concepções de leitura demonstradas pelos professores investigados. Já Portos de Passagem também não foi referenciado em ESP08, FMT06a e FRS10. A essas duas últimas, fizemos menção no que disse respeito à não-referência a obras de Bakhtin anteriormente mencionadas. FRS10 tratou da análise de textos discentes e FMT06a propôs uma comparação entre alguns documentos legais ou curriculares e a prática docente investigada. ESP08 deteve- 
se na discussão sobre a formação docente continuada, por meio da proposição da inserção de jogos de improvisação teatral para professores que ensinavam leitura em escolas do estado de São Paulo.

O panorama apresentado demonstra quais foram as obras que se destacaram no quadro teórico do nosso corpus, constituindo-se como referências legitimadoras da pesquisa sobre ensino de Língua Portuguesa, no contexto da investigação de mestrado na década analisada.

Ao considerar que os Parâmetros Curriculares Nacionais e as duas últimas referências supramencionadas - O Texto na Sala de Aula e Portos de Passagem - alinham-se à perspectiva teórica de Bakhtin, em Marxismo e Filosofia da Linguagem e Estética da Criação Verbal, corroboramos nossa afirmação inicial de que a pesquisa em ensino de Língua Portuguesa, tal como analisada no corpus desta tese, construiu-se no contexto teórico instaurado pela obra desse autor russo.

Desse enquadramento teórico, emergiram termos como os que seguem: "interação" e "gêneros do discurso". Consoante aos termos, compreendemos que:

[...] o estatuto terminológico de uma unidade lexical define-se por sua dimensão conceptual, sendo, portanto, esta a sua qualificação primeira. Vale dizer, o que faz de um signo linguístico um termo é o seu conteúdo específico, propriedade que o integra a um determinado campo de especialidade. (KRIEGER, 2001, p. 69)

Nessa abordagem, o "termo" define-se por sua associação a um dado conceito, o que também depreendemos do que segue:

Os termos não são escolhidos por seu valor intrínseco, nem por aquilo que representam no conjunto lexical de uma língua. Ainda que primitivamente originários do acervo do léxico geral, ou criados de acordo com as mesmas regras obedecidas no processo de construção do léxico comum, os termos começam a existir quando se unem indissoluvelmente a conceitos determinados dentro de um conjunto conceitual estruturado em uma área de especialidade. Só então, no interior desse sistema, as unidades lexicais se 
constituem em unidades terminológicas e passam a constituir uma terminologia. (MACIEL, 2001, p. 41)

Em investigações terminológicas, a análise conceptual volta-se para a discussão do conteúdo semântico de um termo, a fim de que sejam avaliadas suas características, os modos como são compreendidos e a inter-relação entre conceitos. Vale dizer que propostas atuais de estudo dos termos técnico-científicos não os dissociam do seu contexto de produção, ou seja, avaliam que o caráter científico da terminologia em questão não é fixo, relativiza-se de acordo com o ambiente em que se insere, pois defendem que os termos "adquirem estatuto terminológico no âmbito das comunicações especializadas”. (KRIEGER; FINATTO, 2004, p. 35)

Ainda que não estejamos propondo, no interior desta tese, uma pesquisa de caráter terminológico, o fato de refletirmos sobre os termos constantes do nosso corpus determina que nos apoiemos, em parte, no construto teórico-metodológico advindo da Terminologia, tendo em vista que:

A constituição de uma terminologia própria marca, em toda ciência, o advento ou o desenvolvimento de uma conceitualização nova, assinalando, assim, um momento decisivo de sua história. Poder-se-ia mesmo dizer que a história particular de uma ciência se resume na de seus termos específicos. Uma ciência só começa a existir ou consegue se impor na medida em que faz existir e em que impõe seus conceitos, através de sua denominação. (BENVENISTE, 2006, p. 252)

Como tratado anteriormente, o referencial bakhtiniano mostrou-se recorrente nas dissertações sob análise, o que, consequentemente, influenciou na escolha da terminologia adotada. "Interação" foi um dos termos que se fez presente no corpus. Retomando Marxismo e Filosofia da Linguagem, verificamos o postulado de que a língua constitui-se na interação da comunicação verbal concreta. Um dos capítulos desse livro intitula-se "A interação verbal”. Trata-se do capítulo 6, em que localizamos o que segue: 
A verdadeira substância da língua não é constituída por um sistema abstrato de formas linguísticas nem pela enunciação monológica isolada, nem pelo ato psicofisiológico de sua produção, mas pelo fenômeno social da interação verbal, realizada através da enunciação ou das enunciações. A interação verbal constitui assim a realidade fundamental da língua. (BAKHTIN, 2004, p. 123) (grifos do autor)

A breve citação traz à tona a definição de língua enquanto "interação verbal", ressaltando-se nisso sua constituição como parte dos fenômenos sociológicos, que evoluem historicamente e que, desse modo, compreende sua caracterização enquanto um "signo ideológico":

[...] classes sociais diferentes servem-se de uma só e mesma língua. Consequentemente, em todo signo ideológico confrontam-se índices de valor contraditórios. O signo se torna a arena onde se desenvolve a luta de classes. (BAKHTIN, 2004, p. 46) (grifos do autor)

A abordagem marxista na conceptualização e na reflexão sobre a língua aparece registrada, como na última citação, por meio da vinculação entre os signos, dentre os quais os linguísticos, e sua dimensão ideológica. Essa abordagem dos signos linguísticos opõe-se a outras formas de tratamento, voltadas tanto para o subjetivismo do falante quanto para a objetividade do sistema abstrato de elementos linguísticos disponíveis aos seus usuários. Portos de Passagem retomam o referencial bakhtiniano, afirmando que:

A construção deste "modo de ver o mundo" e portanto de representá-lo para nós mesmos é atravessada por confrontos que se dão na existência histórica. Assim, numa sociedade de classes, a desigualdade de relações leva à formulação de universos discursivos diferenciados, antes de mais nada pela segregação que uma classe impõe, através dos mais diversos mecanismos, pela articulação e retomada dos produtos herdados do passado na produção do universo discursivo do presente. [...] 
Encontramos aqui talvez a mais visível forma de ação da linguagem sobre os sujeitos: suas consciências se constituem e operam, conforme Bakhtin, através do material sígnico que "adquirem" nos espaços das interações que a própria formação social lhes permite [...]. (GERALDI, 1991, p. 55-6)

Na citação de Geraldi, também comparece a evolução histórica inerente aos modos como o mundo é representado e, por sua vez, constituído discursivamente em meio à luta de classes. Nesse contexto, a "interação verbal" destaca-se como forma de ação na formação de discursos não-neutros.

A concepção de língua pelo prisma da interação também é trazida à tona pelos Parâmetros Curriculares Nacionais de Língua Portuguesa:

Interagir pela linguagem significa realizar uma atividade discursiva: dizer alguma coisa a alguém, de uma determinada forma, num determinado contexto histórico e em determinadas circunstâncias de interlocução. Isso significa que as escolhas feitas ao produzir um discurso não são aleatórias ainda que possam ser inconscientes -, mas decorrentes das condições em que o discurso é realizado. (BRASIL, 1998, p. 20-1)

O sentido histórico das interações também comparece nos Parâmetros, conforme citação anterior, na qual elas aparecem definidas enquanto uma atividade discursiva. De acordo com esse documento, as atividades discursivas ocorrem na:

[...] prática constante de escuta de textos orais e leitura de textos escritos e de produção de textos orais e escritos, que devem permitir, por meio da análise e reflexão sobre os múltiplos aspectos envolvidos, a expansão e construção de instrumentos que permitam ao aluno, progressivamente, ampliar sua competência discursiva. (BRASIL, 1998, p. 27)

Outro termo facilmente localizável nos Parâmetros é "competência discursiva", com a qual se encerra a última citação. A competência discursiva aparece, nesse documento, 
relacionada ao exercício de cidadania e é descrita como um dos aspectos implicados na capacidade de alguém "utilizar a língua de modo variado, para produzir diferentes efeitos de sentido e adequar o texto a diferentes situações de interlocução oral e escrita". (BRASIL, 1998, p. 27)

As 18 dissertações sob análise, conforme tratamos anteriormente, citaram os Parâmetros Curriculares Nacionais de Língua Portuguesa e neles se apoiaram nas menções a termos como "competência discursiva". Decorre daí que, em muitos trabalhos, não localizamos mais a origem do termo citado, pois, ao ser extraído dos Parâmetros, por vezes ele já não remete à sua fonte conceptual. Marinho (2003) aborda essa questão ao problematizar os Parâmetros quanto à divulgação dos conhecimentos científicos no contexto pedagógico, citando, para tanto, Portos de Passagem, de João Wanderley Geraldi, como se depreende do que segue:

Não se poderia ignorar [...] processos de apagamento ou de esquecimento constitutivos do discurso, o que não é especificidade do discurso pedagógico, da vulgarização. $\mathrm{O}$ apagamento/esquecimento das origens faz com que, paulatinamente, determinados conceitos e expressões, que carregaram em determinados momentos o nome do pai, passem a um domínio do "anônimo", ou, como diz Geraldi (1991), se estabilizem. Seriam, então, os PCN (e os currículos oficiais) um dos mecanismos históricos de estabilização de conceitos no campo pedagógico? Essa estabilização significaria uma uniformização dos sentidos e uma transparência que permitem o seu reconhecimento por parte de qualquer leitor?

$[\ldots]$

Mas não estariam aí também escondidos outros elementos invisíveis das condições de produção desse discurso? Esses textos curriculares podem significar a duplicação ou mesmo a ambigüidade e complexidade do lugar do pesquisador e dos intelectuais, posicionados entre a erudição e a divulgação ou transposição didática, entre a pesquisa e as políticas públicas. (MARINHO, 2003, p. 133)

Observamos, na passagem anterior, o questionamento dos Parâmetros Curriculares Nacionais quanto ao seu papel na divulgação do conhecimento científico e quanto ao apagamento/esquecimento das referências originais de dados termos e conceitos. Trata-se de ampla discussão, que envolve refletir tanto sobre o caráter expansivo desses documentos, que 
assumem, como destinatários, professores das várias regiões brasileiras, quanto sobre sua expressividade em relação ao arcabouço teórico-científico que incorpora.

Mesmo sendo muitas as possibilidades de posicionar-se quanto a esse debate, importa, no interior desta tese, reconhecer que os Parâmetros apresentaram-se como uma referência unânime nas produções pesquisadas, o que sinaliza o seu caráter "estabilizador" no interior da pesquisa de mestrado em ensino de Língua Portuguesa, a considerar o corpus sob enfoque.

Esse aspecto "estabilizador" dos Parâmetros é sinalizado, inclusive, por esses documentos terem sido citados em todas as dissertações que analisamos. Isso redunda que o ideário apresentado por eles e sua terminologia também compõem as produções de pesquisa que os referenciam, seja mantendo a autoria original dos termos em xeque ou não.

Sobre isso, destacam-se às referências aos "gêneros do discurso", constantes dos Parâmetros e em mais de uma dissertação do corpus, como será detalhado na seção posterior. Vale recordar que os "gêneros do discurso", numa abordagem bakhtiniana, referem-se a formas relativamente estáveis de produção discursiva relacionadas às diferentes esferas de organização social, sejam elas jurídica, religiosa, educacional, jornalística ou outra.

Em Estética da Criação Verbal (BAKHTIN, 2011, p. 261), define-se que os "gêneros do discurso" refletem:

[...] as condições específicas e as finalidades de cada referido campo não só por seu conteúdo (temático) e pelo estilo da linguagem, ou seja, pela seleção dos recursos lexicais, fraseológicos e gramaticais da língua mas, acima de tudo, por sua construção composicional. Todos esses três elementos - o conteúdo temático, o estilo, a construção composicional - estão indissoluvelmente ligados no todo do enunciado e são igualmente determinados pela especificidade de um determinado campo de comunicação. Evidentemente, cada enunciado particular é individual, mas cada campo de utilização da língua elabora seus tipos relativamente estáveis de enunciados, os quais denominamos gêneros do discurso. (grifos do autor)

Essa concepção é absorvida pelos Parâmetros Curriculares Nacionais de Língua Portuguesa, direcionados ao ensino de $1^{\mathrm{a}}$ a $4^{\mathrm{a}}$ série (BRASIL, 1997, p. 23), que afirmam que: 
Todo texto se organiza dentro de um determinado gênero. Os vários gêneros existentes, por sua vez, constituem formas relativamente estáveis de enunciados, disponíveis na cultura, caracterizados por três elementos: conteúdo temático, estilo e construção composicional.

Associada a este trecho, comparece referência, em nota de rodapé, aos "gêneros" como um "termo proposto por Bakhtin e desenvolvido por Bronckart e Schneuwly". No tocante a essa informação, observamos que são dados os créditos aos três autores mencionados, contudo apagam-se os dados condizentes às obras em que a terminologia em questão foi consultada.

Os Parâmetros direcionados à segunda etapa do Ensino Fundamental, denominada no documento como "terceiro e quarto ciclo", destacam a noção de "gênero" como objeto de ensino:

Os textos organizam-se sempre dentro de certas restrições de natureza temática, composicional e estilística, que os caracterizam como pertencentes a este ou aquele gênero. Desse modo, a noção de gênero, constitutiva do texto, precisa ser tomada como objeto de ensino.

Nessa perspectiva, necessário contemplar, nas atividades de ensino, a diversidade de textos e gêneros, e não apenas em função de sua relevância social, mas também pelo fato de que textos pertencentes a diferentes gêneros são organizados de diferentes formas. A compreensão oral e escrita, bem como a produção oral e escrita de textos pertencentes a diversos gêneros, supõem o desenvolvimento de diversas capacidades que devem ser enfocadas nas situações de ensino. (BRASIL, 1998, p. 23-4)

Neste fragmento, efetiva-se o apagamento das referências teóricas da noção que é prescrita para o ensino, como fica evidenciado pela afirmação de que "a noção de gênero [...] precisa ser tomada como objeto de ensino", na qual localizamos o teor impositivo presente na acepção do verbo "precisar".

A constante referência a Bakhtin, no que concerne ao conceito de "gênero" e sua relação com o ensino, é pontuada por Brait e Pistori (2012, p. 371) ao afirmarem que a "maioria dos leitores que se socorre do conceito de gênero, especialmente para salvar o ensino 
no que se refere à leitura e produção de textos, em algum momento se depara com (ou a ele é dirigido) o clássico 'Os gêneros do discurso'”.

Nos dois fragmentos dos Parâmetros anteriormente transcritos, observamos que a influência bakhtiniana faz-se presente e é desdobrada na direção de trabalhos atribuídos a Bronckart e Schneuwly. Esse arcabouço teórico-metodológico resulta numa flutuação denominativa que atualiza os termos "gêneros do discurso", "gêneros textuais" ou somente "gêneros".

Essa oscilação foi identificada no nosso corpus, em especial quanto ao uso reduzido do termo, concretizado somente por "gêneros", conforme se verificará a partir de 4.2, em que iniciamos as reflexões acerca da configuração dos objetos de pesquisa. Nos Parâmetros Curriculares Nacionais de Língua Portuguesa, essa redução terminológica comparece em larga escala.

Diante do exposto, verificamos que os Parâmetros absorvem o conceito de "gêneros" a partir da fonte bakhtiniana e também de outras discussões que lhe são decorrentes, provenientes de pesquisadores caracterizados como interlocutores de Bakhtin. Nos documentos citados, essas referências aos "gêneros", vindas de mais de uma esfera de discussão, materializam-se na redução terminológica em questão e, no decorrer do texto, as alusões ao termo reduzido vão operando apagamentos em relação, por exemplo, às obras de referência, conforme mencionamos anteriormente.

Ocorre que, ao analisarmos o nosso corpus, avaliamos um efeito "estabilizador" causado pelos Parâmetros ao verificarmos que tal redução terminológica também comparece em dissertações que pesquisamos. Essa consequência de tipo "estabilizador" diz respeito às recorrências que fomos identificando e que analisamos em termos de regularidades. No que tange à concepção de "gêneros", ela se faz constante em parte do material que pesquisamos, tendo sido influenciada pela flutuação denominativa que abordamos.

Sobre isso, vale menção ao livro Gêneros Textuais \& Ensino, organizado por Angela P. Dionísio, Anna Rachel Machado e Maria Auxiliadora Bezerra, uma vez que nele há apontamentos quanto às noções de "gêneros discursivos" e "gêneros textuais" e, em especial, porque esse livro também compareceu dentre aqueles citados com recorrência no nosso corpus, identificado em 09 dissertações, isso é, em metade do material que coletamos.

Esclarecemos que esse livro divide-se em duas partes, a primeira intitulada "Suportes teóricos e práticas de ensino", composta por oito textos assinados por diferentes autores, e a 
segunda, "Gêneros textuais na mídia escrita e ensino", constituída de sete textos, também com autores diversificados. O diálogo com os Parâmetros Curriculares Nacionais é marcado na apresentação da obra, que afirma que:

A proposta dos PCN de fundamentar o ensino da língua materna, tanto oral quanto escrita, nos gêneros do discurso, desencadeou uma relevante e significativa atividade de pesquisa visando, primeiro, descrever uma diversidade considerável de gêneros a partir dos heterogêneos textos que os atualizam e, segundo, apresentar sugestões didáticas para o uso dos textos enquanto exemplares e fonte de referência de um determinado gênero. (KLEIMAN, 2007, p. 7)

O segundo capítulo desse livro, intitulado "Ensino de língua portuguesa e contextos teórico-metodológicos", de Maria Auxiliadora Bezerra, citando Dominique Maingueneau ${ }^{30}$, faz a seguinte distinção:

Em geral, são chamados gêneros textuais os textos particulares, que têm organização textual, funções sociais, locutor e interlocutor definidos; e gêneros discursivos, aqueles cuja caracterização está baseada em critérios tais como: fator de economia cognitiva, rotina, atividade social, finalidade reconhecida, interlocutores legítimos, lugar e tempo legítimos, suporte material e organização textual (Maingueneau, 2001). Dessa forma, esses gêneros são tidos como dispositivos de comunicação que só podem aparecer quando certas condições sócio-históricas estão presentes [...] o que de certa maneira está subjacente à concepção de gêneros textuais, já que as pesquisas analisam os textos empíricos, que circulam na sociedade e que, por isso, são determinados no espaço e no tempo. (BEZERRA, 2007, p. 40-1)

Conforme discutido, no nosso corpus, observamos a presença tanto do termo "gêneros do discurso", quanto de "gêneros textuais" e, principalmente, de sua redução terminológica "gêneros", o que é passível de constatação nos fragmentos das dissertações que expomos na próxima seção e também no Apêndice C.

\footnotetext{
${ }^{30}$ Cita-se "MAINGUENEAU, D. Análise de textos de comunicação. São Paulo: Cortez, 2001".
} 
Não se trata de um diagnóstico referente unicamente às produções que analisamos, haja vista que, na citação anterior, localizamos a preocupação em distinguir e, também, aproximar os dois termos. Ademais, constatamos que, nos Parâmetros Curriculares Nacionais, a referência à concepção de "gêneros" fez-se, preponderantemente, dessa forma, por meio da redução terminológica, o que permitiu que o mesmo fosse compreendido pelas duas perspectivas conceptuais referidas na citação anterior.

A dimensão "estabilizadora" dos Parâmetros Curriculares Nacionais de Língua Portuguesa caracteriza-o como um documento que, efetivamente, tem gerado efeitos reguladores, não especificamente pelo seu direcionamento prescritivo, mas por desfrutar de aceitabilidade em investigações sobre ensino de Língua Portuguesa, como o nosso corpus dá mostra.

Outra constatação que demonstrou essa aceitabilidade foi a referente recorrência, nas dissertações que analisamos, a A prática de linguagem em sala de aula: praticando os PCNs, organizado por Roxane Rojo. Esse livro foi referenciado em 08 trabalhos que constituem o nosso corpus. Ele é composto por quatro partes mais a apresentação da obra.

Essas partes são intituladas "Os PCNs e a sala de aula", "Práticas de leitura e de produção de textos", "Práticas de formação de professor" e "Prática de professores: os gêneros argumentativos". Ao todo, o livro constitui-se de onze textos, assinados por diversos autores.

Desde o título do livro, assinala-se o seu alinhamento aos Parâmetros Curriculares Nacionais, que é divulgado também no seu primeiro capítulo, conforme segue:

Gostaria de dizer que este livro é especialmente dedicado a professores e a multiplicadores e formadores de professores em serviço e pré-serviço, identificados com as propostas presentes nos PCNs de Língua Portuguesa do Ensino Fundamental, seus leitores prefigurados. Assim sendo, insere-se em um movimento atual de discussão da proposta e de ensaios de concretização de seus princípios e em diálogo com outras iniciativas de mesmas finalidades, sobretudo no que diz respeito à formação de professores e à elaboração de currículos, programas e projetos. (ROJO, 2000, p. 7) 
Conforme dados tratados na presente tese, a pesquisa de mestrado em ensino de Língua Portuguesa configura-se em um quadro teórico constituído por obras de Mikhail Bakhtin ou por textos de que podemos depreender sua influência, como é o caso dos livros de autoria ou organização de João Wanderley Geraldi e os Parâmetros Curriculares Nacionais. Destacamos o papel exercido por esses Parâmetros, apontando para a sua aceitabilidade nas dissertações de nosso corpus e também de obras que se alinham a eles, como é o caso dos dois últimos livros que citamos. Essa aceitabilidade, como discutido, voltou-se em larga escala à concepção de "gêneros do discurso" e aos seus desdobramentos teóricometodológicos.

No que tange à legitimação dos Parâmetros Curriculares Nacionais enquanto referência para a pesquisa sobre ensino de Língua Portuguesa, verificamos que além do conceito de "gêneros", uma ideia que é por eles atualizada e que apareceu em parte das dissertações de mestrado sob enfoque foi o de ensinar a escrita sem desconsiderar a produção de várias versões do mesmo texto, o que, no nosso corpus, compareceu sob o termo "reescrita". Nos Parâmetros, a ideia de várias produções de um mesmo texto é tratada enquanto processo de "refacção", como se vê no que segue:

[...] a refacção faz parte do processo de escrita: durante a elaboração de um texto, se relêem trechos para prosseguir a redação, se reformulam passagens. Um texto pronto será quase sempre produto de sucessivas versões. Tais procedimentos devem ser ensinados e podem ser aprendidos. (BRASIL, 1998, p. 77)

Nesta citação, a produção de várias versões de um mesmo texto é proposta para o ensino de escrita. Tal direcionamento também foi localizado em parte das dissertações que analisamos. Em algumas delas, esse procedimento é contraposto à concepção de "redação escolar".

Em texto da década de 80, João Wanderley Geraldi caracteriza a "redação" como um "exercício simulado da produção de textos". A respeito desse exercício, ele completa afirmando que "[...] na escola não se produzem textos em que um sujeito diz sua palavra, mas simula-se o uso da modalidade escrita, para que o aluno se exercite no uso da escrita [...]". (Geraldi, 2006, p. 128) No nosso corpus, localizamos avaliações negativas sobre esse tipo de 
exercício, alegando-se, então, a necessidade de outras propostas de ensino de escrita, como aquelas que contemplam os "gêneros".

Além dessas avaliações negativas, outra que compareceu, nas dissertações que analisamos, foi quanto à leitura e à abordagem de textos com propósitos de estudos gramaticais. Esse tipo de apontamento voltou-se para um parecer contrário ao uso do texto como pretexto para discussões de caráter gramatical.

Trata-se de uma crítica recorrente aos modos de tratamento da gramática no ensino de Língua Portuguesa. O livro Gramática e interação: uma proposta para o ensino de gramática, de Luiz Carlos Travaglia, foi referenciado em 09 dissertações do nosso corpus. Nele, já se contemplava esse tipo de ponderação, em forma de retrospectiva sobre os estudos gramaticais no ensino de Língua Portuguesa.

Nessa retrospecção, Travaglia retoma um texto de Magda Soares ${ }^{31}$ para distinguir três propostas metodológicas comuns para o ensino de gramática, dentre as quais, ele cita:

[...] questionando a eficácia das regras da gramática normativa e das atividades de análise sintática e morfológica para ensinar a falar, escrever/ouvir, ler, valoriza-se a proposta de que se aprende a fazer, fazendo. Todavia, essa orientação não teria levado a uma real modificação, pois, nas atividades de sala de aula, a gramática (teoria) continuou prestigiada, pois apenas passou-se a partir dos exemplos para a teoria em vez do que se fazia antes: da teoria para os exemplos. O texto passou a ser usado apenas como pretexto. (TRAVAGLIA, 2005, p. 104)

Diante do exposto, corroboramos que, no nosso corpus, foi possível identificar a rejeição ao ensino de gramática que tomava o texto como fonte de exemplos, conforme discorreu a citação anterior.

A última refutação que foi identificada no nosso corpus e que vamos destacar aqui diz respeito às avaliações feitas quanto ao ensino de Língua Portuguesa em um modelo que toma a linguagem por uma perspectiva estruturalista ou como instrumento de comunicação.

\footnotetext{
${ }^{31}$ Cita-se "SOARES, Magda Becker et al. (1979). Ensinando comunicação em língua portuguesa no $1^{o}$ grau Sugestões metodológicas $5^{a}$ a $8^{a}$ séries. Rio de Janeiro, MEC/Departamento de Ensino Fundamental/FENAME”.
} 
As referências bibliográficas recorrentes nas dissertações sob enfoque trazem textos que discutem tais conceitos sobre a linguagem. Tanto Travaglia (2005), quanto Geraldi (2006), apresentam ponderações acerca disso:

Fundamentalmente, três concepções podem ser apontadas:

A linguagem é a expressão do pensamento: essa concepção ilumina, basicamente, os estudos tradicionais. Se concebemos a linguagem como tal, somos levados a afirmações - correntes - de que pessoas que não conseguem se expressar não pensam.

A linguagem é instrumento de comunicação: essa concepção está ligada à teoria da comunicação e vê a língua como código (conjunto de signos que se combinam segundo regras) capaz de transmitir ao receptor certa mensagem. Em livros didáticos, é a concepção confessada nas instruções ao professor, nas introduções, nos títulos, embora em geral seja abandonada nos exercícios gramaticais.

A linguagem é uma forma de interação: mais do que possibilitar uma transmissão de informações de um emissor a um receptor, a linguagem é vista como um lugar de interação humana. Por meio dela, o sujeito que fala pratica ações que não conseguiria levar a cabo, a não ser falando; com ela o falante age sobre o ouvinte, constituindo compromissos e vínculos que não preexistam à fala.

Grosso modo, essas três concepções correspondem às três grandes correntes dos estudos linguísticos:

a gramática tradicional;

o estruturalismo e o transformacionalismo;

a linguística da enunciação. (GERALDI, 2006, p. 41) (grifos do autor)

Travaglia (2005, p. 21-3) também se volta para essa diferenciação entre as concepções de linguagem, associando-as aos referidos estudos linguísticos, já apontados pela citação anterior. No que condiz à "linguagem como expressão do pensamento", essa concepção é relacionada aos estudos da "gramática normativa". Já aquela definida enquanto "linguagem como instrumento de comunicação" é descrita em relação ao "estruturalismo", sobre o qual se cita Saussure, e ao "transformacionalismo", quanto ao que se cita Chomsky. Por fim, apresenta-se a "linguagem como forma ou processo de interação", sobre a qual se afirma:

Dessa forma o diálogo em sentido amplo é que caracteriza a linguagem. Essa concepção é representada por todas as correntes de estudo da língua que podem ser reunidas sob o rótulo de linguística da enunciação. Aqui estariam 
incluídas correntes e teorias tais como a Linguística Textual, a Teoria do Discurso, a Análise do Discurso, a Análise da Conversação, a Semântica Argumentativa e todos estudos de alguma forma ligados à Pragmática.

No nosso corpus, muitas dissertações buscaram alinhar-se a essa última concepção de linguagem, ancorando-se na refutação dos outros dois conceitos, conforme será tratado na próxima seção, a respeito da configuração dos objetos de pesquisa e também dos métodos percorridos nos processos de investigação. Tendo em vista essa proposta de compreensão da linguagem, defende-se, dentre outros aspectos, que a "multiplicidade de leituras que um mesmo texto pode ter não nos parece resultado do próprio texto em si, produzido em condições específicas, mas sim resultado dos múltiplos sentidos que se produzem nas diferentes condições de produção de leitura". (GERALDI, 2006, p. 108)

Como se verá, no que segue, a constituição dos objetos no interior das dissertações pesquisadas reflete as discussões teóricas que corroboram e que também refutam. Claro está que, se analisássemos outros livros referenciados pelas dissertações, abordaríamos demais conceitos e debates teóricos pertinentes. Contudo, em conformidade com os propósitos desta tese, atemo-nos às referências bibliográficas mais recorrentes no nosso corpus, a partir das quais delineamos o quadro teórico que, em larga escala, é mobilizado pelos trabalhos de mestrado sob enfoque.

\subsection{A constituição dos objetos e os métodos empregados}

O material investigado pela presente tese demonstrou que o espaço da "sala de aula" emerge como o principal ponto de interesse, porque nele se encontra o professor - que, no âmbito das pesquisas integradas pelo nosso corpus, será entrevistado -, e lá também está o aluno a produzir os seus textos - que, por sua vez, serão incorporados para análise. Os livros didáticos também se mostraram presentes na pesquisa sobre ensino de Língua Portuguesa, observados como parte da dinâmica instaurada em sala de aula. É também na sala de aula que 
adentra o pesquisador, seja para observá-la, seja para exercer algumas ações com finalidade de pesquisa. Dessa sua entrada, consolidam-se os registros escritos, fotográficos, em vídeo.

Enfim, o espaço da "sala de aula" aparece como a principal instância a guardar as possibilidades de se pesquisar sobre ensino de Língua Portuguesa, pois é a partir do que acontece ou do que se propõe para acontecer no seu interior que podem ser estabelecidos métodos de pesquisa que tornam visíveis e enunciáveis os objetos a serem abordados cientificamente.

Compreendemos que esses objetos constituem-se no interior do discurso de pesquisa sobre ensino de Língua Portuguesa. Nessa constituição, observam-se algumas consolidações em relação ao "o que se investiga" quando a proposta se volta para o tipo de pesquisa sob enfoque. Esse "o que" aparece intrinsecamente relacionado ao "como" as investigações organizam-se, ou seja, aos métodos científicos que adota.

Tais consolidações foram abordadas enquanto recorrências. Desse modo, em meio à dispersão de objetos passíveis de serem delimitados no interior das dissertações que analisamos, destacamos, no interior desta tese, aqueles que verificamos como consistentes em mais de uma produção que compõe o nosso corpus.

Antes de passarmos aos objetos configurados na pesquisa de mestrado sobre ensino de Língua Portuguesa, é válido esclarecer que, na sua constituição, houve distintos modos de fazer menção a eles. Isso significa que o "ensino de escrita", identificado como um dos objetos de pesquisa materializados no nosso corpus, foi referido de mais de uma maneira no interior das dissertações em que compareceu. O que também ocorreu quanto ao "ensino de leitura" e ao "ensino de oralidade", por exemplo. No interior da presente tese, uniformizamos uma nomenclatura, formada por "ensino de" e sua continuidade, de modo a marcar nosso interesse em refletir sobra a composição da "escrita", da "leitura", da "oralidade" e da "gramática" como objetos do ensino de Língua Portuguesa.

O quadro a seguir aponta para as construções linguistícas que transpareceram na constituição dos objetos de pesquisa investigados: 


\section{QUADRO B: Formações sintagmáticas de menção aos objetos de pesquisa}

\begin{tabular}{lll}
\hline Ensino de escrita & Ensino de leitura & Ensino de oralidade \\
& & \\
"aulas de escrita"; & "ato de leitura"; & "competência discursiva \\
"competência discursiva & "aulas de leitura"; & oral"; \\
escrita"; & "propostas de leitura"; & "trabalho com a \\
"ensino da produção & "trabalho com a leitura". & modalidade oral da \\
textual escrita"; & & "trabalho com a \\
"ensino de língua escrita"; & & oralidade". \\
"estudo de um gênero"; & & \\
"exercício da escrita"; & & \\
"proposta de escrita"; & & \\
"trabalho com produções & & \\
textuais".
\end{tabular}

As formulações linguísticas apontadas nesse quadro podem ser observadas nos fragmentos do corpus transcritos a partir da próxima seção e também no Apêndice C.

Quanto ao objeto configurado como "livro didático", esclarecemos que não houve diversidade de formas linguísticas na sua referência e que o "ensino de gramática" foi, predominantemente, abordado por meio dessa construção lexical.

No que se refere à caracterização das construções lexicais, em Estruturas Linguísticas do Português (POTTIER; AUDUBERT; PAIS, 1973), define-se como "lexia" uma unidade lexical memorizada. Como exemplo disso, cita-se uma combinação como "pé de cabra", no sentido de ferramenta, distinguindo-se, assim, de uma construção sintática do discurso que poderia, literalmente, estar se referindo ao pé do animal em questão, no caso, a cabra.

$\mathrm{O}$ quadro $\mathrm{B}$, que expusemos anteriormente, apresenta diversas nomenclaturas passíveis de serem postas à prova no que tange a caracterizarem-se, ou não, como unidades 
lexicais memorizadas. Pottier (1978) classifica as lexias em quatro tipos: lexia simples, lexia composta, lexia complexa e lexia textual.

Como exemplos de lexia simples aparecem: "cadeira", "para", "comia", que se caracterizam por serem monolexemáticas, isso é, por possuírem um radical apenas. A lexia composta é descrita como sendo resultante da integração semântica ocorrida, por exemplo, em "saca-rolhas", compreendida enquanto um instrumento específico. A lexia complexa é caracterizada como uma sequência em vias de lexicalização, isso é, em vias de ser gerada a partir do processo de opacificação das palavras, às quais passa a ser atribuído um sentido enquanto unidade lexical memorizada e não mais como partes isoladas. Na referida obra, Pottier exemplifica as lexias complexas com os casos de "sinal vermelho" e "um complexo industrial”. Por fim, são exemplificadas como lexias textuais os hinos nacionais e as preces. (POTTIER, 1978, p. 269-70)

Pottier considera, dentre as propriedades das lexias, o seu grau de "rigidez" ou "variabilidade", uma vez que elas podem ser identificadas como sequências memorizadas invariáveis, como "caso de honra" e "procurado pela justiça", ou como sequências que se compõem de um quadro estável e de uma zona instável, como exemplificam "tudo leva a crer que" em relação a "tudo leva a supor que" e "tudo leva a pensar que". (POTTIER, 1978, p. 270-1)

Sobre as unidades léxicas, afirma Alves (2002, p. 50):

Processa-se a composição sintagmática quando os membros integrantes de um elemento frasal encontram-se numa íntima relação sintática, tanto morfológica quanto semanticamente, de forma a constituírem uma única unidade léxica.

Em consonância com essa definição, Oliveira (2007), na tese de doutorado intitulada $A$ Terminologia da Genética Molecular: aspectos morfológicos e semânticos - voltada para a identificação e a descrição das formações sintagmáticas presentes em textos da Genética Molecular - observou que, no corpus por ela analisado, a ordem determinado-determinante frequentemente mantinha-se, ora contendo preposição, ora não. Verificou, ainda, que as formações recorrentes compunham-se, de modo geral, por substantivo mais adjetivo, por 
substantivo mais sintagma preposicional e por substantivo mais adjetivo mais sintagma preposicional. (OLIVEIRA, 2007, p. 62)

Interessa citar esta tese na medida em que ela trata de aspectos terminológicos localizados nos textos que investiga. Nesse sentido, esclarecemos que, no quadro B, em que expusemos as construções lexicais constantes do corpus da presente tese, foram identificadas semelhanças quanto aos modelos de formação sintagmática indicados na citação anterior.

Majoritariamente, verificamos, no referido quadro, a presença de composições constituídas por substantivo mais sintagma preposicional, como foi o caso de "aulas de escrita"; "estudo de um gênero"; "exercício da escrita"; "proposta de escrita"; "ato de leitura"; "aulas de leitura"; "propostas de leitura"; "trabalho com a leitura"; "trabalho com a oralidade".

Quanto às propriedades dessas formações sintagmáticas, no que diz respeito ao seu grau de "variabilidade" ou "rigidez", importa indicar que algumas delas são localizáveis não somente no nosso corpus, mas também em outras produções que se voltam a reflexões sobre o ensino de Língua Portuguesa.

A consulta a alguns números da revista Atualidades Pedagógicas ${ }^{32}$ demonstra a presença de formações sintagmáticas que também foram localizadas nas dissertações que pesquisamos, apesar de haver certas alterações, demonstrando algum grau de variabilidade. Foi o caso das composições "aula de leitura" (ROCHA, 1950, p. 31), "estudo de textos" (ROCHA, 1950, p. 32) e "exercícios de composição" (BUDIN, 1951, p. 33).

No nosso corpus, as formações sintagmáticas, quando comparadas àquelas localizadas nas revistas supracitadas, apresentam distinções quanto à flexão em singular/ plural e à palavra que ocupa o lugar de determinante no conjunto substantivo mais sintagma preposicional. Exemplo disso é que, no nosso corpus, identificamos "exercício da escrita", enquanto nas revistas citadas, formação similar foi apresentada com o substantivo no plural "exercícios" - e com o sintagma preposicionado dando espaço a outro determinante, no caso, “de composição", ao invés "da escrita".

Essa comparação pontual traz à tona a curiosidade de se saber como tais composições sintagmáticas, recorrentes na pesquisa sobre ensino de Língua Portuguesa, mantiveram-se ou modificaram-se no decorrer do tempo. Os dados que apresentamos demonstraram que

\footnotetext{
32 A comparação com alguns números desta revista foi motivada pela intenção de pensarmos acerca da manutenção e transformação da terminologia tendo em vista publicações, diacronicamente, distantes.
} 
formações iniciadas por "aula(s)", "estudo(s)", "exercício(s)" seguidas de sintagma preposicional estavam presentes tanto nos textos extraídos de revistas da década de 50, quanto nas dissertações que compõem o nosso corpus.

O mesmo não foi percebido em relação às composições sintagmáticas iniciadas por "proposta de", "ato de", "trabalho com". Vem daí o interesse de se pensar em que momento essa terminologia começa a ser adotada pela pesquisa em ensino de Língua Portuguesa e como ela reflete o quadro teórico que passa a legitimar. Tal questão pode ser ampliada se considerarmos as demais construções lexicais presentes no quadro B, dentre as quais citamos: a) formações compostas por substantivo mais adjetivos, como é o caso de "competência discursiva oral"; b) por substantivo seguido de sintagma preposicional que inclui um substantivo e um adjetivo, como ocorre em "trabalho com produções textuais"; e c) por substantivo seguido de um primeiro sintagma preposicional que inclui um substantivo mais um adjetivo e de um segundo sintagma preposicional que inclui unicamente um substantivo, como se verifica em "trabalho com a modalidade oral da língua".

Para tais verificações, parece necessário um amplo corpus, constituído de produções acerca do ensino de Língua Portuguesa e que tenham sido publicadas em diversas esferas de circulação e em diferentes períodos. A partir das dissertações que analisamos, não se torna possível nenhuma ponderação conclusiva, mas a sinalização dessa questão traz elementos para investigações futuras. De todo modo, fica demonstrado que quando nos referimos aos objetos recorrentes na pesquisa em ensino de Língua Portuguesa, não os compreendemos por uma denominação unívoca, pelo contrário, verificamos que na abordagem ao mesmo objeto como "ensino de escrita", por exemplo - a terminologia para referir-se a ele é vária.

\subsubsection{Recorrências quanto ao ensino de escrita}

Um objeto evidentemente construído no discurso analisado foi o "ensino de escrita". Esse foi focalizado por 08 dissertações sob análise. A construção desse objeto, alçando-o ao lugar do visível e em relação ao qual se deve falar algo, consolidou-se a partir da adoção de 
diferentes métodos de pesquisa: intervenção e observação em sala de aula, realização de entrevistas, aplicação de questionários e de teste em ambiente virtual, análise de livros didáticos, de diários de classe e de produções discentes.

$\mathrm{Na}$ constituição desse objeto, foi bastante pontuado o que se negava e o que deveria ser alcançado. Quanto ao que se colocou na esfera daquilo a ser alcançado, o "ensino de escrita" configurou-se no nosso corpus, preponderantemente, pelo prisma dos "gêneros"33.

Para que se efetivasse essa forma de tratamento, em que o objeto "ensino de escrita" fosse constituído em torno da ideia de "gêneros", foram evidenciadas as concepções e as propostas didáticas classificadas como refutáveis. Houve, então, uma dinâmica de constituição discursiva pontuada pelo contraste entre o que se defendia como aceitável e como refutável, conforme ocorreu, por exemplo, em FSC03, FMT06a, FMT06b e ESP09.

Em FSC03, a pesquisa foi categorizada como uma "intervenção colaborativa", sendo descrita como um trabalho realizado em uma turma do ciclo II do Ensino Fundamental, por meio da parceria entre a pesquisadora e a professora regente dessa turma. Ao relatar e analisar essa proposta de trabalho, a pesquisadora contrapõe-se à abordagem que a professora regente cedia aos gêneros. Sobre isso, ela afirma:

Na atividade com o jornal, a professora acabou por propor uma certa descaracterização do gênero, pedindo que os alunos recortassem três matérias de dias diferentes e as colassem em uma folha. (FSC03, p. 71)

Observa-se, neste trecho, a refutação ao tratamento docente em relação ao jornal, pois, segundo se argumenta, haveria uma descaracterização do gênero em questão. Para que se evite esse tipo de abordagem, a pesquisadora propõe:

Seguindo a abordagem sócio-histórica de Bakhtin, poderia preservar o gênero (notícia, crônica, artigo) no hipergênero jornal e sugerir uma análise dos vários gêneros que ali circulam, seus temas, autores e possíveis leitores. (FSC03, p. 71)

Na recomendação para que se ensine privilegiando os gêneros, ocorre a remissão ao aporte teórico incluído dentre os referenciais citados pelo trabalho em questão. Nota-se que a proposta trazida pela pesquisadora afirma ancorar-se em uma abordagem que preservaria o

\footnotetext{
${ }^{33}$ A seção 4.1 trata dos termos e dos referenciais teóricos utilizados nas dissertações.
} 
sentido original dos "gêneros", em conformidade com sua fonte bakhtiniana. Ressaltamos que a terminologia presente nesse trabalho está diretamente relacionada aos referenciais teóricos adotados, conforme discutido na seção 4.1.

Do entrechoque entre as concepções e propostas didáticas que devem ser rejeitadas e aquelas que devem ser aceitas, constitui-se o objeto "ensino de escrita" como tópico sobre o qual se fala e para o qual se olha com interesse investigativo. Na dissertação em questão, ele aparece por meio do "trabalho de produção escrita de alguns gêneros do discurso". No caso, tratou-se da proposta da pesquisadora de criar, juntamente com os alunos da turma em que interveio, um álbum personalizado, composto por produções discentes.

Dessa experiência, defendeu-se como aceitável ao "ensino de escrita" pensá-lo como atividade na qual os gêneros sejam estudados em conformidade com a demanda que ocorre no interior da prática docente, sem que se priorize a pré-seleção dos gêneros:

Desde o início de nossa intervenção, surgiram motivações sociais/culturais que nos impulsionavam a trabalhar um determinado gênero do discurso em vez de outro, então entendemos que o melhor era deixar a pré-seleção de gêneros de lado e voltar a atenção ao que as situações comunicativas demandavam. (FSC03, p. 44)

A demanda de se focalizar gêneros diferentes passa então a ser, segundo a dissertação em questão, um aspecto a ser contemplado pelo "ensino de escrita". Continuando a abordagem desse objeto de pesquisa e tendo em vista a observação de como os alunos respondiam às atividades que eram propostas para serem realizadas, também se afirmou que:

As produções foram feitas pelos alunos em sala para que pudéssemos presenciar os momentos interlocutivos. Priorizamos, então, atividades em duplas ou em grupos sempre que possível, pois acreditamos que, partindo desse exercício de discussão, o aluno pode perceber a importância do interlocutor para a construção do seu discurso. (FSC03, p. 44)

O espaço da sala de aula como aquele que dá visibilidade ao "ensino de escrita" é então focalizado pelo olhar da pesquisadora que passa a enunciar sobre esse objeto de pesquisa configurando-o a partir do estudo dos "gêneros", como se vê neste trecho:

[...] se levarmos em conta que, como professores, devemos desenvolver atividades significativas para o aluno e que o ambiente escolar é caracterizado justamente por nele se criarem condições favoráveis para que haja interlocução, o estudo de um gênero não pode 
ser considerado um mero exercício de escrita, pois esse objeto contempla outras dimensões além da materialidade lingüística. (FSC03, p. 80)

Na dissertação em questão, constitui-se como positivo, ou seja, como passível de ser categorizado enquanto aceitável, o "ensino de escrita" como um objeto que alcança sua legitimidade no trabalho de sala de aula que contempla o estudo dos "gêneros", favorecendo a interlocução entre os alunos e, assim, deixando de lado aquilo que deveria ser refutado, que diz respeito ao que é classificado como "mero exercício de escrita".

Esse movimento de contrapor o que é aceito ao que é negado também se concretiza na constituição desse mesmo objeto em FMT06b. Essa dissertação, assim como FSC03, também foi elaborada a partir da intervenção da pesquisadora em sala de aula. A motivação para a pesquisa, conforme se afirma no trabalho em questão, veio do desafio de:

[...] despertar nos discentes essa necessidade de buscar sua competência discursiva escrita com uma atividade de linguagem que fugisse da prática descontextualizada das redações escolares. (FMT06b, p. 123)

Identificamos que, nessa dissertação, defendida em 2006 em universidade federal do Mato Grosso, o "ensino de escrita" configura-se enquanto "competência discursiva" que se contrapõe à "prática descontextualizada das redações escolares". O procedimento de colocar lado a lado o que se defende e o que se refuta é o mesmo localizado em FSC03, defendida três anos antes, em IES federal de Santa Catarina, na qual se repelia o "ensino de escrita" que se caracterizaria como "mero exercício de escrita" em relação àquela que contemplaria outras instâncias além da materialidade linguística.

Lembramos que a terminologia adotada por esses trabalhos está diretamente relacionada aos referenciais teóricos adotados, conforme discutido na seção 4.1. Voltando a FMT06b, verificamos que o objeto "ensino de escrita" é definido como uma competência discursiva inerente ao ensino de Língua Portuguesa que visa:

[...] aprimorar nos educandos a habilidade comunicativa, colocando-os em contato com diferentes gêneros discursivos para que compreendam o que os caracteriza, considerando suas condições de produção (finalidade e especificidade do gênero, lugar preferencial de circulação e interlocutor eleito), o emprego de procedimentos adequados à situação de produção e a utilização de recursos lingüístico-textuais específicos para a organização do texto, dentre outros aspectos. (FMT06b, p. 52) 
Conforme demonstra esta passagem, a "habilidade comunicativa" a ser aprimorada nos alunos relaciona-se à sua compreensão dos gêneros. Foi por essa perspectiva conceptual que o objeto "ensino de escrita" foi delineado, na dissertação em questão. Toda a configuração desse ensino, tendo em vista os gêneros, foi defendida em relação à intervenção da pesquisadora em sala de aula com uma proposta de trabalho com "cartas do leitor", isso é, um trabalho com enfoque na correspondência enviada a revistas e jornais por seus leitores, com comentários e outras abordagens dirigidas a esses meios de comunicação. A delimitação da carta do leitor como material de trabalho pode ser verificada no excerto a seguir:

A opção pela carta do leitor revela-se uma atividade motivadora para os alunos e importante para o ensino, porque possibilita o reconhecimento da CL [Carta do leitor] como fato social, valendo-se dos conhecimentos prévios do aluno e possibilitando o desenvolvimento de habilidades lingüísticas em geral, textuais e discursivas específicas do gênero em questão. (FMT06b, p. 14)

O "ensino de escrita" foi, então, defendido como objeto de investigação ao ser abarcado em relação ao estudo do gênero "carta do leitor". Em referência a esse trabalho, sua configuração foi aferida positivamente, considerada legítima, conforme se depreende do que segue:

Podemos, pelos exemplos [...], perceber que algumas das incoerências presentes nas primeiras produções como grafia, concordância, escolha lexical e estrutura do gênero foram sendo eliminadas a cada novo texto produzido. Os alunos tiveram o cuidado de corrigir seus textos adequando-os aos propósitos enunciativos do gênero. Muitas cartas foram reescritas sem que o professor solicitasse tal atividade. O próprio aluno ou um colega percebia que o texto ainda não estava bom para o suporte em questão. (FMT06b, p. 121)

Desta passagem, apreendemos a abordagem dada à escrita enquanto atividade que redunda em um produto que se torna alvo de contínuas refacções. No que diz respeito à reescrita dos textos, a pesquisadora aborda desde questões de grafia àquelas que denomina como "estrutura do gênero". O processo de revisão e reelaboração da escrita pelos discentes é avaliado positivamente no fragmento anterior. Do que se infere que, na dissertação sob enfoque, valida-se como sendo aceitável ao "ensino de escrita" um encaminhamento da prática docente que pudesse resultar em um trabalho como o descrito. 
Quanto ao que foi explorado até este ponto, buscamos apresentar como as dissertações partem de algo que deveria ser rejeitado quanto ao "ensino de escrita" - em relação à sua descontextualização e ao que foi classificado como "mero exercício de escrita" - para defenderem o que creditam como sendo legítimo a esse ensino, o que, no caso das dissertações mencionadas, volta-se para a discussão dos "gêneros".

Em FMT06a, o "ensino de escrita" também se constituiu a partir do embate entre duas formas de abordagem, uma tida como ultrapassada e, por isso, ilegítima, e a outra, atual, e, sendo assim, aferida como aquela que deveria preponderar:

Tomando os aspectos didático-pedagógicos que foram percebidos nos materiais coletados, pude constatar que os métodos de ensino da produção textual escrita se assemelhavam na ênfase aplicada ao ensino gramatical antes e depois da promulgação da LDB 9.394/96 persistindo até 1998 nas práticas das professoras. A partir de então, começaram a se diferenciar a partir da inclusão de um trabalho voltado ao texto, pois a promulgação da última LDB contribuiu para a constituição/consolidação de novos referenciais teóricometodológicos (PCN, CBA, Escola Ciclada), que acabaram por fundamentar outras propostas de organização do ensino e, em especial, o ensino de língua escrita. (FMT06a, p. 182-3)

Nessa dissertação, foram analisados diários de classe de turmas do Ensino Fundamental I e foram entrevistados alguns professores a fim de se verificar como as orientações trazidas pela Lei de Diretrizes e Bases 9.394/96 haviam repercutido nas aulas de produção escrita, no período de 1990 a 2000.

Nela, o objeto "ensino de escrita" constituiu-se a partir da análise de como os professores recusaram ou aceitaram tais abordagens para esse ensino, buscando compreender como se instaurava um ensino voltado para o texto em detrimento daquele focalizado nos estudos gramaticais. Ao colocar em xeque, então, como o "ensino de escrita" comparecia no material analisado, a dissertação sob enfoque defendeu como lhe sendo pertinente o ensino dos "gêneros", como se verifica no fragmento a seguir:

Mesmo não incorporando totalmente o que estava prescrito por escrito, muitas das professoras procuraram trazer para suas práticas situações que favoreciam a aprendizagem, como, por exemplo, o trabalho com produções textuais em gêneros variados: a carta, o bilhete, a fábula, entre outros. (FMT06a, p. 185) 
Em ESP09, o "ensino de escrita" também se constitui na abordagem dos gêneros. Nesse caso, o enfoque é dado a roteiros para produção de vídeos digitais:

A criação de roteiros para as produções de vídeo digital é apenas uma das opções que o professor tem para incentivar o exercício da escrita de forma contextualizada. $O$ envolvimento das tecnologias, presentes em nosso cotidiano, na educação - como a filmadora, a máquina digital e o computador - é também algo que ainda está sendo trilhado e merece a nossa atenção [...]. (ESP09, p. 87)

Nessa dissertação, a configuração do "ensino de escrita", uma vez mais, ocorre a partir do que deve ser recusado, que novamente refere-se à prática descontextualizada, como se percebe no que segue:

Dentro dessa concepção, que quer que o aluno aprenda a produzir e interpretar textos, $o$ texto passa a ser a unidade de ensino, e não mais a letra, a sílaba, a palavra, ou a frase, que, quando trabalhadas de forma descontextualizada, pouco acrescentam no desenvolvimento da competência discursiva do aluno. (ESP09, p. 26)

O texto adotado como unidade de ensino, em ESP09, foi o roteiro para produção de vídeo digital. Como abordado quanto aos trabalhos anteriores, aqui também a pesquisadora adentrou na sala de aula, mas, no caso dessa investigação, essa entrada objetivou mais a observação das aulas do que sua intervenção. Essa observação ocorreu em uma escola municipal, em turmas do ciclo I do Ensino Fundamental, nas quais era desenvolvido o "Projeto TV Digital". Da entrada da pesquisadora em sala de aula, resultou a investigação de ESP09, na qual foram analisadas as produções discentes de roteiros escritos. No que diz respeito a essa produção, é destacada a liberdade das professoras na construção dos roteiros, já que puderam:

[...] adequá-los ao nível de exigência de cada turma - já que cada série e cada classe apresentam características diferenciadas - e também aos gêneros que pretendiam trabalhar em determinado projeto. Na proposta das animações, a professora pretendia analisar a construção de uma narração pelos estudantes. Nas aulas que antecederam a proposta, foram feitas leituras de histórias e discussões sobre as características do gênero, como pode-se citar o "final feliz", típico do universo infantil além dos ensinamentos retirados da ação dramática apresentada em determinada história. Salientou-se também questões gramaticais, por exemplo as pontuações freqüentes nesse gênero, a criação dos diálogos, as formas de se expressar dúvidas, alegrias e outros sentimentos. (ESP09, p. 39-40) 
Como se verifica, a discussão sobre a atuação docente no comando das aulas voltadas para a escrita dos roteiros é alinhada à temática dos "gêneros". Não fica evidente, neste excerto, de que gênero se trata, uma vez que é citada, unicamente, "a construção de uma narração". Sem nos prolongarmos nesta discussão, importa-nos chamar a atenção para a opção da pesquisadora em fazer com que o seu relato da prática docente seja permeado pela concepção de "gênero". O que também ocorre no próximo fragmento, em que, uma vez mais, aparece esse conceito vinculado ao relato feito pela pesquisadora:

[...] Refletindo, foi possível determinar que as produções de roteiros para produção de vídeo digital ocorreram de forma eficiente e motivadora aos alunos, conforme observações feitas durante todo o estudo. Os roteiros foram se adequando aos gêneros a que se queria explorar, favorecendo essa aproximação dos estudantes nas propostas. Não houve a formulação de um modelo único e fechado de roteiro a ser seguido, mas uma adaptação aos gêneros, priorizando a finalidade de cada produção, a apropriação de saberes pelos alunos e o exercício de uma escrita que fizesse sentido, contextualizada. (ESP09, p. 85)

O que se nota nestes dois últimos fragmentos é que, apesar de a pesquisadora não se deter na especificação das características dos "gêneros" a que ela se refere, há da parte dela uma opção conceptual em relação ao que considera adequado constar do relato feito das aulas observadas. Sendo assim, do mesmo modo como verificamos nas três dissertações discutidas anteriormente, em ESP09, o objeto de pesquisa "ensino de escrita" é abordado a partir da tentativa de alinhamento à perspectiva do "gênero". Essa proposta de alinhar-se a esse referencial conceptual-teórico também aparece na seguinte afirmação:

Uma boa proposta de escrita precisa de propósitos comunicativos claros, ou seja, os estudantes devem saber o que vão escrever, para que e para quem e então definirem a forma que o texto deve tomar: diferentes objetivos exigem diferentes gêneros que devem ter suas características apreendidas. (ESP09, p. 83)

Aqui, comparece a relação entre "uma boa proposta de escrita" e "propósitos comunicativos claros". Dessa relação, redundam explicações que se acoplam à ideia dos "gêneros" que atendem a distintos objetivos e, sendo assim, exigem que suas características sejam aprendidas. 
Por meio da reflexão efetuada em relação às quatro dissertações supramencionadas, verificamos que um aspecto recorrente na configuração do objeto "ensino de escrita" foi sua tematização a partir da tentativa de abordá-lo em relação aos "gêneros do discurso". Outra dissertação que propôs um alinhamento a essa mesma perspectiva foi ESP01. Contudo, nela, ao contrário do que se veio observando, não houve o movimento de procurar estabelecer o que se negava no "ensino de escrita" em relação ao que lhe era passível de ser aceito.

Em ESP01, não se consolidaram reflexões a respeito do que pode ou não ser concebido em relação ao objeto "ensino de escrita". Ele foi tratado a partir de um viés nãopolêmico e a pesquisadora, tendo em vista sua suposta conformidade, passou a tratá-lo não em si, mas a abordá-lo como um objeto pronto a ser incorporado pelas novas tecnologias. Nessa dissertação, foi afirmado que "A história em quadrinhos (HQ) é um dos gêneros adequados para o trabalho com a linguagem escrita”. (ESP01, p. 10). Considerando essa constatação, a discussão nesse trabalho voltou-se para a descrição e discussão de um software. No excerto a seguir, faz-se uma breve referência a ele:

O HagáQuê destina-se à criação de histórias em quadrinhos por alunos do $1^{o}$ e $2^{\circ}$ ciclos do Ensino Fundamental, mas, com a criatividade do professor, pode ser usado por alunos de outros ciclos. (ESP01, p. 35)

Neste fragmento, verifica-se que o software tratado pela dissertação em questão foi denominado "HagáQuê". Nessa pesquisa, citam-se consultas a diferentes softwares que trabalhavam com edição de texto, em especial voltados para as histórias em quadrinho. Da análise desse material, sucederam considerações a respeito dos seus aspectos negativos e positivos. Posteriormente a isso, o próprio ambiente virtual "HagáQuê" foi testado com alunos do ciclo I do Ensino Fundamental de uma escola localizada em Campinas/SP. Desses testes, resultaram algumas ponderações como a que segue:

O ambiente virtual HagaQuê é válido porque oferece ambiente mais propício para as atividades idealizadas pelos professores e poder contribuir para um aprendizado mais efetivo. (ESP01, p. 74)

Destacamos que ESP01 apresenta uma abordagem distinta do "ensino de escrita" quando comparada às quatro dissertações anteriormente citadas. Nelas, mostrou-se recorrente a reflexão direcionada para o relato e para a análise dos pontos positivos de se tomar esse 
objeto pela perspectiva dos gêneros, o que, de acordo com esses trabalhos, seria um meio viável de não o tratar de modo "descontextualizado", conforme expressão constante dos trabalhos supramencionados.

Já em ESP01, também se toma o "ensino de escrita" referindo-se a ele enquanto "gênero", mas isso se faz como ponto de partida para discutir o que, efetivamente, é proposto pelo trabalho em questão, o que, nesse caso, voltou-se para o uso de recursos computacionais como uma ferramenta que pode incorporar e diversificar as formas de acesso a esse objeto.

Continuamos discutindo a configuração do "ensino de escrita" nas dissertações de mestrado pesquisadas, mas, a partir deste ponto, faremos referência aos modos como os trabalhos sob análise constituíram esse objeto não pelo viés do "gênero", mas o destacando a partir da prática da "reescrita".

Esse tipo de abordagem já foi citado em relação a uma das dissertações analisadas anteriormente, a FMT06b. Nela, a "reescrita" apareceu como um elemento legítimo de constar como "ensino de escrita", configurando-se como uma forma de rejeição à redação escolar:

[...] durante as 80 horas-aula da pesquisa-ação, os alunos encontraram nas revistas "Guia Astral" e "Veja" e no jornal "A Tribuna" a oportunidade de escrever textos para realmente serem lidos por seus colegas de sala, da escola e pelos leitores dos suportes. Sentimos que essa atividade de linguagem proporcionou certa desmistificação do ato de escrever. Os alunos não gostavam porque não estavam habituados a escrever. A redação escolar era escrita para ser lida pelo professor, que atribuiria uma nota. Com a produção das cartas $e$ com a certeza de que seus textos seriam analisados mais em função da configuração do gênero do que em função de erros e acertos de gramática, visto que para isso haveria o processo de revisão e de reescrita, os alunos se sentiram mais motivados, confiantes $e$ capazes. (FMT06b, p. 123)

Neste fragmento, verifica-se, uma vez mais, a constituição do objeto "ensino de escrita" na cisão entre o que se nega - a prática escolar da redação - e o que se legitima - a revisão e a reescrita dos textos tendo em vista sua configuração de "gênero".

A visada do "ensino de escrita" pelo prisma da "reescrita" também se faz presente no seguinte excerto:

Outra atividade produtiva foi a refacção individual e coletiva dos textos, uma vez que os alunos demonstraram-se participativos e autocríticos do que produziam. Tal atividade proporcionou a eles momentos de reflexão quanto ao uso da língua materna. Foram capazes de questionar se determinada palavra elou expressão estava compatível com o gênero e o 
suporte estudado. Em alguns momentos, passaram por "iniciação cívica” como, por exemplo, quando, ao reestruturamos um texto que dizia "os prezidentes so promete arruma os bairros e não cumpre a sua promeça...", alguns discentes comentaram que a responsabilidade era do prefeito e não do presidente. (FMT06b, p. 124)

Aí se evidencia a constituição do objeto "ensino de escrita" pela perspectiva de se situar o texto como um produto que se torna alvo de revisões e reescritas. Dinâmica que, segundo a dissertação em questão, favorece oportunidades de melhorar o texto em sua materialidade linguística, tendo em vista os diferentes efeitos que pode provocar no seu leitor.

Outra dissertação que também enunciou sobre o "ensino de escrita", configurando-o em relação à atividade de reescrita, foi EPR02. Dela, extraímos o que segue:

[...] uma prática de revisão e reescrita abrem [sic] espaços e chances não só para o professor refletir sobre sua prática, como também para o aluno colocar-se como autor e apresentar o seu texto. (EPR02, p. 117)

A constituição do "ensino de escrita" pela vertente da reescrita foi concretizada pela recusa de outro modo de lidar com os textos, que, segundo essa dissertação, tornava-os mote para estudos de caráter gramatical. Tal abordagem decorreu à entrada da pesquisadora em sala de aula, que, após a observação e gravação das aulas assistidas, pontua o que deve ser rejeitado nesse ensino e o que lhe falta:

Constatamos também, que os textos revisados e reescritos nas primeiras aulas não foram tratados pela professora como unidade complexa de comunicação e de significação, destinado a um interlocutor que com ele deveria interagir. Nesses casos o texto serviu apenas como pretexto para exercícios gramaticais, tal como os textos fragmentados dos livros didáticos, que são desapropriados de seus autores e de seu contexto, servindo a um exercício mecânico de análise lingüística. Consideramos que a ênfase no sentido literal dos textos e a preocupação com as convenções ortográficas reduziram as possibilidades de leitura do texto. (EPR02, p. 116)

Neste trecho, o enfoque volta-se para o que foi observado, pela pesquisadora, quanto à atividade de revisão e de reescrita de textos em sala de aula. A problematização apresentada em EPR02 origina-se do embate entre o que é classificado como ilegítimo - o tratamento do texto a partir de critérios gramaticais e ortográficos e de valorização da literalidade de sua 
mensagem - e o que seria legítimo à proposta de revisão e reescrita - sua compreensão a partir de um aporte conceptual que destacasse sua importância no processo de interação entre aquele que escreve e os seus destinatários.

Conforme o exposto, observa-se que, nessa dissertação, evidencia-se aquilo que se trata como impertinente à caracterização do "ensino de escrita". Essa impertinência aparece, em EPR02, relacionada à conduta docente, que é qualificada como "tradicional", como se vê a seguir:

Essas aulas de escrita reprodução, observadas por nós, sempre seguiram o mesmo ritual [...] e apresentaram o mesmo objetivo: fixar normas e regras através de exercícios mecânicos $e$ repetitivos. Classificamos essa conduta da professora como uma prática atrelada a uma perspectiva tradicional de ensino de língua portuguesa, fundamentada em uma concepção estruturalista de linguagem, na qual os exercícios mecânicos e repetitivos são considerados excelentes recursos para promover uma aprendizagem disciplinada. (EPR02, p. 100)

A postura docente descrita relaciona-se, de acordo com este excerto, a uma concepção estruturalista da linguagem, que resultaria em exercícios mecânicos e repetitivos que fazem parte de um tipo de ensino categorizado, na dissertação em questão, como "escrita reprodução", que é, por sua vez, aferido negativamente em relação ao objeto "ensino de escrita", tal como se buscou legitimá-lo na referida dissertação. Como já foi abordado, a terminologia adotada, em EPR02 e nos demais trabalhos sob análise, é influenciada pelo seu referencial teórico, discutido na seção 4.1 .

As análises apresentadas até este ponto destacaram como recorrente a configuração do objeto "ensino de escrita" a partir da contraposição entre o que se aceita e o que se refuta. Em EPR02, por exemplo, verificou-se o entrechoque entre a concepção estruturalista e aquela interacionista, sendo essa legitimada pelo trabalho em questão e aquela recusada.

EPR06 é outra dissertação em que comparecem a recusa a uma abordagem do "ensino de escrita" pela perspectiva do estruturalismo e a defesa de sua configuração pelo prisma interacionista, sendo essa última avaliada como estando distante da atuação docente observada:

[...] apesar da boa vontade do professor; do seu empenho em trabalhar com textos; de oferecer atividades diversificadas de produções textuais; de mudar o procedimento metodológico, quanto ao atendimento individualizado ao aluno; consideramos que a prática 
significativa e efetiva, na dimensão interacionista, ainda está por acontecer, mesmo após cursos e reuniões de estudos. (EPR06, p. 106)

Essa dissertação apresentou investigação que envolveu a aplicação de questionários a professores do Programa "Sala de Apoio à Aprendizagem em Língua Portuguesa" (SAALP), além da análise de documentos que normatizavam esse programa e de algumas produções discentes. A SAALP foi implantada em escolas estaduais de Maringá/PR no ano de 2004, segundo informações expostas em EPR06, com a finalidade de contribuir para o aprendizado de alunos que foram identificados com dificuldades em aspectos de leitura e de escrita.

Da passagem a seguir, depreende-se a descrição do que foi observado quanto aos professores do referido programa, em relação ao que, na dicotomização presente no trabalho em questão, tornou-se alvo de refutação:

[...] a grande maioria dos professores da SAALP não só concebe a língua, a linguagem, a oralidade, a leitura e a produção textual na esteira tradicional do Estruturalismo, como as professam em suas práticas diárias. Nesse sentido podemos afirmar a consonância entre teoria e prática. Isto significa dizer que o espírito da antiga lei no 5.692/71, juntamente com todo o arsenal teórico-metodológico do Estruturalismo, continua presente e vivo. Ele se manifesta materialmente em todas as ações docentes: na seleção do material didático, na seleção dos conteúdos, nos objetivos elencados, na metodologia utilizada, nos instrumentos e nas formas de avaliação. Sobretudo, na relação professor-aluno. (EPR06, p. 138)

Já em FRS10, a configuração do "ensino de escrita" não se deu pela dicotomia entre duas vertentes conceptuais e teóricas, mas se efetivou na legitimação dos resultados alcançados a partir de intervenção da pesquisadora em sala de aula. No caso, a pesquisadora interveio em turma do ciclo II do Ensino Fundamental, na qual recolheu 48 produções textuais como material de pesquisa. A legitimidade do "ensino de escrita" configurou-se, nesse trabalho, em relação à atividade de reescrita:

Considerando o primeiro resumo produzido e a sua subsequente reescrita, nove meses depois, após o desenvolvimento de um trabalho intenso voltado para a produção textual, é possível observar uma tendência à diminuição do uso de lexemas idênticos. Esse resultado possivelmente sofre a influência do trabalho realizado em sala de aula, o qual visou à apresentação de outras formas para a realização da referenciação, dentre as quais o uso de expressões sinônimas ou quase. (FRS10, p. 62) 
Em FRS10, foi defendido o "ensino de escrita" que percorresse, dentre diversas versões de textos produzidos pelos alunos, as alterações ocorridas que demonstrassem avanços em relação aos tópicos de elaboração textual observados, que, no caso, relacionavamse aos modos de referenciação no interior do texto, em especial, quanto ao uso de expressões sinônimas, de lexemas idênticos e de elipses.

No âmbito dessa dissertação, o objeto "ensino de escrita" constituiu-se, pois, pela validação dos resultados alcançados pelos alunos quanto à compreensão e ao uso adequado de elementos de produção textual focalizados em sala de aula, tal como pode ser percebido na passagem a seguir:

[...] há uma grande diferença entre os dois textos, não apenas em relação à carga informativa, que é apresentada de modo mais preciso no segundo, mas especialmente em relação à tentativa de uso de expressões sinônimas. Os personagens principais, Marcão e Serginho, no primeiro texto, são referidos sempre pelo nome. Na reescrita, porém, observa-se a utilização de expressões sinônimas quando o aluno escreve "o rapaz que gostava de beber vodca", ao ser referir a Marcão, e "o amigo", para fazer referência a Serginho. A escolha de Felipe pela expressão sinônima demonstra maior controle do autor sobre seu texto, exatamente porque ele busca essa expressão no primeiro parágrafo e obtém assim o efeito coesivo desejado por meio da referência a uma característica marcante do personagem, o seu gosto por vodca. Vale salientar, também, a utilização dos termos "morrido" e "falecido" que resultam em um uso adequado desse recurso. (FRS10, p. 47)

Trata-se, nos dados abordados pela pesquisadora, de uma avaliação positiva do resumo discente e de sua reescrita produzidos a partir de livro intitulado Veneno Lento, que foi focalizado na intervenção de pesquisa em sala de aula. FRS10 corrobora a recorrência já verificada em outras dissertações, quanto à constituição do objeto "ensino de escrita" pela legitimação da atividade de reescrita.

Como demonstrado, da comparação entre as dissertações de mestrado analisadas, foi possível destacar recorrências quanto ao que se delimitou enquanto foco de atenção, isso é, enquanto objeto a ser observado e sobre o qual se deve enunciar algo. Esse objeto não se caracteriza por sua concretude, por ser palpabilidade, apesar de ser localizável em espaços concretos, que, no caso de nossa discussão, foi a sala de aula.

Para contornar a abstração do objeto, focalizado nas investigações em questão, foram adotados métodos de pesquisa que viabilizassem a delimitação de seu contorno. Tais métodos mostraram-se recorrentes nas dissertações supracitadas, com especial destaque para a intervenção do pesquisador em sala de aula. Mais de um trabalho citou esse procedimento 
para a coleta dos registros nos quais "o ensino de escrita" poderia aparecer como objeto de reflexão. Foram então citados registros das aulas observadas, das intervenções realizadas com os alunos pesquisados e também as produções textuais discentes.

A partir desses registros foram, então, pontuados, de um lado, o que se acreditava impertinente ao "ensino de escrita", aspecto abordado, pelas dissertações sob enfoque, especialmente quanto à atuação docente observada, e, de outro lado, o que se creditava como lhe sendo pertinente, que se voltou, preponderantemente, para a configuração desse objeto de pesquisa pela perspectiva do "gênero" e pelas propostas de reescrita. No que segue, continuamos analisando outras recorrências identificadas, agora concernentes ao "ensino de leitura".

\subsubsection{Recorrências quanto ao ensino de leitura}

$\mathrm{O}$ "ensino de leitura" configurou-se como objeto de investigação em 05 dissertações de mestrado. Nelas, destacou-se como método de pesquisa o registro da fala docente, por meio de entrevistas e de questionários. Além desses registros, outros decorreram da observação em sala de aula. Ademais, compareceram livros didáticos e diários de classe, dentre outros documentos, como materiais pesquisados.

Do mesmo modo como procedemos, na seção anterior, em relação à configuração do objeto "ensino de escrita", no que segue também nos deteremos na apresentação do que se delineou como recorrente, no caso, quanto ao "ensino de leitura".

A polaridade observada no que disse respeito ao "ensino de escrita", na qual se estabeleceu como recusável a perspectiva de ensino orientada por concepções estruturalistas, também foi identificada quanto ao "ensino de leitura". Em EPR06, essa abordagem constituiu-se pela oposição entre o que seria a visão estruturalista do "ensino de leitura" e aquela que se caracterizaria como "crítica e reflexiva", conforme se depreende do fragmento a seguir: 
A visão estruturalista, explicitamente assumida pelos professores 2, 3 e 10, segue a coerência dada em outros contextos. Nesse sentido, observamos que o trabalho com a leitura, não busca resposta significativa, no sentido de o aluno se posicionar critica e reflexivamente, concordando ou refutando os argumentos do texto. (EPR06, p. 147)

A referência aos professores, nesta passagem, diz respeito às respostas que eles forneceram a um questionário aplicado pela pesquisadora. As perguntas foram direcionadas a docentes da "Sala de Apoio à Aprendizagem em Língua Portuguesa" (SAALP).

Conforme informado em EPR06, esse foi um programa implantado em algumas escolas estaduais de Maringá, Paraná, em 2004, que se direcionava a alunos que eram tidos como aqueles que demonstravam dificuldades tanto em tópicos de Língua Portuguesa quanto de Matemática. O referido questionário abrangeu aspectos relacionados, especificamente, ao ensino de Língua Portuguesa, quanto aos seus objetivos, tanto no ensino regular, quanto na SAALP, e às concepções de língua e de linguagem orientadoras da prática pedagógica. Uma das análises propostas para as respostas obtidas a partir da aplicação dos questionários pode ser observada no trecho a seguir:

[...] a grande maioria dos professores da SAALP não só concebe a língua, a linguagem, a oralidade, a leitura e a produção textual na esteira tradicional do Estruturalismo, como as professam em suas práticas diárias. Nesse sentido podemos afirmar a consonância entre teoria e prática. Isto significa dizer que o espírito da antiga lei no 5.692/71, juntamente com todo o arsenal teórico-metodológico do Estruturalismo, continua presente e vivo. Ele se manifesta materialmente em todas as ações docentes: na seleção do material didático, na seleção dos conteúdos, nos objetivos elencados, na metodologia utilizada, nos instrumentos e nas formas de avaliação. Sobretudo, na relação professor-aluno. (EPR06, p. 138)

Tendo em vista este tipo de análise, EPR06 aponta para a concepção estruturalista como aquela subjacente aos vários aspectos envolvidos no ensino de Língua Portuguesa e, a partir dessa percepção, acusa a ausência de transformações que provocassem a transposição do antigo modelo, no que se refere também ao "ensino de leitura":

Não houve [...] no ensino de língua portuguesa, mudanças internas significativas. A concepção de língua continuou fundamentada num sistema em que a gramática era instrumento de expressão, e a leitura direcionava-se a textos que fossem modelos para o conhecimento e a apropriação da língua padrão. (EPR06, p. 24) 
Outra dissertação que também propôs o objeto "ensino de leitura" a partir da verificação e da avaliação das concepções que lhe eram subjacentes foi FPB07. Nela, também a concepção "estruturalista" compareceu como tendo sido identificada na prática docente. No caso dessa dissertação, além da realização de entrevistas, foram gravadas e transcritas em áudio aulas ministradas, aproximadamente por três meses, em turmas do ciclo II do Ensino Fundamental de uma escola estadual, localizada em Campina Grande, Paraíba. Da observação dessas aulas, advieram ponderações como a seguinte:

A concepção teórica de leitura que estava subjacente à prática de sala de aula da docente era a estruturalista. Essa nossa descoberta só foi possível a partir da observação das aulas da professora, pois, durante a entrevista que realizamos com a mesma, ela não conseguiu falar sobre nenhuma concepção de leitura que tenha estudado em sua graduação, especialização ou em algum dos cursos de reciclagem que tenha participado. Ou seja, percebemos que a professora está trabalhando em sala de aula sem ter uma percepção clara de que há uma concepção teórica subjacente à sua prática docente e de que concepção teórica é essa (FPB07, p. 110)

Essa ancoragem conceptual foi aferida negativamente, tendo em vista que, de acordo com FPB07, ela redundava em aulas como as descritas na próxima passagem:

As discussões em sala de aula em torno dos textos partem do e retornam ao conhecimento de mundo dos alunos, não aprofundando as informações que esses alunos já têm. Acreditamos que esse é um aspecto que está diretamente relacionado à concepção teórica da docente. Os conteúdos, nos editoriais trabalhados em sala de aula, estavam relacionados a assuntos que os alunos conheciam (epidemia de dengue e novas tecnologias). Do ponto de vista da textualidade, seria importante o destaque para a estrutura composiconal e o estilo desses textos, relacionando-os aos suportes onde eles circulam, à função social que eles exercem e ao público ao qual se destinam. Todo esse percurso suscitará, naturalmente, sentidos na leitura. E essa abordagem não aconteceu justamente porque a professora parece não ter um conhecimento teórico mais aprofundado sobre os gêneros textuais (FPB07, p. 111)

Mais uma vez o procedimento da dicotomização compareceu na constituição dos objetos de investigação nas dissertações sob análise. No caso do "ensino de leitura", tal como ele foi delineado em FPB07, de um lado, apareceu o estruturalismo e, de outro lado, a perspectiva dos "gêneros" e o "sociointeracionismo", sendo esse último destacado no excerto a seguir: 
A professora construiu os sentidos dos textos em sala de aula e restringiu a participação dos alunos nesse processo. Na maioria das vezes, os alunos esperavam que ela fornecesse "a interpretação correta" do que foi lido. Dessa forma, a interpretação final dos textos era sempre dela. Os alunos participavam apenas contribuindo com o seu conhecimento de mundo sobre os temas tratados nos textos e pareciam ter receio ou estarem acomodados diante das discussões desses temas. A atitude dos alunos de esperar "a leitura correta" nos evidencia que, tanto professora quanto alunos, não trabalham com textos numa perspectiva sóciointeracionista de leitura em que mais de um sentido é permitido para os textos. (FPB07, p. 111)

Deste tipo de abordagem do objeto em questão, desdobraram-se considerações acerca do despreparo docente para abordar o "ensino de leitura" pela perspectiva, então, defendida como aquela que seria a mais adequada:

[...] momento da fala da professora que merece destaque na nossa análise, pois aqui constatamos que ela confunde vários gêneros textuais. Notemos que ela classifica o texto lido como reportagem jornalística e como notícia, e, no entanto, não se trata de nenhum desses gêneros, mas sim, de um de um editorial. Essa fala da professora nos demonstra que ela provavelmente desconhece a teoria de gêneros textuais ou conhece tal teoria, mas não faz uso de suas contribuições em sala de aula. Esse trecho também nos ajuda a compreender a maneira como os demais textos foram trabalhados em sala de aula. Apenas o conteúdo temático destes foi abordado; estilo e estrutura composicional não foram discutidos. Possivelmente, se a professora conhecesse a teoria de gêneros textuais, esses outros aspectos constituintes dos gêneros teriam sido devidamente elucidados nas aulas de leitura. (FPB07, p. 86)

A passagem anterior remete-se aos "gêneros textuais". No que se refere ao "ensino de leitura", outras dissertações, além de FPB07, delimitaram-no pela perspectiva dos "gêneros", como se pode observar nos excertos que seguem:

Em alguns livros, como o "Viver e aprender português", "Projeto pintanguá: português" e o "L.E.R.: leitura, escrita e reflexão", há também propostas de leitura que objetivam estabelecer a comparação entre gêneros e destacar a função de alguns elementos lingüísticos no texto. Nesses livros, observamos o tratamento de um tema a partir de diferentes gêneros. Por exemplo, na unidade 1 do primeiro livro, para a discussão do tema Esporte, são utilizados três gêneros diferentes, a saber: poema, reportagem e charge. (FPA07, p. 101)

O trabalho com gêneros mais acentuado nos quatro livros apresenta-se na seleção de textos de diferentes gêneros. O objetivo dos autores é trazer os textos que circulam nas variadas esferas sociais para o meio escolar, por isso, os artigos de jornais e revistas, propaganda, sites estão presentes em grande porcentagem. A preocupação com a diversidade faz com que os livros disponibilizem outras fontes de pesquisa para o aluno entrar em contato (pela 
internet, em livros ou filmes), além dos textos que o livro já oferece para leituras. Nesse sentido, consideramos que os livros proporcionam uma oportunidade de trabalho com leitura de maneira discursiva, ou seja, desenvolvem a capacidade leitora porque os exercícios de interpretação, com raras exceções, promovem reflexão sobre as situações de produção e uso. (ESP07, p. 97)

Estes dois fragmentos possuem similaridade não somente pela referência aos textos pela perspectiva dos "gêneros", tal como havíamos antecipado, mas também por deterem-se na análise de livros didáticos, com a finalidade de observarem como o "ensino de leitura" comparecia nesse material.

As duas dissertações assinaladas, FPA07 e ESP07, focalizaram na análise de livros didáticos. Junto a esse procedimento metodológico, foram adotadas também a observação em sala de aula e a realização de entrevistas. Em FPA07, foram feitas entrevistas com os professores investigados, e, em ESP07, também se procedeu à realização de entrevistas, mas com autores do material didático pesquisado.

A discussão dessas dissertações foi permeada pela preocupação com a descrição e com a discussão sobre o material didático, voltando-se ou para a reflexão sobre como se dava a seleção dos livros e como era o seu uso em sala de aula e/ou sobre as concepções que lhe eram subjacentes. Daí terem aparecido junto à análise desse material, a realização de entrevistas e/ou a observação em sala de aula.

Dessa abordagem investigativa, chegou-se a conclusões como a seguinte:

[...] os textos aproveitados do LD [Livro didático] foram focalizados apenas quanto ao pólo da língua (sistema), porquanto, ainda que as perguntas de compreensão tenham sido aproveitadas, o contexto dialógico em que foi produzido e a idéia de que o sentido é determinado pela interação entre sujeitos e outros enunciados não estiveram em foco. (FPA07, p. 160)

Como tem sido demonstrado em mais de um ponto do presente capítulo, de análise da configuração discursiva do ensino de Língua Portuguesa nas dissertações de mestrado pesquisadas, a oposição entre o que é identificado nos registros e materiais pesquisados e o que se pontua como sendo o ideal presentificou-se tanto no delineamento do objeto "ensino de escrita", quanto no "ensino de leitura".

No caso do "ensino de leitura" e tendo em vista o último excerto transcrito, verifica-se que se avaliou negativamente o tratamento dos textos pelo viés da língua enquanto sistema em 
contraste àquele em que o contexto dialógico da produção textual ganharia relevância. Uma vez mais compreendemos que os termos adotados nos trabalhos sob enfoque refletem o seu referencial teórico, conforme discutido na seção 4.1.

Terminamos a presente seção, expondo o modo como o "ensino de leitura" configurou-se em ESP08. Nela, foram detectadas recorrências semelhantes ao que viemos expondo, quanto à constituição desse objeto nas demais dissertações citadas, mas também houve aspectos que não encontraram correspondência às formas de tratamento supramencionadas.

No que diz respeito às recorrências, que é o eixo norteador da discussão que propomos, verificamos que houve, em ESP08, a ênfase em um "ensino de leitura" que se constitua pela rejeição à uniformidade de interpretação dos sentidos de um texto. Esse tipo de configuração do objeto em questão já havia sido explicitado, por exemplo, em FPB07. Em ESP08, essa abordagem compareceu do seguinte modo:

Os jogos de improvisação teatral permitem desvelar uma rede de sentidos construídos na relação entre os jogadores, constituindo-se para além de uma estratégia eficiente para a leitura, mas, no ato de leitura em si, produzido coletivamente e evidenciado na elaboração do discurso cênico. Este aspecto dos jogos se concilia com os objetivos da Hora da Leitura porque permite ao professor desenvolver com seus alunos a noção de composição de um discurso estético como um ato de leitura, na medida em que o conteúdo manifestado no jogo surge de uma compreensão leitora do jogador em relação à obra. Além disso, o ato de leitura de que se constitui o jogo solicita do leitor o desapego à rigidez de uma interpretação única e correta. (ESP08, p. 156)

Este fragmento relaciona os "jogos de improvisação teatral" aos objetivos docentes do projeto "Hora da Leitura". Vale dizer que, conforme explica ESP08, esse foi um projeto criado no primeiro semestre de 2004, com a finalidade de trabalhar com alunos identificados como sendo aqueles que apresentavam mais dificuldades de leitura, em escolas estaduais de São Paulo.

$\mathrm{Na}$ dissertação em questão, a discussão apresentada foi proveniente da investigação realizada a partir de jogos feitos com professores do referido projeto, da análise dos seus diários de classe e também a partir de questionários que lhes foram aplicados.

Dos diários, foram extraídos, por exemplo, dados acerca de como se dava a atuação docente no comando do projeto "Hora da Leitura". O mesmo tipo de informação também foi 
coletado a partir da aplicação de questionários, nos quais também se perguntou a respeito das expectativas docentes.

De acordo com ESP08, atividades teatrais foram expressivamente relatadas pelos professores quanto ao trabalho que realizavam na "Hora da Leitura". Tendo em vista esse contexto, essa dissertação voltou-se à experimentação e à análise de "jogos de improvisação teatral" como sendo pertinentes para a constituição das atuais necessidades do "ensino de leitura".

Quanto a essas demandas, como se observa no último trecho transcrito, ressaltam-se os benefícios desses jogos no que concerne à possibilidade de se pensar a construção de um texto estético coletivamente, sem se restringir ao parâmetro de unicidade interpretativa de um texto. Sobre os “jogos de improvisação teatral”, afirma-se:

Os jogos de improvisação teatral, sem dar primazia à promoção de eventos espetaculares, permitem que atividades teatrais sejam experienciadas por todos os alunos de uma turma. Divididos em dois, três, quatro ou mais grupos, eles participam ativamente, assumindo ora a função de jogadores-atores (alunos que atuam em cena), ora a função de jogadoresespectadores (alunos que observam as realizações cênicas de seus parceiros) [...] Nos jogos de improvisação teatral, os jogadores-atores acolhem a proposta de investigação colocada pelo coordenador do processo. Nos casos em que os jogos de improvisação teatral são desenvolvidos no meio escolar, o papel de coordenador é exercido pelo professor. Os jogadores-atores, a partir da ação improvisada (brevemente combinada ou não), elaboram um discurso cênico capaz de comunicar não só o conteúdo da proposta, mas a compreensão que o grupo tem a respeito deste conteúdo, enquanto o grupo de jogadores-espectadores observa e, finalizada a ação, avalia o discurso elaborado na medida em que expõe sua reação ao que foi apresentado e, conseqüentemente, sua compreensão da cena, colaborando, assim, com os jogadores-atores no aprimoramento desta. (ESP08, p. 60-1)

Neste excerto, corrobora-se a viabilidade de tais jogos ao serem considerados no contexto escolar. $\mathrm{Na}$ abordagem proposta, ressaltam-se os mecanismos adotados para efetivação dessa atividade lúdica. Conforme afirma ESP08, essa prática, pensada no âmbito da "Hora da Leitura", aparece como um dispositivo eficiente para o "ensino de leitura" que se configura enquanto ato de constituição coletiva dos sentidos sem priorizar uma única interpretação tida como a correta.

A defesa da multiplicidade de sentidos possíveis de serem atribuídos a um mesmo texto compareceu em mais de uma dissertação analisada, coadunando com a configuração do objeto "ensino de leitura" pela perspectiva interacionista em oposição àquela estruturalista. Essa foi uma abordagem recorrente na constituição do que seja legítimo considerar quando se 
trata de "ensino de leitura", ainda que tenhamos localizado no nosso corpus abordagens que tenham privilegiado outros modos de cercear o objeto em questão, como foi o caso de ESP08, na qual a discussão voltou-se menos para a definição do que seria o "ensino de leitura" e mais para o modo como ele poderia ocorrer por meio dos jogos teatrais propostos.

Observamos que o cerceamento dos objetos de pesquisa pela oposição entre o que lhe seria pertinente ou impertinente deu-se tanto na configuração do que seria o "ensino de escrita" quanto do que seria o "ensino de leitura". Já quanto aos métodos de pesquisa empregados, avaliamos que, em relação ao "ensino de leitura", destacaram-se a observação em sala de aula, a coleta de pareceres docentes, por meio de questionário ou de entrevista, e também a análise de livros didáticos. Já no que se refere ao "ensino de escrita", predominou a intervenção do pesquisador em sala de aula. Continuamos esta discussão, voltando-nos agora para as abordagens recorrentes quanto ao "livro didático".

\subsubsection{Recorrências quanto ao livro didático}

Outro objeto constituído foi o "livro didático", como se identificou em 04 dissertações de mestrado analisadas. Sua configuração ocorreu, em especial, a partir da análise desses livros, pelo delineamento dos problemas aferidos como existentes nesse material e pela exposição do seu conteúdo. Em relação a esse segundo ponto, tanto ESP07 quanto FPA07 abordaram o "livro didático" considerando, por exemplo, o tratamento cedido aos "gêneros" e à gramática, como se vê no que segue:

O trabalho com gêneros mais acentuado nos quatro livros [Referência aos livros didáticos analisados] apresenta-se na seleção de textos de diferentes gêneros. $O$ objetivo dos autores é trazer os textos que circulam nas variadas esferas sociais para o meio escolar, por isso, os artigos de jornais e revistas, propaganda, sites estão presentes em grande porcentagem. A preocupação com a diversidade faz com que os livros disponibilizem outras fontes de pesquisa para o aluno entrar em contato (pela internet, em livros ou filmes), além dos textos que o livro já oferece para leituras. (ESP07, p. 97) 
Em alguns livros [Referência aos livros didáticos analisados], como o "Viver e aprender português", "Projeto pintanguá: português" e o "L.E.R.: leitura, escrita e reflexão", há também propostas de leitura que objetivam estabelecer a comparação entre gêneros $e$ destacar a função de alguns elementos lingüísticos no texto. Nesses livros, observamos o tratamento de um tema a partir de diferentes gêneros. Por exemplo, na unidade 1 do primeiro livro, para a discussão do tema Esporte, são utilizados três gêneros diferentes, a saber: poema, reportagem e charge. (FPA07, p. 101)

Como se observa, os dois excertos demonstram que as dissertações mencionadas, ESP07 e FPA07, voltaram-se para a apresentação de como os livros didáticos incluíram os "gêneros" em seu conteúdo. Os trechos em questão destacaram a variedade dos textos apresentados aos alunos. Verificamos, no que segue, outras abordagens desses trabalhos, agora quanto à gramática:

Constatamos que a gramática tem um tratamento especial nos livros que procuram explicar o conteúdo sem expor as regras desnecessariamente, ou seja, os exercícios trazem elementos do próprio texto da unidade. O livro "Língua Portuguesa: Rumo ao Letramento" é o melhor exemplo de contextualização do conteúdo gramatical se comparado aos outros que analisamos neste capítulo. $O$ ensino com propósito de desenvolver a capacidade lingüística tem trazido oportunidades para os alunos reconhecerem seu cotidiano através de sua própria língua. Podemos confirmar essa característica nas respostas dos autores [Referência aos autores dos livros didáticos pesquisados] que muito se preocupam em "destradicionalizar" esse estudo. (ESP07, p. 95)

Nos livros, quanto ao conhecimento lingüístico, há conteúdos e exercícios gramaticais e alguns textos pequenos que servem para o tratamento de aspectos relacionados à estrutura, ao reconhecimento de classes gramaticais e à ortografia. Encontramos diferentes conteúdos gramaticais, como: encontro vocálico, separação em sílabas, encontro consonantal, dígrafo, sílaba tônica, ortografia ( $g, j, q u, g u, c ̧, c, s s, s, z, s c)$, tipos de acento, pontuação, tipos de frase, substantivos, adjetivos, locução adjetiva, pronomes, verbo, preposição e advérbios. (FPA07, p. 108)

Estes dois fragmentos demonstram considerações distintas em relação ao tratamento cedido à gramática nos livros que analisaram. O primeiro excerto apresentou os estudos gramaticais por um prisma inovador - voltado à "contextualização do conteúdo gramatical". Já o segundo trecho descreveu os conteúdos identificados nos material didático, que foram, por sua vez, alvo de ponderações como a que segue:

Por meio da análise dos $L D$ [Livro didático] verificamos que o ensino da gramática, nos aspectos ortográficos e morfológicos, está centrado no reconhecer, no catalogar, na nomeação de entidades da língua. Dessa forma, é possível afirmar que a competência 
prevista, nas seções destinadas a esse conteúdo, não é a produção e a compreensão de textos orais e escritos nem a reflexão sobre a língua, mas sim a identificação de classes e a memorização de regras ortográficas. (FPA07, p. 151-2)

Os modos como o objeto "livro didático" foi constituído no nosso corpus demonstraram distinções quanto a certos aspectos, como, por exemplo, quanto à incorporação da gramática nesse material, voltada para uma abordagem inovadora ou relacionada a um formato tradicional, como pode ser verificado nos fragmentos anteriormente transcritos.

Já no âmbito das recorrências, identificamos o mesmo procedimento metodológico adotado, no caso, o de análise de livros didáticos. Observou-se, ainda, que, a partir de tal análise, as dissertações ESP07 e FPA07 apontaram para questões acerca dos textos identificados nesse material por meio da perspectiva dos "gêneros". Outra similaridade adveio da sistemática, presente nessas dissertações, de voltarem-se para a exposição do conteúdo privilegiado no material didático objeto de reflexão.

A apresentação do conteúdo constante dos materiais didáticos também foi um procedimento utilizado por FMT07. Nesse trabalho, concretizou-se o recurso de apresentar uma análise diacrônica das formas como a gramática compareceu nos livros analisados, conforme se depreende do que segue:

O autor [Referência ao autor do livro didático sob análise] focaliza a questão de usar as formas gramaticais corretas, porque acredita que o aluno internalizará regras lingüísticas diferentes daquela que usa, a partir do momento que entra em contato com as noções sobre o que a linguagem faz e como faz. Nesse sentido a gramática da língua preocupa-se em descrever e relatar relações que se estabelecem entre os elementos do sistema lingüístico, ou seja, a maneira como se organizam esses sistemas. Por isso enfoca os estudos gramaticais, pois compreende que utilizando os exercícios estruturais vai treinar os alunos para usar as estruturas lingüísticas convencionais. (FMT07, p. 122)

O uso de atividades gramaticais como treino, como uma técnica, visava a [sic] automatização de estruturas lingüísticas para uso, em situação de comunicação. Esse tipo de uso gramatical vai ao encontro da corrente estruturalista em vigor na época que tem a língua como meio de comunicação, mas considera que o processo de interlocução não interfere nela, exclui o papel da história e das reais relações entre os falantes. (FMT07, p. 122)

O livro [Referência ao livro didático sob análise], de um modo geral, atende aos preceitos do ensino descritivo, apresentando um destaque à gramática, com atividades bem definidas, pautada no estudo de regras e na repetição de exercícios. (FMT07, p. 137)

Com relação à parte gramatical, observa-se que ALP [Referência ao livro didático "Análise, Linguagem e Pensamento"] reserva um lugar notadamente menor aos exercícios gramaticais, 
assim como para as definições de conceitos da gramática. Os estudos gramaticais são chamados de gramática textual, o que denota que ela está a serviço do texto e não, ao contrário, o texto a serviço da gramática. Vale ressaltar que, quase sempre estes estudos, [sic] são critérios estabelecidos para a avaliação da produção de texto [...]. Essa diminuição de espaços reservados para os estudos gramaticais, para a ortografia, por exemplo, em função do maior destaque apresentado para trabalhos com práticas de leitura e produção de textos. (FMT07, p. 145)

As duas primeiras passagens transcritas dizem respeito ao livro didático Estudo Dirigido de Português, edição de 1976. O segundo fragmento refere-se ao Reflexão e Ação, editado em 1984, e o terceiro faz menção ao Análise, Linguagem e Pensamento (ALP), edição de 1993. Como se vê, o objeto "livro didático" foi, em grande medida, constituído, no nosso corpus, pela descrição do seu conteúdo e por ponderações que seguiram a essa parte descritiva.

Outro fator recorrente na configuração do objeto "livro didático" foi o apontamento de falhas relacionadas ao tratamento dos livros quanto aos "gêneros" e quanto à oralidade. No que segue, transcrevemos parte dessas avaliações:

[...] podemos concluir que embora os gêneros discursivos estejam presentes nesses instrumentos didáticos [Referência aos livros analisados], eles não são tomados como objeto, uma vez que os aspectos ligados à situação de produção, os elementos da ordem do social e do histórico, o conteúdo temático, a construção composicional e o estilo verbal não são tratados de modo sistemático. Percebemos que eles são suportes de conteúdos e favorecem o desenvolvimento de várias atividades que levam as professoras a intervir sobre a temática, daí afirmarmos que as informações veiculadas no texto são os objetos de ensino priorizados nas propostas do LD [Livro Didático]. (FPA07, p. 153)

As atividades nos livros analisados, quanto à linguagem oral, limitam-se à leitura em voz alta, dramatizações e eventos proporcionados pelo próprio ambiente escolar. Falta, nesse sentido, um material adequado, que relacione, de forma contextualizada, a linguagem oral como objeto de ensino em cada unidade. (ESP07, p. 95)

[...] pudemos constatar que a modalidade oral já vem ocupando certo espaço nos livros didáticos, o que a nosso ver reflete preocupação de seus autores em atender às orientações dos PCN, tendo em vista a avaliação desse material realizada pelo Programa Nacional do Livro Didático. Faz-se necessário, entretanto, ressaltar que as atividades com a modalidade oral são ainda pouco representativas e eficientes e quase sempre não correspondem ao que prognosticam os PCN, sendo ineficazes para tornar os alunos proficientes no uso da modalidade oral da sua língua materna. (FPB08a, p. 108)

Nestes fragmentos, destacam-se as avaliações feitas quanto à abordagem dos "gêneros discursivos" e dos estudos da língua oral tendo em vista os livros didáticos analisados. A 
esses dois tópicos, tecem-se críticas voltadas à insuficiência do tratamento que lhes foi cedido no material sob enfoque.

Conforme discussão apresentada nesta seção, verificamos que o objeto "livro didático" constituiu-se, nas dissertações que analisamos, principalmente pela descrição do seu conteúdo e pelo apontamento de falhas quanto às propostas de estudo envolvendo os "gêneros discursivos" e a modalidade oral da língua, avaliadas como limitantes. Tal configuração decorreu, em especial, da adoção da análise de livros como método de pesquisa empreendido por ESP07, FMT07, FPA07 e FPB08a. No que segue, damos continuidade à discussão sobre outras recorrências localizadas no nosso corpus.

\subsubsection{Recorrências quanto ao ensino de oralidade}

O "ensino de oralidade" como foco de investigação configurou-se em 03 dissertações, foram elas: EPR04, EPA08 e FPB08a. Os contornos desse objeto delinearam-se como elemento a ser problematizado a partir da observação e gravação de aulas, em EPR04. Esse trabalho voltou-se para um corpus de registros de vinte aulas ministradas em duas turmas do Ensino Fundamental II. Além disso, ainda citou planejamentos docentes anuais e documentos curriculares oficiais como material investigado.

A análise documental também foi referida como método de pesquisa em EPA08. Nesse caso, o interesse direcionou-se para documentos oriundos de curso de formação docente continuada, haja vista a assunção de um curso de formação para professores de Oriximiná, cidade do Pará, como foco de investigação. Além desses documentos, compuseram o material analisado entrevistas realizadas com professores partícipes do curso de formação focalizado. FPB08a deteve-se na análise de livros didáticos.

Desse conjunto de métodos de pesquisa adotados, o objeto "ensino de oralidade" constituiu-se por três vias. Uma delas foi a discussão sobre a legitimidade de se considerar o ensino da língua na sua modalidade oral nas aulas de Língua Portuguesa. Outra se efetivou no apontamento de falhas quanto a algumas abordagens relacionadas ao objeto em questão. E o 
terceiro modo de sua configuração deu-se pela defesa quanto ao que foi tomado como pertinente de ser considerado tratando-se do "ensino de oralidade".

Sobre esse último encaminhamento, transcrevemos as passagens a seguir:

A oralidade autêntica, como a consideramos, é aquela que surge espontaneamente, tanto da parte do professor quanto do aluno, no interior do tratamento seja de um tópico gramatical, estudo ou produção de texto cujo tema seja do interesse dos alunos. Porém, como já dissemos anteriormente, para que situações assim ocorram, faz-se necessário que o professor esteja também disposto a ouvir. (EPR04, p. 77)

É preciso ficar claro que trabalhar com a modalidade oral em sala de aula é, antes de tudo, identificar a imensa riqueza e variedades de seus usos no cotidiano e respeitar as diferenças, como também, conhecer e dominar os gêneros orais públicos, para que o aluno compreenda que apresentar um seminário não significa ler em voz alta um texto previamente escrito, nem tampouco, estar à frente de uma turma para "bater um papo", sobre o que pesquisou. Estas são outras formas de manifestação da oralidade que não se devem "misturar" com os objetivos pretendidos quando se trabalha com os gêneros orais públicos. (FPB08a, p. 109)

Em conformidade com os objetivos da presente pesquisa, importa-nos, não a descrição das diferenças conceptuais por meio das quais cada dissertação focaliza os seus objetos de pesquisa, mas a detecção das recorrências, que, nos excertos anteriores, configuram-se na abordagem do que é tomado como pertinente ao ensino da língua na sua modalidade oral. $\mathrm{O}$ primeiro fragmento avalia positivamente a espontaneidade de falas no contexto de aula. Já o segundo ressalta o conhecimento sobre os gêneros orais públicos no ensino da língua oral.

Contrapondo-se a essa abordagem de indicação do que é tido como pertinente ao ensino de Língua Portuguesa, há as afirmações que julgam negativamente modos de tratamento da oralidade no contexto de aula:

[...] nosso estudo verificou que ainda ocorrem equívocos a respeito do que realmente seja a língua oral. $O$ fato de os alunos utilizarem o meio sonoro para manifestarem-se não significa que, de fato, estejam desenvolvendo sua oralidade; há, conforme, concluiu-se, oralização da escrita, que não oferece condições para que se desenvolva a competência discursiva oral dos alunos. (EPR04, 90-1)

No que diz respeito às práticas de ensino, as professoras manifestam uma concepção de oralidade circunscrita à expressividade dos alunos. Não há preocupação com as regras sociais que estão em jogo nas situações comunicativas. No trabalho com a oralidade, as professoras sempre buscam a homogeneização da fala e da escrita, segundo a norma culta escrita. Nas estratégias para o desenvolvimento de atividades de escrita fica evidente a preocupação com as correções e inadequações em relação ao padrão estabelecido. Não há 
preocupação com a utilização de mecanismos discursivos e lingüísticos de coerência e coesão textuais, conforme o gênero e o propósito do texto. O objeto de estudo da Língua Portuguesa ainda é língua em sua variedade culta, deixando-se de considerar a língua como um fato social. (EPA08, p. 185)

[...] verificamos que a forma como escola desenvolve a oralidade dos alunos ainda é muito precária, não é difícil nos deparamos com alunos que já estão concluindo o Ensino Fundamental e não têm habilidade para apresentar um trabalho oralmente, seja nas formas orais públicas, um seminário, uma exposição etc., seja nas formas orais cotidianas, um debate informal com colegas, com professor etc. (FPB08a, p. 109)

Como se observa, os três fragmentos defendem a insuficiência do tratamento cedido ao ensino da língua na sua modalidade oral. As abordagens são criticadas por serem limitantes, seja porque não ultrapassam o nível da manifestação oral de textos escritos, seja porque se restringem à expressividade dos alunos ou porque não os preparam para apresentações orais, conforme depreendemos dos trechos anteriormente transcritos.

O segundo excerto dos três supracitados, extraído de EPA08, discute a insuficiência do tratamento cedido à oralidade no ensino de Língua Portuguesa problematizando-o em relação ao predomínio dos padrões da língua culta. Relacionando-se a isso, finaliza o fragmento em questão a seguinte afirmação: “O objeto de estudo da Língua Portuguesa ainda é língua em sua variedade culta, deixando-se de considerar a língua como um fato social". (EPA08, p. 185)

Esta asseveração compõe a abordagem, identificada nas dissertações analisadas, com enfoque na língua oral pela defesa de sua legitimidade enquanto tópico de ensino a ser considerado na aula de Língua Portuguesa:

Acreditamos que não seja mais uma função a ser atribuída ao professor de Língua Portuguesa, mas uma questão de reorganização dos conteúdos, que busque colocar língua escrita e língua falada no mesmo nível de importância. [...]. (EPR04, p. 94)

Esperamos, com o nosso estudo, ter destacado a importância do trabalho com a modalidade oral da língua no Ensino Fundamental, fazendo ver a necessidade de práticas pedagógicas que considerem a oralidade como conteúdo indispensável para desenvolvimento da competência discursiva dos alunos. (FPB08a, p. 109)

No caso destas passagens, observa-se a discussão sobre a importância de o ensino de língua oral comparecer nas aulas de Língua Portuguesa, o que coaduna com a reflexão 
anteriormente exposta, que alegou preponderância de estudos voltados para a língua culta escrita.

A última recorrência no que concerne à configuração dos objetos e à adoção de métodos de pesquisa no nosso corpus disse respeito ao "ensino de gramática", conforme se observa no que segue.

\subsubsection{Recorrências quanto ao ensino de gramática}

No nosso corpus, identificamos que o "ensino de gramática", enquanto objeto de investigação, configurou-se em 02 dissertações pesquisadas. Nelas, o "ensino de gramática" foi focalizado de modo setorizado, ou seja, ele não foi tratado globalmente, pois se constituiu em torno de duas abordagens específicas, foram elas: o "ensino de gêneros gramaticais" e o "ensino de morfossintaxe".

A investigação de EPR07 efetivou-se por meio de entrevistas com professores e alunos e de testes aplicados a esses últimos. Em tais testes, tematizaram-se os gêneros gramaticais:

Ao investigar os conceitos de gênero gramatical dos alunos, confirmarmos, por meio da prova escrita e das entrevistas, que, em todas as séries investigadas, eles utilizaram com grande freqüência seus conceitos semânticos para proceder à identificação do gênero das palavras. O conceito gramatical fora relegado a um segundo plano na $2^{a}$, na $4^{a}$ e na $6^{a}$ série, predominando somente na $8^{a}$ série. Este desempenho assinala a confusão conceitual estabelecida pelos alunos em torno do tema gênero, uma confusão que se deve, em grande parte, ao fato de que as noções que podem ser consideradas "naturais" são construídas desde o nascimento da categoria de gênero e, apesar de atualmente constituírem critérios parciais, ainda continuam fortes e muito presentes na abordagem do tema nas séries investigadas. (EPR07, p. 141)

Nessa dissertação, a constituição do objeto "ensino de gramática" também se deu pela contraposição entre o que lhe seria pertinente e impertinente. Ocorre que, nesse caso, essa compreensão desdobrou-se das análises que feitas a uma das partes que integram o "ensino de gramática" como um todo. No caso, tratou-se do "ensino de gêneros gramaticais", quanto ao 
que se opôs sua abordagem fundamentada em conceitos semânticos àquela baseada em conceitos gramaticais propriamente ditos:

A categoria de gênero caracteriza-se por ser uma categoria nominal responsável pela divisão dos nomes em classes. Na língua portuguesa, todos os nomes estão agrupados, quanto ao gênero, na dicotomia masculino/feminino, e ela se impõe de maneira tão forte que, quando se pensa em um nome, um gênero é imediatamente agregado a ele. Entretanto, há uma tendência de se pensar em gênero por meio da diferença entre o sexo masculino e o sexo feminino, idéia frágil e parcial que acaba por criar confusão conceitual. (EPR07, p. 10)

No interior desse trabalho, o "ensino de gêneros gramaticais" constituiu-se pela recusa da abordagem em que eles são propostos como equivalentes às relações entre os sexos feminino e masculino. Em EPR07, essa abordagem foi classificada como semântica e foi avaliada como insuficiente:

[...] necessidade de que os conhecimentos espontâneos que os alunos possuem sobre o gênero gramatical, normalmente aquele relacionado à idéia sexual, sejam repensados em situação escolar de forma tal que não sejam simplesmente substituídos, mas sim ampliados, transformando-se gradativamente em um conceito científico escolar, adequado, portanto, à luz da teoria lingüística anteriormente apresentada. (EPR07, p. 140)

A configuração do objeto "ensino de gramática", em EPR07, deu-se pelo enfoque a um dos tópicos que é tomado como parte desse objeto e pela reatualização da oposição entre o que se observou, em especial por meio de entrevistas com os alunos investigados e de testes que lhes foram aplicados, e a perspectiva defendida como sendo a mais pertinente à abordagem do "ensino de gêneros gramaticais", tendo em vista o referencial teórico mobilizado.

Em FPB08b, "o ensino de gramática" também se constituiu por um enfoque setorizado, uma vez que essa dissertação tratou de um dos tópicos - análise morfossintática que compõe o conjunto dos estudos gramaticais. Ou seja, nesse trabalho, a configuração do objeto "ensino de gramática" deu-se de modo fragmentado, constituindo-se, especificamente, em relação ao "ensino de análise morfossintática". Quanto a esse recorte, observou-se que ele não foi interrogado quanto ao que lhe seria ou não pertinente. Ele foi tomado como um objeto pronto e disponível para ser incorporado ao ambiente da informática: 
[...] para aprender gramática da língua materna de forma significativa, que se converta em ações práticas diárias, nesse caso, na arte de escrever bem e se comunicar verbalmente com clareza, testamos um objeto de aprendizagem digital intitulado 'Análise Morfológica e Sintática' para verificar se haveria eficácia num ensino de gramática com utilização de ferramentas da informática educativa e mapas conceituais. (FPB08b, p. 79)

Como se vê, o "ensino de gramática" foi abordado enquanto subsídio para se escrever bem e se comunicar com clareza. Observa-se que sua constituição enquanto objeto de reflexão, na dissertação em questão, não ocorreu pelo seu aprofundamento conceptual, mas por sua validação enquanto elemento pertinente para ser tratado digitalmente. Sem problematizar o que fundamenta essa validação, FPB08b restringiu seu interesse à análise morfossintática e tomou esse tópico dos estudos gramaticais como foco do "ensino de gramática" constituído no uso da informática.

Uma vez configurado desse modo o "ensino de gramática", passou-se, na sequência, a comparar os resultados alcançados quando esse objeto constitui-se com ou sem os recursos computacionais, como se depreende dos seguintes excertos:

Observou-se ainda que a quantidade de estudantes do grupo Experimental que superaram a nota oito $(8,0)$ no pós-teste, é pelo menos duas vezes maior que a quantidade de estudantes do grupo Controle, onde apenas três (3) conseguiram essa façanha. (FPB08b, p. 112)

[...] há evidência estatística de que o grupo Experimental apresentou nota média superior à nota média do grupo Controle. É muito provável que a aprendizagem significativa tenha sido favorecida com o uso do OA e que isso contenha um diferencial estatístico comprovadamente superior à metodologia padrão. (FPB08b, p. 113)

Sem nos determos na análise dos cálculos apresentados em referência aos dois grupos citados, esclarecemos que, segundo a dissertação em questão, o grupo Experimental compôsse de alunos que tiveram aulas no Laboratório de Informática de uma escola de João Pessoa, Paraíba, nas quais se focalizou a apresentação e a exploração de jogo para análise morfossintática de orações. Já o grupo Controle reuniu os alunos que estudavam o mesmo tema, análise morfossintática, em sala de aula com o uso de livro didático e de quadro-negro.

Compreendemos que, em FPB08b, a configuração do "ensino de gramática" deu-se pela tomada de um tópico específico para discussão, que foi, por sua vez, constituído a partir da comparação entre abarcá-lo ou não por meio dos recursos computacionais. Nesse tipo de 
abordagem, a discussão deu-se em termos de "eficiência" e "ineficiência", quanto ao que se concluiu que:

Essa diferença significativa de melhora de desempenho de um grupo sobre o outro [referência aos grupos Controle e Experimental] apresenta uma relação entre o uso do objeto digital e envolvimento dos alunos nas atividades focalizadas no $O A$ [Objeto de aprendizagem], relacionando positivamente, informática e pedagogia. Esse dado permite supor que o uso do OA [Objeto de aprendizagem] pode ter influenciado de alguma maneira o resultado, ainda que não seja um dado conclusivo. (FPB08b, p. 118)

Considerou-se nesse estudo que uma maneira eficiente de ensinar gramática é mergulhar o aluno num ambiente onde o desafio estivesse naturalmente presente, em forma de jogo inserido num objeto digital de aprendizagem. (FPB08b, p. 116)

Como se vê nos fragmentos transcritos, o "ensino de gramática" configurou-se pela defesa de seu tratamento por meio do jogo digital, pois isso resultaria em um melhor rendimento dos alunos ao lidar com o tópico gramatical - análise morfossintática, no caso por meio de recursos computacionais.

Das dissertações citadas, depreendemos que o "ensino de gramática" foi focalizado de modo setorizado, com abordagem voltada para alguns tópicos dos estudos gramaticais, no caso "ensino de morfossintaxe" e "ensino de gêneros gramaticais". Este foi configurado pela contraposição entre o que seria "legítimo" e "ilegítmo" no seu ensino, considerando-se a influência que a distinção de sexo teria na categorização dos gêneros gramaticais. Aquele foi tratado enquanto conteúdo apropriado para ser ensinado por meio de recursos computacionais, sem, contudo, ter se tornado, antes, alvo de abordagem conceptual acerca da caracterização do ensino gramatical. Ou seja, nesse caso, privilegiou-se o tratamento do "ensino de gramática" a partir de recursos computacionais, que foi tomado como um objeto pronto e disponível para ser incorporado pelas novas tecnologias, de modo que sua caracterização propriamente dita não foi discutida.

Antes de passarmos à análise das proposições defendidas como legítimas, no interior do nosso corpus, apresentaremos, na seção que segue, a recapitulação do que se discutiu quanto aos objetos e aos métodos constantes da pesquisa em ensino de Língua Portuguesa. 


\subsection{Entre objetos e métodos: as recorrências}

Ao discutirmos os objetos de pesquisa que se configuraram nas dissertações de mestrado sobre ensino de Língua Portuguesa, o primeiro ponto verificado foi a efetiva relação entre os métodos de pesquisa e a constituição dos objetos investigados. O "ensino de gramática" dá exemplo disso ao considerarmos que ele compareceu somente em dois trabalhos do corpus e, em ambos, ele foi abordado, de modo setorizado, a partir da realização de entrevistas com os alunos partícipes da pesquisa e de testes que lhes foram aplicados.

Essa alegada setorização refere-se à abordagem efetivada de modo que não tenha sido privilegiada a discussão global dos estudos gramaticais, mas o estreitamento da investigação a dois tópicos especificamente, foram eles: "gêneros gramaticais" e "análise morfossintática".

Dos testes aplicados aos alunos, foram mobilizados dados referentes ao seu rendimento, quanto aos tópicos gramaticais focalizados, considerando-se o formato tradicional como eles eram trabalhados no contexto de ensino investigado e as abordagens propostas pelas pesquisas em questão. Nas duas dissertações, defenderam-se avanços no aprendizado dos tópicos em foco quando considerados a partir do referencial teóricometodológico tratado nesses trabalhos.

Recordamos que, quanto ao "ensino de gêneros gramaticais", avaliou-se negativamente sua abordagem a partir da distinção entre os sexos feminino e masculino e, a partir disso, defendeu-se outro modo de tratamento dessa questão, como pode ser retomado na seção anterior. Em relação à "análise morfossintática", propôs-se seu ensino por meio de um jogo virtual.

Acerca da presença de recursos computacionais no ensino de Língua Portuguesa, houve duas produções que se voltaram para essa discussão. Uma delas foi a que se citou anteriormente, que tratou de morfossintaxe, e a outra se voltou para a incorporação de histórias em quadrinhos nas aulas de português dos anos iniciais do Ensino Fundamental.

Nesses dois trabalhos, chamou atenção a ausência de aprofundamento conceptual sobre os objetos "ensino de gramática" e "ensino de escrita". Em relação a este, foi abordado um tópico especificamente. No caso, a produção de histórias em quadrinhos, que foi validada como pertinente para ser tratada digitalmente, sem que houvesse reflexão anterior acerca do 
"ensino de escrita" propriamente dito. O mesmo ocorreu em relação à abordagem estabelecida para o "ensino de análise morfossintática", que foi defendido como válido para sua abordagem informatizada, sem que, antes, se discutissem os alcances e as problemáticas do “ensino de gramática” em si.

Isso sinaliza que, nessas dissertações, a reflexão voltou-se mais para o debate acerca da inserção de recursos computacionais no contexto escolar e menos para o ensino de Língua Portuguesa, propriamente dito. Por tratar-se de propostas de softuares educativos, as duas dissertações apresentaram como método de pesquisa o procedimento de testar, com os alunos investigados, o recurso computacional elaborado, do qual advieram os resultados discutidos nas pesquisas em questão.

A relação entre objeto e método de pesquisa também foi perceptível quanto à constituição do "livro didático". Como esperado, a análise desse tipo de material evidenciouse como o método mais utilizado nas investigações em que esse objeto de pesquisa compareceu. Os resultados decorrentes da análise desses livros apontaram, por exemplo, os modos como a oralidade aparecia incorporada neles. Sobre isso, destacaram-se avaliações negativas que afirmaram ser insuficiente, nos livros didáticos analisados, o tratamento cedido ao "ensino de oralidade".

Ressaltamos que o objeto "livro didático" dispôs de abordagens acerca da escrita, da leitura, da gramática e da oralidade. $\mathrm{O}$ que o configurou como um objeto específico foi a metodologia de pesquisa adotada, que focalizou a descrição e a apreciação do que o constituía - quanto aos seus conteúdos e à sua adequação ou inadequação, tendo em vista um referencial teórico específico -, bem como os motivos que subjaziam às opções docentes quanto a usar ou não um dado livro.

Se a análise de material didático destacou-se como principal método de investigação quanto ao "livro didático", outras abordagens metodológicas evidenciaram-se quanto ao "ensino de oralidade", "ensino de leitura" e "ensino de escrita". Isso corroborou a existência do "livro didático" como um objeto específico, ainda que ele tenha elencado aspectos que também compuseram os demais objetos de pesquisa.

Quanto ao "ensino de oralidade", por exemplo, a análise de documentos apareceu enquanto método pertinente. Esses documentos foram planejamentos docentes anuais e material destinado à formação docente continuada, dentre outros. Dessa análise, provieram afirmações sobre a insuficiência do tratamento cedido à oralidade nas aulas de Língua 
Portuguesa, em relação às quais, por sua vez, defendeu-se haver um predomínio dos estudos da língua escrita culta.

No que tange ainda aos métodos de pesquisa, ressaltamos que, quanto ao "ensino de escrita", destacaram-se as intervenções das pesquisadoras em sala de aula, na qual efetivaram suas propostas de abordagem da escrita no ensino de Língua Portuguesa, e a análise de produções escritas discentes. Quanto ao "ensino de leitura”, houve predomínio da coleta e da análise de pareceres docentes, por meio da realização de entrevistas e da aplicação de questionários.

Da efetivação dos procedimentos metodológicos defendidos como pertinentes ao tratamento do "ensino de escrita" e do "ensino de leitura", predominantemente os resultados constituíram-se pela negação daquilo que foi observado em sala de aula e nos pareceres docentes e pela defesa de outro modo de considerar a escrita e a leitura no ensino de Língua Portuguesa.

Esse outro modo apareceu filiado a uma perspectiva interacionista em oposição àquela estruturalista e àquela que redundava, conforme exposto nas dissertações em questão, em uma prática descontextualizada da escrita. A defesa do ensino de leitura e de escrita por meio dessa terminologia retoma o referencial bakhtiniano, conforme expusemos na seção 4.1.

Também relacionado a esse mesmo referencial, compareceu, em larga medida, a defesa do tratamento dos objetos "ensino de escrita" e "ensino de leitura" a partir dos "gêneros do discurso". Ressaltamos que, ao nos determos no que compareceu como recorrente em relação a esses dois objetos de pesquisa, estamos nos referindo ao que foi mais presente no nosso corpus de um modo geral, haja vista que tais objetos foram, em conjunto, configurados em 12 distintas dissertações de mestrado. Número que, ao ser contrastado ao todo analisado, representa mais da metade de trabalhos incluídos no nosso corpus, 18 ao todo.

Destacamos, por fim, que objetos de pesquisa distintos foram, em alguns casos, constituídos em uma mesma dissertação. Isso foi observado, por exemplo, em EPR06, que abordou tanto o "ensino de escrita" quanto o "ensino de leitura". No que segue, voltamo-nos a outro aspecto disciplinar da pesquisa de mestrado em ensino de Língua Portuguesa, que concerne à legitimação de algumas proposições como verdadeiras. 


\subsection{Proposições e âmbitos de legitimação}

Ao focalizarmos a "disciplina", tal como faz a presente tese, torna-se central a verificação do valor de verdade-falsidade no que tange às proposições relacionadas ao ensino de Língua Portuguesa. Como tratado anteriormente, as proposições desfrutam de legitimidade de acordo com a sua aceitabilidade no interior de uma dada produção discursiva.

$\mathrm{Na}$ abordagem do quadro proposicional localizável na pesquisa de mestrado sobre ensino de Língua Portuguesa, expomos as proposições invocando a abstração de suas formulações, ou seja, elas não foram linguisticamente concretizadas nas dissertações sob enfoque, mas foram identificadas como possíveis de serem defendidas a partir de frases que reiteravam um mesmo sistema de axiomas.

Desse modo, no que segue, apresentamos uma relação com todas as proposições identificadas como recorrentes. As dissertações de mestrado foram compreendidas como os âmbitos nos quais se estabeleceu o sistema de axiomas com que tais formulações proposicionais deviam estabelecer coerência. Esclarecemos que tais recorrências foram localizadas em um total que variou de 2 a 9 dissertações, como pode ser verificado no seguinte inventário de proposições:

a) As propostas teórico-metodológicas de ensino de Língua Portuguesa são falhas - (09 dissertações)

b) A formação docente do professor de Língua Portuguesa é deficitária - (07 dissertações)

c) A relação entre a teoria e as prescrições curriculares com a prática docente é conflitante - (07 dissertações)

d) As condições docentes são problemáticas - (06 dissertações)

e) As concepções e práticas de ensino de Língua Portuguesa são indefinidas - (04 dissertações)

f) A concepção de linguagem no ensino de Língua Portuguesa é estruturalista - (03 dissertações) 
g) A concepção de linguagem no ensino de Língua Portuguesa é de instrumento de comunicação - (03 dissertações)

h) Os textos são pretextos para o ensino de gramática - (03 dissertações)

i) O desempenho linguístico discente é insatisfatório - (03 dissertações)

j) O ensino de Língua Portuguesa é tradicional - (02 dissertações)

1) Aulas de Língua Portuguesa tradicionais são limitantes - (02 dissertações)

m) Reescrever é refletir sobre o texto escrito - (02 dissertações)

Afirmar a recorrência dessas proposições significa dizer que elas são passíveis de serem aceitas como verdadeiras no interior das dissertações em que foram localizadas. Nas estruturas proposicionais listadas, verificamos relações de atribuição instauradas pelo verbo "ser". Foucault, preponderantemente, trata a proposição como uma estrutura passível de ser verdadeira ou falsa, tendo em vista as condições de legitimidade que preenche ou não. Seu nível de aparecimento pressupõe laços lógicos, "de coerência formal ou encadeamentos conceituais". (FOUCAULT, 2005, p. 131)

Conforme se observa nesta citação, o autor destaca que uma proposição pode ser formalizada. Essa característica já havia sido explorada em um exemplo que citamos na seção 3.1.1, acerca da "equivalência entre duas adições", formalizada na estrutura proposicional “A+B = C+D”. (FOUCAULT, 2005, p. 131) Dentre as proposições que identificamos no nosso corpus, nenhuma se enquadrou nesse formato.

Algumas delas demonstraram encadeamentos conceptuais na base das atribuições estabelecidas, como verificamos nas proposições referidas pelas letras $\mathrm{f}, \mathrm{g}, \mathrm{h}, \mathrm{m}$. Nas duas primeiras, coloca-se em jogo um referente conceptual na compreensão do que se defendeu como predominante no ensino de Língua Portuguesa em termos de linguagem, com enfoque nas abordagens teóricas do "estruturalismo" e da "teoria da comunicação". Essa vinculada às funções de linguagem tratadas pelo linguista Roman Jakobson e aquela aos postulados saussureanos no seu Curso de Linguística Geral, de acordo com o que expusemos na seção 4.1 - “A constituição do quadro teórico".

A proposição indicada em (f) - a concepção de linguagem no ensino de Língua Portuguesa é estruturalista - pôde ser formulada a partir de frases como as que seguem: 
- [...] conduta da professora como uma prática atrelada a uma perspectiva tradicional de ensino de língua portuguesa, fundamentada em uma concepção estruturalista de linguagem, na qual os exercícios mecânicos e repetitivos são considerados excelentes. (EPR02, p. 27)

- Como apresentamos reiteradamente, a grande maioria dos professores da SAALP [Sala de Apoio à Aprendizagem em Língua Portuguesa] não só concebe a língua, a linguagem, a oralidade, a leitura e a produção textual na esteira tradicional do Estruturalismo, como as professam em suas práticas diárias. (EPR06, p. 138)

- A concepção teórica de leitura que estava subjacente à prática de sala de aula da docente era a estruturalista. Essa nossa descoberta só foi possível a partir da observação das aulas da professora, pois, durante a entrevista que realizamos com a mesma, ela não conseguiu falar sobre nenhuma concepção de leitura que tenha estudado em sua graduação, especialização ou em algum dos cursos de reciclagem que tenha participado. (FPB07, p. 110)

Nos fragmentos citados, observa-se que os pesquisadores, das dissertações indicadas entre parênteses, concluem sobre o tipo de abordagem que os professores, partícipes da pesquisa, cedem à linguagem, nos seus diversos desdobramentos, leitura, produção de texto, oralidade.

A conclusão afirmada é de que a abordagem docente sobre a linguagem é condizente com a perspectiva estruturalista dos estudos linguísticos. Desse modo, verificamos que a proposição "a concepção de linguagem no ensino de Língua Portuguesa é estruturalista" é legitimada como verdadeira no interior das três produções supramencionadas.

Outra proposição construída tendo em vista um encadeamento conceptual foi indicada na letra (g) - a concepção de linguagem no ensino de Língua Portuguesa é de instrumento de comunicação. Ela pôde ser estabelecida a partir de frases como as que seguem:

- Nas diferentes propostas de atividade que desenvolve em sala de aula [Referência à professora observada], toma a linguagem como instrumento de comunicação e não como constitutiva do sujeito, como afirma Bakhtin. Com isso, acaba trabalhando em uma concepção pseudoenunciativa da linguagem. (FSC03, p. 71)

- A consonância entre o planejamento anual da professora Aline e seus registros oficiais manifestados [...] fortalecia a negação às prescrições de caráter estadual e afirmava a aceitação das normas prescritas na LDB 5.692/71, que regulamentou 
como meta para o ensino de Língua Portuguesa a formação de um aluno que tivesse desenvolvidas suas habilidades funcionais, ou seja, apto para atuar no mercado de trabalho, induzindo a um ensino tecnicista, com uma concepção de linguagem voltada à comunicação. (FMT06a, p. 119-20)

- Quando o autor [Referência ao autor do livro didático "Português no Ginásio"] anuncia que o ensino da língua portuguesa visa, primordialmente, oferecer condições para a comunicação, quer como emissor ou como receptor de mensagens, fica evidente a concepção de língua empregada pelo autor, na obra. Logo no início, temse a presença da concepção da língua como um instrumento para comunicação. (FMT07, p. 121-2)

A proposição acerca do ensino de Língua Portuguesa pela perspectiva da linguagem como instrumento de comunicação, assim como aquela que o concebe em uma perspectiva estruturalista, anteriormente tratada, podem ser consideradas verdadeiras no interior dos trabalhos dos quais tais proposições foram desdobradas.

Nos últimos três fragmentos transcritos, verificamos que se defende que, no ensino de Língua Portuguesa, a linguagem é trabalhada enquanto instrumento de comunicação. Tais constatações são tratadas a partir da observação de sala de aula e da análise documental e de livro didático.

Além das proposições até então discutidas, outras também denotaram a mobilização de encadeamentos conceptuais no processo de cópula entre um sujeito e um atributo, tal como foi o caso daquelas indicadas pelas letras $(h)$ e $(m)$. A proposição $(h)-o$ s textos são pretextos para o ensino de gramática - é passível de ser legitimada na pesquisa sobre ensino de Língua Portuguesa, conforme testemunham as seguintes frases:

- [...] o texto serviu apenas como pretexto para exercícios gramaticais, tal como os textos fragmentados dos livros didáticos, que são desapropriados de seus autores e de seu contexto, servindo a um exercício mecânico de análise lingüística. (EPR02, p. 46)

- Se o fator determinante para escolher um e não outro material é prioritariamente o texto, parece evidente que há intenção em utilizá-lo em sala de aula. Todavia, percebemos, por meio das observações, que duas professoras (PEE2 e PEF2) não o utilizaram em sala de aula e que as outras usaram-no esporadicamente. Por exemplo, durante 12 horas-aula de observação na escola EE1, ele foi tomado uma única vez, exclusivamente, para identificação de questões gramaticais. (FPA07, p. 140-1) 
- Há um uso freqüente da utilização do texto para pretexto da gramática. [...] esse procedimento é um tanto frágil, uma vez que o texto é dissecado apenas para as estruturas gramáticas, e o texto em si, suas estruturas e características são valorizadas em estudo. (FMT07, p. 126)

Nestes excertos, identificamos as afirmações em torno da leitura de textos com o objetivo de discutir aspectos gramaticais. Tais asseverações resultam da observação da sala de aula, da realização de entrevistas com professores e da análise de material didático.

A proposição $(\mathrm{m})$, supramencionada, foi estabelecida como "Reescrever é refletir sobre o texto escrito", tendo sido desdobrada de frases como as que seguem:

- Outra atividade produtiva foi a refacção individual e coletiva dos textos, uma vez que os alunos demonstraram-se participativos e autocríticos do que produziam. Tal atividade proporcionou a eles momentos de reflexão quanto ao uso da língua materna. Foram capazes de questionar se determinada palavra elou expressão estava compatível com o gênero e o suporte estudado. (FMT06b, p. 124)

- [...] há uma grande diferença entre os dois textos [Referência à produção escrita de um dos alunos], não apenas em relação à carga informativa, que é apresentada de modo mais preciso no segundo, mas especialmente em relação à tentativa de uso de expressões sinônimas. Os personagens principais, Marcão e Serginho, no primeiro texto, são referidos sempre pelo nome. Na reescrita, porém, observa-se a utilização de expressões sinônimas quando o aluno escreve "o rapaz que gostava de beber vodca", ao ser referir a arcão, e "o amigo", para fazer referência a Serginho. A escolha de Felipe pela expressão sinônima demonstra maior controle do autor sobre seu texto, exatamente porque ele busca essa expressão no primeiro parágrafo e obtém assim o efeito coesivo desejado por meio da referência a uma característica marcante do personagem, o seu gosto por vodca. (FRS10, p. 47)

As duas passagens avaliam positivamente a "reescrita" como forma de revisão dos textos escritos, pois defendem que elas resultam em reflexões a respeito da adequabilidade de determinados usos lexicais e de certas expressões sinônimas. Desse modo, nas duas dissertações indicadas entre parênteses, a proposição (m) desfruta de legitimidade.

As proposições até então discutidas foram enquadradas como sendo do tipo "conceptual" porque, nelas, a relação estabelecida pelo verbo "ser" reportou-se a propostas teóricas como o "estruturalismo" e a "teoria da comunicação", anteriormente situadas, e 
também a um termo como "reescrita" e a uma fraseologia como "o texto serviu apenas como pretexto para exercícios gramaticais", que se mostram recorrentes na pesquisa sobre ensino de Língua Portuguesa.

Contudo, a maior parte das proposições estabelecidas a partir do nosso corpus não pode ser compreendida nem em conformidade com uma estrutura formal nem conceptual. Elas somente se sustentam em relação à argumentação de cada uma das dissertações em que puderam ser legitimadas.

Retomando essas proposições, verificamos que nelas atribuíram-se características como "falho", "deficitário", "conflitante", "problemático", "indefinido", "insatisfatório", "tradicional", "limitante" tanto às propostas teórico-metodológicas, concepções e práticas de ensino de Língua Portuguesa, à formação docente, ao desempenho linguístico, quanto a demais aspectos inclusos na argumentação das dissertações sob análise.

Considerando o exposto, iremos nos referir a essas proposições como "argumentativas", compreendendo que, juntamente àquelas de caráter conceptual, elas compõem o quadro proposicional da pesquisa de mestrado em ensino de Língua Portuguesa, conforme resultados a que chegamos na presente tese.

Se comparadas, observamos que, das doze proposições apresentadas, 08 foram caracterizadas como "argumentativas" e 04 como sendo embasadas por encadeamentos conceptuais. Sobre essas últimas, já exploramos os aspectos julgados necessários. Sobre as outras, vamos tratar dos elementos que lhes são pertinentes a partir das proposições (a) e (b), considerando que as análises das demais não destoam destas que passamos a discorrer.

A proposição (a) - as propostas teórico-metodológicas de ensino de Língua Portuguesa são falhas - foi estabelecida a partir de frases como as que seguem:

- Na atividade com o jornal, a professora acabou por propor uma certa descaracterização do gênero, pedindo que os alunos recortassem três matérias de dias diferentes e as colassem em uma folha. (FSC03, p. 71)

- [...] nosso estudo verificou que ainda ocorrem equívocos a respeito do que realmente seja a língua oral. $O$ fato de os alunos utilizarem o meio sonoro para manifestarem-se não significa que, de fato, estejam desenvolvendo sua oralidade; há, conforme, concluiu-se, oralização da escrita, que não oferece condições para que se desenvolva a competência discursiva oral dos alunos. (EPR04, 90-1) 
- Outro problema nos livros é o excesso de gêneros, uma vez que numa mesma unidade chegam a aparecer três ou mais, o que dificulta um trabalho mais sistemático que permita ao aluno a apropriação de diferentes gêneros. (FPA07, p. 150-1)

Nestas frases, as falhas apontadas dizem respeito à "descaracterização do gênero jornal", ao que seja "a língua oral" e ao "excesso de gêneros". Somente essa última falha concerne ao livro didático, as outras duas dizem respeito ao ensino de Língua Portuguesa tal como concebido e praticado pelo professor.

Tais apontamentos somente podem ser defendidos em relação ao construto argumentativo consolidado nas dissertações, o que significa que, nelas, elegem-se algumas verdades quanto ao "o quê" deve ter lugar na aula de Língua Portuguesa e ao "como" isso deve ser ensinado. Tendo em vista a argumentação proposta no que concerne a esses dois tópicos, as dissertações em questão vão legitimar a negação daquilo que julgam ir contrário ao que foi no interior desses trabalhos defendido como sendo o "correto", como se depreende do trecho que segue:

- [...] averiguamos que em relação aos dados analisados referentes à $8^{a}$ série, alguns aspectos são relevantes para a nossa pesquisa e se assemelham aos dados observados na $7^{a}$ série. São eles: $1^{o}$ ) O trabalho com o texto realizado pela docente é bastante superficial, pois apenas o conteúdo temático ("tecnologia”) é abordado. Não há uma discussão sobre a estrutura composicional e o estilo do editorial; $2^{\circ}$ ) Novamente percebemos que o conhecimento de mundo dos alunos é o ponto de partida para a discussão do texto, mas esse conhecimento não é aproveitado pela professora para auxiliar na construção de sentido do texto; $3^{\circ}$ ) Assim como ocorreu na $7^{a}$ série, o único aspecto do texto sobre o qual a professora inicia e conclui uma discussão é sobre o significado do título do texto, mas essa conclusão é feita sem a aceitação das contribuições dos alunos nessa discussão; $4^{\circ}$ ) A professora constrói os sentidos dos textos e não permite que os alunos o façam. Esses sentidos construídos pela docente sempre se realizam de modo ascendente, ou seja, do texto para o leitor. (FPB07, p. 109)

Se tomarmos cada uma das negações apresentadas neste fragmento, identificaremos um exemplo das referências que permitem que a proposição (a) seja legitimada no interior de FPB07, conforme segue: 
- não se aborda a estrutura composicional e o estilo do editorial;

- o conhecimento de mundo do aluno não contribui para a construção de sentido do texto;

- não se aceita a contribuição dos alunos nas discussões desenvolvidas;

- os alunos não constroem, por si sós, os sentidos do texto.

Se suprimirmos as negações linguisticamente concretizadas por meio do advérbio "não", verificamos o que é afirmado como sendo o "correto" e, assim, finalizamos o quadro de referências adotadas para legitimação da proposição sob enfoque. Vale esclarecer que apesar de as proposições caracterizadas como "argumentativas" não materializarem alusões conceptuais, ao investigarmos as frases que lhes dão legitimidade, identificamos um conjunto de formulações conceptuais delimitadas, como, nos exemplos expostos, "os gêneros do discurso" e "a construção de sentidos de um texto".

No que segue, passamos à discussão da proposição indicada pela letra (b) - a formação docente do professor de Língua Portuguesa é deficitária -, desdobrada de frases como as que seguem:

Em ambos os momentos ([de] escrita reprodução e escrita produção) foi possível detectar que a professora apresentava um déficit na sua formação, no que diz respeito ao ensinar língua portuguesa no ensino fundamental (EPR02, p. 18)

As professoras parecem não estar preparadas para lidar com as propostas do material [Referência aos livros didáticos analisados],uma vez que estas exigem um conhecimento mais aprofundado sobre a língua [...]. (FPA07, p. 161)

[...] as professoras procuravam refutar o ensino gramatical "puro" com todas as dificuldades, dúvidas e medos que enfrentavam, pois, segundo elas, em seus relatos, não recebiam formação adequada e acabavam ficando no escuro, sem método, sem saber que caminhos deveriam percorrer. (FMT06a, p. 185)

Observamos que a atribuição do qualificativo "deficitário" à formação docente sustenta-se na argumentação de que o professor é despreparado para ensinar a escrita, como 
afirma o primeiro fragmento transcrito, também para utilizar o material didático, conforme aponta o segundo trecho citado, e, por fim, também não mostra preparo suficiente para ultrapassar o ensino gramatical "puro", de acordo com o que está colocado no terceiro excerto dentre os supramencionados. Essa situação demonstra que o valor de verdade da proposição em questão está calcado no tipo de argumentação apresentado pelas dissertações em questão.

Esse formato de legitimação das proposições, no que diz respeito a estabelecerem coerência com o sistema de axiomas em relação ao qual se argumenta a favor, encontra-se perceptível nas demais proposições "argumentativas", sendo que, algumas vezes, essa legitimação ancora-se em formulações conceptuais, outras vezes não, conforme demonstraram as análises que efetivamos quanto às proposições (a) e (b).

Esclarecemos que o apêndice D inclui todos os aspectos disciplinares tratados nesta tese - os objetos, os métodos, os referenciais teóricos e também as proposições. Dessas últimas, pode ser verificado o total de proposições localizadas no nosso corpus e todas as frases que funcionam como âmbitos de sua legitimação.

Concluímos, assim, as análises acerca dos elementos coercitivos da produção discursiva de mestrado sobre ensino de Língua Portuguesa. No que segue, passamos ao capítulo de congregar todas as análises e todos os resultados até então apresentados, bem como de provocar novas reflexões acerca do nosso corpus. 


\section{A ANÁLISE DO DISCURSO CIENTÍFICO-ACADÊMICO SOBRE ENSINO DE LÍNGUA PORTUGUESA}

A análise do discurso que propusemos em relação às dissertações do nosso corpus organizou-se, inicialmente, em torno da avaliação de suas coerções disciplinares. Essa proposta analítica foi condizente ao material que coletamos, pois, a partir da verificação do que caracterizava "disciplinarmente" a pesquisa em ensino de Língua Portuguesa, conseguimos delinear aspectos do seu quadro teórico-metodológico, bem como os objetos e proposições que, recorrentemente, legitima.

O conceito de "disciplina", mobilizado nesta tese, ancora-se na argumentação de que o discurso concretiza-se em relação a coerções que impedem sua livre produção. Desse modo, torna-se possível a observação de regularidades decorrentes de elementos coercitivos que subjazem à constituição dos saberes.

Tendo em vista essa caracterização, em consonância com o que foi tratado ao longo desta tese, o discurso constitui-se de "enunciados", compreendidos enquanto "condições de possibilidade" segundo as quais determinadas frases e proposições serão enunciadas.

Em relação ao nosso corpus, localizamos na dispersão de frases, com diversos propósitos argumentativos, algumas proposições recorrentes. Da análise dessas proposições em conjunto com os objetos, os métodos e o quadro teórico legitimados, verificamos que o discurso científico-acadêmico em ensino de Língua Portuguesa concretiza-se a partir da regularidade da negação.

A negação materializa enunciados marcados pela polêmica entre, de um lado, a perspectiva "interacionista", e, de outro lado, a perspectiva "estruturalista" ou da "gramática tradicional". Ao que, por sua vez, seguiram-se polêmicas:

- entre "gêneros do discurso" e "reescrita" versus "mero exercício da escrita" e "redação escolar";

- entre "gêneros do discurso" e "multiplicidade de sentidos interpretáveis" versus "uniformidade interpretativa"; 
- entre "ensino de oralidade" versus "predomínio de estudos da língua padrão escrita".

Lembramos, em primeiro lugar, que essas polêmicas mostraram-se intrinsecamente relacionadas ao quadro teórico e aos métodos de pesquisa legitimados e, em segundo lugar, que essas foram as polêmicas mais recorrentes no nosso corpus. Outras apareceram pontualmente, como foi o caso daquela relacionada ao "ensino dos gêneros gramaticais", em que se divergia quanto ao privilégio de uma abordagem fundamentada na distinção entre "sexo feminino e masculino" ao invés da priorização de aspectos conceptuais de outra ordem.

Esse argumento foi extraído de uma das dissertações em que identificamos a constituição do objeto "ensino de gramática". Objeto configurado somente em duas dissertações de nosso corpus. Esse número evidencia um lugar restrito ocupado pelo "ensino de gramática" como objeto de pesquisa, ainda mais se considerarmos que o tratamento que lhe foi cedido focalizou alguns temas, sem se voltar para a discussão sobre as implicações do "ensino de gramática" como um todo.

Tal ponderação partilha da compreensão de que, na pesquisa em ensino de Língua Portuguesa, o "texto" assumiu centralidade, enfoque que é privilegiado na bibliografia amplamente referida pelos trabalhos que compõem o nosso corpus, tais como os Parâmetros Curriculares Nacionais de Língua Portuguesa e $O$ texto na sala de aula, organizado por João Wanderley Geraldi.

Vale também retomar que as polêmicas que ressaltamos foram defendidas pelas dissertações de mestrado a partir de pesquisas que, em larga medida, voltaram-se para a análise de situações de aula, de pareceres docentes, de produções discentes e de análise de documentos diversos e de livros didáticos. Esses últimos apareceram, no nosso corpus, tanto como o suporte em que objetos como "ensino de escrita" e "ensino de leitura", por exemplo, foram configurados, quanto como um objeto de pesquisa em si. Nesse último sentido, o "livro didático" foi analisado quanto às alterações que, diacronicamente, sofreu, quanto aos usos que os docentes faziam deles e quanto aos critérios para a sua escolha.

Os resultados a que chegamos demonstram, então, que o discurso científico-acadêmico em ensino de Língua Portuguesa configura-se na negação dos aspectos que elencamos anteriormente, constituindo-se de enunciados que polemizam entre alguns saberes afirmados e outros refutados. 
Para discorrer de modo detalhado sobre as negações que fundam o discurso de que tratamos, recorremos à obra de Oswald Ducrot, inicialmente ao seu "Esboço de uma teoria polifônica da enunciação”. (DUCROT, 1987) Tal abordagem demanda algumas considerações que elucidem o seu uso na análise que propusemos.

Primeiramente, consideramos que não haja incompatibilidade entre as concepções de “discurso" em Foucault e Ducrot. Compreendemos que existam distinções quanto ao nível de análise objetivado. Ducrot, em entrevista cedida à revista Investigações (XAVIER, 2012), é questionado sobre a existência de alguma relação entre o seu trabalho e o de Michel Foucault. A resposta apresentada é a que segue:

Sim, certamente. Eu estou muito mais perto dele do que de Pêcheux. Foucault nunca fez Linguística no sentido estrito. Ele se interessava pelas ideias gerais sobre a linguagem. Mas ele nunca fez um trabalho linguístico propriamente dito. Eu sempre estive interessado em fazer o trabalho verdadeiramente linguístico, como dizemos em francês: "mettre les mains à la pâtes" (botar a mão na massa), de trabalhar na língua, mas Foucault de fato não se interessava por isso. (XAVIER, 2012, p. 14)

Entendemos que esse "botar a mão na massa" aponta para os diferentes níveis de análise. No texto de Ducrot anteriormente citado, ele descreve o "discurso" enquanto um fenômeno observável e que é "constituído de uma sequência linear de enunciados". (DUCROT, 1987, p. 164) Tal definição não se contrapõe ao postulado foucaultiano sobre discurso, no qual o "enunciado" também aparece como elemento constitutivo. Contudo, há diferenças na própria concepção de "enunciado", haja vista propostas de pesquisa distintas.

Ducrot volta-se para o "enunciado" a partir de uma concepção polifônica da enunciação, fundamentada por pressupostos bakhtinianos, e segundo a qual todo "enunciado assinala, em sua enunciação, a superposição de diversas vozes". (DUCROT, 1987, p. 172) Essas diversas vozes transparecerão na divisão que o autor propõe em "sujeito no mundo", "locutor" e "enunciador". Na teoria da argumentação na língua, interessarão as duas últimas posições, mas não a primeira, identificada como a do "sujeito no mundo" ou "sujeito empírico", que se refere uma pessoa específica no mundo. 
O locutor é definido como o "sujeito do discurso", como fonte de enunciação que será responsabilizada pelo "eu” que é dito. Trata-se da instância responsável pela materialidade linguística. O enunciador é, por sua vez, retratado como o "centro de perspectiva", isso é, como o "ponto de vista". O tratamento polifônico do "enunciado" advém de que, como mostram exemplos de ironia e de negação, pontos de vista apresentados, na enunciação, podem ser rejeitados pelo locutor.

Diante do exposto, compreende-se que o interesse de análise dos "enunciados" a partir da concepção de polifonia instaura-se na verificação de como, linguisticamente, tornam-se apreensíveis os diferentes pontos de vista colocados sob responsabilidade de um mesmo locutor.

Foucault, ao tratar dos "enunciados", também considera a dispersão de vozes passíveis de ser configuradas em uma enunciação, mas se volta a eles tendo em vista um "diz-se", ou seja, as condições de possibilidade concretizadas na produção de um discurso. O "enunciado" enquanto "condição de existência", que permite que certa ideia seja manifestada em um dado momento, remete ao a priori kantiano, que pode ser relacionado ao a priori histórico de Foucault, que Deleuze (2005, p. 69) chamará de "neo-kantismo".

Por meio dessa abordagem, o "enunciado" foucaultiano propicia a reflexão sobre as coerções discursivas, mas não sobre aquelas situadas no nível da língua, tal como é propiciado pela teoria apresentada por Ducrot e colaboradores. Por isso que, no que segue, trataremos do "enunciado" na perspectiva teórica polifônica, pois entendemos que isso fortalecerá a compreensão de como a regularidade da negação constitui o discurso da pesquisa em ensino de Língua Portuguesa.

\subsection{A negação polêmica em investigações de mestrado sobre ensino de Língua Portuguesa}

Ducrot (1987), em seu "Esboço de uma teoria polifônica da enunciação", distingue três tipos de negação. A maior parte, ele categoriza como sendo "polêmica". A negação "polêmica", nesse texto, caracteriza-se como sendo aquela que inclui no próprio enunciado o 
ponto de vista rejeitado. A explicação para isso é que o locutor não faz oposição a outro locutor, ele nega um enunciador (o ponto de vista) que ele próprio insere no seu discurso. Por meio do exemplo "Pedro não é gentil", ele defende que a atitude positiva que é rejeitada pelo locutor, no caso, "Pedro é gentil", é interna ao discurso.

Justificando sua tese, Ducrot defende que o uso de uma expressão como "ao contrário" demonstra que, em um enunciado negativo, tal expressão se opõe ao ponto de vista positivo que integra uma formulação como a que segue: "Pedro não é gentil, ao contrário, ele é insuportável”. Pensando no ponto de vista positivo aí inserido, poderíamos ter como equivalente a essa formulação o seguinte: “Ao contrário de Pedro ser gentil, ele é insuportável”. (DUCROT, 1987, p. 202-3)

Os outros dois tipos de negação são classificados como "negação metalinguística" e "negação descritiva". A primeira é caracterizada por contradizer os termos da formulação a que se opõe. Quanto ao exemplo "Pedro parou de fumar", o que seria negado seria a própria palavra "parou" em uma argumentação como "Pedro nunca fumou e, assim, não pode ter parado". A segunda remete-se à representação de um estado de coisas, sem que houvesse oposição a outro discurso. Essa negação, de tipo "descritivo", exemplifica-se na resposta de que "não há nenhuma nuvem no céu" à pergunta de outro locutor sobre as condições climáticas observadas. (DUCROT, 1987, p. 203-4)

Ducrot, em colaboração com Carel, irá rever a análise da negação, especialmente aquela categorizada como "polêmica", em texto traduzido para o português como "Descrição argumentativa e descrição polifônica: o caso da negação”. (CAREL; DUCROT, 2008) Sucintamente, as modificações são decorrentes da preocupação em analisarem-se os encadeamentos que um enunciado evoca.

Tais encadeamentos podem, na articulação de dois segmentos, serem "transgressores" (por meio de conectivos como "no entanto", "porém", “apesar de") ou "normativos" (por meio de conectivos como "então", portanto") (PINTO, 2009, p. 326), de que dá demonstração uma negação como "João não foi prudente, então se acidentou".

Considerando os dois textos anteriormente referidos a Ducrot, observa-se que as mudanças propostas para a análise da negação não deixaram de enquadrá-la em uma perspectiva polifônica, na qual o "enunciado" persiste como ocorrência particular da frase, em "que o locutor põe em cena enunciadores, assimila-os, e toma posição em relação a eles" (CAREL, DUCROT, 2008, p. 7) , sendo que essa tomada de posição concretiza-se na 
assunção do ponto de vista de um dos enunciadores ou opõe-se "ao enunciador de um ponto de vista - como faz o locutor de um enunciado negativo em relação ao que seria dito no enunciado positivo correspondente". (CAREL, DUCROT, 2008, p. 8)

As reflexões sobre a negação no que concerne à multiplicidade de enunciadores a que o locutor toma posição priorizam a análise da chamada "negação polêmica" ou "comum", por ser a mais recorrente. Como viemos defendendo que a polêmica constitui o discurso de pesquisa em ensino de Língua Portuguesa, vamos, no que segue, discorrer sobre como essa "negação polêmica" comparece no nosso corpus, tendo em vista também as observações de Indursky (1990, p. 121), que defende que a negação produz um efeito de polêmica quando ocorre "o confronto entre duas redes antagônicas e o enunciado negativo refuta a que se lhe opõe ideologicamente".

Os fragmentos do nosso corpus, transcritos a seguir, foram, inicialmente, expostos no capítulo 4, de "configuração disciplinar" do discurso, e, a partir deles, propomos a visualização da presença de mais de um enunciador em jogo, dada sua polifonia característica, e buscamos apontar para os focos de polêmica veiculados pela negação:

1) Constatamos também, que os textos revisados e reescritos nas primeiras aulas não foram tratados pela professora como unidade complexa de comunicação e de significação, destinado [sic] a um interlocutor que com ele deveria interagir. Nesses casos o texto serviu apenas como pretexto para exercícios gramaticais [...]. (EPR02, p. 116)

2) A atitude dos alunos de esperar "a leitura correta" nos evidencia que, tanto professora quanto alunos, não trabalham com textos numa perspectiva sócio-interacionista de leitura em que mais de um sentido é permitido para os textos. (FPB07, p. 111)

3) Os conteúdos, nos editoriais trabalhados em sala de aula, estavam relacionados a assuntos que os alunos conheciam (epidemia de dengue e novas tecnologias). Do ponto de vista da textualidade, seria importante o destaque para a estrutura composicional e o estilo desses textos, relacionando-os aos suportes onde eles circulam, à função social que eles exercem e ao público ao qual se destinam. Todo esse percurso suscitará, naturalmente, sentidos na leitura. E essa abordagem não aconteceu justamente porque a professora parece não ter um conhecimento teórico mais aprofundado sobre os gêneros textuais. (FPB07, p. 111)

4) [...] podemos concluir que embora os gêneros discursivos estejam presentes nesses instrumentos didáticos [Referência aos livros analisados], eles não são tomados como objeto, 
uma vez que os aspectos ligados à situação de produção, os elementos da ordem do social e do histórico, o conteúdo temático, a construção composicional e o estilo verbal não são tratados de modo sistemático. Percebemos que eles são suportes de conteúdos e favorecem o desenvolvimento de várias atividades que levam as professoras a intervir sobre a temática, daí afirmarmos que as informações veiculadas no texto são os objetos de ensino priorizados nas propostas do LD. (FPA07, p. 153)

5) Nas estratégias para o desenvolvimento de atividades de escrita fica evidente a preocupação com as correções e inadequações em relação ao padrão estabelecido. Não há preocupação com a utilização de mecanismos discursivos e lingüísticos de coerência e coesão textuais, conforme o gênero e o propósito do texto. O objeto de estudo da Língua Portuguesa ainda é língua em sua variedade culta, deixando-se de considerar a língua como um fato social. (EPA08, p. 185)

Dos excertos anteriores, depreendem-se os pontos de vista positivos internos aos enunciados de negação, são eles respectivamente:

1) os textos revisados e reescritos nas primeiras aulas foram tratados pela professora como unidade complexa de comunicação e de significação, destinados a um interlocutor que com ele deveria interagir;

2) tanto professora quanto alunos trabalham com textos numa perspectiva sócio-interacionista de leitura em que mais de um sentido é permitido para os textos;

3) essa abordagem aconteceu justamente porque a professora parece ter um conhecimento teórico mais aprofundado sobre os gêneros textuais;

4) eles são tomados como objeto, uma vez que os aspectos ligados à situação de produção, os elementos da ordem do social e do histórico, o conteúdo temático, a construção composicional e o estilo verbal são tratados de modo sistemático;

5) há preocupação com a utilização de mecanismos discursivos e lingüísticos de coerência e coesão textuais, conforme o gênero e o propósito do texto.

Estes pontos de vista são introduzidos nos enunciados e são refutados, pois eles aparecem como incompatíveis com a atuação docente observada e também com os livros 
didáticos citados. Isso significa que a sua incorporação e negação funcionam como exemplos de polêmica instaurada entre diferentes enunciadores, com pontos de vista inconciliáveis, rivalizando entre o que deveria ser e o que de fato acontece em sala de aula.

Essa polêmica pode ser avaliada de duas maneiras. A primeira, em 1) e 2), funda-se na concepção de que a abordagem dos textos com objetivo de estudos gramaticais e também a crença em um único sentido a ser decifrado em um texto é inaceitável no que diz respeito à desejada atuação docente embasada por perspectivas de caráter interacionista. A segunda, em 3), 4) e 5), destaca a ausência de tópicos como estrutura composicional, estilo e função social bem como a prioridade concedida à língua escrita padrão como inaceitáveis em propostas de ensino de Língua Portuguesa que contemplem o estudo dos "gêneros".

Considerando-se as refutações materializadas nos enunciados anteriores, verifica-se que são negados justamente os postulados condizentes com as perspectivas teóricas constituintes do quadro teórico legitimado pelas dissertações sob análise. A partir disso, concluímos que as negações em questão sustentam-se na cisão entre o que tais postulados defendem e o que ocorre em situações e materiais de ensino de Língua Portuguesa. A polêmica instaurada concretiza-se, pois, na negação do que ocorre em sala de aula e que é propagado pelos livros didáticos.

A polêmica, entre o que ocorre no ensino de Língua Portuguesa e o que deveria ocorrer, já havia sido caracterizada, em termos disciplinares, na configuração dos objetos de pesquisa e na legitimação de certas proposições. Por meio da análise de "negações polêmicas" do nosso corpus, confirmamos como o contraste entre o que efetivamente acontece e aquilo que deveria acontecer consolidou-se em relação a distintos enunciadores materializados linguisticamente nos enunciados analisados.

A regularidade da negação, nos termos tratados ao longo desta tese, não foi evidenciada em três dissertações, foram elas: ESP01, FPB08b e FRS10. Não parece negligenciável o dado de que, tanto ESP01 quanto FPB08b, tenham proposto a utilização de recursos computacionais. Esse resultado reforça o que foi percebido por meio da comparação entre esses dois trabalhos e os demais analisados.

A percepção foi de que essas dissertações, que se voltaram para a discussão sobre o ensino de Língua Portuguesa por meio de recursos computacionais, não abordaram os objetos desse ensino em si, mas tomaram a "história em quadrinhos" e a "análise morfossintática" como conteúdos passíveis de serem incorporados pelas tecnologias educativas. De modo que 
tais conteúdos foram o ponto de partida para a discussão efetivamente em foco metodologias de ensino com o uso da computação - e, sendo assim, não foram situados como mote de reflexão em si mesmo.

No caso de FRS10, observamos que a investigação acerca do objeto "ensino de escrita" destacou os resultados decorrentes de várias reescritas discentes sobre os seus textos. As alterações entre as versões produzidas foram analisadas tendo em vista a substituição de uma expressão por outra sinônima, bem como a elipse e outros recursos de coesão referencial, como descreve a dissertação em questão. Essa proposta de investigação não se fundamentou na polêmica entre como deveria ser o ensino de escrita e como de fato ele ocorria. Para tanto, a pesquisadora voltou-se para os resultados alcançados a partir de sua intervenção em uma turma do ciclo II do Ensino Fundamental.

Torna-se válida, pois, a reflexão sobre o aparecimento dessa dissertação, configurada de outro modo em relação ao que se constituiu como regular na pesquisa sobre o ensino de Língua Portuguesa, porque ela sinaliza a configuração de um discurso que terá de sustentar-se em algo que não seja mais a polêmica entre o que se legitima e o que se deslegitima.

A importância desse exemplo remete aos modos de constituição do discurso em questão pela demanda de que as pesquisas erijam-se pela validade de suas propostas, sejam elas relacionadas ao referencial bakhtiniano, como se mostrou predominante, ou outro. A fundamentação dessas pesquisas por um caminho que não seja a da polêmica abre espaço para que as investigações em ensino de Língua Portuguesa sejam analisadas em si mesmas. Isso se diferencia do discurso em que se contrapõe "aquilo que é" ao "aquilo que deveria ser", uma vez que não poderá incluir em sua argumentação a ideia de que "em relação ao que já há, o que se propõe é bom".

O fragmento que segue também colabora para ilustrar a reflexão que propomos:

Nessa primeira produção, o aluno não releu seu texto e por isso não se ateve a algumas inadequações gráficas, como "feis", "trabralo", "sobe", "menos", "tabem", "poriso", "fasio". (FMT06b, p. 108).

Este excerto, retirado da dissertação FMT06b, permite que se discuta como uma dada abordagem, como essa que diz respeito às inadequações gráficas decorrentes da ausência de 
releitura pelos alunos, poderia ser sustentada pela proposta de pesquisa em si, voltada para os "gêneros do discurso".

Esse ponto destaca que pode ocorrer de algumas dissertações, apoiando-se na refutação daquilo que compõe o polo desacreditado em uma polêmica, implicarem-se com menos vigor na justificação do que propõem. Situação que pode ser vista como decorrente de as propostas apresentadas comparecem como o ponto de vista positivo no interior daquilo que se nega, de modo que a análise sobre elas pode, por vezes, ocupar um espaço menor de reflexão e discussão.

Tendo em vista o exposto, passamos às nossas considerações finais. 


\section{CONSIDERAÇÕES FINAIS}

E quando a polêmica estabiliza-se?

Terminamos a presente tese expondo essa pergunta porque, ao longo da investigação, verificamos, por diferentes meios, a configuração de um discurso científico-acadêmico sobre ensino de Língua Portuguesa regularizado pela polêmica entre o que se defende como legítimo e o que se refuta como ilegítimo, de modo a contrapor "o que efetivamente ocorre nesse ensino" e "o que deveria ocorrer".

Tal polêmica compareceu ocupando uma função regulamentadora do discurso analisado, transparecendo na configuração dos objetos de pesquisa e na legitimação de determinadas proposições. É válido retomar que os métodos de pesquisa mostraram-se fundamentais para que os enunciados polêmicos constituíssem-se, uma vez que tais métodos propiciaram, em especial, contraposições entre o que era verificado em sala de aula e em pareceres docentes e o que era associado ao quadro teórico adotado.

O nosso corpus demonstrou a expressiva recorrência de algumas obras enquanto referências bibliográficas. Identificou-se, sobretudo, a regular influência dos postulados de Mikhail Bakhtin na constituição do discurso sob enfoque. As retomadas a esse referencial compuseram um dos lados da polêmica instaurada, aquele relacionado ao "o que deveria ocorrer no ensino de Língua Portuguesa”, divergindo do que se descreveu como efetivamente presente em aulas observadas, em questionários e entrevistas respondidos por professores e em livros didáticos.

Voltando à pergunta com que abrimos este capítulo, ela se torna essencial, no interior da presente tese, porque ela provoca a reflexão de que a "polêmica" também pode ser consensual. O paradoxo desfaz-se ao ser analisado em termos de regularidade. De modo que o alegado consenso não se localiza na polêmica em si, mas na sua legitimação e decorrente repetição.

Essa avaliação resultou da análise do discurso em 18 dissertações de mestrado, defendidas em diversas instituições do nosso país. Todas elas foram publicadas no período de 2001 a 2010. Nelas, percebeu-se uma "variável constante" (DELEUZE, 2005), a constituição do discurso pela instauração da polêmica a que viemos nos referindo. 
Como "variável constante" compreende-se que, no nosso corpus, foram citados diferentes professores, diversas escolas, distintos materiais didáticos - indicando variabilidade nos dados coletados - e em relação aos quais se verificou constância condizente à contraposição desses dados ao referencial teórico legitimado e às decorrentes propostas de ensino defendidas. Tal variação e constância também foram localizadas quando nos propusemos a analisar enunciados negativos em uma abordagem polifônica. Os resultados alcançados demonstraram que as "negações polêmicas" analisadas responderam ao mesmo padrão de inserir como ponto de vista positivo as propostas de ensino almejadas, relacionadas ao quadro teórico legitimado, e negá-lo tendo em vista o que se defendia como efetivamente ocorrendo no ensino de Língua Portuguesa.

Uma vez apontados esses aspectos, compreendemos, por um lado, o papel multiplicador dos enunciados disciplinares, já que, conforme afirma Foucault (2004a, p. 30), "para que haja disciplina é preciso, pois, que haja possibilidade de formular, e de formular indefinidamente, proposições novas".

Sendo assim, a polêmica estabelecida entre "o que ocorre no ensino de Língua Portuguesa" e "o que deveria ocorrer" exerce a função de mola propulsora na constituição dos saberes que regularmente constituem o discurso científico-acadêmico sob enfoque. Tal configuração discursiva compareceu em toda a década analisada e mostrou-se "produtiva", em conformidade com a citação anterior.

Ocorre que, por outro lado, a produção do conhecimento também se constitui a partir de sua "autofagia". Ou seja, a partir de sua "autodestruição", tendo em vista que novos conhecimentos científicos são produzidos a partir da desconstrução das estabilizações anteriormente erigidas.

No livro A Estrutura das Revoluções Científicas, de Thomas S. Kuhn, comparecem algumas definições com as quais o presente trabalho consegue fazer aproximações. O diálogo pode ser estabelecido, por exemplo, em relação ao que se caracteriza como "ciência normal", a respeito do que se afirma:

Homens cuja pesquisa está baseada em paradigmas compartilhados estão comprometidos com as mesmas regras e padrões para a prática científica. Esse comprometimento e o consenso aparente que produz são pré-requisitos 
para a ciência normal, isto é, para a gênese e a continuação de uma tradição de pesquisa determinada. (KUHN, 1987, p. 30-1)

No detalhamento do que sejam os paradigmas que fundamentam uma ciência normal, discorre-se sobre eles conforme segue:

Os paradigmas adquirem seu status porque são mais bem sucedidos que seus competidores na resolução de alguns problemas que o grupo de cientistas reconhece como graves. Contudo, ser bem sucedido não significa nem ser totalmente bem sucedido com um único problema, nem notavelmente bem sucedido com um grande número. De início, o sucesso de um paradigma [...] é, em grande parte, uma promessa de sucesso que pode ser descoberta em exemplos selecionados e ainda incompletos. (KUHN, 1987, p. 44)

Destacamos, por fim, um último trecho, em que se classificam, como padrão usual de desenvolvimento de uma ciência amadurecida, as "revoluções científicas", isso é, as modificações de paradigmas e também as sucessivas passagens de um paradigma a outro. (KUHN, 1987, p. 32)

A reflexão sobre a "ciência normal" e as "revoluções científicas", tal como comparecem na obra citada, fomenta considerarmos o nosso corpus quanto às relações concernentes a esses dois polos de produção científico-acadêmica. Compreendemos que as análises demonstradas, ao longo desta tese, apontam para a existência de estabilizações que se aproximam dos paradigmas supramencionados.

Tais estabilizações concerniram tanto aos métodos de pesquisa, quanto à configuração dos objetos e, também, às proposições legitimadas. Observou-se que, como aspecto central, compareceu o predomínio de concepções e/ou abordagens fundamentadas em um quadro teórico bakhtiniano.

Contudo, ficou evidenciado, pelos nossos dados, que entre o "paradigma" e a "revolução", há regularidades que não se enquadram em nenhuma dessas extremidades. O que se percebeu, no nosso corpus, é que a tensão presente na constituição do discurso sobre a pesquisa em ensino de Língua Portuguesa não se dá entre "ciência normal" e "revolução 
científica", pois as recorrências presentes nas dissertações que analisamos apontam para estabilizações que, todavia, não se sustentam em si próprias, mas que se configuram nas refutações que divulga.

Desse modo, se, por um lado, tais estabilizações não se sustentam por si sós, mas sim no âmbito da refutação, é porque ainda não se caracterizam como paradigmas, tal como propostos por Kuhn (1987). Por outro lado, também não podem ser caracterizadas como revolucionárias, porque aparecem sob a marca da estagnação.

Isso significa que a polêmica, na configuração do discurso científico-acadêmico sobre ensino de Língua Portuguesa, deixa de assumir aspectos "revolucionários", concretizando-se enquanto "regularidade" nos enunciados que configuram o discurso sob análise.

Compreendemos a regularidade da polêmica, no nosso corpus, como a efetivação de uma "vontade de verdade" que prepondera no discurso sob análise. Essa "vontade" é concebida por Foucault (2004a, p. 18) como tendendo "a exercer sobre os outros discursos [...] uma espécie de pressão e como que um poder de coerção". O que é exemplificado conforme segue: "Penso na maneira como a literatura ocidental teve de buscar apoio, durante séculos, no natural, no verossímil, na sinceridade, na ciência também - em suma, no discurso verdadeiro".

O importante de se destacar é que esse "discurso verdadeiro" não impera absoluto, pelo contrário ele é uma construção histórica. E é como resultante do sistema histórico que a polêmica consolida-se como um enunciado regulamentador da produção discursiva sob enfoque.

Uma vez considerada essa "vontade de verdade" como construção, historicamente e institucionalmente estabelecida, e não como "verdade absoluta", verifica-se a validade de se questionar os enunciados que constituem o discurso de pesquisa em ensino de Língua Portuguesa por uma tomada de posição em que prevaleça "o direito de interrogar a verdade sobre seus efeitos de poder e o poder sobre seus discursos de verdade". (FOUCAULT, 2000, p. 173)

Desse modo, se a polêmica constitui o "discurso verdadeiro" é porque, por trás do seu pretenso caráter revolucionário, ela atua de modo coercivo, normativo, na produção da pesquisa em ensino de Língua Portuguesa. 
Uma constatação como essa dialoga com outras análises acerca do discurso caracterizado pela divergência entre "o que efetivamente ocorre no ensino de Língua Portuguesa e o que deveria ocorrer", conforme se vê no que segue:

[...] a década de 80 era marcada pela crença na possibilidade de reconstrução da democracia que, na disciplina de Língua Portuguesa, passava, entre outras coisas, pelo deslocamento da gramática do centro da aula e pela colocação do texto em seu lugar. Então, era dito ao professor, nos cursos de formação, que ele precisava mudar, que deveria romper com os modelos da cartilha, da gramática, de tudo o que era considerado fator de limitação às possibilidades de ler e de produzir textos mais criativos e com mais validade nos embates ideológicos. (BARZOTTO, 2013, p. 09)

A partir da afirmação anterior, o autor sinaliza que, desde a década de 80, já lhe causava desconforto a constituição do discurso sobre ensino de Língua Portuguesa pelo prisma da negação do que lhe foi precedente. O embate assumido quanto aos posicionamentos largamente divulgados de reiteração de avaliações negativas sobre a atuação docente perpassa a afirmação de que "se os problemas apontados se mantêm, merecendo novos trabalhos que os explicitam e problematizam, então, no mínimo a eficiência destes trabalhos e das proposições que fazem merecem também um questionamento". (BARZOTTO, 2004, apud BARZOTTO, 2013, p. 26)

Concordando com o autor, compreendemos que, no que se refere à produção do conhecimento, os "discursos verdadeiros" são colocados em xeque quando são questionados em relação ao que têm de homogêneo, de normatizador.

Desse modo, podemos concluir esta tese confirmando nossa hipótese inicial, de que há regularidades verificáveis no discurso científico-acadêmico sobre ensino de Língua Portuguesa. Também constatamos que sua análise aponta para a compreensão de como esse saber é passível de ser interrogado quanto às suas estabilizações.

Para chegar a estas palavras finais, percorremos um percurso orientado em direção aos objetivos elencados no capítulo introdutório, que foram: 
- Delinear a produção de conhecimento sobre ensino de Língua Portuguesa em dissertações de mestrado.

- Caracterizar quantitativamente a produção de mestrado sobre ensino de Língua Portuguesa do período de 2001 a 2010;

- Avaliar a configuração disciplinar de dissertações de mestrado, em conformidade com o conceito foucaultiano de "disciplina";

- Problematizar a constituição disciplinar dessas dissertações em relação às produções que lhes são posteriores.

Tendo-os em vista, consideramos que eles foram atingidos neste trabalho de pesquisa, de modo que as principais contribuições desta tese referem-se à proposta de reflexão sobre as regularidades que vão constituindo a produção do conhecimento, em especial, quando ela se expande, como ficou caracterizado pelas abordagens quantitativas que apresentamos.

Em decorrência desse aumento quantitativo expressivo, destacam-se as ponderações necessárias acerca das distinções entre "coleta de dados" e "composição do corpus", conforme abordado no capítulo 2. No que tange a isso, corrobora-se a importância de pesquisas que questionem a própria produção de conhecimento em que se inserem ou com a qual dialoguem.

A proposta de análise do discurso por enfoques que o consideram desde perspectivas globalizantes até outras mais pontuais também se concretizou como uma das possíveis contribuições desta tese. Sobre isso, ressaltamos que os procedimentos investigativos adotados demandaram a compreensão do discurso como regularizado por coerções que atuam de modo disperso e, a partir disso, buscaram-se formas de verificação de como "dispersão" e “constância" imbricavam-se na constituição do discurso sob enfoque.

De acordo com esse propósito, expusemos modos de análise que partiram da composição do nosso corpus por meio da verificação de como o discurso poderia ser, em termos retóricos, delimitado. A isso, seguiu-se a discussão sobre sua configuração disciplinar, na qual determinada "terminologia" aflorou e em que foi possível localizar a reiteração de operações linguísticas, como foi o caso da "negação polêmica". 
Dessa investigação, verificamos a possibilidade de refletir sobre a produção do conhecimento não somente em termos de "paradigmas" e de "revoluções", mas interrogando como o próprio efeito de "polêmica", entre o "paradigma" anterior e o que lhe é posterior, pode ter suas características "revolucionárias" amenizadas e passar a constituir-se pela sua estabilização, colocando, assim, a possibilidade de ser questionada. 


\section{REFERÊNCIAS}

ALVES, I. M. Neologismo: criação lexical. 2. ed. São Paulo: Editora Ática, 2002.

ARISTÓTELES. Órganon. 2. ed. Bauru, SP: EDIPRO, 2010. (Série Clássicos Edipro)

Retórica. Bauru, SP: EDIPRO, 2011.

AULETE. Disponível em: http://aulete.uol.com.br/site.php?mdl=aulete_digital. Acesso em 15 dez. 2013.

BARZOTTO, V. H. Língua portuguesa e prática docente: ouvindo vozes e tomando sustos, 2004. In: . Leitura, escrita e relação com o conhecimento. 2013. 147 f. Tese (Livre-docência) - Faculdade de Educação, Universidade de São Paulo, 2013.

Leitura, escrita e relação com o conhecimento. 2013. 147 f. Tese (Livredocência) - Faculdade de Educação, Universidade de São Paulo, 2013.

BAKHTIN, M. Marxismo e filosofia da linguagem: problemas fundamentais do método sociológico na ciência da linguagem. 11. ed. São Paulo: Hucitec, 2004.

BAKHTIN, M. Estética da criação verbal. 6. ed. São Paulo: Editora WMF Martins Fontes, 2011.

BENVENISTE, É. Problemas de linguística geral II. 2. ed. Campinas, SP: Pontes Editora, 2006.

BEZERRA, M. A. Ensino de língua portuguesa e contextos teórico-metodológicos. In: ; DIONÍSIO, A. P.; MACHADO, A. R. Gêneros textuais \& ensino. 5. ed. Rio de Janeiro: Lucerna, 2007. p. 37-46.

BIKLEN, S.; BOGDAN, R. Investigação qualitativa em educação: uma introdução à teoria e aos métodos. Porto: Porto Editora, 1994.

BRAIT, B.; PISTORI, M. H. C.. A produtividade do conceito de gênero em Bakhtin e o Círculo. Alfa, rev. linguíst., São Paulo, v. 56, n. 2, Dez. 2012. Disponível em: $<$ http://www.scielo.br/scielo.php?script=sci_arttext\&pid=S1981-

$57942012000200002 \& \operatorname{lng}=\mathrm{en} \& n r m=$ iso $>$. Acesso em 12 nov. 2013. 
BRASIL. Secretaria de Educação Fundamental. Parâmetros Curriculares Nacionais: língua portuguesa. Brasília: MEC/SEF, 1997.

BRASIL. Secretaria de Educação Fundamental. Parâmetros Curriculares Nacionais: terceiro e quarto ciclos do ensino fundamental, língua portuguesa. Brasília: MEC/SEF, 1998.

BRASIL. Ministério da Educação. Coordenação de Aperfeiçoamento de Pessoal de Nível Superior. Plano Nacional de Pós-Graduação: PNPG 2011-2020. Brasília, DF: CAPES, 2010.

BUDIN, J. O ensino da composição. Revista Atualidades Pedagógicas. São Paulo: Companhia Editora Nacional, Jan./Fev., 1951. p. 33-4.

CALDERÓN, A. I. Universidade mercantis: a institucionalização do mercado universitário em questão. São Paulo em Perspectiva, São Paulo, v. 14, n. 1, Mar. 2000. Disponível em: $<$ http://www.scielo.br/scielo.php?script=sci_arttext\&pid=S0102-

88392000000100007\&lng=en\&nrm=iso> . Acesso em: 20 out. 2012.

CHAUÍ, M. de S. Escritos sobre a universidade. São Paulo: Editora UNESP, 2001.

CORACINI, M. J. R. F. Um fazer persuasivo: o discurso subjetivo da ciência. Campinas, São Paulo: Pontes: Educ, 1991.

CUNHA, L. A. Desenvolvimento desigual e combinado no ensino superior: Estado e mercado. Educ. Soc., Campinas, v. 25, n. 88, p. 795-817, Out. 2004. Disponível em: $<$ http://www.scielo.br/scielo.php?script=sci_arttext\&pid=S0101-

73302004000300008\&lng=en\&nrm=iso> . Acesso em: 17 nov. 2012

DELEUZE, G. Foucault. São Paulo: Brasiliense, 2005.

DESCARTES, R. Discurso sobre o método. 2. ed. Bauru, SP: EDIPRO, 2006. (Série Clássicos Edipro)

DREYFUS, H. L.; RABINOW, P. Michel Foucault: uma trajetória filosófica, para além do estruturalismo e da hermenêutica. 2. ed. rev. Rio de Janeiro: Forense Universitária, 2010.

DUCROT, O. O dizer e o dito. Campinas, SP: Pontes, 1987.

DUCROT, O.; CAREL, M. Descrição argumentativa e descrição polifônica: o caso da negação. Letras de hoje. Porto Alegre, v. 43, n.1, p. 7-18, Jan./Mar. 2008. Disponível em: 
http://revistaseletronicas.pucrs.br/ojs/index.php/fale/article/viewFile/2865/2804. Acesso em 13 mar. 2013.

EUFRÁSIO, D. A. Traços das formações discursivas do dogma e da investigação em relatórios de pesquisa e de estágio: reflexão sobre o papel da pesquisa na formação docente. 2007. 196 f. Dissertação (Mestrado em Educação) - Faculdade de Educação, Universidade de São Paulo, São Paulo, 2007.

FOUCAULT, M. Isto não é um cachimbo. Rio de Janeiro: Paz e Terra, 1988.

(Coleção tópicos)

. As palavras e as coisas. 8. ed. São Paulo: Martins Fontes, 1999.

. O que é a crítica? (Crítica e Aufklärung). In: Cadernos da F.F.C: Michel

Foucault: histórias e destinos de um pensamento. Marília, v.9, n.1, 2000. p.169-189.

. A ordem do discurso. 11. ed. São Paulo: Edições Loyola, 2004a.

. Microfísica do poder. 20. ed. Rio de Janeiro: Graal, 2004b.

. Arqueologia do saber. 7. ed. Rio de Janeiro: Forense Universitária, 2005.

. História da loucura. 9. ed. São Paulo: Perspectiva, 2010.

. O nascimento da clínica. 7. ed. Rio de Janeiro: Forense Universitária,

2011.

GERALDI, J. W. Portos de passagem. 4. ed. São Paulo: Martins Fontes, 1991.

. Escrita, uso da escrita e avaliação. In:

(Org). O texto

na sala de aula. 4. ed. São Paulo: Ática, 2006, p. 127-131.

INDURSKY, F. Polêmica e denegação: dois funcionamentos discursivos da negação. Cad. Est. Ling. Campinas, n. 19, p. 117-122, Jul./Dez. 1990. Disponível em: http://www.iel.unicamp.br/revista/index.php/cel/article/view/3017. Acesso em 04 mar. 2013.

KLEIMAN, A. B. Apresentação. In: BEZERRA, M. A.; DIONÍSIO, A. P.; MACHADO, A. R. Gêneros textuais \& ensino. 5. ed. Rio de Janeiro: Lucerna, 2007. p. 7 -12. 
KRIEGER, M. da G. O termo: questionamentos e configurações. In:

MACIEL, A. M. B. (Orgs). Temas de Terminologia. Porto Alegre/São Paulo: Ed. Universidade/UFRGS/Humanitas/USP, 2001. p. 62-81.

KRIEGER, M. da G.; FINATTO, M. J. B. Introdução à Terminologia: teoria e prática. São Paulo: Contexto, 2004.

KUHN, T. S. A estrutura das revoluções científicas. São Paulo: Editora Perspectiva, 2. ed.,1987.

LAKATOS, E. M.; MARCONI, M. de A. Fundamentos de metodologia científica. 7. ed. São Paulo: Atlas, 2010.

MACHADO, R. Introdução. In: FOUCAULT, M. Microfísica do poder. 20. ed. Rio de Janeiro: Graal, 2004. p. VII - XXIII.

MACIEL, A. M. B. Terminologia, linguagem de especialidade e dicionários. In: KRIEGER, M. da G.; . (Orgs). Temas de Terminologia. Porto Alegre/São Paulo: Ed. Universidade/UFRGS/Humanitas/USP, 2001. p. 39-46.

MARINHO, M. O discurso da ciência e da divulgação em orientações curriculares de língua Portuguesa. Revista Brasileira de Educação. Rio de Janeiro, n. 24, Dez. 2003. Disponível em: $<$ http://www.scielo.br/scielo.php?script=sci_arttext\&pid=S1413-

24782003000300010\&lng=en\&nrm=iso >. Acesso em: 14 nov. 2012.

MOSCA, L. L. S. (Org.). Retóricas de Ontem e de Hoje. 2. ed. São Paulo: Associação Editorial Humanitas, 2001.

OLIVEIRA, F. de. et al. Disciplinas da licenciatura voltadas para o ensino de Língua Portuguesa: cooperação Acadêmica entre UNIFAL-MG e USP. Versão digital, 2009.

OLIVEIRA, L. P. A terminologia da genética molecular: aspectos morfológicos e semânticos. 2007. 130 f. Dissertação (Mestrado em Filologia e Língua Portuguesa) - Faculdade de Filosofia, Letras e Ciências Humanas, Universidade de São Paulo, São Paulo.

PERELMAN, C.; OLBRECHTS-TYTECA, L. Tratado da argumentação: a nova retórica. São Paulo: Editora Martins Fontes, 2002. 
PIETRI, E. de. A constituição do discurso da mudança do ensino de língua materna no Brasil. 2003. 202 f. Tese (Doutorado em Linguística Aplicada) - Instituto de Estudos da Linguagem, Universidade Estadual de Campinas, São Paulo, 2003.

PINTO, B. V. C. C. O funcionamento semântico-argumentativo da negação na paráfrase judicial. Estudos linguísticos, São Paulo, v. 38, n. 1, p. 323-334, Jan./Abr. 2009. Disponível em: http://gel.org.br/estudoslinguisticos/volumes/38/EL_V38N1_26.pdf. Acesso em 24 Jan. 2013.

POTTIER, B. Linguística Geral: teoria e descrição. Rio de Janeiro: Presença, Universidade Santa Úrsula, 1978.

POTTIER, B.; AUDUBERT, A.; PAIS, C. T. Estruturas linguísticas do português. 2. ed. São Paulo: Difusão Européia do Livro, 1973.

REVEL, J. Michel Foucault: conceitos essenciais. São Carlos: Claraluz, 2005.

ROCHA, M. P. A aula de leitura na escola secundária. Revista Atualidades Pedagógicas. São Paulo: Companhia Editora Nacional, Mai./Jun., 1950. p. 31-2.

ROJO, R. Os PCNs, as práticas de linguagem (dentro e fora da sala de aula) e a formação de professores. In: (Org.). A prática de linguagem em sala de aula: praticando os PCNs. São Paulo: EDUC; Campinas: Mercado de Letras, 2000. p. 7-11.

SAUSSURE, F. de. Curso de Linguística Geral. 27. ed. São Paulo: Cultrix, 2006.

SALOMON, D. V. Como fazer uma monografia. 11. ed. São Paulo: Martins Fontes, 2004.

SEVERINO, A. J. Metodologia do trabalho científico. 23. ed. rev. e atual. São Paulo: Cortez, 2007.

TRAVAGLIA, L. C. Gramática e interação: uma proposta para o ensino de gramática. 10. ed. São Paulo: Cortez, 2005.

VIEIRA, R. de A.; MACIEL, L. S. B. Fonte investigadora em Educação: registros do banco de teses da CAPES. Educ. Pesqui., São Paulo, v. 33, n. 2, Ago. 2007. Disponível em: $<$ http://www.scielo.br/scielo.php?script=sci_arttext\&pid=S1517-

97022007000200012\&lng=en\&nrm=iso>. Acesso em: 21 jan. 2012. 
XAVIER, A. C. Trajetória e legado de um filósofo da linguagem: Oswald Ducrot. Investigações, Pernambuco, v. 25, n. 2, Jul. 2012. Disponível em: http://www.revistainvestigacoes.com.br/Volumes/Vol.25.N2/Investigacoes-25N2_AntonioCarlos-Xavier.pdf. Acesso em: 21 Out. 2013. 


\section{APÊNDICE A - MATERIAL COLETADO}

Neste apêndice, o leitor encontrará informações centrais de todo o material coletado para o desenvolvimento da presente pesquisa. Nos quadros que apresentamos a seguir, estão disponibilizados todos os resumos que foram localizados no Banco de Teses da CAPES ${ }^{34}$, por meio do preenchimento dos campos de busca da forma como segue: o campo "assunto" foi respondido com a expressão exata "ensino de Língua Portuguesa", a informação "mestrado" foi colocada no campo "nível” e os anos de 2001 a 2010, no campo "ano". A descrição e a explicação de cada um dos cinco itens que compõe estes quadros podem ser encontradas no capítulo 1 - Coleta do material para análise. Deste montante de trabalhos, foram extraídas as dissertações que constituíram o nosso corpus.

\begin{tabular}{|c|c|c|c|c|}
\hline $\begin{array}{l}\text { Ano } \\
\text { de } \\
\text { defesa }\end{array}$ & $\begin{array}{l}\text { Contexto } \\
\text { pesquisado }\end{array}$ & $\begin{array}{l}\text { Vínculo } \\
\text { administrativo/ } \\
\text { Localização }\end{array}$ & $\begin{array}{l}\text { Transcrição parcial dos } \\
\text { resumos }^{35}\end{array}$ & $\begin{array}{l}\text { Disponível } \\
\text { on-line }\end{array}$ \\
\hline \multirow[t]{3}{*}{2001} & $\begin{array}{l}\text { Educação } \\
\text { Básica }\end{array}$ & IES Federal/DF & $\begin{array}{l}\text { "Esta dissertação constitui-se de uma } \\
\text { reflexão sobre práticas de letramento e } \\
\text { ensino de Língua Portuguesa (LP). } \\
\text { Para discutirmos esta questão } \\
\text { fundamentada em práticas } \\
\text { efetivamente } \\
\text { desenvolvemos pesquisa de caráter } \\
\text { etnográfico com professores(as) de LP, } \\
\text { em uma escola pública do DF". }\end{array}$ & Não \\
\hline & $\begin{array}{l}\text { Educação de } \\
\text { Jovens e } \\
\text { Adultos }\end{array}$ & IES Estadual/SP & $\begin{array}{l}\text { "Este trabalho objetiva mostrar o nível } \\
\text { da produção lingüística de uma turma } \\
\text { concluinte de } 1^{\circ} \text { grau, ancorando-se } \\
\text { nos conceitos de textualidade da } \\
\text { moderna Lingüística Textual [...] É } \\
\text { analisado um corpus de } 100 \text { (cem) } \\
\text { redações, do Centro de Educação } \\
\text { Aberta, Continuada, a Distância - } \\
\text { CEAD, de Toledo-Pr., escola para } \\
\text { jovens e adultos, ensino a distância". }\end{array}$ & Não \\
\hline & $\begin{array}{l}\text { Educação } \\
\text { Profissional }\end{array}$ & IES Federal/MG & $\begin{array}{l}\text { "[...] propõe-se a verificar se as } \\
\text { atividades de leitura no ensino e } \\
\text { Língua Portuguesa (LP) no Ensino }\end{array}$ & Sim \\
\hline
\end{tabular}

\footnotetext{
${ }_{35}^{34}$ Disponível em http://capesdw.capes.gov.br/capesdw/. Acesso em mar. 2013.

${ }^{35} \mathrm{Na}$ transcrição dos trechos dos resumos das dissertações de mestrado em foco não há uniformidade na quantidade de palavras da cada um deles, o que se explica pelo fato de, nos textos originais, também termos nos deparado com resumos de diversos tamanhos. Alguns apresentavam as informações acerca do tema analisado, da metodologia empregada, do referencial teórico mobilizado e dos resultados alcançados de modo mais abreviado do que se encontrava em outros. Também houve resumos que não abordaram estas informações, as quais, por sua vez, foram privilegiadas na elaboração dos quadros apresentados neste primeiro apêndice.
} 


\begin{tabular}{|c|c|c|c|}
\hline $\begin{array}{l}\text { Técnica de } \\
\text { Nível Médio }\end{array}$ & & $\begin{array}{l}\text { Médio do Centro Federal de Educação } \\
\text { Tecnológica do Piauí (CEFET-PI) } \\
\text { contribuem para a formação de um } \\
\text { sujeito-leitor, capaz de posicionar-se } \\
\text { criticamente frente às informações do } \\
\text { mundo contemporâneo. [...] O } \\
\text { universo compreende os alunos } \\
\text { matriculados no Ensino Médio no ano } \\
2000 \text { e os professores de LP que } \\
\text { ministram aulas neste nível de ensino. } \\
\text { Enquanto a coleta de dados abrangeu } \\
\text { todos os docentes, no caso dos } \\
\text { discentes, através da técnica de } \\
\text { amostra probabilística simples, foram } \\
\text { sorteados o total de } 200 \text { ". }\end{array}$ & \\
\hline $\begin{array}{l}\text { Educação } \\
\text { Profissional } \\
\text { Técnica de } \\
\text { Nível Médio }\end{array}$ & $\begin{array}{l}\text { IES } \\
\text { Particular/SP }\end{array}$ & 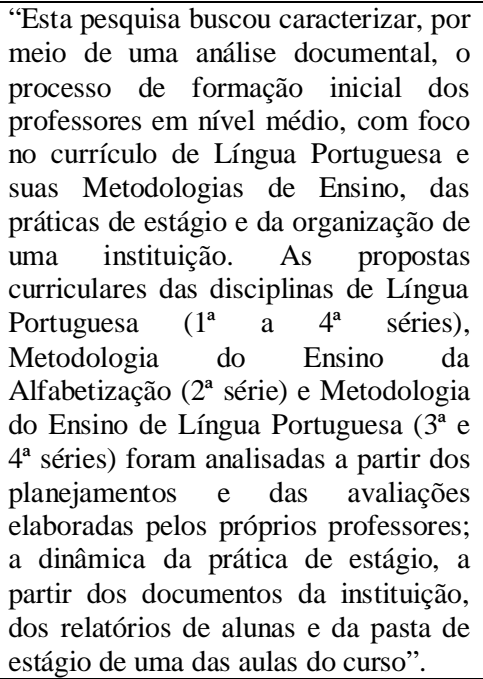 & Não \\
\hline $\begin{array}{l}\text { Educação } \\
\text { Superior }\end{array}$ & $\begin{array}{l}\text { IES } \\
\text { Particular/PR }\end{array}$ & $\begin{array}{l}\text { "A presente pesquisa propôs investigar } \\
\text { se a prática pedagógica da poesia } \\
\text { como elemento articulador no Ensino } \\
\text { da Língua Portuguesa contribui na } \\
\text { transformação da atividade de } \\
\text { aprendizagem, da aquisição do } \\
\text { conhecimento para a proposição de } \\
\text { uma prática docente inovadora na } \\
\text { Educação Superior, num processo } \\
\text { colaborativo. Os sujeitos da pesquisa } \\
\text { foram: 1 Fase (30 sujeitos) e Vil Fase } \\
\text { (21 sujeitos) do Curso de Pedagogia do } \\
\text { Centro de Ensino Superior- UNERJ". }\end{array}$ & Não \\
\hline $\begin{array}{l}\text { Educação } \\
\text { Superior }\end{array}$ & $\begin{array}{l}\text { IES } \\
\text { Particular/SP }\end{array}$ & $\begin{array}{l}\text { "O ponto de partida é uma análise do } \\
\text { ensino de Língua Portuguesa, em curso } \\
\text { superior, que se volta quase que } \\
\text { totalmente para aspectos gramaticais. } \\
\text { [...] Tendo por esteio teórico a } \\
\text { lingüística textual, aliada à teoria } \\
\text { funcional da gramática e à pragmática, } \\
\text { propõe-se analisar o ensino de Língua } \\
\text { Portuguesa no Curso de Bacharelado } \\
\text { em Hotelaria do Senac. Para dar conta } \\
\text { da proposta da pesquisa, selecionamos } \\
\text { três conjuntos de dados que foram } \\
\text { analisados segundo um procedimento } \\
\text { qualitativo e exploratório: o programa } \\
\text { da disciplina Língua Portuguesa, as } \\
\text { entrevistas realizadas com professores } \\
\text { que ministram disciplinas de formação } \\
\text { básica e produções textuais dos } \\
\text { estudantes do primeiro ano". }\end{array}$ & Não \\
\hline
\end{tabular}




\begin{tabular}{|c|c|c|c|}
\hline $\begin{array}{l}\text { Ensino } \\
\text { Fundamental } \\
\text { I }\end{array}$ & IES Estadual/SP & $\begin{array}{l}\text { "O uso de recursos computacionais no } \\
\text { processo de aprendizagem torna-se } \\
\text { cada vez mais evidente. [...] Na fase de } \\
\text { alfabetização a produção textual } \\
\text { realizada com editores de texto } \\
\text { sofisticados não é interessante pois } \\
\text { distância o aprendiz de seu objetivo } \\
\text { principal uma vez que ele deve voltar } \\
\text { sua atenção para a aprendizagem dos } \\
\text { recursos computacionais oferecidos. } \\
\text { Visando minimizar os problemas } \\
\text { mencionados, neste trabalho é } \\
\text { proposto o ambiente HagáQuê para a } \\
\text { criação e edição de história em } \\
\text { quadrinhos, sendo esta uma das } \\
\text { primeiras formas textuais trabalhadas } \\
\text { no ensino de Língua Portuguesa". }\end{array}$ & Sim \\
\hline $\begin{array}{l}\text { Ensino } \\
\text { Fundamental } \\
\text { II }\end{array}$ & IES Estadual/SP & $\begin{array}{l}\text { "O presente trabalho pretende analisar } \\
\text { diversos aspectos no que concerne ao } \\
\text { ensino da Língua Portuguesa, a fim de } \\
\text { verificar se há relevância e qualidade } \\
\text { no ensino atrelado a parâmetros e } \\
\text { propostas pré-estabelecidos. São eles: } \\
\text { a) como vem sendo ensinada a língua } \\
\text { portuguesa de 5. a } 8 .^{\text {a }} \text { série do ensino } \\
\text { fundamental; b) se o programa } \\
\text { curricular de tais séries está baseado na } \\
\text { proposta curricular do Estado de São } \\
\text { Paulo; c) se as aulas vêm sendo } \\
\text { ministradas com base nos PCN/LP } \\
\text { (Parâmetros Curriculares Nacionais de } \\
\text { Língua Portuguesa); d) de que maneira } \\
\text { os PCNs são interpretados pelos } \\
\text { professores e especialistas; e) se o que } \\
\text { é ensinado em Língua Portuguesa nas } \\
\text { séries acima citadas torna o aluno } \\
\text { capacitado a ingressar no Ensino } \\
\text { Médio, Técnico Profissionalizante ou } \\
\text { ser absorvido pelo mercado de } \\
\text { trabalho; f) como os professores } \\
\text { adaptaram suas estratégias, a fim de } \\
\text { atender ao novo conceito de ensino de } \\
\text { língua". }\end{array}$ & Não \\
\hline $\begin{array}{l}\text { Ensino } \\
\text { Fundamental } \\
\text { II }\end{array}$ & IES Estadual/SP & $\begin{array}{l}\text { "Neste trabalho, busca-se - a partir da } \\
\text { análise de textos produzidos por } \\
\text { alunos surdos - compreender como a } \\
\text { língua de sinais interfere nas } \\
\text { produções escrita apresentadas por } \\
\text { eles. Também analisa o papel da } \\
\text { educação para surdos com forte } \\
\text { influência do modelo oralista (ênfase } \\
\text { na memorização e na repetição) e } \\
\text { como essa influência se dá no ensino } \\
\text { da língua portuguesa aos surdos. [...] } \\
\text { Esta pesquisa foi realizada com alunos } \\
\text { surdos que frequientavam o ensino } \\
\text { fundamental de 5a à 8a série, tendo por } \\
\text { base a discussão de temas em Libras } \\
\text { realizados em sala de aula e a posterior } \\
\text { produção escrita dos temas debatidos". }\end{array}$ & Sim \\
\hline $\begin{array}{l}\text { Ensino } \\
\text { Fundamental } \\
\text { II }\end{array}$ & IES Federal/RJ & $\begin{array}{l}\text { "O objetivo central desta dissertação } \\
\text { foi a análise da prática de uma } \\
\text { professora de Língua Portuguesa de } 5^{\text {a }} \\
\text { série de uma escola pública de Minas } \\
\text { Gerais, investigando o modo como o } \\
\text { conhecimento/leitura de mundo dos } \\
\text { alunos é trabalhado. Constitui-se em }\end{array}$ & Não \\
\hline
\end{tabular}




\begin{tabular}{|c|c|c|c|}
\hline & & $\begin{array}{l}\text { um estudo exploratório; a coleta de } \\
\text { dados se deu pela observação das aulas } \\
\text { no seu contexto natural, bem como } \\
\text { pela entrevista com a professora, } \\
\text { conduzida por um roteiro } \\
\text { semiestruturado". }\end{array}$ & \\
\hline $\begin{array}{l}\text { Ensino } \\
\text { Fundamental } \\
\text { II }\end{array}$ & IES Federal/RN & 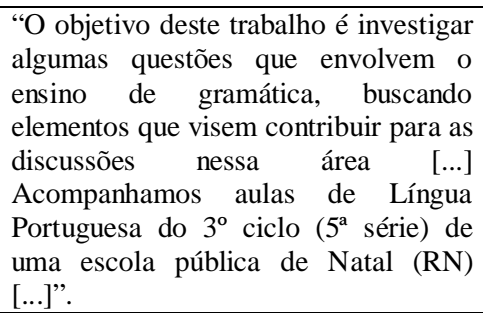 & Não \\
\hline $\begin{array}{l}\text { Ensino } \\
\text { Fundamental } \\
\text { II }\end{array}$ & $\begin{array}{l}\text { IES Particular/ } \\
\text { GO }\end{array}$ & 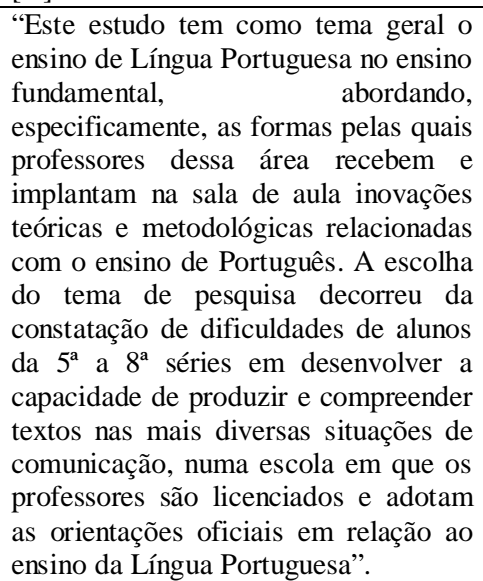 & Sim \\
\hline $\begin{array}{l}\text { Ensino } \\
\text { Fundamental } \\
\text { II }\end{array}$ & $\begin{array}{l}\text { IES } \\
\text { Particular/RS }\end{array}$ & $\begin{array}{l}\text { "Longos anos de trabalho como } \\
\text { professora de Língua Portuguesa no } \\
\text { ensino fundamental e superior e } \\
\text { recente experiência em setor } \\
\text { administrativo na área de educação } \\
\text { levaram à constatação de que os } \\
\text { professores estão muito inseguros na } \\
\text { condução das atividades voltadas ao } \\
\text { ensino da língua portuguesa como } \\
\text { língua materna e, em razão disso, } \\
\text { buscam o apoio dos livros didáticos, a } \\
\text { cuja metodologia acabam se } \\
\text { submetendo com pouca restrição e } \\
\text { crítica. Tal fato levou à realização } \\
\text { deste trabalho, cujo objetivo geral é } \\
\text { investigar os princípios e métodos do } \\
\text { ensino da língua proposto nesses } \\
\text { manuais e, dentro desse objetivo, o } \\
\text { propósito específico é mostrar como } \\
\text { neles é trabalhada a sintaxe. Nesse } \\
\text { sentido analisaram-se quatro coleções } \\
\text { de manuais didáticos de 5a. a 8a. série, } \\
\text { adotados nas escolas municipais do } \\
\text { município de Passo Fundo - RS". }\end{array}$ & Não \\
\hline $\begin{array}{l}\text { Ensino } \\
\text { Fundamental } \\
\text { II }\end{array}$ & $\begin{array}{l}\text { IES } \\
\text { Particular/RS }\end{array}$ & $\begin{array}{l}\text { "Esta investigação teve como objetivo } \\
\text { demonstrar que as oficinas } \\
\text { pedagógicas de Língua Portuguesa } \\
\text { podem contribuir para aprendizagens } \\
\text { prazerosas e significativas através de } \\
\text { uma metodologia que privilegie a } \\
\text { interação social, favorecendo a leitura } \\
\text { e a produção de textos dos educandos. } \\
\text { Realizou-se em uma escola estadual, } \\
\text { do Rio Grande do Sul, durante o ano } \\
\text { 2000. Participaram a professora }\end{array}$ & Não \\
\hline
\end{tabular}




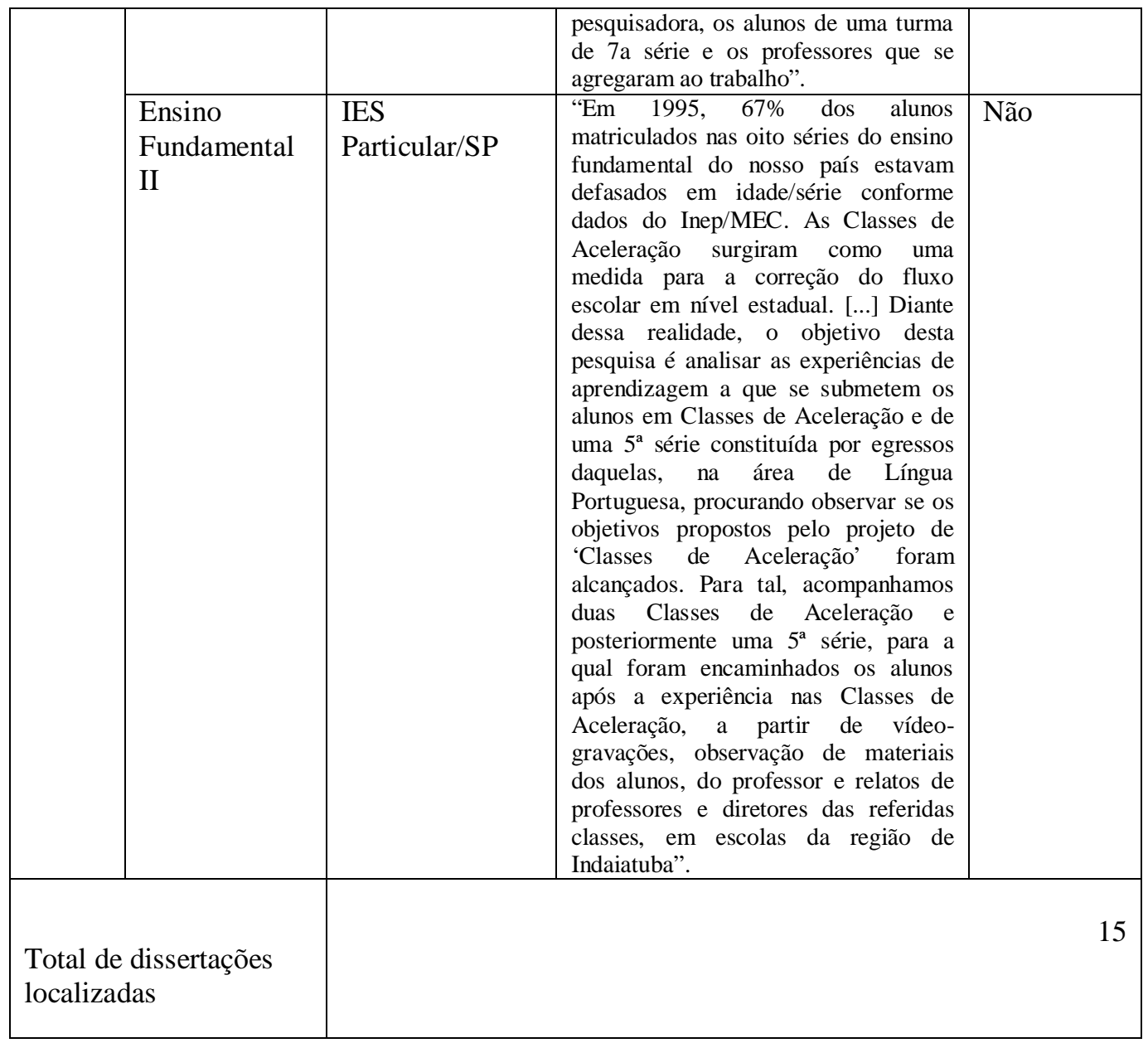

\begin{tabular}{|c|c|c|c|c|}
\hline $\begin{array}{l}\text { Ano } \\
\text { de } \\
\text { defesa }\end{array}$ & $\begin{array}{l}\text { Contexto } \\
\text { pesquisado }\end{array}$ & $\begin{array}{l}\text { Vínculo } \\
\text { administrativo } \\
\text { /Localização }\end{array}$ & $\begin{array}{l}\text { Transcrição parcial dos } \\
\text { resumos }\end{array}$ & $\begin{array}{l}\text { Disponível } \\
\text { on-line }\end{array}$ \\
\hline 2002 & $\begin{array}{l}\text { Educação } \\
\text { Básica }\end{array}$ & IES Federal/PE & $\begin{array}{l}\text { "Este trabalho tem por objetivo mostrar } \\
\text { que a aplicação de abordagens } \\
\text { linguísticas pode contribuir para um } \\
\text { eficaz ensino-aprendizagem de língua } \\
\text { materna. [...] procuramos verificar que } \\
\text { abordagens linguísticas os oito } \\
\text { professores sujeitos da pesquisa } \\
\text { conheciam e se as aplicavam em suas } \\
\text { aulas de língua portuguesa. [...] Os } \\
\text { resultados mostraram que a concepção } \\
\text { de gramática prevalecente nas turmas } \\
\text { dos professores investigados e a } \\
\text { normativa, associada a uma prática de } \\
\text { ensino tradicional, em que o aluno só } \\
\text { recebe os conteúdos } \\
\text { descontextualizados, e participa de um } \\
\text { processo como membro passivo. A nossa } \\
\text { conclusão é que uma das causas da } \\
\text { ineficácia do ensino de língua } \\
\text { portuguesa é o desconhecimento dos } \\
\text { possíveis beneficios resultantes da } \\
\text { aplicaçao pedagógica de princípios } \\
\text { básicos da linguística. O conhecimento e } \\
\text { a aplicação desses princípios poderiam }\end{array}$ & Não \\
\hline
\end{tabular}




\begin{tabular}{|c|c|c|c|}
\hline & & $\begin{array}{l}\text { muito provavelmente contribuir para } \\
\text { uma prática mais produtiva e eficaz" }\end{array}$ & \\
\hline $\begin{array}{l}\text { Educação } \\
\text { Básica/ } \\
\text { Educação } \\
\text { Superior }\end{array}$ & $\begin{array}{l}\text { IES } \\
\text { Particular/DF }\end{array}$ & $\begin{array}{l}\text { "A pesquisa [...] resultou da experiência } \\
\text { educacional da autora em todos os níveis } \\
\text { de ensino, constatando, precocemente, } \\
\text { que a progressão escolar do aluno se } \\
\text { efetiva sem o domínio das habilidades de } \\
\text { leitura, compreensão e interpretação dos } \\
\text { códigos lingüísticos, permeando todos os } \\
\text { níveis de ensino, se estendendo até o } \\
\text { Ensino Superior. Tal constatação } \\
\text { conduziu a autora a uma incursão ao } \\
\text { estado da arte, à necessidade de } \\
\text { investigar com maior rigor, os } \\
\text { paradigmas que norteiam a Educação, } \\
\text { sobretudo, no âmbito das Diretrizes } \\
\text { Pedagógicas que regem o ensino Médio. } \\
\text { Em segunda instância, a autora buscou } \\
\text { realizar uma intervenção didático- } \\
\text { pedagógica, destinada aos alunos } \\
\text { iniciantes no Ensino Superior, à luz das } \\
\text { Teorias da Aprendizagem voltadas para } \\
\text { o estudo da linguagem como fonte } \\
\text { socializadora do indivíduo [...] Em } \\
\text { conclusão, a autora sugere o } \\
\text { desdobramento do tema em outras } \\
\text { vertentes susceptíveis de maior } \\
\text { aprofundamento, visando a re- } \\
\text { significação da prática docente no } \\
\text { Ensino Superior." }\end{array}$ & Não \\
\hline $\begin{array}{l}\text { Educação } \\
\text { Superior }\end{array}$ & $\begin{array}{l}\text { IES } \\
\text { Particular/RS }\end{array}$ & $\begin{array}{l}\text { "A presente pesquisa [...] teve como } \\
\text { objetivo proceder a um levantamento e } \\
\text { análise das necessidades e exigências de } \\
\text { domínio de Língua Portuguesa para } \\
\text { formação profissional na área de } \\
\text { Secretariado Executivo." }\end{array}$ & Não \\
\hline $\begin{array}{l}\text { Ensino } \\
\text { Fundamental }\end{array}$ & IES Federal/PB & $\begin{array}{l}\text { "A nossa pesquisa tem como objetivo } \\
\text { observar a aplicação da teoria dos } \\
\text { gêneros em uma coleção didática do } \\
\text { Ensino Fundamental e se a forma, como } \\
\text { essa teoria é aplicada no Livro Didático, } \\
\text { contribui para o crescimento textual e } \\
\text { discursivo do aluno." }\end{array}$ & Não \\
\hline $\begin{array}{l}\text { Ensino } \\
\text { Fundamental } \\
\text { I }\end{array}$ & $\begin{array}{l}\text { IES } \\
\text { Estadual/PR }\end{array}$ & $\begin{array}{l}\text { "Neste trabalho de dissertação, } \\
\text { objetivamos contribuir para uma } \\
\text { reflexão crítica a respeito da formação } \\
\text { docente e da prática de produção textual } \\
\text { desenvolvida por uma professora junto a } \\
\text { alunos do segundo ciclo do ensino } \\
\text { fundamental. [...] realizamos um estudo } \\
\text { investigativo junto a uma classe do } \\
\text { segundo ciclo do ensino fundamental de } \\
\text { uma escola pública do município de } \\
\text { Guarapuava-PR, acompanhando-a } \\
\text { durante todo um ano letivo, com o } \\
\text { intuito de coletar registros da prática } \\
\text { docente". }\end{array}$ & Sim \\
\hline $\begin{array}{l}\text { Ensino } \\
\text { Fundamental } \\
\text { I }\end{array}$ & IES Federal/CE & $\begin{array}{l}\text { "O objetivo principal deste trabalho é } \\
\text { analisar o curso da construção do gênero } \\
\text { textual escrito carta por crianças de } \\
\text { alfabetização a segunda série do ensino } \\
\text { fundamental ( } 6 \text { a } 8 \text { anos) em ambiente } \\
\text { escolar. [...] corpus composto por } 208 \\
\text { textos, escritos por } 104 \text { sujeitos [...]." }\end{array}$ & Não \\
\hline $\begin{array}{l}\text { Ensino } \\
\text { Fundamental }\end{array}$ & IES Federal/PE & $\begin{array}{l}\text { "A maioria da população brasileira } \\
\text { apresenta dificuldades no emprego das } \\
\text { marcas prestigiadas de concordância }\end{array}$ & Não \\
\hline
\end{tabular}




\begin{tabular}{|c|c|c|c|}
\hline I & & $\begin{array}{l}\text { verbo-nominal, constituindo esse } \\
\text { subtópico da norma lingüística um dos } \\
\text { aspectos mais estigmatizadores dos } \\
\text { falantes brasileiros e uma fonte de } \\
\text { preocupação para os professores no } \\
\text { ensino de Língua Portuguesa. Diante } \\
\text { disso, esta pesquisa teve por objetivo } \\
\text { geral analisar o processo de ensino e de } \\
\text { aprendizagem da concordância verbo- } \\
\text { nominal (CVN), a partir do trabalho } \\
\text { didático realizado numa rede pública de } \\
\text { ensino, desvelando que fatores } \\
\text { ajudariam ou dificultariam as crianças a } \\
\text { se apropriarem das marcas de CVN de } \\
\text { prestígio. [...] Nossos sujeitos foram } \\
\text { duas professoras e seus alunos, crianças } \\
\text { de escolas públicas da rede municipal de } \\
\text { Recife, pertencentes a duas turmas (uma, } \\
\text { de } 3^{\mathrm{a}} \text { série e uma, de } 4{ }^{\mathrm{a}} \text { série)." }\end{array}$ & \\
\hline $\begin{array}{l}\text { Ensino } \\
\text { Fundamental } \\
\text { II }\end{array}$ & IES Federal/SC & $\begin{array}{l}\text { "Esta pesquisa tem por objetivo, à luz da } \\
\text { teoria bakhtiniana, analisar como a } \\
\text { noção de gênero do discurso está sendo } \\
\text { incorporada nas atividades propostas } \\
\text { para as práticas de produção textual } \\
\text { escrita nos livros didáticos (LDs) de } \\
\text { língua portuguesa, bem como quais os } \\
\text { gêneros do discurso priorizados para } \\
\text { essas atividades. A fim de alcançar o } \\
\text { objetivo proposto, a metodologia para a } \\
\text { coleta dos dados consta do levantamento } \\
\text { das propostas de atividades de produção } \\
\text { textual escrita nos LDs de língua } \\
\text { portuguesa de } 3^{\circ} \text { e } 4^{\circ} \text { ciclos do Ensino } \\
\text { Fundamental, escolhidos em maior } \\
\text { número pelas escolas municipais da } \\
\text { cidade de Joinville (SC)." }\end{array}$ & Não \\
\hline $\begin{array}{l}\text { Ensino } \\
\text { Fundamental } \\
\text { II }\end{array}$ & $\begin{array}{l}\text { IES } \\
\text { Particular/RS }\end{array}$ & 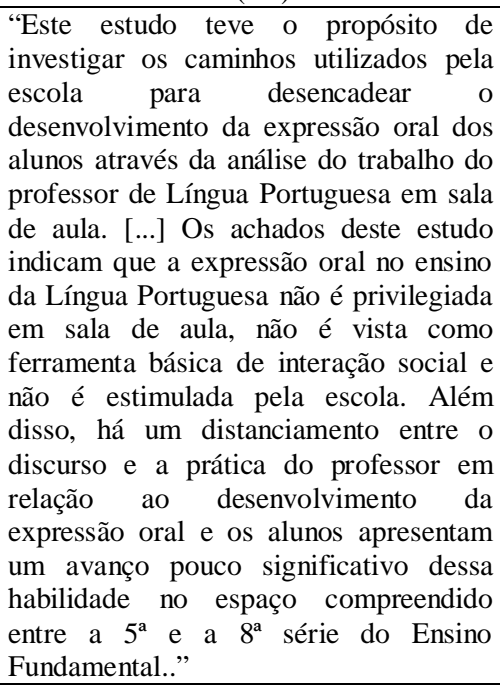 & Não \\
\hline $\begin{array}{l}\text { Ensino } \\
\text { Fundamental } \\
\text { II }\end{array}$ & $\begin{array}{l}\text { IES } \\
\text { Particular/SP }\end{array}$ & $\begin{array}{l}\text { "O tema deste estudo é a revisão } \\
\text { curricular em suas diferentes relações } \\
\text { com a pesquisa. O problema: quais as } \\
\text { práticas realizadas na revisão curricular } \\
\text { de Língua Portuguesa - de } 5^{a} \text { à } 8^{\mathrm{a}} \text { séries - } \\
\text { propostas pela SME-SP (1983-1985)? } \\
\text { Que relações foram estabelecidas com a } \\
\text { pesquisa? Este estudo objetivou } \\
\text { investigar: as práticas desencadeadas } \\
\text { desde o início da gestão; as relações } \\
\text { estabelecidas com a pesquisa; que }\end{array}$ & Não \\
\hline
\end{tabular}




\begin{tabular}{|c|c|c|c|}
\hline & & 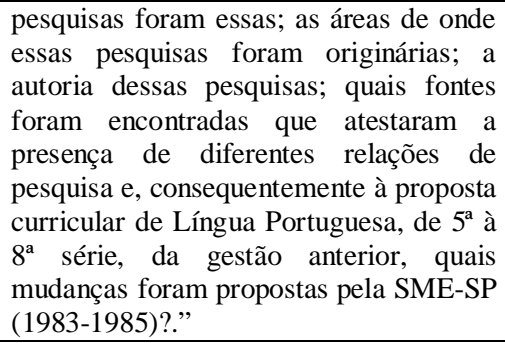 & \\
\hline $\begin{array}{l}\text { Ensino } \\
\text { Fundamental } \\
\text { /Ensino } \\
\text { Médio }\end{array}$ & $\begin{array}{l}\text { IES } \\
\text { Estadual/SP }\end{array}$ & $\begin{array}{l}\text { "Esta pesquisa está centrada na } \\
\text { preocupação com os problemas que } \\
\text { envolvem o ensino de leitura e produção } \\
\text { de textos nos níveis fundamental e } \\
\text { médio. A partir de experiências em sala } \\
\text { de aula de escolas públicas, procuramos } \\
\text { discutir questões como motivação, auto- } \\
\text { estima, conhecimento prévio etc., a fim } \\
\text { de verificar a importância desses } \\
\text { elementos para a bom desempenho do } \\
\text { aluno nas atividades de aprendizagem da } \\
\text { língua materna." }\end{array}$ & Não \\
\hline $\begin{array}{l}\text { Ensino } \\
\text { Médio }\end{array}$ & $\begin{array}{l}\text { IES } \\
\text { Estadual/PR }\end{array}$ & $\begin{array}{l}\text { "Com este trabalho, pretendemos } \\
\text { analisar a perspectiva curricular e } \\
\text { pedagógica do ensino da Língua } \\
\text { Portuguesa e Literatura no Ensino Médio } \\
\text { dos estabelecimentos públicos estaduais } \\
\text { do município de Ponta Grossa entre os } \\
\text { anos de } 1999 \text { a 2002." }\end{array}$ & Não \\
\hline $\begin{array}{l}\text { Ensino } \\
\text { Médio }\end{array}$ & $\begin{array}{l}\text { IES } \\
\text { Estadual/PR }\end{array}$ & $\begin{array}{l}\text { "Este trabalho apresenta resultados de } \\
\text { uma investigação sobre a Língua } \\
\text { Portuguesa na prova do ENEM (Exame } \\
\text { Nacional do Ensino Médio), em suas três } \\
\text { primeiras edições (1998, } 1999 \text { e 2000). } \\
\text { A pergunta que norteia essa pesquisa } \\
\text { constitui o objetivo maior do trabalho: é } \\
\text { o ENEM um mecanismo de } \\
\text { reformulação ou de avaliação do ensino } \\
\text { de Língua Portuguesa? Outro objetivo é } \\
\text { servir de contribuição para o ensino da } \\
\text { língua, a partir da análise, discussões e } \\
\text { reflexões desenvolvidas." }\end{array}$ & Sim \\
\hline $\begin{array}{l}\text { Ensino } \\
\text { Médio }\end{array}$ & $\begin{array}{l}\text { IES } \\
\text { Federal/AM }\end{array}$ & $\begin{array}{l}\text { "Esta pesquisa fundamenta-se na prática } \\
\text { pedagógica de cinco professoras que } \\
\text { ministram aulas de Língua Portuguesa } \\
\text { numa escola pública em Manaus, } \\
\text { objetivando compreender como essas } \\
\text { professoras, desenvolvem suas } \\
\text { atividades, como ministram os } \\
\text { conteúdos de Língua Portuguesa em sala } \\
\text { de aula, como trabalham as DCNEM } \\
\text { (Diretrizes Curriculares Nacionais para o } \\
\text { Ensino Médio) prescritas nos PCNEM } \\
\text { (Parâmetros Curriculares Nacionais para } \\
\text { o Ensino Médio), tentando verificar não } \\
\text { só se é possível perceber, em suas aulas, } \\
\text { as orientações contidas nos PCNEM, } \\
\text { bem como quais as habilidades e } \\
\text { competências necessárias para o } \\
\text { professor de Língua Portuguesa } \\
\text { desenvolver práticas de ensino } \\
\text { contextualizadas e interdisciplinares. } \\
\text { Inicia-se com a observação de sala de } \\
\text { aula, realização de entrevistas e análise } \\
\text { do livro dos PCNEM." }\end{array}$ & Não \\
\hline Ensino & IES Federal/ & $\begin{array}{l}\text { "Esta pesquisa, de caráter etnográfico, } \\
\text { tem por objetivo investigar as }\end{array}$ & Não \\
\hline
\end{tabular}




\begin{tabular}{|c|c|c|c|c|}
\hline & Médio & $\mathrm{GO}$ & $\begin{array}{l}\text { concepções de linguagem que subjazem } \\
\text { à prática docente dos professores de } \\
\text { Língua Portuguesa no ensino médio. } \\
\text { Para isso, verificam-se, em duas turmas } \\
\text { de uma instituição federal de ensino, os } \\
\text { conceitos de primeira língua (L1), e de } \\
\text { ensino de L1, o ensino de gramática, a } \\
\text { avaliação, o programa e o currículo, o } \\
\text { planejamento, a metodologia, o papel do } \\
\text { professor e do aluno, além das } \\
\text { expectativas dos professores em relação } \\
\text { à reforma do ensino médio." }\end{array}$ & \\
\hline & $\begin{array}{l}\text { Exame } \\
\text { Vestibular }\end{array}$ & $\begin{array}{l}\text { IES } \\
\text { Estadual/PR }\end{array}$ & $\begin{array}{l}\text { "[...] esta pesquisa analisa a construção } \\
\text { da informatividade, bem como a origem } \\
\text { das informações em redações do } \\
\text { Vestibular de Verão/2001 da } \\
\text { Universidade Estadual de Maringá- } \\
\text { UEM." }\end{array}$ & Sim \\
\hline $\begin{array}{l}\text { Total o } \\
\text { localiz }\end{array}$ & $\begin{array}{l}\text { issertações } \\
\text { s }\end{array}$ & & & 16 \\
\hline
\end{tabular}

\begin{tabular}{|c|c|c|c|c|}
\hline $\begin{array}{l}\text { Ano } \\
\text { de } \\
\text { defesa }\end{array}$ & $\begin{array}{l}\text { Contexto } \\
\text { pesquisado }\end{array}$ & $\begin{array}{l}\text { Vínculo } \\
\text { administrativo } \\
\text { /Localizacão }\end{array}$ & $\begin{array}{l}\text { Transcrição parcial dos } \\
\text { resumos }\end{array}$ & $\begin{array}{l}\text { Disponível } \\
\text { on-line }\end{array}$ \\
\hline \multirow[t]{3}{*}{2003} & $\begin{array}{l}\text { Educação } \\
\text { Básica }\end{array}$ & $\begin{array}{l}\text { IES } \\
\text { Estadual/PR }\end{array}$ & $\begin{array}{l}\text { "Nesta pesquisa, objetivamos refletir } \\
\text { sobre a política de ensino de língua no } \\
\text { Brasil, nas últimas três décadas, e sobre } \\
\text { sua concretização na prática escolar, } \\
\text { buscando investigar a relação entre } \\
\text { teoria e prática. [...] analisamos os } \\
\text { pressupostos teóricos subjacentes às Leis } \\
\text { de Diretrizes e Bases no } 5.692 / 71 \text { e } \text { n }^{\circ} \\
9.394 / 96 \text {, bem como o instrumento que } \\
\text { norteia a operacionalização desta última } \\
\text { LDB, atualmente em vigor: os } \\
\text { Parâmetros Curriculares Nacionais. } \\
\text { Feitas as considerações teóricas, } \\
\text { procedemos à análise de entrevistas } \\
\text { realizadas com professores de língua } \\
\text { portuguesa que atuam há pelo menos } \\
\text { vinte e cinco anos, tendo estado, } \\
\text { portanto, sob a égide de ambas as leis.". }\end{array}$ & Sim \\
\hline & $\begin{array}{l}\text { Educação } \\
\text { Básica }\end{array}$ & $\begin{array}{l}\text { IES } \\
\text { Estadual/RJ }\end{array}$ & $\begin{array}{l}\text { "Apresentamos um estudo reflexivo } \\
\text { sobre o espaço que tem sido dedicado ao } \\
\text { exercício da oralidade em sala de aula, } \\
\text { levando questões como as orientações } \\
\text { dos Parâmetros Curriculares Nacionais } \\
\text { quanto ao ensino da língua oral e seus } \\
\text { efeitos concretos na inclusão desse novo } \\
\text { conteúdo no ensino da Língua } \\
\text { Portuguesa. Elaborada em forma de } \\
\text { pesquisa qualitativa, onde foram } \\
\text { analisados os diários e relatórios } \\
\text { avaliativos, nossa reflexão é também } \\
\text { pautada nas entrevistas com as } \\
\text { professoras de uma Escola Pública da } \\
\text { Rede Municipal, onde a mesma se } \\
\text { efetivou." }\end{array}$ & Não \\
\hline & $\begin{array}{l}\text { Educação } \\
\text { Básica }\end{array}$ & $\begin{array}{l}\text { IES } \\
\text { Particular/SP }\end{array}$ & $\begin{array}{l}\text { "Um dos objetivos gerais do ensino de } \\
\text { língua portuguesa é desenvolver no } \\
\text { educando habilidades para comunicar-se } \\
\text { eficazmente dentro do seu grupo social. }\end{array}$ & Não \\
\hline
\end{tabular}




\begin{tabular}{|c|c|c|c|}
\hline & & $\begin{array}{l}\text { Tendo isso em mente, este trabalho } \\
\text { partirá de princípios capazes de oferecer } \\
\text { respostas à seguinte pergunta: Será que } \\
\text { as pessoas que freqüentam os bancos } \\
\text { escolares apresentam de fato uma } \\
\text { desenvoltura de linguagem que lhes } \\
\text { possibilite uma leitura adequada às mais } \\
\text { variadas situações de sua vida? [...] } \\
\text { nossa proposta centra-se na idéia de que } \\
\text { diversidade textual configurada nos } \\
\text { textos literários, informativos, práticos e } \\
\text { extraverbais proporciona ao aluno acesso } \\
\text { seguro pra desenvolver a sua capacidade } \\
\text { de comunicação. Nesse sentido, } \\
\text { apresentaremos sugestões relativas à } \\
\text { maneira como esses textos podem ser } \\
\text { trabalhados." }\end{array}$ & \\
\hline $\begin{array}{l}\text { Educação } \\
\text { Básica }\end{array}$ & $\begin{array}{l}\text { IES } \\
\text { Particular/SP }\end{array}$ & $\begin{array}{l}\text { "[...] É função da escola ensinar a } \\
\text { modalidade culta da língua materna, mas } \\
\text { esse ensino pressupõe o reconhecimento } \\
\text { e a aceitação da existência de diversas } \\
\text { modalidades lingüísticas e, } \\
\text { conseqüentemente, a recusa da } \\
\text { exclusividade de um dialeto padrão } \\
\text { legitimado por convenções sociais. Todo } \\
\text { o aluno traz consigo um patrimônio } \\
\text { lingüístico interiorizado que a escola não } \\
\text { pode desconsiderar. Assim, o aluno não } \\
\text { substitui o seu dialeto, mas acrescenta a } \\
\text { ele novas formas de expressão, torna-se } \\
\text { capaz de optar pela modalidade } \\
\text { lingüística mais adequada a determinada } \\
\text { situação comunicativa e faz uso da } \\
\text { língua materna de modo consciente e } \\
\text { significativo. Este trabalho realiza uma } \\
\text { reflexão sobre o ensino da língua } \\
\text { portuguesa em sua modalidade culta e } \\
\text { descreve uma experiência de prática } \\
\text { docente articulada ao universo do aluno, } \\
\text { para que ele se aproprie da língua, não } \\
\text { só como instrumento de comunicação, } \\
\text { mas também como elemento vivo de um } \\
\text { processo histórico-cultural que assegure } \\
\text { aos homens uma consciência crítica } \\
\text { necessária para sua ação-reflexão } \\
\text { (práxis) no mundo." }\end{array}$ & Não \\
\hline $\begin{array}{l}\text { Educação } \\
\text { Superior }\end{array}$ & $\begin{array}{l}\text { IES } \\
\text { Estadual/PR }\end{array}$ & $\begin{array}{l}\text { "Neste trabalho procuramos fazer uma } \\
\text { reflexão sobre a formação dos } \\
\text { acadêmicos dos Cursos de Letras } \\
\text { Português-Literatura e Português-Inglês } \\
\text { da Universidade Estadual do Centro- } \\
\text { Oeste, UNICENTRO, no Paraná, no que } \\
\text { se refere às suas competências para } \\
\text { atuarem no ensino de língua materna, e, } \\
\text { de forma mais específica, no ensino da } \\
\text { leitura. [...] Numa tentativa de detectar } \\
\text { aspectos problemáticos que podem } \\
\text { interferir negativamente no } \\
\text { desenvolvimento das habilidades de } \\
\text { compreensão da leitura e, } \\
\text { conseqüentemente, na formação do } \\
\text { leitor, tomamos como objeto de análise } \\
\text { os seguintes registros: a) planos de aula } \\
\text { elaborados por esses acadêmicos, b) } \\
\text { entrevistas com professores e c) } \\
\text { relatórios apresentados pelos acadêmicos } \\
\text { na disciplina de } \text { Estágio }\end{array}$ & $\mathrm{Sim}$ \\
\hline
\end{tabular}




\begin{tabular}{|c|c|c|c|}
\hline & & Supervisionado." & \\
\hline $\begin{array}{l}\text { Educação } \\
\text { Superior }\end{array}$ & $\begin{array}{l}\text { IES } \\
\text { Estadual/PR }\end{array}$ & $\begin{array}{l}\text { "O tema deste trabalho é a leitura no } \\
\text { Ensino Superior, com enfoque na análise } \\
\text { da disciplina de Prática de Ensino de } \\
\text { Língua Portuguesa, do curso de Letras, } \\
\text { da Universidade Estadual de Maringá, } \\
\text { mediante observação de teorias e } \\
\text { práticas de leitura arroladas nos } \\
\text { relatórios dos estágios supervisionados." }\end{array}$ & Sim \\
\hline $\begin{array}{l}\text { Educação } \\
\text { Superior }\end{array}$ & $\begin{array}{l}\text { IES } \\
\text { Estadual/PR }\end{array}$ & $\begin{array}{l}\text { "Esta dissertação analisou os aspectos } \\
\text { relacionados à coesão e coerência } \\
\text { textuais e à informatividade, empregados } \\
\text { (in)adequadamente em r textos } \\
\text { dissertativos dos alunos formandos do } 4^{\circ} \\
\text { ano de Letras de uma instituição pública } \\
\text { de ensino do Paraná, do ano de } 2001 \text {, } \\
\text { buscando-se conhecer se possuem a } \\
\text { habilidade necessária na articulação do } \\
\text { discurso escrito, para que possa, } \\
\text { ingressar na vida profissional sabendo } \\
\text { como irão trabalhar e avaliar as } \\
\text { produções textuais de seus futuros } \\
\text { alunos." }\end{array}$ & Não \\
\hline $\begin{array}{l}\text { Ensino } \\
\text { Fundamental }\end{array}$ & $\begin{array}{l}\text { IES } \\
\text { Federal/MG }\end{array}$ & $\begin{array}{l}\text { "Esta dissertação relata pesquisa que } \\
\text { visou a analisar o desenvolvimento } \\
\text { lingüístico-discursivo insatisfatório dos } \\
\text { alunos do ensino fundamental na escola } \\
\text { pública, relacionando-o às mediações de } \\
\text { reprodução e de mudança que se } \\
\text { encontram presentes no processo de } \\
\text { ensino-aprendizagem de Língua } \\
\text { Portuguesa. Trata-se da realização de } \\
\text { uma leitura investigativa de textos e } \\
\text { unidades de ensino elaborados por } \\
\text { professores e também do texto dos } \\
\text { Parâmetros Curriculares Nacionais de } \\
\text { Língua Portuguesa no intuito de se } \\
\text { captarem, nesses instrumentos, os fatores } \\
\text { que direcionam a prática pedagógica } \\
\text { desses profissionais de forma a } \\
\text { reproduzir antigas práticas, através do } \\
\text { ensino gramatical, ou de forma a } \\
\text { transformar as práticas tradicionais, } \\
\text { tendo em vista a ampliação do } \\
\text { conhecimento lingüístico-discursivo dos } \\
\text { alunos." }\end{array}$ & Não \\
\hline $\begin{array}{l}\text { Ensino } \\
\text { Fundamental }\end{array}$ & $\begin{array}{l}\text { IES } \\
\text { Particular/SP }\end{array}$ & $\begin{array}{l}\text { "[Reflexões sobre a (re)significação das } \\
\text { aulas de português no Ensino } \\
\text { Fundamental] [...] tem por objetivo } \\
\text { auxiliar o professor no ensino da língua } \\
\text { portuguesa. Apresentam-se, para tanto, } \\
\text { conceitos de linguagem, língua, } \\
\text { gramática e texto que podem contribuir } \\
\text { com uma prática mais significativa. Não } \\
\text { se trata de uma proposta de ensino, mas } \\
\text { de reflexões sobre a prática em } \\
\text { Português." }\end{array}$ & Não \\
\hline $\begin{array}{l}\text { Ensino } \\
\text { Fundamental } \\
\text { I }\end{array}$ & $\begin{array}{l}\text { IES } \\
\text { Federal/MG }\end{array}$ & $\begin{array}{l}\text { "O presente trabalho teve por objetivo } \\
\text { investigar como um grupo de } \\
\text { professores do segundo ciclo do Ensino } \\
\text { Fundamental da Rede Municipal de Juiz } \\
\text { de Fora- MG compreende a proposta de } \\
\text { gêneros discursivos presente nos PCNs } \\
\text { de Lingua Portuguesa e no Projeto } \\
\text { Caminho Novo - Caderno } 2 \text { e a coloca } \\
\text { em prática no seu trabalho pedagógico." }\end{array}$ & Não \\
\hline Ensino & IES Federal/PE & "Esta pesquisa teve o propósito de & Não \\
\hline
\end{tabular}




\begin{tabular}{|c|c|c|c|}
\hline $\begin{array}{l}\text { Fundamental } \\
\text { I }\end{array}$ & & 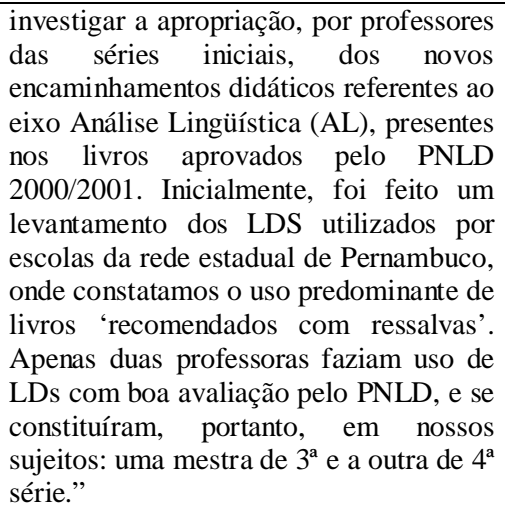 & \\
\hline $\begin{array}{l}\text { Ensino } \\
\text { Fundamental } \\
\text { I }\end{array}$ & $\begin{array}{l}\text { IES Particular/ } \\
\text { MG }\end{array}$ & $\begin{array}{l}\text { "Este trabalho descreve } 0 \\
\text { desenvolvimento de um projeto de } \\
\text { intervenção na prática de leitura dos } \\
\text { alunos do terceiro ano do Ciclo Básico, } \\
\text { com a participação dos pais. O objetivo } \\
\text { foi de demonstrar como a técnica da } \\
\text { 'leitura Conjunta' de Topping (1989) } \\
\text { pode auxiliar os alunos com dificuldades } \\
\text { na leitura e escrita no ensino da Língua } \\
\text { Portuguesa." }\end{array}$ & Sim \\
\hline $\begin{array}{l}\text { Ensino } \\
\text { Fundamental } \\
\text { II }\end{array}$ & $\begin{array}{l}\text { IES } \\
\text { Estadual/SP }\end{array}$ & $\begin{array}{l}\text { "Este estudo teve como objetivo } \\
\text { investigar, por meio de uma pesquisa } \\
\text { qualitativa, ou mais especificamente de } \\
\text { um estudo de caso, o modo como um } \\
\text { professor de língua portuguesa, de uma } \\
\text { escola pública, trabalha com a } \\
\text { linguagem oral de uma } 5^{\text {a }} \text { série do } \\
\text { Ensino Fundamental." }\end{array}$ & Não \\
\hline $\begin{array}{l}\text { Ensino } \\
\text { Fundamental } \\
\text { II }\end{array}$ & IES Federal/SC & $\begin{array}{l}\text { "Com o intuito de contribuir para a } \\
\text { melhoria do ensino da Língua } \\
\text { Portuguesa, desenvolvi nesta pesquisa de } \\
\text { mestrado a proposta de trabalhar gêneros } \\
\text { do discurso em sala de aula no ensino } \\
\text { fundamental, procurando estabelecer } \\
\text { uma ponte entre as teorias de } \\
\text { ensino/aprendizagem - Bakhtin e } \\
\text { Vygotsky - e as possibilidades de } \\
\text { prática. Por meio de intervenção } \\
\text { colaborativa, metodologia que permite } \\
\text { uma participação maior do pesquisador } \\
\text { com relação ao objeto pesquisado, } \\
\text { investiguei o processo de produção } \\
\text { escrita de gêneros do discurso numa 5a } \\
\text { série do Colégio de Aplicação da } \\
\text { Universidade Federal de Santa } \\
\text { Catarina." }\end{array}$ & Sim \\
\hline $\begin{array}{l}\text { Ensino } \\
\text { Fundamental } \\
\text { II }\end{array}$ & $\begin{array}{l}\text { IES Particular/ } \\
\text { MG }\end{array}$ & $\begin{array}{l}\text { "Neste trabalho procurei investigar o } \\
\text { papel da (não) - construção da leitura e } \\
\text { as causas da repetência escolar. O foco } \\
\text { da pesquisa está voltado para a } 5^{\text {a }} \text { série } \\
\text { do ensino fundamental, por ser a série } \\
\text { considerada o segundo gargalo do } \\
\text { ensino. O objetivo foi demonstrar como } \\
\text { o trabalho com a Língua Portuguesa na } \\
\text { sala de aula é ineficaz na condução do } \\
\text { aluno a um amplo domínio da língua na } \\
\text { sua modalidade oral e escrita, } \\
\text { contribuindo assim para o fracasso } \\
\text { escolar dos estudantes provenientes de } \\
\text { todas as camadas sociais." }\end{array}$ & Sim \\
\hline Ensino & IES & $\begin{array}{l}\text { "Este trabalho tem como objetivo } \\
\text { estudar as vozes discursivas envolvidas }\end{array}$ & Sim \\
\hline
\end{tabular}




\begin{tabular}{|c|c|c|c|}
\hline $\begin{array}{l}\text { Fundamental } \\
\text { II }\end{array}$ & Particular/RJ & $\begin{array}{l}\text { no ensino de gramática da língua } \\
\text { portuguesa no contexto escolar: a voz do } \\
\text { sistema educacional, de instituições } \\
\text { escolares, de professores, de alunos e da } \\
\text { família. [...] O corpus principal da } \\
\text { pesquisa compóe-se de dados do } \\
\text { discurso oral, tendo sido gravadas e } \\
\text { transcritas } 52 \text { entrevistas, com } \\
\text { professoras, alunos e mães de alunos de } \\
5 \text { a a 8a série de duas escolas, uma } \\
\text { particular e outra municipal. Uma vice- } \\
\text { diretora e uma coordenadora foram } \\
\text { entrevistadas, representando as duas } \\
\text { escolas." }\end{array}$ & \\
\hline $\begin{array}{l}\text { Ensino } \\
\text { Médio }\end{array}$ & IES Federal/PB & $\begin{array}{l}\text { "Compreendendo que há uma crise no } \\
\text { ensino de língua portuguesa, língua } \\
\text { materna do Brasil, decorrente, } \\
\text { principalmente, da falta de revisão dos } \\
\text { conteúdos e de metodologias de ensino, } \\
\text { nesta pesquisa, buscamos demonstrar } \\
\text { que vincular práticas de escrita na escola } \\
\text { a práticas cotidianas do aluno garante } \\
\text { melhoras no ensino/aprendizagem de } \\
\text { escrita e no ensino de língua, por } \\
\text { conseguinte. [...] realizamos um trabalho } \\
\text { de intervenção junto a uma turma de 1a } \\
\text { série do ensino médio, na qual } \\
\text { desenvolvemos uma metodologia de } \\
\text { ensino de escrita com bases no estudo de } \\
\text { temas ( meio ambiente e amor) e de } \\
\text { gêneros de textos (notícia, entrevista e } \\
\text { texto de opinião)." }\end{array}$ & Não \\
\hline $\begin{array}{l}\text { Exame de } \\
\text { Proficiência } \\
\text { em Língua } \\
\text { Portuguesa } \\
\text { para } \\
\text { Estrangeiros }\end{array}$ & IES Federal/RJ & $\begin{array}{l}\text { "Estudo do ensino de língua portuguesa } \\
\text { para estrangeiros a fim de prepará-los } \\
\text { para os exames de proficiência do } \\
\text { CELPE-Bras (Certificado de } \\
\text { Proficiência em Língua Portuguesa para } \\
\text { Estrangeiros), instituído na década de } \\
90 \text {, pelo Ministério da Educação e } \\
\text { Cultura. É destacada e analisada em } \\
\text { especial a tarefa IV desse exame, a qual } \\
\text { consiste na verificação da habilidade de } \\
\text { leitura, compreensão e elaboração de } \\
\text { textos pelos candidatos, a partir de } \\
\text { matéria jornalística publicada } \\
\text { principalmente na grande imprensa." }\end{array}$ & Não \\
\hline Indefinido & $\begin{array}{l}\text { IES } \\
\text { Particular/RS }\end{array}$ & $\begin{array}{l}\text { "Modernidade e suas características; } \\
\text { desenvolvimento capitalista alicerçado } \\
\text { no racionalismo econômico, resultando } \\
\text { em um 'desenvolvimentismo' } \\
\text { marginalizador da maioria da população } \\
\text { dentro de seus próprios países e na } \\
\text { marginalização de países } \\
\text { subdesenvolvidos em relação aos mais } \\
\text { desenvolvidos; implicações desses } \\
\text { processos no desenvolvimento sócio- } \\
\text { cultural de municípios da Região do } \\
\text { Vale do Rio Pardo (Sinimbu, Vale do } \\
\text { Sol); possibilidade de se pensar e/ou } \\
\text { planejar o desenvolvimento regional a } \\
\text { partir de uma leitura crítica preliminar de } \\
\text { sua realidade. [...] Vislumbrou-se nas } \\
\text { áreas da linguagem e da educação } \\
\text { caminhos possíveis para buscar uma } \\
\text { maior e melhor compreensão dos } \\
\text { processos de desenvolvimento sócio- } \\
\text { cultural do mundo e, mais }\end{array}$ & Não \\
\hline
\end{tabular}




\begin{tabular}{|c|c|c|c|c|}
\hline & & & $\begin{array}{l}\text { especificamente desta região. Chegou-se } \\
\text { à conclusão de que, sem a leitura crítica } \\
\text { da atual realidade sócio-cultural, fica } \\
\text { difícil mudá-la para melhor, e que o } \\
\text { ensino de língua portuguesa, desde que } \\
\text { promova a formação de leitores e } \\
\text { "escritores' críticos, pode contribuir em } \\
\text { muito para a promoção de } \\
\text { transformações sociais em prol de uma } \\
\text { melhor vida para todos". }\end{array}$ & \\
\hline & Indefinido & $\begin{array}{l}\text { IES } \\
\text { Particular/RJ }\end{array}$ & $\begin{array}{l}\text { "O estudo do Sujeito é de extrema } \\
\text { importância na prática pedagógica do } \\
\text { ensino da Língua Portuguesa. Muitas } \\
\text { questões têm sido levantadas sobre a } \\
\text { impropriedade com que as definições se } \\
\text { aplicam aos exemplos e exercícios das } \\
\text { gramáticas escolares. Nessa dissertação } \\
\text { apresentamos uma revisão dessas } \\
\text { definições, estabelecendo comparações } \\
\text { com os exemplos dados nas gramáticas } \\
\text { tradicionais, materiais didáticos e frases } \\
\text { que surgem no uso não-padrão da língua. } \\
\text { Nosso arcabouço teórico é pautado na } \\
\text { abordagem funcionalista, na qual } \\
\text { priorizamos a gramática de valências } \\
\text { que coloca o sujeito gramatical como um } \\
\text { complemento e a gramática sistêmica de } \\
\text { M. A K. Halliday que apresenta o sujeito } \\
\text { desempenhando papéis definidos pelos } \\
\text { verbos." }\end{array}$ & Sim \\
\hline & Mídia & IES Federal/PE & $\begin{array}{l}\text { "Este trabalho analisa as concepções de } \\
\text { língua, de gramática e de norma } \\
\text { lingüística dos programas Programa de } \\
\text { Palavra, Nossa Língua Portuguesa e } \\
\text { Afinando a Língua. [...] nossas análises } \\
\text { constataram que o Programa de Palavra } \\
\text { e o Nossa Língua Portuguesa vêem a } \\
\text { língua como código, a gramática como } \\
\text { um conjunto de regras a serem seguidas } \\
\text { e a norma lingüística como ideal de } \\
\text { língua, sendo o ensino da norma-padrão } \\
\text { o objetivo principal, diferentemente do } \\
\text { Afinando a Língua, que vê a língua, a } \\
\text { gramática e a norma lingüística, } \\
\text { respectivamente, como atividade social } \\
\text { e cognitiva, como a própria língua em } \\
\text { funcionamento e como resultado dos } \\
\text { usos que fazemos da língua, ficando o } \\
\text { ensino de língua destinado ao domínio } \\
\text { da norma-padrão, ao funcionamento da } \\
\text { língua e ao raciocínio científico". }\end{array}$ & Sim \\
\hline otal de & ssertações & & & 21 \\
\hline
\end{tabular}

\begin{tabular}{|c|l|l|l|l|}
\hline $\begin{array}{l}\text { Ano } \\
\text { de } \\
\text { defesa }\end{array}$ & $\begin{array}{l}\text { Contexto } \\
\text { pesquisado }\end{array}$ & $\begin{array}{l}\text { Vínculo } \\
\text { administrativo } \\
\text { /Localização }\end{array}$ & $\begin{array}{l}\text { Transcrição parcial dos } \\
\text { resumos }\end{array}$ & $\begin{array}{l}\text { Disponível } \\
\text { on-line }\end{array}$ \\
\hline 2004 & $\begin{array}{l}\text { Antiga } \\
\text { Educação } \\
\text { Escolar }\end{array}$ & $\begin{array}{l}\text { IES } \\
\text { Particular/SP }\end{array}$ & $\begin{array}{l}\text { "Esta Dissertação apresenta como tema } \\
\text { um estudo histórico-descritivo das } \\
\text { Noções de Grammatica Portugueza de } \\
\text { Pacheco da Silva Junior e Lameira de } \\
\text { Andrade, compêndio produzido no final } \\
\text { do século XIX, com o objetivo de }\end{array}$ & Não \\
\hline
\end{tabular}




\begin{tabular}{|c|c|c|c|}
\hline & & $\begin{array}{l}\text { atender ao Programa Oficial para os } \\
\text { Exames Preparatórios ao Ensino } \\
\text { Superior. Além disso, o documento } \\
\text { selecionado correspondia às exigências } \\
\text { dos Parâmetros Curriculares que } \\
\text { regulamentavam o ensino de língua } \\
\text { portuguesa, àquela época no Brasil.” }\end{array}$ & \\
\hline $\begin{array}{l}\text { Antiga } \\
\text { Educação } \\
\text { Escolar }\end{array}$ & IES Federal/PE & $\begin{array}{l}\text { "Este trabalho buscou reconstruir as } \\
\text { práticas cotidianas do ensino de Língua } \\
\text { Portuguesa no curso secundário, em } \\
\text { Pernambuco, nas décadas de } 40 \text { e } 50 \text { do } \\
\text { século XX. Para isso, foi necessário } \\
\text { conhecer como a Língua Portuguesa se } \\
\text { configurou, historicamente, em uma } \\
\text { disciplina curricular. Apóia-se, teórica e } \\
\text { metodologicamente, nas pesquisas sobre } \\
\text { história oral, história da educação e } \\
\text { história das disciplinas escolares Foram } \\
\text { utilizados, como fontes principais, o } \\
\text { relato oral de ex-alunos e ex-professores, } \\
\text { livros didáticos, revistas pedagógicas, } \\
\text { leis e programas de ensino." }\end{array}$ & Não \\
\hline $\begin{array}{l}\text { Curso } \\
\text { Virtual }\end{array}$ & $\begin{array}{l}\text { IES } \\
\text { Particular/SP }\end{array}$ & $\begin{array}{l}\text { "Este trabalho insere-se nos campos da } \\
\text { Educação a Distância (EaD), da Teoria } \\
\text { da Enunciação e da Lingüística Textual e } \\
\text { consiste no estudo da interação em um } \\
\text { conteúdo didático voltado para um curso } \\
\text { de língua portuguesa via Internet. Nele, } \\
\text { nosso objetivo maior não é apresentar } \\
\text { resultados que possam ser comprovados } \\
\text { em outros contextos, mas observar e } \\
\text { analisar como ocorre a interação em um } \\
\text { ambiente específico, para, assim, } \\
\text { aprimorarmos nossa prática pedagógica } \\
\text { em ambientes virtuais e contribuirmos } \\
\text { com estudos futuros na área de EaD." }\end{array}$ & Não \\
\hline $\begin{array}{l}\text { Educação } \\
\text { Básica }\end{array}$ & $\begin{array}{l}\text { IES } \\
\text { Estadual/SP }\end{array}$ & $\begin{array}{l}\text { "O trabalho de pesquisa em questão } \\
\text { consiste em refletir sobre a implantação } \\
\text { dos documentos oficiais PCLP (Proposta } \\
\text { Curricular de Língua Portuguesa) e } \\
\text { PCNs (Parâmetros Curriculares } \\
\text { Nacionais) lançados pela Secretaria da } \\
\text { Educação do Estado de São Paulo, } \\
\text { atentando para a possível dificuldade de } \\
\text { implantação desses documentos na } \\
\text { escola e para sua aplicabilidade em sala } \\
\text { de aula." }\end{array}$ & Não \\
\hline $\begin{array}{l}\text { Educação } \\
\text { Básica }\end{array}$ & $\begin{array}{l}\text { IES } \\
\text { Estadual/SP }\end{array}$ & $\begin{array}{l}\text { "A fim de contribuir para a compreensão } \\
\text { da história do ensino de língua } \\
\text { portuguesa no Brasil e para a } \\
\text { compreensão da proposta de João } \\
\text { Wanderley Geraldi acerca desse ensino, } \\
\text { são analisados, nesta dissertação, } \\
\text { aspectos da coletânea 'O texto na sala de } \\
\text { aula', organizada por Geraldi e editada } \\
\text { pela ASSOESTE, em 1984, e pela Ática, } \\
\text { em 1997. Foram utilizados, para a } \\
\text { pesquisa de que resultou esta } \\
\text { dissertação, procedimentos de } \\
\text { localização, reunião e ordenação da } \\
\text { bibliografia de João Wanderley Geraldi } \\
\text { e sobre sua obra e atuação profissional, } \\
\text { que viabilizaram a análise da } \\
\text { configuração textual da coletânea O } \\
\text { texto na sala de aula, com ênfase nos } \\
\text { artigos assinados por Geraldi." }\end{array}$ & Não \\
\hline Educação & IES Federal/RS & "Este trabalho objetiva buscar & Não \\
\hline
\end{tabular}




\begin{tabular}{|c|c|c|c|}
\hline Básica & & $\begin{array}{l}\text { aproximações com os imaginários } \\
\text { docentes construídos sobre o ensino da } \\
\text { Língua Portuguesa, nos processos de } \\
\text { formação e na prática pedagógica, } \\
\text { através das histórias de vida de quatro } \\
\text { professoras de escolas públicas." }\end{array}$ & \\
\hline $\begin{array}{l}\text { Educação } \\
\text { Básica }\end{array}$ & $\begin{array}{l}\text { IES } \\
\text { Particular/PR }\end{array}$ & $\begin{array}{l}\text { "O objetivo deste trabalho é verificar os } \\
\text { níveis de proficiência em leitura e } \\
\text { compreensão, desejáveis a um estudante } \\
\text { ao término da Educação Básica, segundo } \\
\text { os programas de avaliação PISA; SAEB } \\
\text { e INAF." [...]Esta dissertação apresenta } \\
\text { um cruzamento entre os níveis de } \\
\text { proficiência dos programas de avaliação } \\
\text { e como estes podem favorecer na } \\
\text { superação da crise instalada no ensino de } \\
\text { Ler e Compreender na Educação Básica. } \\
\text { Propõe-se, também, neste trabalho, uma } \\
\text { pesquisa de análise de conteúdos, } \\
\text { pautada na inferência, possível, dada } \\
\text { pelas respostas de professores, atuantes } \\
\text { na Educação Básica, a respeito do nível } \\
\text { de conhecimento dos mecanismos } \\
\text { avaliadores, dos Parâmetros Curriculares } \\
\text { Nacionais e do que vem a ser um projeto } \\
\text { político-pedagógico, refletido na missão } \\
\text { escolar." }\end{array}$ & Não \\
\hline $\begin{array}{l}\text { Educação } \\
\text { Básica }\end{array}$ & $\begin{array}{l}\text { IES } \\
\text { Particular/SP }\end{array}$ & $\begin{array}{l}\text { "Este estudo tem como objetivo } \\
\text { investigar os elementos que caracterizam } \\
\text { uma imagem e as maneiras como a } \\
\text { imagem pode contribuir para o processo } \\
\text { ensino-aprendizagem da língua } \\
\text { portuguesa. Para isso, serão feitas } \\
\text { análises de signos e códigos usados na } \\
\text { comunicação baseados em estudos sobre } \\
\text { a percepção da imagem e nos conceitos } \\
\text { de símbolos, signo, índice, ícone e } \\
\text { fotografia que também farão parte deste } \\
\text { trabalho. [...] O trabalho se baseia em } \\
\text { materiais discursivos veiculados na } \\
\text { sociedade, acompanhados ou compostos } \\
\text { por imagens, que podem ser aplicados } \\
\text { em sala de aula para a prática do ensino } \\
\text { da língua. O trabalho também se baseia } \\
\text { em experiências cotidianas referentes à } \\
\text { composição discursiva executada por } \\
\text { alunos envolvendo imagem e poderá } \\
\text { interessar tanto a docentes quanto a } \\
\text { produtores de material didático" }\end{array}$ & Não \\
\hline $\begin{array}{l}\text { Educação de } \\
\text { Jovens e } \\
\text { Adultos }\end{array}$ & $\begin{array}{l}\text { IES } \\
\text { Federal/MS }\end{array}$ & $\begin{array}{l}\text { "Este estudo teve como objetivos } \\
\text { conhecer e analisar as concepções } \\
\text { teórico-metodológicas de língua(gem) e } \\
\text { leitura dos professores de Português da } \\
\text { Educação de Jovens e Adultos (EJA), do } \\
\text { Ensino Fundamental, da rede municipal } \\
\text { de Campo Grande/MS. Os sujeitos } \\
\text { colaboradores da pesquisa foram } \\
\text { professores de Língua Portuguesa da } \\
\text { Educação de Jovens e Adultos, de 5a a } \\
\text { 8a séries, do Ensino Fundamental, da } \\
\text { referida rede de ensino." }\end{array}$ & Não \\
\hline $\begin{array}{l}\text { Educação } \\
\text { Profissional } \\
\text { Técnica de } \\
\text { Nível Médio }\end{array}$ & IES Federal/PB & $\begin{array}{l}\text { "Esta dissertação buscou focalizar, } \\
\text { mediante um estudo de caso no Centro } \\
\text { Federal de Educação Tecnológica de } \\
\text { Alagoas, alguns aspectos relevantes } \\
\text { quanto ao uso da variedade padrão da } \\
\text { Língua Portuguesa. O primeiro deles }\end{array}$ & Não \\
\hline
\end{tabular}




\begin{tabular}{|c|c|c|c|}
\hline & & $\begin{array}{l}\text { consistiu na tentativa de definir um } \\
\text { marco referencial para o } \\
\text { desenvolvimento do projeto de pesquisa } \\
\text { que articulasse a visão das condições de } \\
\text { uso da norma culta da língua materna, } \\
\text { pelos alunos dos vários cursos técnicos, } \\
\text { quando da produção escrita dos } \\
\text { relatórios de conclusão de tais cursos. O } \\
\text { segundo compreendeu o estabelecimento } \\
\text { de uma metodologia de pesquisa } \\
\text { documental com abordagem qualitativa } \\
\text { que, mediante a análise de conteúdo, } \\
\text { pesquisasse todo o material selecionado. } \\
\text { Posteriormente, fez algumas pontuações, } \\
\text { tais como: a escola como espaço } \\
\text { aglutinador das variedades lingüísticas; a } \\
\text { formação do professor; o padrão } \\
\text { brasileiro; o preconceito em relação às } \\
\text { variedades lingüísticas usadas pelas } \\
\text { classes populares; a linguagem vista } \\
\text { como dominação simbólica, diálogo e } \\
\text { interação. [...]" }\end{array}$ & \\
\hline $\begin{array}{l}\text { Educação } \\
\text { Profissional } \\
\text { Técnica de } \\
\text { Nível Médio }\end{array}$ & $\begin{array}{l}\text { IES } \\
\text { Particular/RS }\end{array}$ & $\begin{array}{l}\text { "Em minha ação docente, desde que } \\
\text { ingressei na Escola Agrotécnica Federal } \\
\text { de Sertão (EAFS), chamou-me a atenção } \\
\text { a fala de alunos em língua portuguesa, } \\
\text { marcada pela influência de dialetos do } \\
\text { italiano e do alemão. [...] objetivo é } \\
\text { estudar a realidade lingüística dos alunos } \\
\text { da EAFS, buscando identificar a } \\
\text { dimensão do preconceito lingüístico que } \\
\text { paira sobre os que falam a língua } \\
\text { portuguesa fonético-fonologicamente } \\
\text { marcada por influências do italiano e do } \\
\text { alemão. Para tanto, levantei, } \\
\text { inicialmente manifestações } \\
\text { representativas dos sotaques em questão } \\
\text { e dados que configurassem a formação } \\
\text { lingüística dos alunos investigados." }\end{array}$ & Não \\
\hline $\begin{array}{l}\text { Educação } \\
\text { Superior }\end{array}$ & IES Federal/RS & $\begin{array}{l}\text { "Este trabalho estuda como é virar } \\
\text { professora de professoras por meio da } \\
\text { análise de aulas de Português } \\
\text { trabalhadas com alunas do primeiro ano } \\
\text { do Curso Normal durante o período } \\
\text { letivo de 2003, sendo a professora a } \\
\text { própria pesquisadora. A hipótese } \\
\text { analisada é a seguinte: o ensino da } \\
\text { escrita e da leitura como habilidades a } \\
\text { serem desenvolvidas e a serem } \\
\text { processadas ensina Português e ensina a } \\
\text { ensinar Português, ao mesmo tempo em } \\
\text { que valoriza os alunos o o professor nele } \\
\text { envolvidos como produtores de } \\
\text { conhecimento, produzindo a auto-estima } \\
\text { tão necessitada por eles para } \\
\text { empenharem-se no processo de ensino- } \\
\text { aprendizagem?" }\end{array}$ & Sim \\
\hline $\begin{array}{l}\text { Ensino } \\
\text { Fundamental } \\
\text { I }\end{array}$ & IES Federal/ES & 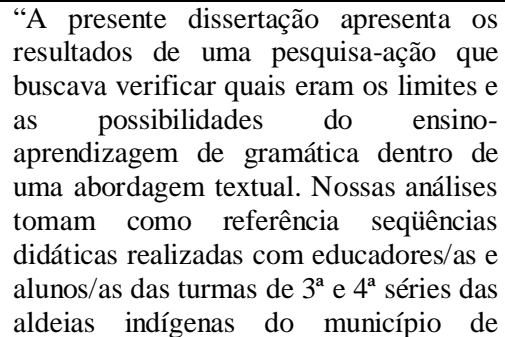 & Não \\
\hline
\end{tabular}




\begin{tabular}{|c|c|c|c|}
\hline & & $\begin{array}{l}\text { Aracruz, litoral norte do Espírito Santo. } \\
\text { [...] Este trabalho permitiu-nos uma } \\
\text { reflexão teórica e metodológica sobre o } \\
\text { ensino de língua portuguesa, } \\
\text { especialmente, sobre as possibilidades } \\
\text { do ensino-aprendizagem de gramática } \\
\text { com textos." }\end{array}$ & \\
\hline $\begin{array}{l}\text { Ensino } \\
\text { Fundamental } \\
\text { II }\end{array}$ & $\begin{array}{l}\text { IES } \\
\text { Estadual/PR }\end{array}$ & $\begin{array}{l}\text { "Esta dissertação investiga as interações } \\
\text { orais que ocorrem em aulas de Língua } \\
\text { Portuguesa após o surgimento dos } \\
\text { Parâmetros Curriculares Nacionais } \\
\text { (PCNs). Para isso, utilizamos a pesquisa } \\
\text { qualitativa, por meio da qual observamos } \\
\text { e gravamos um córpus de vinte aulas em } \\
\text { duas turmas de quinta série do ensino } \\
\text { fundamental: dez em uma turma de } \\
\text { escola pública estadual e outras dez em } \\
\text { uma escola particular. Além disso, } \\
\text { analisamos também os planejamentos } \\
\text { anuais das duas turmas e os } \\
\text { confrontamos com as orientações dos } \\
\text { PCNs acerca do trabalho com oralidade } \\
\text { em sala de aula." }\end{array}$ & Sim \\
\hline $\begin{array}{l}\text { Ensino } \\
\text { Fundamental } \\
\text { II }\end{array}$ & $\begin{array}{l}\text { IES } \\
\text { Federal/MG }\end{array}$ & $\begin{array}{l}\text { "O presente trabalho objetiva analisar as } \\
\text { mudanças e as permanências que os } \\
\text { livros didáticos de Língua Portuguesa de } \\
\text { autoria de Hermínio Sargentim, dos anos } \\
\text { de } 1974 \text { e } 1999 \text {, apresentam em relação } \\
\text { ao ensino da disciplina na } 5 \text { a série do } \\
\text { ensino fundamental. Este autor produziu } \\
\text { livros didáticos por mais de três décadas } \\
\text { na área de Língua Portuguesa para o } \\
\text { Ensino Fundamental e Médio. Esse } \\
\text { tempo de permanência no mercado } \\
\text { editorial garantiu-lhe uma inserção } \\
\text { importante na escola e o levou a } \\
\text { acompanhar e sofrer influências das } \\
\text { mudanças históricas ocorridas na } \\
\text { disciplina escolar de Língua } \\
\text { Portuguesa." }\end{array}$ & Não \\
\hline $\begin{array}{l}\text { Ensino } \\
\text { Fundamental } \\
\text { II }\end{array}$ & IES Federal/PE & $\begin{array}{l}\text { "O presente trabalho de pesquisa situa-se } \\
\text { entre os avanços da Ciência Lingüística, } \\
\text { as dificuldades no ensino de línguas e a } \\
\text { tentativa de modernização da escola pelo } \\
\text { aparato tecnológico do computador. } \\
\text { Enfoca os softwares educativos como } \\
\text { um construto social novo, oriundo das } \\
\text { transformações tecnológicas. Revela, } \\
\text { através do discurso e da mídia, a forma } \\
\text { de inserção e apresentação que a } \\
\text { sociedade faz desse objeto. Tem por } \\
\text { objetivo primeiro contribuir com o } \\
\text { ensino de Língua Portuguesa à medida } \\
\text { que deita o olhar sobre os 'software } \\
\text { educativos', objeto pedagógico ainda } \\
\text { pouco explorado pela maioria das } \\
\text { escolas de ensino fundamental e médio. } \\
\text { Para tanto, foram pesquisados os } \\
\text { software destinados ao trabalho com a } \\
\text { língua portuguesa - Creative Writer, Fine } \\
\text { Artist, Quadrinhos Turma do Chico } \\
\text { Bento, Revistinha do Senninha, Story } \\
\text { Book Weaver, My Own Stories, Oficina } \\
\text { de Histórias Ortografando, Ortografando } \\
\text { II, Quero Aprender Portiguês - Fábrica } \\
\text { de Palavras, Escrevendo ao pé da Letra, } \\
\text { Professor PC - Curso de Portiguês, }\end{array}$ & Não \\
\hline
\end{tabular}




\begin{tabular}{|c|c|c|c|}
\hline & & $\begin{array}{l}\text { Desafio da Língua Portuguesa e } \\
\text { Objetivo Educação Digital -, no ensino } \\
\text { fundamental II das escolas públicas e } \\
\text { particulares da cidade de Petrolina - PE." }\end{array}$ & \\
\hline $\begin{array}{l}\text { Ensino } \\
\text { Fundamental } \\
\text { II }\end{array}$ & IES Federal/PR & $\begin{array}{l}\text { "Este trabalho discute os Parâmetros } \\
\text { Curriculares de Língua Portuguesa, em } \\
\text { especial, o documento voltado ao } 3^{\circ} \text {. e } \\
4^{\circ} \text {. ciclos do Ensino Fundamental }\left(5^{\mathrm{a}} \text { a } 8^{\mathrm{a}}\right. \\
\text { série). O foco da dissertação é entender } \\
\text { criticamente como se deu a apropriação } \\
\text { de alguns conceitos sobre concepção de } \\
\text { linguagem, supostamente baseados no } \\
\text { teórico russo M. Bakhtin, e, sobretudo, a } \\
\text { partir de quais pressupostos o texto } \\
\text { oficial define os gêneros do discurso } \\
\text { como objeto do ensino de Língua } \\
\text { Portuguesa." }\end{array}$ & Não \\
\hline $\begin{array}{l}\text { Ensino } \\
\text { Fundamental } \\
\text { II }\end{array}$ & $\begin{array}{l}\text { IES Particular/ } \\
\text { GO }\end{array}$ & $\begin{array}{l}\text { "[...] As escolas organizadas em ciclos } \\
\text { propõem romper com essas duas lógicas } \\
\text { que sustentam a escola seriada, o modelo } \\
\text { de avaliação e a organização disciplinar, } \\
\text { esta última seria substituída por uma } \\
\text { organização interdisciplinar ou } \\
\text { transdisciplinar. Entretanto, o que se } \\
\text { pôde constatar nessa pesquisa foi uma } \\
\text { acentuada preocupação com o ensino da } \\
\text { Língua Portuguesa. Apesar disso, na } \\
\text { avaliação dos professores, as } \\
\text { dificuldades com a língua escrita } \\
\text { continuam sendo o problema maior dos } \\
\text { alunos. Partindo dessa contradição, esta } \\
\text { pesquisa, que tem como tema o ensino } \\
\text { de Língua Portuguesa nas escolas } \\
\text { organizadas por ciclos, busca responder } \\
\text { às seguintes questões: Como está sendo } \\
\text { trabalhado o ensino de Língua } \\
\text { Portuguesa, no terceiro período do ciclo } \\
\text { II, na Rede Municipal de Ensino de } \\
\text { Goiânia? Que concepção de linguagem } \\
\text { orienta o ensino da disciplina, nessa } \\
\text { etapa de escolarização? Que mudanças } \\
\text { essa forma de organização escolar trouxe } \\
\text { para o ensino da língua materna nessas } \\
\text { escolas?" }\end{array}$ & Sim \\
\hline $\begin{array}{l}\text { Grupo de } \\
\text { Estudo para } \\
\text { Formação } \\
\text { Continuada }\end{array}$ & $\begin{array}{l}\text { IES } \\
\text { Estadual/SP }\end{array}$ & $\begin{array}{l}\text { "Nesse trabalho será abordado um relato } \\
\text { e uma análise da constituição e das } \\
\text { atividades desenvolvidas por um grupo } \\
\text { de estudos, sem fins lucrativos, criado } \\
\text { em Santa Bárbara D`Oete /SP, } \\
\text { denominado Reuniões para Estudos de } \\
\text { Ensino de Língua Portuguesa. [...] Por } \\
\text { meio de entrevistas com os membros da } \\
\text { diretoria do grupo e com algumas } \\
\text { professoras que mais participaram das } \\
\text { atividades reconstituímos uma versão do } \\
\text { que foi esse projeto de autoformação } \\
\text { continuada." }\end{array}$ & Sim \\
\hline Indefinido & $\begin{array}{l}\text { IES } \\
\text { Estadual/RJ }\end{array}$ & $\begin{array}{l}\text { "Este dissertação desenvolve a análise } \\
\text { semiótico-lingüístico-discursiva de } \\
\text { textos publicitários impressos que } \\
\text { trazem a mulher como protagonista, e } \\
\text { que são veiculados por revistas de boa } \\
\text { circulação. O objetivo é verificar como a } \\
\text { publicidade, mediante o diálogo entre as } \\
\text { linguagens verbal e não-verbal, e } \\
\text { valendo-se de recursos estético- } \\
\text { persuasivos, efetiva a transferência de }\end{array}$ & Não \\
\hline
\end{tabular}




\begin{tabular}{|c|c|c|c|}
\hline & & $\begin{array}{l}\text { significações dos produtos que promove } \\
\text { para a figura feminina posta em cena e, } \\
\text { assim, constrói o sentido de reificação da } \\
\text { mulher [...] O debate evidencia que os } \\
\text { textos publicitários podem construir } \\
\text { ótimo material para subsidiar o ensino de } \\
\text { língua portuguesa, para que se forme um } \\
\text { leitor crítico, que reconheça o texto } \\
\text { como o diálogo entre o verbal e o não- } \\
\text { verbal, reiterando a importância do } \\
\text { domínio verbal, sem, contudo, } \\
\text { minimizar a do não-verbal." }\end{array}$ & \\
\hline Indefinido & IES Federal/RJ & $\begin{array}{l}\text { "Esta dissertação desenvolve uma } \\
\text { análise dos fatores pragmáticos da } \\
\text { textualidade em dez letras de canções de } \\
\text { Caetano Veloso, a saber: Alegria, } \\
\text { alegria; Tropicália; Não identificado; } \\
\text { Um índio; Terra; Trem das cores; Luz do } \\
\text { Sol; Você é linda; O quereres e Livros } \\
\text { [...]. Este trabalho tem por objetivo } \\
\text { levantar os procedimentos textuais mais } \\
\text { utilizados pelo compositor e por meio } \\
\text { dos quais se constrói um sentido para o } \\
\text { texto. Além disso, ressalta as vantagens } \\
\text { da utilização do gênero canção popular } \\
\text { no ensino da Língua Portuguesa, } \\
\text { considerando que associa a linguagem } \\
\text { verbal à musical (rítmica e melódica), o } \\
\text { que torna o ensino atrativo e dinâmico, } \\
\text { auxiliando, assim, o aprendizado." }\end{array}$ & Não \\
\hline Indefinido & $\begin{array}{l}\text { IES Municipal/ } \\
\text { SC }\end{array}$ & $\begin{array}{l}\text { "Esta pesquisa situada na área do } \\
\text { discurso e da educação, analisa um } \\
\text { corpus formado pelas doze produções } \\
\text { /pesquisas, cuja abordagem temática é a } \\
\text { leitura, apresentadas ao/no GT } \\
\text { Alfabetização, Leitura, Escrita por } \\
\text { ocasião das 24ª/2001 e } 25^{\mathrm{a}} / 2002 \\
\text { reuniões da ANPED (Associação } \\
\text { Nacional de Pesquisa em Educação). } \\
\text { Neste contexto, esta pesquisa teve por } \\
\text { objetivo geral verificar que aspectos } \\
\text { estão sendo privilegiados e quais estão } \\
\text { deixando de ser abordados nas pesquisas } \\
\text { sobre leitura. [...]através da análise de } \\
\text { fragmentos pinçados das pesquisas, } \\
\text { ampliar as compreensões e desvelar mais } \\
\text { a respeito das diferentes categorizações } \\
\text { estabelecidas e suas implicações no } \\
\text { ensino aprendizagem da leitura. [...]" }\end{array}$ & Não \\
\hline Indefinido & $\begin{array}{l}\text { IES } \\
\text { Estadual/SP }\end{array}$ & $\begin{array}{l}\text { "Os livros paradidáticos têm se } \\
\text { constituído como uma produção bastante } \\
\text { rendosa no mercado editorial nos } \\
\text { últimos } 30 \text { anos, havendo se tornado } \\
\text { objeto de estudos acadêmicos desde a } \\
\text { década de 1980. O presente trabalho } \\
\text { pretende analisar a Coleção Currupaco, } \\
\text { da Editora Scipione, como um } \\
\text { paradidático que aborda explicitamente } \\
\text { um conteúdo curricular de Língua } \\
\text { Portuguesa, objeto ainda não investigado } \\
\text { no campo das produções culturais } \\
\text { impressas para crianças no universo } \\
\text { escolar. Através do estudo da Coleção } \\
\text { Currupaco, tentamos responder às } \\
\text { seguintes questões: que fórmula editorial } \\
\text { é esta denominada paradidático de } \\
\text { Língua Portuguesa e que tematiza um }\end{array}$ & Sim \\
\hline
\end{tabular}




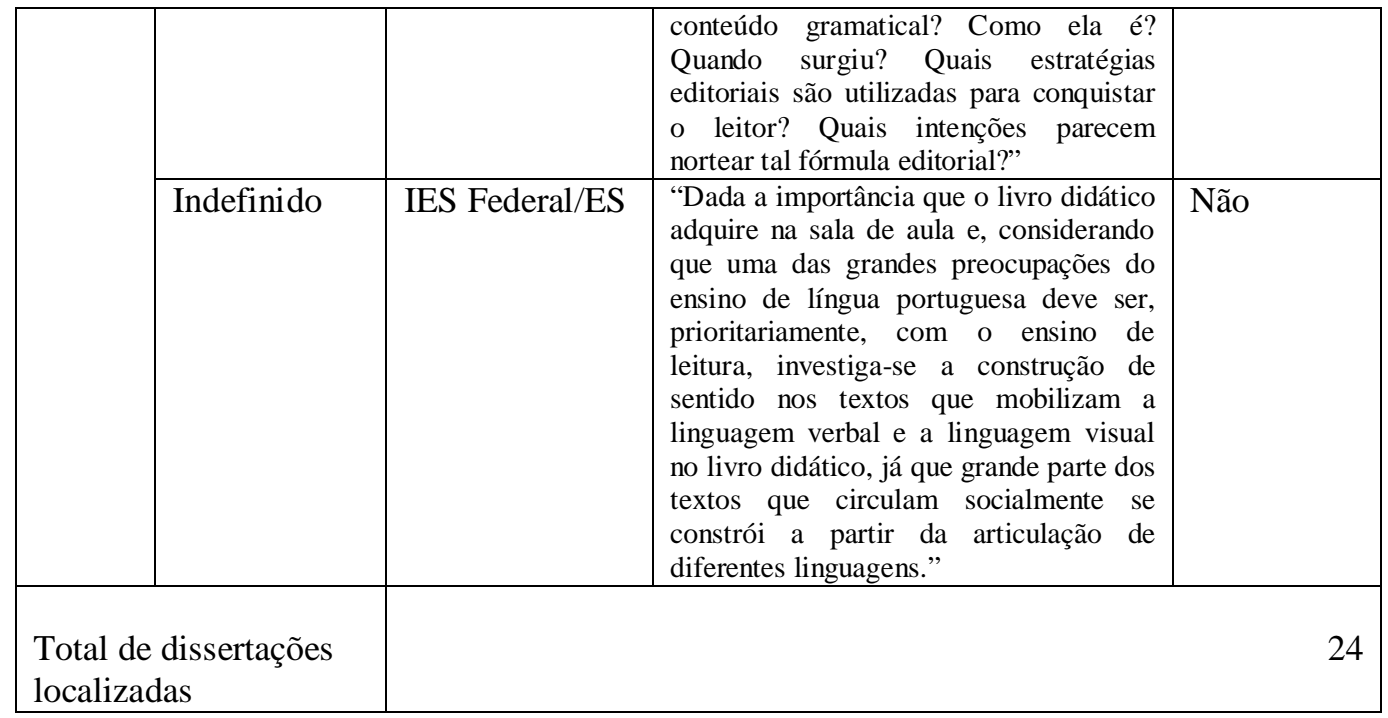

\begin{tabular}{|c|c|c|c|c|}
\hline $\begin{array}{l}\text { Ano } \\
\text { de } \\
\text { defesa }\end{array}$ & $\begin{array}{l}\text { Contexto } \\
\text { pesquisado }\end{array}$ & $\begin{array}{l}\text { Vínculo } \\
\text { administrativo } \\
\text { /Localização }\end{array}$ & $\begin{array}{l}\text { Transcrição parcial dos } \\
\text { resumos }\end{array}$ & $\begin{array}{l}\text { Disponível } \\
\text { on-line }\end{array}$ \\
\hline \multirow[t]{3}{*}{2005} & $\begin{array}{l}\text { Antiga } \\
\text { Educação } \\
\text { Escolar }\end{array}$ & $\begin{array}{l}\text { IES } \\
\text { Particular/SP }\end{array}$ & $\begin{array}{l}\text { "Esta dissertação, cuja finalidade é } \\
\text { contribuir para a compreensão da } \\
\text { história do ensino da Língua Portuguesa } \\
\text { no Brasil, é o resultado do estudo de três } \\
\text { edições do livro Flor do Lácio, de } \\
\text { Cleófano Lopes de Oliveira, publicadas } \\
\text { em } 1953 \text {, } 1958 \text { e } 1969 \text {. Na pesquisa de } \\
\text { que se originou esta dissertação, os } \\
\text { procedimentos de localização re reunião } \\
\text { foram utilizados para possibilitar a a } \\
\text { análise da configuração textual da obra. } \\
\text { Consideraram-se os objetivos do autor } \\
\text { do livro, a organização e apresentação de } \\
\text { suas propostas para as aulas de } \\
\text { Português nas décadas de } 1950 / 60 \text { e a } \\
\text { legislação da época para o referido } \\
\text { ensino." }\end{array}$ & Não \\
\hline & $\begin{array}{l}\text { Antiga } \\
\text { Educação } \\
\text { Escolar }\end{array}$ & $\begin{array}{l}\text { IES } \\
\text { Particular/SP }\end{array}$ & $\begin{array}{l}\text { "Este trabalho }[. . .] \text { aborda o processo de } \\
\text { implementação do ensino da Língua } \\
\text { Portuguesa no Maranhão, local em que, } \\
\text { na segunda metade do século XIX, } \\
\text { surgem em território nacional gramáticas } \\
\text { que impulsionam o processo de } \\
\text { gramatização. Seus autores, professores } \\
\text { militantes nos principais colégios da } \\
\text { época, pretendiam contribuir para a } \\
\text { cientificidade dos estudos gramaticais. } \\
\text { Considerando tais gramáticas, pudemos } \\
\text { traçar o percurso historiográfico do } \\
\text { ensino de Língua Portuguesa no } \\
\text { Maranhão, na segunda metade do século } \\
\text { XIX." }\end{array}$ & Não \\
\hline & $\begin{array}{l}\text { Antiga } \\
\text { Educação } \\
\text { Escolar }\end{array}$ & $\begin{array}{l}\text { IES } \\
\text { Particular/SP }\end{array}$ & $\begin{array}{l}\text { "Esta dissertação fundamentada na } \\
\text { História das Idéias Lingüísticas estuda } \\
\text { como a cultura nacional e as diferenças } \\
\text { da Língua Portuguesa no Brasil foram } \\
\text { absorvidas pela escola brasileira da } \\
\text { República Velha. Para fazê-lo analisa os } \\
\text { Programas de Ensino do Colégio de }\end{array}$ & Não \\
\hline
\end{tabular}




\begin{tabular}{|c|c|c|c|}
\hline & & $\begin{array}{l}\text { Pedro II, a Antologia Nacional de Fausto } \\
\text { Barreto e Carlos de Laet, a História da } \\
\text { Literatura Brasileira de Sílvio Romero e } \\
\text { a Gramática Portuguesa de Júlio Ribeiro, } \\
\text { a fim de conhecer e interpretar os } \\
\text { caminhos seguidos pelo ensino de } \\
\text { Língua Portuguesa e de leitura, suas } \\
\text { dificuldades e seu relacionamento com a } \\
\text { cultura brasileira." }\end{array}$ & \\
\hline $\begin{array}{l}\text { Contexto } \\
\text { Bilíngue }\end{array}$ & $\begin{array}{l}\text { IES } \\
\text { Estadual/PR }\end{array}$ & $\begin{array}{l}\text { "Este trabalho procura abordar a questão } \\
\text { da educação escolar indígena na Escola } \\
\text { Cacique Salvador Venhy e na Escola } \\
\text { Cacique Gregório Kaekchot localizadas } \\
\text { na Terra Indígena do Ivaí, município de } \\
\text { Manoel Ribas. Para abordar esta } \\
\text { questão, temos, como ponto de partida, o } \\
\text { ensino da língua portuguesa em ambas } \\
\text { as escolas." }\end{array}$ & Sim \\
\hline $\begin{array}{l}\text { Contexto } \\
\text { Bilíngue }\end{array}$ & $\begin{array}{l}\text { IES } \\
\text { Particular/RJ }\end{array}$ & $\begin{array}{l}\text { "O objetivo desta pesquisa é descrever } \\
\text { como os brasileiros realizam o ato de } \\
\text { agradecer no português do Brasil, de } \\
\text { forma a apresentar uma contribuição } \\
\text { para a descrição do português como } \\
\text { língua materna com aplicabilidade no } \\
\text { português como segunda língua (PL2) e, } \\
\text { assim, dar subsídios aos professores que } \\
\text { se dedicam à tarefa de ensinar a língua } \\
\text { portuguesa a alunos estrangeiros." }\end{array}$ & Sim \\
\hline $\begin{array}{l}\text { Educação } \\
\text { Básica }\end{array}$ & $\begin{array}{l}\text { IES } \\
\text { Federal/MS }\end{array}$ & $\begin{array}{l}\text { "Esta dissertação procura analisar as } \\
\text { proposições de ensino na educação de } \\
\text { alunos surdos no Brasil. Para fins desta } \\
\text { análise foram selecionadas, publicações } \\
\text { do MEC (1979, 1997, 2002) onde se } \\
\text { apresenta propostas curriculares e } \\
\text { orientações metodológicas destinadas a } \\
\text { alunos com surdez. O problema que nos } \\
\text { moveu, foi compreender se havia uma } \\
\text { proposta de ensino de Língua portuguesa } \\
\text { aos surdos, já que esta é apontada por } \\
\text { especialista como uma questão } \\
\text { problemática, delineou-se uma hipótese } \\
\text { de partida." }\end{array}$ & Sim \\
\hline $\begin{array}{l}\text { Educação } \\
\text { Básica }\end{array}$ & $\begin{array}{l}\text { IES } \\
\text { Particular/DF }\end{array}$ & $\begin{array}{l}\text { "O objetivo desta investigação foi } \\
\text { analisar os reflexos de um programa de } \\
\text { avaliação de âmbito nacional, o ENEM, } \\
\text { na prática pedagógica da disciplina } \\
\text { Língua Portuguesa. Face à importância } \\
\text { dessa disciplina, se procurou verificar } \\
\text { em que medida os resultados do ENEM } \\
\text { contribuem para a melhoria da qualidade } \\
\text { do ensino em Língua Portuguesa no } \\
\text { contexto da escola pública e da escola } \\
\text { particular. Para tanto, foi realizada uma } \\
\text { pesquisa qualitativa, onde se utilizou o } \\
\text { modelo de estudo de caso. As técnicas } \\
\text { de coleta de dados foram a entrevista } \\
\text { semi-estruturada e o grupo focal. Foi } \\
\text { ouvida uma amostra de alunos, de } \\
\text { professores de Língua Portuguesa, } \\
\text { coordenadores e gestores de oito escolas, } \\
\text { sendo quatro particulares e } 04 \text { da rede } \\
\text { pública." }\end{array}$ & Sim \\
\hline $\begin{array}{l}\text { Educação } \\
\text { Profissional } \\
\text { Técnica de } \\
\text { Nível Médio }\end{array}$ & $\begin{array}{l}\text { IES } \\
\text { Federal/MT }\end{array}$ & $\begin{array}{l}\text { "Nesta dissertação estão registrados os } \\
\text { resultados de uma pesquisa qualitativa, } \\
\text { desenvolvida no contexto do ensino } \\
\text { técnico-profissionalizante do Centro } \\
\text { Federal de Educação Tecnológica de }\end{array}$ & Não \\
\hline
\end{tabular}




\begin{tabular}{|c|c|c|c|}
\hline & & $\begin{array}{l}\text { Mato Grosso - CEFETMT, motivada } \\
\text { pelos constantes embates entre } \\
\text { professores da área técnica e da área de } \\
\text { humanas, em torno do ensino de Língua } \\
\text { Portuguesa nos cursos técnicos de nível } \\
\text { médio [...] Buscando analisar as relações } \\
\text { entre as práticas sociais e as práticas } \\
\text { discursivas, o estudo procurou mostrar } \\
\text { como os professores, tanto da área } \\
\text { técnica quanto de Língua Portuguesa, } \\
\text { concebem o ensino de Português nos } \\
\text { cursos de Construções Prediais, } \\
\text { Telecomunicações e Hotelaria." }\end{array}$ & \\
\hline $\begin{array}{l}\text { Educação } \\
\text { Profissional } \\
\text { Técnica de } \\
\text { Nível Médio }\end{array}$ & IES Federal/PB & $\begin{array}{l}\text { "O objetivo deste estudo é analisar como } \\
\text { se dá a relação entre a aquisição de } \\
\text { novos conhecimentos no ensino da } \\
\text { Língua Portuguesa (LP) e as novas } \\
\text { Tecnologias da Informação e } \\
\text { Comunicação (TIC's) no Centro Federal } \\
\text { de Educação Tecnológica -AL - se da } \\
\text { mesma forma tradicional ou } \\
\text { incorporando as transformações que as } \\
\text { TIC's impõem." }\end{array}$ & Não \\
\hline $\begin{array}{l}\text { Educação } \\
\text { Profissional } \\
\text { Técnica de } \\
\text { Nível Médio }\end{array}$ & IES Federal/RJ & $\begin{array}{l}\text { "Este estudo discute a produção de } \\
\text { textos em escolas agrotécnicas sob a } \\
\text { ótica da Lingüística textual e da } \\
\text { interdisciplinaridade. O objetivo da } \\
\text { pesquisa foi buscar uma metodologia } \\
\text { adequada para auxiliar os alunos de } \\
\text { essas escolas produzirem textos coesos e } \\
\text { coerentes, através do uso de um } \\
\text { tratamento interdisciplinar. A } \\
\text { metodologia que conduziu a pesquisa foi } \\
\text { prioritariamente qualitativa e a amostra } \\
\text { constituiu-se de redações feitas por } 13 \\
\text { alunos, DO Curso Técnico em } \\
\text { Agropecuária do CEFET- Urutaí/UNED } \\
\text { - Morrinhos, com idades entre } 15 \text { e } 46 \\
\text { anos." }\end{array}$ & Sim \\
\hline $\begin{array}{l}\text { Educação } \\
\text { Profissional } \\
\text { Técnica de } \\
\text { Nível Médio }\end{array}$ & IES Federal/RJ & $\begin{array}{l}\text { "Este estudo tem, como objeto de } \\
\text { pesquisa, o ensino de Língua Portuguesa } \\
\text { e, como objetivo maior, analisar } \\
\text { aprendizagens significativas no ensino } \\
\text { médio do CEFET de Uberaba, no ano de } \\
\text { 2003. Objeto e objetivo maior se inter- } \\
\text { relacionam a partir dos objetivos } \\
\text { específicos: identificar as dificuldades } \\
\text { dos alunos no ensino de Língua } \\
\text { Portuguesa; analisar abordagens } \\
\text { metodológicas que facilitam } \\
\text { aprendizagens significativas e utilizar a } \\
\text { metodologia de projetos enquanto um } \\
\text { desses recursos." }\end{array}$ & Sim \\
\hline $\begin{array}{l}\text { Educação } \\
\text { Superior }\end{array}$ & IES Federal/DF & $\begin{array}{l}\text { "[...] meu objetivo nesta dissertação é } \\
\text { mostrar que o ensino de Língua } \\
\text { Portuguesa deve ser revisto em uma } \\
\text { perspectiva multimodal em todos os } \\
\text { níveis de escolaridade, principalmente os } \\
\text { cursos de Letras, licenciatura, contexto } \\
\text { formador de docentes." }\end{array}$ & Não \\
\hline $\begin{array}{l}\text { Educação } \\
\text { Superior }\end{array}$ & $\begin{array}{l}\text { IES } \\
\text { Federal/GO }\end{array}$ & $\begin{array}{l}\text { "Esta pesquisa tem como objetivo } \\
\text { investigar sobre a construção da } \\
\text { identidade do aluno de Letras, a partir da } \\
\text { participação desse sujeito no universo do } \\
\text { saber da gramática como proposta de } \\
\text { ensino-aprendizagem de Língua } \\
\text { Portuguesa na Universidade e na }\end{array}$ & Não \\
\hline
\end{tabular}




\begin{tabular}{|c|c|c|c|}
\hline & & Escola." & \\
\hline $\begin{array}{l}\text { Educação } \\
\text { Superior }\end{array}$ & $\begin{array}{l}\text { IES } \\
\text { Federal/MG }\end{array}$ & $\begin{array}{l}\text { "Este trabalho visa a analisar a relação } \\
\text { entre o ensino da gramática tradicional e } \\
\text { o domínio da norma padrão, bem como } \\
\text { seus reflexos na produção escrita de } \\
\text { profissionais graduados. Os demais } \\
\text { objetivos são: avaliar as opiniões dos } \\
\text { sujeitos sobre o conhecimento de } \\
\text { Português e a importância da escrita } \\
\text { padrão; investigar o conhecimento } \\
\text { gramatical dos mesmos; examinar o } \\
\text { domínio da norma culta através de } \\
\text { textos; relacionar os resultados e analisar } \\
\text { os reflexos do ensino gramatical na } \\
\text { escrita." }\end{array}$ & Não \\
\hline $\begin{array}{l}\text { Educação } \\
\text { Superior }\end{array}$ & $\begin{array}{l}\text { IES } \\
\text { Particular/SP }\end{array}$ & $\begin{array}{l}\text { "A proposta deste trabalho é analisar a } \\
\text { visão que os educadores do curso } \\
\text { Normal Superior de uma Instituição de } \\
\text { Ensino Superior de Jacareí tem do } \\
\text { ensino da língua portuguesa, a partir de } \\
\text { suas trajetórias profissionais." }\end{array}$ & Não \\
\hline $\begin{array}{l}\text { Ensino } \\
\text { Fundamental }\end{array}$ & $\begin{array}{l}\text { IES } \\
\text { Estadual/PR }\end{array}$ & $\begin{array}{l}\text { "Objetiva-se, com o presente trabalho, } \\
\text { fornecer dados ao Ensino Fundamental } \\
\text { das escolas de Cascavel e aos } \\
\text { profissionais de ensino de Língua } \\
\text { Portuguesa que utilizam o livro didático, } \\
\text { especificamente as coleções 'Linguagem } \\
\text { Nova' e 'Português: Linguagens'." }\end{array}$ & Não \\
\hline $\begin{array}{l}\text { Ensino } \\
\text { Fundamental }\end{array}$ & IES Federal/SC & $\begin{array}{l}\text { "Esta dissertação trata de uma análise } \\
\text { sociolingüística realizada em livros } \\
\text { didáticos recomendados pelo Ministério } \\
\text { da Educação (MEC) para o ensino de } \\
\text { língua portuguesa no Brasil no nível } \\
\text { fundamental. O foco principal da análise } \\
\text { foi a concepção de língua e de gramática } \\
\text { que está presente nos livros didáticos } \\
\text { (LD) e a forma como tal concepção } \\
\text { evidencia aspectos sociolingüísticos } \\
\text { (como a noção de 'certo' e 'errado', } \\
\text { variação lingüística, mudança lingüística } \\
\text { e preconceito lingüístico, além do papel } \\
\text { da norma padrão) para os alunos através } \\
\text { das atividades elaboradas." }\end{array}$ & Não \\
\hline $\begin{array}{l}\text { Ensino } \\
\text { Fundamental } \\
\text { I }\end{array}$ & $\begin{array}{l}\text { IES } \\
\text { Estadual/RJ }\end{array}$ & $\begin{array}{l}\text { "Este trabalho tem como objetivo relatar } \\
\text { os resultados de uma pesquisa de } \\
\text { mestrado na área da Análise do Discurso } \\
\text { que visa investigar a hipótese de que } \\
\text { essas mudanças sociais no ambiente } \\
\text { educacional. A pesquisa investiga a } \\
\text { hipótese de que essas mudanças estão } \\
\text { diretamente relacionadas com as práticas } \\
\text { discursivas representadas, } \\
\text { principalmente, pela interdiscursividade } \\
\text { entre o discurso pedagógico e o discurso } \\
\text { da administração empresarial, } \\
\text { materializada no texto dos Parâmetros } \\
\text { Curriculares Nacionais para o Ensino da } \\
\text { Língua Portuguesa no primeiro ciclo." }\end{array}$ & Não \\
\hline $\begin{array}{l}\text { Ensino } \\
\text { Fundamental } \\
\text { I }\end{array}$ & $\begin{array}{l}\text { IES } \\
\text { Particular/RS }\end{array}$ & $\begin{array}{l}\text { "O presente estudo pretende } \\
\text { compreender em que medida as } \\
\text { concepções expressas pelos professores } \\
\text { de classes de } 2^{\mathrm{a}}, 3^{\mathrm{a}} \text { e } 4^{\mathrm{a}} \text { séries do ensino } \\
\text { fundamental da rede pública municipal } \\
\text { de Passo Fundo se relacionam com a } \\
\text { abordagem teórica e metodológica } \\
\text { contemporânea sobre o ensino da língua } \\
\text { portuguesa." }\end{array}$ & Não \\
\hline
\end{tabular}




\begin{tabular}{|c|c|c|c|}
\hline $\begin{array}{l}\text { Ensino } \\
\text { Fundamental } \\
\text { II }\end{array}$ & $\begin{array}{l}\text { IES } \\
\text { Estadual/PR }\end{array}$ & $\begin{array}{l}\text { "Neste trabalho, privilegiaremos a } \\
\text { contemplação de algumas orientações } \\
\text { sugeridas nos PCNs de Língua } \\
\text { Portuguesa para o Terceiro e Quarto } \\
\text { Ciclos do Ensino Fundamental, } \\
\text { interessando-nos, particularmente, pelas } \\
\text { orientações para o ensino de leitura. Por } \\
\text { fim, após essa trajetória percorrida por } \\
\text { diferentes propostas acerca do ensino de } \\
\text { leitura, teceremos reflexões em tomo da } \\
\text { teoria semiótica de Greimas, que, por } \\
\text { meio da desconstrução do texto, } \\
\text { possibilita o aperfeiçoamento das } \\
\text { práticas do professor em sala de aula. } \\
\text { Ressaltaremos, ainda, alguns aspectos } \\
\text { que tomam essa abordagem uma grande } \\
\text { aliada no desenvolvimento do processo } \\
\text { de leitura." }\end{array}$ & Não \\
\hline $\begin{array}{l}\text { Ensino } \\
\text { Fundamental } \\
\text { II }\end{array}$ & $\begin{array}{l}\text { IES } \\
\text { Federal/MT }\end{array}$ & 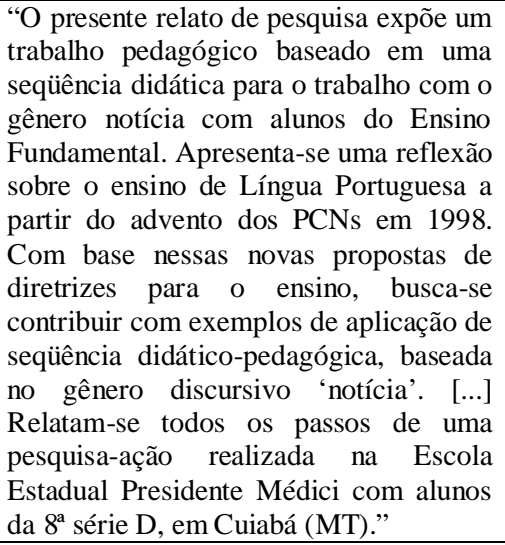 & Não \\
\hline $\begin{array}{l}\text { Ensino } \\
\text { Fundamental } \\
\text { II }\end{array}$ & IES Federal/PA & $\begin{array}{l}\text { "Este trabalho trata da } \\
\text { interdisciplinaridade e transversalidade } \\
\text { do ponto de vista do ensino da língua } \\
\text { portuguesa. Numa perspectiva } \\
\text { essencialmente metodológica, procura-se } \\
\text { relacionar esta proposta de tratamento } \\
\text { dos conteúdos escolares com as } \\
\text { concepções atuais de ensino da língua e } \\
\text { formação escolar, presentes nos PCN, } \\
\text { buscando, desta forma, fundamentar o } \\
\text { desenvolvimento de competências de } \\
\text { uso da língua em situações concretas de } \\
\text { interlocução. À luz das principais } \\
\text { características pedagógicas do Projeto } \\
\text { Político-Pedagógico da Escola Cabana - } \\
\text { Município de Belém - analisam-se as } \\
\text { práticas de professores de Português do } \\
\text { Ciclo Básico III, no que diz respeito à } \\
\text { inter e transdisciplinaridade, } \\
\text { estabelecendo-se relações entre o modo } \\
\text { como o projeto Cabano está implantado } \\
\text { nas escolas em que estes docentes atuam } \\
\text { e as concepções que subjazem a suas } \\
\text { práticas." }\end{array}$ & Não \\
\hline $\begin{array}{l}\text { Ensino } \\
\text { Fundamental } \\
\text { II }\end{array}$ & $\begin{array}{l}\text { IES Particular/ } \\
\text { MG }\end{array}$ & $\begin{array}{l}\text { "Os estudos sobre gêneros textuais } \\
\text { (Bakthin, 2000) assumem substancial } \\
\text { importância no processo de } \\
\text { ensino/aprendizagem de leitura e } \\
\text { produção de texto por trazerem uma } \\
\text { nova visão sobre o texto, pensado em } \\
\text { seu contexto de produção, circulação e } \\
\text { recepção. [...] em projetos de ensino de } \\
\text { Língua Portuguesa, desenvolvidos na } 7 \text { a }\end{array}$ & Sim \\
\hline
\end{tabular}




\begin{tabular}{|c|c|c|c|}
\hline & & $\begin{array}{l}\text { e } 8^{\text {a }} \text { série do Ensino Fundamental de } \\
\text { uma escola particular de Belo Horizonte, } \\
\text { privilegiamos atividades de leitura e } \\
\text { escrita que possibilitassem aos alunos } \\
\text { uma reflexão sobre os gêneros textuais } \\
\text { envolvidos. [...] importância do trabalho } \\
\text { integrado dos três projetos de ensino: } \\
\text { Projeto Gêneros Textuais, Projeto } \\
\text { Autoria (produção textual) e Projeto } \\
\text { Biblioteca: Passaporte de Leitura, } \\
\text { selecionamos como objeto de pesquisa } \\
\text { deste trabalho apenas as atividades de } \\
\text { retextualização desse último projeto, } \\
\text { assim como as retextualizações } \\
\text { produzidas no Projeto Autoria, nas } \\
\text { orelhas e contracapas dos livros } \\
\text { construídos pelos alunos." }\end{array}$ & \\
\hline $\begin{array}{l}\text { Ensino } \\
\text { Fundamental } \\
\text { II }\end{array}$ & $\begin{array}{l}\text { IES } \\
\text { Particular/SP }\end{array}$ & 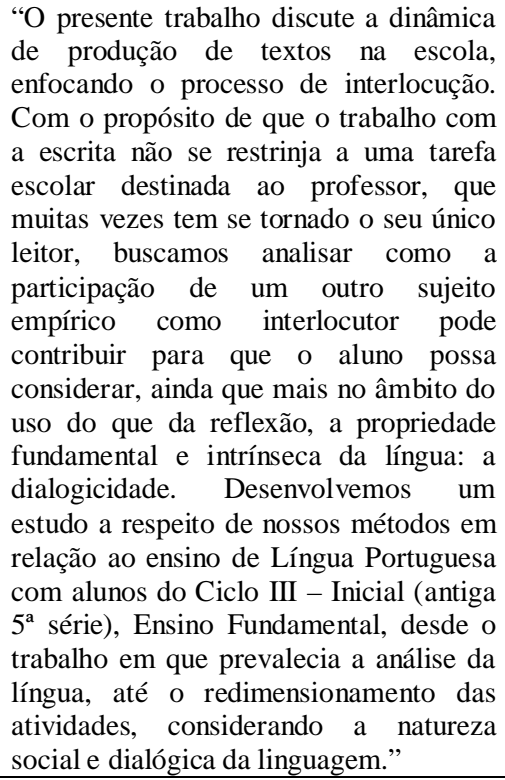 & Não \\
\hline $\begin{array}{l}\text { Ensino } \\
\text { Médio }\end{array}$ & $\begin{array}{l}\text { IES } \\
\text { Federal/GO }\end{array}$ & $\begin{array}{l}\text { "Este trabalho apresenta algumas } \\
\text { reflexões sobre a proposta de ensino de } \\
\text { Língua Portuguesa numa perspectiva } \\
\text { definida como "interdiciplinar' pelos } \\
\text { Parâmetros Curriculares Nacionais para } \\
\text { o Ensino Médio (PCNEM, 1999)." }\end{array}$ & Não \\
\hline $\begin{array}{l}\text { Ensino } \\
\text { Médio }\end{array}$ & $\begin{array}{l}\text { IES } \\
\text { Federal/MG }\end{array}$ & $\begin{array}{l}\text { "Esta pesquisa está embasada na } \\
\text { perspectiva de análise e reflexão da } \\
\text { relação entre professor, monitor e aluno } \\
\text { no processo de ensino e aprendizagem } \\
\text { da Língua Portuguesa em situação } \\
\text { escolar do ensino médio em uma escola } \\
\text { particular de Belo Horizonte. O objeto } \\
\text { de estudo é interação professor, monitor } \\
\text { estagiário e alunos do curso do primeiro } \\
\text { ano do ensino médio em atividades de } \\
\text { revisão e ou reescrita de textos escolares } \\
\text { na modalidade escrita da Língua } \\
\text { Portuguesa [...] Este trabalho busca } \\
\text { analisar a relação interativa e } \\
\text { interventiva entre professor, monitor e } \\
\text { aluno no processo de aprendizagem } \\
\text { escolar da produção de textos no ensino } \\
\text { médio. Pretende apresentar uma } \\
\text { metodologia que auxilie novos } \\
\text { profissionais da área de ensino de } \\
\text { Língua Portuguesa nas questões de }\end{array}$ & Não \\
\hline
\end{tabular}




\begin{tabular}{|c|c|c|c|}
\hline & & $\begin{array}{l}\text { produção de textos embasados na } \\
\text { perspectiva de gêneros e tipos textuais." }\end{array}$ & \\
\hline $\begin{array}{l}\text { Ensino } \\
\text { Médio }\end{array}$ & IES Federal/SC & $\begin{array}{l}\text { "O presente trabalho detém-se no estudo } \\
\text { das propriedades com que alunos do } \\
\text { ensino médio organizam seus textos, } \\
\text { fazendo uso das Estratégias de } \\
\text { Progressão Referencial (nesta } \\
\text { dissertação EPR), como meio para } \\
\text { melhor comunicarem o seu dizer de } \\
\text { forma escrita. Coletou-se [sic] quatro } \\
\text { textos de cada uma das atividades de } \\
\text { produção textual argumentativa de vinte } \\
\text { e dois alunos sujeitos, totalizando oitenta } \\
\text { e oito textos que passaram por } \\
\text { mapeamento e por análises teóricas dos } \\
\text { dados colhidos, à luz das teorias da } \\
\text { lingüística textual." }\end{array}$ & Não \\
\hline $\begin{array}{l}\text { Ensino } \\
\text { Médio }\end{array}$ & $\begin{array}{l}\text { IES } \\
\text { Particular/SP }\end{array}$ & $\begin{array}{l}\text { "O propósito desta pesquisa é discutir o } \\
\text { ensino de Língua Portuguesa no Ensino } \\
\text { Médio, buscando compreender os limites } \\
\text { e possibilidades formativas do atual } \\
\text { currículo. A investigação se realizou em } \\
\text { uma escola pública do centro urbano da } \\
\text { cidade de São Paulo e tem foco na } \\
\text { primeira série do ensino Médio, } \\
\text { baseando-se em observações em sala de } \\
\text { aula e em estudos de documentos } \\
\text { escolares. O desenvolvimento da } \\
\text { disciplina supracitada é analisado a } \\
\text { partir de um olhar para o currículo } \\
\text { dentro da escola, mas considera também } \\
\text { seus limites e possibilidades, marcados } \\
\text { pelo contexto maior." }\end{array}$ & Não \\
\hline Indefinido & $\begin{array}{l}\text { IES } \\
\text { Particular/RS }\end{array}$ & $\begin{array}{l}\text { "Este trabalho procura, à luz da noção de } \\
\text { isotopia discursiva, descrever a estrutura } \\
\text { do texto humorístico, a fim de } \\
\text { demonstrar como os sentidos nele se } \\
\text { constituem. Com isso, pretende-se } \\
\text { contribuir para qualificar o ensino de } \\
\text { Língua Portuguesa, principalmente no } \\
\text { que se refere ao trabalho com leitura e } \\
\text { interpretação de textos humorísticos." }\end{array}$ & Não \\
\hline Indefinido & $\begin{array}{l}\text { IES Particular/ } \\
\text { MG }\end{array}$ & $\begin{array}{l}\text { "Este trabalho foi realizado a partir da } \\
\text { perceptível 'contaminação' que os } \\
\text { mecanismos gramaticais da língua } \\
\text { sofrem pelo significado de palavras e } \\
\text { expressões. Procurou-se mostrar } \\
\text { situações em que a concordância formal } \\
\text { e lógica foi substituída pela } \\
\text { concordância ideológica e psicológica. } \\
\text { [..] A proposta deste trabalho é } \\
\text { explicitar a necessidade de uma análise } \\
\text { mais coerente da estrutura da língua para } \\
\text { alcançar formação gramatical mais } \\
\text { completa (não descartando a } \\
\text { consideração do estilo), o que deve nos } \\
\text { levar a um exame mais racional e } \\
\text { rigoroso da língua, a partir de sua prática } \\
\text { como um todo. [...] acredita-se que o } \\
\text { aluno possa conseguir fazer a conexão } \\
\text { entre a coesão e a coerência, com a } \\
\text { finalidade de alcançar a prática } \\
\text { satisfatória do texto no processo } \\
\text { sociocomunicativo." }\end{array}$ & Não \\
\hline Indefinido & IES Federal/RJ & $\begin{array}{l}\text { "Este trabalho tem por objetivo a criação } \\
\text { de uma metodologia didática para o } \\
\text { ensino de Língua Portuguesa a partir de }\end{array}$ & Não \\
\hline
\end{tabular}




\begin{tabular}{|c|c|c|}
\hline & $\begin{array}{lrrr}\text { textos da } & \text { Internet. Adotamos } & \text { o } \\
\text { pressuposto do continnum entre } & \text { a } \\
\text { modalidade oral e a escrita a fim } & \text { de } \\
\text { estabelecer } & \text { critérios para } & \text { a } \\
\text { retextualização de comentários } & \text { em } \\
\text { weblogs." } & & & \\
\end{array}$ & \\
\hline $\begin{array}{l}\text { Total de dissertações } \\
\text { localizadas }\end{array}$ & & 31 \\
\hline
\end{tabular}

\begin{tabular}{|c|c|c|c|c|}
\hline $\begin{array}{l}\text { Ano } \\
\text { de } \\
\text { defesa }\end{array}$ & $\begin{array}{l}\text { Contexto } \\
\text { pesquisado }\end{array}$ & $\begin{array}{l}\text { Vínculo } \\
\text { administrativo } \\
\text { /Localização }\end{array}$ & $\begin{array}{l}\text { Transcrição parcial dos } \\
\text { resumos }\end{array}$ & $\begin{array}{l}\text { Disponível } \\
\text { on-line }\end{array}$ \\
\hline \multirow[t]{4}{*}{2006} & $\begin{array}{l}\text { Antiga } \\
\text { Educação } \\
\text { Escolar }\end{array}$ & $\begin{array}{l}\text { IES } \\
\text { Particular/PR }\end{array}$ & $\begin{array}{l}\text { "A presente pesquisa investiga a (s) } \\
\text { concepção (ões) de Educação presente } \\
\text { (s) na formação de professores de } \\
\text { Língua Portuguesa sob o enfoque } \\
\text { histórico nos anos } 50 \text { e } 60 \text { do século XX. } \\
\text { Para entender tais concepções, realiza-se } \\
\text { uma breve retrospectiva histórica do } \\
\text { período em questão recuperando } \\
\text { aspectos políticos e econômicos que o } \\
\text { caracterizaram. [...] O fio condutor da } \\
\text { investigação são as orientações } \\
\text { normativas contidas na Nomenclatura } \\
\text { Gramatical Brasileira (NGB), instituída } \\
\text { no ano de 1958, cujas concepções } \\
\text { vinculam-se ao Funcionalismo, ao } \\
\text { Estruturalismo e ao Nacionalismo. Esse } \\
\text { documento estabeleceu uma nova } \\
\text { compreensão sobre o que deveria ser } \\
\text { considerado como conteúdo no ensino } \\
\text { da Língua Portuguesa." }\end{array}$ & Sim \\
\hline & $\begin{array}{l}\text { Antiga } \\
\text { Educação } \\
\text { Escolar }\end{array}$ & $\begin{array}{l}\text { IES Particular/ } \\
\text { MG }\end{array}$ & $\begin{array}{l}\text { "O presente trabalho de pesquisa tem } \\
\text { como objetivo a reconstrução da história } \\
\text { da disciplina escolar Língua Portuguesa, } \\
\text { no período de } 1880 \text { a } 1889 \text {, na Escola } \\
\text { Normal Oficial de Diamantina. Para a } \\
\text { realização dessa pesquisa buscou-se } \\
\text { reconstituir os contextos sócio-históricos } \\
\text { externos e internos à escola que } \\
\text { oportunizaram o reconhecimento da } \\
\text { disciplina Língua Portuguesa nos } \\
\text { espaços escolares e de como ela se } \\
\begin{array}{l}\text { incorporou, gradativamente, nos } \\
\text { currículos, transformando-se em um } \\
\text { saber escolar." }\end{array}\end{array}$ & Não \\
\hline & $\begin{array}{l}\text { Antiga } \\
\text { Educação } \\
\text { Escolar }\end{array}$ & $\begin{array}{l}\text { IES } \\
\text { Particular/SP }\end{array}$ & $\begin{array}{l}\text { "Tem-se por tema os fatores contextuais } \\
\text { de produção de manuais de ensino de } \\
\text { Língua Portuguesa, da década de } 70 \text {, do } \\
\text { século XX. O objetivo desta pesquisa } \\
\text { consiste em examinar o contexto } \\
\text { histórico desse período e evidenciar, por } \\
\text { meio da análise de dois manuais de } \\
\text { ensino de Língua Portuguesa, as marcas } \\
\text { lingüísticas, reveladoras das influências } \\
\text { políticas e ideológicas, que embasaram a } \\
\text { elaboração desses manuais." }\end{array}$ & Não \\
\hline & $\begin{array}{l}\text { Antiga } \\
\text { Educação } \\
\text { Escolar }\end{array}$ & $\begin{array}{l}\text { IES } \\
\text { Particular/SP }\end{array}$ & $\begin{array}{l}\text { "Esta pesquisa focaliza o ensino da } \\
\text { gramática, nas décadas de } 60 \text { e de } 70 \text {, a } \\
\text { partir da Gramática Normativa da } \\
\text { Língua Portuguesa (8a. e 19a. edições), } \\
\text { de Rocha Lima e das Leis de Diretrizes e }\end{array}$ & Não \\
\hline
\end{tabular}




\begin{tabular}{|c|c|c|c|}
\hline & & $\begin{array}{l}\text { Bases, a Lei } \mathrm{n}^{\circ} 4.024 / 61 \text { e a Lei } \mathrm{n}^{\circ} \\
5.692 / 71, \text { em uma abordagem da } \\
\text { Historiografia Lingüística, seguindo os } \\
\text { princípios da contextualização, } \\
\text { imanência e adequação. A partir desse } \\
\text { quadro, interessamo-nos descrever e } \\
\text { explicar a permanência da tradição do } \\
\text { ensino da gramática ea e, } \\
\text { conseqüentemente, da sobrevivência da } \\
\text { autoridade da Gramática Normativa da } \\
\text { Língua Portuguesa, de Rocha Lima, nas } \\
\text { décadas de } 60 \text { e } 70 \text {, um período em que } \\
\text { inovadoras teorias da linguagem } \\
\text { chegavam ao Brasil." }\end{array}$ & \\
\hline $\begin{array}{l}\text { Curso } \\
\text { Preparatório } \\
\text { para } \\
\text { Concurso }\end{array}$ & $\begin{array}{l}\text { IES } \\
\text { Particular/SP }\end{array}$ & $\begin{array}{l}\text { "Esta dissertação apresenta uma } \\
\text { proposta de ensino de Língua Portuguesa } \\
\text { que fuja das perspectivas tradicionais. O } \\
\text { público alvo são alunos egressos do } \\
\text { ensino médio, que fazem cursinhos para } \\
\text { Concurso Público e precisam } \\
\text { (re)aprender o Português." }\end{array}$ & Não \\
\hline $\begin{array}{l}\text { Educação } \\
\text { Básica }\end{array}$ & IES Federal/PE & $\begin{array}{l}\text { "Este trabalho analisa as propostas } \\
\text { didáticas para o ensino da linguagem } \\
\text { oral em duas coleções de livros didáticos } \\
\text { recomendadas pelo Programa Nacional } \\
\text { do Livro Didático - PNLD 2004 } \\
\text { ('Português uma Proposta para o } \\
\text { Letramento' e 'Vitória-Régia - Língua } \\
\text { Portuguesa'), com vistas a saber se as } \\
\text { estratégias presentes nesses manuais } \\
\text { contribuem para que os alunos se } \\
\text { apropriem das práticas discursivas da } \\
\text { oralidade." }\end{array}$ & Não \\
\hline $\begin{array}{l}\text { Educação } \\
\text { Básica }\end{array}$ & $\begin{array}{l}\text { IES Municipal/ } \\
\text { SP }\end{array}$ & $\begin{array}{l}\text { "Este trabalho apresenta uma pesquisa } \\
\text { cujo escopo consistiu em investigar, a } \\
\text { partir das representações docentes, como } \\
\text { os professores de ensino básico e rede } \\
\text { pública concebem e administram o } \\
\text { ensino da gramática teórica em seu } \\
\text { cotidiano esccolar." }\end{array}$ & Sim \\
\hline $\begin{array}{l}\text { Educação } \\
\text { Básica/ } \\
\text { Educação } \\
\text { Superior }\end{array}$ & $\begin{array}{l}\text { IES } \\
\text { Estadual/SP }\end{array}$ & $\begin{array}{l}\text { "Nosso trabalho de pesquisa em } \\
\text { Lingüística Aplicada, especificamente na } \\
\text { área de língua materna, busca investigar } \\
\text { a oralidade concebida como objeto de } \\
\text { ensino-aprendizagem, seja no nível } \\
\text { básico - fundamental e médio -, seja no } \\
\text { superior. As preocupações nesse sentido } \\
\text { surgiram a partir do questionamento } \\
\text { sobre as relações entre o aprendizado } \\
\text { dos estudantes de Letras na área de } \\
\text { Lingüística e sua posterior atuação como } \\
\text { professores de ensino fundamental e } \\
\text { médio." }\end{array}$ & Sim \\
\hline $\begin{array}{l}\text { Educação } \\
\text { Profissional } \\
\text { Técnica de } \\
\text { Nível Médio }\end{array}$ & IES Federal/RJ & $\begin{array}{l}\text { "Esta pesquisa investigou o nível de } \\
\text { aquisição lingüística dos educandos ao } \\
\text { iniciarem a } 1^{a} \text { série do Ensino Médio na } \\
\text { Escola Agrotécnica Federal de Santa } \\
\text { Teresa-ES, tendo como objetivo dirimir } \\
\text { distorções e dificuldades que sempre se } \\
\text { arrastaram até o fim do ensino básico." }\end{array}$ & Sim \\
\hline $\begin{array}{l}\text { Educação } \\
\text { Superior }\end{array}$ & $\begin{array}{l}\text { IES } \\
\text { Estadual/PR }\end{array}$ & $\begin{array}{l}\text { "Neste trabalho, problematizamos a } \\
\text { questão do ensino da produção textual na } \\
\text { formação, em nível superior, do } \\
\text { professor de Língua Portuguesa e } \\
\text { realizamos um diagnóstico da formação } \\
\text { que o acadêmico do curso de Letras da } \\
\text { UEM recebe sobre o processo de ensinar }\end{array}$ & Sim \\
\hline
\end{tabular}




\begin{tabular}{|c|c|c|c|}
\hline & & a escrita." & \\
\hline $\begin{array}{l}\text { Educação } \\
\text { Superior }\end{array}$ & $\begin{array}{l}\text { IES } \\
\text { Particular/SP }\end{array}$ & $\begin{array}{l}\text { "Este trabalho situa-se na Linha de } \\
\text { Pesquisa de Leitura, Escrita e Ensino de } \\
\text { Língua Portuguesa, especificamente em } \\
\text { Produção de Textos para Fins } \\
\text { Específicos que prioriza um ensino de } \\
\text { uma língua em funcionamento numa } \\
\text { dada realidade, voltada para a solução de } \\
\text { problemas de comunicação em áreas } \\
\text { específicas, a partir de conhecimentos } \\
\text { prévios dos aprendizes. Com base em } \\
\text { Análise de Necessidades foram } \\
\text { diagnosticadas dificuldades dos alunos } \\
\text { do } 1^{\circ} \text { ano noturno de Administração da } \\
\text { Faculdade de Ciências Econômicas, } \\
\text { Administrativas e Contábeis de São } \\
\text { Sebastião do Paraíso, Minas Gerais." }\end{array}$ & Sim \\
\hline $\begin{array}{l}\text { Ensino em } \\
\text { País } \\
\text { Africano }\end{array}$ & $\begin{array}{l}\text { IES } \\
\text { Particular/SP }\end{array}$ & $\begin{array}{l}\text { "O presente trabalho adopta os } \\
\text { princípios da abordagem histórico-social } \\
\text { justificada pelo facto de ela tomar o } \\
\text { aspecto social como elemento } \\
\text { constitutivo do desenvolvimento } \\
\text { humano. Revê a história da educação em } \\
\text { Moçambique, África, país multilingue e } \\
\text { multiétnico, desde a colonização } \\
\text { portuguesa aos momentos actuais. [...] A } \\
\text { necessidade de uma maior clareza das } \\
\text { concepções de língua, linguagem e } \\
\text { processo de ensino-aprendizagem que } \\
\text { embasam as práticas pedagógicas e a } \\
\text { didáctica do ensino de língua portuguesa } \\
\text { justifica parcialmente o estudo, que tem } \\
\text { como objectivo essencial apontar uma } \\
\text { nova perspectiva para a formação de } \\
\text { professores primários na disciplina de } \\
\text { português, tendo em vista a superação do } \\
\text { insucesso escolar dos formandos e das } \\
\text { crianças nos primeiros anos de } \\
\text { frequência escolar." }\end{array}$ & Sim \\
\hline $\begin{array}{l}\text { Ensino em } \\
\text { País } \\
\text { Africano }\end{array}$ & $\begin{array}{l}\text { IES } \\
\text { Particular/SP }\end{array}$ & $\begin{array}{l}\text { "A presente dissertação tem como } \\
\text { objecto de estudo o ensino de Língua } \\
\text { Portuguesa em Moçambique na } \\
\text { perspectiva das desigualdades } \\
\text { sociolinguísticas e produção textual e } \\
\text { objectiva examinar a relação entre as } \\
\text { desigualdades sociolinguísticas e a } \\
\text { leitura na produção de fracasso escolar e } \\
\text { discutir as formas de violência e } \\
\text { exclusão que decorrem no sistema } \\
\text { educativo vigente." }\end{array}$ & Não \\
\hline $\begin{array}{l}\text { Ensino em } \\
\text { País } \\
\text { Africano }\end{array}$ & $\begin{array}{l}\text { IES } \\
\text { Particular/SP }\end{array}$ & $\begin{array}{l}\text { "Esta dissertação apresenta como tema o } \\
\text { ensino da Língua Portuguesa em } \\
\text { Moçambique, no período colonial de } \\
1940 \text { a 1960, sob uma visão } \\
\text { historiográfica. Para fazer uma reflexão } \\
\text { sobre os meios e os modelos } \\
\text { pedagógicos de que se valeu o aparelho } \\
\text { ideológico português, pareceu-nos } \\
\text { relevante focalizar o ensino das missões } \\
\text { católicas e protestantes destinado aos } \\
\text { moçambicanos." }\end{array}$ & Sim \\
\hline $\begin{array}{l}\text { Ensino } \\
\text { Fundamental } \\
\text { I }\end{array}$ & IES Federal/AL & $\begin{array}{l}\text { "Nos últimos anos, diversas pesquisas } \\
\text { realizadas sobre os instrumentos } \\
\text { didáticos no processo de ensino- } \\
\text { aprendizagem têm se dedicado a } \\
\text { investigar os Livros Didáticos (LD), e o } \\
\text { Ministério da Educação, através do }\end{array}$ & Não \\
\hline
\end{tabular}




\begin{tabular}{|c|c|c|c|}
\hline & & $\begin{array}{l}\text { Programa Nacional do Livro Didático } \\
\text { (PNLD), desde } 1997 \text {, iniciou o processo } \\
\text { de avaliação sistemática e contínua dos } \\
\text { LD, os quais têm passado por } \\
\text { significativas transformações, resultando } \\
\text { em avanços nos aspectos teóricos- } \\
\text { metodológicos. Nesta pesquisa, tendo } \\
\text { como fundamentação dos estudos } \\
\text { recentes sobre o LD e o ensino da } \\
\text { Língua Portuguesa na escola, } \\
\text { investigamos as propostas de produção } \\
\text { de texto nos } 5 \text { livros didáticos de } \\
\text { Português, de } 2^{2} \text { série do Ensino } \\
\text { Fundamental, mais utilizamos nas } \\
\text { escolas públicas municipais de Maceió." }\end{array}$ & \\
\hline $\begin{array}{l}\text { Ensino } \\
\text { Fundamental } \\
\text { I }\end{array}$ & $\begin{array}{l}\text { IES } \\
\text { Federal/MT }\end{array}$ & $\begin{array}{l}\text { "Esta pesquisa perscrutou aspectos de } \\
\text { como foi o ensino da produção textual } \\
\text { escrita, na última década do século XX, } \\
\text { nas } 4 \text { a séries de uma escola cuiabana. O } \\
\text { estudo teve como objetivo contribuir } \\
\text { para a compreensão de parte dessa } \\
\text { história educacional em Cuiabá e no } \\
\text { Estado de Mato Grosso, e para o } \\
\text { desenvolvimento da pesquisa histórica } \\
\text { em alfabetização." }\end{array}$ & Sim \\
\hline $\begin{array}{l}\text { Ensino } \\
\text { Fundamental } \\
\text { I }\end{array}$ & $\begin{array}{l}\text { IES Particular/ } \\
\text { RJ }\end{array}$ & $\begin{array}{l}\text { "O presente trabalho teve por objetivo } \\
\text { investigar a concepção que os } \\
\text { professores de ensino fundamental têm } \\
\text { da teoria dos gêneros discursivos } \\
\text { aplicada ao ensino de Língua } \\
\text { Portuguesa, preconizada pelas diretrizes } \\
\text { curriculares nacionais. Participaram } \\
\text { dessa investigação professoras da rede } \\
\text { estadual de ensino da cidade mineira de } \\
\text { Juiz de Fora; professoras do ciclo } \\
\text { introdutório de alfabetização e de } 1^{\circ} \text { e } 2^{\circ} \\
\text { ciclo, inseridas no processo de } \\
\text { implantação do ensino fundamental de } 9 \\
\text { anos, para atender crianças desde os } 6 \\
\text { anos." }\end{array}$ & Sim \\
\hline $\begin{array}{l}\text { Ensino } \\
\text { Fundamental } \\
\text { II }\end{array}$ & $\begin{array}{l}\text { IES } \\
\text { Estadual/PR }\end{array}$ & $\begin{array}{l}\text { "Esta pesquisa, de cunho qualitativo, } \\
\text { objetivou investigar os resultados } \\
\text { obtidos em 2004, pelos alunos da Sala de } \\
\text { Apoio à Aprendizagem em Língua } \\
\text { Portuguesa, de algumas escolas } \\
\text { estaduais de Maringá (PR). A Sala de } \\
\text { Apoio é um Programa implantado pela } \\
\text { Secretaria de Estado da Educação } \\
\text { (SEED), para atender a alunos da } 5^{a} \text { série } \\
\text { da rede pública com dificuldades na } \\
\text { leitura e na escrita. A investigação } \\
\text { analisa a concepção de linguagem dos } \\
\text { professores e como esta se materializa } \\
\text { nas práticas diárias." }\end{array}$ & Sim \\
\hline $\begin{array}{l}\text { Ensino } \\
\text { Fundamental } \\
\text { II }\end{array}$ & $\begin{array}{l}\text { IES } \\
\text { Estadual/SP }\end{array}$ & $\begin{array}{l}\text { "Este trabalho tem como objetivo um } \\
\text { estudo a respeito do lugar que o ensino } \\
\text { de Gramática ocupa no ensino de Língua } \\
\text { Portuguesa, delimitado ao ensino } \\
\text { fundamental II. Nele, partimos de uma } \\
\text { revisão bibliográfica de alguns conceitos } \\
\text { teóricos sobre a Linguagem, a Língua e a } \\
\text { Gramática e, em seguida, de uma } \\
\text { reflexão a respeito do papel } \\
\text { desempenhado pela Lingüística aplicada } \\
\text { aos estudos referentes à linguagem. } \\
{[\ldots] \text { desenvolvemos uma reflexão a }} \\
\text { respeito do papel do ensino de }\end{array}$ & Não \\
\hline
\end{tabular}




\begin{tabular}{|c|c|c|c|}
\hline & & $\begin{array}{l}\text { Gramática dentro do ensino da língua } \\
\text { portuguesa nas escolas, cotejando-o com } \\
\text { os resultados obtidos por estudantes em } \\
\text { exames de avaliação externa do } \\
\text { fundamental II." }\end{array}$ & \\
\hline $\begin{array}{l}\text { Ensino } \\
\text { Fundamental } \\
\text { II }\end{array}$ & IES Federal/BA & $\begin{array}{l}\text { "Este trabalho é o resultado de uma } \\
\text { pesquisa de cunho etnográfico sobre o } \\
\text { espaço exercido pela oralidade no ensino } \\
\text { de língua portuguesa no ensino } \\
\text { fundamental, realizada numa escola } \\
\text { pública de Salvador. A preocupação } \\
\text { principal foi investigar se a oralidade, no } \\
\text { contexto da sala de aula de uma escola } \\
\text { pública, é, de fato, uma prática nas aulas } \\
\text { de língua portuguesa. Com tal objetivo, } \\
\text { duas classes de } 8^{\mathrm{a}} \text { série foram } \\
\text { observadas durante a pesquisa de campo, } \\
\text { nas quais foram analisadas as relações } \\
\text { entre professores e alunos no processo } \\
\text { de interação verbal." }\end{array}$ & Não \\
\hline $\begin{array}{l}\text { Ensino } \\
\text { Fundamental } \\
\text { II }\end{array}$ & $\begin{array}{l}\text { IES } \\
\text { Federal/MT }\end{array}$ & $\begin{array}{l}\text { "Esta dissertação é resultado de uma } \\
\text { pesquisa desenvolvida em sala de aula } \\
\text { com a } 5^{\text {a }} \text { série 'C' do Ensino } \\
\text { Fundamental da Escola Estadual José } \\
\text { Moraes, localizada no município de } \\
\text { Rondonópolis-MT. Durante a pesquisa- } \\
\text { ação, trabalhamos com atividades } \\
\text { organizadas em módulos didáticos, de } \\
\text { acordo com Dolz e Schneuwly (2004), } \\
\text { com o gênero Carta do Leitor veiculado } \\
\text { na revista Guia Astral, revista Veja e } \\
\text { jornal A Tribuna." }\end{array}$ & Sim \\
\hline $\begin{array}{l}\text { Ensino } \\
\text { Fundamental } \\
\text { II }\end{array}$ & IES Federal/PA & $\begin{array}{l}\text { "O presente trabalho expõe uma prática } \\
\text { de pesquisa-ação realizada em uma sala } \\
\text { de aula de língua portuguesa durante o } \\
\text { ano de } 2003 \text {. Ele traz à tona produções } \\
\text { textuais, geradas neste contexto, que nos } \\
\text { servem para discutir mecanismos de } \\
\text { escrita utilizados pelos sujeitos da } \\
\text { pesquisa (alunos de 5a série do ensino } \\
\text { fundamental) em seus textos." }\end{array}$ & Não \\
\hline $\begin{array}{l}\text { Ensino } \\
\text { Fundamental } \\
\text { II }\end{array}$ & IES Federal/PE & $\begin{array}{l}\text { "A pesquisa desenvolvida neste trabalho } \\
\text { pretendeu analisar o tratamento didático } \\
\text { proposto para o ensino de análise } \\
\text { lingüística (AL), nos eixos da } \\
\text { normatividade e da textualidade, em } \\
\text { duas coleções de livros didáticos } \\
\text { recomendados pelo guia de livros } \\
\text { didáticos do Programa Nacional do } \\
\text { Livro Didático - PNLD 2005, destinadas } \\
\text { ao Ensino Fundamental ( } 5^{\mathrm{a}} \text { a } 8^{\mathrm{a}} \text { séries)." }\end{array}$ & Não \\
\hline $\begin{array}{l}\text { Ensino } \\
\text { Fundamental } \\
\text { II }\end{array}$ & IES Federal/RN & 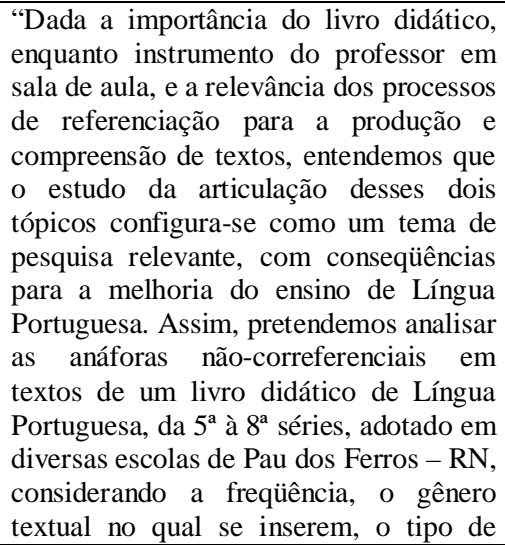 & Não \\
\hline
\end{tabular}




\begin{tabular}{|c|c|c|c|}
\hline & & anáfora e a forma de manifestação." & \\
\hline $\begin{array}{l}\text { Ensino } \\
\text { Fundamental } \\
\text { II }\end{array}$ & $\begin{array}{l}\text { IES } \\
\text { Particular/SP }\end{array}$ & $\begin{array}{l}\text { "Este trabalho tem como objetivo geral } \\
\text { integrar os procedimentos do texto } \\
\text { narrativo e da crônica no ensino de } \\
\text { Língua Portuguesa, para que os alunos } \\
\text { possam construir novos conhecimentos e } \\
\text { produção de sentidos, e, como objetivo } \\
\text { específico apresentar o resultado de uma } \\
\text { proposta de sequiência didática de } \\
\text { aplicação do texto narrativo e do gênero } \\
\text { crônica, de forma mais comprometida } \\
\text { com o contexto escolar. A base teórica } \\
\text { que norteou esta pesquisa está nos } \\
\text { princípios da Lingüística Textual a tem } \\
\text { por tema uma proposta de utilização do } \\
\text { gênero crônica em sala de aula com o } \\
\text { apoio do texto narrativo. O trabalho } \\
\text { atém-se em analisar as crônicas } \\
\text { produzidas pelos alunos da } 6^{\text {a }} \text { série do } \\
\text { Ensino Fundamental, utilizando uma } \\
\text { ficha de avaliação, que propõe uma } \\
\text { melhor verificação do processo de } \\
\text { ensino-aprendizagem por meio do } \\
\text { refazimento do texto [...]" }\end{array}$ & Não \\
\hline $\begin{array}{l}\text { Ensino } \\
\text { Fundamental } \\
\text { II }\end{array}$ & $\begin{array}{l}\text { IES } \\
\text { Particular/SP }\end{array}$ & $\begin{array}{l}\text { "O objetivo dessa pesquisa foi } \\
\text { compreender o uso do livro didático de } \\
\text { português na relação que com ele } \\
\text { estabeleceram professoras dos quatro } \\
\text { anos finais do Ensino Fundamental. [...] } \\
\text { Considerando a teoria crítica do } \\
\text { currículo e a classificação dos livros } \\
\text { didáticos no Programa Nacional do } \\
\text { Livro Didático de } 2002 \text { (PNLD/2002), } \\
\text { foram analisados os discursos sobre a } \\
\text { prática docente no uso do livro didático } \\
\text { presentes nos relatórios de estágio de } \\
\text { observação dos alunos de licenciatura } \\
\text { em português da Faculdade de Educação } \\
\text { da Universidade de São Paulo (FEUSP) } \\
\text { e os discursos das professoras } \\
\text { observadas, concedidas por meio de } \\
\text { entrevistas." }\end{array}$ & Não \\
\hline $\begin{array}{l}\text { Ensino } \\
\text { Fundamental } \\
\text { II }\end{array}$ & $\begin{array}{l}\text { IES } \\
\text { Particular/SP }\end{array}$ & $\begin{array}{l}\text { "O presente estudo tem como objetivo } \\
\text { abordar o texto publicitário no livro } \\
\text { didático de Português, avaliar a } \\
\text { funcionalidade desses textos na } \\
\text { formação da competência leitora nos } \\
\text { alunos da } 7^{\mathrm{a}} \text { (sétima) série do Ensino } \\
\text { Fundamental." }\end{array}$ & Sim \\
\hline $\begin{array}{l}\text { Ensino } \\
\text { Fundamental } \\
\text { /Ensino } \\
\text { Médio }\end{array}$ & $\begin{array}{l}\text { IES } \\
\text { Particular/RS }\end{array}$ & $\begin{array}{l}\text { "Esta dissertação versa sobre as vozes } \\
\text { verbais, utilizando a Teoria da Regência } \\
\text { e Ligação, proposta por Chomsky } \\
\text { (1981), que fornecerá subsídios para a } \\
\text { análise de conceitos e exemplos trazidos } \\
\text { por quatro gramáticas do Português } \\
\text { Brasileiro amplamente adotadas pelos } \\
\text { falantes brasileiros, especialmente por } \\
\text { alunos e professores de escolas de } \\
\text { Ensino Fundamental e Médio". }\end{array}$ & Sim \\
\hline $\begin{array}{l}\text { Ensino } \\
\text { Médio }\end{array}$ & $\begin{array}{l}\text { IES } \\
\text { Estadual/SP }\end{array}$ & $\begin{array}{l}\text { "Trata-se de um estudo exploratório de } \\
\text { natureza qualitativa e quantitativa para } \\
\text { minimizar o poder de alguns mitos } \\
\text { existentes na escola, entre eles: 'ensinar } \\
\text { língua portuguesa equivale a ensinar } \\
\text { gramática', que pressupõem uma série } \\
\text { de atividades voltadas para um 'aluno } \\
\text { ideal'. Nesse sentido, investigar-se-á, }\end{array}$ & Sim \\
\hline
\end{tabular}




\begin{tabular}{|c|c|c|c|}
\hline & & $\begin{array}{l}\text { por meio da análise do discurso, as } \\
\text { representações sobre norma gramatical } \\
\text { que povoam o imaginário dos alunos do } \\
\text { ensino médio e a auto-avaliação desses } \\
\text { alunos sobre suas produções escritas." }\end{array}$ & \\
\hline $\begin{array}{l}\text { Ensino } \\
\text { Médio }\end{array}$ & $\begin{array}{l}\text { IES Federal/ } \\
\text { DF }\end{array}$ & $\begin{array}{l}\text { "A profusão de imagens, nas práticas de } \\
\text { escrita, abriu espaço para mudanças do } \\
\text { discurso, colocando em evidência a } \\
\text { linguagem visual. Hoje em dia, os textos } \\
\text { requerem além de aparato tecnológico, } \\
\text { cores variadas e sofisticados recursos } \\
\text { visuais. Entram em alta os textos } \\
\text { multimodais, ou seja, aqueles que } \\
\text { empregam duas ou mais modalidades } \\
\text { semióticas em sua composição. A } \\
\text { presença de textos compostos pelas } \\
\text { modalidades verbal e visual no livro } \\
\text { didático de Português motivou-me a } \\
\text { desenvolver pesquisa sobre o assunto. } \\
\text { Então surgiu o objetivo deste trabalho: } \\
\text { analisar, sob a perspectiva da Análise de } \\
\text { Discurso Crítica (ADC) e da Teoria da } \\
\text { Semiótica Social, a forma como a } \\
\text { multimodalidade dos textos é explorada } \\
\text { nos livros didáticos de Português do } \\
\text { Ensino Médio selecionados para análise, } \\
\text { de forma a conduzir ou não os alunos à } \\
\text { interpretação de todos os modos } \\
\text { semióticos presentes no texto." }\end{array}$ & Sim \\
\hline $\begin{array}{l}\text { Ensino } \\
\text { Médio }\end{array}$ & $\begin{array}{l}\text { IES } \\
\text { Particular/SP }\end{array}$ & $\begin{array}{l}\text { "A pesquisa empírica aqui relatada tem } \\
\text { por objetivo caracterizar o perfil (dados } \\
\text { pessoais, familiares, sócio-econômicos, } \\
\text { culturais, trajetória de formação e } \\
\text { experiência profissional) de } 60 \text { (de um } \\
\text { total de aproximadamente 200) } \\
\text { professores de Língua Portuguesa do } \\
\text { atual Ensino Médio, atuantes em escolas } \\
\text { públicas estaduais da periferia do } \\
\text { município de São Paulo vinculadas à } \\
\text { Diretoria Regional de Ensino Sul 1, } \\
\text { desta Capital, e a visão que expressam } \\
\text { dos conteúdos postos em ação em suas } \\
\text { aulas, ou seja, do trabalho que realizam } \\
\text { para desenvolver o conhecimento } \\
\text { lingüístico necessário aos alunos deste } \\
\text { segmento de ensino." }\end{array}$ & $\mathrm{Sim}$ \\
\hline $\begin{array}{l}\text { Ensino } \\
\text { Médio }\end{array}$ & $\begin{array}{l}\text { IES } \\
\text { Particular/SP }\end{array}$ & $\begin{array}{l}\text { "Este estudo insere-se na linha de } \\
\text { pesquisa de Leitura, Escrita e Ensino de } \\
\text { Língua Portuguesa e tem como tema a } \\
\text { produção de textos dissertativo- } \\
\text { argumentativos no } 1 .^{\circ} \text { ano do Ensino } \\
\text { Médio. Nosso objetivo é verificar } \\
\text { problemas relacionados ao uso dos } \\
\text { princípios de textualidade: coesão e } \\
\text { coerência e ao emprego da } \\
\text { superestrutura, à luz dos pressupostos } \\
\text { teóricos de estudiosos da Lingüística } \\
\text { Textual, numa perspectiva } \\
\text { sociocognitivo-interacional." }\end{array}$ & $\mathrm{Sim}$ \\
\hline $\begin{array}{l}\text { Exame } \\
\text { Vestibular }\end{array}$ & IES Federal/RN & $\begin{array}{l}\text { "Nesta dissertação, analisamos os } \\
\text { processos argumentativos do texto } \\
\text { escrito de vestibulandos, tendo, como } \\
\text { corpus, redações do Concurso Vestibular } \\
\text { da UFRN (Universidade Federal do Rio } \\
\text { Grande do Norte) da área de } \\
\text { Humanística, feitas "em respostas à } \\
\text { quinta questão da prova discursiva de }\end{array}$ & $\mathrm{Sim}$ \\
\hline
\end{tabular}




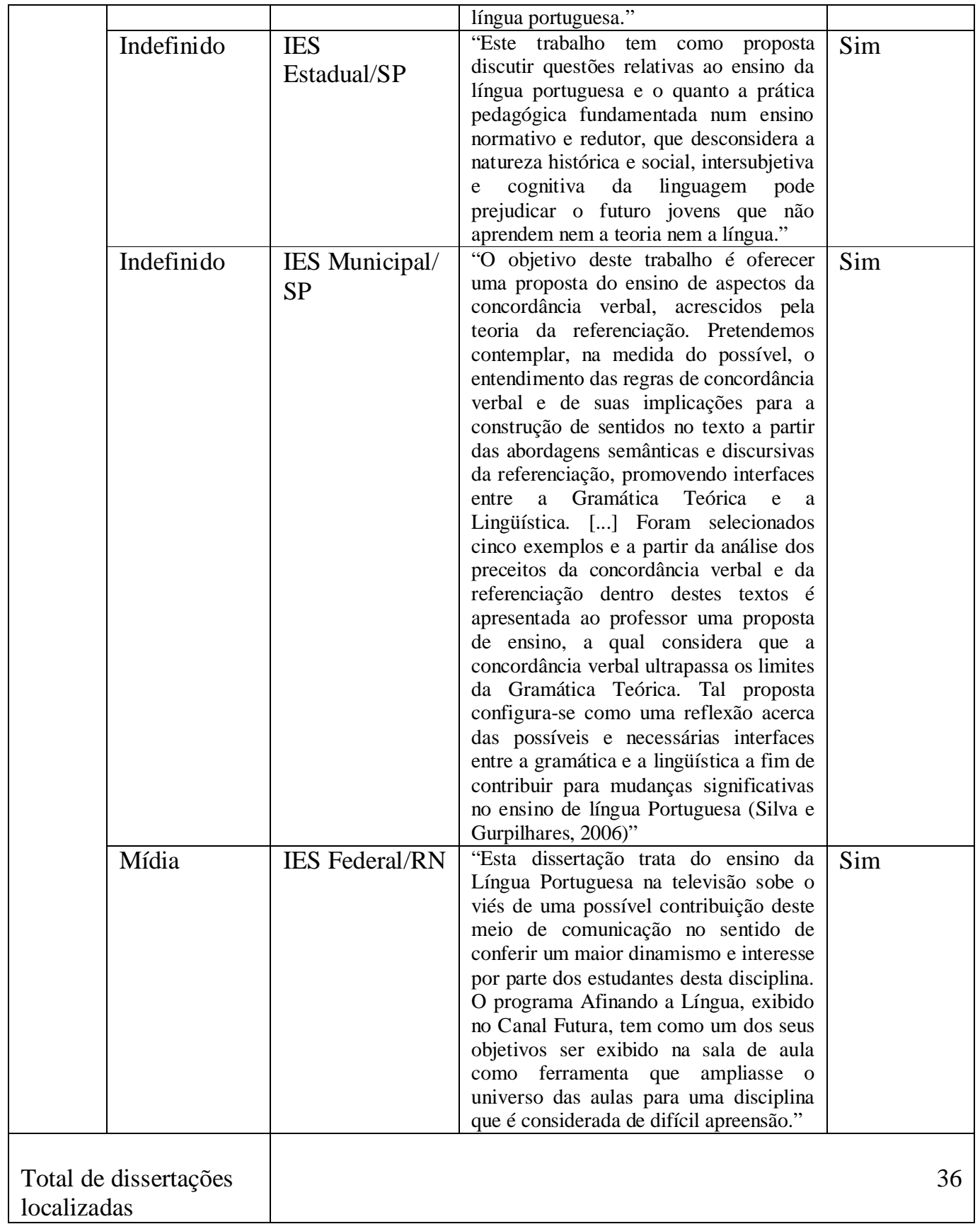

\begin{tabular}{|c|l|l|l|l|}
\hline $\begin{array}{l}\text { Ano } \\
\text { de } \\
\text { defesa }\end{array}$ & $\begin{array}{l}\text { Contexto } \\
\text { pesquisado }\end{array}$ & $\begin{array}{l}\text { Vínculo } \\
\text { administrativo } \\
\text { /Localização }\end{array}$ & $\begin{array}{l}\text { Transcrição parcial dos } \\
\text { resumos }\end{array}$ & $\begin{array}{l}\text { Disponível } \\
\text { on-line }\end{array}$ \\
\hline 2007 & $\begin{array}{l}\text { Antiga } \\
\text { Educação }\end{array}$ & $\begin{array}{l}\text { IES } \\
\text { Particular/SP }\end{array}$ & $\begin{array}{l}\text { "Esta dissertação situa-se na linha de } \\
\text { pesquisa História e Descrição da Língua } \\
\text { Portuguesa. Tem por tema as reformas } \\
\text { dos programas de Língua Portuguesa do } \\
\text { final do século XIX e início do século } \\
\text { XX, e, por objeto de estudo, os } \\
\text { Programas Oficiais da Grade Curricular } \\
\text { de Língua Portuguesa entre os anos de } \\
1882 \text { a 1912 do curso secundário do }\end{array}$ & \\
& & & & \\
\hline
\end{tabular}




\begin{tabular}{|c|c|c|c|}
\hline & & $\begin{array}{l}\text { Colégio Pedro II (RJ). O objetivo deste } \\
\text { trabalho é examinar os programas de } \\
\begin{array}{l}\text { Língua Portuguesa } \\
\text { delimitado." }\end{array}\end{array}$ & \\
\hline $\begin{array}{l}\text { Antiga } \\
\text { Educação } \\
\text { Escolar }\end{array}$ & IES Federal/BA & $\begin{array}{l}\text { "Esta dissertação pretende identificar o } \\
\text { grau de interferência do processo de } \\
\text { escolarização na constituição da norma } \\
\text { culta do português brasileiro, } \\
\text { considerando, por um lado, o papel da } \\
\text { escola como condutora da padronização } \\
\text { lingüística e, por outro, o número de } \\
\text { indivíduos que teve acesso à instrução } \\
\text { pública, na Bahia, na segunda metade do } \\
\text { século XIX, momento de profundas } \\
\text { transformações na sociedade baiana, } \\
\text { com a abolição da escravatura e a } \\
\text { implantação do regime republicano. [...] } \\
\text { Os dados expostos neste trabalho foram } \\
\text { levantados em documentos oficiais e } \\
\text { não-oficiais, identificando-se os } \\
\text { conteúdos ensinados e os métodos } \\
\text { utilizados no ensino de língua } \\
\text { portuguesa, bem como índices } \\
\text { relacionados à população escolar e ao } \\
\text { sistema de ensino." }\end{array}$ & Sim \\
\hline $\begin{array}{l}\text { Contexto } \\
\text { Bilíngue }\end{array}$ & IES Federal/PR & $\begin{array}{l}\text { "A presente pesquisa teve como objetivo } \\
\text { verificar o domínio da escrita no } \\
\text { português do Brasil em crianças } \\
\text { bilíngües francês-português. Os sujeitos } \\
\text { são } 12 \text { crianças com idade entre } 6 \text { e } 11 \\
\text { anos, de língua materna francesa e que } \\
\text { estudam em uma escola francesa situada } \\
\text { dentro das instalações de uma escola } \\
\text { particular em Curitiba." }\end{array}$ & Sim \\
\hline $\begin{array}{l}\text { Educação } \\
\text { Básica }\end{array}$ & $\begin{array}{l}\text { IES } \\
\text { Estadual/PR }\end{array}$ & $\begin{array}{l}\text { "Esta pesquisa qualitativo-etnográfica } \\
\text { investigou a abordagem que três } \\
\text { diferentes coleções didáticas fazem do } \\
\text { gênero texto publicitário. [...] } \\
\text { Primeiramente, realizou-se um estudo } \\
\text { minucioso das propostas dos Parâmetros } \\
\text { Curriculares Nacionais para o ensino de } \\
\text { língua portuguesa. Depois, estudou-se o } \\
\text { que cada livro didático abordou em } \\
\text { relação ao trabalho com textos do gênero } \\
\text { publicitário, considerando os quatro } \\
\text { eixos: leitura - produção - oralidade - } \\
\text { análise lingüística. Em seguida, passou- } \\
\text { se à análise dos capítulos relacionados } \\
\text { ao gênero, comparando-os com a teoria } \\
\text { esboçada no Manual do professor, a fim } \\
\text { de detectar se ela efetivamente se } \\
\text { concretizava nas propostas de atividades. } \\
\text { Percebidas as virtudes e os equívocos } \\
\text { presentes nos capítulos, realizou-se uma } \\
\text { entrevista com os professores que } \\
\text { utilizam os livros didáticos analisados } \\
\text { em suas salas de aula, para constatar se } \\
\text { os equívocos são percebidos pelos } \\
\text { docentes e para diagnosticar o que eles } \\
\text { fazem para suprir as lacunas deixadas } \\
\text { pelo livro didático." }\end{array}$ & Sim \\
\hline $\begin{array}{l}\text { Educação } \\
\text { Básica }\end{array}$ & $\begin{array}{l}\text { IES } \\
\text { Estadual/SP }\end{array}$ & $\begin{array}{l}\text { "Esta dissertação pretende, a partir de } \\
\text { uma revisão de literatura e da análise dos } \\
\text { dados coletados pelos alunos da } \\
\text { disciplina de Metodologia do Ensino de } \\
\text { Língua Portuguesa da Universidade de } \\
\text { São Paulo, colocar em pauta algumas }\end{array}$ & Não \\
\hline
\end{tabular}




\begin{tabular}{|c|c|c|c|}
\hline & & $\begin{array}{l}\text { questões relativas ao trabalho de leitura } \\
\text { na escola e ao papel da biblioteca escolar } \\
\text { na formação do leitor literário nos dias } \\
\text { de hoje." }\end{array}$ & \\
\hline $\begin{array}{l}\text { Educação } \\
\text { Básica }\end{array}$ & $\begin{array}{l}\text { IES } \\
\text { Federal/MS }\end{array}$ & $\begin{array}{l}\text { "[...] o objetivo desta dissertação é } \\
\text { analisar o tratamento dado à } \\
\text { concordância nominal em três livros } \\
\text { didáticos publicados antes e após a } \\
\text { 'criação' dos PCN para verificar se } \\
\text { houve mudanças, ou seja, se a proposta } \\
\text { dos referenciais de analisar a linguagem } \\
\text { em uso e realizar um trabalho reflexivo } \\
\text { sobre a língua está contribuindo para } \\
\text { uma remodelagem dos livros." }\end{array}$ & Não \\
\hline $\begin{array}{l}\text { Educação } \\
\text { Básica }\end{array}$ & $\begin{array}{l}\text { IES } \\
\text { Federal/MS }\end{array}$ & $\begin{array}{l}\text { "Sob o crivo das asserções legadas aos } \\
\text { estudos críticos da linguagem e, em } \\
\text { especial, aos que concebem ao discurso, } \\
\text { este texto propõe-se construir um espaço } \\
\text { de 'confronto' entre lingüistas e } \\
\text { gramáticos, a fim de analisar esse } \\
\text { polêmico, inquieto e ainda novo } \\
\text { relacionamento - que sustenta as } \\
\text { implicações acerca dos estudos da língua } \\
\text {-, além de aspectos do status da } \\
\text { gramática normativa no ensino de língua } \\
\text { portuguesa. Para alcançar a meta, esta } \\
\text { pesquisa ocupa-se do exame } \\
\text { pretensamente dialógico dos textos: } \\
\text { 'Emitia no Pais da Gramática', de } \\
\text { Monteiro Lobato, 'A Língua de Eulália', } \\
\text { de Marcos Bagno, e o documento } \\
\text { 'Parâmetros Curriculares Nacionais' } \\
\text { (BRASIL. 1998). Essa intencionalidade } \\
\text { reclama, pois, a investigação dos } \\
\text { caminhos que percorrem os textos em } \\
\text { questão, pata a absorção das } \\
\text { possibilidades de sentidos com que essas } \\
\text { obras trabalham, a produção dos } \\
\text { discursos que veiculam, a fim de } \\
\text { desvendar o como e o do quê eles se } \\
\text { constituem." }\end{array}$ & Não \\
\hline $\begin{array}{l}\text { Educação } \\
\text { Básica }\end{array}$ & IES Federal/PR & $\begin{array}{l}\text { "Este trabalho analisa o debate em torno } \\
\text { dos conceitos de norma lingüística e a } \\
\text { preocupação com o ensino de língua } \\
\text { portuguesa. [...] A intenção inicial é } \\
\text { mostrar o contexto do debate normativo } \\
\text { e sua relevância para o ensino de língua } \\
\text { portuguesa. O segundo capítulo } \\
\text { desenvolve os principais conceitos que } \\
\text { envolvem as reflexões sobre a norma e } \\
\text { de que forma isso chega a interferir na } \\
\text { escola. O capítulo final realiza o } \\
\text { segundo objetivo da dissertação, que é, a } \\
\text { partir das idéias sobre linguagem } \\
\text { desenvolvidas por Bakhtin-Volochínov, } \\
\text { propor uma leitura discursiva do debate } \\
\text { em torno da norma lingüística e sua } \\
\text { interferência no ensino de língua } \\
\text { materna." }\end{array}$ & Sim \\
\hline $\begin{array}{l}\text { Educação } \\
\text { Básica }\end{array}$ & IES Federal/SP & $\begin{array}{l}\text { "Esta dissertação pretende analisar sob a } \\
\text { ótica dos professores de Língua } \\
\text { Portuguesa como está o ensino da } \\
\text { disciplina junto aos jovens. Isso porque é } \\
\text { notório que com o advento da Internet } \\
\text { foi instalada na sociedade atual uma } \\
\text { nova forma de linguagem, o Internetês. } \\
\text { No entanto, o Internetês não é um fato }\end{array}$ & Não \\
\hline
\end{tabular}




\begin{tabular}{|c|c|c|c|}
\hline & & $\begin{array}{l}\text { isolado. [..] Este trabalho pretende } \\
\text { avaliar em que medida o arrefecimento } \\
\text { da educação está sob influências do } \\
\text { fortalecimento dos veículos de } \\
\text { comunicação de massa na sociedade, } \\
\text { especialmente a Internet". }\end{array}$ & \\
\hline $\begin{array}{l}\text { Educação } \\
\text { Básica }\end{array}$ & $\begin{array}{l}\text { IES } \\
\text { Particular/SP }\end{array}$ & $\begin{array}{l}\text { "Escolhemos, como corpus, as narrativas } \\
\text { de enigma 'O inimigo Secreto', de Caio } \\
\text { Fernando de Abreu; 'A Sombra', de } \\
\text { Coelho Neto; e 'Os idos de Março', de } \\
\text { Luís Martins. Fizemos essa opção } \\
\text { baseados no fato de que textos } \\
\text { desafiantes que se apresentam } \\
\text { ludicamente como jogos facilitam o } \\
\text { ensino e a aprendizagem de estratégias } \\
\text { de leitura. Para o desenvolvimento de } \\
\text { nossa investigação, elaboramos - à luz } \\
\text { de teóricos da Lingüística Textual e da } \\
\text { Teoria do Processamento do Discurso - } \\
\text { as seguintes perguntas de pesquisa: que } \\
\text { estratégias de processamento textual } \\
\text { orientam o leitor na construção dos } \\
\text { sentidos e como essas estratégias podem } \\
\text { contribuir para a formação de leitores } \\
\text { independentes em sala de aula." }\end{array}$ & $\mathrm{Sim}$ \\
\hline $\begin{array}{l}\text { Educação } \\
\text { Básica }\end{array}$ & $\begin{array}{l}\text { IES } \\
\text { Particular/SP }\end{array}$ & $\begin{array}{l}\text { "A presente dissertação situa-se na linha } \\
\text { de pesquisa Leitura, Escrita e Ensino de } \\
\text { Língua Portuguesa e tem como tema a } \\
\text { construção de sentidos na leitura de } \\
\text { crônicas, investigando a importância, } \\
\text { para esse processo, dos conhecimentos } \\
\text { prévios, do princípio de intertextualidade } \\
\text { e dos conteúdos pressupostos. Partindo } \\
\text { do pressuposto de que tais elementos } \\
\text { constituem estratégias facilitadoras da } \\
\text { construção de sentidos na leitura, e tendo } \\
\text { como corpus quatro crônicas, o trabalho } \\
\text { teve como objetivo a realização de um } \\
\text { estudo sobre a intertextualidade, os } \\
\text { conhecimentos prévios e os conteúdos } \\
\text { pressupostos nesse gênero de texto, } \\
\text { verificando como eles atuam no } \\
\text { processo de interação entre o leitor e o } \\
\text { texto. O trabalho se justificou pela } \\
\text { importância conferida pelos PCN ao } \\
\text { trabalho com a diversidade de gêneros } \\
\text { textuais, entre os quais destacamos a } \\
\text { crônica, enfocando a participação ativa } \\
\text { do leitor, enfatizando a formação de um } \\
\text { leitor crítico conforme preconizam os } \\
\text { PCN." }\end{array}$ & $\mathrm{Sim}$ \\
\hline $\begin{array}{l}\text { Educação } \\
\text { Básica }\end{array}$ & $\begin{array}{l}\text { IES } \\
\text { Particular/SP }\end{array}$ & $\begin{array}{l}\text { "O presente trabalho apresenta um } \\
\text { panorama do uso de atividades lúdicas } \\
\text { no ensino e aprendizagem de Língua } \\
\text { Portuguesa e enfatiza o uso de jogos e } \\
\text { brincadeiras na escola, com o intuito de } \\
\text { aumentar o conhecimento das crianças } \\
\text { acerca de sua língua-mãe e de seus } \\
\text { papéis no seio da sociedade em que } \\
\text { vivem." }\end{array}$ & $\mathrm{Sim}$ \\
\hline $\begin{array}{l}\text { Educação } \\
\text { Básica }\end{array}$ & $\begin{array}{l}\text { IES } \\
\text { Particular/SP }\end{array}$ & $\begin{array}{l}\text { "Com o foco na organização do texto } \\
\text { expositivo-argumentativo, na } \\
\text { perspectiva da educação lingüística, } \\
\text { [esta dissertação] tem por objetivo } \\
\text { verificar a aplicabilidade de teorias } \\
\text { lingüísticas e da educação na prática } \\
\text { pedagógica, tendo em vista examinar o }\end{array}$ & $\mathrm{Sim}$ \\
\hline
\end{tabular}




\begin{tabular}{|c|c|c|c|}
\hline & & $\begin{array}{l}\text { procedimento metodológico de ensino de } \\
\text { professores de língua materna da Rede } \\
\text { Pública, para a estruturação deste mesmo } \\
\text { texto. [...] O material de análise foi } \\
\text { coletado por questionário, aplicado a } \\
\text { professores de língua materna e os } \\
\text { resultados obtidos indicaram que a } \\
\text { interação, entre os conhecimentos dados } \\
\text { e novos contribui para a ampliação do } \\
\text { repertório lingüístico de educandos, mas } \\
\text { não é suficiente para construir } \\
\text { competências, relativas à apreensão e } \\
\text { uso eficazes das categorias lingüísticas, } \\
\text { estruturantes do texto expositivo- } \\
\text { argumentativo". }\end{array}$ & \\
\hline $\begin{array}{l}\text { Educação } \\
\text { Básica / } \\
\text { Educação } \\
\text { Superior }\end{array}$ & IES Federal/BA & $\begin{array}{l}\text { "A partir do referencial teórico e } \\
\text { metodológico da Análise de Discurso de } \\
\text { linha francesa, o trabalho de pesquisa } \\
\text { consistiu na constituição e análise de um } \\
\text { corpus formado por respostas de } \\
\text { professores de Língua Portuguesa do } \\
\text { ensino básico, graduados em Letras no } \\
\text { Campus V da UNEB, de Santo Antônio } \\
\text { de Jesus, de alunos recém-ingressos } \\
\text { nesse curso de Letras, e de professores } \\
\text { do magistério superior em atuação no } \\
\text { mesmo campus e curso, a um formulário } \\
\text { contendo três questões: 'O que é } \\
\text { conteúdo de ensino-aprendizagem da } \\
\text { disciplina Língua Portuguesa? Que } \\
\text { conteúdo ensinar em Língua Portuguesa } \\
\text { e por que ensiná-lo? De que maneira o } \\
\text { conteúdo de Língua Portuguesa poderá } \\
\text { contribuir para a formação cidadã do } \\
\text { educando?"” }\end{array}$ & Não \\
\hline $\begin{array}{l}\text { Educação de } \\
\text { Jovens e } \\
\text { Adultos }\end{array}$ & IES Federal/PA & $\begin{array}{l}\text { "Este trabalho propõe-se a discutir sobre } \\
\text { os instrumentos didáticos utilizados em } \\
\text { práticas de ensino de textos narrativos. } \\
\text { Essa discussão consiste na descrição e } \\
\text { análise dos modos como o professor } \\
\text { utiliza tais instrumentos para } \\
\text { proporcionar aos alunos o encontro com } \\
\text { o objeto de ensino, levando-os a } \\
\text { apropriarem-se da capacidade de } \\
\text { produção de textos narrativos, } \\
\text { transformando, assim, o objeto de ensino } \\
\text { em objeto efetivamente ensinado. Nesse } \\
\text { contexto, o corpus de que nos ocupamos } \\
\text { decorre de entrevistas, questionários, } \\
\text { gravações em áudio e vídeo e anotações } \\
\text { em diário de campo sobre as aulas de } \\
\text { língua portuguesa observadas no } \\
\text { segundo semestre do ano letivo de } 2006 \text {. } \\
\text { A coleta de dados aconteceu em uma } \\
\text { turma de } 4^{a} \text { etapa da Educação de Jovens } \\
\text { e Adultos de uma escola pública da } \\
\text { periferia da cidade de Castanhal no } \\
\text { Pará". }\end{array}$ & Sim \\
\hline $\begin{array}{l}\text { Educação } \\
\text { Superior }\end{array}$ & IES Federal/DF & $\begin{array}{l}\text { "Esta dissertação descreve e analisa, sob } \\
\text { uma perspectiva variacionista, as } \\
\text { estratégias de relativização de sintagmas } \\
\text { preposicionais do português brasileiro. } \\
\text { Nos propomos a averiguar a ocorrência e } \\
\text { a frequiência de usos [- padrão] desses } \\
\text { processos em contextos de alto grau de } \\
\text { monitoramento estilístico, tendo como } \\
\text { informantes professores com formação }\end{array}$ & Sim \\
\hline
\end{tabular}




\begin{tabular}{|c|c|c|c|}
\hline & & $\begin{array}{l}\text { universitária e estudantes do curso de } \\
\text { Letras em fase de conclusão do } \\
\text { curso.[...] O perfil sociocultural dos } \\
\text { informantes pode levar a fatores } \\
\text { condicionadores da 'escolha' de uma } \\
\text { variante em vez de outra, trazendo } \\
\text { implicações para o ensino de língua } \\
\text { portuguesa nas escolas brasileiras" }\end{array}$ & \\
\hline $\begin{array}{l}\text { Educação } \\
\text { Superior }\end{array}$ & $\begin{array}{l}\text { IES } \\
\text { Particular/SP }\end{array}$ & $\begin{array}{l}\text { "Esta dissertação trata do ensino de } \\
\text { Língua Portuguesa em cursos de } \\
\text { graduação em tecnologia, abordando-se } \\
\text { estudos da leitura e compreensão de } \\
\text { textos à luz da Ciência Cognitiva e da } \\
\text { Lingüística Textual como ferramentas } \\
\text { pedagógicas de apoio à prática docente." }\end{array}$ & Não \\
\hline $\begin{array}{l}\text { Educação } \\
\text { Superior }\end{array}$ & $\begin{array}{l}\text { IES } \\
\text { Particular/SP }\end{array}$ & $\begin{array}{l}\text { "Esta Dissertação insere-se na Linha de } \\
\text { Pesquisa Leitura, escrita e ensino de } \\
\text { Língua Portuguesa e tem por objetivo } \\
\text { fazer um estudo sobre o resumo } \\
\text { acadêmico. Para tanto, recorremos à } \\
\text { literatura especializada para esclarecer } \\
\text { aspectos concernentes à conceitualização } \\
\text { desse gênero textual, suas características } \\
\text { e princípios de elaboração. Aos } \\
\text { fundamentos teóricos adotados } \\
\text { articulamos a análise de dezenove } \\
\text { resumos produzidos por estudantes do } \\
\text { VI semestre do Curso de Letras de uma } \\
\text { faculdade da rede particular de ensino da } \\
\text { capital de São Paulo, com o intuito de } \\
\text { verificar em que medida resumos } \\
\text { produzidos por acadêmicos estão em } \\
\text { consonância com os princípios de } \\
\text { elaboração apontados." }\end{array}$ & Não \\
\hline $\begin{array}{l}\text { Ensino } \\
\text { Fundamental }\end{array}$ & $\begin{array}{l}\text { IES } \\
\text { Estadual/PR }\end{array}$ & $\begin{array}{l}\text { "A categoria de gênero caracteriza-se } \\
\text { pela divisão dos nomes em classes. Na } \\
\text { língua portuguesa os nomes estão } \\
\text { agrupados, quanto ao gênero, na } \\
\text { dicotomia masculino/feminino, porém há } \\
\text { uma tendência a se pensar em gênero por } \\
\text { meio da diferença entre o sexo } \\
\text { masculino e o sexo feminino, idéia frágil } \\
\text { e parcial que resulta em confusão } \\
\text { conceitual. Tendo esse fato como ponto } \\
\text { de partida e destacando a importância da } \\
\text { intervenção escolar no processo de } \\
\text { tomada de consciência que permite a } \\
\text { compreensão adequada de um conceito, } \\
\text { este trabalho propõe-se a investigar a } \\
\text { compreensão do conceito de gênero } \\
\text { gramatical por parte de alunos do Ensino } \\
\text { Fundamental." }\end{array}$ & $\mathrm{Sim}$ \\
\hline $\begin{array}{l}\text { Ensino } \\
\text { Fundamental } \\
\text { I }\end{array}$ & $\begin{array}{l}\text { IES Federal/ } \\
\text { PA }\end{array}$ & $\begin{array}{l}\text { "Nesta dissertação de mestrado, } \\
\text { objetivamos investigar a relação entre o } \\
\text { professor e o livro didático na } 4^{\mathrm{a}} \text { série do } \\
\text { ensino fundamental em seis escolas } \\
\text { públicas, localizadas na cidade de } \\
\text { Belém. Para tanto, buscamos perceber } \\
\text { quais critérios adotados na seleção, quais } \\
\text { objetos de ensino evidenciados no livro e } \\
\text { nas aulas de língua portuguesa, quais } \\
\text { seções usadas e quais estratégias } \\
\text { instauradas pelas professoras no } \\
\text { momento em que usam o livro didático." }\end{array}$ & $\mathrm{Sim}$ \\
\hline $\begin{array}{l}\text { Ensino } \\
\text { Fundamental }\end{array}$ & $\begin{array}{l}\text { IES Municipal/ } \\
\text { SP }\end{array}$ & $\begin{array}{l}\text { "A orientação para o ensino de Língua } \\
\text { Portuguesa fundamentada, em parte, na } \\
\text { teoria dos gêneros discursivos já é }\end{array}$ & Sim \\
\hline
\end{tabular}




\begin{tabular}{|c|c|c|c|}
\hline I & & $\begin{array}{l}\text { bastante difundida no meio acadêmico e } \\
\text { tem despertado o interesse de } \\
\text { professores, porém, esses profissionais } \\
\text { ainda se encontram carentes tanto de } \\
\text { fundamentação teórica quanto de } \\
\text { exemplos práticos. Partindo desse } \\
\text { quadro, a presente pesquisa apresenta } \\
\text { dois objetivos, sendo o primeiro a } \\
\text { criação de uma sequiência didática por } \\
\text { meio da qual se pretende desenvolver a } \\
\text { compreensão e a produção do gênero } \\
\text { textual fábula por alunos do segundo } \\
\text { ciclo do ensino fundamental. Como } \\
\text { segundo objetivo, este trabalho busca } \\
\text { investigar as capacidades de linguagem } \\
\text { trabalhadas em cada dos exercícios } \\
\text { constitutivas da seqüência em questão." }\end{array}$ & \\
\hline $\begin{array}{l}\text { Ensino } \\
\text { Fundamental } \\
\text { II }\end{array}$ & $\begin{array}{l}\text { IES } \\
\text { Estadual/SP }\end{array}$ & $\begin{array}{l}\text { "Esta dissertação pretende, mediante a } \\
\text { análise de livros didáticos aprovados } \\
\text { pelo PNLD } 2005 \text { - Plano Nacional do } \\
\text { Livro Didático, trazer à luz discussões a } \\
\text { respeito dos gêneros narrativos } \\
\text { ficcionais nas escolas hoje. [...] Com a } \\
\text { discussão teórica sobre a presença dos } \\
\text { gêneros do discurso e tipos de texto nos } \\
\text { documentos oficiais e livros didáticos e a } \\
\text { análise do livro didático de Português } \\
\text { para o Ensino Fundamental II, } \\
\text { pretendemos levantar questões sobre a } \\
\text { importância da produção do texto } \\
\text { narrativo ficcional na escola hoje." }\end{array}$ & Não \\
\hline $\begin{array}{l}\text { Ensino } \\
\text { Fundamental } \\
\text { II }\end{array}$ & $\begin{array}{l}\text { IES } \\
\text { Estadual/SP }\end{array}$ & $\begin{array}{l}\text { "Em consonância com os pressupostos } \\
\text { teóricos mais atuais para o ensino de } \\
\text { Língua Portuguesa que favorece uma } \\
\text { postura reflexiva em relação à } \\
\text { linguagem, esta dissertação pretende } \\
\text { verificar como o material didático } \\
\text { adotado para a } 7^{\mathrm{a}} \text { série do Ensino } \\
\text { Fundamental aborda os conceitos de } \\
\text { gêneros discursivos." }\end{array}$ & Sim \\
\hline $\begin{array}{l}\text { Ensino } \\
\text { Fundamental } \\
\text { II }\end{array}$ & IES Federal/AL & $\begin{array}{l}\text { "Considerando mais especificamente a } \\
\text { prática da leitura no ensino fundamental, } \\
\text { esta dissertação trata da questão da } \\
\text { mediação do professor em aulas de } \\
\text { leitura em língua portuguesa em turmas } \\
\text { de } 5^{\text {a }} \text { série de duas escolas municipais da } \\
\text { cidade de Arapiraca, AL. O trabalho teve } \\
\text { como objetivo analisar a qualidade da } \\
\text { mediação do professor nas interações } \\
\text { ocorridas durante as práticas de leitura } \\
\text { em sala de aula." }\end{array}$ & Não \\
\hline $\begin{array}{l}\text { Ensino } \\
\text { Fundamental } \\
\text { II }\end{array}$ & IES Federal/CE & $\begin{array}{l}\text { "Este estudo decorre de inquietações } \\
\text { provindas de nossa reflexão acerca do } \\
\text { tratamento dado à variação lingüística no } \\
\text { ensino de Língua Portuguesa na } 8^{\text {a }} \text { série } \\
\text { do Ensino Fundamental da escola } \\
\text { pública de Fortaleza. Levando em conta } \\
\text { que os Parâmetros Curriculares } \\
\text { Nacionais - PCN abordam a variação } \\
\text { lingüística, objetivamos estabelecer } \\
\text { inicialmente a correlação entre o que } \\
\text { trazem os PCN sobre o assunto com os } \\
\text { Referenciais Curriculares Básicos - } \\
\text { RCB. Em seguida buscamos estabelecer } \\
\text { a correlação do que vem nos documentos } \\
\text { oficiais com o que é expresso pela escola } \\
\text { em seu projeto político pedagógico - }\end{array}$ & Não \\
\hline
\end{tabular}




\begin{tabular}{|c|c|c|c|}
\hline & & $\begin{array}{l}\text { PPP e com as práticas que a mesma } \\
\text { desenvolve." }\end{array}$ & \\
\hline $\begin{array}{l}\text { Ensino } \\
\text { Fundamental } \\
\text { II }\end{array}$ & $\begin{array}{l}\text { IES } \\
\text { Federal/MT }\end{array}$ & $\begin{array}{l}\text { "O presente trabalho tem como objetivo } \\
\text { descrever a veiculação e uso de livros } \\
\text { didáticos de língua portuguesa, } \\
\text { articulados à história de carreiras } \\
\text { docentes, destinados ao Ensino } \\
\text { Fundamental, especialmente, à } 5^{\text {a }} \text { série, } \\
\text { no período de } 1970 \text { a } 2000 \text {, em Mato } \\
\text { Grosso." }\end{array}$ & Sim \\
\hline $\begin{array}{l}\text { Ensino } \\
\text { Fundamental } \\
\text { II }\end{array}$ & IES Federal/PB & 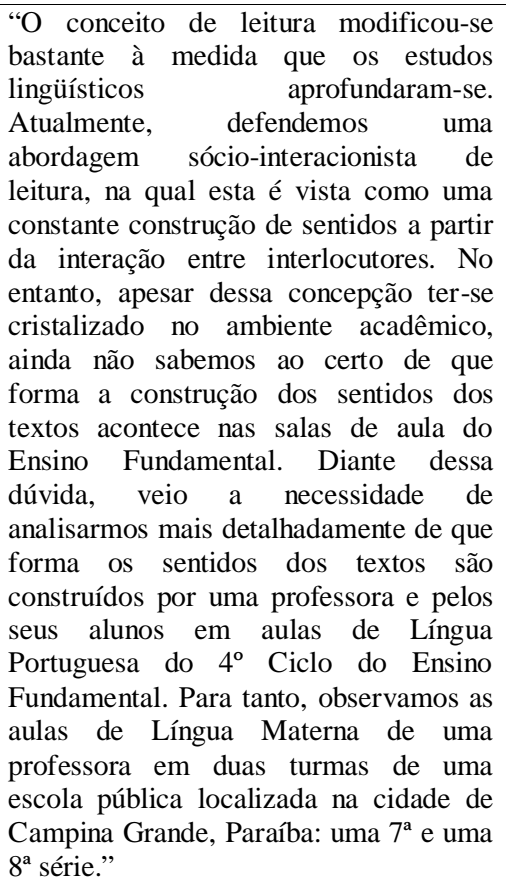 & Sim \\
\hline $\begin{array}{l}\text { Ensino } \\
\text { Fundamental } \\
\text { II }\end{array}$ & $\begin{array}{l}\text { IES Municipal/ } \\
\text { SP }\end{array}$ & $\begin{array}{l}\text { "A pesquisa faz uma caracterização da } \\
\text { Teledramaturgia como mega-gênero } \\
\text { discursivo e discute suas possíveis } \\
\text { aplicações, por meio da televisão, como } \\
\text { recurso de ensino-aprendizagem da } \\
\text { Leitura nas aulas de Língua Portuguesa } \\
\text { nos anos finais do ensino Fundamental. } \\
\text { [...]. Tem como objetivo geral investigar } \\
\text { como relacionar a linguagem televisiva } \\
\text { com a prática escolar para promover a } \\
\text { aprendizagem dos alunos, no sentido de } \\
\text { desenvolver uma metodologia de } \\
\text { trabalho interativa, dirigida para } \\
\text { relacionar, e tirar proveito para o ensino, } \\
\text { do discurso televisivo e como objetivo } \\
\text { específico, fazer a análise discursiva das } \\
\text { cenas constituintes de um capítulo da } \\
\text { telenovela 'Celebridade'." }\end{array}$ & Sim \\
\hline $\begin{array}{l}\text { Ensino } \\
\text { Fundamental } \\
\text { II }\end{array}$ & $\begin{array}{l}\text { IES Municipal/ } \\
\text { SP }\end{array}$ & $\begin{array}{l}\text { "A educação nas escolas brasileiras vem } \\
\text { atravessando um longo período de crise, } \\
\text { fruto de distorções e mal-entendidos } \\
\text { entre as diferentes políticas oficiais de } \\
\text { ensino, de intervenções nas práticas } \\
\text { pedagógicas nem sempre pautadas em } \\
\text { critérios bem definidos, da lentidão no } \\
\text { processo de produção de pesquisa e de } \\
\text { saberes na universidade e na sua } \\
\text { disponibilização aos professores que } \\
\text { atuam no ensino fundamental e médio e, } \\
\text { ainda, das dificuldades sociais, políticas } \\
\text { e econômicas que atingem o país e }\end{array}$ & Sim \\
\hline
\end{tabular}




\begin{tabular}{|c|c|c|c|}
\hline & & $\begin{array}{l}\text { afetam a clientela. Conscientes de que } \\
\text { essa crise atinge também a educação } \\
\text { lingüística e, em especial, o ensino da } \\
\text { gramática, procedemos a uma pesquisa } \\
\text { em escola pública com um grupo de } \\
\text { professores do ensino fundamental, com } \\
\text { o objetivo de conhecer-lhes as } \\
\text { representações docentes quanto ao } \\
\text { ensino da língua portuguesa, em especial } \\
\text { da gramática. [...] A pesquisa foi } \\
\text { realizada mediante um questionário, } \\
\text { sobre o trabalho docente com a } \\
\text { gramática da língua materna, proposto a } \\
15 \text { professores da rede municipal de } \\
\text { ensino da cidade de Lorena, interior de } \\
\text { São Paulo, que lecionam Língua } \\
\text { Portuguesa para as quatro últimas séries } \\
\text { do ensino fundamental." }\end{array}$ & \\
\hline $\begin{array}{l}\text { Ensino } \\
\text { Fundamental } \\
\text { II }\end{array}$ & $\begin{array}{l}\text { IES } \\
\text { Particular/SP }\end{array}$ & $\begin{array}{l}\text { "A presente Dissertação situa-se na linha } \\
\text { de pesquisa Leitura, Escrita e Ensino de } \\
\text { Língua Portuguesa e tem como tema a } \\
\text { interação pela linguagem em avaliações } \\
\text { de produções escritas no ensino } \\
\text { fundamental II, tendo em vista o ensino } \\
\text { e a aprendizagem da escrita. } \\
\text { Justificamos a escolha do tema pelo fato } \\
\text { de a avaliação de produções escritas ser } \\
\text { uma inquietação presente na prática } \\
\text { docente. O trabalho objetiva estudar as } \\
\text { estratégias lingüísticas de interação e as } \\
\text { marcas de subjetividade nas devolutivas } \\
\text { de avaliação do professor sobre a } \\
\text { produçãa escrita do aluno." }\end{array}$ & $\mathrm{Sim}$ \\
\hline $\begin{array}{l}\text { Ensino } \\
\text { Fundamental } \\
\text { /Ensino } \\
\text { Médio }\end{array}$ & $\begin{array}{l}\text { IES } \\
\text { Estadual/SP }\end{array}$ & $\begin{array}{l}\text { "Este trabalho teve como motivação a } \\
\text { situação atual do ensino de língua } \\
\text { portuguesa nas escolas, tida como } \\
\text { problemática especialmente no que diz } \\
\text { respeito ao ensino de gramática. } \\
\text { Verificou-se, a partir de entrevistas com } \\
\text { professores do Ensino Fundamental e } \\
\text { Médio e a partir da análise de diversos } \\
\text { manuais de gramática tradicional, que o } \\
\text { apego ao formalismo é um dos fatores } \\
\text { que limitam o ensino da língua que tem, } \\
\text { como objetivo principal, desenvolver as } \\
\text { habilidades comunicativas do aluno. [...] } \\
\text { O estudo focalizou as conjunçôes } \\
\text { QUANDO e ENQUANTO, mais } \\
\text { suscetíveis de receber outros valores } \\
\text { superpostos ao temporal. Espera-se que } \\
\text { este trabalho ofereça subsídios ao ensino } \\
\text { de língua portuguesa - nas questões } \\
\text { gramaticais - de forma a considerar seus } \\
\text { aspectos semânticos e pragmáticos, } \\
\text { incorporando a reflexão do do } \\
\text { funcionamento da língua em sala de } \\
\text { aula." }\end{array}$ & Sim \\
\hline $\begin{array}{l}\text { Ensino } \\
\text { Médio }\end{array}$ & $\begin{array}{l}\text { IES } \\
\text { Estadual/SP }\end{array}$ & $\begin{array}{l}\text { "Esta pesquisa foi realizada com o } \\
\text { objetivo de observar as propagandas } \\
\text { como aparecem no livro didático e de } \\
\text { que maneira as professoras de segunda e } \\
\text { terceira séries de língua portuguesa no } \\
\text { ensino médio do Colégio de Aplicação } \\
\text { da Universidade Federal de Viçosa } \\
\text { (CAP-COLUNI-UFV), } \\
\text { trabalhando esse gênero textual em suas } \\
\text { aulas." }\end{array}$ & Não \\
\hline
\end{tabular}




\begin{tabular}{|c|c|c|c|}
\hline $\begin{array}{l}\text { Ensino } \\
\text { Médio }\end{array}$ & IES Federal/BA & $\begin{array}{l}\text { "A globalização da educação deu } \\
\text { origem, no Brasil, aos Parâmetros } \\
\text { Curriculares Nacionais. As novas } \\
\text { demandas do mundo produtivo fizeram } \\
\text { com que o Ensino Médio merecesse } \\
\text { atenção especial, a ponto de se promover } \\
\text { esse nível ao status de etapa terminal da } \\
\text { educação básica. Esta dissertação } \\
\text { analisou as divergências entre as } \\
\text { orientações curriculares contidas nos } \\
\text { Parâmetros Curriculares Nacionais do } \\
\text { Ensino Médio (PCNEM) e a prática } \\
\text { pedagógica do ensino de língua materna. } \\
\text { Buscou dois objetivos. O primeiro } \\
\text { consiste em apontar contradições na } \\
\text { constituição dos PCNEM no que tange } \\
\text { às orientações referentes ao ensino de } \\
\text { Língua Portuguesa; e o segundo, em } \\
\text { fornecer subsídios teóricos e práticos } \\
\text { para a formulação de uma proposta de } \\
\text { ensino de linguagem no nível médio que } \\
\text { não a considere como objeto de estudo, } \\
\text { mas, principalmente, como prática } \\
\text { sociocultural e política." }\end{array}$ & Sim \\
\hline $\begin{array}{l}\text { Ensino } \\
\text { Médio }\end{array}$ & $\begin{array}{l}\text { IES } \\
\text { Particular/RS }\end{array}$ & $\begin{array}{l}\text { "A motivação é fator determinante no } \\
\text { processo de aquisição de uma segunda } \\
\text { língua.O uso de estratégias } \\
\text { motivacionais em sala de aula pode se } \\
\text { constituir um importante auxiliar na } \\
\text { tarefa despertar e manter a motivação do } \\
\text { aluno na aprendizagem de L2. Uma } \\
\text { proposta de ensino de língua portuguesa } \\
\text { para alunos surdos deve considerar as } \\
\text { atividades pedagógicas como parte } \\
\text { integrante dessas estratégias } \\
\text { motivacionais. O uso das atividades } \\
\text { pedagógicas como estratégia de } \\
\text { motivação contribuirá para aumentar a } \\
\text { motivação para a aprendizagem da } \\
\text { língua portuguesa e implicará melhor } \\
\text { desempenho dos alunos na modalidade } \\
\text { escrita dessa língua. Para comprovar } \\
\text { empiricamente essas hipóteses foi } \\
\text { desenvolvida uma pesquisa experimental } \\
\text { junto a duas turmas de } 1 \text { ano do Ensino } \\
\text { Médio de uma escola para surdos." }\end{array}$ & Não \\
\hline $\begin{array}{l}\text { Ensino } \\
\text { Médio }\end{array}$ & $\begin{array}{l}\text { IES } \\
\text { Particular/RS }\end{array}$ & $\begin{array}{l}\text { "A presente dissertação pretende refletir } \\
\text { sobre o que vem ressignificando de } \\
\text { alguma forma minha vida profissional: } \\
\text { tornar significativa a aprendizagem da } \\
\text { Língua Portuguesa para mim e para meu } \\
\text { aluno. E vou apoiar-me na idéia de } \\
\text { formação, de auto-formação para } \\
\text { delinear o caminho metodológico deste } \\
\text { meu trabalho. [...] Em minha pesquisa, } \\
\text { refiro-me, em especial, a quatro turmas } \\
\text { de alunos de ensino médio, entre quinze } \\
\text { e dezessete anos, classe de média a alta, } \\
\text { estudantes do Colégio Dom Feliciano, } \\
\text { em Gravataí." }\end{array}$ & Sim \\
\hline $\begin{array}{l}\text { Ensino } \\
\text { Médio }\end{array}$ & $\begin{array}{l}\text { IES } \\
\text { Particular/SP }\end{array}$ & $\begin{array}{l}\text { "Este trabalho propõe-se ao estudo da } \\
\text { Retextualização como um processo } \\
\text { auxiliar para o desenvolvimento da } \\
\text { redação, partindo-se da oralidade como } \\
\text { premissa para a posterior expressão } \\
\text { escrita. Aborda-se se os níveis de } \\
\text { compreensão e de coerência em relação }\end{array}$ & Não \\
\hline
\end{tabular}




\begin{tabular}{|c|c|c|c|}
\hline & & $\begin{array}{l}\text { ao texto base (oral) estão representados } \\
\text { nos fatos lingüísticos escritos e se as } \\
\text { alterações no ato de escrever } \\
\text { comprometeram ou não o entendimento } \\
\text { do assunto, o que constitui objetivo } \\
\text { maior desta pesquisa. Para tanto, utiliza } \\
\text { como corpus selecionado o caso } \\
\text { 'Mensalão' e as redações produzidas por } \\
\text { alunos do nível médio de uma escola da } \\
\text { periferia de São Paulo, ao longo do } \\
\text { segundo semestre de 2005." }\end{array}$ & \\
\hline $\begin{array}{l}\text { Ensino } \\
\text { Médio }\end{array}$ & $\begin{array}{l}\text { IES } \\
\text { Particular/SP }\end{array}$ & $\begin{array}{l}\text { "Este trabalho insere-se na linha de } \\
\text { pesquisa Leitura, Escrita e Ensino de } \\
\text { Língua Portuguesa e consiste no estudo } \\
\text { dos limites da produção textual escrita } \\
\text { no contexto escolar, no intuito de sugerir } \\
\text { alguns procedimentos didáticos para o } \\
\text { tratamento da produção de textos } \\
\text { dissertativos, os quais podem auxiliar o } \\
\text { professor a aprimorar sua prática } \\
\text { pedagógica. Para tanto, realizamos uma } \\
\text { pesquisa-piloto com seis professores e } \\
\text { sessenta alunos, em seis escolas de } \\
\text { ensino médio da rede pública estadual, } \\
\text { situadas na região de Jundiaí, São Paulo, } \\
\text { considerando os resultados obtidos na } \\
\text { avaliação SARESP, edição } 2004 \text {, com o } \\
\text { objetivo de retratar o quadro atual das } \\
\text { aulas de produção de texto." }\end{array}$ & Sim \\
\hline $\begin{array}{l}\text { Ensino } \\
\text { Médio }\end{array}$ & $\begin{array}{l}\text { IES Municipal/ } \\
\text { SP }\end{array}$ & $\begin{array}{l}\text { "Devido aos avanços tecnológicos e à } \\
\text { Globalização, o mercado de trabalho, as } \\
\text { relações sociais e o pleno exercício da } \\
\text { cidadania exigem que a pessoa tenha } \\
\text { concluído no mínimo o Ensino Médio, } \\
\text { por isso há uma grande demanda por } \\
\text { vagas nos cursos de suplência. Por outro } \\
\text { lado, ainda não há diferenciação } \\
\text { metodológica entre o Ensino Regular e o } \\
\text { Ensino Supletivo, no entanto é } \\
\text { necessário que se busquem } \\
\text { procedimentos de ensino-aprendizagem } \\
\text { que levem em conta as especificidades } \\
\text { do aluno trabalhador para que a escola } \\
\text { atenda a suas necessidades. Esta } \\
\text { pesquisa, realizada em uma turma de } \\
\text { Supletivo de Ensino Médio, numa escola } \\
\text { pública, objetivou estimular a prática de } \\
\text { leitura e produção escrita a partir de } \\
\text { atividades com gêneros discursivos de } \\
\text { natureza ficcional ou autobiográfica e } \\
\text { elevar auto-estima dos alunos." }\end{array}$ & Sim \\
\hline $\begin{array}{l}\text { Exame } \\
\text { Vestibular }\end{array}$ & $\begin{array}{l}\text { IES } \\
\text { Estadual/PR }\end{array}$ & $\begin{array}{l}\text { "O objetivo desta pesquisa consiste em } \\
\text { investigar o papel modalizador do } \\
\text { predicado nominal em posição temática } \\
\text { a partir da análise de recortes de nível } \\
\text { frasal retirados de redações produzidas } \\
\text { por candidatos ao vestibular da Unioeste } \\
\text { em } 2004 \text {. O interesse em promover uma } \\
\text { análise neste contexto reflete uma } \\
\text { tentativa de contribuir, mesmo que } \\
\text { minimamente, com o ensino de língua } \\
\text { portuguesa, considerando-se que } \\
\text { atividades de escrita no ensino médio } \\
\text { visam ao preparo de habilidades } \\
\text { lingüístico-discursivas dos alunos para a } \\
\text { produção da redação de vestibular." }\end{array}$ & Sim \\
\hline Formação & IES & "[...] buscou-se um objeto de pesquisa & Sim \\
\hline
\end{tabular}




\begin{tabular}{|c|c|c|c|c|}
\hline & Continuada & Estadual/PR & $\begin{array}{l}\text { que visasse à formação docente. Essa } \\
\text { busca deparou-se com o Projeto Folhas - } \\
\text { cujos objetivos são a produção de } \\
\text { material didático (elaborado por } \\
\text { professores) e a formação continuada do } \\
\text { professor. A pesquisa em tela tem como } \\
\text { foco principal verificar como o ensino de } \\
\text { Língua Portuguesa é conduzido pelos } \\
\text { professores/autores de Folhas em suas } \\
\text { produções didáticas." }\end{array}$ & \\
\hline & $\begin{array}{l}\text { Formação } \\
\text { Continuada }\end{array}$ & $\begin{array}{l}\text { IES } \\
\text { Particular/SP }\end{array}$ & $\begin{array}{l}\text { "Essa dissertação apresenta uma } \\
\text { pesquisa qualitativa, inserida na linha do } \\
\text { cotidiano da escola, e teve como } \\
\text { objetivo principal, relatar uma } \\
\text { experiência, sobre orientação técnica, } \\
\text { realizada com um grupo de vinte e seis } \\
\text { professoras, do Projeto de Recuperação e } \\
\text { Reforço da Diretoria de Ensino de } \\
\text { Votorantim, cidade do interior de São } \\
\text { Paulo. [...] Tendo como hipótese que as } \\
\text { mediações planejadas e não planejadas, } \\
\text { com significado e trabalho coletivo, } \\
\text { podem provocar novos conhecimentos, } \\
\text { foi possível identificar sinais de } \\
\text { mudanças no modo de interagir das } \\
\text { professoras com os instrumentos e } \\
\text { signos relacionadas ao ensino da Língua } \\
\text { Portuguesa, na prática pedagógica com } \\
\text { seus alunos" }\end{array}$ & Sim \\
\hline $\begin{array}{l}\text { Total de } \\
\text { localiza }\end{array}$ & $\begin{array}{l}\text { dissertações } \\
\text { as }\end{array}$ & & & 41 \\
\hline
\end{tabular}

\begin{tabular}{|c|c|c|c|c|}
\hline $\begin{array}{l}\text { Ano } \\
\text { de } \\
\text { defesa }\end{array}$ & $\begin{array}{l}\text { Contexto } \\
\text { pesquisado }\end{array}$ & $\begin{array}{l}\text { Vínculo } \\
\text { administrativo } \\
\text { /Localização }\end{array}$ & $\begin{array}{l}\text { Transcrição parcial dos } \\
\text { resumos }\end{array}$ & $\begin{array}{l}\text { Disponível } \\
\text { on-line }\end{array}$ \\
\hline \multirow[t]{2}{*}{2008} & $\begin{array}{l}\text { Antiga } \\
\text { Educação } \\
\text { Escolar }\end{array}$ & $\begin{array}{l}\text { IES Federal/ } \\
\text { PB }\end{array}$ & $\begin{array}{l}\text { "Essa pesquisa consiste na análise de } \\
\text { documentos oficiais da Secretaria de } \\
\text { Educação da Prefeitura da Cidade do } \\
\text { Recife - PE. Em primeiro momento, o } \\
\text { trabalho concentra-se em um } \\
\text { levantamento bibliográfico de } \\
\text { documentos oficiais do país desde } \\
\text { Século XIX, como as primeiras Leis e } \\
\text { Decretos estabelecidos ao longo do I e II } \\
\text { Império até a implementação dos } \\
\text { Parâmetros Curriculares Nacionais } \\
\text { PCNs/98 e da Proposta Curricular para } \\
\text { Jovens e Adultos - PCEJA/02. O } \\
\text { objetivo é observar os critérios } \\
\text { estabelecidos por tais documentos com } \\
\text { relação ao ensino da linguagem oral e } \\
\text { como eles se desenvolveram ao longo do } \\
\text { tempo. Verificamos que os documentos } \\
\text { oficiais no Brasil foram elaborados com } \\
\text { o propósito de estabelecer a organização } \\
\text { do ensino e que só a partir dos PCNs se } \\
\text { iniciou uma organização de critérios } \\
\text { para o ensino da língua portuguesa, } \\
\text { procurando assim direcionar práticas } \\
\text { discursivas sobre a linguagem oral." }\end{array}$ & Sim \\
\hline & $\begin{array}{l}\text { Concurso } \\
\text { Público }\end{array}$ & $\begin{array}{l}\text { IES Particular/ } \\
\text { SP }\end{array}$ & $\begin{array}{l}\text { "Esta dissertação insere-se na linha de } \\
\text { pesquisa Leitura, Escrita e Ensino em } \\
\text { Língua Portuguesa e tem como objetivo }\end{array}$ & Sim \\
\hline
\end{tabular}




\begin{tabular}{|c|c|c|c|}
\hline & & $\begin{array}{ll}\text { analisar estratégias requeridas aos } \\
\text { candidatos de concursos públicos nas } \\
\text { questões de compreensão leitora das } \\
\text { provas de Língua Portuguesa." }\end{array}$ & \\
\hline $\begin{array}{l}\text { Contexto } \\
\text { Bilíngue }\end{array}$ & $\begin{array}{l}\text { IES Federal/ } \\
\text { DF }\end{array}$ & $\begin{array}{l}\text { "O ensino da língua portuguesa como } \\
\text { segunda língua, em específico, o gênero } \\
\text { e o número nominal do português para } \\
\text { os waimiri atroari é o foco desta } \\
\text { pesquisa, que faz a análise contrastiva do } \\
\text { gênero e do número nominal das duas } \\
\text { línguas, explicando as distinções } \\
\text { estruturais das mesmas." }\end{array}$ & Sim \\
\hline $\begin{array}{l}\text { Contexto } \\
\text { Bilingue }\end{array}$ & $\begin{array}{l}\text { IES } \\
\text { Particular/SP }\end{array}$ & $\begin{array}{l}\text { "Este trabalho tece considerações sobre } \\
\text { as práticas pedagógicas, no ensino de } \\
\text { língua portuguesa, voltadas às pessoas } \\
\text { surdas. Para encaminhar a reflexão sobre } \\
\text { o tema em questão foi necessário } \\
\text { desnaturalizar termos que circulam } \\
\text { livremente no campo dos estudos sobre a } \\
\text { surdez. Entre eles, destaca-se o de língua } \\
\text { materna, L1 e L2, uma vez que, na } \\
\text { abordagem bilingüísta, entende-se a } \\
\text { Língua de Sinais como L1, enquanto a } \\
\text { escrita do português é considerada como } \\
\text { segunda língua -L.2." }\end{array}$ & Sim \\
\hline $\begin{array}{l}\text { Educação } \\
\text { Básica }\end{array}$ & $\begin{array}{l}\text { IES Federal/ } \\
\text { MT }\end{array}$ & $\begin{array}{l}\text { "Esta pesquisa se insere no âmbito das } \\
\text { investigações que buscam discutir e } \\
\text { compreender o processo de avaliação da } \\
\text { aprendizagem. Ela tem como referência } \\
\text { as abordagens qualitativas da pesquisa e } \\
\text { tem como questão fazer um estudo das } \\
\text { concepções e práticas dos professores de } \\
\text { Língua Portuguesa no campo da } \\
\text { avaliação da aprendizagem. [...] Os } \\
\text { sujeitos desta pesquisa foram quatro } \\
\text { professores de Língua Portuguesa da } \\
\text { rede pública de ensino da cidade de } \\
\text { Caçu-Estado de Goiás." } 36\end{array}$ & Sim \\
\hline $\begin{array}{l}\text { Educação } \\
\text { Básica }\end{array}$ & IES Federal/SC & $\begin{array}{l}\text { "Este é um estudo qualitativo sobre as } \\
\text { políticas educacionais para surdos e suas } \\
\text { práticas pedagógicas no que se refere ao } \\
\text { ensino de língua portuguesa. Trata-se } \\
\text { deste assunto por haver considerável } \\
\text { descompasso entre as práticas } \\
\text { pedagógicas respaldadas pelas políticas } \\
\text { educacionais vigentes e a realidade dos } \\
\text { alunos surdos. Assim, na tentativa de } \\
\text { verificar como os saberes surdos estão } \\
\text { presentes nas aulas de língua portuguesa, } \\
\text { a qual é uma segunda língua para os } \\
\text { surdos, realizou-se a presente pesquisa } \\
\text { numa Escola denominada como Pólo, } \\
\text { pela Política de Educação de Surdos do } \\
\text { Estado de Santa Catarina (2004), } \\
\text { observando-se as aulas de língua } \\
\text { portuguesa nos dois semestres de 2007." }\end{array}$ & Sim \\
\hline $\begin{array}{l}\text { Educação } \\
\text { Básica }\end{array}$ & $\begin{array}{l}\text { IES } \\
\text { Estadual/PR }\end{array}$ & $\begin{array}{l}\text { "O livro didático é um dos poucos } \\
\text { materiais aos quais professores e alunos } \\
\text { têm acesso. Além disso, é um poderoso } \\
\text { instrumento no processo de ensino e } \\
\text { aprendizagem de língua, pois, muitas } \\
\text { vezes, delimita conteúdos, metodologias }\end{array}$ & Sim \\
\hline
\end{tabular}

36 Esta dissertação, apesar de citar o ensino de Língua Portuguesa no resumo, apresenta uma discussão abrangente sobre avaliação, sem se deter nas especificidades do referido ensino. 


\begin{tabular}{|c|c|c|c|}
\hline & & $\begin{array}{l}\text { de ensino e, especialmente, as } \\
\text { concepções de linguagem que permeiam } \\
\text { a esfera escolar (SOUZA, 1999; } \\
\text { CORACINI, 1999). Nesse sentido, } \\
\text { acreditamos que o livro didático atue } \\
\text { como uma das principais molas } \\
\text { propulsoras responsáveis por } \\
\text { transformações na esfera educacional. } \\
\text { [...] esta pesquisa bibliográfica de cunho } \\
\text { analítico-descritivo, busca compreender } \\
\text { como as atividades de análise lingüística } \\
\text { estão propostas em uma coleção } \\
\text { didática, cujo eixo de progressão e } \\
\text { articulação para o ensino da língua } \\
\text { portuguesa são os gêneros discursivos, a } \\
\text { fim de verificar se elas estão } \\
\text { relacionadas às práticas de leitura, } \\
\text { conforme os dizeres dos documentos } \\
\text { prescritivos." }\end{array}$ & \\
\hline $\begin{array}{l}\text { Educação } \\
\text { Básica }\end{array}$ & $\begin{array}{l}\text { IES } \\
\text { Estadual/SP }\end{array}$ & $\begin{array}{l}\text { "Este estudo acerca da leitura do } \\
\text { fotojornalismo na escola básica visa } \\
\text { atender à demanda por análises da } \\
\text { utilização de material iconográfico nas } \\
\text { escolas. A pouca atenção dedicada à } \\
\text { linguagem imagética nos Parâmetros } \\
\text { Curriculares Nacionais (PCN), a falta de } \\
\text { estudos sobre as aplicações didáticas do } \\
\text { fotojornalismo e a ausência desse tema } \\
\text { nos cursos de formação de professores } \\
\text { de Língua Portuguesa foram os } \\
\text { motivadores desta pesquisa." }\end{array}$ & $\mathrm{Sim}$ \\
\hline $\begin{array}{l}\text { Educação } \\
\text { Básica }\end{array}$ & $\begin{array}{l}\text { IES } \\
\text { Federal/MG }\end{array}$ & $\begin{array}{l}\text { "Com o objetivo de se adequarem às } \\
\text { sugestões dos Parâmetros Curriculares } \\
\text { Nacionais que orientam o ensino da } \\
\text { língua portuguesa nas escolas de todo o } \\
\text { país, os manuais didáticos vêm } \\
\text { incorporando em suas páginas diversos } \\
\text { gêneros discursivos. [...] a incorporação } \\
\text { do gênero notícia de jornal ao manual } \\
\text { didático traz algumas modificações nas } \\
\text { características situacionais que definem } \\
\text { o próprio gênero discursivo, já que a } \\
\text { mudança situacional trará alterações nas } \\
\text { restrições e parâmetros característicos do } \\
\text { gênero. Essas "mudanças' nas } \\
\text { propriedades características do gênero } \\
\text { proporcionam o que chamamos neste } \\
\text { trabalho de reconfigurações, conceito } \\
\text { pertinente pela postura assumida na nova } \\
\text { situação de comunicação - a situação } \\
\text { sala de aula: de um gênero discurivo } \\
\text { ligado a práticas sociais a um tipo de } \\
\text { texto usado para simular práticas } \\
\text { comunicativas." }\end{array}$ & Sim \\
\hline $\begin{array}{l}\text { Educação } \\
\text { Básica }\end{array}$ & $\begin{array}{l}\text { IES Federal/ } \\
\text { PB }\end{array}$ & $\begin{array}{l}\text { "O fato de o ensino de gramática ser um } \\
\text { dos principais desafios a ser enfrentado } \\
\text { pelos professores que se preocupam em } \\
\text { dar um sentido funcional ao estudo da } \\
\text { Gramática na sala de aula, despertou-nos } \\
\text { o interesse em desenvolver uma pesquisa } \\
\text { sobre esse ensino, enquanto saber. [...] } \\
\text { A fim de refletirmos sobre a construção } \\
\text { desse saber, realizamos um estudo de } \\
\text { caso com uma professora de Língua } \\
\text { Portuguesa que leciona há } 18 \text { anos em } \\
\text { uma escola pública de Campina Grande, } \\
\text { e cujo perfil delineia uma profissional }\end{array}$ & Sim \\
\hline
\end{tabular}




\begin{tabular}{|c|c|c|c|}
\hline & & que está continuamente se formando." & \\
\hline $\begin{array}{l}\text { Educação } \\
\text { Básica }\end{array}$ & IES Federal/ RJ & $\begin{array}{l}\text { "O presente projeto de pesquisa tem por } \\
\text { objetivo investigar como se organiza o } \\
\text { discurso oficial da Secretaria Estadual de } \\
\text { Educação do Rio de Janeiro para o } \\
\text { ensino da Língua Portuguesa nas escolas } \\
\text { públicas do Estado. Almeja também } \\
\text { compreender como se articulam as vozes } \\
\text { discursivas que organizam esse discurso, } \\
\text { considerando que o professor é leitor } \\
\text { privilegiado. Para tanto, toma-se como } \\
\text { objeto de análise a proposta curricular } \\
\text { para o ensino de Língua Portuguesa, } \\
\text { produzida no documento de } \\
\text { Reorientação Curricular entregue às } \\
\text { escolas em 2006, incluindo os materiais } \\
\text { didáticos elaborados pelos professores." }\end{array}$ & Sim \\
\hline $\begin{array}{l}\text { Educação } \\
\text { Básica }\end{array}$ & $\begin{array}{l}\text { IES } \\
\text { Particular/RS }\end{array}$ & $\begin{array}{l}\text { "Esta dissertação tem como objetivo } \\
\text { demonstrar a complexidade de fatores } \\
\text { envolvidos na produção e na leitura de } \\
\text { textos de divulgação científica } \\
\text { (doravante textos DC). [...] foi possível } \\
\text { compreender que a leitura de textos DC } \\
\text { depende de um conjunto de estratégias } \\
\text { de reconhecimento de que o leitor desses } \\
\text { textos precisa dispor para a produção do } \\
\text { sentido. O estudo permitiu fundamentar } \\
\text { a crítica de que a dimensão lingüística da } \\
\text { alfabetização científica requer muito } \\
\text { mais do que o domínio de um } \\
\text { vocabulário básico da ciência. A } \\
\text { relevância deste estudo está em } \\
\text { contribuir, no que diz respeito à } \\
\text { linguagem, tanto para a leitura de textos } \\
\text { DC quanto para o cumprimento das } \\
\text { orientações dos PCNs para o ensino da } \\
\text { Língua Portuguesa." }\end{array}$ & Sim \\
\hline $\begin{array}{l}\text { Educação } \\
\text { Básica }\end{array}$ & $\begin{array}{l}\text { IES Particular/ } \\
\text { SP }\end{array}$ & $\begin{array}{l}\text { "Este trabalho coloca-se no âmbito da } \\
\text { Historiografia Lingüística, procurando } \\
\text { investigar a formação dos professores da } \\
\text { educação básica, especialmente na } \\
\text { ênfase dada à formação para o ensino de } \\
\text { Língua Portuguesa. O enfoque, a partir } \\
\text { do qual o trabalho que aqui propomos se } \\
\text { desenvolveu, parte do pressuposto de } \\
\text { que a educação, como um fenômeno } \\
\text { cultural, encontra-se inserida em um } \\
\text { contexto social, econômico e político e, } \\
\text { portanto, a análise que se buscou fazer } \\
\text { situa-se dentro da História e da } \\
\text { Historiografia Lingüística, as quais nos } \\
\text { permitem observar as interações que } \\
\text { ocorrem entre as dimensões política, } \\
\text { social e educativa." }\end{array}$ & Sim \\
\hline $\begin{array}{l}\text { Educação } \\
\text { Básica }\end{array}$ & $\begin{array}{l}\text { IES Particular/ } \\
\text { SP }\end{array}$ & $\begin{array}{l}\text { "Nesta pesquisa tivemos como objetivos } \\
\text { verificar o modo como o texto tem sido } \\
\text { trabalhado nas práticas de ensino; } \\
\text { analisar se esse trabalho segue, ou não, } \\
\text { as indicações dos Parâmetros } \\
\text { Curriculares Nacionais (PCN) e } \\
\text { investigar como os professores } \\
\text { compreendem e aplicam as indicações } \\
\text { do documento, no que diz respeito ao } \\
\text { ensino de produção textual numa } \\
\text { abordagem de gêneros. [...] Para a } \\
\text { consecução dos objetivos delineados, } \\
\text { optamos por uma pesquisa qualitativa, }\end{array}$ & Sim \\
\hline
\end{tabular}




\begin{tabular}{|c|c|c|c|}
\hline & & $\begin{array}{l}\text { realizando entrevistas com seis } \\
\text { informantes: dois docentes da rede } \\
\text { pública estadual que atuam em oficina } \\
\text { pedagógica; dois que, além de atuarem } \\
\text { em sala de aula, são militantes do } \\
\text { sindicato (APEOESP) e dois que atuam } \\
\text { em salas de aula do Ensino Fundamental } \\
\text { II." }\end{array}$ & \\
\hline $\begin{array}{l}\text { Educação } \\
\text { Básica / } \\
\text { Educação } \\
\text { Superior }\end{array}$ & $\begin{array}{l}\text { IES Federal/ } \\
\text { MT }\end{array}$ & $\begin{array}{l}\text { "Trata-se de um estudo de natureza } \\
\text { qualitativa, realizado com quatro } \\
\text { professoras das redes municipal e } \\
\text { estadual de ensino das cidades de Cuiabá } \\
\text { e Várzea Grande, no Estado de Mato } \\
\text { Grosso. Esta pesquisa, de base } \\
\text { enunciativo-discursiva, tem como um } \\
\text { dos objetivos observar a relação entre as } \\
\text { dificuldades na efetivação das propostas } \\
\text { dos Parâmetros Curriculares Nacionais } \\
\text { de Língua Portuguesa (PCNLP, 1998) e } \\
\text { a formação inicial e continuada dessas } \\
\text { professoras. Por meio da observação } \\
\text { participante, de entrevistas formais e } \\
\text { informais e de registro em fotografias, } \\
\text { procuramos conhecer e compreender } \\
\text { como esse grupo de professoras efetiva o } \\
\text { trabalho com a teoria dos gêneros, } \\
\text { partindo da reflexão sobre sua prática e } \\
\text { sua formação. Buscamos, ainda, } \\
\text { verificar em cursos de graduação em } \\
\text { Letras, elegendo as quatro principais } \\
\text { instituições de nossa região e outras três } \\
\text { universidades que se destacam no } \\
\text { cenário acadêmico nacional, em que } \\
\text { momento do curso os futuros professores } \\
\text { de Língua Portuguesa têm acesso } \\
\text { 'oficial/efetivo' à teoria dos gêneros." }\end{array}$ & $\mathrm{Sim}$ \\
\hline $\begin{array}{l}\text { Educação de } \\
\text { Jovens e } \\
\text { Adultos }\end{array}$ & $\begin{array}{l}\text { IES Federal/ } \\
\text { DF }\end{array}$ & $\begin{array}{l}\text { "A pesquisa tem por escopo desenvolver } \\
\text { uma metodologia de leiturização que } \\
\text { abarque a leitura explícita, a leitura } \\
\text { inferencial e a leitura crítica dos alunos } \\
\text { da Educação de Jovens e Adultos (EJA), } \\
\text { analisando o ensino de Língua } \\
\text { Portuguesa como uma prática de } \\
\text { letramento." }\end{array}$ & Sim \\
\hline $\begin{array}{l}\text { Educação de } \\
\text { Jovens e } \\
\text { Adultos }\end{array}$ & $\begin{array}{l}\text { IES Federal/ } \\
\text { MS }\end{array}$ & $\begin{array}{l}\text { "Este trabalho interessa-se pelo estudo } \\
\text { das propostas curriculares para o ensino } \\
\text { de Língua Portuguesa na modalidade } \\
\text { Educação de Jovens e Adultos - EJA. } \\
\text { Em primeiro lugar pela necessidade } \\
\text { existente de estudos que possam } \\
\text { contribuir nas ações pedagógicas das } \\
\text { escolas. Em segundo lugar pela intenção } \\
\text { de investigar como o ensino de Língua } \\
\text { Portuguesa foi concebido nos } \\
\text { documentos oficiais do Ministério da } \\
\text { Educação - MEC para subsidiar o } \\
\text { trabalho das Secretarias de Estado de } \\
\text { Educação em atividades de orientação e } \\
\text { formação continuada aos professores } \\
\text { dessa modalidade de ensino e na } \\
\text { elaboração das propostas pedagógicas } \\
\text { escolares." }\end{array}$ & $\mathrm{Sim}$ \\
\hline $\begin{array}{l}\text { Educação de } \\
\text { Jovens e } \\
\text { Adultos }\end{array}$ & $\begin{array}{l}\text { IES Particular/ } \\
\text { SP }\end{array}$ & $\begin{array}{l}\text { "Este trabalho insere-se na linha de } \\
\text { pesquisa de Leitura, Escrita e Ensino de } \\
\text { Língua Portuguesa e tem como tema o } \\
\text { estudo da expansão do grau de } \\
\text { letramento de um sujeito já alfabetizado }\end{array}$ & $\mathrm{Sim}$ \\
\hline
\end{tabular}




\begin{tabular}{|c|c|c|c|}
\hline & & $\begin{array}{l}\text { e estudante do Ensino Fundamental II da } \\
\text { Educação de Jovens e Adultos (EJA), } \\
\text { por meio do ensino de uma leitura } \\
\text { significativa, desenvolvido no âmbito } \\
\text { escolar. [...] Temos como objetivos } \\
\text { específicos contribuir para o ensino da } \\
\text { leitura significativa, desenvolvida nas } \\
\text { aulas de Língua Portuguesa, ministradas } \\
\text { para os(as) alunos(as) da EJA, e, } \\
\text { contribuir para o ensino da leitura } \\
\text { significativa na escola pública, } \\
\text { instituição em que trabalhamos e onde } \\
\text { acreditamos que seja possível } \\
\text { desenvolver um trabalho voltado para o } \\
\text { ensino dessa leitura." }\end{array}$ & \\
\hline $\begin{array}{l}\text { Educação de } \\
\text { Jovens e } \\
\text { Adultos }\end{array}$ & $\begin{array}{l}\text { IES Particular/ } \\
\text { SP }\end{array}$ & $\begin{array}{l}\text { "O corpus é composto por quatro } \\
\text { anúncios publicitários extraídos de um } \\
\text { livro didático de Língua Portuguesa } \\
\text { fornecido pela Prefeitura do Município } \\
\text { de São Paulo, destinado à Educação de } \\
\text { Jovens e Adultos, ciclo II }-1^{\circ} \text { e } 2^{\circ} \\
\text { termos do Ensino Fundamental. O } \\
\text { problema que norteia a pesquisa é se a } \\
\text { metodologia de leitura proposta pelo } \\
\text { referido livro colabora para que o } \\
\text { educando realize uma leitura } \\
\text { significativa, de modo a auxiliar o seu } \\
\text { desenvolvimento como leitor ativo e } \\
\text { autônomo. Este estudo pretende } \\
\text { contribuir para a elaboração de novas } \\
\text { estratégias voltadas para atividades } \\
\text { relacionadas à prática de leitura, } \\
\text { mediante a construção de sentidos a } \\
\text { partir de recursos lingüísticos presentes } \\
\text { nos textos." }\end{array}$ & Sim \\
\hline $\begin{array}{l}\text { Educação de } \\
\text { Jovens e } \\
\text { Adultos }\end{array}$ & $\begin{array}{l}\text { IES } \\
\text { Particular/SP }\end{array}$ & $\begin{array}{l}\text { "A pesquisa realizada verifica como são } \\
\text { dadas as aulas de leitura para jovens e } \\
\text { adultos, se os professores utilizam } \\
\text { estratégias de ensino de leitura ou não e } \\
\text { se foram preparados para ensinar esse } \\
\text { público. O corpus analisado é formado } \\
\text { pelas respostas dadas a um questionário, } \\
\text { aplicado a professores, de três escolas } \\
\text { vizinhas, do município de São Paulo. Os } \\
\text { resultados demonstram que a maioria } \\
\text { dos professores não teve formação } \\
\text { especializada para trabalhar com jovens } \\
\text { e adultos, o que contribui para a falta de } \\
\text { identidade da EJA, já que as aulas são } \\
\text { basicamente as mesmas preparadas para } \\
\text { o ensino regular." }\end{array}$ & Sim \\
\hline $\begin{array}{l}\text { Educação } \\
\text { Profissional } \\
\text { Técnica de } \\
\text { Nível Médio }\end{array}$ & $\begin{array}{l}\text { IES Estadual/ } \\
\text { PR }\end{array}$ & $\begin{array}{l}\text { "O trabalho focaliza o ensino de Língua } \\
\text { Materna no curso de formação de } \\
\text { docentes em nível médio oferecido por } \\
\text { um colégio de Maringá. A pesquisa } \\
\text { investiga os eixos do ensino de leitura, } \\
\text { produção textual e reflexão sobre a } \\
\text { língua no curso denominado Ensino } \\
\text { médio - Modalidade Normal, cujo } \\
\text { objetivo é formar professores para atuar } \\
\text { nas primeiras séries do Ensino } \\
\text { Fundamental (zero a dez anos)." }\end{array}$ & Sim \\
\hline $\begin{array}{l}\text { Educação } \\
\text { Profissional } \\
\text { Técnica de } \\
\text { Nível Médio }\end{array}$ & IES Federal/RJ & $\begin{array}{l}\text { "Esta pesquisa constitui-se de uma } \\
\text { análise investigativa sobre o tratamento } \\
\text { da oralidade no ensino da língua materna } \\
\text { nas Escolas Agrotécnicas, a partir de } \\
\text { uma investigação da atuação do Técnico }\end{array}$ & Sim \\
\hline
\end{tabular}




\begin{tabular}{|c|c|c|c|}
\hline & & $\begin{array}{l}\text { Agrícola no exercício de sua função de } \\
\text { Agente Rural, principalmente no que } \\
\text { concerne a sua relação comunicativa } \\
\text { com o produtor rural, verificando como } \\
\text { se dá o processo interlocutivo entre esses } \\
\text { sujeitos, bem como detectando quais as } \\
\text { competências requeridas nessa interação } \\
\text { comunicativa e quais as contribuições da } \\
\text { disciplina de Língua Portuguesa na } \\
\text { formação profissional desses agentes, } \\
\text { alunos egressos das Agrotécnicas." }\end{array}$ & \\
\hline $\begin{array}{l}\text { Educação } \\
\text { Superior }\end{array}$ & $\begin{array}{l}\text { IES Estadual/ } \\
\text { SP }\end{array}$ & $\begin{array}{l}\text { "Esta pesquisa trata de reflexões acerca } \\
\text { da formação de alunos de Letras de uma } \\
\text { universidade pública paulista e de meu } \\
\text { primeiro ano de exercício profissional } \\
\text { como professora de língua portuguesa } \\
\text { em uma escola estadual. A partir da } \\
\text { observação de minha prática de ensino, } \\
\text { constatei que minha ação como } \\
\text { professora era direcionada por vivências } \\
\text { que havia tido como aluna e não por uma } \\
\text { concepção de ensino que estivesse } \\
\text { fundamentada teoricamente. Comecei, } \\
\text { então, a questionar o fato de uma } \\
\text { professora recém-formada ingressar no } \\
\text { magistério sem ter uma fundamentação } \\
\text { teórica consciente acerca do trabalho que } \\
\text { desenvolveria com os alunos. Desta } \\
\text { forma, decidi investigar como as } \\
\text { dificuldades que tive ao ingressar no } \\
\text { magistério eram também sentidas entre } \\
\text { os alunos do quarto ano do curso de } \\
\text { Letras que participaram da pesquisa." }\end{array}$ & Sim \\
\hline $\begin{array}{l}\text { Educação } \\
\text { Superior }\end{array}$ & $\begin{array}{l}\text { IES Federal/ } \\
\mathrm{AL}\end{array}$ & $\begin{array}{l}\text { "Esta pesquisa trata da estrutura e } \\
\text { funcionamento da disciplina Português } \\
\text { nos cursos de Direito de seis instituições } \\
\text { privadas de Maceió. Como o domínio da } \\
\text { língua oficial é o instrumento básico } \\
\text { para o bom desempenho profissional dos } \\
\text { operadores do direito, o objetivo deste } \\
\text { trabalho está pautado na análise da } \\
\text { disciplina Português no curso de Direito, } \\
\text { com destaque para a formação do } \\
\text { professor que nela atua. Nesta } \\
\text { perspectiva, foram estudados também } \\
\text { alguns aspectos curriculares, os } \\
\text { conteúdos, os enfoques metodológicos, } \\
\text { os recursos materiais e didáticos." }\end{array}$ & Sim \\
\hline $\begin{array}{l}\text { Educação } \\
\text { Superior }\end{array}$ & $\begin{array}{l}\text { IES Particular/ } \\
\text { RS }\end{array}$ & $\begin{array}{l}\text { "Este estudo, fundamentado na } \\
\text { abordagem qualitativa, está centrado na } \\
\text { formação inicial e apresenta um } \\
\text { entrecruzamento entre Educação, Arte e } \\
\text { Língua Portuguesa. O objetivo central } \\
\text { foi analisar, a partir da compreensão de } \\
\text { alunos que estão concluindo } \\
\text { Licenciatura em Arte, se e de que forma } \\
\text { o componente curricular Língua } \\
\text { Portuguesa, direcionado à dimensão } \\
\text { estética, contribui na sua formação como } \\
\text { futuros professores." }\end{array}$ & Sim \\
\hline $\begin{array}{l}\text { Ensino em } \\
\text { País } \\
\text { Africano }\end{array}$ & IES Federal/BA & $\begin{array}{l}\text { "Esta dissertação tem como tema as } \\
\text { interferências do crioulo no ensino de } \\
\text { língua portuguesa na Guiné Bissau, um } \\
\text { país plurilíngüe e que tem como língua } \\
\text { oficial a língua portuguesa, falada como } \\
\text { língua materna por apenas } 10 \% \text { da sua } \\
\text { população. [...] O principal objetivo foi o }\end{array}$ & Não \\
\hline
\end{tabular}




\begin{tabular}{|c|c|c|c|}
\hline & & $\begin{array}{l}\text { de contribuir para o desenvolvimento do } \\
\text { ensino de português na Guiné Bissau, } \\
\text { fornecendo subsídios para elaboração de } \\
\text { estratégias didático-pedagógicas que se } \\
\text { ajustem a um contexto de alfabetização } \\
\text { que tem como veículo uma segunda } \\
\text { língua." }\end{array}$ & \\
\hline $\begin{array}{l}\text { Ensino } \\
\text { Fundamental }\end{array}$ & $\begin{array}{l}\text { IES Federal/ } \\
\text { PB }\end{array}$ & $\begin{array}{l}\text { "A introdução da modalidade oral como } \\
\text { conteúdo a ser trabalhado na escola } \\
\text { representa uma nova perspectiva de } \\
\text { estudo da língua materna, já que a língua } \\
\text { não mais é concebida como um sistema } \\
\text { uniforme e homogêneo que se basta em } \\
\text { si mesmo, mas como um conjunto de } \\
\text { variedades, caracterizada pela riqueza de } \\
\text { seus usos. O presente estudo se insere no } \\
\text { campo da lingüística interacional e tem } \\
\text { como foco analisar como os manuais } \\
\text { didáticos têm tratado a oralidade no } \\
\text { ensino de língua materna no Ensino } \\
\text { Fundamental, para alcançar um dos } \\
\text { objetivos propostos nos PCN que é o } \\
\text { desenvolvimento da competência } \\
\text { discursiva do aluno no momento da } \\
\text { interação." }\end{array}$ & Sim \\
\hline $\begin{array}{l}\text { Ensino } \\
\text { Fundamental } \\
\text { I }\end{array}$ & $\begin{array}{l}\text { IES } \\
\text { Particular/PR }\end{array}$ & $\begin{array}{l}\text { "“A prática pedagógica com gêneros } \\
\text { textuais no segundo ciclo do Ensino } \\
\text { Fundamental" é um estudo de natureza } \\
\text { qualitativa, cujo objetivo é analisar e } \\
\text { sistematizar as práticas com gêneros } \\
\text { textuais desenvolvidas por professores } \\
\text { do segundo ciclo do Ensino } \\
\text { Fundamental da rede pública de ensino } \\
\text { do Paraná, a partir de um estudo de caso } \\
\text { realizado em uma escola municipal da } \\
\text { cidade de Campo Largo." }\end{array}$ & Sim \\
\hline $\begin{array}{l}\text { Ensino } \\
\text { Fundamental } \\
\text { I }\end{array}$ & IES Federal/DF & $\begin{array}{l}\text { "Essa pesquisa apresenta uma análise do } \\
\text { vocabulário de três crianças ouvintes, } \\
\text { falantes nativas da língua portuguesa, na } \\
\text { faixa etária de cinco anos de idade, que } \\
\text { freqüentam a escola e estão no início do } \\
\text { processo de alfabetização. O principal } \\
\text { objetivo do trabalho é caracterizar o } \\
\text { português usado nessa faixa etária a fim } \\
\text { de fornecer subsídio para elaboração e } \\
\text { produção de material didático para o } \\
\text { ensino da língua portuguesa para } \\
\text { crianças surdas a partir da } \\
\text { alfabetização." }\end{array}$ & Sim \\
\hline $\begin{array}{l}\text { Ensino } \\
\text { Fundamental } \\
\text { II }\end{array}$ & $\begin{array}{l}\text { IES } \\
\text { Estadual/PA }\end{array}$ & $\begin{array}{l}\text { "Esta Dissertação de Mestrado analisa a } \\
\text { êfase dada a procedimentos e a } \\
\text { orientações didático-metodológicas } \\
\text { acerca do fenômeno lingüístico, } \\
\text { encaminhados aos professores de Língua } \\
\text { Portuguesa do terceiro e quarto ciclos do } \\
\text { Ensino Fundamental do município de } \\
\text { Oriximiná - PA, no ano de } 2001 \text {, com } \\
\text { base nos Parâmetros Curriculares } \\
\text { Nacionais - PCN. Destaca a trajetória da } \\
\text { formação de professores no contexto } \\
\text { nacional e as etapas de transição das } \\
\text { perspectivas de formação, provocadas } \\
\text { pelos modelos culturais, sociais e } \\
\text { econômicos." }\end{array}$ & Sim \\
\hline $\begin{array}{l}\text { Ensino } \\
\text { Fundamental }\end{array}$ & $\begin{array}{l}\text { IES Estadual/ } \\
\text { SP }\end{array}$ & $\begin{array}{l}\text { "Historicamente, professores de Língua } \\
\text { Portuguesa têm utilizado práticas teatrais } \\
\text { em suas aulas. Há, no entanto, um grupo }\end{array}$ & Sim \\
\hline
\end{tabular}




\begin{tabular}{|c|c|c|c|}
\hline II & & $\begin{array}{l}\text { de professores, em especial, que vem } \\
\text { articulando práticas de leitura e práticas } \\
\text { teatrais. São aqueles que atuam na Hora } \\
\text { da Leitura, um projeto implantado em } \\
2005 \text { pela Secretaria de Estado da } \\
\text { Educação de São Paulo, que introduz } \\
\text { uma aula semanal dedicada à leitura de } \\
\text { textos literários na matriz curricular das } \\
\text { escolas estaduais de Ciclo II do Ensino } \\
\text { Fundamental. Este trabalho investigou as } \\
\text { motivações e o desenvolvimento destas } \\
\text { práticas. Além disso, desenvolveu um } \\
\text { experimento que reuniu leitura de textos } \\
\text { e jogos de improvisação teatral com um } \\
\text { grupo de professores da Hora da Leitura. } \\
\text { [...] o desenvolvimento e a análise do } \\
\text { experimento, recorremos aos } \\
\text { pressupostos teóricos que sustentam os } \\
\text { jogos improvisacionais, bem como às } \\
\text { teorias lingüísticas que estão na base do } \\
\text { ensino de Língua Portuguesa, em } \\
\text { especial, no que se refere à formação do } \\
\text { leitor." }\end{array}$ & \\
\hline $\begin{array}{l}\text { Ensino } \\
\text { Fundamental } \\
\text { II }\end{array}$ & $\begin{array}{l}\text { IES Federal/ } \\
\text { PB }\end{array}$ & $\begin{array}{l}\text { "Esse trabalho apresenta uma reflexão } \\
\text { sobre a informática educativa, a teoria da } \\
\text { aprendizagem significativa e o estudo de } \\
\text { gramática, tomando para investigação e } \\
\text { análise um objeto digital de } \\
\text { aprendizagem, planejado, produzido e } \\
\text { testado a fim de detectar aprendizagem } \\
\text { significativa de um conteúdo com a } \\
\text { mediação da informática educativa. [...] } \\
\text { A pesquisa foi de caráter experimental e } \\
\text { teve como objetivo primordial } \\
\text { comprovar, de forma sistemática, a } \\
\text { eficiência de um instrumento que visa } \\
\text { proporcionar a aprendizagem de } \\
\text { conceitos de gramática dos escolares do } \\
7^{\circ} \text { ano do ensino fundamental." }\end{array}$ & $\mathrm{Sim}$ \\
\hline $\begin{array}{l}\text { Ensino } \\
\text { Fundamental } \\
\text { II }\end{array}$ & $\begin{array}{l}\text { IES } \\
\text { Particular/RS }\end{array}$ & $\begin{array}{l}\text { "[...] esta pesquisa tem o objetivo geral } \\
\text { de verificar se o livro didático Português } \\
\text { - Texto e Voz, de Lídio Tesoto, } \\
\text { aprovado pelo PNLD e adotado entre } \\
2005 \text { e } 2007 \text { em uma } 5 \text { a série de uma } \\
\text { escola da rede estadual de Pelotas, } \\
\text { contempla o gênero discursivo como } \\
\text { objeto de ensino, conforme sugerem os } \\
\text { PCNs, e como, no trabalho com o } \\
\text { referido livro, o professor desenvolve } \\
\text { sua atividade docente. Dentre os } \\
\text { objetivos específicos, esta pesquisa visa } \\
\text { (a) averiguar se a abordagem do texto no } \\
\text { livro didático contempla as condições de } \\
\text { produção dos discursos de acordo com } \\
\text { os gêneros discursivos e (b) averiguar } \\
\text { características do trabalho do professor } \\
\text { de língua portuguesa bem como } \\
\text { renormalizaçôes efetuadas ao utilizar o } \\
\text { livro didático" }\end{array}$ & Sim \\
\hline $\begin{array}{l}\text { Ensino } \\
\text { Fundamental } \\
\text { II }\end{array}$ & $\begin{array}{l}\text { IES Particular/ } \\
\text { SP }\end{array}$ & $\begin{array}{l}\text { "Esta dissertação insere-se na linha de } \\
\text { pesquisa Leitura, Escrita e Ensino de } \\
\text { Língua Portuguesa, e tem como foco a } \\
\text { produção de inferências e avaliação da } \\
\text { compreensão leitora. [...] Tendo em vista } \\
\text { o objetivo de verificar inferências } \\
\text { produzidas no processo de leitura, } \\
\text { selecionamos um texto e solicitamos a }\end{array}$ & $\mathrm{Sim}$ \\
\hline
\end{tabular}




\begin{tabular}{|c|c|c|c|}
\hline & & $\begin{array}{l}\text { alunos de } 6^{\mathrm{a}} \text { série do Ensino } \\
\text { Fundamental II de uma escola pública da } \\
\text { cidade de São Paulo que expressassem } \\
\text { por escrito a compreensão que tiveram } \\
\text { do texto lido." }\end{array}$ & \\
\hline $\begin{array}{l}\text { Ensino } \\
\text { Fundamental } \\
\text { II }\end{array}$ & $\begin{array}{l}\text { IES Particular/ } \\
\text { SP }\end{array}$ & $\begin{array}{l}\text { "Esta dissertação situa-se na linha de } \\
\text { pesquisa sobre Leitura, Escrita e Ensino } \\
\text { de Língua Portuguesa e tem o propósito } \\
\text { de contribuir para os estudos acerca do } \\
\text { desenvolvimento da competência leitora } \\
\text { de estudantes no Ensino Fundamental. } \\
\text { [...] Esta pesquisa realizada verifica, } \\
\text { especificamente, qual o desempenho dos } \\
\text { alunos da } 8^{\text {a }} \text { série do Ensino } \\
\text { Fundamental na competência leitora de } \\
\text { identificação do tema e quais estratégias } \\
\text { de ensino da leitura auxiliam na busca } \\
\text { pela compreensão global do texto. O } \\
\text { corpus analisado é formado pelas } \\
\text { atividades de leitura presentes em dois } \\
\text { livros didáticos que circulam nas escolas } \\
\text { da rede pública de ensino." }\end{array}$ & Sim \\
\hline $\begin{array}{l}\text { Ensino } \\
\text { Fundamental } \\
\text { /Ensino } \\
\text { Médio }\end{array}$ & $\begin{array}{l}\text { IES Federal/ } \\
\mathrm{MG}\end{array}$ & $\begin{array}{l}\text { "Este trabalho procura fazer uma análise } \\
\text { crítica acerca do papel exercido pela } \\
\text { gramática normativa nos bancos } \\
\text { escolares, mais especificamente no que } \\
\text { respeita ao Ensino Fundamental. Procura } \\
\text { verificar ainda os reflexos do ensino } \\
\text { puramente gramatical no desempenho } \\
\text { lingüístico-discursivo desses alunos. } \\
\text { Para tanto, realizou-se uma pesquisa } \\
\text { com } 102 \text { alunos matriculados na } 1^{a} \text { série } \\
\text { do Ensino Médio." }\end{array}$ & Sim \\
\hline $\begin{array}{l}\text { Ensino } \\
\text { Médio }\end{array}$ & $\begin{array}{l}\text { IES Federal/ } \\
\mathrm{CE}\end{array}$ & $\begin{array}{l}\text { "Esta dissertação mostra como é tratado } \\
\text { o ensino de Língua Portuguesa, através } \\
\text { dos gêneros textuais/discursivos, em } \\
\text { atividades de linguagem propostas em } \\
\text { três dos nove livros Didáticos de Língua } \\
\text { Portuguesa do Ensino Médio, } \\
\text { recomendados pelo PNLEM (BRASIL, } \\
\text { 2005)." }\end{array}$ & Não \\
\hline $\begin{array}{l}\text { Ensino } \\
\text { Médio }\end{array}$ & $\begin{array}{l}\text { IES } \\
\text { Federal/MT }\end{array}$ & $\begin{array}{l}\text { "Este estudo, de natureza qualitativa, } \\
\text { teve por objetivo investigar o processo } \\
\text { de apropriação do novo paradigma de } \\
\text { ensino de língua portuguesa, } \\
\text { consolidado em documentos oficiais } \\
\text { como Diretrizes Curriculares Nacionais } \\
\text { para o Ensino Médio (DCNEM/1998), } \\
\text { Parâmetros Curriculares Nacionais do } \\
\text { Ensino Médio (PCNEM/1999), } \\
\text { Orientações Curriculares para o Ensino } \\
\text { Médio (OCEM/2006), por uma escola da } \\
\text { rede pública de ensino de Cuiabá, a } \\
\text { Escola Cidade Verde. Por meio da } \\
\text { investigação em ambiente natural, do } \\
\text { exame do Projeto Político Pedagógico } \\
\text { (PPP) da escola, de entrevistas formais e } \\
\text { informais com professores de português } \\
\text { e da observação de aulas numa turma de } \\
\text { primeiro ano, buscamos perscrutar se o } \\
\text { novo paradigma vem permeando as } \\
\text { práticas pedagógicas cotidianas dos } \\
\text { professores de língua portuguesa." }\end{array}$ & Sim \\
\hline $\begin{array}{l}\text { Ensino } \\
\text { Médio }\end{array}$ & IES Federal/PA & $\begin{array}{l}\text { "O trabalho tematiza acerca do ensino de } \\
\text { objetos gramaticais durante as práticas } \\
\text { de ensino da disciplina escolar Língua } \\
\text { Portuguesa. O estudo busca analisar o }\end{array}$ & Não \\
\hline
\end{tabular}




\begin{tabular}{|c|c|c|c|}
\hline & & $\begin{array}{l}\text { processo de institucionalização de tais } \\
\text { objetos a partir do trabalho docente, isto } \\
\text { é, investigar quais os gestos e } \\
\text { instrumentos utilizados pelo professor } \\
\text { para que o referido objeto de ensino } \\
\text { passe a ser efetivamente ensinado. O } \\
\text { corpus a ser analisado consiste em aulas } \\
\text { de língua portuguesa gravadas em vídeo } \\
\text { e MP3, no primeiro semestre do ano de } \\
\text { 2007. Seguindo as orientações teóricas } \\
\text { da pesquisa etnográfica (Moita Lopes, } \\
\text { 1994; André, 1995), realizamos a } \\
\text { geração de dados, observando uma } \\
\text { turma do primeiro ano do Ensino Médio, } \\
\text { de uma escola da rede particular de } \\
\text { ensino, da cidade de Belém-PA." }\end{array}$ & \\
\hline $\begin{array}{l}\text { Ensino } \\
\text { Médio }\end{array}$ & $\begin{array}{l}\text { IES Municipal/ } \\
\text { SP }\end{array}$ & $\begin{array}{l}\text { "Este trabalho consiste em uma pesquisa } \\
\text { realizada junto a pais e a alunos das três } \\
\text { séries do Ensino Médio de uma escola } \\
\text { da rede particular de ensino do sul de } \\
\text { Minas Gerais. O objetivo foi investigar } \\
\text { quais são suas expectativas com relação } \\
\text { ao ensino de Língua Portuguesa. Os } \\
\text { fatores que motivaram a realização da } \\
\text { pesquisa foram as contínuas reclamações } \\
\text { e questionamentos de pais e alunos para } \\
\text { com o material didático utilizado, pois } \\
\text { este suprimia o ensino da teoria } \\
\text { gramatical de seu conteúdo e, } \\
\text { conseqüentemente, limitava as aulas ao } \\
\text { ensino de leitura e produção de texto.[...] } \\
\text { solicitamos aos pais e aos alunos que } \\
\text { respondessem a um questionário } \\
\text { contendo perguntas objetivas a respeito } \\
\text { da importância do ensino da teoria } \\
\text { gramatical nas aulas de Língua } \\
\text { Portuguesa." }\end{array}$ & $\mathrm{Sim}$ \\
\hline $\begin{array}{l}\text { Ensino } \\
\text { Médio }\end{array}$ & $\begin{array}{l}\text { IES } \\
\text { Particular/SP }\end{array}$ & $\begin{array}{l}\text { "Este trabalho busca analisar as } \\
\text { propostas de ensino de gêneros textuais } \\
\text { em livros didáticos de Língua } \\
\text { Portuguesa de Ensino Médio indicados } \\
\text { pelo PNLEM/2009. Especificamente, } \\
\text { analisaremos as atividades didáticas } \\
\text { propostas ao ensino dos gêneros notícia } \\
\text { e reportagem e as respectivas } \\
\text { capacidades de linguagem do aluno que } \\
\text { poderão ser desenvolvidas por meio } \\
\text { delas." }\end{array}$ & $\mathrm{Sim}$ \\
\hline $\begin{array}{l}\text { Ensino } \\
\text { Médio }\end{array}$ & $\begin{array}{l}\text { IES Particular/ } \\
\text { SP }\end{array}$ & $\begin{array}{l}\text { "Esta dissertação situa-se na linha de } \\
\text { pesquisa Leitura, Escrita e Ensino de } \\
\text { Língua Portuguesa, seu tema é a } \\
\text { produção de inferências, e o problema } \\
\text { que a motivou tem sua origem nas } \\
\text { dificuldades observadas na compreensão } \\
\text { da leitura realizada por alunos do Ensino } \\
\text { Médio. Selecionamos, como corpus, um } \\
\text { texto de Machado de Assis, Crônica } \\
\text { publicada no jornal Gazeta de Notícias, } \\
\text { em } 19 \text { de maio de 1888, baseados, } \\
\text { sobretudo, na ativação de elementos do } \\
\text { conhecimento prévio que ele requer do } \\
\text { leitor. O objetivo geral deste trabalho é } \\
\text { situar o processo inferencial como um } \\
\text { processo que contribui para a } \\
\text { compreensão da leitura, e, } \\
\text { especificamente, verificar qual é o } \\
\text { conhecimento prévio que o leitor }\end{array}$ & $\mathrm{Sim}$ \\
\hline
\end{tabular}




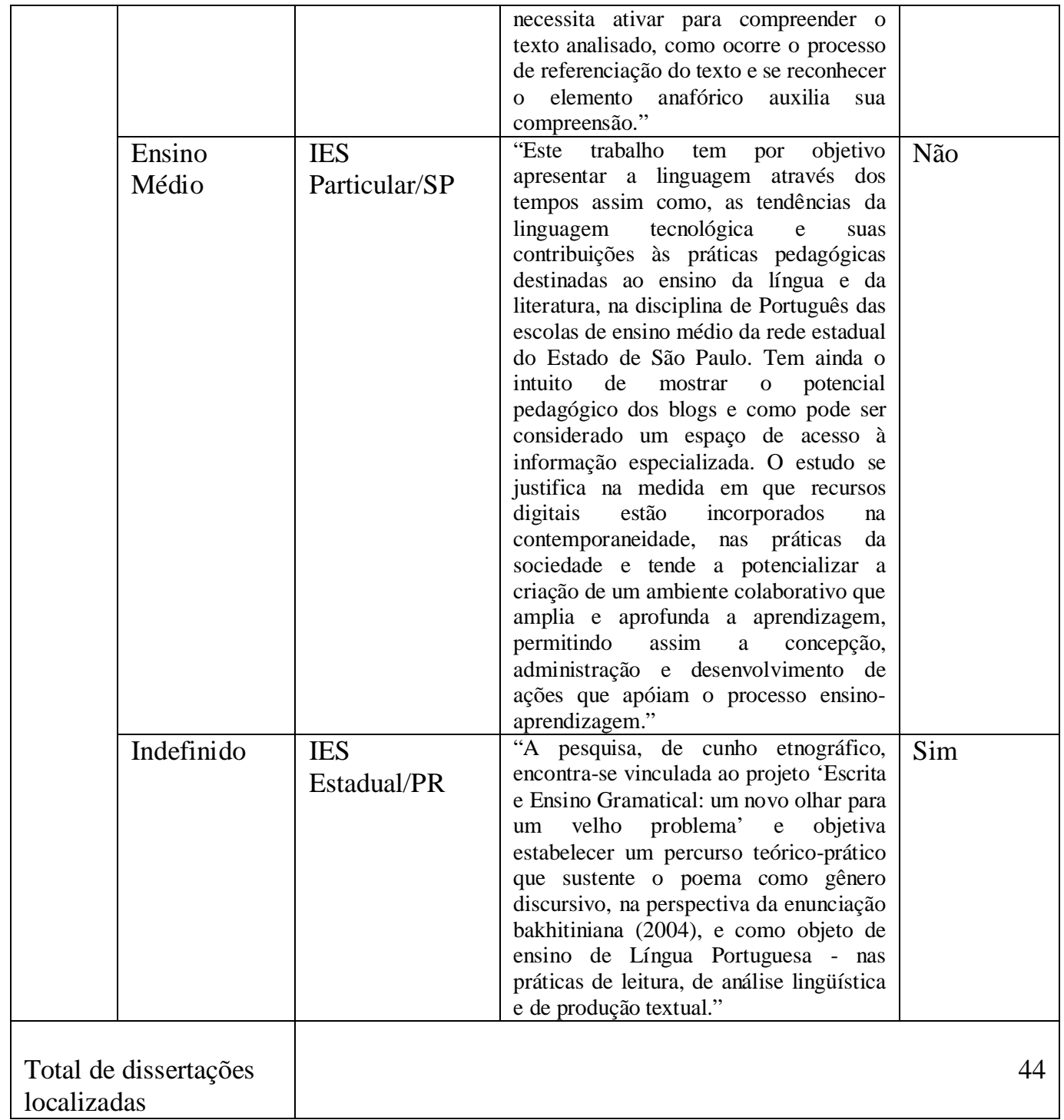

\begin{tabular}{|l|l|l|l|l|}
\hline $\begin{array}{l}\text { Ano } \\
\text { de } \\
\text { defesa }\end{array}$ & $\begin{array}{l}\text { Contexto } \\
\text { pesquisado }\end{array}$ & $\begin{array}{l}\text { Vínculo } \\
\text { administrativo } \\
\text { /Localização }\end{array}$ & $\begin{array}{l}\text { Transcrição parcial dos } \\
\text { resumos }\end{array}$ & $\begin{array}{l}\text { Disponível } \\
\text { on-line }\end{array}$ \\
\hline 2009 & $\begin{array}{l}\text { Antiga } \\
\text { Educação } \\
\text { Escolar }\end{array}$ & $\begin{array}{l}\text { IES } \\
\text { Particular/SP }\end{array}$ & $\begin{array}{l}\text { "Esta dissertação situa-se na área da } \\
\text { Historiografia Linguística e tem por } \\
\text { tema a Intolerância Linguística, com a } \\
\text { intenção de contribuir para a reflexão do } \\
\text { ensino da língua portuguesa. Para a } \\
\text { realização do nosso estudo, focamos } \\
\text { como objetivo geral a contribuição com } \\
\text { ensino da língua portuguesa, } \\
\text { apresentando o primeiro ato de } \\
\text { intolerância linguística, no Brasil do } \\
\text { século XVIII, caracterizado pelo } \\
\text { documento Diretório dos Índios (Anexo } \\
\text { I) que mostra explicitamente o tema de } \\
\text { intolerância linguística e o o } \\
\text { redirecionamento linguístico com fins } \\
\text { políticos e econômicos. Além disso, } \\
\text { pretendemos ainda identificar a a } \\
\text { maneira como ocorreu a intolerância }\end{array}$ & \\
\hline
\end{tabular}




\begin{tabular}{|c|c|c|c|}
\hline & & $\begin{array}{l}\text { linguística, no Brasil do século XVIII, } \\
\text { mostrando a importância de se } \\
\text { compreender o que houve na política de } \\
\text { línguas. É de suma importância } \\
\text { apresentar o modo de ensino de língua, } \\
\text { naquela época, em que se estabelece a } \\
\text { língua como a língua da nação e, ainda, } \\
\text { comparar a proposta de ensino no século } \\
\text { XVIII e a proposta de ensino atual, a fim } \\
\text { de compreender o tema, intolerância } \\
\text { linguística, nos diferentes séculos." }\end{array}$ & \\
\hline $\begin{array}{l}\text { Antiga } \\
\text { Educação } \\
\text { Escolar }\end{array}$ & $\begin{array}{l}\text { IES Estadual/ } \\
\text { PR }\end{array}$ & $\begin{array}{l}\text { "Há tempos, o ensino de Língua } \\
\text { Portuguesa é alvo de discussões entre } \\
\text { pesquisadores e professores. Discute-se } \\
\text { para chegar a um consenso sobre qual } \\
\text { método é o melhor para ensinar a língua } \\
\text { portuguesa. [...] Neste trabalho, } \\
\text { objetivamos verificar as mudanças } \\
\text { ocorridas no ensino, principalmente o de } \\
\text { Língua Portuguesa, no estado do Paraná. } \\
\text { Analisamos a concepção de linguagem } \\
\text { que permeava o ensino neste Estado, no } \\
\text { século XIX, a linguagem como forma de } \\
\text { pensamento, e comparamos com as } \\
\text { orientações estabelecidas pelos PCNs } \\
\text { atuais e pelas Diretrizes Curriculares do } \\
\text { Estado do Paraná, que priorizam a } \\
\text { concepção de linguagem como forma de } \\
\text { interação." }\end{array}$ & Não \\
\hline $\begin{array}{l}\text { Antiga } \\
\text { Educação } \\
\text { Escolar }\end{array}$ & $\begin{array}{l}\text { IES } \\
\text { Estadual/SP }\end{array}$ & $\begin{array}{l}\text { "Com os objetivos de contribuir para a } \\
\text { produção de uma história do ensino de } \\
\text { língua e literatura no Brasil e para a } \\
\text { compreensão de um importante } \\
\text { momento da história do ensino da leitura } \\
\text { em nosso país, focaliza-se a proposta } \\
\text { para o ensino da leitura pelo método } \\
\text { analítico defendida pelo professor } \\
\text { paulista Theodoro Jeronymo Rodrigues } \\
\text { de Moraes (1877-1956), conforme } \\
\text { apresentada nos textos de sua autoria, } \\
\text { que integram o corpus escolhido para } \\
\text { análise: o livreto 'A leitura analytica' } \\
\text { (1909), o documento oficial 'Como } \\
\text { ensinar leitura e linguagem nos diversos } \\
\text { annos do curso preliminar' (1911) e dos } \\
\text { seguintes livros didáticos destinados ao } \\
\text { ensino da leitura a crianças: 'Meu livro: } \\
\text { primeiras leituras de accôrdo com o } \\
\text { methodo analytico' (1909), 'Meu livro: } \\
\text { segundas leituras de accôrdo com o } \\
\text { methodo analytico' (1910?), 'Sei lêr: } \\
\text { leituras intermediárias' (1928), 'Sei lêr: } \\
\text { primeiro livro' (1928) e 'Sei lêr: } \\
\text { segundo livro' (1930)." }\end{array}$ & $\mathrm{Sim}$ \\
\hline $\begin{array}{l}\text { Curso } \\
\text { Preparatório } \\
\text { para } \\
\text { Concurso } \\
\text { Público }\end{array}$ & $\begin{array}{l}\text { IES } \\
\text { Estadual/RJ }\end{array}$ & $\begin{array}{l}\text { "Encontrar caminhos para ensinar a } \\
\text { concordância verbal a candidatos ao } \\
\text { provimento de vagas no Serviço Público, } \\
\text { a despeito de seu desconhecimento da } \\
\text { estruturação sintática do português, } \\
\text { tornou-se meta de trabalho e, portanto, } \\
\text { baldrame para esta Dissertação de } \\
\text { Mestrado em Língua Portuguesa." }\end{array}$ & $\mathrm{Sim}$ \\
\hline $\begin{array}{l}\text { Curso } \\
\text { Virtual }\end{array}$ & $\begin{array}{l}\text { IES } \\
\text { Estadual/SP }\end{array}$ & $\begin{array}{l}\text { "Esta pesquisa teve por propósito } \\
\text { investigar o tratamento dado à gramática } \\
\text { de língua portuguesa em um contexto de } \\
\text { ensino e aprendizagem de tandem à } \\
\text { distância (teletandem) e em livros }\end{array}$ & $\mathrm{Sim}$ \\
\hline
\end{tabular}




\begin{tabular}{|c|c|c|c|}
\hline & & $\begin{array}{l}\text { didáticos de português como língua } \\
\text { estrangeira. Especificamente, foca-se nas } \\
\text { chamadas sessões de feedback } \\
\text { linguístico, as quais consistem em uma } \\
\text { parte da sessão de teletandem na qual os } \\
\text { interagentes discutem a respeito de } \\
\text { aspectos da linguagem. Esta pesquisa } \\
\text { envolve também a análise de três livros } \\
\text { didáticos de português como língua } \\
\text { estrangeira - Fala Brasil, Tudo bem? e } \\
\text { Avenida Brasil - com o intuito de } \\
\text { verificar o lugar ocupado pela gramática } \\
\text { nesses livros." }\end{array}$ & \\
\hline $\begin{array}{l}\text { Curso } \\
\text { Virtual }\end{array}$ & $\begin{array}{l}\text { IES } \\
\text { Particular/RS }\end{array}$ & $\begin{array}{l}\text { "O uso de objetos digitais de } \\
\text { aprendizagem (ODAs) em uma sala de } \\
\text { aula virtual pode ser uma boa estratégia } \\
\text { para ensino de Língua Portuguesa - } \\
\text { afinal, se os meios e os estudantes já não } \\
\text { são mais os mesmos, não faz sentido } \\
\text { manter velhas fórmulas. Assim, em um } \\
\text { curso de português redacional básico a } \\
\text { distância foram propostos objetos } \\
\text { digitais de aprendizagem -instrumentos } \\
\text { de coleta dos dados desta pesquisa - } \\
\text { com conteúdo determinado pelas } \\
\text { necessidades mostradas pelos } \\
\text { participantes. [... ] este trabalho de } \\
\text { pesquisa tem como objetivo principal } \\
\text { investigar o uso de objetos digitais de } \\
\text { aprendizagem no incremento da } \\
\text { produção textual de estudantes } \\
\text { universitários." }\end{array}$ & Sim \\
\hline $\begin{array}{l}\text { Curso } \\
\text { Virtual }\end{array}$ & $\begin{array}{l}\text { IES } \\
\text { Particular/SP }\end{array}$ & $\begin{array}{l}\text { "Este trabalho }[\ldots] \text { tem como tema a } \\
\text { potencialização da aprendizagem } \\
\text { colaborativa e da autonomia discente na } \\
\text { educação a distância, por meio de } \\
\text { estratégias lingüísticas, aliadas a } \\
\text { procedimentos pedagógicos." }\end{array}$ & Sim \\
\hline $\begin{array}{l}\text { Educação } \\
\text { Básica }\end{array}$ & $\begin{array}{l}\text { IES } \\
\text { Particular/SP }\end{array}$ & $\begin{array}{l}\text { "[...] o tema desenvolvido - o ensino e a } \\
\text { aprendizagem da palavra escrita - foi } \\
\text { orientado por um olhar historiográfico. } \\
\text { O foco desse olhar, fundado numa } \\
\text { perspectiva digressiva, possibilitou } \\
\text { resgatar pela história da invenção do } \\
\text { alfabeto os marcos da cognição social } \\
\text { que orientaram o ensino e a } \\
\text { aprendizagem da palavra escrita, nas } \\
\text { chamadas formações sócio-culturais } \\
\text { históricas, que tipificam a Civilização da } \\
\text { escrita e, ainda hoje, orientam o seu } \\
\text { 'ensino formal' nas sociedades } \\
\text { contemporâneas". }\end{array}$ & Não \\
\hline $\begin{array}{l}\text { Educação } \\
\text { Básica }\end{array}$ & IES Federal/PE & $\begin{array}{l}\text { "Esta pesquisa originou-se da } \\
\text { necessidade de mais estudos sobre a } \\
\text { escolha e o uso de livros didáticos de } \\
\text { português. Ela tem como objetivo, entre } \\
\text { outros aspectos, compreender como o } \\
\text { livro didático de português vem sendo } \\
\text { escolhido e usado pelos professores nas } \\
\text { escolas públicas da rede municipal de } \\
\text { ensino da Prefeitura do Recife, verificar } \\
\text { se o fato de um professor usar um livro } \\
\text { escolhido ou não por ele interfere em } \\
\text { suas práticas e reconhecer as relações, os } \\
\text { distanciamentos e as aproximações } \\
\text { existentes entre os discursos e as práticas } \\
\text { dos professores." }\end{array}$ & Não \\
\hline
\end{tabular}




\begin{tabular}{|c|c|c|c|}
\hline $\begin{array}{l}\text { Educação } \\
\text { Básica }\end{array}$ & $\begin{array}{l}\text { IES Federal/ } \\
\text { PB }\end{array}$ & $\begin{array}{l}\text { "A discussão que trazemos nesta } \\
\text { dissertação tem por finalidade refletir } \\
\text { sobre a relação entre a perspectiva } \\
\text { teórico-metodológica para o ensino da } \\
\text { escrita em uma coleção de LDP e as } \\
\text { adaptações nela efetuadas por } \\
\text { professores de língua portuguesa, na } \\
\text { prática de ensino da escrita. Abordamos } \\
\text { dois objetos de pesquisa (uma coleção de } \\
\text { livros didáticos de português, a seleção e } \\
\text { o uso desse material e os discursos dos } \\
\text { professores da rede municipal de ensino } \\
\text { de uma cidade do interior paraibano)." }\end{array}$ & Sim \\
\hline $\begin{array}{l}\text { Educação } \\
\text { Básica }\end{array}$ & $\begin{array}{l}\text { IES } \\
\text { Federal/GO }\end{array}$ & $\begin{array}{l}\text { "Este trabalho objetiva fazer uma } \\
\text { abordagem discursiva do livro didático } \\
\text { de português (LDP), tomando como } \\
\text { objeto de estudo os textos de } \\
\text { apresentação, tratando-os como } \\
\text { processos de objetivação do sujeito } \\
\text { aluno com base nos dispositivos teóricos } \\
\text { e analíticos da Análise do Discurso } \\
\text { (AD)." }\end{array}$ & Não \\
\hline $\begin{array}{l}\text { Educação } \\
\text { Básica }\end{array}$ & $\begin{array}{l}\text { IES } \\
\text { Federal/MG }\end{array}$ & $\begin{array}{l}\text { "Neste trabalho, objetivou-se investigar } \\
\text { uma sala de aula para compreender } \\
\text { melhor como tem sido o ensino de } \\
\text { Língua Portuguesa, decorrendo, deste } \\
\text { fato, a opção pelo Método de Estudo de } \\
\text { Caso para condução da pesquisa. } \\
\text { Assumindo que o ensino de língua } \\
\text { materna deve privilegiar as práticas } \\
\text { discursivas e ser organizado nos eixos da } \\
\text { leitura, produção de textos, gramática e } \\
\text { oralidade e que a unidade básica de } \\
\text { ensino deve ser o texto, materializado } \\
\text { em gêneros, como sugerem os } \\
\text { Parâmetros Curriculares Nacionais [...]" }\end{array}$ & Não \\
\hline $\begin{array}{l}\text { Educação } \\
\text { Básica }\end{array}$ & IES Federal/PR & $\begin{array}{l}\text { "Este estudo apresenta uma investigação } \\
\text { sobre quais concepções embasam a } \\
\text { teoria e prática dos professores de } \\
\text { Língua Portuguesa, tendo como } \\
\text { referência a escrita utilizada na internet, } \\
\text { também conhecida como internetês. O } \\
\text { objetivo desta pesquisa foi investigar } \\
\text { qual a concepção de Língua Portuguesa } \\
\text { e ensino de língua apresentada pelos } \\
\text { professores, da disciplina, perante a } \\
\text { escrita na/da Internet. [...] A pesquisa foi } \\
\text { iniciada com a realização de um projeto- } \\
\text { piloto com } 100 \text { participantes, professores } \\
\text { e alunos, que responderam a uma única } \\
\text { questão por meio virtual (Orkut). } \\
\text { Posteriormente, na tentativa de delimitar } \\
\text { a pesquisa, aplicou-se um questionário a } \\
\text { professores de Língua Portuguesa } \\
\text { (selecionados no site de relacionamento } \\
\text { Orkut, porém não sendo os mesmos do } \\
\text { projeto-piloto), por meio de e-mails, fase } \\
\text { esta denominada exploratória. Por fim, } \\
\text { optou-se em realizar a pesquisa final } \\
\text { presencialmente em uma escola da rede } \\
\text { municipal de Curitiba, por proporcionar } \\
\text { um contato maior com as professoras } \\
\text { respondentes, evitando a permanência de } \\
\text { dúvidas durante a coleta dos dados." }\end{array}$ & Sim \\
\hline $\begin{array}{l}\text { Educação } \\
\text { Básica }\end{array}$ & $\begin{array}{l}\text { IES } \\
\text { Particular/PE }\end{array}$ & $\begin{array}{l}\text { "Este trabalho versou sobre as } \\
\text { concepções do professor no contexto } \\
\text { educacional inclusivo acerca do texto }\end{array}$ & Sim \\
\hline
\end{tabular}




\begin{tabular}{|c|c|c|c|}
\hline & & $\begin{array}{l}\text { escrito do aluno surdo. De modo geral, } \\
\text { na formação desses docentes, o ensino } \\
\text { da língua portuguesa para surdos, não é } \\
\text { tratado e isso acarreta dificuldades na } \\
\text { compreensão dos elementos que } \\
\text { compõem o texto desse aprendiz, } \\
\text { geralmente, atravessado pela língua de } \\
\text { sinais." }\end{array}$ & \\
\hline $\begin{array}{l}\text { Educação } \\
\text { Básica }\end{array}$ & IES Federal/SP & $\begin{array}{l}\text { "Sabe-se que as conquistas dos } \\
\text { movimentos sociais de mulheres } \\
\text { concederam a esse grupo direitos } \\
\text { historicamente negados, porém avalia-se } \\
\text { que ainda hoje valores socialmente } \\
\text { construídos reproduzem conceitos } \\
\text { machistas no âmbito das relações } \\
\text { sociais; sabe-se também o importante } \\
\text { papel que exerce a educação escolar na } \\
\text { tentativa de criar atitudes de repúdio ao } \\
\text { sexismo. Nesse sentido, a pesquisa tem } \\
\text { como tema de análise as ideias sobre a } \\
\text { condição da mulher na } \\
\text { contemporaneidade de educandos (as) de } \\
\text { uma escola pública, no contexto da } \\
\text { disciplina de Língua Portuguesa, com o } \\
\text { objetivo de refletir sobre como tal } \\
\text { componente curricular pode contribuir } \\
\text { para com o debate sobre o sexismo, por } \\
\text { meio de uma proposta metodológica que } \\
\text { possibilite o desenvolvimento das } \\
\text { habilidades escritora e leitora e também } \\
\text { colabore para a formação de alunos (as) } \\
\text { críticos (as) às relações sociais." }\end{array}$ & Não \\
\hline $\begin{array}{l}\text { Educação } \\
\text { Profissional } \\
\text { Técnica de } \\
\text { Nível Médio }\end{array}$ & $\begin{array}{l}\text { IES } \\
\text { Federal/MA }\end{array}$ & $\begin{array}{l}\text { "Este trabalho apresenta o currículo no } \\
\text { Ensino Médio e o desenvolvimento da } \\
\text { Competência Leitora proposto por } \\
\text { professores de Língua Portuguesa (LP), } \\
\text { no Instituto Federal de Educação, } \\
\text { Ciência e Tecnologia do Maranhão." }\end{array}$ & Não \\
\hline $\begin{array}{l}\text { Educação } \\
\text { Profissional } \\
\text { Técnica de } \\
\text { Nível Médio }\end{array}$ & IES Federal/RJ & $\begin{array}{l}\text { "Este estudo foi realizado na Escola } \\
\text { Agrotécnica Federal de São João } \\
\text { Evangelista - Minas Gerais (EAFSJE - } \\
\text { MG) com vinte e seis alunos do } 3^{\circ} \text { ano } \\
\text { do Ensino Médio profissionalizante dos } \\
\text { Cursos Técnicos em Agropecuária e } \\
\text { Alimentação no ano letivo de } 2007 \text {, com } \\
\text { a colaboração e a participação de três } \\
\text { professores. Como professora de Língua } \\
\text { Portuguesa, atuando há } 15 \text { anos no } \\
\text { exercício da docência, temos nos } \\
\text { preocupado com o ensino-aprendizagem } \\
\text { dessa disciplina, em especial o que } \\
\text { ocorre nessa escola. Na prática cotidiana } \\
\text { do ensino, temos convivido com a } \\
\text { contradição que se estabelece entre a } \\
\text { escola real e a escola desejada e o } \\
\text { ensino-aprendizagem que prioriza o } \\
\text { dialeto-padrão, mas não proporciona } \\
\text { uma aprendizagem significativa, na qual } \\
\text { o aluno possa se preparar para uma } \\
\text { transformação, ou seja, que possibilite o } \\
\text { acesso à escrita e aos discursos que se } \\
\text { organizam a partir dela. O caminho } \\
\text { metodológico utilizado fundamentou-se } \\
\text { na pesquisa qualitativa descritiva, o } \\
\text { estudo de caso. Os instrumentos de } \\
\text { pesquisa utilizados foram: questionário, } \\
\text { Plano de Ensino, produções textuais em }\end{array}$ & Sim \\
\hline
\end{tabular}




\begin{tabular}{|c|c|c|c|}
\hline & & $\begin{array}{l}\text { dois momentos distintos, no Processo } \\
\text { Seletivo/2005 e em } 2008 \text { no } 3^{\circ} \text { ano." }\end{array}$ & \\
\hline $\begin{array}{l}\text { Educação } \\
\text { Superior }\end{array}$ & $\begin{array}{l}\text { IES } \\
\text { Particular/SP }\end{array}$ & $\begin{array}{l}\text { "Esta pesquisa discute a oferta de } \\
\text { disciplinas de Língua Portuguesa em } \\
\text { cursos superiores de diversas áreas do } \\
\text { conhecimento. Parte-se da constatação } \\
\text { de que há um discurso corrente segundo } \\
\text { o qual os estudantes universitários têm } \\
\text { dificuldades de leitura e escrita } \\
\text { (CARONE, 1976; LEMOS, 1977; } \\
\text { PÉCORA, 1989 [1984]; HANSEN, } \\
\text { 1989; ROCCO, 1981, 1982; BRIT-TO, } \\
\text { 1983; CARVALHO; SILVA, 1996; } \\
\text { CASTELLO-PEREIRA, 2003) e que, } \\
\text { diante de tal situação, admite-se como } \\
\text { plenamente justificável o ensino de } \\
\text { Língua Portuguesa em cursos superiores, } \\
\text { não se observando o necessário debate } \\
\text { em torno das razões da oferta dessa } \\
\text { disciplina em cursos não específicos da } \\
\text { área da linguagem, nem as concepções } \\
\text { de língua que sustentam seus programas. } \\
\text { Visando investigar como se considera a } \\
\text { questão do conhecimento da escrita na } \\
\text { Educação Superior brasileira } \\
\text { contemporânea, buscou-se mapear a } \\
\text { oferta de Língua Portuguesa por } \\
\text { diferentes IES; verificar as razões que } \\
\text { levam à oferta da disciplina em curso } \\
\text { não específico da área da linguagem; } \\
\text { examinar as propostas de ensino, } \\
\text { identificando o caráter predominante e } \\
\text { suas concepções de linguagem e de } \\
\text { formação acadêmica." }\end{array}$ & Sim \\
\hline $\begin{array}{l}\text { Educação } \\
\text { Superior }\end{array}$ & $\begin{array}{l}\text { IES } \\
\text { Particular/RS }\end{array}$ & $\begin{array}{l}\text { "Levando em consideração a } \\
\text { importância do estágio supervisionado } \\
\text { na formação docente e a complexidade } \\
\text { dessa atividade, esta pesquisa tem como } \\
\text { objetivo geral investigar características } \\
\text { do trabalho de professores-estagiários de } \\
\text { língua portuguesa, a fim de contribuir } \\
\text { para a compreensão dos conflitos dessa } \\
\text { etapa de formação." }\end{array}$ & Sim \\
\hline $\begin{array}{l}\text { Educação } \\
\text { Superior }\end{array}$ & IES Federal/CE & $\begin{array}{l}\text { "Analisamos relatórios de estágio, } \\
\text { escritos por professores de Língua } \\
\text { Portuguesa em formação inicial, para } \\
\text { investigar a organização textual na } \\
\text { construção desse gênero acadêmico. } \\
\text { Para isso, procedemos à análise da } \\
\text { organização do contexto de produção, da } \\
\text { estrutura composicional e do conteúdo } \\
\text { informacional (organização tópica) dos } \\
\text { relatórios de estágio. [...] Selecionamos } \\
\text { amostras de relatórios dos alunos do } \\
\text { Curso de Letras da UFMA, inscritos na } \\
\text { disciplina Prática de Ensino de Língua } \\
\text { Portuguesa, referentes aos semestres } \\
\text { 2007.2 e 2008.1, escolhidas } \\
\text { aleatoriamente, correspondendo a } 17 \\
\text { relatórios." }\end{array}$ & Sim \\
\hline $\begin{array}{l}\text { Educação } \\
\text { Superior }\end{array}$ & $\begin{array}{l}\text { IES } \\
\text { Particular/PE }\end{array}$ & $\begin{array}{l}\text { "A observação da influencia da } \\
\text { oralidade na produção dos alunos } \\
\text { universitários do curso de licenciatura } \\
\text { em letras revelam que as marcas de } \\
\text { oralidade diminuem com o } \\
\text { desenvolvimento das atividades } \\
\text { acadêmicas, mas não desaparecem em }\end{array}$ & Sim \\
\hline
\end{tabular}




\begin{tabular}{|c|c|c|c|}
\hline & & $\begin{array}{l}\text { definitivo. A pesquisa teve como } \\
\text { objetivo analisar a as produções textuais } \\
\text { em português, dos alunos do } 1^{\circ} \mathrm{e} 8^{\circ} \\
\text { períodos em uma mesma turma do curso } \\
\text { de letras da Faculdade de Formação de } \\
\text { Professores da Mata Sul na cidade de } \\
\text { Palmares-PE." }\end{array}$ & \\
\hline $\begin{array}{l}\text { Educação } \\
\text { Superior }\end{array}$ & $\begin{array}{l}\text { IES } \\
\text { Particular/SP }\end{array}$ & $\begin{array}{l}\text { "Um grande desafio do professor é } \\
\text { transformar um conhecimento científico } \\
\text { em conteúdo didático e, para isso, teorias } \\
\text { complexas, sem perder suas } \\
\text { propriedades e características, precisam } \\
\text { ser transformadas para serem } \\
\text { assimiladas pelos alunos. Assim, a } \\
\text { transposição didática pode ser concebida } \\
\text { como um conjunto de ações } \\
\text { transformadoras que tornam um saber } \\
\text { sábio' em 'saber ensinável', que traz em } \\
\text { seu bojo a concepção de que a docência } \\
\text { se constrói numa articulação da } \\
\text { competência acadêmica com a } \\
\text { competência pedagógica. Nesse } \\
\text { contexto, percebemos que a formação } \\
\text { inadequada do professor o impede de } \\
\text { refletir sobre a prática da transposição } \\
\text { didática para o ensino de língua } \\
\text { portuguesa. Refletimos aqui sobre a } \\
\text { transposição didática para um ensino de } \\
\text { língua portuguesa mais eficaz. Para } \\
\text { tanto, refletimos sobre as teorias de texto } \\
\text { adequadas ao ensino de língua } \\
\text { portuguesa, e, partindo da hipótese de } \\
\text { que as universidades não contemplam a } \\
\text { transposição didática, analisamos os } \\
\text { programas de Prática de Ensino de } \\
\text { Letras de uma universidade pública e } \\
\text { uma particular, buscamos a transposição } \\
\text { didática para aplicar na sala de aula de } \\
\text { língua portuguesa pe propomos atividades } \\
\text { que percorram os caminhos da Educação } \\
\text { Lingüística." }\end{array}$ & Sim \\
\hline $\begin{array}{l}\text { Educação } \\
\text { Superior }\end{array}$ & $\begin{array}{l}\text { IES } \\
\text { Particular/SP }\end{array}$ & $\begin{array}{l}\text { "Estudo sobre interação, em ensino de } \\
\text { Língua Portuguesa a distância, realizado } \\
\text { em curso semipresencial no ensino } \\
\text { superior. A investigação partiu do } \\
\text { seguinte questionamento: Como atingir a } \\
\text { interação, visando à construção do } \\
\text { conhecimento e à aprendizagem de LPO, } \\
\text { em ambientes Virtuais? Na busca da } \\
\text { resposta assumiu como objetivo analisar } \\
\text { o desenvolvimento das possíveis } \\
\text { estratégias de interação no ambiente } \\
\text { virtual de ensino e aprendizagem em } \\
\text { Língua Portuguesa, numa perspectiva } \\
\text { coletiva, utilizando a disciplina } \\
\text { Comunicação e Expressão para verificar } \\
\text { a interação entre os participantes e o } \\
\text { papel do professor como mediador } \\
\text { pedagógico desse processo." }\end{array}$ & Sim \\
\hline $\begin{array}{l}\text { Ensino } \\
\text { Fundamental }\end{array}$ & $\begin{array}{l}\text { IES } \\
\text { Estadual/SP }\end{array}$ & $\begin{array}{l}\text { "Esta investigação teve por objetivos } \\
\text { elaborar e experimentar uma proposta de } \\
\text { intervenção colaborativa junto à } \\
\text { professora que atua em Sala de Apoio } \\
\text { Pedagógico de uma Escola Municipal de } \\
\text { Ensino Fundamental de São Paulo; } \\
\text { analisar, criticamente, reu } \\
\text { encaminhamento e discutir os resultados }\end{array}$ & Não \\
\hline
\end{tabular}




\begin{tabular}{|c|c|c|c|}
\hline & & $\begin{array}{l}\text { das ações pedagógicas, empreendidas e } \\
\text { do percurso formativo da professora } \\
\text { colaboradora." }\end{array}$ & \\
\hline $\begin{array}{l}\text { Ensino } \\
\text { Fundamental }\end{array}$ & IES Federal/RJ & $\begin{array}{l}\text { "A investigação busca compreender o } \\
\text { que dizem os estudantes surdos sobre o } \\
\text { aprendizado (ensino) da Língua } \\
\text { Portuguesa escrita no Ensino } \\
\text { Fundamental do Instituto Nacional de } \\
\text { Educação de Surdos, situado no } \\
\text { município do Rio de Janeiro." }\end{array}$ & Sim \\
\hline $\begin{array}{l}\text { Ensino } \\
\text { Fundamental }\end{array}$ & $\begin{array}{l}\text { IES Municipal/ } \\
\text { SP }\end{array}$ & $\begin{array}{l}\text { "A partir da observação da dificuldade } \\
\text { de aprendizagem da língua portuguesa } \\
\text { por parte dos alunos tanto em relação às } \\
\text { normas gramaticais quanto à produção } \\
\text { escrita e da dificuldade dos professores } \\
\text { em ensinar a língua materna, é que se } \\
\text { realizou esta pesquisa com o objetivo } \\
\text { geral de investigar se a transposição } \\
\text { didática da proposta dos Parâmetros } \\
\text { Curriculares Nacionais - PCN - para a } \\
\text { produção escrita de gêneros discursivos } \\
\text { está sendo realizada de forma adequada } \\
\text { em aulas da Língua Portuguesa do } \\
\text { Ensino Fundamental por um grupo de } \\
\text { professores de um município do interior } \\
\text { do Estado do Rio de Janeiro." }\end{array}$ & Sim \\
\hline $\begin{array}{l}\text { Ensino } \\
\text { Fundamental } \\
\text { I }\end{array}$ & $\begin{array}{l}\text { IES } \\
\text { Particular/SP }\end{array}$ & $\begin{array}{l}\text { "Nas sociedades contemporâneas, saber } \\
\text { ler e escrever, saber utilizar-se da leitura } \\
\text { e da escrita em diferentes situações do } \\
\text { cotidiano são necessidades } \\
\text { imprescindíveis, para que qualquer } \\
\text { pessoa possa exercer sua cidadania plena } \\
\text { e para que as nações em geral se } \\
\text { desenvolvam nos níveis social, cultural e } \\
\text { político. Apesar disso, nota-se que } \\
\text { muitas têm sido as dificuldades da escola } \\
\text { para garantir efetivamente aos } \\
\text { indivíduos o aprendizado da leitura e da } \\
\text { escrita. Para tanto, faz-se necessário } \\
\text { pensar num ensino de língua materna } \\
\text { cada vez mais útil e contextualmente } \\
\text { significativo, com vistas à Educação } \\
\text { Linguística e ao fenômeno do } \\
\text { Letramento. Nesse sentido, esta } \\
\text { dissertação aborda a questão da } \\
\text { formação inicial de professores de } \\
\text { Língua Portuguesa sob o foco da } \\
\text { Educação Linguística e do Letramento, } \\
\text { baseada na metodologia de pesquisa } \\
\text { 'Estudo de Caso', focalizando a análise } \\
\text { da prática educativa das professoras do } \\
5^{\circ} \text { ano do Ensino Fundamental I." }\end{array}$ & Sim \\
\hline $\begin{array}{l}\text { Ensino } \\
\text { Fundamental } \\
\text { I }\end{array}$ & IES Federal/AL & $\begin{array}{l}\text { "O presente trabalho pretende investigar } \\
\text { as direções de sentido na interpretação } \\
\text { de uma professora de } 3^{\mathrm{a}} \text { serie do Ensino } \\
\text { Fundamental ao efetivar propostas de } \\
\text { texto inseridas em um livro didático de } \\
\text { português 'Projeto Pintaguá, } 3^{\mathrm{a}} \text { série', } \\
\text { adotado no ano de } 2007 \text { em uma } \\
\text { escolada rede municipal de ensino de } \\
\text { Maceió. Partimos da hipótese de que, } \\
\text { apesar da maneira parcialmente linear } \\
\text { com que uma atividade de produção de } \\
\text { texto pode ser tratada pelos documentos } \\
\text { oficiais, a execução pela professora, e } \\
\text { em particular sua proferição quanto da } \\
\text { orientação da proposta, pode trazer }\end{array}$ & Não \\
\hline
\end{tabular}




\begin{tabular}{|c|c|c|c|}
\hline & & $\begin{array}{l}\text { elementos presentes em seu universo } \\
\text { simbólico." }\end{array}$ & \\
\hline $\begin{array}{l}\text { Ensino } \\
\text { Fundamental } \\
\text { I }\end{array}$ & $\begin{array}{l}\text { IES } \\
\text { Estadual/SP }\end{array}$ & $\begin{array}{l}\text { "Esta pesquisa pretende discutir questões } \\
\text { relacionadas à produção de vídeo digital } \\
\text { na sala de aula com a criação de roteiro } \\
\text { pelos estudantes, em trabalho } \\
\text { desenvolvido com auxilio da professora. } \\
\text { A pesquisa está baseada no processo de } \\
\text { escrita dos estudantes, na apropriação } \\
\text { dos conheciemntos sobre os gêneros e } \\
\text { num maior domínio sobre a linguagem, } \\
\text { seguindo as propostas dos PCN de } \\
\text { Língua Portuguesa. Trata-se de um } \\
\text { Estudo de caso ambientado em uma } \\
\text { escola municipal de Campinas, em salas } \\
\text { de terceiras e quartas séries." }\end{array}$ & Sim \\
\hline $\begin{array}{l}\text { Ensino } \\
\text { Fundamental } \\
\text { II }\end{array}$ & $\begin{array}{l}\text { IES } \\
\text { Particular/SP }\end{array}$ & $\begin{array}{l}\text { "Neste trabalho de pesquisa, temos por } \\
\text { tema a referenciação e objetivamos } \\
\text { verificar como ocorre o processo de } \\
\text { introdução e de retomada/manutenção de } \\
\text { referentes textuais em retextualizações } \\
\text { produzidas por alunos no Ensino } \\
\text { Fundamental II de uma escola pública da } \\
\text { cidade de Mogi Guaçu - SP." }\end{array}$ & Sim \\
\hline $\begin{array}{l}\text { Ensino } \\
\text { Fundamental } \\
\text { II }\end{array}$ & $\begin{array}{l}\text { IES } \\
\text { Particular/SP }\end{array}$ & $\begin{array}{l}\text { "A presente pesquisa vislumbrou } \\
\text { responder de que maneira podemos levar } \\
\text { os alunos do ciclo básico de ensino a } \\
\text { dominarem a variante culta, sem } \\
\text { desprestigiar as demais variantes, as } \\
\text { quais eles podem, ou não ter mais } \\
\text { acesso. Tivemos como objetivo geral, } \\
\text { contribuir para a implementação de uma } \\
\text { Educação Linguística (EL) eficaz e } \\
\text { como objetivos específicos, apresentar a } \\
\text { Sociolinguística e a EL e suas } \\
\text { contribuições para o ensino de língua } \\
\text { portuguesa; investigar de que maneira o } \\
\text { trabalho com as variações pode } \\
\text { contribuir para uma EL mais eficaz; e } \\
\text { elaborar uma sequência didática que } \\
\text { pudesse ser aplicada em uma sala de } \\
\text { nono ano do Ensino Fundamental II e } \\
\text { que percorresse os caminhos da } \\
\text { Educação Linguística, contemplando, } \\
\text { então, as variaçôes linguísticas." }\end{array}$ & $\mathrm{Sim}$ \\
\hline $\begin{array}{l}\text { Ensino } \\
\text { Fundamental } \\
\text { II }\end{array}$ & $\begin{array}{l}\text { IES } \\
\text { Particular/PE }\end{array}$ & $\begin{array}{l}\text { "Este trabalho propõe parâmetros para } \\
\text { avaliação de produções textuais, numa } \\
\text { visão humanizadora, acompanhados da } \\
\text { grade de correção que os } \\
\text { embasa.Tomou-se como ponto de } \\
\text { partida estudos sobre a necessidade da } \\
\text { inserção de positividade no ensino da } \\
\text { Língua Portuguesa numa concepção } \\
\text { instrumentalista e não normativista da } \\
\text { mesma, tanto no que diz respeito à } \\
\text { investigação dos fatos linguísticos } \\
\text { envolvidos na produção escrita de textos, } \\
\text { quanto no que concerne à prática } \\
\text { avaliativa dos mesmos. [...]Como } \\
\text { metodologia, foi usada a pesquisa de } \\
\text { campo, aplicada a alunos do } 6^{\circ} \text { ano do } \\
\text { Ensino Fundamental do Colégio Militar } \\
\text { do Recife, antecedida da bibliografia } \\
\text { embasadora." }\end{array}$ & $\mathrm{Sim}$ \\
\hline $\begin{array}{l}\text { Ensino } \\
\text { Fundamental }\end{array}$ & $\begin{array}{l}\text { IES } \\
\text { Particular/SP }\end{array}$ & $\begin{array}{l}\text { "Esta dissertação insere-se na linha de } \\
\text { pesquisa Leitura, Escrita e Ensino de } \\
\text { Língua Portuguesa e tem como tema a }\end{array}$ & Sim \\
\hline
\end{tabular}




\begin{tabular}{|c|c|c|c|}
\hline II & & $\begin{array}{l}\text { análise da abordagem de gêneros digitais } \\
\text { em manuais didáticos de Língua } \\
\text { Portuguesa no Ensino Fundamental ciclo } \\
\text { II ( } 5^{\mathrm{a}} \text { a } 8^{\mathrm{a}} \text { séries)." }\end{array}$ & \\
\hline $\begin{array}{l}\text { Ensino } \\
\text { Fundamental } \\
\text { II }\end{array}$ & $\begin{array}{l}\text { IES } \\
\text { Federal/MS }\end{array}$ & $\begin{array}{l}\text { "Esta pesquisa tem como objeto o ensino } \\
\text { de Língua Portuguesa proposto nos } \\
\text { documentos curriculares de 1992, 2000 e } \\
2003 \text {, da Secretaria Municipal de } \\
\text { Educação para a Rede Municipal de } \\
\text { Ensino de Campo Grande, MS. O } \\
\text { objetivo é investigar a concepção de } \\
\text { ensino de Língua Portuguesa que } \\
\text { fundamenta sugestões às práticas nesses } \\
\text { documentos, utilizando procedimentos } \\
\text { próprios da análise documental e tendo } \\
\text { como referência os Parâmetros } \\
\text { Curriculares Nacionais: terceiro e quarto } \\
\text { ciclos do Ensino Fundamental: Língua } \\
\text { Portuguesa (INEP/MEC, 1998). O } \\
\text { corpus da pesquisa foi constituído por } \\
\text { três documentos curriculares: } \\
\text { Alternativa Curricular de Língua } \\
\text { Portuguesa (1992), Sequiência Didática } \\
\text { (2000) e Diretrizes Curriculares (2003), } \\
\text { sendo recortadas dos dois últimos apenas } \\
\text { aquilo que se refere à área de Língua } \\
\text { Portuguesa." }\end{array}$ & Não \\
\hline $\begin{array}{l}\text { Ensino } \\
\text { Fundamental } \\
\text { II }\end{array}$ & IES Federal/RN & $\begin{array}{l}\text { "Esta dissertação apresenta um estudo de } \\
\text { caso desenvolvido em uma escola da } \\
\text { rede estadual de ensino, em uma cidade } \\
\text { do interior do Estado do Rio Grande do } \\
\text { Norte, numa turma de } 6^{\circ} \text { ano, durante os } \\
\text { anos letivos de } 2007 \text { e } 2008 \text {. A pesquisa } \\
\text { teve como principal objetivo investigar o } \\
\text { modo como se dá o processo de ensino- } \\
\text { aprendizagem de língua portuguesa. Para } \\
\text { tanto, foi preciso verificar e caracterizar } \\
\text { as concepções de linguagem e de ensino } \\
\text { de língua que orientam as ações do } \\
\text { professor de língua materna em sala de } \\
\text { aula." }\end{array}$ & Não \\
\hline $\begin{array}{l}\text { Ensino } \\
\text { Fundamental } \\
\text { /Ensino } \\
\text { Médio }\end{array}$ & $\begin{array}{l}\text { IES } \\
\text { Particular/SP }\end{array}$ & $\begin{array}{l}\text { "Pretendemos evidenciar, por meio da } \\
\text { análise de quatro crônicas, a importância } \\
\text { da modalização para a argumentação do } \\
\text { autor. O fato de atuarmos como } \\
\text { professora no ensino fundamental e } \\
\text { médio justificou a realização desta } \\
\text { pesquisa, cujos objetivos específicos } \\
\text { foram assim definidos: } 1 \text {. verificar como } \\
\text { se dá a modalização nas crônicas de } \\
\text { Carlos Heitor Cony, publicadas no jornal } \\
\text { Folha de S. Paulo (página } 2 \text {, seção } \\
\text { Opinião); 2. refletir, com base na } \\
\text { análise, sobre a modalização como } \\
\text { estratégia argumentativa do autor. [...] } \\
\text { Consideramos que o desenvolvimento do } \\
\text { trabalho nos permitiu aprofundar nossos } \\
\text { conhecimentos sobre o tema, assim } \\
\text { como repensar nossa prática pedagógica } \\
\text { e, conseqüentemente, trazer algumas } \\
\text { contribuições para o ensino da leitura" }\end{array}$ & Sim \\
\hline $\begin{array}{l}\text { Ensino } \\
\text { Fundamental } \\
\text { /Ensino } \\
\text { Médio }\end{array}$ & IES Federal/RN & $\begin{array}{l}\text { "O trabalho em tela } \begin{array}{c}\text { analisa o } \\
\text { comportamento dos }\end{array} \text { conectores } \\
\text { adversativos na fala do usuário } \\
\text { natalense, com vistas a sugerir } \\
\text { implicações para o ensino de gramática } \\
\text { nas escolas de ensino Fundamental e }\end{array}$ & Não \\
\hline
\end{tabular}




\begin{tabular}{|c|c|c|c|}
\hline & & $\begin{array}{l}\text { Médio. É uma investigação que se } \\
\text { assenta no paradigma funcionalista, } \\
\text { especificamente nas idéias defendidas } \\
\text { por Givón. Para tanto, utilizam-se dados } \\
\text { de situações de fala do corpus Discurso } \\
\text { \& Gramática - a língua falada e escrita } \\
\text { da cidade do Natal (FURTADO DA } \\
\text { CUNHA, 1998)." }\end{array}$ & \\
\hline $\begin{array}{l}\text { Ensino } \\
\text { Fundamental } \\
\text { / Ensino } \\
\text { Médio }\end{array}$ & $\begin{array}{l}\text { IES } \\
\text { Estadual/SP }\end{array}$ & $\begin{array}{l}\text { "Neste trabalho analisamos redações de } \\
\text { alunos de uma sexta, uma sétima, uma } \\
\text { oitava série do Ciclo II do Ensino } \\
\text { Fundamental e de uma primeira série do } \\
\text { Ensino Médio de uma Escola Pública } \\
\text { Estadual no município de Campinas, em } \\
\text { São Paulo. O corpus é constituído de } 40 \\
\text { redações, sendo } 10 \text { redações por série. } \\
\text { Nosso objetivo é mostrar como se } \\
\text { manifesta a oralidade em textos desses } \\
\text { alunos." }\end{array}$ & Sim \\
\hline $\begin{array}{l}\text { Ensino } \\
\text { Médio }\end{array}$ & $\begin{array}{l}\text { IES } \\
\text { Federal/MG }\end{array}$ & $\begin{array}{l}\text { "Neste trabalho, analisamos os } \\
\text { resultados da aplicação de uma } \\
\text { sequência didática com artigo de } \\
\text { opinião, proposta pela Olimpíada de } \\
\text { Língua Portuguesa 2008, em uma turma } \\
\text { de } 3^{\circ} \text { ano do Ensino Médio, de uma } \\
\text { escola da rede pública estadual de Minas } \\
\text { Gerais. Procuramos responder à seguinte } \\
\text { pergunta: até que ponto a utilização de } \\
\text { uma sequência, com atividades } \\
\text { sistematizadas de leitura e escrita, tendo } \\
\text { por base as características de um gênero } \\
\text { textual, pode contribuir para o } \\
\text { desenvolvimento de capacidades do } \\
\text { aluno como produtor de textos?" }\end{array}$ & $\mathrm{Sim}$ \\
\hline $\begin{array}{l}\text { Ensino } \\
\text { Médio }\end{array}$ & $\begin{array}{l}\text { IES } \\
\text { Particular/SP }\end{array}$ & $\begin{array}{l}\text { "[...] esta pesquisa busca suscitar uma } \\
\text { reflexão sobre a possibilidade de } \\
\text { aproximação entre teoria e prática, a } \\
\text { partir da verificação dos resultados } \\
\text { obtidos nos textos dos alunos de } 1^{\circ} \text { ano } \\
\text { de Ensino Médio, usuários de variação } \\
\text { linguística de ordem diastrática, por } \\
\text { meio de estratégias de ensino pautadas } \\
\text { no estudo do texto, em suas macro e } \\
\text { micro estruturas." }\end{array}$ & $\mathrm{Sim}$ \\
\hline $\begin{array}{l}\text { Ensino } \\
\text { Médio }\end{array}$ & $\begin{array}{l}\text { IES } \\
\text { Estadual/PR }\end{array}$ & $\begin{array}{l}\text { "Em conformidade com a postura } \\
\text { metodológica da pesquisa-ação } \\
\text { (ANDRÉ, 1995) e para testar estratégias } \\
\text { didáticas que contribuam para o } \\
\text { desenvolvimento de capacidades de } \\
\text { linguagem, tanto na leitura quanto na } \\
\text { produção de textos oriundos das } \\
\text { diferentes esferas da comunicação } \\
\text { humana (NASCIMENTO, 2008), o } \\
\text { nosso objetivo é o de relatar as fases de } \\
\text { implantação de um projeto didático de } \\
\text { produção, editoração e circulação de } \\
\text { jornal escolar e as ações implicadas } \\
\text { nesse processo: desde a análise e } \\
\text { descrição de diferentes gêneros da mídia } \\
\text { impressa que constituirão modelos } \\
\text { didáticos (DOLZ; SCHNEUWLY, 2004) } \\
\text { e seqüências didáticas, até a fase final } \\
\text { das transposições didáticas. Nesse } \\
\text { processo, a descoberta das regularidades } \\
\text { dos gêneros textuais que irão compor o } \\
\text { jornal escolar, constituem os objetivos } \\
\text { de ensino-aprendizagem que norteiam as }\end{array}$ & $\mathrm{Sim}$ \\
\hline
\end{tabular}




\begin{tabular}{|c|c|c|c|}
\hline & & $\begin{array}{l}\text { atividades das oficinas a serem } \\
\text { implementadas em uma turma da } \\
\text { primeira série do ensino médio, no } \\
\text { município de Apucarana." }\end{array}$ & \\
\hline $\begin{array}{l}\text { Ensino } \\
\text { Médio }\end{array}$ & $\begin{array}{l}\text { IES } \\
\text { Federal/AM }\end{array}$ & $\begin{array}{l}\text { "Nosso estudo é um convite a uma } \\
\text { reflexão sobre o ensino de Língua } \\
\text { Portuguesa à luz do letramento, no } \\
\text { Ensino Médio, frente à formação de } \\
\text { professor, visto que o debate atual em } \\
\text { torno do que se deva ensinar não traz a } \\
\text { clareza do que se deve fazer no e do } \\
\text { ensino de LP. Razão que conduziu esta } \\
\text { pesquisa a ser de natureza qualitativa de } \\
\text { cunho fenomenológico, com aplicação } \\
\text { de questionário e observação não- } \\
\text { participante, envolvendo professoras de } \\
\text { três escolas públicas de Boa Vista - RR. } \\
\text { O objetivo principal de diagnosticar } \\
\text { como ocorre o ensino de LP no EM e } \\
\text { verificar se e como a prática do } \\
\text { letramento foi desenvolvida." }\end{array}$ & Não \\
\hline $\begin{array}{l}\text { Ensino } \\
\text { Médio }\end{array}$ & IES Federal/DF & $\begin{array}{l}\text { "Esta dissertação de mestrado é um } \\
\text { estudo de caso que faz uso de } \\
\text { instrumentos da micro-etnografia com o } \\
\text { objetivo de analisar pela primeira vez a } \\
\text { abordagem de ensinar Língua } \\
\text { Portuguesa de uma professora, ouvinte, } \\
\text { de Produção de Texto que rege uma } \\
\text { turma de inclusão com alunos surdos } \\
\text { bilaterais/profundos e ouvintes do } 2^{\circ} \text { ano } \\
\text { do Ensino Médio de uma Escola Pólo, } \\
\text { pública, de uma cidade satélite de } \\
\text { Brasília." }\end{array}$ & Sim \\
\hline $\begin{array}{l}\text { Ensino } \\
\text { Médio }\end{array}$ & $\begin{array}{l}\text { IES } \\
\text { Particular/SP }\end{array}$ & $\begin{array}{l}\text { "Esta dissertação, inserida na linha de } \\
\text { pesquisa Leitura, Escrita e Ensino de } \\
\text { Língua Portuguesa, fundamenta-se em } \\
\text { estudos do texto na perspectiva } \\
\text { sociocognitivo-interacional e tem o } \\
\text { propósito de contribuir para o ensino de } \\
\text { leitura em contexto digital. Para o } \\
\text { desenvolvimento do estudo, foi realizada } \\
\text { uma pesquisa de campo com alunos de } \\
\text { ensino médio de escolas da rede pública } \\
\text { e privada, a fim de conhecer e identificar } \\
\text { o perfil dos hiperleitores e as estratégias } \\
\text { por eles utilizadas na leitura do } \\
\text { hipertexto." }\end{array}$ & Sim \\
\hline $\begin{array}{l}\text { Ensino } \\
\text { Médio }\end{array}$ & $\begin{array}{l}\text { IES } \\
\text { Federal/MG }\end{array}$ & $\begin{array}{l}\text { "Como profissional do ensino da Língua } \\
\text { Portuguesa, percebemos a dificuldade } \\
\text { dos alunos do Ensino Médio em utilizar } \\
\text { adequadamente a língua oral nas } \\
\text { diferentes situações comunicativas } \\
\text { formais a que estão expostos. Em função } \\
\text { disso, interessamo-nos em analisar de } \\
\text { que forma a modalidade oral da Língua } \\
\text { Portuguesa, na sua variedade padrão } \\
\text { escolarizada, tem sido trabalhada no } \\
\text { Ensino Médio." }\end{array}$ & Sim \\
\hline $\begin{array}{l}\text { Ensino } \\
\text { Médio }\end{array}$ & $\begin{array}{l}\text { IES Particular/ } \\
\text { GO }\end{array}$ & $\begin{array}{l}\text { "Esta dissertação pretende analisar o } \\
\text { processo de melhoria do ensino e } \\
\text { aprendizagem da produção do texto } \\
\text { dissertativo-argumentativo conforme as } \\
\text { competências do ENEM. [...] O objetivo } \\
\text { geral desta pesquisa foi analisar como se } \\
\text { dá o processo de ensino e aprendizagem } \\
\text { da produção escrita do texto dissertativo } \\
\text { argumentativo na } 3^{\text {a }} \text { série 'A' do ensino }\end{array}$ & Sim \\
\hline
\end{tabular}




\begin{tabular}{|c|c|c|c|}
\hline & & $\begin{array}{l}\text { médio do Colégio Estadual Ângelo } \\
\text { Urzêda durante o ano de 2008." }\end{array}$ & \\
\hline $\begin{array}{l}\text { Ensino } \\
\text { Médio }\end{array}$ & $\begin{array}{l}\text { IES } \\
\text { Estadual/SP }\end{array}$ & $\begin{array}{l}\text { "O trabalho de pesquisa consistiu em um } \\
\text { estudo dos documentos oficiais que } \\
\text { orientaram o ensino de Língua } \\
\text { Portuguesa e Literatura para o } 2^{\circ} \text { grau } \\
\text { (antiga nomenclatura do ensino médio) } \\
\text { tendo em vista a possibilidade de } \\
\text { compreender a relação entre as } \\
\text { proposições inovadoras ali contidas e o } \\
\text { trabalho de pesquisa acadêmica com o } \\
\text { qual dialogam. Partiu-se de uma } \\
\text { concepção de currículo como um } \\
\text { artefato cultural, uma invenção escolar e, } \\
\text { portanto, como prática sócio-histórica e } \\
\text { culturalmente constituída. O objetivo } \\
\text { desta pesquisa foi verificar em que } \\
\text { medida os documentos curriculares } \\
\text { balizam a seleção de conteúdos e de que } \\
\text { modo ocorre esta seleção, em outras } \\
\text { palavras, como se constituiu, } \\
\text { historicamente, o currículo de literatura } \\
\text { como disciplina escolar." }\end{array}$ & Sim \\
\hline $\begin{array}{l}\text { Ensino } \\
\text { Médio }\end{array}$ & IES Federal/CE & $\begin{array}{l}\text { "Este trabalho teve como objetivo } \\
\text { descrever e analisar as práticas de leitura } \\
\text { e escrita de } 50 \text { alunos do } 3^{\circ} \text { ano do } \\
\text { Ensino Médio de uma escola pública } \\
\text { estadual, situada na cidade de Fortaleza } \\
\text { - CE." }\end{array}$ & Não \\
\hline $\begin{array}{l}\text { Exame } \\
\text { Vestibular }\end{array}$ & $\begin{array}{l}\text { IES } \\
\text { Estadual/RJ }\end{array}$ & $\begin{array}{l}\text { "Esta tese objetiva a análise de provas } \\
\text { discursivas de Língua Portuguesa de } \\
\text { vestibulares, na perspectiva da leitura, } \\
\text { focando a compreensão de texto, suas } \\
\text { estratégias e os conhecimentos prévios } \\
\text { necessários ao egresso do ensino médio } \\
\text { para a realização de tais provas." }\end{array}$ & Sim \\
\hline Indefinido & $\begin{array}{l}\text { IES } \\
\text { Particular/SP }\end{array}$ & $\begin{array}{l}\text { "O presente trabalho tem por finalidade } \\
\text { apresentar uma análise da referenciação } \\
\text { em fóruns digitais, mais } \\
\text { especificamente, no tocante à } \\
\text { constituição de anáforas indiretas no } \\
\text { desenvolvimento de um tópico } \\
\text { discursivo.[...] Tendo em vista o objetivo } \\
\text { da pesquisa foi selecionado um fórum } \\
\text { digital constituído na rede mundial de } \\
\text { computadores e, desse fórum, extraídas } \\
\text { mensagens produzidas por participantes } \\
\text { no curso da discussão de um } \\
\text { determinado tópico discursivo. Os } \\
\text { resultados da análise indicam que no } \\
\text { curso da interação em fórum digital os } \\
\text { interactantes constroem anáforas cujo } \\
\text { referente não pode ser localizado } \\
\text { pontualmente no texto, visto que estão } \\
\text { apenas sugeridos na memória discursiva } \\
\text { ou no cotexto por meio de palavras ou } \\
\text { expressões que servem de âncoras'. No } \\
\text { entanto, essas anáforas, longe de } \\
\text { comprometer a interação, assinalam a } \\
\text { multilinearidade constitutiva do texto e } \\
\text { contribuem para a progressão textual e o } \\
\text { plano da coerência global." }\end{array}$ & Sim \\
\hline Indefinido & $\begin{array}{l}\text { IES } \\
\text { Particular/SP }\end{array}$ & $\begin{array}{l}\text { "[...] estudo da organização e } \\
\text { funcionamento da oralidade como } \\
\text { modalidade de língua e da importância } \\
\text { de sua aplicação pedagógica. [...] Os }\end{array}$ & Sim \\
\hline
\end{tabular}




\begin{tabular}{|c|c|c|c|c|}
\hline & & & $\begin{array}{l}\text { objetivos específicos são: 1) identificar } \\
\text { as características estruturais e funcionais } \\
\text { da modalidade oral; 2) mostrar a } \\
\text { relevância da relação dialógica entre } \\
\text { oralidade e escrita; 3) reiterar a } \\
\text { importância da contextualização } \\
\text { situacional para a interacão } \\
\text { comunicativa; 4) possibilitar a } \\
\text { observação das variantes lingüísticas, } \\
\text { compreendendo e respeitando sua } \\
\text { formação e uso; 5) apresentar uma } \\
\text { proposta para o ensino da oralidade, a } \\
\text { partir do processo de retextualização e } \\
\text { dos dados obtidos nesta investigação, } \\
\text { visando ao desenvolvimento da } \\
\text { competência comunicativa do aluno." }\end{array}$ & \\
\hline & Indefinido & $\begin{array}{l}\text { IES } \\
\text { Estadual/SP }\end{array}$ & $\begin{array}{l}\text { "A luz da concepção bakhtiniana de } \\
\text { linguagem e do pressuposto de que } \\
\text { ensinar a língua não é ensinar gramática } \\
\text { normativa, o trabalho tem por objetivo } \\
\text { analisar uma gramática considerada } \\
\text { como modelo da indústria cultural, a } \\
\text { Gramática da Língua Portuguesa, de } \\
\text { Pasquale e Ulisses. Este exame parte de } \\
\text { quatro eixos de investigação, a saber: } \\
\text { concepções teóricas, abordagem } \\
\text { didático-metodológica, enfoque } \\
\text { relacional e dimensão mercadológica. } \\
\text { Levando em conta a relevância dos } \\
\text { estudos sobre os livros didáticos no } \\
\text { ensino de língua materna, a pesquisa } \\
\text { objetiva contribuir para os debates } \\
\text { educacionais e para a revisão das } \\
\text { concepções de ensino de língua } \\
\text { portuguesa, com fundamentação na } \\
\text { linguística moderna e nos postulados de } \\
\text { Giroux, Bakhtin, Bourdieu, Freire, Eco e } \\
\text { Bonazzi, Nozella e Olson." }\end{array}$ & Não \\
\hline $\begin{array}{l}\text { Total de } \\
\text { localiza }\end{array}$ & $\begin{array}{l}\text { lissertações } \\
\text { as }\end{array}$ & & & 52 \\
\hline
\end{tabular}

\begin{tabular}{|c|c|c|c|c|}
\hline $\begin{array}{l}\text { Ano } \\
\text { de } \\
\text { defesa }\end{array}$ & $\begin{array}{l}\text { Contexto } \\
\text { pesquisado }\end{array}$ & $\begin{array}{l}\text { Vínculo } \\
\text { administrativo/ } \\
\text { Localizacão }\end{array}$ & $\begin{array}{l}\text { Transcrição parcial dos } \\
\text { resumos }\end{array}$ & $\begin{array}{l}\text { Disponível } \\
\text { on-line }\end{array}$ \\
\hline \multirow[t]{2}{*}{2010} & $\begin{array}{l}\text { Antiga } \\
\text { Educação } \\
\text { Escolar }\end{array}$ & IES Estadual/SP & $\begin{array}{l}\text { "Com o objetivo de contribuir para a } \\
\text { compreensão de um importante } \\
\text { momento da história do ensino da } \\
\text { leitura no Brasil, focaliza-se a proposta } \\
\text { para esse ensino apresentada pelo } \\
\text { professor paulista Antonio Firmino de } \\
\text { Proença (1880-1946), nos livros } \\
\text { didáticos que integram a 'Série de } \\
\text { leitura Proença', a saber: Cartillha } \\
\text { Proença (1926), Leitura do } \\
\text { principiante (1926), } 1^{\circ} \text {. livro de leitura } \\
\text { (1926), } 2^{\circ} \text {. Livro de leitura (1927), } 3^{\circ} \text {. } \\
\text { livro de leitura (1928) e } 4^{\circ} \text {. livro de } \\
\text { leitura (1948).". }\end{array}$ & Sim \\
\hline & $\begin{array}{l}\text { Antiga } \\
\text { Educação } \\
\text { Escolar }\end{array}$ & IES Estadual/SP & $\begin{array}{l}\text { "Com o objetivo de contribuir para a } \\
\text { produção de uma história do ensino de } \\
\text { língua e literatura no Brasil, focalizou- } \\
\text { se a proposta para o ensino de leitura } \\
\text { apresentada pelo professor Francisco }\end{array}$ & Sim \\
\hline
\end{tabular}




\begin{tabular}{|c|c|c|c|}
\hline & & $\begin{array}{l}\text { Furtado Mendes Vianna (1876-1935) } \\
\text { nos livros didáticos que integram a } \\
\text { Série 'Leituras Infantis', a saber: } \\
\text { Cartilha: leituras infantis [1912?]; } \\
\text { Primeiros passos na leitura (1915); } \\
\text { Leitura preparatória (1908); Primeiro } \\
\text { livro de leituras infantis; Segundo livro } \\
\text { de leituras infantis; Terceiro livro de } \\
\text { leituras infantis; e Quarto livro de } \\
\text { leituras infantis (Apanhados e factos } \\
\text { hitóricos) (1919). [...] Concluiu-se que } \\
\text { nos livros que integram essa série é } \\
\text { apresentada uma proposta de aplicação } \\
\text { do método analítico para o ensino da } \\
\text { leitura, relacionada com as demais } \\
\text { propostas de aplicação desse método e } \\
\text { sua repercussão, por pelo menos cinco } \\
\text { décadas, entre gerações de professores } \\
\text { e alunos do curso primário, no Brasil." }\end{array}$ & \\
\hline $\begin{array}{l}\text { Educação } \\
\text { Básica }\end{array}$ & $\begin{array}{l}\text { IES } \\
\text { Estadual/BA }\end{array}$ & $\begin{array}{l}\text { "Entendendo a identidade como } \\
\text { construção ideológica, esta pesquisa } \\
\text { busca refletir sobre a identidade do } \\
\text { professores de língua portuguesa } \\
\text { construída nos } \\
\text { Curriculares Parâmetros } \\
\text { Orientações Currionais e nas } \\
\text { para o ensino de língua portuguesa, os } \\
\text { quais impõem uma nova postura } \\
\text { teórica e prática a estes profissionais." }\end{array}$ & Não \\
\hline $\begin{array}{l}\text { Educação } \\
\text { Básica }\end{array}$ & IES Estadual/PR & $\begin{array}{l}\text { "Esta pesquisa emerge da necessidade } \\
\text { de se repensar continuamente o ensino } \\
\text { de Língua Portuguesa nas escolas. } \\
\text { Mais especificamente, discute-se a } \\
\text { importância de se tomar a análise } \\
\text { linguística como uma prática constante } \\
\text { na disciplina. Dentre os diversos } \\
\text { aspectos linguísticos a serem } \\
\text { abordados em sala, este estudo } \\
\text { considera os elementos que colaboram } \\
\text { para a tessitura do texto, enfocando o } \\
\text { processo de referenciação. [...]. Parte- } \\
\text { se do pressuposto de que a abordagem } \\
\text { desse recurso linguísticos em sala de } \\
\text { aula pode contribuir para a formação } \\
\text { de leitores e produtores de textos } \\
\text { competentes, uma vez que ocupa } \\
\text { função importante na tessitura do texto } \\
\text { e é responsável por imprimir sentidos } \\
\text { aos enunciados ao revelar intenções, } \\
\text { valores e posições que o produtor do } \\
\text { texto quer expressar. Para verificar } \\
\text { como essa estratégia linguística } \\
\text { contribui para a produção de } \\
\text { sentido(s), selecionou-se como corpus } \\
\text { de análise o conto 'O defunto', de Eça } \\
\text { de Queirós." }\end{array}$ & Não \\
\hline $\begin{array}{l}\text { Educação } \\
\text { Básica }\end{array}$ & IES Estadual/RJ & $\begin{array}{l}\text { "Esta pesquisa se propõe a analisar a } \\
\text { fala de professores de Língua } \\
\text { Portuguesa da rede municipal de } \\
\text { ensino, do Rio de Janeiro sobre o seu } \\
\text { trabalho, inserido num período de } \\
\text { mudanças para essa rede de ensino. } \\
\text { Para tal, foi realizado um grupo de } \\
\text { discussão (GD), um momento coletivo } \\
\text { de fala dos professores sobre o seu } \\
\text { trabalho, através do qual se verificou a } \\
\text { expressiva incidência de enunciados }\end{array}$ & Sim \\
\hline
\end{tabular}




\begin{tabular}{|c|c|c|c|}
\hline & & $\begin{array}{l}\text { negativos de caráter polêmico, } \\
\text { segundo definição de Ducrot (1987). } \\
\text { Assim, tais enunciados e seus } \\
\text { respectivos pontos de vista subjacentes } \\
\text { formaram o CORPUS da pesquisa." }\end{array}$ & \\
\hline $\begin{array}{l}\text { Educação } \\
\text { Básica }\end{array}$ & IES Estadual/SP & $\begin{array}{l}\text { "Apoiada em Street (1984) e nos } \\
\text { Novos Estudos do letramento, a } \\
\text { análise aqui empreendida buscou } \\
\text { investigar o(s) modelo(s) de } \\
\text { letramento subjacente em um novo } \\
\text { material docente produzido e } \\
\text { distribuído, a partir de 2008, pela } \\
\text { Secretaria de Educação do Estado de } \\
\text { São Paulo para o ensino de Língua } \\
\text { Portuguesa. Procurou-se também, por } \\
\text { meio da análise, discutir em que } \\
\text { medida as concepções de letramento, } \\
\text { expressas ou implícitas, contribuem } \\
\text { para o preparo dos alunos para o uso } \\
\text { social da escrita. Nesse intuito, foi } \\
\text { examinado tanto o material didático, } \\
\text { constituído por caderno do aluno e do } \\
\text { professor, quanto a proposta oficial } \\
\text { que os suporta." }\end{array}$ & Sim \\
\hline $\begin{array}{l}\text { Educação } \\
\text { Básica }\end{array}$ & IES Federal/MT & $\begin{array}{l}\text { "A presente investigação científica } \\
\text { busca verificar a articulação entre os } \\
\text { gêneros do narrar com os livros } \\
\text { didáticos de língua portuguesa, } \\
\text { contribuindo para caracterizar o atual } \\
\text { estado da arte no trabalho com a } \\
\text { literatura nesse âmbito." }\end{array}$ & Não \\
\hline $\begin{array}{l}\text { Educação } \\
\text { Básica }\end{array}$ & $\begin{array}{l}\text { IES } \\
\text { Particular/SP }\end{array}$ & $\begin{array}{l}\text { "Este trabalho tem como objetivo } \\
\text { analisar a maneira pela qual a } \\
\text { gramática normativa é imposta no } \\
\text { ensino de língua portuguesa como } \\
\text { principal objeto de conhecimento na } \\
\text { formação intelectual do cidadão } \\
\text { brasileiro. [...] Assim, depois de } \\
\text { discutir a construção da gramática } \\
\text { normativa e da constituição da norma } \\
\text { padrão no Brasil, analisou-se a } \\
\text { imposição da gramática normativa nas } \\
\text { escolas, mesmo com a divulgação dos } \\
\text { PCNs que direciona o ensino de língua } \\
\text { portuguesa para a formação do } \\
\text { indivíduo-cidadão crítico, por meio } \\
\text { dos estudos de textos escritos e orais, } \\
\text { observando os mais variados gêneros, } \\
\text { e das análises linguísticas" }\end{array}$ & Sim \\
\hline $\begin{array}{l}\text { Educação de } \\
\text { Jovens e } \\
\text { Adultos }\end{array}$ & IES Federal/DF & $\begin{array}{l}\text { "Esta dissertação é o resultado de uma } \\
\text { pesquisa realizada com as quatro } \\
\text { turmas do } 2^{\circ} \text { segmento da Educação de } \\
\text { Jovens e Adultos (EJA) com o objetivo } \\
\text { de (i) mapear os gêneros textuais } \\
\text { estudados em aulas de Língua } \\
\text { Portuguesa, (ii) definir as } \\
\text { Configurações Contextuais (CC) e as } \\
\text { Estruturas Potenciais de Gênero } \\
\text { (EPG), (iii) estabelecer as estruturas } \\
\text { esquemáticas das EPGs de cada texto } \\
\text { trabalhado nesse segmento da } \\
\text { educação, durante três meses de aula e } \\
\text { (iv) discutir, a partir da abordagem de } \\
\text { gênero textual da sistêmico-funcional, } \\
\text { as implicações dessa teoria para o } \\
\text { trabalho com a Língua Portuguesa em } \\
\text { sala de aula." }\end{array}$ & Sim \\
\hline
\end{tabular}




\begin{tabular}{|c|c|c|c|}
\hline $\begin{array}{l}\text { Educação de } \\
\text { Jovens e } \\
\text { Adultos }\end{array}$ & IES Federal/RN & $\begin{array}{l}\text { "Abordo nesta pesquisa questões } \\
\text { concernentes às concepções de } \\
\text { linguagem e ensino de língua escrita } \\
\text { apresentadas pelo Programa Nacional } \\
\text { de Inclusão de Jovens - PROJOVEM. } \\
\text { No que se refere à metodologia, a } \\
\text { pesquisa está situado no campo da } \\
\text { Linguística Aplicada, é de natureza } \\
\text { qualitativa e documental e se constrói } \\
\text { por meio da análise de dois } \\
\text { documentos que constituem o seu } \\
\text { corpus, a saber: Manual de } \\
\text { Orientações Gerais e os Guias de } \\
\text { Estudo. Busco nesses documentos } \\
\text { conhecer as orientações teórico- } \\
\text { metodológicas apontadas pelo Manual, } \\
\text { documento que é destinado aos } \\
\text { professores e verificar como essas } \\
\text { orientações se presentificam nos Guias } \\
\text { de Estudo, documentos destinado aos } \\
\text { alunos." }\end{array}$ & Não \\
\hline $\begin{array}{l}\text { Educação de } \\
\text { Jovens e } \\
\text { Adultos }\end{array}$ & IES Federal/MS & $\begin{array}{l}\text { "Esta pesquisa tem por objetivo } \\
\text { interpretar a construção da identidade } \\
\text { de dois professores e de quatro alunos } \\
\text { da EJA, por meio de suas } \\
\text { representações frente às orientações } \\
\text { contidas na Proposta curricular para o } \\
\text { ensino de jovens e adultos (EJA), uma } \\
\text { vez que, de acordo com Coracini } \\
\text { (2003b), a ideologia da globalização e } \\
\text { da homogeneização que é comum a } \\
\text { todos, tende a desconsiderar as } \\
\text { particularidades de cada um. Assim, o } \\
\text { discurso institucional das Propostas } \\
\text { Curriculares para o ensino de Língua } \\
\text { Portuguesa da Educação de Jovens e } \\
\text { Adultos constitui subsídios na } \\
\text { construção da identidade desses } \\
\text { sujeitos-professores e sujeitos-alunos } \\
\text { que atuam em duas escolas da rede- } \\
\text { pública, no interior do estado de São } \\
\text { Paulo, tendo como base o arcabouço } \\
\text { teórico da Análise do Discurso de } \\
\text { linha francesa, a partir de Pêcheux } \\
\text { (1988), Coracini (2003b) e Foucault } \\
\text { (2002)." }\end{array}$ & Não \\
\hline $\begin{array}{l}\text { Educação de } \\
\text { Jovens e } \\
\text { Adultos }\end{array}$ & IES Federal/RS & $\begin{array}{l}\text { "Esta dissertação investiga a } \\
\text { importância atribuída à Língua } \\
\text { Portuguesa na vida de estudantes e do } \\
\text { professor da última etapa do Ensino } \\
\text { Médio, na modalidade Educação de } \\
\text { Jovens e Adultos, em uma escola } \\
\text { pública estadual, no município de } \\
\text { Santa Maria-RS. Na perspectiva desta } \\
\text { análise, definiu-se como objetivo } \\
\text { geral: reconhecer como as práticas } \\
\text { escolares do professor de Língua } \\
\text { Portuguesa da última etapa do ensino } \\
\text { médio na referida modalidade, de uma } \\
\text { escola pública estadual, podem } \\
\text { contribuir para a formação destes } \\
\text { alunos." }\end{array}$ & $\mathrm{Sim}$ \\
\hline $\begin{array}{l}\text { Educação } \\
\text { Profissional } \\
\text { Técnica de } \\
\text { Nível Médio }\end{array}$ & IES Federal/RJ & $\begin{array}{l}\text { "Esta pesquisa, realizada no IFNMG - } \\
\text { Campus Salinas / MG, tem o objetivo } \\
\text { de analisar se a utilização prévia de } \\
\text { atividades faladas pode interferir na } \\
\text { produção escrita dos alunos da } 3^{\text {a }} \text { série }\end{array}$ & Sim \\
\hline
\end{tabular}




\begin{tabular}{|c|c|c|c|}
\hline & & $\begin{array}{l}\text { do curso técnico em Agropecuária } \\
\text { integrado ao ensino médio. Sendo } \\
\text { assim, assumimos que o estudo da } \\
\text { interface fala-escrita, como um } \\
\text { fenômeno inerente ao uso funcional da } \\
\text { língua, pode tornar-se produtivo } \\
\text { quanto à prática do ensino da Língua } \\
\text { Portuguesa." }\end{array}$ & \\
\hline $\begin{array}{l}\text { Educação } \\
\text { Profissional } \\
\text { Técnica de } \\
\text { Nível Médio }\end{array}$ & IES Federal/RJ & $\begin{array}{l}\text { "Muitos estudiosos da área de ensino } \\
\text { da língua materna têm se voltado para } \\
\text { os problemas e dificuldades } \\
\text { encontradas no ensino de língua } \\
\text { portuguesa de um modo geral. } \\
\text { Buscando contribuir para melhorar } \\
\text { esse cenário, a presente pesquisa, de } \\
\text { natureza quanti-qualitativa, objetivou } \\
\text { conhecer e evidenciar as percepções } \\
\text { dos alunos e egressos dos Cursos } \\
\text { Técnicos de Agropecuária da } \\
\text { modalidade Integrada ao Ensino } \\
\text { Médio no Campus São Vicente do Sul } \\
\text { do Instituto Federal Farroupilha, RS, } \\
\text { acerca da importância da disciplina em } \\
\text { sua formação técnica. [...] Ficou } \\
\text { evidente que, a partir do momento que } \\
\text { o professor utiliza uma abordagem } \\
\text { interdisciplinar em sua prática } \\
\text { pedagógica e traz para a sala de aula } \\
\text { situações com as quais os alunos se } \\
\text { identificam, ou seja, } \\
\text { contextualização, melhores condições } \\
\text { de aprendizado emergem como } \\
\text { decorrência das relações estabelecidas } \\
\text { entre aquilo que o aluno aprende e o } \\
\text { seu contexto sociocultural." }\end{array}$ & Sim \\
\hline $\begin{array}{l}\text { Educação } \\
\text { Superior }\end{array}$ & IES Federal/MG & $\begin{array}{l}\text { "Neste trabalho, dedicamo-nos a um } \\
\text { levantamento de informações que se } \\
\text { resumem a um discurso sobre o fazer e } \\
\text { um discurso do fazer, produzidos por } \\
\text { treze professores de disciplinas } \\
\text { introdutórias de língua portuguesa a } \\
\text { distância no âmbito do ensino superior. } \\
\text { Foram utilizados: 1) um questionário } \\
\text { com perguntas que versavam sobre a } \\
\text { prática de ensino a distância, com } \\
\text { destaque para a elaboração de } \\
\text { atividades didáticas e a comparação } \\
\text { entre as modalidades presencial e a } \\
\text { distância; 2) atividades didáticas que } \\
\text { nortearam a prática dos professores e } \\
\text { 3) a interação numa disciplina online } \\
\text { de um semestre." }\end{array}$ & Sim \\
\hline $\begin{array}{l}\text { Educação } \\
\text { Superior }\end{array}$ & IES Federal/PA & $\begin{array}{l}\text { "[...] tem como objetivo principal } \\
\text { investigar as formas de utilização de } \\
\text { gêneros argumentativos como } \\
\text { instrumentos didáticos, em práticas de } \\
\text { ensino de leitura e de escrita, no curso } \\
\text { de Letras da Universidade Federal do } \\
\text { Pará, no campus universitário de } \\
\text { Bragança." }\end{array}$ & Não \\
\hline $\begin{array}{l}\text { Educação } \\
\text { Superior }\end{array}$ & IES Federal/RO & $\begin{array}{l}\text { "Ao observar a situação atual das } \\
\text { Grades Curriculares de três Cursos de } \\
\text { Letras, da Universidade Federal de } \\
\text { Rondônia, e de como está sendo o } \\
\text { ensino da Língua Portuguesa nas } \\
\text { escolas de Educação Básica da rede } \\
\text { pública, estadual e municipal, }\end{array}$ & Sim \\
\hline
\end{tabular}




\begin{tabular}{|c|c|c|c|}
\hline & & $\begin{array}{l}\text { comprovamos a necessidade de uma } \\
\text { reformulação de tais Grades } \\
\text { Curriculares no curso referido, com a } \\
\text { inclusão de novas disciplinas, como a } \\
\text { Análise Linguística e a } \\
\text { Sociolinguística. Este trabalho sugere } \\
\text { uma proposta alternativa para o Ensino } \\
\text { de Língua Portuguesa, que é o uso de } \\
\text { Mapas Histórico-Geográficos, físicos, } \\
\text { políticos e temáticos como } \\
\text { metodologia para identificação dos } \\
\text { diversos fenômenos linguísticos e } \\
\text { culturais contextualizados, no tempo e } \\
\text { no espaço". }\end{array}$ & \\
\hline $\begin{array}{l}\text { Educação } \\
\text { Superior }\end{array}$ & IES Federal/SE & $\begin{array}{l}\text { "O Ensino de Língua Materna há } \\
\text { muito vem sendo trabalhado sob a } \\
\text { ótica da tradição gramatical normativa } \\
\text { apenas, e com a inserção da } \\
\text { Linguística nos currículos dos Cursos } \\
\text { de Letras, emergiram diversas } \\
\text { propostas para a Educação Linguística. } \\
\text { Dentro desse contexto, o que pensam } \\
\text { os alunos de Letras sobre o ensino de } \\
\text { Língua Portuguesa na Educação } \\
\text { Básica? Que idéias eles têm sobre as } \\
\text { novas teorias aplicadas ao ensino de } \\
\text { Língua Materna? Como essas idéias } \\
\text { aparecem nos seus discursos? O nosso } \\
\text { trabalho é resultado da análise dos } \\
\text { discursos dos alunos de Licenciatura } \\
\text { em Letras da Faculdade José Augusto } \\
\text { Vieira - Lagarto-SE e da Universidade } \\
\text { Federal de Sergipe - São Cristóvão- } \\
\text { SE, a partir de três variáveis: 1.alunos } \\
\text { que não estudaram as novas teorias } \\
\text { aplicadas ao ensino de Língua } \\
\text { Materna; 2.alunos que já estudaram } \\
\text { essas teorias; 3.alunos que já atuam } \\
\text { como docentes e estão em processo de } \\
\text { formação." }\end{array}$ & Não \\
\hline $\begin{array}{l}\text { Educação } \\
\text { Superior }\end{array}$ & $\begin{array}{l}\text { IES } \\
\text { Particular/PE }\end{array}$ & $\begin{array}{l}\text { "Objetivando analisar os gêneros } \\
\text { textuais como ferramenta didática para } \\
\text { o ensino da linguagem, investigou-se, } \\
\text { por meio de metodologia empírica, a } \\
\text { familiaridade dos alunos do curso de } \\
\text { Letras com o tema gêneros textuais, no } \\
\text { campus de uma Instituição privada de } \\
\text { Ensino Superior, na cidade de Escada, } \\
\text { Pernambuco." }\end{array}$ & Sim \\
\hline $\begin{array}{l}\text { Ensino } \\
\text { Fundamental }\end{array}$ & IES Estadual/SP & $\begin{array}{l}\text { "[...] Pesquisas nacionais enfatizam } \\
\text { que os surdos apresentam dificuldade } \\
\text { no uso da flexão verbal de tempo na } \\
\text { escrita do português. Esta afirmação é } \\
\text { inquestionável, contudo a origem desta } \\
\text { dificuldade é atribuída a vários fatores, } \\
\text { tais como: influência da Língua de } \\
\text { Sinais, dificuldade de acesso à Língua } \\
\text { Portuguesa e práticas de ensino } \\
\text { descontextualizadas. } \\
\text { compreender melhor este processo, o } \\
\text { presente estudo teve como objetivos } \\
\text { verificar se e como os surdos } \\
\text { flexionam os verbos na Língua } \\
\text { Portuguesa Escrita e se eles utilizam } \\
\text { outros marcadores de tempo nesta } \\
\text { língua e na Língua Brasileira de } \\
\text { Sinais. [...] O estudo foi realizado com }\end{array}$ & Sim \\
\hline
\end{tabular}




\begin{tabular}{|c|c|c|c|}
\hline & & $\begin{array}{l}18 \text { sujeitos com perda auditiva } \\
\text { neurossensorial profunda bilateral pré- } \\
\text { lingüística, com idade entre } 15 \text { e } 23 \\
\text { anos, escolaridade de } 3^{\text {a a }} 6^{\text {a }} \text { série do } \\
\text { Ensino Fundamental, matriculados em } \\
\text { sala regular de escola pública, usuários } \\
\text { da Língua Brasileira de Sinais, filhos } \\
\text { de pais ouvintes e sem } \\
\text { comprometimentos associados à } \\
\text { surdez." }\end{array}$ & \\
\hline $\begin{array}{l}\text { Ensino } \\
\text { Fundamental }\end{array}$ & $\begin{array}{l}\text { IES } \\
\text { Particular/PE }\end{array}$ & $\begin{array}{l}\text { "O objetivo deste trabalho é analisar se } \\
\text { estratégias e métodos empregados } \\
\text { professores de língua portuguesa para } \\
\text { surdos que estudam no Ensino } \\
\text { Fundamental na rede de escolas do } \\
\text { Recife que oferecem salas de aula } \\
\text { bilíngües, verificando a adequação dos } \\
\text { objetivos pedagógicos pretendidos." }\end{array}$ & Sim \\
\hline $\begin{array}{l}\text { Ensino } \\
\text { Fundamental }\end{array}$ & $\begin{array}{l}\text { IES } \\
\text { Particular/SP }\end{array}$ & $\begin{array}{l}\text { "Tematiza a compreensão leitora e o } \\
\text { prazer da leitura, e, por objeto de } \\
\text { estudo, tem-se o conto Biruta de Lygia } \\
\text { F.Telles. O objetivo deste trabalho é } \\
\text { contribuir com estudos para desvendar } \\
\text { o porquê de a leitura ser um ato de } \\
\text { desprazer, no ensino fundamental, na } \\
\text { escolaridade. Pretende-se, observar a } \\
\text { postura dos aprendizes nos momentos } \\
\text { das atividades de leituras; descrever o } \\
\text { comportamento da criança participante } \\
\text { das atividades propostas para aquele } \\
\text { momento; verificar a possibilidade de } \\
\text { incentivo, para que os alunos sejam } \\
\text { inseridos nos grupos dos leitores." }\end{array}$ & Não \\
\hline $\begin{array}{l}\text { Ensino } \\
\text { Fundamental } \\
\text { I }\end{array}$ & IES Federal/AL & $\begin{array}{l}\text { "A presente dissertação se propôs a } \\
\text { investigar os procedimentos } \\
\text { pedagógicos utilizados por uma } \\
\text { professora que atua nas séries iniciais } \\
\text { do ensino fundamental. O objetivo } \\
\text { central desta pesquisa foi analisar os } \\
\text { conhecimentos básicos adquiridos } \\
\text { durante a formação no curso de Mídias } \\
\text { em Educação, e os procedimentos por } \\
\text { ela utilizados no que se refere à } \\
\text { linguagem verbal veiculada pela mídia } \\
\text { televisiva nos programas assistidos por } \\
\text { alunos do ensino fundamental para } \\
\text { trabalhar questões de linguagem, } \\
\text { sobretudo da variação linguística em } \\
\text { sala de aula. [...]. Por fim, o trabalho } \\
\text { apresenta que a formação inicial em } \\
\text { pedagogia, como também a formação } \\
\text { continuada, nesse caso o curso de } \\
\text { Mídias em Educação, foi pouco } \\
\text { suficiente par desenvolvimento de uma } \\
\text { prática sistemática em relação aos } \\
\text { estudos de linguagem com auxílio de } \\
\text { um programa televisivo, dessa forma, } \\
\text { a não transposição didática pode } \\
\text { auxiliar em outras pesquisas futuras." }\end{array}$ & Não \\
\hline $\begin{array}{l}\text { Ensino } \\
\text { Fundamental } \\
\text { I }\end{array}$ & $\begin{array}{l}\text { IES } \\
\text { Particular/SP }\end{array}$ & $\begin{array}{l}\text { "Considerando que a Educação } \\
\text { Linguística focaliza a aprendizagem do } \\
\text { estudante e também a do professor, } \\
\text { que é realizada por meio da formação, } \\
\text { inicial e contínua, analisamos, nessa } \\
\text { pesquisa, a formação e a atuação do } \\
\text { professor de Língua Portuguesa nas } \\
\text { séries iniciais, para verificarmos se }\end{array}$ & $\mathrm{Sim}$ \\
\hline
\end{tabular}




\begin{tabular}{|c|c|c|c|}
\hline & & $\begin{array}{l}\text { atendem às concepções de ensino da } \\
\text { Educação Linguística. Traçamos o } \\
\text { perfil de um grupo de professores de } 4 . \\
\text { e 5. ano (3. e } 4 \text {. série) atuantes na rede } \\
\text { Estadual de Educação por meio de um } \\
\text { questionário e de uma reflexão do } \\
\text { grupo, realizada em uma reunião } \\
\text { pedagógica." }\end{array}$ & \\
\hline $\begin{array}{l}\text { Ensino } \\
\text { Fundamental } \\
\text { I }\end{array}$ & $\begin{array}{l}\text { IES } \\
\text { Particular/SP }\end{array}$ & $\begin{array}{l}\text { "Esta dissertação, cujo tema é o cordel } \\
\text { em sala de aula, decorre devido à } \\
\text { necessidade de se resgatar a cultura } \\
\text { popular brasileira no ambiente escolar, } \\
\text { uma vez que é preciso que nossos } \\
\text { educandos conheçam e valorizem } \\
\text { aspectos que fazem parte de nossa } \\
\text { história. Além desse objetivo inicial, } \\
\text { visa a contribuir com os estudos acerca } \\
\text { do ensino de Língua Portuguesa, mais } \\
\text { especificamente no incentivo à leitura } \\
\text { e à produção escrita. Tendo caráter } \\
\text { teórico-prático, apresentamos a } \\
\text { fundamentação teórica, partindo da } \\
\text { Linguística Textual, que, na década de } \\
70 \text {, passou a trabalhar o texto e não } \\
\text { mais as palavras e as frases, até chegar } \\
\text { aos gêneros, partindo dos estudos de } \\
\text { Bakhtin e outros pesquisadores. Por } \\
\text { ser o gênero de caráter social, o } \\
\text { popular, que era, até algun anos, } \\
\text { 'desprestigiado' no ensino, também } \\
\text { passou a ser valorizado; dessa forma, } \\
\text { prosseguimos com um panorama da } \\
\text { literatura de cordel e, em seguida, } \\
\text { discorremos acerca das sugestões dos } \\
\text { mais recentes documentos, } \\
\text { desenvolvidos pelo MEC, que } \\
\text { orientam a educação brasileira: os } \\
\text { Parâmetros Curriculares Nacionais } \\
\text { (PCN). Para aplicarmos a proposta } \\
\text { teórica, desenvolvemos um projeto } \\
\text { com alunos de 5o ano do Ensino } \\
\text { Fundamental de um renomado colégio } \\
\text { particular de São Paulo e o resultado } \\
\text { final foi a edição de um livro com a } \\
\text { coletânea de trinta e nove } \\
\text { retextualizações, em cordel, do épico } \\
\text { A Odisseia." }\end{array}$ & Sim \\
\hline $\begin{array}{l}\text { Ensino } \\
\text { Fundamental } \\
\text { II }\end{array}$ & IES Federal/RS & $\begin{array}{l}\text { "O presente trabalho é resultado de } \\
\text { pesquisa realizada com alunos } \\
\text { pertencentes à } 5^{\text {a }} \text { série/ } / 6^{\circ} \text { ano de uma } \\
\text { escola da rede municipal do Rio } \\
\text { Grande-RS, no ano letivo de } 2008 \text {. O } \\
\text { objetivo do estudo é descrever e } \\
\text { analisar o uso de elementos de coesão } \\
\text { referencial em } 48 \text { textos de oito alunos } \\
\text { da turma." }\end{array}$ & Sim \\
\hline $\begin{array}{l}\text { Ensino } \\
\text { Fundamental } \\
\text { II }\end{array}$ & $\begin{array}{l}\text { IES } \\
\text { Particular/SC }\end{array}$ & $\begin{array}{l}\text { "Esta dissertação tem por objetivo } \\
\text { geral investigar o comprometimento } \\
\text { dos educadores dos anos finais do } \\
\text { ensino fundamental do município de } \\
\text { Urussanga com o ensino de língua } \\
\text { portuguesa. Para tanto, foram } \\
\text { entrevistados cinco educadores de } \\
\text { diversas disciplinas dos anos finais do } \\
\text { Ensino Fundamental do município de } \\
\text { Urussanga. [...] conclui-se que há o } \\
\text { reconhecimento, por parte dos }\end{array}$ & Sim \\
\hline
\end{tabular}




\begin{tabular}{|c|c|c|c|}
\hline & & $\begin{array}{l}\text { educadores, da importância e dos } \\
\text { benefícios do uso da língua portuguesa } \\
\text { tanto nas práticas pedagógicas quanto } \\
\text { no processo de ensino e aprendizagem. } \\
\text { Demonstra-se, com isso, que há um } \\
\text { comprometimento dos educadores com } \\
\text { o ensino da língua portuguesa nas } \\
\text { diversas disciplinas do processo ensino } \\
\text { e aprendizagem." }\end{array}$ & \\
\hline $\begin{array}{l}\text { Ensino } \\
\text { Fundamental } \\
\text { II }\end{array}$ & $\begin{array}{l}\text { IES } \\
\text { Particular/SP }\end{array}$ & $\begin{array}{l}\text { "A presente pesquisa [...] tem como } \\
\text { objetivo identificar as concepções } \\
\text { teóricas e metodológicas de ensino da } \\
\text { leitura e de produção de textos, no } \\
\text { Caderno do Professor e as atividades } \\
\text { discentes no Caderno do Aluno, } \\
\text { contidas na Proposta Curricular de } \\
\text { Língua Portuguesa (SP, } 5 \text { a série)." }\end{array}$ & $\mathrm{Sim}$ \\
\hline $\begin{array}{l}\text { Ensino } \\
\text { Fundamental } \\
\text { II }\end{array}$ & $\begin{array}{l}\text { IES } \\
\text { Particular/SP }\end{array}$ & $\begin{array}{l}\text { "Sabemos que o professor da educação } \\
\text { básica utiliza-se do livro didático } \\
\text { como principal ferramenta para o } \\
\text { ensino de sua disciplina. Para o ensino } \\
\text { de Língua Portuguesa, o livro é a fonte } \\
\text { quase exclusiva de textos oferecidos } \\
\text { para leitura de seus aprendentes. Em } \\
\text { relação à produção textual, também } \\
\text { não é diferente; o material didático } \\
\text { escolhido é o instrumento utilizado } \\
\text { para as propostas de redação. Nesse } \\
\text { contexto, com essa pesquisa, } \\
\text { analisamos livros didáticos de } \\
\text { Português, de oitavas séries/ nonos } \\
\text { anos do ensino fundamental, nas } \\
\text { seções voltadas para a leitura e a } \\
\text { produção de texto, a fim de } \\
\text { verificarmos quais as concepções } \\
\text { teóricas que subjazem aos materiais, } \\
\text { bem como verificar a sua adequação } \\
\text { para o ensino de Língua à luz das } \\
\text { concepções da Educação Linguística." }\end{array}$ & $\mathrm{Sim}$ \\
\hline $\begin{array}{l}\text { Ensino } \\
\text { Fundamental/ } \\
\text { Ensino Médio }\end{array}$ & $\begin{array}{l}\text { IES Particular/ } \\
\text { MG }\end{array}$ & $\begin{array}{l}\text { "Esta pesquisa descreve e analisa a } \\
\text { experiência vivenciada por professores } \\
\text { de Português do ensino fundamental e } \\
\text { médio, da escola básica estadual de } \\
\text { Diamantina, Minas Gerais. Analisa as } \\
\text { relações entre esta experiência e a } \\
\text { formação recebida nos cursos de } \\
\text { licenciatura, as especificidades e } \\
\text { questões do ensino da Língua } \\
\text { Portuguesa, às exigências curriculares } \\
\text { e escolares e os desafios e limites } \\
\text { encontrados, atualmente, pelos } \\
\text { professores nas situações de ensino da } \\
\text { disciplina em questão." }\end{array}$ & Não \\
\hline $\begin{array}{l}\text { Ensino } \\
\text { Fundamental/ } \\
\text { Ensino Médio }\end{array}$ & $\begin{array}{l}\text { IES } \\
\text { Particular/SP }\end{array}$ & $\begin{array}{l}\text { "O ensino de língua portuguesa, } \\
\text { geralmente, está atrelado ao ensino da } \\
\text { gramática normativa nas escolas do } \\
\text { ensino fundamental e médio. Mas, de } \\
\text { que maneira o professor se apropria } \\
\text { das teorias linguísticas, como a } \\
\text { Análise do Discurso e a Linguística } \\
\text { Textual? Será que esses mestres } \\
\text { orientam suas atividades pedagógicas, } \\
\text { buscando ampliar as competências } \\
\text { comunicativas interacionais dos } \\
\text { alunos? Essas questões nortearam este } \\
\text { estudo de caso, realizado na Escola } \\
\text { Estadual Paulo Madureira e Castro, }\end{array}$ & $\mathrm{Sim}$ \\
\hline
\end{tabular}




\begin{tabular}{|c|c|c|c|}
\hline & & $\begin{array}{l}\text { situada no município de Tietê, estado } \\
\text { de São Paulo, com } 11 \text { professores de } \\
\text { português, por meio de questionário. } \\
\text { As análises evidenciaram que, em sua } \\
\text { prática docente, não havia uma } \\
\text { concepção linguística de gramática } \\
\text { claramente definida, mas apenas o uso } \\
\text { de uma nomenclatura gramatical. O } \\
\text { objetivo, portanto, deste trabalho é o } \\
\text { de contribuir para a reflexão acerca do } \\
\text { ensino de língua portuguesa nas } \\
\text { escolas públicas de São Paulo, } \\
\text { apontando os aspectos social, } \\
\text { interacional e funcional da língua a } \\
\text { serem considerados na prática } \\
\text { docente." }\end{array}$ & \\
\hline $\begin{array}{l}\text { Ensino } \\
\text { Fundamental/ } \\
\text { Ensino Médio }\end{array}$ & IES Federal/ RN & $\begin{array}{l}\text { "A maioria dos falantes tem uma falsa } \\
\text { impressão de que a língua é uma } \\
\text { entidade estanque, ou seja, de que, ao } \\
\text { longo do tempo, ela não sofre } \\
\text { alterações. Entretanto, em seu processo } \\
\text { evolutivo, é comum encontrarmos na } \\
\text { língua novas funções linguísticas para } \\
\text { itens lexicais ordinários. Um exemplo } \\
\text { disso é o que vamos apresentar neste } \\
\text { trabalho, que toma como objeto de } \\
\text { análise o item TUDO, o qual, nas } \\
\text { gramáticas normativas, tem sido } \\
\text { classificado apenas como pronome } \\
\text { indefinido. No entanto, podemos } \\
\text { encontrá-lo desempenhando outros } \\
\text { papéis, dependendo dos elementos aos } \\
\text { quais está ligado no discurso, } \\
\text { sobretudo na modalidade oral , } \\
\text { podendo ser, inclusive, classificado } \\
\text { como definido como: definido, fórico, } \\
\text { dêitico, inferidor, entre outros. [...] } \\
\text { Neste trabalho propomos também } \\
\text { uma atividade com esse item a fim de } \\
\text { ser realizada em sala de aula. Através } \\
\text { dela, desejamos fomentar uma } \\
\text { discussão e contribuir para a } \\
\text { conscientização dos professores de } \\
\text { língua portuguesa dos níveis } \\
\text { fundamental e médio a respeito da } \\
\text { estrutura maleável e dinâmica da } \\
\text { língua e de seu processo emergente e } \\
\text { inacabado (HOPPER, 1991), pois a } \\
\text { prática do ensino de língua portuguesa } \\
\text { em sala de aula tem sido calcada no } \\
\text { conteúdo da gramática normativa.” }\end{array}$ & Não \\
\hline $\begin{array}{l}\text { Ensino } \\
\text { Fundamental / } \\
\text { Ensino Médio }\end{array}$ & $\begin{array}{l}\text { IES } \\
\text { Particular/SP }\end{array}$ & $\begin{array}{l}\text { "Diante da situação da leitura no } \\
\text { Brasil, que está mais relacionada ao } \\
\text { fracasso que ao sucesso, este trabalho } \\
\text { tem como objetivo analisar, do ponto } \\
\text { de vista da concepção de leitura } \\
\text { sociointeracionalcognitiva, } \\
\text { Cadernos do Professor da SEE-SP } \\
\text { destinados à série final do Ensino } \\
\text { Fundamental (EF) - } 8^{\text {a }} \text { série - e da série } \\
\text { final do Ensino Médio (EM) - } 3^{\text {a }} \text { série } \\
\text { e verificar, no conjunto dos conteúdos } \\
\text { e atividades propostos nos Cadernos, a } \\
\text { proporção de atividades de leitura em } \\
\text { relação às de gramática." }\end{array}$ & Sim \\
\hline Ensino Médio & IES Federal/AC & $\begin{array}{l}\text { "A pesquisa Discurso da/na prática } \\
\text { decente teve como objetivo analisar os }\end{array}$ & Sim \\
\hline
\end{tabular}




\begin{tabular}{|c|c|c|c|}
\hline & & $\begin{array}{l}\text { discursos de professores de língua } \\
\text { portuguesa sobre o ensino de produção } \\
\text { textual de duas escolas de Rio Branco } \\
\text { - Acre: uma da rede particular e outra } \\
\text { da rede pública de Ensino Médio. } \\
\text { Realizei a pesquisa no terceiro ano } \\
\text { com o intuito de compreender, por } \\
\text { meio do discurso de docentes, qual a } \\
\text { concepção de linguagem, língua, texto, } \\
\text { leitura, leitor e produtor de texto que o } \\
\text { professor está formando." }\end{array}$ & \\
\hline Indefinido & IES Estadual/RJ & $\begin{array}{l}\text { "A orientação sociolingüística sustenta } \\
\text { nossas reflexões acerca da importância } \\
\text { da inserção dos diversos usos } \\
\text { linguísticos na prática de ensino de } \\
\text { língua portuguesa, que precisa } \\
\text { acompanhar a vida da linguagem na } \\
\text { comunicação cotidiana, com vistas à } \\
\text { valorização e à democratização da } \\
\text { língua. Ademais, impõe-se reconhecer } \\
\text { a heterogeneidade linguística como } \\
\text { fator de riqueza da língua. O trabalho } \\
\text { de análise consiste em uma } \\
\text { metodologia que permite associar o } \\
\text { texto a uma imagem com significado } \\
\text { representativo das particularidades } \\
\text { linguístico-discursivas de uma cultura } \\
\text { regional. Os resultados esperados } \\
\text { incluem a afirmação da potencialidade } \\
\text { linguístico-semiótica da letra-de- } \\
\text { música como gênero textual suficiente } \\
\text { para a demonstração dos valores } \\
\text { socioculturais impressos na língua e, } \\
\text { possivelmente, como um gênero de } \\
\text { importante valor literário que se pode } \\
\text { aproveitar para dinamizar aulas de } \\
\text { língua portuguesa." }\end{array}$ & Sim \\
\hline Indefinido & IES Federal/ SE & $\begin{array}{l}\text { "Nossa pesquisa discute a 'crise da } \\
\text { leitura' e, consequentemente, a 'crise } \\
\text { do leitor', enquanto sujeito capaz de } \\
\text { (re)construir conhecimentos pela } \\
\text { habilidade de deslocar-se por } \\
\text { diferentes dimensões espácio- } \\
\text { temporais, que ultrapassam o 'aqui' e } \\
\text { 'agora' da enunciação, visto tratar-se } \\
\text { de uma questão complexa que afeta } \\
\text { não apenas o processo de ensino- } \\
\text { aprendizagem da própria língua e de } \\
\text { outras disciplinas, mas principalmente } \\
\text { as condições de efetiva participação } \\
\text { desses sujeitos como agentes } \\
\text { transformadores da realidade social." }\end{array}$ & Sim \\
\hline Indefinido & $\begin{array}{l}\text { IES Municipal/ } \\
\text { SP }\end{array}$ & $\begin{array}{l}\text { "O objetivo desta pesquisa é, a partir } \\
\text { de um corpus de seis propagandas } \\
\text { impressas propor atividades de leitura } \\
\text { baseadas em pressupostos teóricos } \\
\text { atuais e que possam servir de } \\
\text { parâmetro para o trabalho pedagógico } \\
\text { de leitura de propaganda em sala de } \\
\text { aula, visando com isso contribuir para } \\
\text { a formação de leitores mais } \\
\text { proficientes desse gênero e com visão } \\
\text { mais crítica da publicidade." }\end{array}$ & Sim \\
\hline Indefinido & $\begin{array}{l}\text { IES } \\
\text { Particular/SP }\end{array}$ & $\begin{array}{l}\text { "A dificuldade de leitura e } \\
\text { compreensão observada em sala de } \\
\text { aula orientou a realização da pesquisa. } \\
\text { O objetivo deste trabalho é contribuir }\end{array}$ & Sim \\
\hline
\end{tabular}




\begin{tabular}{|c|c|c|c|}
\hline & & $\begin{array}{l}\text { para os estudos de Língua Portuguesa } \\
\text { com especial destaque para a leitura. } \\
\text { Os objetivos específicos são: } 1 \text { - } \\
\text { Observar e refletir sobre as estratégias } \\
\text { de referenciação empregadas pelo } \\
\text { leitor para processar as informações } \\
\text { inscritas no artigo de opinião, tendo } \\
\text { por parâmetro o estudo das relações } \\
\text { anafóricas. } 2 \text { - Verificar e demonstrar } \\
\text { o papel das anáforas para assegurar a } \\
\text { progressão semântica da referência } \\
\text { textual, bem como a produção de } \\
\text { sentido decorrente de seu uso." }\end{array}$ & \\
\hline Indefinido & $\begin{array}{l}\text { IES } \\
\text { Particular/SP }\end{array}$ & $\begin{array}{l}\text { "No presente trabalho, examinamos a } \\
\text { importância da intertextualidade para o } \\
\text { estabelecimento de novas e } \\
\text { diferenciadas leituras. Como corpus, } \\
\text { elegemos a obra 'Libertinagem', de } \\
\text { Manuel Bandeira, que integra o } \\
\text { período modernista do autor. [...] A } \\
\text { intertextualidade enriquece o processo } \\
\text { de leitura e pode ser usada como } \\
\text { importante ferramenta em sala de aula } \\
\text { pelos professores de língua materna." }\end{array}$ & Sim \\
\hline Indefinido & $\begin{array}{l}\text { IES } \\
\text { Particular/SP }\end{array}$ & $\begin{array}{l}\text { "O objetivo deste trabalho é contribuir } \\
\text { com os conceitos fundamentais do } \\
\text { ponto de vista teórico sobre a } \\
\text { formação do professor Língua de } \\
\text { Portuguesa e Educação Linguística. } \\
\text { São objetivos específicos: 1) } \\
\text { apresentar conceitos de gênero à luz da } \\
\text { Educação Linguística; 2)analisar a } \\
\text { formação do professor e as } \\
\text { implicações em sua formação docente } \\
\text { a partir da formação reflexiva do } \\
\text { professor de Língua Portuguesa, } \\
\text { estabelecendo o percurso histórico; 3) } \\
\text { propor uma Sequência Didática. A } \\
\text { fundamentação teórica situa-se na } \\
\text { Educação Linguística. O procedimento } \\
\text { adotado nesta pesquisa, foi teórico- } \\
\text { analítico e indutivo. Foi proposto um } \\
\text { estudo de caso sobre a formação do } \\
\text { professor. O resultado obtido indicou } \\
\text { que a formação continuada do } \\
\text { professor propicia reflexão de sua } \\
\text { prática pedagógica." }\end{array}$ & Sim \\
\hline Indefinido & $\begin{array}{l}\text { IES } \\
\text { Estadual/RN }\end{array}$ & $\begin{array}{l}\text { "Este trabalho é o resultado de uma } \\
\text { pesquisa que teve como objetivo } \\
\text { investigar o processo de argumentação } \\
\text { em artigos científicos publicados em } \\
\text { Anais do VI Congresso Internacional } \\
\text { da Associação Brasileira de } \\
\text { Lingüística (ABRALIN), produzidos } \\
\text { por alunos graduados e por } \\
\text { pesquisadores doutores, observando } \\
\text { como são construídos os sentidos para } \\
\text { as suas temáticas de pesquisa, a fim de } \\
\text { provocar a adesão de seus possíveis } \\
\text { interlocutores e de justificar a } \\
\text { pertinência de suas idéias e de seu } \\
\text { trabalho. A relevância desta pesquisa } \\
\text { centra-se em dois pontos essenciais. } \\
\text { Em primeiro lugar, por estudar o } \\
\text { processo de construção argumentativa } \\
\text { em trabalhos acadêmico-científicos de } \\
\text { pesquisadores iniciantes }\end{array}$ & Sim \\
\hline
\end{tabular}




\begin{tabular}{|c|c|c|}
\hline & $\begin{array}{l}\text { pesquisadores doutores, aponta as } \\
\text { estratégias argumentativas da redação } \\
\text { acadêmica, demonstrando que uma } \\
\text { análise lógica seria insuficiente para a } \\
\text { compreensão de um discurso que se } \\
\text { pretende científico; em segundo lugar, } \\
\text { por verificar se os processos e os } \\
\text { mecanismos de argumentação se } \\
\text { apresentam de forma difente de } \\
\text { acordo com as condições de produção } \\
\text { dos textos, tais como níveis de } \\
\text { formação e maturidade intelectual. } \\
\text { Considerando a perspectiva de } \\
\text { abordagem do ensino de língua } \\
\text { materna, em especial leitura e } \\
\text { produção de texto, a pesquisa é } \\
\text { bibliográfica e de análise de corpus, } \\
\text { com procedimento descritivo e } \\
\text { interpretativo." }\end{array}$ & \\
\hline $\begin{array}{l}\text { Total de dissertações } \\
\text { localizadas }\end{array}$ & & 41 \\
\hline
\end{tabular}




\section{APÊNDICE B - DISSERTAÇÕES MANTIDAS NO CORPUS}

Neste apêndice, o leitor encontrará o código de referência a cada uma das dissertações a partir das quais constituímos o corpus desta pesquisa, bem como informações sobre o ano e a IES de publicação destas produções.

\begin{tabular}{|l|l|l|}
\hline Ano de defesa & $\begin{array}{l}\text { Vínculo } \\
\text { administrativo/Localização }\end{array}$ & Código \\
\hline 2001 & IES Estadual/SP & ESP01 \\
\hline Total de dissertações & \multicolumn{2}{|c}{01} \\
\hline
\end{tabular}

\begin{tabular}{|l|l|l|}
\hline Ano de defesa & $\begin{array}{l}\text { Vínculo } \\
\text { administrativo/Localização }\end{array}$ & Código \\
\hline 2002 & IES Estadual/PR & EPR02 \\
\hline Total de dissertações & \multicolumn{2}{|c|}{} \\
\hline
\end{tabular}

\begin{tabular}{|l|l|l|}
\hline Ano de defesa & $\begin{array}{l}\text { Vínculo } \\
\text { administrativo/Localização }\end{array}$ & Código \\
\hline $\mathbf{2 0 0 3}$ & IES Federal/SC & FSC03 \\
\hline Total de dissertações & \multicolumn{2}{|c}{01} \\
\hline
\end{tabular}

\begin{tabular}{|l|l|r|}
\hline Ano de defesa & $\begin{array}{l}\text { Vínculo } \\
\text { administrativo/Localização }\end{array}$ & Código \\
\hline $\mathbf{2 0 0 4}$ & IES Estadual/PR & EPR04 \\
\hline Total de dissertações & \multicolumn{2}{|}{01} \\
\hline
\end{tabular}




\begin{tabular}{|l|l|l|}
\hline Ano de defesa & $\begin{array}{l}\text { Vínculo } \\
\text { administrativo/Localização }\end{array}$ & Código \\
\hline $\mathbf{2 0 0 6}$ & IES Estadual/PR & EPR06 \\
\cline { 2 - 3 } & IES Federal/MT & FMT06a \\
\cline { 2 - 3 } & IES Federal/MT & FMT06b \\
\hline Total de dissertações & \multicolumn{2}{|c}{03} \\
\hline
\end{tabular}

\begin{tabular}{|l|l|l|}
\hline Ano de defesa & $\begin{array}{l}\text { Vínculo } \\
\text { administrativo/Localização }\end{array}$ & Código \\
\hline $\mathbf{2 0 0 7}$ & IES Estadual/PR & EPR07 \\
\cline { 2 - 3 } & IES Federal/PA & FPA07 \\
\cline { 2 - 3 } & IES Estadual/SP & FSP07 \\
\cline { 2 - 3 } & IES Federal/MT & FPB07 \\
\cline { 2 - 3 } & IES Federal/PB & \\
\hline Total de dissertações & \multicolumn{2}{|c}{05} \\
\hline
\end{tabular}

\begin{tabular}{|l|l|l|}
\hline Ano de defesa & $\begin{array}{l}\text { Vínculo } \\
\text { administrativo/Localização }\end{array}$ & Código \\
\hline $\mathbf{2 0 0 8}$ & IES Federal/ PB & FPB08a \\
\cline { 2 - 3 } & IES Federal/ PB & FPB08b \\
\cline { 2 - 3 } & IES Estadual/PA & EPA08 \\
\cline { 2 - 3 } & IES Estadual/ SP & ESP08 \\
\hline Total de dissertações & & 04 \\
\hline
\end{tabular}




\begin{tabular}{|l|l|r|}
\hline Ano de defesa & $\begin{array}{l}\text { Vínculo } \\
\text { administrativo/Localização }\end{array}$ & Código \\
\hline 2009 & IES Estadual/SP & ESP09 \\
\hline Total de dissertações & \multicolumn{2}{|}{} \\
\hline
\end{tabular}

\begin{tabular}{|l|l|l|}
\hline Ano de defesa & $\begin{array}{l}\text { Vínculo } \\
\text { administrativo/Localização }\end{array}$ & Código \\
\hline $\mathbf{2 0 1 0}$ & IES Federal/RS & FRS10 \\
\hline Total de dissertações & \multicolumn{2}{|}{} \\
\hline
\end{tabular}




\section{APÊNDICE C - DEMAIS DADOS E INTERPRETAÇÕES CONSTITUINTES DO CORPUS}

Neste apêndice, há a transcrição de fragmentos que apresentaram interpretações e dados com presença destacada nas dissertações investigadas. Os excertos expostos, neste apêndice, acoplam-se aos outros tratados no corpo desta tese.

- "Fatos" apresentados como decorrentes de situações de ensino que contemplaram os "gêneros do discurso" / os "gêneros textuais":

No caso do trabalho com gêneros em sala de aula, foco desta pesquisa, a presença do outro contribuiu nas escolhas das marcas lingüísticas culturalmente apropriadas aos gêneros trabalhados. Foi nos momentos de interlocução que os alunos moldaram seus discursos, que tiraram suas dúvidas sobre o que caberia ou não escrever em seus textos e que tipo de linguagem usar. (FSC03, p. 30)

Salientamos que, como o trabalho com gêneros está intrinsecamente ligado às situações comunicativas, houve ainda a necessidade de se trabalhar outros gêneros que afloraram das atividades que estavam sendo desenvolvidas em aula. Esses gêneros incidentais foram: convite e cartilha (e os demais gêneros que dela se fizeram necessários, como questionário e entrevista). (FSC03, p. 45)

No período de intervenção foram trabalhados alguns dos gêneros do discurso que se fizeram presentes no cotidiano escolar da $5 a$ série " $C$ " do Colégio de Aplicação. Seguindo cronologicamente os gêneros que foram ensinados, temos: resenha, biografia $e$ autobiografia. (FSC03, p. 44)

As produções foram feitas pelos alunos em sala para que pudéssemos presenciar os momentos interlocutivos. Priorizamos, então, atividades em duplas ou em grupos sempre que possível, pois acreditamos que, partindo desse exercício de discussão, o aluno pode perceber a importância do interlocutor para a construção do seu discurso. (FSC03, p. 44)

Os roteiros 1, 2, 3 e 4 trazem uma estrutura adaptada, ou seja, houve empenho dos grupos em produzir o texto adequando-se às características daquele tipo de gênero. No Roteiro 2 houve a preocupação em organizar as perguntas da entrevista por assuntos, relacionando-as, visando um bom entendimento para quem pudesse assistir ao vídeo depois. Para isso, algumas questões foram colocadas propositalmente, mesmo que as crianças já soubessem a 
resposta, para haver uma contextualização dos assuntos. Ao questionarem sobre a profissão do entrevistado, os estudantes estavam preocupados apenas em passar essa informação ao expectador [sic], pois já sabiam qual era o seu trabalho pelo fato do entrevistado ser um morador do bairro que todos conheciam por causa da sua profissão. (ESP09, p. 70-1)

Nessa primeira produção, não nos detivemos na refacção da estrutura da $C L$ [referência às cartas do leitor que foram mencionadas no decorrer da dissertação], porque não era o objetivo, somente solicitamos aos alunos que reescrevessem, atentando para aspectos lingüístico-textuais mais evidentes, como grafia, pontuação, organização das idéias, clareza, concordância, etc. Para essa atividade de escrita, apresentamos apenas sugestões, algumas durante o próprio processo de elaboração; outras, após a redação, marcando o que deveria ser modificado. (FMT06b, p. 62-3)

A nossa função, durante o processo de reescrita dos textos, foi apenas de mediadora, levando os próprios alunos a corrigirem-nos. Apenas questionávamos se a forma usada estava de acordo com o texto e, quando sugeriam, perguntávamos aos demais colegas se poderíamos fazer a alteração recomendada. Em caso negativo, outras sugestões eram apresentadas. No total, analisamos seis frases. Como empreendimento final, colocamos na lousa uma "carta de leitor" veiculada na revista "Guia Astral” (Fizemos alterações nessa carta similares aos aspectos lingüísticos, discursivos e textuais inadequados ocorridos nas CLs [Cartas do leitor] dos alunos) para reescrevermos a fim de nos certificarmos da apreensão do gênero. Com toda a turma, reescrevemos o texto. Os alunos não tiveram dificuldade em perceber as inadequações. (FMT06b, p. 67)

Para iniciarmos esta fase, apresentamos aos alunos duas cartas sem que lhes indicássemos a fonte: a primeira da "Veja" e, a segunda, da "Guia Astral" [...]. Antes mesmo que fizéssemos a leitura oral dos textos, um dos alunos comentou que a segunda só poderia ser de uma revista "nacional, como a Veja", porque falava de um assunto que não era amoroso, mas do Papa João Paulo II e, segundo ele, um assunto desse não sairia em outra revista. Além disso, os alunos perceberam que havia palavras mais "dificeis" na segunda carta e quem escreveu havia escrito nome completo, cidade e o estado de onde era. Comentamos sobre o assunto da CL [Carta do leitor] da "Veja", já que era o que se falava no momento. Também foi apresentada aos alunos a revista que trazia a matéria à qual a carta fazia referência. Em sua capa, havia uma imagem "impressionante" do Papa (06 de abril de 2005- "A grandeza da fé”). Levantamos discussão acerca da foto escolhida e as cores utilizadas [...]. Alguns alunos mencionaram que o fundo preto da imagem poderia estar relacionado ao sofrimento do Papa, à morte, ao luto já iminente. (FMT06b, p. 70-1)

As duas CLs [Cartas do leitor] foram escritas na lousa e as reestruturamos com toda a turma. Alguns alunos ficaram "bravos" porque também queriam que suas cartas fossem enviadas. Explicamos que a democracia tinha de prevalecer, que as demais cartas seriam divulgadas no mural da escola, mas, para a revista, só seriam encaminhadas as escolhidas pela turma. (FMT06b, p. 78)

De volta à sala de aula, cada grupo apresentou aos demais colegas as conclusões a que chegou. Para esta etapa, não indicamos quais grupos falariam. Solicitamos apenas que alguém iniciasse a apresentação. À medida que foram falando, os demais acrescentaram informações que julgavam importantes para a compreensão das CLs [Cartas do leitor]. Um aluno mencionou que só percebeu que a carta a era da revista "Veja", porque continha o 
nome do colunista André Petry. Caso contrário, teria apontado como sendo do jornal "A Tribuna". Segundo ele, as CLs [Cartas do leitor] do jornal "A Tribuna" e as da revista "Veja” são muito parecidas com relação a alguns assuntos. (FMT06b, p. 83)

Depois que todos produziram a primeira versão, selecionamos duas CLs [Cartas do leitor] para que juntos as reestruturássemos na lousa. Como os textos produzidos eram curtos, não escolhemos um ou dois aspectos a serem observados, mas todos os que os alunos percebessem. Escrevemos os textos em cartolinas e as fixamos no quadro para agilizar o trabalho. Antes que fizéssemos a primeira leitura oral ou que questionássemos sobre os textos, os alunos foram apontando o que deveria ser alterado. Dentre as sugestões, incluíram correções gráficas, concordância, pontuação, idéias incompletas, frases sem sentido, etc. Discutimos na CL 01 [Referência à carta do leitor 01, exposta na dissertação] a troca das letras " $f$ " $e$ "v". Gostaram de ficar pronunciando os fonemas para perceber a proximidade dos sons. Esse foi um assunto que muito interessou à turma; por isso, sugerimos à professora titular que o retomasse com maior ênfase em aulas posteriores. Também discutimos os nomes dos acentos, principalmente o circunflexo, conhecido até então como "chapeuzinho". $O$ aluno produtor da C.L. [Carta do leitor] fora indagado se tinha certeza de que os bairros mencionados por ele em seu texto estavam de fato recebendo asfalto na linha de ônibus. Segundo ele, não tinha certeza. Havia apenas posto os nomes. Assim, a turma achou mais conveniente citar só o exemplo do bairro que conheciam e tinham certeza da veracidade dos fatos. Também comentaram o fato de a carta estar sem identificação. (FMT06b, p. 85-6)

Podemos [...] perceber que algumas das incoerências presentes nas primeiras produções como grafia, concordância, escolha lexical e estrutura do gênero foram sendo eliminadas a cada novo texto produzido. Os alunos tiveram o cuidado de corrigir seus textos adequando-os aos propósitos enunciativos do gênero. Muitas cartas foram reescritas sem que o professor solicitasse tal atividade. O próprio aluno ou um colega percebia que o texto ainda não estava bom para o suporte em questão. (FMT06b, p. 121)

- Dados relacionados às interpretações voltadas para a comparação das prescrições curriculares ao que ocorria em sala de aula. Neles, foram expostos, em especial, opiniões docentes ou registros das aulas observadas, tratados enquanto "fatos" provenientes da realidade escolar:

No cenário paranaense, mesmo com o lançamento do Currículo Básico - CB, há mais de 16 anos, de abordagem interacionista ou Teoria da Enunciação, fundamentada em Bakhtin, poucas mudanças ocorreram no ensino de Língua Portuguesa, no Estado. (EPR06, p. 44)

A estrutura do documento [referência ao planejamento escolar analisado] deu-se em papel almaço, com cinco folhas escritas em frente e verso. Não possuía capa, data e identificação. $O$ documento apresentava um certo desgaste em decorrência do tempo. A primeira folha era seguida do título: "- Conteúdo Programático" e, abaixo, era discriminada a série que correspondia desde a Pré-escolar até a $4^{a}$ série do Ensino Fundamental. Na seqüência, vinha a listagem dos conteúdos a serem trabalhados referentes ao ensino da Língua Portuguesa, no qual deu-se grande ênfase aos estudos gramaticais, perpassando pela leitura oral e produção de textos em alguns gêneros textuais, como: carta, bilhete, relatório, etc. Outros conteúdos de Matemática aparecem no mesmo plano. (FMT06a, p. 101) 
Os relatos das professoras também manifestaram que houve abandono na formação continuada do professor: "Nunca na escola tivemos cursos de formação [...]. Nas escolas não foi o apoio de ninguém, nenhum acompanhamento pedagógico da SEDUC nós tivemos" (Professora Natércia). (FMT06a, p. 164)

Esses conteúdos, contemplados por ela, continuavam a dar elevada ênfase no estudo da gramática normativa como sendo o objeto principal de ensino da Língua Portuguesa. A resistência dessa professora, em relação às propostas, fossem elas de âmbito federal, estadual ou escolar, consistia em questões que não eram propriamente referentes só ao conteúdo das prescrições, mas o reflexo delas em suas práticas, já que o "outro" exigia estudo, reflexão, mudança, criação de novas "ferramentas" para o trabalho acontecer. E, provavelmente, ela não se sentia pronta para aplicar as prescrições na sala de aula $e$ “mexer" com seus conceitos, suas ações. (FMT06a, p. 171)

As atividades distribuídas em forma de tópicos, já em meados da década de 90, explicitavam que ainda não havia acontecido uma apropriação das propostas federal e estadual para o ensino de Língua Portuguesa, levando a uma compreensão e aplicação de um ensino mais gramatical do que textual na EEGK [Referência à escola focalizada na pesquisa]. (FMT06a, p. 103)

Não houve o cumprimento do prescrito para o ensino de Língua Portuguesa nos anos de 1991-1992, com o que foi materializado no planejamento anual e nos diários de classe da professora Aline. Para elaborar o Planejamento, segundo a Proposta Curricular (1991), o professor deveria elencar, primeiramente, atividades variadas de produção de textos orais e escritos. E, só a partir dessas atividades, planejar-se-ia um trabalho com a modalidade padrão da língua portuguesa, fato esse que não ocorreu no planejamento escolar e nem nos registros oficiais da professora. (FMT06a, p. 119)

Percebe-se que não houve um "rompimento" com a cópia e o ditado. As professoras não registravam a cópia para não contradizer nem o prescrito escrito e nem o prescrito oral (subjacente na administração escolar, que parece não ter cedido espaço enunciativo para as professoras dizerem o que estavam fazendo), porém, fizeram de um prescrito de si e para si, de natureza oral, o realizado, por se apropriarem de um discurso que produzia o efeito de sentido de "eficácia" daquele tipo de prática. (FMT06a, p. 161)

Considerando-se os problemas que envolvem a transposição dos conteúdos a serem ensinados na sala de aula, a professora A declara que a escola onde ela exerce sua função não oferece condições para realizar um melhor trabalho: "A escola onde eu trabalho não oferece, em parte, condições para que eu possa desenvolver um bom trabalho. Ela não possui biblioteca. Há uma salinha onde estão amontoados uns livros. O prefeito da época ficou de montar uma biblioteca naquele local, pois a antiga biblioteca foi cedida para o laboratório da escola. Ele disse que faria uma biblioteca e não fez. Hoje ele já saiu do poder e não fez, não cumpriu." (Professora A). (EPA08, p. 150)

A professora $C$ deixa clara a sua idéia de que os PCN, visto a partir do curso recebido, serviu apenas como reflexões iniciais para que fosse posteriormente lido: "Os PCN foram facilitadores para que a gente fosse buscar os conhecimentos noutras fontes. Foi no curso que passamos a conhecer a importância dos PCN e fomos orientados a buscar as leituras neles." (Professora C). (EPA08, p. 175-6) 
A professora $C$ demonstra que os PCN por si não têm contribuído para resolver os problemas vivenciados na escola como, por exemplo, a repetência. E os concebe como mais um modismo desencadeado pelas políticas para a educação: "Nós não conseguimos ainda minimizar a questão da reprovação na quinta série. E o objeto de estimação já deixou de ser admiração. Foi junto com a moda que passou. E também acabou o nosso querer buscar dentro dos PCN novidades, auxílio para trabalharmos nossa prática na sala de aula. É como se os PCN tivessem sido descartados.” (Professora C). (EPA08, p. 179)

A professora $C$ justifica sua atitude de conceber os PCN como modismo descartável, ao dizer que isso pode ser reflexo da inconclusão da formação recebida no município de Oriximiná. Ela destaca a busca desse referencial como de suma importância para seu aprendizado, ou seja, para superar aquilo que possivelmente tenha deixado de aprender: "Eu não sei se, tivéssemos finalizado todos os módulos, todo ele por completo, eu teria uma resposta diferente. Ele iria acontecer em várias etapas. Se isso iria nos ajudar ou não, não posso dizer. Mas a minha busca pelo conhecimento, com certeza, melhoraria. O que eu aprendi, com certeza, foi pela minha própria busca do conhecimento”. (Professora C). (EPA08, p. 179)

Nas suas falas, as professoras parecem reconhecer suas limitações acerca de conhecimentos mais aprofundado dos PCN. Ao expressarem suas representações de PCN, os interpretam à sua maneira, fazendo uso de conhecimentos que já traziam em sua bagagem de saberes adquiridos no seu cotidiano. Podemos dizer que as professoras não conseguem analisar muito bem as ideologias presentes nessas orientações, mas, mesmo assim, têm consciência de que é preciso trabalhá-las com seus alunos, ou isso poderá levá-los ao insucesso. (EPA08, p. 180)

Ao falar sobre o que avalia como negativo nos PCN de Língua Portuguesa, a professora C destaca a forma como esses parâmetros foram implantados nas escolas. Ela descreve a falta de participação dos professores nas discussões que envolviam as diretrizes $e$ a implementação do programa: "Eu acho que o que é negativo nos PCN, é o fato de eles virem muito prontos. Eles vêm pronto pra te engolir eles todinhos. Não se faz uma reunião com os professores para ouvir opiniões ou discutir essas inovações. Não é que achamos que eles estejam muito fora de nossa realidade, não estão. Mas, por exemplo, são propostos kits tecnológicos que a gente sabe que as nossas escolas não possuem. Há coisas que ainda são inacessíveis pra gente. Por isso ainda não dá para trabalhar de determinada forma. Mas a gente sabe que tudo isso é muito válido. Nos PCN há muita coisa glamurosa." (Professora C). (EPA08, p. 137-8)

Na esteira das questões que se relacionam à autonomia e à gestão democrática da educação, a organização do tempo é um fator fundamental. E esse é um ponto que emerge constantemente nas falas dos sujeitos e que precisa ser analisado, pois isso também reflete a necessidade de escuta dos professores nas atividades que se destinam a eles e que pretendem melhor orientar a organização de suas atividades docentes. (EPA08, p. 140)

Como se observa no relato da professora A, as mudanças são imaginadas isoladamente, ou seja, não são conduzidas democraticamente, desconsideram as condições em que poderão estar imersas. É necessário pensar os meios para que se consiga chegar aos resultados esperados, o que implica um conjunto de atividades articuladas e contextualizadas para que seja assegurada a eficácia dos objetivos. A crise desencadeada por esses fatores que cercam 
a profissão docente conduzem muitos profissionais à indiferença e à desmotivação para o trabalho que desenvolvem. (EPA08, p. 135-6)

A professora entende os docentes como meros receptores dessa política educacional e critica a falta de atenção de seus mentores com a realidade dos contextos para os quais foram encaminhados. (EPA08, p. 138)

- Interpretações que propuseram o contraste entre o prescrito para o ensino de Língua Portuguesa e o que foi efetivado em sala de aula e focalizaram, também, os pareceres docentes referentes a estas prescrições:

Mesmo não incorporando totalmente o que estava prescrito por escrito, muitas das professoras procuraram trazer para suas práticas situações que favoreciam a aprendizagem, como, por exemplo, o trabalho com produções textuais em gêneros variados: a carta, o bilhete, a fábula, entre outros. Mesmo não contemplando muitos outros aspectos que poderiam ter feito parte do processo, as professoras procuravam refutar o ensino gramatical "puro" com todas as dificuldades, dúvidas e medos que enfrentavam, pois, segundo elas, em seus relatos, não recebiam formação adequada e acabavam ficando no escuro, sem método, sem saber que caminhos deveriam percorrer. (FMT06a, p. 185)

[...] os discursos contidos nos prescritos escritos indicavam que era preciso mudar, mas as professoras não sabiam como mudar. Já que a formação continuada não ocorria com a intensidade necessária para apropriação daquelas novas tendências de ensino que trancorreram nos anos 90 e se caracterizavam como uma mudança em curso, o que exigia além da formação, estudos e reflexões das próprias professoras ao se depararem com àquela transição teórica-metodológica. O fato de rejeitar as propostas, fossem elas de âmbito federal, estadual ou escolar, configurava-se também como uma maneira de se acomodar diante do "novo" para continuar atribuindo sustenção às suas práticas anteriores. A formação continuada não depende apenas da escola, ou da Secretaria de Estado e Educação, mas também de cada professor que demonstre interesse em ler, conhecer, discutir e aplicar as orientações advindas dessas propostas, já que as prescrições escritas são elaboradas com caráter orientador e chegam às escolas para que as sugestões para o ensino sejam estudadas e colocadas em prática no desempenho do "métier". (FMT06a, p. 185-6)

No que se refere à autonomia dos professores e à gestão democrática da educação, as falas e os sentimentos dos sujeitos nos orientam que as mudanças são imaginadas isoladamente, ou seja, não são conduzidas democraticamente, desconsiderando as condições em que poderão estar imersas. A crise desencadeada por esses fatores conduz muitos profissionais à indiferença e à desmotivação para o trabalho que desenvolvem. As professoras destacam a falta de participação nas discussões que envolviam as diretrizes e a implementação do programa. Os docentes percebem-se como mero receptores dessa política educacional e criticam a falta de atenção de seus mentores com a realidade dos contextos para os quais ela foi encaminhada. (EPA08, p. 184)

Em resposta ao objetivo de verificar se os professores compreendem e aplicam as orientações apresentadas nos PCN, podemos dizer que a maioria dos relatos demonstra que as professoras não compreendem e não seguem as orientações dos PCN de como trabalhar a 
oralidade, a escrita e a questão da variação lingüística. Quando trabalham, elas seguem as orientações das atividades descritas nos livros didáticos. Como essas atividades geralmente são bastante resumidas e pouco fundamentadas, as professoras não conseguem explicar as razões e os objetivos desse fazer. Quando explicam, suas falas expressam as mesmas limitações dos manuais que são seguidos. (EPA08, p. 186)

[...] muito há ainda que se caminhar para se chegar ao que foi proposto e defendido como adequado nos PCN Língua Portuguesa e, parece que o foco do problema neste contexto está na organização do processo de formação e no tempo disponível para que os docentes pudessem assimilar os conteúdos. Dessa forma, podemos inferir que há que se pensar mediações mais amplas, que possibilitem a reflexão sobre o indivíduo e as numerosas situações políticas e sociais a que ele possa estar exposto, que considerem o sentimento de incerteza suscitado ao adquirir um conjunto de conhecimentos normatizadores, pois não se podem mudar as práticas, as estruturas, as representações e as culturas por decreto. (EPA08, p. 187-8)

As justificativas mais comuns para a não efetivação da proposta dos PCN de Língua Portuguesa estão relacionadas à falta de condições das escolas (é preciso melhorar a biblioteca e seu acervo bibliográfico e há carência de recursos didáticos) para que elas possam desenvolver uma melhor prática de ensino. A sobrecarga de trabalho é uma questão recorrente e, segundo as professoras, isso sempre interferiu na efetivação da proposta. Em suas falas, elas se voltam constantemente aos recursos e às condições necessárias para que esses conteúdos possam ser trabalhados. (EPA08, p. 186)

- Relato factual com remissão à "Sala de Apoio à Aprendizagem em Língua Portuguesa" (SAALP):

[...] demonstram progresso significativo na qualidade argumentativa dos textos produzidos pelos alunos $A$ e B, da escola A. Essa qualidade destaca os avanços dos alunos, provavelmente como resposta positiva ao trabalho dispendido pelo professor, ao longo do processo [...]. (EPR06, p. 112)

- Relatos factuais com remissão ao trabalho com gêneros gramaticais:

[...] foram selecionados para compor a amostra da pesquisa um total de 120 alunos - trinta de cada série investigada $\left(2^{a}, 4^{a}, 6^{a}\right.$ e $8^{a}$ séries $)$ - oriundos de uma escola pública estadual do município de Maringá/PR (escolhida pela receptividade e aceitação para o desenvolvimento do trabalho) e selecionados pelas professoras das classes conforme a aceitação $e$ disponibilidade dos alunos. (EPR07, p. 87)

A opção pelas $2^{a}, 4^{a}, 6^{a}$ e $8^{a}$ séries baseia-se no fato de que elas se constituem séries finais do primeiro, segundo, terceiro e quarto ciclos deste grau de ensino, momentos significativos do processo de formação dos alunos do Ensino Fundamental. (EPR07, p. 87) 
Os substantivos selecionados para as provas são, basicamente, de três tipos diferentes, com base em Câmara Jr. (1984b, p. 92) que propôs, como visto anteriormente, uma forma de simplificação nos estudos relativos ao gênero gramatical: tipo 1: nomes substantivos de gênero único; tipo 2: nomes de 2 gêneros sem flexão e tipo 3: nomes substantivos de 2 gêneros, com uma flexão redundante. (EPR07, p. 87)

Em sua maioria, portanto, os sujeitos só conseguem começar a estabelecer algum tipo de relação relativa a esse conteúdo a partir do momento em que lhes é solicitado que justifiquem como eles procedem para diferenciar substantivos masculinos de substantivos femininos. Vejamos alguns exemplos: A2,1: "Você conhece gramática?" Não. "Sabe do que trata?" Não. "Você sabe o que é substantivo?" Não. "Você sabe o que é gênero dos substantivos?" Não. "Como você faz para diferenciar quando uma palavra é masculina e quando é feminino?" A feminina assim? A feminina, depois da feminina vem o feminino e depois do feminino vem a masculina. "Ah é? Como assim?" É (pensa bastante) Não sei. "Vamos supor que você é uma professora, e tem que explicar isso para os seus alunos, como que você faria?" Não sei. [destaque em negrito presente no original] (EPR07, p. 107)

No que diz respeito aos resultados observáveis por meio da entrevista inicial, realizada antes da atividade escrita, podemos perceber que a grande maioria dos sujeitos entrevistados não apresenta conceitos referentes ao termo "gênero gramatical", o conteúdo principal da pesquisa. (EPR07, p. 106)

[...] nossos dados revelam que os alunos de $4^{a}, 6^{a}$ e $8^{a}$ séries, principalmente os das duas primeiras, parecem não ter se beneficiado do processo de escolarização. Esses resultados confirmam dados do Saeb (Inep, 2002), segundo os quais os alunos do ensino fundamental não estariam apresentando progresso na construção do conhecimento relacionado à língua portuguesa no decorrer do processo de escolarização. (EPR07, p. 113)

Analisados em conjunto, os dados permitem a observação de que a $2^{a}$ série obtivera um percentual menor de êxitos (50,8\%) - se comparada às demais séries - na tarefa de identificação do gênero masculino/feminino de todas as palavras (30) selecionadas para realização da pesquisa. Esse pode ser considerado um resultado esperado, pois neste período escolar o aluno ainda está construindo as diferenças, as semelhanças e as relações existentes entre as idéias, as noções e os objetos, e se encontra, portanto, num processo de levantamento de hipóteses sobre os conceitos. (EPR07, p. 98)

A $4^{a}$ série obteve, nesse momento, um percentual de êxitos de 64,2\%, percentual este maior que a série anterior. Já na $\sigma^{a}$ série o percentual de êxito sofre queda, ficando em $60,1 \%$, uma quantidade maior de êxitos em relação à $2^{a}$ série, porém menor em relação à série anterior. Na $8^{a}$ série, por fim, o percentual de êxito na realização da atividade volta a crescer, atingindo seu ponto máximo (76,1\%). A comparação de todos esses dados permite a observação de que a $8^{a}$ série teve maior percentual de êxito no que diz respeito à identificação do gênero dos substantivos. Em seguida, nesse contexto, ficou a $4^{a}$ série, apesar de sua diferença com a $6^{a}$ série ser inexpressiva. (EPR07, p. 99)

[...] em todas as séries houve destaque de êxito em relação às palavras do grupo 3, ou seja, referentes àqueles substantivos que possuem dois gêneros e flexão redundante. Palavras 
desse tipo são comumente relacionadas à noção semântica de sexo dos seres, pois admitem flexão que costuma ser associada à questão sexual, como ocorre, por exemplo, nos substantivos aluno/aluna, em que a flexão de gênero coincide com a referência a seres de sexo oposto. Podemos observar ainda, por meio desses dados, que o segundo tipo de substantivos que apresentou maior percentual de êxito na identificação do gênero gramatical foi o grupo 1, referente a palavras que possuem apenas um gênero gramatical, como, por exemplo, o garfo. Por fim, em todas as séries podemos observar maior dificuldade de êxito na identificação do gênero de substantivos do grupo 2, ou seja, substantivos que possuem dois gêneros, porém sem a flexão comum ao grupo 3. (EPR07, p. 102-3)

[...] em todas as séries, há um percentual maior de êxito no que diz respeito à identificação do gênero gramatical em palavras nas quais há coincidência entre o gênero gramatical e o sexo dos seres. $\mathrm{Na} 2^{a}$ série, obteve-se em percentual de $56 \%$ de êxito nas palavras do primeiro tipo, em oposição a 38,5\% nas do segundo tipo, perfazendo uma diferença percentual de $17,5 \%$. Na $4^{a}$ série, uma diferença de $24,7 \%$ de êxito entre as palavras de primeiro tipo e as palavras de segundo tipo é reveladora de um percentual de $71,4 \%$ de êxito em oposição a 46,7\%. Na $6^{a}$ série, o êxito na identificação de palavras em que há identidade entre gênero e sexo foi de 65,6\% em oposição a 47,4\% nos substantivos em que não há essa identidade. A $8^{a}$ série, por fim, apresentou menor diferença no percentual de êxito entre esses dois tipos de palavras, apenas $7,7 \%$, resultante de um êxito de $78,4 \%$ de êxito na identificação do primeiro tipo de substantivos em oposição a 70,7\% nos de segundo tipo. (EPR07, p. 104-5)

[...] necessidade de que os conhecimentos espontâneos que os alunos possuem sobre o gênero gramatical, normalmente aquele relacionado à idéia sexual, sejam repensados em situação escolar de forma tal que não sejam simplesmente substituídos, mas sim ampliados, transformando-se gradativamente em um conceito científico escolar, adequado, portanto, à luz da teoria lingüística anteriormente apresentada. (EPR07, p. 140)

[...] os alunos apresentaram algumas confusões conceituais que deixam explícita a influência da base semântica em suas classificações. (EPR07, p. 141)

A utilização dos conceitos prévios dos alunos investigados nesse tipo de atividade pôde ser confirmada no momento em que nos propusemos, na análise do fazer, a separar os substantivos utilizados na pesquisa em três grupos distintos. Observamos que, em todas as séries, houve maior percentual de êxito nas palavras do grupo 3 (84\%), referentes aos substantivos que possuem dois gêneros e flexão redundante. Isso se deve ao fato de que palavras desse tipo admitem flexão que costuma ser associada à questão sexual, pois a flexão de gênero coincide com a referência a seres de sexo oposto. (EPR07, p. 142)

Tendo em vista que uma das funções da escola é promover a tomada de consciência de conceitos, por meio da modificação dos conceitos prévios dos alunos em conhecimento formal, seria esperado que os alunos investigados nesta pesquisa, no decorrer do ensino fundamental, tivessem modificado seus conceitos sobre gênero, ampliando seu conhecimento a respeito do tema. Salvo a evolução observada na $8^{a}$ série, constatamos que a movimentação 
cognitiva desenvolvida por meio de reflexão e interações sociais não vem se efetivando durante o processo de escolarização. (EPR07, p. 144-5)

[...] os resultados desta pesquisa oferecem um exemplo significativo de uma situação na qual a tomada de consciência e a conceituação que ela supõe encontram-se deformadas. Nosso corpus, a exemplo do corpus analisado por Piaget nas duas obras clássicas de sua literatura, "A tomada de consciência" e "Fazer e compreender", revela que os alunos, ao lidarem com o conceito de gênero gramatical, embora em grande parte das vezes consigam identificá-lo, não conseguem explicar como o fizeram, demonstrando que a ação não garante a conceituação, pois esta depende, essencialmente, da transformação conceitual obtida por meio da tomada de consciência. (EPR07, p. 145)

- No que diz respeito ao ensino do gênero gramatical, EPR07 apresenta as seguintes "verdades":

A aprendizagem de conceitos admite a aquisição de um conhecimento a partir do momento em que o indivíduo se torna capaz de dotar de significado um material ou uma informação, compreendendo determinado conteúdo, e podendo, então, traduzi-lo para suas próprias palavras (Coll, 1998). Este tipo de aprendizagem permite ao aluno explicar e justificar o conceito aprendido, o que, de acordo com Piaget (1978a), explicita a tomada de consciência de suas ações. De tal forma, o sujeito torna-se capaz de integrar o novo conhecimento aos seus esquemas prévios e de torná-lo um recurso cognitivo disponível para novas aprendizagens. Nesses esquemas prévios, enquadram-se os conhecimentos construídos informalmente pelo sujeito, ou seja, os conceitos espontâneos, aqueles construídos fora da sala de aula por meio de experiências particulares. (EPR07, p. 11)

[...] de acordo com Câmara Jr. (1980, 1984a/b, 2000), um dos maiores problemas inerentes à classificação de gênero é o fato de ela ser pensada muitas vezes através de uma confusão semântica com o sexo dos seres. A respeito disso, o lingüista afirma: "há o afã de equiparar a categoria de gênero com a distinção dos sexos do reino animal”. (EPR07, p. 33)

Em obra intitulada "A tomada de consciência" (1978a), Jean Piaget promove um estudo do processo que intitula a sua obra, considerando que a tomada de consciência constitui-se uma construção, e, assim sendo, exige a intervenção de atividades das quais o sujeito depende e as quais se torna capaz de modificar. Essa percepção surgira, de acordo com o autor, de uma preocupação da psicologia filosófica, que teria percebido o poder da "introspecção" para trazer à consciência, por meio de intervenções, conhecimentos que permaneciam num nível de inconsciência. Esse movimento que permite "trazer à tona" conhecimentos antes interiorizados depende, essencialmente, de um estabelecimento de relações que só é possível por meio do pensar, ou melhor, da atividade de reflexão, ponto incansavelmente destacado pela teoria de aprendizagem conceitual. (EPR07, p. 66)

- Registros "factuais" incorporados à argumentação de FPB07 - citação de aulas observadas pela pesquisadora e remissão a falas docente e discentes: 
Constatamos, logo de início, que um aluno relaciona o assunto "futebol" tratado na tira ao seu conhecimento de mundo atual sobre o tema. Diante da fala do aluno, a professora pergunta: Professora: só faz perder? SE O FLAMENGO, só sabe perder, o que a tirinha está passando aí pra gente? vamos, explica aí pra colega que não entendeu nada. Vemos, portanto, que a professora utiliza a fala do aluno e o seu conhecimento de mundo para tentar iniciar uma discussão sobre o conteúdo textual. É interessante atentarmos para a fala da professora quando ela pergunta "o que a tirinha está passando aí pra gente?". A Idéia de que o texto tem uma mensagem a ser transmitida e esta deve ser decifrada pelos alunos está implícita nessa fala. Em seguida, a professora pede para que os meninos que entendem de futebol expliquem a tira para quem não a compreendeu. Os meninos calam. A professora então, diante da dificuldade dos alunos, faz outra leitura oral do texto, e após essa leitura faz uma pergunta aos alunos que está diretamente relacionada ao conhecimento de mundo deles: Professora: quando É que um TIme, em 99\% das vezes, muda de técnico?. Uma aluna responde: Aluna: quando tá perdendo. Diante da resposta, a professora questiona os alunos novamente. Uma outra aluna afirma que não entende nada de futebol: Aluna: eu num sei não, não entendo nada de futebol. Novamente confirmamos a importância do conhecimento de mundo para a leitura que os alunos fazem dos textos. Quando essa aluna afirma não entender nada de futebol, em outras palavras ela diz que não consegue dar sentido ao texto a partir desse tema pelo fato de não conhecê-lo. A professora, entretanto, continua insistindo no tema "futebol" e complementa a fala anterior dos alunos: Professora: quando o time está dando certo? quando o time só faz perder ou? empatar, aí veja os coitados oh (( a professora continua a leitura do texto até o fim)) e agora, entenderam?. Como vemos, ela vai construindo o sentido do texto de acordo com a sua leitura. A fala dos alunos praticamente inexiste nesse momento em que ela está construindo esse sentido. Percebemos ainda que, mesmo os meninos que demonstram conhecer o tema "futebol" mais do que as meninas, não se manifestam no momento em que a interpretação do texto está sendo realizada pela professora. A aluna, que até então dizia não ter compreendido o texto, afirma agora tê-lo compreendido, isso após a leitura realizada pela professora: Aluna: entendi. Ou seja, será que de fato ela não compreendia o texto, ou será que estava esperando que alguém, no caso, a professora, lhe fornecesse a "leitura correta" do texto? (FPB07, p. 75-6)

Um outro aspecto que nos desperta o interesse nesse trecho da aula é a rápida passagem da professora pelo texto. Após esse momento da aula acima transcrito, a docente já inicia a discussão do texto seguinte denominado "À deriva". É importante salientar que os alunos fizeram apenas uma leitura oral do texto e já se iniciou uma discussão sobre ele. E percebemos que são raras as falas dos alunos nesse trecho da aula, justamente porque é bastante provável que eles não tenham compreendido o texto a ponto de se sentirem seguros para fazerem parte de uma discussão em sala de aula. Não estando seguros, a interpretação que a professora faz do texto é a única existente e a única que prevalece. A construção de sentidos que prevalece em sala de aula é a da docente. Quanto aos alunos, não sabemos se eles construíram algum sentido do texto; se construíram, que sentido foi esse, porque suas falas não aparecem na aula. Acreditamos, portanto, que eles estão simplesmente aceitando os sentidos construídos pela professora. (FPB07, p. 87)

[...] os alunos começam a responder a pergunta da professora (Aluna: é como se fosse Titanic / Aluna: porque a dengue está se espalhando). Como vemos, os alunos parecem ter tido uma maior facilidade de compreensão do conteúdo temático desse texto, e isso pode ser devido ao fato de a professora ter discutido anteriormente o título do texto com eles. Uma 
aluna relaciona o título ao conteúdo textual e fala no navio Titanic, citado no texto. Uma outra aluna faz de imediato a leitura que parecia pretendida pela professora, e conseguimos perceber isto porque a docente utiliza-se da fala dessa aluna para concluir a respeito da relação de sentido entre o título e o conteúdo do texto (Professora: a dengue está se espalhando SEM....); as alunas apenas complementam a fala da professora e a construção de sentido por ela conduzido (Alunas: SEM CONTROLE / Professora: sem controle, exatamente). Mais uma vez, a palavra "exatamente" aparece na fala da professora, novamente confirmando que as alunas estão trilhando o mesmo caminho da construção de sentido realizado por ela. Isto fica ainda mais evidente, quando a reação das alunas é vibrar ao perceberem que conseguiram chegar onde a professora queria que elas chegassem; as alunas comemoram ao perceber que deram a "resposta certa", a resposta que a professora queria escutar (Alunas: [ehhhhhhhh]). (FPB07, p. 90-1)

[...] em resumo, até esse momento da nossa análise, algumas questões são de bastante relevância para o nosso trabalho. A primeira delas é a constatação da concepção estruturalista de leitura da professora: ler é captar o pensamento do autor que está implícito no texto, restando aos leitores identificar esse pensamento. A construção de sentidos nessa perspectiva torna-se um ato mecânico de simples decodificação, não havendo possibilidade de haver mais de uma leitura aceitável para o texto; este então passa a ser um produto lógico e acabado. Dessa forma, o texto é abordado de maneira superficial, apenas o tema é trabalhado em sala de aula, a estrutura composicional e o estilo não são debatidos e por isso mesmo não se chega a uma discussão sobre o gênero, ou seja, as demais informações relevantes para o conhecimento do gênero, como as suas características básicas, o suporte, $o$ autor, ano de publicação, etc não são trabalhados pela professora. (FPB07, p. 78)

E, mais uma vez, a professora evidencia a concepção de leitura que embasa a sua prática docente quando novamente pergunta: Professora: qual é a mensagem?. Como vemos, desde o início dessa aula, a intenção da professora é fazer com que os alunos encontrem essa "mensagem" que está presente no texto e que deve ser por eles decifrada. A aluna, que afirmava não estar compreendendo nada do texto, responde ao questionamento da professora: Aluna: que:: o time perdia demais, aí chegou um novo técnico que trazia um pensamento positivo pra eles. (FPB07, p. 76)

[...] momento da fala da professora que merece destaque na nossa análise, pois aqui constatamos que ela confunde vários gêneros textuais. Notemos que ela classifica o texto lido como reportagem jornalística e como notícia, e, no entanto, não se trata de nenhum desses gêneros, mas sim, de um de um editorial. Essa fala da professora nos demonstra que ela provavelmente desconhece a teoria de gêneros textuais ou conhece tal teoria, mas não faz uso de suas contribuições em sala de aula. Esse trecho também nos ajuda a compreender a maneira como os demais textos foram trabalhados em sala de aula. Apenas o conteúdo temático destes foi abordado; estilo e estrutura composicional não foram discutidos. Possivelmente, se a professora conhecesse a teoria de gêneros textuais, esses outros aspectos constituintes dos gêneros teriam sido devidamente elucidados nas aulas de leitura. (FPB07, p. 86)

- Dados que se voltaram para características do livro didático de Língua Portuguesa e para o seu uso: 
Já os últimos docentes entrevistados, Ivonete e Ademar [Referência a professores partícipes da pesquisa], acrescentam que lançam mão das estratégias além do livro, vale ressaltar que com suave alargamento, em função das novas tecnologias, para viabilizar a ampliação de habilidades dos alunos, geralmente, relacionadas com o texto. São as concepções arraigadas dos sujeitos, embora não tenham, no transcorrer das suas falas, negados a gramática. Porém, no transcorrer das entrevistas, e, mais precisamente, no último questionamento apresentado, os professores são convictos em afirmar que, seja pra enfocar gramática, seja para enfocar textos, o livro didático não sai do cenário da sala de aula, tanto o livro adotado quanto, outros livros que servem de apoio e pesquisa para retirada de textos, exercícios, dentre outros, com a intencionalidade de ampliação e suavização do processo de ensino e de aprendizagem. (FMT07, p. 200-1)

Quando perguntamos se houve o contato com o Guia de Livros Didáticos, cinco professoras disseram que sim, mas, em seguida, percebemos que elas estavam se referindo à ficha de seleção, na qual se colocam os códigos das coleções escolhidas [...]. [Destaques em negrito presentes no original] (FPA07, p. 113)

Ainda no tocante à seleção do material, consideramos que os PCN, entre outras coisas, poderiam auxiliá-las nesse processo, já que os critérios avaliativos presentes no Guia são baseados nesse documento. Por isso, procuramos saber se as entrevistadas já os tinham lido. Uma reconheceu não ter lido e cinco disseram sim, entretanto, ao serem questionadas sobre a proposta referente à $L P$, apresentaram respostas imprecisas, demonstrando o desconhecimento desta [...]. [Destaques em negrito presentes no original] (FPA07, p. 113-4)

Eles também se mostram inconsistentes porque, das seis professoras, cinco afirmaram priorizar o texto no momento da escolha, mas, quando consultadas sobre os pontos negativos do material, quatro delas citaram a presença de textos longos. Se o fator determinante para escolher um e não outro material é prioritariamente o texto, parece evidente que há intenção em utilizá-lo em sala de aula. Todavia, percebemos, por meio das observações, que duas professoras (PEE2 e PEF2) não o utilizaram em sala de aula e que as outras usaram-no esporadicamente. Por exemplo, durante 12 horas-aula de observação na escola EE1, ele foi tomado uma única vez, exclusivamente, para identificação de questões gramaticais. [Destaques em negrito presentes no original] (FPA07, p. 140-1)

Quanto ao Guia, não foi possível saber ao certo, por meio das entrevistas, se a escola não o recebeu ou se a diretora não o repassou às professoras. O fato é que elas não o consultaram e algumas confundiram-no com a ficha de seleção [...]. (FPA07, p. 141)

[...] uma professora declara não conhecer os PCN de LP e as outras dão respostas evasivas e até inviáveis, como ler os PCN todos os dias que não informam sobre o conteúdo desses documentos, demonstrando que, embora eles estejam funcionando há 10 anos como referência teórico-metodológica para o ensino, muito ainda precisa ser feito para que as professoras possam analisar as suas propostas e, com base nelas, escolher aqueles LD [Livros Didáticos] que tomem o uso da linguagem como ponto de partida e chegada e a reflexão como uma prática a ser associada ao trabalho de compreensão e produção de textos orais e escritos. (FPA07, p. 143)

[...] a não consulta ao Guia e o desconhecimento da proposta dos PCN influenciam no momento da definição de critérios de seleção, porquanto faltam informações sobre os eixos 
que devem nortear o ensino e sobre os objetos a serem priorizados na sala de aula. Essa falta de informação, por sua vez, faz com que o ensino continue a ser regido por meio de normas de bom uso da língua. (FPA07, p. 144)

Nos livros, quanto ao conhecimento lingüístico, há conteúdos e exercícios gramaticais e alguns textos pequenos que servem para o tratamento de aspectos relacionados à estrutura, ao reconhecimento de classes gramaticais e à ortografia. Encontramos diferentes conteúdos gramaticais, como: encontro vocálico, separação em sílabas, encontro consonantal, dígrafo, sílaba tônica, ortografia (g,j, qu,gu,ç,c,ss,s,z,sc), tipos de acento, pontuação, tipos de frase, substantivos, adjetivos, locução adjetiva, pronomes, verbo, preposição e advérbios. (FPA07, p. 108)

Em outros ainda, como no "Viver e aprender português" e "L.E.R.: leitura, escrita $e$ reflexão”, encontramos textos utilizados como suportes de adjetivos, substantivos, de questões gramaticais em geral, cabendo, pois, ao aluno identificá-los elou nomeá-los. Por exemplo, no livro "Os caminhos de língua portuguesa", é sugerido ao aluno pesquisar propagandas que tenham adjetivos no diminutivo e no aumentativo. Considerando os exercícios presentes em todos os livros incluídos neste trabalho, os predominantes são os de ortografia. Através deles, os alunos são levados a refletir sobre o uso de uma letra em um contexto específico. Por exemplo, no livro "Viver e aprender português", numa atividade envolvendo a letra $h$, os autores primeiramente apresentam os diferentes contextos de uso desta letra no início e no meio da palavra depois sugerem ao aluno concluir a respeito daquele uso. Podemos ainda destacar aquelas atividades que exigem certo raciocínio, como questões que objetivam a descoberta de critérios de agrupamento de palavras pelos alunos $e$ a separação de sílabas a partir da resolução de um exercício. No livro "Coleção vivência e construção: língua portuguesa”, o aluno é levado, por exemplo, a perceber os diferentes sons da letra $x$, as semelhanças na pronúncia e diferenças na escrita das palavras mal e mau, a importância do acento para diferenciar substantivos e verbos de preposição, entre outros. [Destaques em negrito presentes no original] (FPA07, p. 110)

Em suma, esses livros apresentam diferentes propostas que visam, principalmente, ao trabalho com a compreensão escrita e a oralização da escrita. Entretanto, encontramos atividades que focalizam o significado das palavras, as regras da escrita, os aspectos concernentes à estruturação de texto: coesão, coerência, paragrafação etc, as regras gramaticais; mas, raramente, a compreensão e produção oral. (FPA07, p. 112)

No que diz respeito às seções privilegiadas no $L D$ [Livro Didático], essas foram: em primeiro lugar, o texto e, em segundo lugar, os exercícios gramaticais. As outras, como de produção oral e escrita, não foram usadas em nenhuma das escolas. (FPA07, p. 165)

[...] os livros ainda são bastante freqüentados como base para a preparação das aulas, mas, sobretudo, aqueles que privilegiam um ensino baseado no reconhecimento e na catalogação de classes gramaticais e exercícios ortográficos. [...] existe certa incoerência entre o que é declarado pelas professoras e o que foi observado em sala. Por exemplo, o texto não é priorizado em sala e sim exercícios ortográficos. (FPA07, p. 118)

Em resumo, a pesquisa mostrou que o objeto de ensino nas aulas de LP [Língua Portuguesa] é a gramática, principalmente no respeitante às questões ortográficas. Ela é explorada quase 
sempre a partir do texto, que é utilizado como pretexto para a identificação de itens gramaticais e para o treino ortográfico. (FPA07, p. 157)

Em relação à freqüência de uso do $L D$ [Livro Didático] em sala de aula, duas professoras declararam usá-lo constantemente; três afirmaram às vezes e uma disse não. E quando sondadas a respeito da parte do LD [Livro Didático] priorizada, o texto foi o mais mencionado. Elas também disseram aproveitar as perguntas de compreensão e os exercícios gramaticais, mas em menor número. Entretanto, durante as observações, percebemos que apenas duas o usavam com mais constância, a PEF1 e a PEM2. [Destaques em negrito presentes no original] (FPA07, p. 115)

Indagadas em relação às estratégias adotadas na utilização do LD [Livro Didático], apenas uma professora afirmou seguir a proposta, retornando a algum tópico em caso de revisão. Quatro disseram não seguir página por página, mas selecionam partes de acordo com o que estão trabalhando, pois elas têm planejamento próprio. Três delas, quando recorrem ao LD [Livro Didático], procuram por textos para explorarem aspectos gramaticais ou a leitura. Para complementar o trabalho didático, sobretudo em relação à gramática, todas disseram recorrer a outros materiais, principalmente, a LD [Livro Didático], como: Descobrindo a gramática, Eu gosto de português e Marcha Criança. Além disso, citaram como material didático utilizado: dicionários, músicas, figuras, jornais, revistas etc. [Destaques em negrito presentes no original] (FPA07, p. 116)

Entre as professoras apenas uma admitiu não ler o manual, porque adota a sua própria metodologia. Afirmou ainda ser ele importante somente para quem está iniciando no magistério. Realmente, segundo as observações, a PEE1 utilizou o livro apenas para o trabalho com a cópia, exercício de leitura e uma vez tomou um texto para identificação de aspectos gramaticais, demonstrando não seguir nem conhecer as orientações do manual do professor. [Destaques em negrito presentes no original] (FPA07, p. 117)

É interessante destacar que, apesar de a maioria delas [referência às professoras partícipes da pesquisa] apontarem o manual do professor como necessário, as suas respostas nos indicam que talvez elas não detenham um conhecimento mais aprofundado sobre ele o que seria importante, pois ele traz reflexões sobre concepções de língua, orientações sobre o trabalho com o oral, a compreensão e produção escrita, etc [...] (FPA07, p. 117)

Por meio das informações coletadas, percebemos que o livro aparece sobretudo como um "objeto decorativo", porque, diferentemente do que Britto (1997) afirma, os livros atuais não desempenham a função de protagonistas em sala de aula nem determinam a escolha dos conteúdos. Freqüentemente, as professoras usam do LD [Livro Didático] apenas textos (para o ditado, para a leitura oral ou silenciosa) e exercícios para a fixação de conteúdos gramaticais passados no quadro. (FPA07, p. 157-8)

Quanto à modalidade oral da língua, o único livro que aborda a linguagem como conteúdo de estudo, conforme a proposta de Schenewly e Dolz, é o "Língua Portuguesa: Rumo ao Letramento" [...]. Os outros apenas trazem atividades, mas não discutem a linguagem oral, não trabalham com as diferenças das modalidades oral e escrita, não prevêem uma transcrição de um texto falado, nem tão pouco a representação oral de um texto escrito. A maioria das propostas limita-se à leitura em voz alta do texto escrito. (ESP07, p. 94) 
As atividades nos livros analisados, quanto à linguagem oral, limitam-se à leitura em voz alta, dramatizações e eventos proporcionados pelo próprio ambiente escolar. Falta, nesse sentido, um material adequado, que relacione, de forma contextualizada, a linguagem oral como objeto de ensino em cada unidade. Se em algum trabalho forem utilizados recursos audiovisuais em sala de aula, a escolha será dos docentes, sem indicação do material didático. (ESP07, p. 95)

Mato Grosso não apresenta características de um estado produtor de livros didáticos, nem exportador de teorias via publicações de textos didáticos. Ao contrário, ele é nutrido pelas produções didáticas de outros centros. Falo nutrido porque compreendo que à medida que se compra e se adota um determinado material está se nutrindo, valendo-se das teorias $e$ concepções inerentes ao material. No entanto, para contrariar essa assertiva encontrei dois livros didáticos de língua portuguesa produzidos em Mato Grosso. (FMT07, p. 84)

"Trechos Selecionados", denominação do material, é uma obra de seletas de textos: contos e poemas, destinados ao trabalho com a língua materna. Três desses textos chamou-me a atenção, intitulados: Fundação de Cuiabá, de António Fernandes de Sousa, este na primeira parte do livro, A primeira missa, de D. Aquino Corrêa e Cuiabá de outrora, Hebert H. Smith e Carlos Von Den Stein (Condensação e refundição), ambos na quarta parte do livro. $O$ último texto apresentava a seguinte informação: impressões de uma visita feita no século passado por dois estrangeiros ilustres. Chamaram-me a atenção esses três textos, referentes à história de Cuiabá, porque sugerem a leitura de que seria uma seleta realmente para atender ao contexto dos alunos mato-grossenses, ainda que tímida presença, em meio aos demais textos da literatura brasileira e portuguesa, e um texto de Willian Shakespeare. (FMT07, p. 84)

"Produção de leitura e de texto" é o segundo livro didático ao qual me refiro como produção mato-grossense, de Lucia Helena Vendrúsculo Possari e Maria Lucia Cavalli Neder. As autoras são professoras da Universidade Federal de Mato Grosso e o livro produzido pela Editora Universitária, em Cuiabá. O exemplar a que tive acesso é de 1993, e caracterizado como Material Instrucional de produção de leitura e de texto. (FMT07, p. 85)

A década de 70, pode-se assim dizer, foi um período que desencadeou inúmeras pesquisas sobre o livro didático, no conjunto nacional. Na sua grande maioria, eram críticas ao livro didático, em razão dos preconceitos, das ideologias subjacentes ao texto didático utilizado nas salas de aula brasileiras. O Estado de Mato Grosso, carente de salas de aulas e professores habilitados, realidade semelhante em muitos outros Estados brasileiros, pareceme que tinha uma gestão que não deixava em branco a questão abordada. Ao pesquisar documentos no Arquivo Público do Estado, encontrei provas de concurso público para professores, as quais direcionavam algumas reflexões sobre o livro didático e o seu uso no contexto da sala de aula. O fato leva a inferir que, provavelmente, o Estado já vinha discutindo sobre o texto didático. (FMT07, p. 68-9)

A Secretaria de Educação do Estado de Mato Grosso, ainda que com caráter assistencialista, divulga a teoria do livro durável, em lugar do livro consumível. A teoria do Banco do Livro talvez estivesse atendendo mais a uma carência de recursos do estado do que a própria qualidade do livro didático, questão discutida na época com os reclames da implantação do livro não-consumível. Mas o fato é que a ação do estado desencontrava com alguns princípios teóricos divulgados na Revista "Educação em Mato Grosso”, de 1984. (FMT07, p. 73) 
O Brasil viu surgir a discussão do livro descartável e utilizá-lo com o governo militar, já que sua introdução fora assegurada pelos técnicos americanos da USAID, assistindo, assim, aos vários governos militares, desde o golpe de 1964. O livro descartável reúne em um único volume os textos e o caderno de respostas. Seu uso é destinado até o final de um único ano letivo, quando cai em desuso. Em função da vida curta do material, era produzido em papel de má qualidade, com pouca durabilidade, barateando seu custo. As editoras passaram a produzir esse tipo de material por aproximadamente uma década e meia. As editoras nacionais passaram a editar indiscriminadamente este tipo de livro que no início da década de oitenta já ocupava noventa por cento da produção geral de livros didáticos. (FMT07, p. 74)

A partir de 1985, com o advento da Nova República, inicia-se a reintrodução do livro durável, por intermédio de um novo Plano Nacional do Livro Didático. Com o livro didático durável (não-consumível) nasce a possibilidade de um livro de melhor qualidade (papel, tinta, cor, capa, etc). (FMT07, p. 75)

Em âmbito nacional o MEC vinha adotando uma política de centralização e ao mesmo tempo assistencialista, já que o imperativo das decisões era pautado em atender ao aluno carente. Algumas discussões desencadeavam a necessidade de extinguir o livro descartável e substituí-lo por um livro mais durável, prolongando a vida útil. (FMT07, p. 69)

Dentre outros, em circulação nos anos oitenta, "Reflexão e ação em língua portuguesa", de Marilda Prates, parece-me ser um livro que muito bem representa esse período. Esse foi um título mencionado reiteradas vezes pelos professores que fizeram parte da pesquisa preliminar, como sendo utilizado por quase que todos os anos da década de 80, avançando os anos de 2003 a 2005. Ainda foi encontrado no acervo da professora Ivonete e na biblioteca da escola "Presidente Médici". (FMT07, p. 103)

O exemplar do livro "Reflexão e ação", de Marilda Prates, [...] é uma obra atualizada, conforme menção recebida na capa, constando, então, de uma edição original, anterior a de análise. É uma edição de 1984, período em que novas discussões referentes à língua e ao ensino da língua materna enraízam no círculo educacional. (FMT07, p. 127)

[...] cenário de circulação e divulgação do livro "Reflexão e ação" em língua portuguesa [...]. Percebe-se que o próprio título difere das obras circuladas na década de 70 e, de algumas outras contemporâneas, que traziam estampadas a expressão "Comunicação e expressão". Provavelmente já um reflexo da rejeição da prática do ensino da língua materna vigente e em sinal da aprovação do novo quadro teórico emergente. O título "Reflexão e ação" sugere um trabalho diferenciado, proporcionando com as atividades reflexão e uso da língua portuguesa. Ou seja, não levaria em consideração apenas o estudo sobre a língua. (FMT07, p. 129)

O livro "ALP" (Análise, Linguagem e Pensamento) entra em circulação nos anos de 1990. Nesse período, a Educação brasileira é fortemente marcada pela influência do construtivismo $e$ do interacionismo desencadeados a partir de estudos de Vygotsky, Bakhtin e Ferreiro, dentre outros, em décadas anteriores, assim como as contribuições da Psicolingüística, da Lingüística Textual e da Sociolingüística. (FMT07, p. 137) 
A primeira ruptura, nessa obra [referência ao livro "ALP"], que se observa é com relação ao manual do professor. O material apoiado em teorias socioconstrutuvistas rompe com aquela estrutura apresentada por livros didáticos em circulação, no período, em que apresentavam respostas fixas e rígidas, uma vez que os exercícios eram estruturais, baseados em repetições de atividades. As instruções ao professor são mais contidas, com relação às respostas dos exercícios, porque considerando a sala como um lugar de interação verbal, as situações de aprendizagem são promovidas com base na reflexão do uso da linguagem mediando a construção dos saberes. Assim, as respostas são mais abertas e permitem reflexão, com possibilidades de várias respostas para uma única pergunta. Quase sempre, ao invés de uma resposta pronta e acabada, as instruções aparecem, mas se relacionando ao ensino. Comumente, no caderno de resposta, aparecem as seguintes orientações: As respostas deverão girar em torno das experiências dos alunos e das características do lugar onde vive; o professor deverá incentivar os alunos a fazerem perguntas que explorem o conteúdo do texto. Configura-se em uma abordagem diferenciada para o ensino da língua portuguesa. A forma como os autores abordam, no manual dos professores, os subsídios teóricos para justificar e argumentar a estrutura da obra, deixa compreender que o professor/receptor do texto didático "ALP" é preparado para trabalhar com essa abordagem delineada. Assim, apresentam terminologias advindas da lingüistica textual, da análise do discurso, dentre outras, acreditando que o professor já se apropriou dessas teorias. (FMT07, p. 138-9)

No livro do professor os autores se preocupam em argumentar sobre a opção teóricometodológica abordada no material: o socioconstrutivismo. A proposta "ALP - Análise, Linguagem e Pensamento" 37 - fundamenta-se em discussões atuais a partir das pesquisas teóricas de Piaget, Vigotski, Ana Teberosky e outros. Essas pesquisas apontam para um trabalho de linguagem e têm como objetivo o letramento, isto é, capacitar o aluno para a leitura e a escrita em todos os seus aspectos. Nos últimos anos, Liliana Tolchinsky, Gordon Wells, Josette Jolibert têm se preocupado em pesquisar o aspecto comunicacional e funcional da linguagem desenvolvendo trabalhos a respeito dos vários tipos de texto. (FMT07, p. 140)

Com relação à parte gramatical, observa-se que "ALP" reserva um lugar notadamente menor aos exercícios gramaticais, assim como para as definições de conceitos da gramática. Os estudos gramaticais são chamados de gramática textual, o que denota que ela está a serviço do texto e não, ao contrário, o texto a serviço da gramática. Vale ressaltar que, quase sempre estes estudos, são critérios estabelecidos para a avaliação da produção de texto, conforme destacaremos posteriormente. Essa diminuição de espaços reservados para os estudos gramaticais, para a ortografia, por exemplo, em função do maior destaque apresentado para trabalhos com práticas de leitura e produção de textos. (FMT07, p. 145)

A partir dessas avaliações que a SEF elabora o Guia do Livro Didático. O Guia possui resenhas das obras recomendadas e o distribui nas escolas para concretizar a escolha do livro didático a ser utilizado. Vale ressaltar que a linguagem iconográfica das estrelas foi suprimida no PNLD [Programa Nacional do Livro Didático] de 2004, priorizando a leitura crítica do guias pelos professores. (FMT07, p. 83)

Atualmente, o padrão de qualidade estabelecido pelo estado é outro, instituído nas avaliações prévias dos materiais, realizada por uma comissão de professores, docentes das universidades, mas que certamente interferem na produção e na própria escolha do professor. A escolha do livro didático se alterou, atualmente, ela é mais democrática. Os

\footnotetext{
${ }^{37}$ Neste trecho, apresenta-se como "fato" o fragmento retirado do próprio livro didático sob discussão.
} 
professores se reúnem para realizar as análises dos livros que são encaminhados paras as escolas, mas que certamente são influenciados pelos critérios estabelecidos pela comissão que avaliava previamente, por meio dos guias dos livros didáticos encaminhados para as escolas. $O$ guia contém o resumo das obras e a sua avaliação, esta última é indica por menções, que são representadas por estrelas : três estrelas, Recomendado com Distinção; duas estrelas, Recomendado; uma estrela, Recomendado com Ressalvas. O código iconográfico das estrelas deixou de existir, conforme mencionado anteriormente, no PNLD [Programa Nacional do Livro Didático] de 2004. (FMT07, p. 91)

Os sujeitos aos poucos apontam as alterações ocorridas na trajetória da escolha do livro didático. Marlúcia, Marly e Vânia apontam como principal característica das mudanças a escolha coletiva, já que eles anunciam esse processo no final das carreiras docente. Vânia enfatiza a importância dessa escolha no conjunto; várias cabeças pensando ao mesmo tempo, no melhor livro, flui melhor que uma sozinha. $O$ que me parece, com relação a essas professoras, é que apesar do processo de escolha apresentar uma suave melhora, final da década de 1980 até meados da década de 1990, os critérios estabelecidos na escolha permaneceram praticamente os mesmos. (FMT07, p. 181)

Os professores sempre acrescentam estratégias diversificadas para ampliar o trabalho docente e se manifestar de forma mais prazerosa o processo de ensino e de aprendizagem. Percebe-se que o uso de estratégias está sempre relacionado com as concepções que o docente tem da língua e do seu ensino. Por isso, quando as professoras aposentadas acentuam o trabalho com a gramática da língua, mesmo quando levavam materiais além do livro, é porque acreditavam e praticavam o ensino descritivo. Assim, elas pediam jornais, revistas, faziam debates para se realizar um estudo exploratório da gramática, numa tentativa de se trabalhar com os usos, em situações reais, da gramática da língua. (FMT07, p. 199)

[...] títulos sub-adotados em sala, com essa expressão quero dizer que quase sempre o professor adota um livro, por imposição, antes do período de democratização da escolha do livro didático, ou por acatar a opinião da maioria de um grupo, mas, certamente, o professor tem outros livros, que rotineiramente faz suas pesquisas, por isso o chamo de sub-adotados em sala. Essas opções de textos didáticos são notáveis pelas expressões dos sujeitos, a exemplo: ah! Esse aqui é muito bom... nossa, eu era dona de tirar exercícios desse livro... quando tenho dúvidas sempre pesquiso nesse aqui... [...] (FMT07, p. 88)

- Interpretações de dados que se voltaram para características do livro didático de Língua Portuguesa e para o seu uso:

Tendo em vista que a interação verbal é fundamental na produção da linguagem, situações interativas precisam ser criadas, no espaço de sala de aula, para que haja o desenvolvimento das capacidades de linguagem. Porém, no momento da utilização do LD [livro didático], a professora não interage com o aluno, não proporciona momentos de discussão, não desempenha a função de parceira no processo de aprendizagem. Nas situações de sala de aula, o aluno relaciona-se diretamente com o objeto de aprendizagem sem a mediação do outro, o que é extremamente negativo porque a internalização de outros gêneros necessários 
para as atividades e práticas de linguagem só é possível mediante a interação. (FPA07, p. 180)

Refletindo sobre o uso do LD [Livro Didático] pelas professoras, percebemos que as questões ortográficas direcionam a forma de apropriação desse material, uma vez que as atividades construídas a partir do texto focalizam o escrito. A intenção delas parece ser levar o aluno a internalizar as relações grafofonêmicas. (FPA07, p. 179-80)

[...] percebemos que os professores raramente usam o $L D$ [Livro Didático] $e$, quando o fazem, privilegiam a seção do texto para tratar de questões gramaticais. Percebemos também que, ao contrário do que dizem Rojo (2002), Britto (1997) e Lajolo (2006), o livro adotado nas turmas observadas não funciona mais como o regulador dos conteúdos das aulas nem como o protagonista em sala de aula. As análises também indicam que talvez as professoras não conheçam o material com qual trabalham, pois elas não sabem informar a respeito das propostas dos livros, referentes à compreensão e produção de textos, ao conhecimento lingüístico etc. (FPA07, p. 180)

Quanto à produção textual, não podemos deixar de observar que as atividades nem sempre se apresentam de maneira contextualizada para o aluno desenvolver seu texto, principalmente quando nos referimos à modalidade oral. A linguagem oral considerada como conteúdo, conforme mencionado anteriormente, está contemplada apenas no livro "Língua Portuguesa: Rumo ao Letramento”, mas mesmo assim, poucos são os momentos de exposição da situação de produção. Os quatro livros propõem atividades que podem ser resumidas em leitura para os colegas de classe (em voz alta) do texto apresentado na unidade estudada ou debates (geralmente em grupo) sobre um tema polêmico. As produções oral e escrita caminham juntas nas unidades sem explicação das diferenças que envolvem essas duas modalidades $e$ os exercícios limitam-se, quase sempre, à escrita de uma discussão ou exposição oral de um texto produzido pelo aluno. (ESP07, p. 97-8)

[...] dois livros didáticos de língua portuguesa foram identificados como produção matogrossense, em períodos distintos. O primeiro deles é intitulado "Trechos selecionados para leitura”, editado pela Tip. Escola Industrial de Cuiabá. Esse livro foi utilizado por três professores-sujeitos, desta pesquisa, na extinta escola de Cuiabá Ginásio Brasil. Além das informações recebidas das ex-alunas do referido colégio, não encontrei registros que se referissem ao material. (FMT07, p. 201)

O segundo título, localizado como produto do Estado, foi "Produção de leitura e de texto", caracterizado como material instrucional, uma produção fruto da parceria MEC/Secretaria de Educação e a Universidade Federal de Mato Grosso. Professoras do Instituto de Linguagem, da referida Universidade, participaram do projeto. Segundo as informações da revista "Educação em Mato Grosso" (1984) participaram do projeto, além das professoras Lúcia Helena Vendúsculo e Maria Lúcia Cavalli Neder, professoras da UFMT, professores de duas escolas estaduais da capital, os últimos participaram da elaboração e da experiência prática com o material em sala. (FMT07, p. 201)

No cenário educacional brasileiro, as discussões à [sic] respeito do livro didático eram contundentes, em especial a década de 70, com inúmeras críticas ao instrumento de trabalho de centenas de professores. No final dos anos 70, estendendo aos 80, novas discussões 
surgiram concernentes à quantidade e qualidade do material, uma tendência para a edificação dos livros não-consumíveis. (FMT07, p. 202)

A década de 1980, para os sujeitos da pesquisa, foi marcada pela presença do livro "Reflexão \& Ação em Língua Portuguesa”, de Marilda Prates. Um livro intermediário entre os primeiros que inauguraram o livro moderno, as cores nesse material estão mais definidas, e os mais recentes, o livro não-consumível. Representativos dos anos finais de 1990 e iniciais dos anos 2000, estão paralelamente os títulos: "Português: Linguagens", de William Roberto Cerejas e Thereza Cochar Magalhães e "ALP - Análise, Linguagem e Pensamento", de Maria Fernandes Cócco e Marco Antônio Hailer. (FMT07, p. 203)

[...] a autonomia da sala de aula passa, em primeiro lugar, pela possibilidade de escolha do livro didático. Assim, o professor pode conjugar concepções e instrumento didático para melhor atender as reais necessidades tanto do professor quanto do aluno. O processo de escolha do material didático pelo professor, aos poucos veio ganhando espaço no cenário educacional. Gradativamente, os agentes politicos foram destinando méritos às escolhas feitas pelo professor. (FMT07, p. 205)

[...] o livro é um objeto/documento que se caracteriza, por si só, como histórico-socialcultural-educativo e didático, uma vez que viabiliza uma leitura mais próxima possível das representações que constituíram as concepções de educação e da própria disciplina língua portuguesa. Variações aconteceram de acordo com as necessidades surgidas em espaçotempo determinado e em um dado momento, que se constituíram em objetivos e concepções diversas, de acordo com o contexto sócio-político e cultural em que se encontra inserido. (FMT07, p. 204)

Estudos de Lerner (2004) apontam que o "ALP" [referência ao livro "ALP - Análise, Linguagem e Pensamento", de Maria Fernandes Cócco e Marco Antônio Hailer] é um livro que mais se aproxima dos critérios de excelência do PNLD (Programa Nacional do Livro Didático), no entanto, os professores de língua portuguesa apresentam um percentual considerável de rejeição ao material. Contrariando, parcialmente, essa afirmativa, os professores do Mato Grosso apontam com grande recorrência a adoção do título em questão, nas escolas estaduais, que fizeram parte desta investigação. Na análise da entrevista do professor Ademar, o qual utilizou e presenciou o uso do livro por seus pares, evidenciou grandes dificuldades para adequar o material com a prática docente cotidiana. Os dados comprovam que "ALP" não apresentou uma aprovação dos professores, sob a alegação de que estava fora da realidade do Estado. (FMT07, p. 203-4)

- "Fatos" que subsidiaram, em EPA08, a argumentação sobre as dificuldades de se instaurar um ensino de "oralidade" que seja adequado:

É possivel perceber nas falas das professoras que o objeto de estudo da lingüística é apenas a língua em sua variedade culta, deixa-se de considerar a comunidade social em seu aspecto lingüístico, já que a língua é um fato social. (EPA08, p. 170)

Com essa atitude [da professora observada], que possui como conseqüência a concepção tradicional de língua como sistema imutável, que elege apenas um padrão como “correto”, a 
professora $B$ demonstra que não leva em conta a variabilidade da língua e descreve somente a norma culta, comprometendo a noção de uso proposta pela concepção sociointeracionista da língua. (EPA08, p. 168)

- Interpretações de ESP08 decorrentes de análise de uma proposta de formação continuada com "jogos de improvisação teatral":

Ao participar de jogos de improvisação teatral a partir da leitura de textos ou fragmentos de textos literários, além do prazer conquistado por meio da ludicidade que o jogo promove, pela tensão entre liberdade de ação e regras, pela apreensão do fenômeno teatral conquistada por meio de um processo crítico e emancipatório, o aluno tem a seu favor meios eficientes para a compreensão da arte literária e dos recursos expressivos de que ela faz uso. Em outras palavras, o reconhecimento e a compreensão dos efeitos de sentido construídos a partir dos recursos (sonoros, gestuais, de movimentação espacial, entre outros) utilizados para a elaboração da cena possibilita aos jogadores poderem mobilizar tais capacidades para o reconhecimento e a compreensão dos aspectos relacionados à linguagem literária. (ESP08, p. 156-7)

Os jogos de improvisação teatral permitem desvelar uma rede de sentidos construídos na relação entre os jogadores, constituindo-se para além de uma estratégia eficiente para a leitura, mas, no ato de leitura em si, produzido coletivamente e evidenciado na elaboração do discurso cênico. Este aspecto dos jogos se concilia com os objetivos da Hora da Leitura porque permite ao professor desenvolver com seus alunos a noção de composição de um discurso estético como um ato de leitura, na medida em que o conteúdo manifestado no jogo surge de uma compreensão leitora do jogador em relação à obra. Além disso, o ato de leitura de que se constitui o jogo solicita do leitor o desapego à rigidez de uma interpretação única e correta. (ESP08, p. 156)

Nas atividades finais do experimento, os professores demonstraram algumas dificuldades para reconhecer a forma como integrante do conteúdo na elaboração do discurso artísticoliterário. A provocação que fizemos a eles para que tentassem observar os recursos utilizados para construir um modo de narrar lhes parecia incompreensível, quase indecifrável. Uma atividade que pretendia apenas apontar para possibilidades de articulação entre literatura $e$ outras linguagens artísticas acabou por revelar dificuldades dos professores para compreender os elementos constitutivos da obra literária e também de outras elaborações artísticas. (ESP08, p. 157)

Esta pesquisa demonstrou, por um lado, a disposição dos professores da Hora da Leitura em compreender melhor a natureza do fenômeno teatral, sobretudo os jogos de improvisação teatral como ato de leitura sensível das produções literárias, para que possam desenvolver sua articulação com as atividades de leitura do texto literário. Por outro lado, ficou evidenciada a falta de oportunidades que estes profissionais têm para investirem na sua formação e refletirem sobre sua prática. Falta-lhes também espaço para a socialização de experiências entre eles, uma vez que os momentos de formação são escassos, além de não conseguirem incluir todos eles. Soma-se a isto a ausência de referenciais que possam dialogar com estes profissionais que se arriscam em práticas interdisciplinares que transitam pelas diferentes linguagens e seus códigos. (ESP08, p. 158) 
- "Fatos" apresentados em ESP08, relacionados à proposta de formação continuada com "jogos de improvisação teatral":

A Hora da Leitura está inserida no Programa de Enriquecimento Curricular regulamentado pela Resolução SE 16/2005 da Secretaria da Educação. No corpo da referida resolução, estão declaradas as motivações bem como o caráter do projeto de leitura. (ESP08, p. 17)

Com esta Resolução foi instituído, portanto, um projeto de leitura cuja finalidade era ampliar as possibilidades de leitura compreensiva com práticas complementares para além das disciplinas constantes da matriz curricular, incluindo neste grupo a Língua Portuguesa, tradicionalmente responsável pelo desenvolvimento das habilidades e competências relacionadas à língua materna. (ESP08, p. 17-8)

Foi de posse deste estudo analítico, portanto, que a Secretaria de Estado da Educação de São Paulo (SEE) desencadeou uma série de ações (fomento às bibliotecas escolares, formação para professores, descentralização de recursos para o desenvolvimento de projetos de leitura na escola, divulgação de experiências de sucesso, olimpíadas de leitura, premiações) e, entre elas, a implementação de um projeto denominado Hora da Leitura voltado para todos os alunos do Ciclo II do Ensino Fundamental das escolas públicas estaduais no ano de 2005. (ESP08, p. 16)

A despeito das diferenças individuais, os jogos de improvisação teatral possibilitam a inclusão de todos os integrantes de um grupo. Não há a seleção daqueles que, na ótica do coordenador, são os mais habilitados ou vocacionados para o jogo. Nem mesmo há a distribuição de papéis ou funções diferenciadas entre os participantes de acordo com suas "aptidões". No jogo, todos são motivados a manifestar a sua compreensão sobre determinado tema e a explorar possibilidades expressivas para comunicá-la. (ESP08, p. 623)

Alguns professores registraram suas reflexões a respeito da construção do discurso cênico. Nestes registros, ele é compreendido como um processo de construção vivenciado coletivamente, em que cada um colabora com sua experiência. Segundo estes professores, envolve criação, a partir do improviso, da atuação, da reflexão e do aprimoramento da proposta. "Momento de criar, atuar, refletir e de melhorar. (Profa. Patrícia Aparecida Moreira). Mostrar a criatividade, idéias, inovações, mudanças, estar preparado para o novo ou improviso. (Profa. Marineide Gomes da Silva Gama)” [...]. (ESP08, p. 110)

- Verdade assumida no interior de ESP08:

Ryngaer, em suas reflexões acerca do desenvolvimento de jogos dramáticos no meio escolar, ressalta características do jogo para que possamos compreender por que liberdade e regra são aspectos tão relevantes que fazem do jogo dramático um processo lúdico. "No jogo, o sujeito esquece o real, nega a atividade séria, liberta-se dos quadros constrangedores que suporta na execução de suas atividades diárias. Mas, ao mesmo tempo, elabora regras que se 
torna indispensável respeitar, sob pena de se fechar numa atividade rapidamente aborrecida e estupidamente repetitiva". (ESP08, p. 62)

- "Fatos" que se voltam para a argumentação favorável sobre o uso de recursos computacionais no ensino de Língua Portuguesa:

A informática, então, é uma disciplina independente planejada e avaliada com peso e média como uma disciplina curricular. As aulas são divididas em práticas e teóricas e são trabalhadas de forma distinta em cada nível. (FPB08b, p. 103)

Do total das duas turmas de sétimo $\left(7^{\circ}\right)$ ano que participaram dessa pesquisa, 96,38\% afirmaram gostar de informática com as mais variadas justificativas, desde o lazer e entretenimento a ser fonte de estudo e pesquisa, meio de comunicação e informação. Outro dado que interage com a afirmação do professor quanto ao saber trabalhar com computadores, 95,18\% dos alunos pesquisados confirmou que sim e dentre os recursos que mais dominam estão os editores de textos, editores gráficos e internet. Parte desse domínio eles disseram aprender na escola por meio de tarefas simples como digitar textos e fazer planilhas, navegar na internet e estudar um sistema operacional e seus pacotes específicos de softwares (Linux). (FPB08b, p. 104-5)

Com relação a [sic] internet especificamente, $100 \%$ dos alunos disseram que a utilizam sendo que o maior percentual de utilização ficou para pesquisa em sites de busca seguido de utilização de correio eletrônico, sites de relacionamentos e jogos, ficando por fim o acesso de notícias em sites de jornais, TVs e revistas e downloads de programas educativos. (FPB08b, p. 105)

Nosso universo de pesquisa foi formado pelas turmas de sétimo $\left(7^{\circ}\right)$ ano do ensino fundamental, que são cinco (05) nos turnos manhã e tarde, totalizando trezentos e noventa e seis (396) alunos. Contudo nosso experimento foi realizado com oitenta e seis (86) destes, sendo quarenta e sete (47) do grupo experimental e trinta e nove (39) do grupo controle. Esses compõem nossa amostrada não probabilística intencional [...]. (FPB08b, p. 102)

A aplicação de testes conceituais é uma dentre tantas técnicas para averiguar os conhecimentos prévios que os alunos trazem para a sala de aula, tanto os conhecimentos gerais quanto aquele( $s$ ) que compõe(m) um eixo temático específico. (FPB08b, p. 105)

Em nosso experimento, este instrumento, enquanto pré-teste permitiu mapear os subsunçores (conhecimentos prévios relevantes) presentes na estrutura cognitiva do aprendiz referente ao eixo temático: análise morfossintática, e posteriormente, como pós-teste ofereceu informações relevantes de forma a contribuir para a avaliação do processo de aprendizagem nos dois casos, experimental e controle, a partir de uma metodologia inovadora com o uso do objeto de aprendizagem e mapas conceituais no primeiro e a partir da metodologia padrão no segundo. (FPB08b, p. 105)

Frente à demonstração de disposição e motivação dos estudantes, o professor de Informática da escola fez o seguinte comentário: "a impressão que tenho é que, pelo menos no item: 
motivação, o objeto funciona, porque nas minhas aulas alguns costumam se desviarem do que estão fazendo e acessarem outros softwares e até sites da internet”. (FPB08b, p. 110)

De acordo com a análise de regressão/progressão entre as notas do pré e pós-teste, verificou-se que a maioria dos alunos que foram submetidos a intervenção com o objeto de aprendizagem sobre análise morfossintática durante as aulas de gramática e que no período da realização do pré-teste estavam com notas de desempenho relativamente baixas, demonstraram sensível elevação em suas notas com a realização do pós-teste. No geral, vinte e seis (26) alunos do grupo Experimental obtiveram notas maiores no pós-teste. (FPB08b, p. 111-2)

[...] a diferença do desempenho no pré-teste entre os dois grupos certamente tem outras razões que podem ser contextuais (turno, por exemplo) elou emocionais (agitação, raiva, cansaço mental causado por dormir tarde e acordar tarde, etc). O fato é que por ser o grupo Controle uma turma de quantidade de alunos inferior ao grupo Experimental, desafia a afirmação de que 'quanto menor o número de alunos melhor o trabalho e melhor o rendimento'. (FPB08b, p. 114)

Os resultados indicam que o crescimento na diferença entre as médias do desempenho dos sujeitos, pode-se supor que implicitamente exista um crescimento também qualitativo, pois se o grupo Experimental se saiu melhor no pós-teste, deve considerar-se que pelo menos houve maior elou melhor retenção do conteúdo. (FPB08b, p. 115)

Uma das causas da diferença de desempenho no pós-teste poderá estar na eficiência da execução das tarefas pelo grupo Experimental numa atividade lúdica de aplicação dos conceitos de gramática. Evidentemente, podemos constatar que com esses objetos devidamente planejados e orientados, existe pelo menos prática real e efetiva e essa prática poderá de fato interferir no rendimento dos alunos. (FPB08b, p. 114)

- “Interpretações" sobre o uso de dispositivos tecnológicos em aulas de português:

O objeto [virtual] foi explorado com bastante atenção e concentração, tanto que o professor de informática que nos acompanhava nas aulas com OA [Objeto de Aprendizagem] comentou sobre a motivação da turma, pois nenhum dos alunos havia acessado outro software ou site da internet, o que costuma acontecer com os alunos menos motivados nas aulas de informática. (FPB08b, p. 117)

Para o aluno, principalmente os nascidos a partir da década de 1980, a informática faz parte de suas atividades diárias e já mostrou sua contribuição específica em processos de aprendizagem. O uso das TIC [Tecnologias da Informação e Comunicação] com seus sinais $e$ linguagens atrativos, desperta no aluno o interesse em aprender a dominar cada vez mais as técnicas e a adquirir conhecimentos, a esse público é exigida uma nova postura do professor. (FPB08b, p. 120) 
- "Verdades" que tratam dos recursos computacionais como ferramentas de ensino e que discutem a formação docente necessária para que a computação ganhe espaço no ensino:

[...] alguns dos principais problemas identificados na implementação de novas formas de ensino e aprendizagem associadas ao uso das TIC são referentes à 'tecnologia mais dura' da escola (SANCHO, 2006), isto é, uma combinação de legislação, formação de professores, acesso aos recursos adequados e predisposição de todos os envolvidos para promover a mudança. (FPB08b, p. 35)

[...] acredita-se que a implantação da informática na escola exige, primeira e fundamentalmente, a formação do professor nessa área, ou seja, a preocupação com processos de educação profissional, embora, como lembra Valente e Almeida (1997, p. 10) isso: "envolve muito mais do que prover o professor com conhecimento sobre computadores ou metodologias de como usar o computador na sua respectiva disciplina. Existem outras barreiras que nem o professor nem a administração da escola conseguem vencer sem o auxílio de especialistas na área”. (FPB08b, p. 42-3)

- Relatos apresentados em ESP09 sobre metodologia de ensino:

Além de possibilitar a interlocução e atitude dos educandos e aproximá-los, de forma crítica, das linguagens das mídias, essa proposta [de produção de vídeos] proporciona a produção de textos de maneira contextualizada, através dos roteiros. Isso porque o roteiro é que vai direcionar toda a produção audiovisual, sendo desenvolvido pelo aluno, seguindo as orientações do professor e de acordo com o gênero que ali deve ser explanado $e$ concretizado. (ESP09, p. 28)

Entre 2006 e 2007 a escola se dedicou a produzir o "Curta Escola", programa semanal com duração de 30 minutos que seria exibido na TV Comunitária de Campinas, mas que nunca foi ao ar devido a problemas políticos. As produções de vídeo de tema "Lixo" feitas pelos estudantes foram utilizadas para fazer um piloto do programa. Dentro da equipe de produção, eu buscava colaborar ativamente com os estudantes na criação dos roteiros que conduziriam o programa e nas matérias que seriam apresentadas. (ESP09, p. 13)

O roteiro foi feito coletivamente. Os alunos formularam as perguntas que achavam interessantes de acordo com os temas (identificação, pessoais, sobre a infância e sobre o bairro) e as perguntas foram discutidas para serem aprovadas ou não. No dia da entrevista, a sala foi organizada em uma grande roda, com o entrevistado em destaque. Novas questões foram surgindo ao longo da entrevista, mas o roteiro facilitou o direcionamento das perguntas e uma organização para que a conversa não se perdesse. Foi possível observar um grande envolvimento de todos durante a atividade, permitindo à professora conduzir as tarefas de modo a obter bons resultados, de acordo com o planejamento das mesmas. (ESP09, p. 44)

Em 2007, a professora C estava trabalhando o Projeto "Reciclagem" em uma de suas duas turmas $\left(3^{a} B\right)$. Resolvemos, então, dividir a sala em grupos e produzir animações (com 
massinha de modelar) que focassem esse assunto. Foram formados oito grupos (com quatro ou cinco crianças em cada um) e a proposta empolgou a todos. (ESP09, p. 13-4)

Depois disso, grupo a grupo, partimos para a produção da animação: cada grupo escolhia quem ia tirar as fotos, quem ia mover os personagens em cena e quem ia gravar as falas contidas no roteiro. Foi um trabalho minucioso, mas muito gratificante. O único grupo que teve dificuldades nesta fase do trabalho foi aquele que não havia construído o roteiro. Os alunos deste grupo tinham cenário e personagens, mas não tinham uma história formulada, gerando grandes dificuldades de produção e um tempo maior para que algum resultado saísse. (ESP09, p. 14)

Os estudantes revelaram grande interesse quando a proposta da atividade foi feita. Logo se organizaram em oito grupos para escrever o roteiro da animação. A professora apresentou uma forma de organizar o roteiro, que consistia em:- definir os personagens da história; definir o local em que se passava a história; - fazer um pequeno desenho, que seria como um modelo do cenário e personagens; - definir o título; - elaborar a narração. (ESP09, p. 45)

Foram produzidos sete roteiros e oito animações. Foi escolhido um desses roteiros para a análise, denominado Roteiro 3, em que a personagem Julinha Relógio tem uma conversa com o latão de lixo sobre a reciclagem. Uma observação importante a ser feita deste roteiro é que, no momento da produção da animação - ocasião em que o grupo foi tirar as fotos e gravar as falas - pequenas mudanças foram feitas no roteiro, como a supressão de uma pequena descrição da personagem no início do roteiro, que o grupo considerou desnecessária já que decidiram não colocar a voz de um narrador e a ideia de finalizar a história com uma frase sobre a reciclagem, criada posteriormente: "Vamos todos colaborar, ajudando a reciclar". (ESP09, p. 46)

No caso dos Roteiros 1 e 2, a escolha dos gêneros foi decidida previamente com a professora. Nos roteiros 3, 4 e 5, os grupos decidiram a opção depois das orientações da professora. (ESP09, p. 70)

- "Fatos" que destacaram trabalhos que privilegiaram a contínua revisão e reelaboração dos textos:

O trabalho desenvolvido teve início no ano letivo de 2008. O material obtido ao final do ano são 150 textos, contabilizados entre todas as produções escritas (resumo) dos alunos da turma. No entanto, fazem parte da amostra estudada 48 produções textuais, produzidas pelos oito sujeitos de pesquisa no decorrer do processo os quais equivalem a $1 / 3$ da turma. (FRS10, p. 42)

Os sujeitos de pesquisa são oito pré-adolescentes, sete de 11 anos e uma de 15, todos integrantes de uma turma regular de $5^{a}$ série, constituída por 25 alunos. Sete dos sujeitos analisados, quando cursaram a $4^{a}$ série, vivenciaram a mesma proposta de ensino, repetida na $5^{a}$ série, com exceção de Joaquim, que, no ano anterior, não tinha contato com livros $e$ nem era aluno da escola. (FRS10, p. 43) 
O processo de escolha dos alunos ocorreu através de um sorteio, com o objetivo de constituir uma amostra representativa da turma, 1/3 dos alunos, isto é, oito estudantes de um total de 25. No primeiro sorteio, porém, foram selecionados dois alunos que recém estavam ingressando na escola. Considerando que havia três alunos nessa situação, foi feito um ajuste para que a amostra tivesse apenas um aluno nessa condição. Ao final, foram selecionados sete alunos que já frequentavam a escola desde a educação infantil e um que havia recém ingressado. (FRS10, p. 43)

- Interpretação acerca do "ensino de oralidade":

[...] nosso estudo verificou que ainda ocorrem equívocos a respeito do que realmente seja a língua oral. O fato de os alunos utilizarem o meio sonoro para manifestarem-se não significa que, de fato, estejam desenvolvendo sua oralidade; há, conforme, concluiu-se, oralização da escrita, que não oferece condições para que se desenvolva a competência discursiva oral dos alunos. (EPR04, p. 90-1)

- "Fatos" sobre "ensino de oralidade":

Dentre as três situações de oralização da escrita por nós estabelecidas, encontramos, nas aulas da professora E, a ocorrência de uma apenas: a leitura de textos do livro didático. Parece-nos que as professoras acreditam que, com esse procedimento, além de os alunos "melhorarem a leitura", atingirão a compreensão do texto. (EPR04, p. 75)

Apesar de todo o suporte teórico dos PCNs (utilizado pela professora na produção de seu planejamento anual de ensino), sua prática não condiz com a teoria apresentada. O que ela considera "permitir que os alunos falem em sala de aula", consideramos oralização da escrita [...] [destaque em negrito presente no original] (EPR04, p. 72)

A professora considera que os alunos produzem textos apenas quando escrevem. Por não considerar os eventos de oralidade como textos, ela limita o trabalho com a oralidade à mera oportunidade de expressão oral do pensamento. Quando a professora D nos revela que não possui certeza que esta atividade seja a mais recomendada fica evidente a necessidade de orientação sobre a questão do trato da oralidade na sala de aula. (EPA08, p. 155)

De modo geral, as falas das professoras demonstraram uma concepção de oralidade bastante restrita. Não há preocupação com as regras sociais que estão em jogo nas mais diversas situações comunicativas. Quando as professoras descrevem como trabalham a oralidade, sempre buscam a homogeneização da fala e da escrita, segundo a norma culta escrita. (EPA08, p. 155)

A professora B utiliza as mesmas estratégias de correção de textos escritos para a correção dos textos orais, sem explicitar os mecanismos de elaboração de cada uma das modalidades. Podemos observar [...] que as professoras iniciam o processo pela gramática normativa e 
não pelo uso, fazendo o caminho inverso ao que sugerem os PCN no eixo uso-reflexão-uso. Há uma constante preocupação com as regras gramaticais e com sua mera identificação no texto. (EPA08, p. 157-8) 


\section{APÊNDICE D - CONFIGURAÇÃO DISCIPLINAR}

No que segue, apresentamos os aspectos disciplinares constantes do nosso corpus.

a) Os objetos de pesquisa recorrentes foram:

- Ensino de escrita;

- Ensino de leitura;

- Livro didático;

- Ensino de oralidade;

- Ensino de gramática.

b) Os métodos recorrentes foram:

- Realização de entrevistas (com docentes, alunos e/ou autores de livros didáticos) - em EPR02, FMT06a, EPR07, ESP07, FPA07, FPB07, FMT07, EPA08 e ESP09;

- Análise documental (de planejamentos escolares, de diários de classe, de resoluções, de instruções normativas, de livros de almoxarifado, de relatórios de desempenho discente e/ou de documentos oriundos de curso de formação continuada) - em EPR04, EPR06, FMT06a, FMT07, EPA08 e ESP08;

- Observação em sala de aula do Ensino Fundamental - em EPR02, FSC03, EPR04, FPA07, FPB07 e ESP09;

- Análise de livros didáticos - em FMT06a, FPA07, ESP07, FMT07 e FPB08a;

- Análise de produções discentes - em FSC03, EPR06, FMT06b, ESP09 e FRS10;

- Aplicação de questionários - em EPR06, FPB07, FMT07 e ESP08;

- Intervenção do pesquisador em turmas do Ensino Fundamental - em FSC03, FMT06b, ESP09 e FRS10;

- Aplicação de testes para alunos do Ensino Fundamental (sobre ambiente virtual, sobre gêneros gramaticais e sobre morfossintaxe) - em ESP01, EPR07 e FPB08b. 
c) Formulações que indicam as proposições passíveis de legitimação ${ }^{38}$ :

*As propostas teórico-metodológicas de ensino de Língua Portuguesa são falhas - $(09)^{39}$

FSC03 - Na atividade com o jornal, a professora acabou por propor uma certa descaracterização do gênero, pedindo que os alunos recortassem três matérias de dias diferentes e as colassem em uma folha. ( $p .71)$

EPRO4 - [...] nosso estudo verificou que ainda ocorrem equívocos a respeito do que realmente seja a língua oral. $O$ fato de os alunos utilizarem o meio sonoro para manifestarem-se NÃO significa que, de fato, estejam desenvolvendo sua oralidade; há, conforme, concluiu-se, oralização da escrita, que NÃO oferece condições para que se desenvolva a competência discursiva oral dos alunos. (90-1)

EPRO6 - O que falta ao professor é a clareza quanto à organização do nosso sistema de escrita, desmitificar e mostrar que a dificuldade NÃO se encontra nos aprendizes, mas sim no próprio sistema de escrita da língua, mostrando as convenções da escrita ortográfica, de forma sistematizada: as biunívocas, as arbitrárias previsíveis (que se pode recorrer ao campo semântico, à formação das palavras primitivas) ou imprevisíveis (arbitrárias) que exigem memorização ou consulta ao dicionário. (p. 105)

EPR07 - Vemos, portanto, que com base em uma visão ilusória de simplicidade, grande parte dos professores entrevistados costuma ensinar o gênero por meio da correlação semânticoconceitual, como ficou claro, por exemplo, no momento em que o professor diz que "é mais fácil falar do pai, da mãe, do homem, da mulher". Essa visão pode ser considerada ilusória porque, na verdade, a confusão conceitual estabelecida por meio desse tipo de trabalho com o tema acaba, normalmente, por complicar, ao invés de esclarecer o conceito de gênero gramatical. (p. 61)

FPA07 - Verificamos ainda que o tipo de ensino realizado pelas professoras NÃO pode, sequer, ser caracterizado como tradicional, pois parece NÃO haver situações em que elas explicam um conteúdo, passam um exercício e, em seguida, corrigem-no. (p. 181-2)

FPA07 - A maioria [Referência aos livros didáticos analisados] propõe que o aluno produza um texto de um determinado gênero que, muitas vezes, sequer é utilizado na unidade [...]. (p. 149)

FPA07 - Outro problema nos livros é o excesso de gêneros, uma vez que numa mesma unidade chegam a aparecer três ou mais, o que dificulta um trabalho mais sistemático que permita ao aluno a apropriação de diferentes gêneros. (p. 150-1)

FPA07 - Por meio das atividades propostas, percebemos ainda um equívoco na compreensão do que seja ensinar gramática [Referência aos livros didáticos analisados]. A idéia transmitida é que exercícios de reconhecimento de classes ou formulação e memorização de regras contribuem para o aluno falar e escrever corretamente. (p. 152)

FPA07 - [...] podemos concluir que embora os gêneros discursivos estejam presentes nesses instrumentos didáticos, eles NÃO são tomados como objeto, uma vez que os aspectos ligados à situação de produção, os elementos da ordem do social e do histórico, o conteúdo temático, a construção composicional e o estilo verbal NÃO são tratados de modo sistemático. Percebemos que eles são suportes de conteúdos e favorecem o desenvolvimento de várias atividades que levam as professoras a intervir sobre a temática, daí afirmarmos que as

\footnotetext{
${ }^{38}$ As formulações em questão foram propostas considerando-se os fragmentos que as sucedem, os quais, por sua vez, estão correlacionados às proposições passíveis de legitimação.

${ }^{39}$ Entre parênteses, aparece indicada a quantidade de dissertações em que foram localizadas frases que legitimam as proposições em questão.
} 
informações veiculadas no texto são os objetos de ensino priorizados nas propostas do LD. Isso NÃO significa dizer que, quando contempladas, favoreçam a reflexão sobre o que pode ser dito em um dado gênero e em outro, pois as propostas nos livros objetivam, sobretudo, levar o aluno a dominar a temática da unidade, através de diferentes atividades de compreensão de texto escrito, de produção escrita, de gramática e de expressão oral. (p. 153) FMT07- Percebe-se uma certa preocupação com o trabalho pedagógico com a finalidade de formação de leitores e produtores de textos, embora transpareça uma certa aflição com os resultados apresentados pelos discentes. Os professores, que estão em sala de aula, demonstraram insatisfação com as atividades de leitura e escrita propostas pelos livros com vistas ao ler e escrever escolarizado. Desejam atividades que proporcionem condições de letramento, ainda que demonstraram ter dificuldades para efetivá-las na sala de aula. ( $p$. 206)

FPB07 - Nas aulas de leitura em que a docente trabalhou com textos em sala de aula, apenas o conteúdo temático destes foi discutido e de maneira superficial, restringindo-se a discussão ao conhecimento de mundo dos alunos. E mais sério ainda, em sua rotina, a professora iniciava as discussões sobre os conteúdos e NÃO as finalizava, ficando em aberto o estudo mais aprofundado do texto. Em muitos momentos, o próprio objetivo do estudo do gênero editorial, "aprender a identificar a defesa do ponto de vista", permanecia distante dos alunos. (p. 110-111)

FPBO7 - [...] descobrimos que os livros didáticos muitas vezes são o único material ao qual professores e alunos têm acesso; descobrimos ainda que esse material muitas vezes é de qualidade questionável e que, mesmo assim, o professor continua a utilizá-lo indiscriminadamente nas aulas de português [...]. (p. 49-50)

FPB07 - [...] momento da fala da professora que merece destaque na nossa análise, pois aqui constatamos que ela confunde vários gêneros textuais. Notemos que ela classifica o texto lido como reportagem jornalística e como notícia, e, no entanto, NÃO se trata de nenhum desses gêneros, mas sim, de um de um editorial. Essa fala da professora nos demonstra que ela provavelmente desconhece a teoria de gêneros textuais ou conhece tal teoria, mas NÃO faz uso de suas contribuições em sala de aula. Esse trecho também nos ajuda a compreender a maneira como os demais textos foram trabalhados em sala de aula. Apenas o conteúdo temático destes foi abordado; estilo e estrutura composicional NÃO foram discutidos. (p. 86) FPBO7 - [...] averiguamos que em relação aos dados analisados referentes à $8^{a}$ série, alguns aspectos são relevantes para a nossa pesquisa e se assemelham aos dados observados na $7^{a}$ série. São eles: $\left.1^{\circ}\right) O$ trabalho com o texto realizado pela docente é bastante superficial, pois apenas o conteúdo temático ("tecnologia") é abordado. NÃO há uma discussão sobre a estrutura composicional $e$ o estilo do editorial; $2^{\circ}$ ) Novamente percebemos que o conhecimento de mundo dos alunos é o ponto de partida para a discussão do texto, mas esse conhecimento NÃO é aproveitado pela professora para auxiliar na construção de sentido do texto; $3^{\circ}$ ) Assim como ocorreu na $7^{a}$ série, o único aspecto do texto sobre o qual a professora inicia e conclui uma discussão é sobre o significado do título do texto, mas essa conclusão é feita sem a aceitação das contribuições dos alunos nessa discussão; $4^{\circ}$ ) A professora constrói os sentidos dos textos e NÃO permite que os alunos o façam. Esses sentidos construídos pela docente sempre se realizam de modo ascendente, ou seja, do texto para o leitor. (p. 109) EPA08 - Os PCN de Língua Portuguesa NÃO trazem consigo instruções de como manusear e tão pouco avaliar sua aplicabilidade. NÃO deixa claro o que se entende por tratamento didático adequado ou inadequado, e o tratamento requerido está longe das realidades imaginadas. Percebemos também que há necessidade de aprofundamento nas questões metodológicas e nas orientações apontadas. (p. 184) 
EPA08 - A professora B utiliza as mesmas estratégias de correção de textos escritos para a correção dos textos orais, sem explicitar os mecanismos de elaboração de cada uma das modalidades. (p. 157-8)

EPA08 - As falas das professoras A e B demonstram que o trabalho com a oralidade se restringe à reprodução dos registros informais, sem que se promova uma análise aprofundada de como esses eventos estão organizados. (p. 158)

EPA08 - Na fala da professora C chamamos atenção para o fato de que é possível que o gênero utilizado nessa produção sirva como pretexto apenas para a execução de atividades metalingüísticas, sem associá-las ao significado no contexto de produção, preocupação que NÃO foi destacada na fala da professora. (p. 161-2)

EPA08 - $O$ relato de como a professora $B$ intervém quando seus alunos utilizam gírias nos aponta que a mesma, com tal atitude, parte de um modelo de língua, de educação e sociedade que se sustenta numa visão autoritária e discriminatória e reproduz o preconceito; quando sua ação, nesse caso, deveria atentar para como os outros alunos passariam a perceber o discurso dos demais. Assim, o que deveria ser combatido, passa a ser realimentado. (p. 168) ESP08b - Sem tempo para refletir sobre o ensino de Língua Portuguesa e a formação de leitores, mas com a incumbência de desenvolvê-los em sala de aula, o professor esforça-se para acompanhar as mudanças, integra-as ao seu discurso, trazendo para a sua fala ecos da reflexão que os documentos institucionais propagam. $\mathrm{Na}$ emergência de atender às expectativas de mudança, ele passa a alterar o seu discurso, inserindo nele uma seleção de termos e expressões pertencentes à perspectiva enunciativa para o ensino da Língua Portuguesa que orienta para a prática em sala de aula com os diferentes gêneros textuais. No entanto, o que está na base desta mudança - a abordagem sócio-interacionista - dilui-se pela falta de reconhecimento de si próprio em um processo social de interação e participação. (p. 150)

* A formação docente do professor de Língua Portuguesa é deficitária - (07)

EPRO2 - Em ambos os momentos ([de] escrita reprodução e escrita produção) foi possível detectar que a professora apresentava um déficit na sua formação, no que diz respeito ao ensinar língua portuguesa no ensino fundamental ( $p$. )

FMT06a-[...] as professoras procuravam refutar o ensino gramatical "puro" com todas as dificuldades, dúvidas e medos que enfrentavam, pois, segundo elas, em seus relatos, NÃO recebiam formação adequada e acabavam ficando no escuro, sem método, sem saber que caminhos deveriam percorrer. ( $p .185$ )

EPRO6 - Diante da falta de teorias e de práticas voltadas para o desenvolvimento de trabalho na perspectiva interacionista, um curso de 24 horas em Faxinal do Céu e dois encontros de quatro horas coordenados pelo Núcleo NÃO poderiam suprir ou solucionar uma lacuna histórica dos professores da SAALP [Sala de Apoio à Aprendizagem de Língua Portuguesa]. (p. 160)

EPRO6 - [...] alguns cursos de graduação em Letras ainda NÃO estão voltados ao ensino dos processos de aprendizagem da leitura e da escrita em estágio inicial. Pensamos que esse déficit teórico precisa ser urgentemente corrigido, diante da presença de um grande percentual de alunos sem as mínimas condições de leitura e escrita na $5^{a}$ série do Ensino Fundamental. (p. 66)

FPA07 - As professoras parecem NÃO estar preparadas para lidar com as propostas do material [referência aos livros didáticos analisados],uma vez que estas exigem um conhecimento mais aprofundado sobre a lingua, por exemplo, das implicações do contexto de produção na organização do discurso e de questões ligadas à textualidade, à exploração de implícitos. (p. 161) 
FPB07 - Os conteúdos, nos editoriais trabalhados em sala de aula, estavam relacionados a assuntos que os alunos conheciam (epidemia de dengue e novas tecnologias). Do ponto de vista da textualidade, seria importante o destaque para a estrutura composiconal e o estilo desses textos, relacionando-os aos suportes onde eles circulam, à função social que eles exercem e ao público ao qual se destinam. Todo esse percurso suscitará, naturalmente, sentidos na leitura. E essa abordagem NÃO aconteceu justamente porque a professora parece NÃO ter um conhecimento teórico mais aprofundado sobre os gêneros textuais (p. 111)

EPA08 - Podemos afirmar que um dos grandes problemas da formação inicial e continuada é desconsiderar como se dá a aquisição e construção de saberes, ou seja, a transposição didática de conhecimentos em sala de aula. (p. 144)

ESP08b - [...] as ações de formação dos professores inseridos neste projeto [Referência ao projeto "Hora da Leitura"], além de oferecerem algum subsídio teórico sobre literatura e formação de leitores, sugeriam atividades permanentes, seqüências de atividades para um conjunto de cinco ou seis aulas e projetos semestrais. Cada encontro presencial ou videoconferência priorizava um determinado gênero (poemas, contos, fábulas, textos dramáticos). Este modelo de formação, no entanto, apresentava algumas dificuldades. As videoconferências eram bimestrais e atingiam menos de um quinto dos professores que atuavam no projeto, e os encontros presenciais eram semestrais e organizados apenas para noventa assistentes técnico-pedagógicos das Diretorias de Ensino, que, muitas vezes, tinham dificuldades locais para reunir os professores e replicar o conteúdo dos referidos encontros. (p. 152)

ESP08b - Nas atividades finais do experimento, os professores demonstraram algumas dificuldades para reconhecer a forma como integrante do conteúdo na elaboração do discurso artístico-literário. (p. 157)

* A relação entre a teoria e as prescrições curriculares com a prática docente é conflitante (07)

EPRO4 - Apesar de todo o suporte teórico dos PCNs (utilizado pela professora na produção de seu planejamento anual de ensino), sua prática NÃO condiz com a teoria apresentada. $O$ que ela considera "permitir que os alunos falem em sala de aula", consideramos oralização da escrita [...]. (p. 72)

FMT06a - A totalidade das concepções teóricas NÃO foi assimilada e colocada em prática, como a construtivista e a sócio-interacionista, por exemplo. As professoras, ao enfatizarem um ensino meramente decorativo, com atividades prontas e sistematizadas, onde uma pequena falha ortográfica ganhava força de reprovação, negavam o processo de desenvolvimento do conhecimento tão propalado em outra concepção de ensino. (p. 184)

FMT06a - O ensino de Língua Portuguesa ganhou, já nos meados desse período, um formato diferenciado do que ele tinha no início dos anos 90, em que a língua era tratada como algo estático e imutável. [...] ocorreu uma variante entre professoras que aceitaram outras propostas e aquelas que rejeitaram e mantiveram o ensino praticamente na mesma perspectiva dos decênios anteriores. (p. 183-4)

EPRO6 - [...] De uma forma geral, eles [referência aos professores sujeitos de pesquisa] NÃO possuem plena convicção dos pressupostos teóricos que embasam as suas práticas, uma vez que parece haver confusão entre as várias concepções. Isso nos leva a depreender ecletismo ou falta de clareza na fundamentação teórica, no trabalho realizado com afinco no cotidiano, exigente quanto ao domínio da gramática normativa. Esse ativismo - no sentido de excesso de atividades sem a devida reflexão - movido pela busca em conciliar as exigências curriculares ao tempo pedagógico, muitas vezes compromete a capacidade de refletir, pois 
são propostas mais próximas do trabalho braçal do que intelectual; agem dessa forma por acreditarem estar no caminho certo. (p. 79)

EPRO6 - Verificamos uma distância, uma contradição entre aquilo que desejam as propostas curriculares oficiais (CB, PCNs) e todo o acervo bibliográfico de pesquisas teóricas que tratam sobre o ensino de Língua Materna, amplamente publicadas, e o que efetivamente ocorre no dia-a-dia escolar. (p. 159)

EPRO6 - [...] apesar da boa vontade do professor; do seu empenho em trabalhar com textos; de oferecer atividades diversificadas de produções textuais; de mudar o procedimento metodológico, quanto ao atendimento individualizado ao aluno; consideramos que a prática significativa e efetiva, na dimensão interacionista, ainda está por acontecer, mesmo após cursos e reuniões de estudos. (p. 106)

FPA07 - [...] as professoras continuam tomando a gramática (com um fim em si mesma) como objeto de ensino, apesar de os documentos oficiais e os pesquisadores da área defenderem um ensino baseado no uso da linguagem. Esse comportamento delas revelou que algumas $N \tilde{O} O$ se apropriam desse discurso oficial e outras o replicam, pois acham que o estudo da nomenclatura e a identificação de questões gramaticais ajudam o aluno a escrever e a falar corretamente. (p. 178)

FPA07 - [...] o ensino centrado na gramática continua vigorando na escola, apesar das críticas feitas a ele e das diversas pesquisas cujos resultados indicam que ele NÃO contribui efetivamente para o desenvolvimento das habilidades lingüístico-linguageiras dos alunos. ( $p$. 181)

FPA07 - Percebemos que, ainda hoje, no ensino de LP, vigora uma prática lingüística na qual se trabalha a metalinguagem por meio de exercícios de reconhecimento e memorização de nomenclatura, embora os PCN (BRASIL, 2001) apontem o uso da língua oral e escrita e a análise e reflexão sobre a língua como princípios organizadores deste ensino. (p. 46-7)

FMT07 - [...] o professor Ademar chama a atenção para um fator determinante nas transformações dos livros didáticos no transcorrer dos anos: o processo de infiltração das correntes teóricas mais recentes no texto didático e até mesmo na prática pedagógica do professor. Ele destaca a tamanha dificuldade de se trabalhar com o livro "ALP", adotado por seus colegas no ano anterior a sua chegada no grupo, porque era um livro, pode-se dizer assim, que mais se aproxima daquilo que descreve os Parâmetros Curriculares Nacionais, para os objetivos do ensino da língua materna. O material em questão recebe uma das mais altas recomendações no PNLD. Essa dificuldade configura o distanciamento entre a teoria acadêmica e a prática pedagógica do professor, ou seja, elas caminham em tempos diferentes. (p. 186)

FPB07 - Como constatamos, por mais que as discussões sobre a importância da leitura e da construção de sentidos nas aulas de língua portuguesa estejam presentes nos meios acadêmicos, elas ainda parecem um pouco distantes da prática de sala de aula da grande maioria dos professores do Ensino Fundamental. A distância entre teoria e prática pode ser um dos motivos dessa disparidade. (p. 113)

ESP08b - O cotidiano da escola pública afasta-a do epicentro destas mudanças, e ela se recente desta distância. Ainda que alguns profissionais que atuam na escola procurem meios próprios para a sua formação e as instituições (Secretarias Estaduais ou Municipais) promovam programas de formação para atualizar os professores sobre as novas concepções que orientam o currículo, a sala de aula recebe reflexos enfraquecidos das novas concepções sobre o ensino, uma vez que esta reflexão chega de forma fragmentada e descontinua. ( $p$. 149-50)

ESP08b - A contradição entre o discurso e a prática, construída pela forma como as alterações do currículo entram pelos portões da escola, está presente nas respostas dos questionários do grupo de professores da Hora da Leitura. (p. 150) 
* As condições docentes são problemáticas - (06)

EPRO4 - Quando o professor propõe-se trabalhar com a oralidade, apesar do conhecimento teórico, esbarra em vários obstáculos, dentre eles, o excessivo número de alunos em sala de aula, o receio de que interações orais gerem indisciplina, e, principalmente, a falta de diretrizes para um efetivo trabalho com a lingua oral. (p. 90)

FMT06a - O entendimento dessa professora sobre ensino de uma língua e ser um usuário competente dela ultrapassava as barreiras das dificuldades, pois a falta de condições da EEGK NÃO foi impedimento para que ela desenvolvesse um trabalho diversificado com a linguagem. (p. 134)

EPRO6 - A estrutura do ensino de $5^{a}$ a $8^{a}$ série organizada tal como se encontra - com a matriz curricular que fragmenta os saberes escolares nas diferentes disciplinas e que "devem ser vencidos" até o final do ano letivo, com mudança de professores e de conteúdos disciplinares a cada uma ou duas horas-aulas, ritmo frenético construído pelo próprio sistema, com sala numerosa em que se massifica o relacionamento interpessoal de professor e aluno - impossibilita um ensino de qualidade, mormente atender a esse grande contingente de alunos com déficit. (p. 151)

EPR06 - As produções de pesquisa de cunho teórico e prático continuam distantes do professor de LP da rede pública estadual. A interlocução ainda NÃO se efetiva nesse universo porque NÃO há políticas públicas adequadas, no Brasil e no Paraná, que disseminem a socialização do saber por meio da redução de custos nas edições $e$ distribuições de livros técnicos, de incentivos aos professores da rede pública para participarem de eventos científicos, de verbas para que possam desenvolver pesquisas, $e$ principalmente, para o assessoramento didático da IES em forma de cursos de formação continuada. (p. 78)

EPA08 - As justificativas mais comuns para a NÃO efetivação da proposta dos PCN de Língua Portuguesa estão relacionadas à falta de condições das escolas (é preciso melhorar a biblioteca e seu acervo bibliográfico e há carência de recursos didáticos) para que elas possam desenvolver uma melhor prática de ensino. A sobrecarga de trabalho é uma questão recorrente e, segundo as professoras, isso sempre interferiu na efetivação da proposta. Em suas falas, elas se voltam constantemente aos recursos e às condições necessárias para que esses conteúdos possam ser trabalhados. (p. 186)

EPA08 - De modo geral, as críticas apresentadas voltam-se exclusivamente ao trabalho do professor. Nenhuma está relacionada a falta de investimentos na sua formação. Os problemas são vistos como um fim em si mesmos e o professor é o grande responsável por todos esses desajustes. Postura bastante comum nos discursos políticos, esses documentos sempre fazem um diagnóstico da situação e deixam de discutir suas causas mais profundas. (p. 102)

EPA08 - Considerando-se os problemas que envolvem a transposição dos conteúdos a serem ensinados na sala de aula, a professora A declara que a escola onde ela exerce sua função $N \tilde{O} O$ oferece condições para realizar um melhor trabalho: "A escola onde eu trabalho NÃO oferece, em parte, condições para que eu possa desenvolver um bom trabalho. Ela NÃO possui biblioteca. Há uma salinha onde estão amontoados uns livros. O prefeito da época ficou de montar uma biblioteca naquele local, pois a antiga biblioteca foi cedida para o laboratório da escola. Ele disse que faria uma biblioteca e NÃO fez. Hoje ele já saiu do poder e NÃO fez, NÃO cumpriu." (Professora A). (p. 150)

EPA08 - Podemos dizer que a transformação desejada, neste estudo de caso, ainda NÃO aconteceu. Ela está condicionada a determinantes como a possibilidade de formação continuada, que, na maioria dos casos, limita a ação, haja vista que os profissionais se 
encontram submetidos a um sistema educacional com graves problemas, como, por exemplo, a falta de recursos materiais necessários que lhes orientem a prática de ensino. Assim, o professor e o aluno são frutos de um conjunto de condições socio-históricas que produzem o fracasso do ensino e da aprendizagem da linguagem e da Lingua Portuguesa. (p. 181)

ESP08b - Além do documento inicial do projeto Hora da Leitura, muito sucinto na sua abordagem, NÃO há nenhuma publicação que oriente o professor na sua atuação. Este fato é muito relevante na medida em que a Hora da Leitura, por ter um número considerável de professores NÃO concursados, sofre uma grande alteração no seu quadro de professores todo o início de ano letivo. A existência de um documento orientador poderia garantir, pelo menos em linhas gerais, o sucesso de suas ações. As ações de formação destinada aos professores da Hora da Leitura também são afetadas pela grande rotatividade destes profissionais, o que as transforma em uma eterna retomada dos princípios e orientações básicas sem oportunidades de aprofundamento. (p. 152)

ESP08b - Esta pesquisa demonstrou, por um lado, a disposição dos professores da Hora da Leitura em compreender melhor a natureza do fenômeno teatral, sobretudo os jogos de improvisação teatral como ato de leitura sensível das produções literárias, para que possam desenvolver sua articulação com as atividades de leitura do texto literário. Por outro lado, ficou evidenciada a falta de oportunidades que estes profissionais têm para investirem na sua formação e refletirem sobre sua prática. Falta-lhes também espaço para a socialização de experiências entre eles, uma vez que os momentos de formação são escassos, além de NÃO conseguirem incluir todos eles. Soma-se a isto a ausência de referenciais que possam dialogar com estes profissionais que se arriscam em práticas interdisciplinares que transitam pelas diferentes linguagens e seus códigos. (p. 158)

FPB08c - Segundo Sancho (2006), as Tecnologias da Informação e Comunicação (TIC) provocaram uma série de mudanças também na vida acadêmica. Apesar de relevante, essa mudança enfrenta resistência por parte de professores no que diz respeito à qualificação profissional, já que a primeira mudança tem que partir dos mesmos, uma vez que a condução do ensino começa com o educador. Outras dificuldades encontradas referem-se à falta de estrutura física das escolas, como também a ausência de subsídios por parte dos poderes públicos, o que dificulta o ensino e conseqüentemente a aprendizagem. (p. 23)

FPBO8c - O material didático-pedagógico geralmente está em falta ou em quantidade restrita, a remuneração dos nossos pedagogos e professores é baixa, o que provoca a sobrecarga de trabalho para esses profissionais (há professores que trabalham os três turnos), isso significa que esse professor NÃO tem tempo para se aperfeiçoar e planejar bem as sua aulas, na falta de tempo vai o mais fácil: atividade de cópia e explicação oral com quadro e giz. (p. 33)

* As concepções e práticas são indefinidas - (04)

EPRO2 - [...] a professora transitava constantemente de uma prática em uma perspectiva estruturalista para uma prática em uma perspectiva interacionista de ensino e aprendizagem de lingua. (p. )

EPRO4 - [...] a professora interacionista deixa entrever características da professora tradicional. Isso se deve à formação tradicional que também receberam os professores. Embora a professora $E$ tenha cursado sua especialização recentemente, e nela tenha tido contato com teorias lingüísticas que privilegiam a dialogia, o peso da formação secundária e da graduação é muito grande e deixa marcas. (p. 67)

EPRO6 - As concepções de língua, leitura, escrita e fala desse professor, estão ancoradas ora na visão estruturalista ora na interacionista. Observamos, pelo conjunto de atividades 
encaminhadas, que houve uma preocupação em desenvolver trabalho com textos, destacando a língua no seu uso social e real. (p. 111-2)

FMT07 - O livro "Estudo Dirigido", parece-me que se situa entre o inovador e o tradicional. As características do inovador residem nas formas de como se direcionar ao aluno, nas informações apresentadas ao professor, no colorido, no uso excessivo de figuras, mas ainda tradicional na seleção de textos, na forma como aborda os estudos gramaticais. Mas NÃO há como negar a sua presença marcante em uma nova fase para os manuais de língua portuguesa. (p. 127)

* A concepção de linguagem é estruturalista - (03)

EPRO2 - [...] conduta da professora como uma prática atrelada a uma perspectiva tradicional de ensino de língua portuguesa, fundamentada em uma concepção estruturalista de linguagem, na qual os exercícios mecânicos e repetitivos são considerados excelentes. ( $p$. .) EPRO6 - Após a amostra do conjunto de respostas dos dez professores, ratificamos aquilo que é reiterado nas pesquisas em língua materna, há mais de duas décadas, que o Estruturalismo elou Formalismo continuam fundamentando as práticas de grande parte dos professores de Língua Materna do Estado do Paraná. (p. 79)

EPRO6 - Como apresentamos reiteradamente, a grande maioria dos professores da SAALP $N A \tilde{O}$ só concebe a língua, a linguagem, a oralidade, a leitura e a produção textual na esteira tradicional do Estruturalismo, como as professam em suas práticas diárias. Nesse sentido podemos afirmar a consonância entre teoria e prática. Isto significa dizer que o espírito da antiga lei no 5.692/71, juntamente com todo o arsenal teórico-metodológico do Estruturalismo, continua presente e vivo. Ele se manifesta materialmente em todas as ações docentes: na seleção do material didático, na seleção dos conteúdos, nos objetivos elencados, na metodologia utilizada, nos instrumentos e nas formas de avaliação. Sobretudo, na relação professor-aluno. (p. 138)

FPB07 - A concepção teórica de leitura que estava subjacente à prática de sala de aula da docente era a estruturalista. Essa nossa descoberta só foi possível a partir da observação das aulas da professora, pois, durante a entrevista que realizamos com a mesma, ela NÃO conseguiu falar sobre nenhuma concepção de leitura que tenha estudado em sua graduação, especialização ou em algum dos cursos de reciclagem que tenha participado. (p. 110)

FPBO7 - [...] a professora nos revela em sua fala qual a concepção de leitura que parece está subjacente à sua prática: a leitura como uma prática na qual o texto tem uma mensagem que deve ser buscada durante a leitura pelo aluno. Isso é uma indicação de uma concepção estruturalista de leitura (Coracini, 1995/2005), e um exemplo de leitura unicamente no sentido ascendente, ou seja, uma leitura na qual os sentidos estão todos presentes no texto e cabe ao leitor apenas identificá-los (Kleiman, 2004a). (p. 74)

* A concepção de linguagem é de instrumento de comunicação - (03)

FSCO3 - A professora é bastante comprometida com o ensino que promove e essa NÃO continuidade [Referência a atividades que NÃO foram finalizadas conforme o planejado] NÃO lhe parece danosa justamente por NÃO trabalhar na perspectiva enunciativa. Nas diferentes propostas de atividade que desenvolve em sala de aula, toma a linguagem como instrumento de comunicação e NÃO como constitutiva do sujeito, como afirma Bakhtin. Com isso, acaba trabalhando em uma concepção pseudoenunciativa da linguagem. (p. 71)

FMT06a - A consonância entre o planejamento anual da professora Aline e seus registros oficiais manifestados [...] fortalecia a negação às prescrições de caráter estadual e afirmava a aceitação das normas prescritas na LDB 5.692/71, que regulamentou como meta para o ensino de Língua Portuguesa a formação de um aluno que tivesse desenvolvidas suas 
habilidades funcionais, ou seja, apto para atuar no mercado de trabalho, induzindo a um ensino tecnicista, com uma concepção de linguagem voltada à comunicação. (p. 119-20)

FMT07 - Quando o autor [Referência ao autor do livro "Português no Ginásio"] anuncia que o ensino da língua portuguesa visa, primordialmente, oferecer condições para a comunicação, quer como emissor ou como receptor de mensagens, fica evidente a concepção de língua empregada pelo autor, na obra. Logo no início, tem-se a presença da concepção da língua como um instrumento para comunicação. (p. 121-2)

* Os textos são pretextados - (03)

EPRO2 - [...] o texto serviu apenas como pretexto para exercícios gramaticais, tal como os textos fragmentados dos livros didáticos, que são desapropriados de seus autores e de seu contexto, servindo a um exercício mecânico de análise lingüística.

FPA07 - [...] quando comparamos o depoimento das professoras ao que presenciamos em sala, verificamos que as aulas de LP estão centradas no trabalho com a gramática como um fim em si mesma. São diversos os momentos em que as professoras utilizam o texto para explorar itens gramaticais, como no exemplo destacado a seguir, justificando, muitas vezes, que tal trabalho contribui para o aluno aprender a escrever e a falar corretamente. (p. 154) FPAO7 - Em resumo, a pesquisa mostrou que o objeto de ensino nas aulas de LP é a gramática, principalmente no respeitante às questões ortográficas. Ela é explorada quase sempre a partir do texto, que é utilizado como pretexto para a identificação de itens gramaticais e para o treino ortográfico. (p. 157)

FPA07 - [...] embora o texto esteja presente em sala, ele é tomado como oração, porque praticamente nenhuma das professoras enfatiza que, por detrás dele, há um autor, que ele é resposta a outro enunciado, que tem marcas do outro etc. Na situação de sala de aula, ele parece ser vazio quanto ao sentido, pois o objetivo é a exploração de aspectos ortográficos e morfológicos. (p. 178-9)

FPA07 - [...] das seis professoras, cinco afirmaram priorizar o texto no momento da escolha, mas, quando consultadas sobre os pontos negativos do material, quatro delas citaram a presença de textos longos. Se o fator determinante para escolher um e NÃO outro material é prioritariamente o texto, parece evidente que há intenção em utilizá-lo em sala de aula. Todavia, percebemos, por meio das observações, que duas professoras (PEE2 e PEF2) NÃO o utilizaram em sala de aula e que as outras usaram-no esporadicamente. Por exemplo, durante 12 horas-aula de observação na escola EE1, ele foi tomado uma única vez, exclusivamente, para identificação de questões gramaticais. (p. 140-1)

FMT07 - Há um uso freqüente da utilização do texto para pretexto da gramática. Para a época seria uma forma inovadora de estudo da gramática da língua, o que chamariam da gramática a partir do texto. Hoje, esse procedimento é um tanto frágil, uma vez que o texto é dissecado apenas para as estruturas gramáticas, e o texto em si, suas estruturas $e$ características são valorizadas em estudo. (p. 126)

* O desempenho linguístico discente é insatisfatório - (03)

EPRO6 - Sucessivas avaliações oficiais, realizadas ao final da $4^{a}$ ou da $8^{a}$ série do Ensino Fundamental, ou, ainda, ao final do $3^{\circ}$ ano do Ensino Médio, no Brasil e no Estado do Paraná, confirmam ano a ano que o desempenho dos alunos, especialmente em língua materna, tem piorado. Insucesso que ocorre apesar de a academia e de os pesquisadores debaterem, há mais de duas décadas, problemas afetos ao ineficiente desempenho lingüístico dos alunos. (p. 13) 
EPRO6 - Uma leitura sob o viés da produtividade, a respeito [...] do índice total de $36 \%$ de reprovação consideraria que o Programa [Programa Sala de Apoio à Aprendizagem em Língua Portuguesa - SAALP] NÃO obteve sucesso, enxergando apenas aquilo que ele deixou de atingir. Todavia, uma leitura construtiva possibilita refletir e compreender que os problemas de leitura, compreensão e escrita dos alunos diminuíram, apesar de o nível mínimo exigido NÃO ter sido atingido pelos alunos, ao final do ano letivo, para a promoção para a série seguinte. Mesmo porque o tempo estabelecido pelo Programa NÃO coincidiu com aquele compatível com a necessidade do aluno. (p. 157)

FMT06b - Além de inadequações gráficas, nas primeiras versões das CLs [Cartas do leitor], encontramos marcas de oralidade. Nos exemplos [...], os alunos confundem o fonema $\mathrm{i} / \mathrm{l}$ com o grafema " $e$ " [...]. (p. 110)

ESP08b - A idéia de implementar o projeto "Hora da Leitura" nas escolas da rede estadual surgiu no primeiro semestre de 2004, quando os relatórios estatísticos acerca dos resultados de rendimento escolar dos alunos do Ensino Fundamental indicaram índices de acerto preocupantes na prova de compreensão leitora. (p. 16)

* O ensino é tradicional - (02)

EPRO2 - [...] conduta da professora como uma prática atrelada a uma perspectiva tradicional de ensino de língua portuguesa, fundamentada em uma concepção estruturalista de linguagem, na qual os exercícios mecânicos e repetitivos são considerados excelentes.

EPA08 - As representações de PCN são descritas junto aos problemas da formação recebida. Essas imagens, portanto, NÃO nos permitem construir uma idéia de superação da prática tradicional do ensino de Língua Portuguesa, muito criticada pelos especialistas, tendo em vista as orientações do documento. Isso permite afirmar que nem o curso de formação com base nos PCN de Lingua Portuguesa, nem a busca posterior a esse documento, garantiram a tão desejada prática renovadora em sala de aula. (p. 187)

EPA08 - Com essa atitude, que possui como conseqüência a concepção tradicional de língua como sistema imutável, que elege apenas um padrão como "correto", a professora B demonstra que NÃO leva em conta a variabilidade da língua e descreve somente a norma culta, comprometendo a noção de uso proposta pela concepção sociointeracionista da língua. (p. 168)

EPA08 - É possível perceber nas falas das professoras que o objeto de estudo da lingüística é apenas a língua em sua variedade culta, deixa-se de considerar a comunidade social em seu aspecto lingüístico, já que a língua é um fato social. Assim, NÃO é possibilitado aos alunos o conhecimento de novas formas lingüísticas, além da escrita e o padrão de oralidade mais formal orientado pela tradição gramatical. As variedades lingüísticas deixam de ser legitimadas e seu estudo, por conseqüência, NÃO cumpre com a formação da consciência lingüística e a competência discursiva do aluno. Em resumo, ainda predominam práticas pedagógicas assentadas em diretrizes maniqueístas do tipo certo-errado, tomando-se como referência o padrão culto. (p. 170)

* Aulas tradicionais são limitantes - (02)

EPR04 - As observações acerca do trabalho com oralidade levam-nos a concluir [...]: métodos tradicionais admitem apenas o ensino da norma padrão escrita. Práticas inovadoras, entretanto, demonstram que é possível aliar o estudo da língua falada ao da língua escrita, valorizando o discurso dos alunos e ampliando sua competência discursiva, afinal, objetivo maior das aulas de língua materna. (p. 92) 
FPA07 - Desde longa data, o ensino de LP tem sido sinônimo de ensino de gramática tradicional, defendido por muitos professores sob o argumento de que é necessário para o aluno aprender,escrever e falar corretamente. Entretanto, os alunos apresentam, mesmo após 11 anos de estudo,dificuldade de se expressar quer oralmente, quer na forma escrita, como refere Cunha (2000). (p. 46)

* Reescrever é refletir sobre e a partir do texto escrito - (02)

FMT06b - Outra atividade produtiva foi a refacção individual e coletiva dos textos, uma vez que os alunos demonstraram-se participativos e autocríticos do que produziam. Tal atividade proporcionou a eles momentos de reflexão quanto ao uso da língua materna. Foram capazes de questionar se determinada palavra elou expressão estava compatível com o gênero e o suporte estudado. Em alguns momentos, passaram por "iniciação cívica” como, por exemplo, quando, ao reestruturamos um texto que dizia "os prezidentes so promete arruma os bairros e NÃO cumpre a sua promeça..." , alguns discentes comentaram que a responsabilidade era do prefeito e NÃO do presidente [...]. Durante esse processo, os discentes demonstraram-se muito críticos, pois questionavam quanto à veracidade do que os alunos autores das CLs [Cartas de Leitores] diziam. Caso houvesse dúvidas quanto ao exposto, a turma apresentava nova sugestão de reescrita do texto. (p. 124)

FMT06b - Nas primeiras versões produzidas, apareceram alguns desvios acerca da grafia das palavras. Acreditamos que esse fato ocorre por alguns alunos NÃO possuírem o hábito de reler o que escrevem. Afirmamos isso, tendo em vista que, nas versões finais, praticamente todas as inadequações desapareceram. (p. 108)

FMT06b - Nessa carta [Referência à produção discente], o autor também apresenta inadequações gráficas como "viumava, probema, lemtou, mais, consegiu, sabeno, temin ou, a sim”. Em sua última versão, "problemas" assim desapareceram [...]. (p. 109)

FMT06b - Além de inadequações gráficas, nas primeiras versões das CLs [Cartas do leitor], encontramos marcas de oralidade. Nos exemplos [...], os alunos confundem o fonema $/ \mathrm{i} / \mathrm{com}$ o grafema " $e$ " [...]. (p. 110)

FMT06b - À medida que os textos foram sendo reescritos, os alunos adquiram [sic] conhecimento sobre o gênero e sobre a linguagem exigida. O processo de refacção possibilitou a eles adequação da linguagem aos propósitos das CLs [Cartas do leitor] produzidas. (p. 115)

FMT06b - Podemos, pelos exemplos [...], perceber que algumas das incoerências presentes nas primeiras produções como grafia, concordância, escolha lexical e estrutura do gênero foram sendo eliminadas a cada novo texto produzido. Os alunos tiveram o cuidado de corrigir seus textos adequando-os aos propósitos enunciativos do gênero. Muitas cartas foram reescritas sem que o professor solicitasse tal atividade. O próprio aluno ou um colega percebia que o texto ainda NÃO estava bom para o suporte em questão. (p. 121)

FRS10 - [...] há uma grande diferença entre os dois textos [Referência à produção escrita de um dos alunos], NÃO apenas em relação à carga informativa, que é apresentada de modo mais preciso no segundo, mas especialmente em relação à tentativa de uso de expressões sinônimas. Os personagens principais, Marcão e Serginho, no primeiro texto, são referidos sempre pelo nome. Na reescrita, porém, observa-se a utilização de expressões sinônimas quando o aluno escreve "o rapaz que gostava de beber vodca", ao ser referir a arcão, $e$ "o amigo”, para fazer referência a Serginho. A escolha de Felipe pela expressão sinônima demonstra maior controle do autor sobre seu texto, exatamente porque ele busca essa expressão no primeiro parágrafo e obtém assim o efeito coesivo desejado por meio da referência a uma característica marcante do personagem, o seu gosto por vodca. Vale 
salientar, também, a utilização dos termos "morrido" e "falecido" que resultam em um uso adequado desse recurso. (p. 47)

FRS10 - Os resumos referentes a esse livro NÃO tiveram a reescrita como tarefa subsequente, pois os alunos, espontaneamente, reescreviam os parágrafos várias vezes, tentando resolver problemas que eles mesmos começaram a detectar. O exemplo reproduzido em (3) revela a evitação de uso de lexema idêntico, que se expressa pela rasura do nome próprio (Raquel) e a sua substituição pelo pronome reto. (p. 50)

FRS10 - No geral, os alunos que apresentaram mudança de comportamento em relação ao uso de expressões sinônimas utilizavam na escrita inicial a repetição do lexema para a retomada, mais o uso de pronome pessoal reto e algumas elipses. Já na reescrita trocam o nome do personagem, Tistu, por outras palavras que têm sentido semelhante ("o menino", "o garoto" e "o moleque") para fazer remissão. No entanto, NÃO utilizam só desse recurso para referência, mas também a repetição, a elipse, oblíquos, os possessivos e os demonstrativos, o que emprestou maior qualidade aos seus textos. (p. 55)

d) Os referenciais teóricos recorrentes nas dissertações foram:

- Parâmetros Curriculares Nacionais: língua portuguesa, de responsabilidade da Secretaria de Educação Fundamental/Ministério da Educação (publicações de 1997, 1998, 2001, 2002) - em ESP01, EPR02, FSC03, EPR04, EPR06, FMT06a, FMT06b, EPR07, FPA07, FMT07, ESP07, FPB07, FPB08a, FPB08b, EPA08, ESP08, ESP09, FRS10;

- Marxismo e filosofia da linguagem, de Mikhail Bakhtin (V. N. Volochinov) (publicações de 1929, 1979, 1981, 1986, 1990, 1995, 1997, 1999, 2002) - em EPR02, FSC03, EPR04, EPR06, FMT06b, ESP07, FPA07, FMT07, FPB07, EPA08, ESP08, FPB08a, ESP09;

- Estética da criação verbal, de Mikhail Bakhtin (publicações de 1979, 1992, 1997, 1998, 2000, 2003) - em FSC03, EPR04, EPR06, FMT06a, FMT06b, ESP07, FPB07, FPA07, EPA08, FPB08a, ESP08, ESP09;

- O texto na sala de aula, de João Wanderley Geraldi (publicações de 1984, 1985, 1997, 2003, 2004) - em EPR02, EPR04, EPR06, FMT06a, FMT06b, FPA07, FMT07, ESP08, FPB08a, EPA08, FRS10;

- Portos de passagem, de João Wanderley Geraldi (publicações de 1991, 1997, 1998, 2002, 2003) - em EPR02, EPR04, EPR06, FMT06b, FPA07, FMT07, FPB07, FPB08a, EPA08, ESP09;

- Gêneros textuais \& ensino, de Ângela Paiva Dionísio et al (publicações de 2002, 2003, 2005) - em EPR04, FMT06a, FMT06b, ESP07, FMT07, FPA07, FPB07, EPA08, ESP09;

- Gramática e interação: uma proposta para o ensino de gramática no 1o. e 2o. graus, de Luiz Carlos Travaglia (publicações de 1996, 1997, 1998, 2000, 2001, 2002, 2003) - em EPR02, EPR04, FMT06a, FMT06b, EPR07, FPA07, EPA08, FPB08a, FRS10; 
- A prática de linguagem em sala de aula - praticando os PCNs, organização de Roxane Rojo (publicação de 2000) - FSC03, EPR04, FMT06a, FMT06b, ESP07, FPA07, EPA08, ESP09;

- Da fala para a escrita: atividades de retextualização, de Luiz Antonio Marcuschi (publicações de 2001, 2003) - em EPR02, EPR04, EPR06, ESP07, FMT07, EPA08, FPB08a;

- Linguagem e ensino: exercícios de militância e divulgação, de João Wanderley Geraldi (publicações de 1996, 2005) - em EPR02, EPR04, EPR06, FMT07, FPB08a, EPA08, ESP09;

- Pedagogia da autonomia: saberes necessários à prática educativa, de Paulo Freire (publicações de 1996, 1998, 2000, 2004) - em EPR02, EPR06, FMT07, FPA07, ESP08, FPB08b, EPA08;

- Pensamento e linguagem, de L. S. Vygotsky (publicações de 1987, 1989, 1991, 1998, 2003) - em EPR04, EPR06, FPA07, FPB07, ESP07, ESP08, FPB08b;

- Por que (não) ensinar gramática na escola, de Sírio Possenti (publicações de 1996, 1997, 1998, 2002, 2004) - em EPR04, EPR06, EPR07, FPA07, EPA08, FPB08a, FRS10;

- A formação social da mente, de L. S. VYGOTSKY (publicações de 1984, 1991) em ESP01, EPR02, FSC03, FPA07, ESP08;

- Aula de Português: encontro \& interação, de Irandé Antunes (publicação de 2003) em EPR06, FMT06a, FPB07, FPA07, FPB08a;

- Aprender e ensinar com textos, coordenação de Lígia Chiappini (publicações de 1997, 2000, 2001, 2002, 2004) - em EPR02, EPR06, FMT06a, FMT07;

- A sombra do caos, de Percival Leme Brito (publicação de 1997) - em EPR02, EPR04, EPA08, FPB08a;

- Atividade de linguagem, textos e discursos: por um interacionismo sócio-discursivo, de Jean-Paul Bronckart (publicações de 1999, 2003) - em FMT06a, FMT06b, ESP07, FPB07;

- Gêneros Orais e escritos na escola, de Bernard Schneuwly; Joaquim Dolz (publicação de 2004) - em EPR06, FMT06b, FPA07, EPA08;

- Lei de Diretrizes e Bases da Educação. Lei no 9.394, de 20 de dezembro de 1996 em EPR06, FMT06a, FPA07, EPA08;

- Linguiística da norma, organização de Marcos Bagno (publicação de 2002) - em FMT06b, FPA07, FMT07, EPA08;

- Oralidade e escrita: perspectivas para o ensino de língua materna, de Leonor Lopes Fávero; Maria Lúcia C. V. O. Andrade; Zilda G. O. Aquino (publicações de 2000, 2005) - em EPR04, ESP07, FPB08a, EPA08;

- As ciências lingüísticas e o ensino de línguas, de M. A. K Halliday; Angus Mclntosh; Peter Strevens (publicação de 1974) - em EPR02, EPA08, FRS10;

- A coesão textual, de Ingedore Villaça Koch (publicações de 2000, 2001, 2002) - em ESP07, ESP09, FRS10; 
- A gramática: história, teoria e análise, ensino, de Maria Helena de Moura Neves (publicação de 2002) - em EPR07, FPB08a, FRS10;

- A linguística e o ensino da língua portuguesa, de Rodolfo Ilari (publicações de 1986, 1992, 1997) - em EPR04, EPA08, FRS10;

- Alfabetização \& linguística, de Luiz Carlos Cagliari (publicações de 1989, 1999, 2003) - em EPR02, ESP07, FRS10;

- Argumentação e linguagem, de Ingedore Grunfeld Villaça Koch (publicações 1984, 2002) - em FMT06b, ESP07, FRS10;

- Coerência textual, de Ingedore Grunfeld Villaça Koch; Luiz Carlos Travaglia (publicações de 1990, 1991, 2001) - em ESP07, ESP09, FRS10;

- Gêneros: teorias, métodos, debates, de J. L. Meurer; A. Bonini; D. Motta-Roth (publicação de 2005) - em ESP07, FPA07, ESP09;

- Introdução à lingüística: domínios e fronteiras, de Fernanda Mussalim; Anna Christina Benthes (publicação de 2003) - em FMT06a, FPA07, EPA08;

- Leitura, produção de textos e a escola: reflexões sobre o processo de letramento, de Maria de Lourdes Meirelles Matêncio (publicação de 1994) - em EPR02, EPR04, FPA07;

- Língua materna: letramento, variação e ensino, de Marco Bagno; Gilles Gagné; Michael Stubbs (publicação de 2002) - em EPR02, EPR04, EPA08;

- Língua portuguesa: história, perspectivas, ensino, organização de Neusa Barbosa Bastos (publicação de 1998) - em EPR02, EPA08, FPB08a;

- Linguagem e escola: uma perspectiva social, de Magda Soares (publicações de 1986, 1991) - em EPR02, EPR04, EPA08;

- Os sentidos da alfabetização, de Maria do Rosário Longo Mortatti (publicação de 2000) - em EPR02, FMT06a, FMT07;

- Questões de literatura e de estética: a teoria do romance, de Mikhail Bakhtin (publicações de 1988, 1993, 2002) - em FSC03, FPA07, ESP08;

- Texto \& leitor: aspectos cognitivos da leitura, de Ângela Kleiman (publicações de 2000, 2002, 2004) - em EPR06, FPB07, ESP08;

- A história cultural: entre práticas e representações, de Roger Chartier (publicações de 1990, 2002) - em FMT06a, FMT07;

- A língua falada no ensino de português, de Ataliba T. de. Castilho (publicações de 1998, 2002) - em EPR04, FPB08a;

- A nova lei da educação: LDB, trajetória e limites e perspectivas, de Dermeval Saviani (publicações de 1997, 1998) - em EPR02, ESP07;

- A ortografia na escola e na vida, de Luiz Carlos Cagliari (publicado em Isto se aprende com o ciclo básico, responsabilidade da Coordenadoria de Estudos e Normas Pedagógicas/ Secretaria da Educação de São Paulo) (publicações de 1986, 1988) - em FMT06a, EPA08; 
- A pesquisa em história, de Maria do Pilar de Araújo Vieira; Maria do Rosário da Cunha Peixoto; Yara Maria Aun Khoury (publicações de 1998, 2003) - em FMT06a, FMT07;

- A reprodução: elementos para uma teoria dos sistemas de ensino, de Pierre Bourdieu; Jean Claude Passeron (publicações de 1973, 1975) - em EPR02, EPR06;

- A voz do passado: história oral, de Paul Thompson (publicação de 1992) - em FMT06a, FMT07;

- Análise de textos de comunicação, de Dominique Maingueneau (publicações de 2001, 2004) - em FMT06b, ESP07;

- Aula de português: discurso e saberes escolares, de A. A. G. BATISTA (publicação de 1997) - em FPA07, EPA08;

- Aulas de português: perspectivas inovadoras, organização de André Valente (publicação de 1999) - em FMT06a, EPA08;

- Bakhtin: conceitos-chave, organização de Beth Brait (publicação de 2005) - em FPA07, ESP08;

- Bakhtin, dialogismo e construção do sentido, organização de Beth Brait (publicação de 1997) - em FPA07, ESP09;

- Construindo o leitor competente: atividades de leitura interativa para a sala de aula, de R. M. BRAGA; M. de F. B. SILVESTRE (publicação de 2002) - em EPR06, FMT07;

- Currículo Básico para a Escola Pública do Estado do Paraná, responsabilidade da Secretaria de Estado da Educação do Paraná (publicações de 1992, 1997) - em EPR02, EPR06;

- Curso de lingüística geral, de Ferdinand de Saussure (publicações de 1969, 1973) em EPR02, EPA08;

- Educação em língua materna: a sociolingüística na sala de aula, de Stella Maris Bortoni-Ricardo (publicação de 2004) - em EPA08, FRS10;

- Ensino de língua portuguesa: uma abordagem pragmática, de Lívia Suassuna (publicação de 1995) - em EPR02, EPA08;

- Ensino do português e interatividade, de Marcos Gustavo Richter (publicação de 2000) - em EPR02, EPR04;

- Escola e democracia, de Dermeval Saviani (publicações de 1989, 2000) - em EPR06, ESP07;

- Estilística da Língua Portuguesa, de M. Rodrigues Lapa (publicações de 1982, 1998) - em FMT06b, EPR07;

- Estudo de caso: planejamento e métodos, de Robert K. Yin (publicação de 2005) em EPA08, ESP09;

- Estudos enunciativos no Brasil: histórias e perspectivas, organização de Beth BRAIT (publicação de 2001) - em FMT06b, ESP07;

- Exercícios de compreensão ou copiação nos manuais de ensino de língua?, de Luiz Antonio Marcuschi (publicação de 1996) - em EPR02, FMT07; 
- Gramática: ensino plural, de Luiz Travaglia (publicação de 2003) - em FPB08a, FRS10;

- Gramática de usos do português, de Maria Helena de Moura Neves (publicação de 2000) - em FPB08a, FRS10;

- Gramática descritiva do português, de Mário A. Perini (publicações de 1998, 2002) - em EPA08, FRS10;

- Gramática na escola, de Maria Helena de Moura Neves (publicações de 1990, 2002) - em EPR04, EPA08;

- Gramática na escola, de Maria Helena de Moura Neves (publicações de 1994, 2005) - em FPB08a, FRS10;

- Gêneros textuais, tipificação e interação, de Charles Bazerman (publicação de 2005) - em FMT06b, ESP07;

- História das disciplinas escolares: perspectivas de análise, de L. L. de C. P. SANTOS. (publicado na Revista Teoria \& Educação, de 1990) - em FMT07, EPA08;

- História da lingüística, de Joaquim Mattoso Câmara Jr. (publicação de 1975) - em EPR02, EPA08;

- Interpretação, autoria e legitimação do livro didático, organização de Maria José R. Faria Coracini (publicação de 1999) - em EPR04, FPA07;

- Introdução à pesquisa em ciências sociais: a pesquisa qualitativa em educação, de Augusto N. S. Triviños (publicações de 1987, 1997) - em EPR07, FRS10;

- Introdução à Lingüística: fundamentos epistemológicos, organização de Fernanda Mussalim (publicações de 2004, 2005) - em FPB07, FPA07;

- Introduction to Texliguistics, de Roberto de Beuagrande; Wolfgang U. Dressler (publicação de 1981) - em ESP01, FRS10;

- Ler e navegar: espaços e percursos da leitura, organização de Marildes Marinho (publicação de 2001) - em FMT07, FPA07;

- Língua e liberdade: por uma nova concepção da língua materna e seu ensino, de LUFT (publicações de 1985, 1993) - em EPR04, FRS10;

- Língua portuguesa em debate: conhecimento e ensino, organização de José Carlos de Azeredo (publicação de 2000) - em FMT06a, FMT06b;

- Língua portuguesa: uma visão em mosaico, organização de Neusa Barbosa Bastos (publicação de 2002) - em EPR02, EPA08;

- Linguagem, desenvolvimento e aprendizagem, de L. S. VIGOTSKY et al. (publicação de 1988) - em EPR02, ESP08;

- Linguagem, escrita e poder, de Maurizio Gnerre (publicação de 1985) - em EPR02, FMT06b;

- Linguística textual: introdução, de Leonor Lopes Fávero; Ingedore G. Villaça Koch (publicações de 1983, 1988) - em EPR02, FRS10;

- Livro didático de língua portuguesa, letramento e cultura da escrita, organização de Roxane Rojo; A. A. G BATISTA (publicação de 2003) - ESP07, FPA07; 
- Lutar com palavras: coesão e coerência, de Irandé Antunes (publicação de 2005) em EPR06, FRS10;

- Manual de expressão oral e escrita, de Joaquim Mattoso Câmara Jr. (publicações de 1986, 2004) - EPR02, FPB08a;

- Moderna Gramática Portuguesa, de Evanildo Bechara (publicações de 1994, 2004) - em EPR07, FPB08A;

- O construtivismo na sala de aula, de César COLL et al. (publicações de 1996, 1999) - em FMT06a, EPR07;

- Os gêneros escolares: das práticas de linguagem aos objetos de ensino, de Bernard Schneuwly; Joaquim Dolz (publicado na Revista Brasileira de Educação, de 1999) em FMT06a, FRS10;

- O jogo discursivo na aula de leitura, organização de Maria José R. Faria Coracini (publicação de 1995) - em EPR02, FPB07;

- O paradigma educacional emergente, de M. C. Moraes (publicações de 1997, 2004) - em EPA08, FPB08b;

- O que é linguística, de Eni Pulcinelli Orlandi (publicações de1986, 1999) - em EPR02, EPR04;

- Oficina de leitura: teoria e prática, de Ângela Kleiman (publicações de 2004, 2007) em FPB07, FRS10;

- Pesquisa em Educação: abordagens qualitativas, de M. Lüdke e M. André (publicação de 1986) - em FSC03, EPA08;

- Práticas de leitura em livros didáticos, de Circe Maria Fernandes Bittencourt (publicado na Revista da Faculdade de Educação, de 1996) - em FMT06a, FMT07;

- Profissão Professor, organização de Antônio Nóvoa (publicações de 1992, 1995, 1999) - em FMT06a, EPA08;

- Psicogênese da língua escrita, de Emília Ferreiro; Ana Teberosky (publicação de 1999) - em EPR02, FMT07;

- Quem engana quem? Professor x livro didático, de Olga Molina (publicação de 1987) - em EPR02, FPA07;

- Texto e coerência, de Ingedore Grunfeld Villaça Koch; Luiz Carlos Travaglia (publicação de 1989) - em EPR02, FMT06b;

- Tópicos em Lingüística de texto e análise da conversação, organização de Ingedore Grunfeld Villaça Koch; K.S.M. Barros (publicação de 1997) - em FMT06b, ESP07;

- Vygotsky: uma perspectiva histórico-cultural da educação, de Teresa Cristina Rego (publicação de 1995) - em FSC03, ESP08. 